OCCASIONAL PAPERS

MUSEUM OF ZOOLOGY, LOUISIANA STATE UNIVERSITY

NUMBER 21

\title{
A DISTRIBUTIONAL SURVEY \\ OF THE \\ BIRDS OF SONORA, MEXICO
}

BY

A. J. VAN ROSSEM

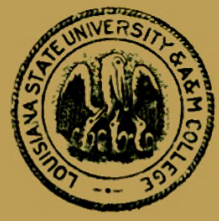

BATON ROUGE

LOUISIANA STATE UNIVERSITY PRESS

OCTOBER 25, 1945 
OCCASIONAL PAPERS

MUSEUM OF ZOOLOGY, LOUISIANA STATE UNIVERSITY

NUMBER 21

\section{A DISTRIBUTIONAL SURVEY OF THE \\ BIRDS OF SONORA, MEXICO}

BY

A. J. VAN ROSSEM

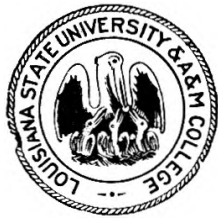

BATON ROUGE

LOUISIANA STATE UNIVERSITY PRESS

OCTOBER 25, 1945 


\section{EDITORIAL COMMITTEE}

Thomas D. Burleigh; James Henry Bruns; William H. Gates; Walter P. Taylor; Josselyn Van Tyne; Alexander Wetmore;

George H. Lowery, Jr., Chairman and Editor 


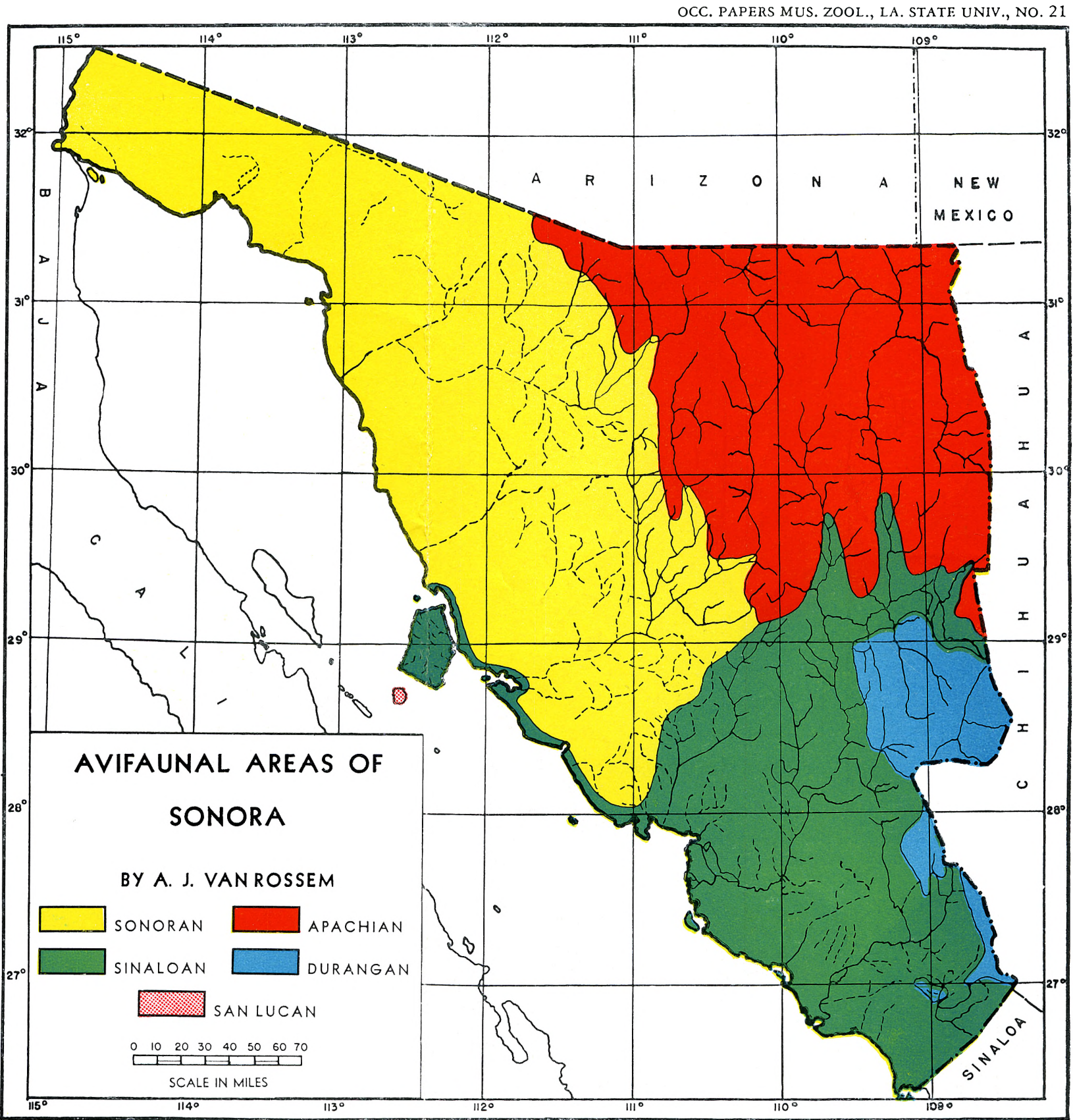

MAP 1. 


\section{FOREWORD}

As INITIALLY PROJECTED, this report would have been considerably larger. Fuller discussion of the systematics of many species would have been desirable and the inclusion of life-history observations and allied subjects would have added considerably to its usefulness. In normal times this would have been possible, for investigation to fill in the not inconsiderable gaps was definitely on schedule for 1942 and 1943. During the enforced postponement of such plans the outlook has been altered somewhat and activity for the post war years has been greatly enlarged in prospect. Indeed, preliminary field work and systematic studies on the larger project have already been initiated and a major part of the bibliography (additional to that incorporated here) has been compiled.

Publication of a distributional paper on the birds of Sonora is justifiable on several grounds, the principal one of which (from a personal standpoint) is the hope of stimulating interest and activity in Mexican ornithology, particularly in regions adjacent to our southern boundary and most particularly in the area of the Gulf of California. This last is a great region of extremely high speciation potency, a natural laboratory the importance of which from a general biological viewpoint is not yet fully comprehended. In it there are innumerable fields for investigation, limited or extensive according to will and ability. Even the ornithology of the peninsula of Baja California, so intensively, and as it seemed at the time so exhaustively, treated by Grinnell in 1928, is in need of review. I refer not alone to the purely systematic aspect, but also to the more comprehensive question of the origin of the avifauna. This has been presumed, justifiably on the then existing evidence, to be almost wholly of northern derivation. But now I, at least, am not sure but that in many instances a cross-Gulf relationship does not provide the better answer. In a few instances this can be well demonstrated, in others it is strongly indicated, and in still others suspected. Many more data must be in hand, though, before reasonably certain conclusions can be advanced for consideration. Similarly, some current conceptions of relationships of parts of the Sonora avifauna doubtless will undergo revision as time and further exploration in the Gulf area dictate. Meanwhile, it is to be hoped that the present distributional synopsis will, by its very incompleteness, provide a stimulus for new work. 
On questions of taxonomy, the identification of doubtful specimens, verification of references, and other matters of a technical nature, I gratefully acknowledge help from John W. Aldrich, Pierce Brodkorb, Herbert Deignan, Herbert Friedmann, Alden H. Miller, H. C. Oberholser, James L. Peters, Alexander Wetmore, and John T. Zimmer. For use of their private collections, or contributions of field notes and other data, thanks are due to Clinton G. Abbott, Seth B. Benson, Louis B. Bishop, Boardman Conover, the late W. Leon Dawson, Laurence M. Huey, Frederick C. Lincoln, Loye H. Miller, Max M. Peet, Allan R. Phillips, W. J. Sheffler, and George Willett. But most especially I wish to thank George $\mathrm{H}$. Lowery, Jr., for his efforts and friendly interest at all stages of seeing this paper through the Louisiana State University Press.

\section{A. J. van Rossem}

University of California, L.os Angeles

March 22, 1945 


\section{CONTENTS}

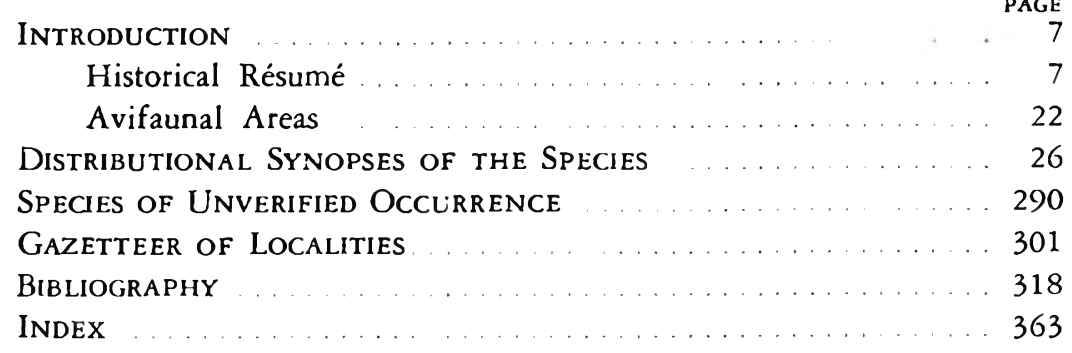

\section{ILLUSTRATIONS}

MAP

Frontispiece

1. Avifaunal areas of Sonora

2. Distribution of Butorides virescens

3. Distribution of Lophortyx gambelii

4. Distribution of Lophortyx douglasii

5. Distribution of the genus Otus
6. Distribution of Phalaenoptilus nutlallii $\ldots \ldots \ldots$

7. Distribution of the genus Amazilia

8. Distribution of Colaptes chrysoides

9. Distribution of Centurus uropygialis

10. Distribution of Dendrocopos scalaris

11. Distribution of two species of the genus Myiarchus ...... 153

12. Distribution of the genera Aphelocoma and Cyanocitta...... 174

13. Distribution of Auriparus flariceps ................ 177

14. Distribution of Psaltriparus minimus _.......... . . 179

15. Distribution of the genus Campylorbynchus ............ 185

16. Distribution of the genera Thryothorus and Thryomanes .. 188

17. Distribution of Toxostoma curvirostre _........... 193

18. Distribution of Polioptila caerulea ................. 205

19. Distribution of Polioptila nigriceps and Polioptila melanura . . 207

20. Distribution of Geothlypis trichas ................ . 228

21. Distribution of Icterus cucullatus ................ . 241

22. Distribution of Richmondena cardinalis ............. . . 250

23. Distribution of Carpodacus mexicanus ................ 259

24. Distribution of two species of Pipilo ................ 264

25. Distribution of Passerculus sandwichensis and two species of Aimophila ........................... 269 269

26. Distribution of Amphispiza bilinea:a . . . . . . . . . . . 279 


\title{
A DISTRIBUTIONAL SURVEY OF THE BIRDS SONORA, MEXICO*
}

\author{
INTRODUCTION
}

\section{Historical Résumé}

ChronologiCalLy, the history of Sonora ornithology began approximately with that of Baja California. In brief comparison, P. E. Botta, on the "Heros," was the first naturalist of record to visit Baja California where, in the Cape region, he observed a number of birds in October and November, 1826. His vessel arrived at the Cape directly from Mazatlan and never, so far as can be ascertained, put in at Guaymas or any other port in Sonora. The first bird known to have been collected in Baja California was a hummingbird taken at Magdalena Bay by Dr. Neboux of the "Venus" in 1837, which Bourcier two years later named Ornismya Costae.

Just when the first bird to reach taxonomic hands was taken in Sonora seems to be indeterminable. However, in 1835, Lafresnaye described a Cactus Wren, Picolaptes brunneicapillus, which he obtained from a dealer who, in turn, had acquired it from a ship's captain whose vessel had visited "California and Peru." The characters of the specimen (now in the Museum of Comparative Zoölogy) would seem beyond question to fix the place of capture as southern Sonora or northern Sinaloa, but whether this was Guaymas or Agiabampo in Sonora, or Topolobampo in Sinaloa, all early ports of call within the range of the subspecies, cannot be ascertained. The first-named has been assumed to be the most likely and the type locality so fixed. To the identity of the person who collected the specimen there is no clue whatever. In this connection I am most grateful to Mr. Henry Dwyer, United States Consul at Guaymas, for his efforts to locate the (seemingly now non-existent) port records of Guaymas previous to 1835 , on the possibility that the name of some foreign vessel might provide a lead.

John Woodhouse Audubon mentioned a number of birds (informally) in his narrative account of the journey across the State from the Sierra Madre to Altar and Sonoyta in August and September, 1849. Any specimens he may have collected were later "lost or destroyed," so that the first

* Contribution from the Department of Zoology, University of California, Los Angeles. 
birds known to have been collected in Sonora are an Eared Grebe and a Ring-billed Gull (now in the British Museum), taken by, or for, Captain Sir Henry Kellett and Gervase Mathew, R. N., respectively, when H.M.S. "Herald" was at Guaymas in late December, 1849. Dr. A. L. Heermann visited Guaymas briefly in April, 1851, at which time he noted a few species (at least one incorrectly), but apparently collected no specimens. Dr. C. B. Kennerly, attached to Major Emory's boundary survey party, collected casual specimens in "June," 1855, at Nogales ("Los Nogales") and Guadalupe Cañon, among them, at the former place, the type of Peucaea aestivalis, var. arizonae, the first bird to be described with a type locality specifically in Sonora. A. J. Grayson is also known to have visited southern Sonora, probably some time in the sixties, and the few observations he made at that time were later recorded by Lawrence. The next visit of records which was productive of specimens, was that of Dr. Thomas Streets in April, 1875, on the surveying steamer "Narragansett," but only some four or five birds seem to have been collected within Sonora limits. Lyman Belding was at Guaymas in December, 1882 and April, 1883, and later published a nominal list of 46 species of birds seen or collected there. Although this list contained little of importance it was the first for any Sonora locality. Dr. Edward Palmer, engaged almost entirely with botanical collecting, was at several points from Guaymas northward along the coast to the Colorado delta in the seventies, eighties, and early nineties but the very few bird skins he prepared are of little interest except for the discovery of the Large-billed Sparrow on what later proved to be its breeding grounds at the mouth of the Colorado River. Thus in the fifty years following the visit of the unknown collector of the type of the Cactus Wren practically all that was known concerning the ornithology of Sonora centered at Guaymas and one or two places along the northern boundary, and consisted of an occasional specimen or casual observations by ships' officers or transient naturalists.

In August, 1884, Frank Stephens, the pioneer naturalist and collector of southwestern birds and mammals, crossed the desert from Sásabe on the Arizona boundary to Puerto Lobos on the Gulf. The number of birds found was not great, only some twenty-five species, but among them was the then almost mythical Masked Bob-white, the type of which he collected about 18 miles southwest of Sásabe. It may be said that this individual bird was the "spark plug" which set off intensive collecting in Sonora, a phase of activity motivated in large part by search for the Masked Bobwhite. This is just as true, perhaps more so, today as it was when Brewster 
sent Cahoon into northeastern Sonora in 1887. Similarly, though in lesser degree, it might be said that the Eared Trogon and Imperial Ivory-bill led to the opening up of the southern part of the State; for it was on his way to the mountains of Chihuahua in search of those rarities that Frazar, in 1888, made his historic collections at Alamos, Mina Abundancia, and Hacienda de San Rafael. Primarily on the same mission, William Lloyd, in the interests of Salvin and Godman, traveled through the southeast in the same year. N. S. Goss, in 1888 also, visited San Pedro Mártir Island in the Gulf and attracted widespread interest to those waters by his discovery of two supposed new species of boobies there. The exploration of the high mountains in the northeast by the Lumholtz party in the fall and winter of 1890 provided the first indication of the avifauna of that area, although the specimens taken were disappointingly few in number.

Dr. Edgar A. Mearns, medical officer and naturalist attached to the International Boundary Commission, introduced the study of avian distribution into the local field; and this in spite of the fact that his great mammal collection formed the chief basis for the delineations of his several "faunal areas." Large collections of birds made along the whole of the northern boundary in the years 1892,1893, and 1894, undoubtedly influenced, equally with the mammals, his concepts of the problems involved. Unfortunately he did not live to finish his final report on the mammals and his bird papers are short and few in number, but the specimens collected have been of inestimable value to later workers. Unfortunately, too, by no means all of the material reached the United States National Museum, for his field books contain many entries of specimens which are not now in that institution nor were ever catalogued there. A study of his field books and the (now) fragmentary notes which accompany them provide a refreshing contrast in discrimination when compared to the activities of some of the collectors who preceded, and also followed, him. Subsequent to 1894 , there has been intermittent activity by numerous collectors and observers among whom may be mentioned E. A. Goldman (1898-1899), W. W. Brown, Jr. (1905), A. J. van Rossem (1925-1937), J. T. Wright (1929-1933), L. M. Huey, (1934-1939), and Seth Benson (1935-1942). The relative amount of field work done by every person of whom I can find record is given in the following list. The number of type specimens of Sonora birds collected by a person is indicated in parentheses. 
Abbott, Clinton $G$. Observations on sea birds in the vicinity of Guaymas in April, 1940.

Anonymous. (1). The collector of Lafresnaye's type of the Cactus Wren (see antea).

Anthony, Alfred $W$. Coastal and insular observations in December, 1930.

Ashcraft, Grenville. Naturalist on the Hancock yacht "Valero III." A few specimens were collected at San Estéban Island and other Gulf points in January, 1940.

Audubon, John Woodhouse. In charge of a party during the gold rush, Audubon crossed the Sierra Madre and traversed Sonora by way of Trinidad, Santa Rosa, Soyopa, Ures, Altar, and Sonoyta in August and September, 1849. However, preoccupation with the difficulties of travel was his main concern and his journal contains disappointingly little in relation to birds observed.

Bailey, Bernard. A few birds collected in November, 1932, between Nogales and the vicinity of Hermosillo are now in the Museum of Comparative Zoölogy and Fish and Wildlife Service collections.

Bancroft, Griffing. Egg collecting activities at various insular and mainland points from April, 1925, to July, 1930. Several hundred skins collected by his assistant, J. Elton Green, are now widely scattered in museum and private collections.

Belding, Lyman. While en route to and from Baja California in December, 1882, and April, 1883, observed at Guaymas 46 species, a few of which were collected. These are now chiefly or entirely in the United States National Museum.

Benson, Lieutenant H.C. (1). Collected a few specimens in the vicinity of Cumpas in February, 1887, including the type series of the Benson Quail. Brewster's collector, J. C. Cahoon, apparently accompanied this military party on his first short trip into Sonora.

Benson, Seth B. Collected, more or less incidentally to mammals, some 200-300 birds at several localities south to Guirocoba between 1935 and 1942. Of chief interest are the collections from Tiburón Island and the Sierra Seri. The specimens are now in the Museum of Vertebrate Zoology.

Brown, Herbert. Observed turkeys and Masked Bob-whites somewhere in north central Sonora but localities and dates not specified,--probably in the seventies.

Brown, Wilmot W., Jr. (3). Collected during most of 1905 in the central and southern parts of the range of the Masked Bob-white. His most interesting collection was made in the Sierra de San Antonio. The several hundred birds taken are now mostly in the Museum of Comparative Zoölogy. 
Bruner, Stephen S. Minor observations at Tubutama in May, 1925.

Cahoon, Jobn C. (7). Made extremely important collections for William Brewster in 1887. His first trip, January 31 to February 8, south as far as Cumpas, was evidently made in company with Lieutenant Benson; the second, from March 11 to June 18 was to "Oposura" (Moctezuma) and the "Mountains near Oposura" (Sierra de Oposura), with one short visit to Granados early in May. The specimens collected are now chiefly in the Museum of Comparative Zoölogy, although a small proportion have bcen scattered by exchange.

Campbell, Berry. Perhaps 50 specimens, now in the Max M. Peet and University of Michigan Museum of Zoology collections, were taken at Pilares and El Tigre Mine in July, 1935.

Canterbury, Robert. Assistant to W. Leon Dawson at Guaymas and Magdalena in the spring of 1925. The few birds taken are in the Dickey collection.

Clark, Josiah. In the nineties made nesting notes on a few species near El Plomo.

Dawson, W. Leon. Collected eggs and made many notes at Magdalena and Guaymas in the spring of 1925. The few skins collected (by Canterbury) now in the Dickey collection.

Dickey, Donald $R$. A few ducks (skeletons) taken in the Colorado delta in December, 1925. Noted a few species on and about Tiburón Island in June, 1928.

Evermann, Barton $W$. Observed (with O. P. Jenkins) numerous species between Nogales and Guaymas in July, 1887.

Ferrari-Perez, Fernando. (1). Presumably in charge of collecting for the Geographical and Exploring Commission of the Republic of México which, from September to December, 1887, worked at Hermosillo and Moctezuma. A number of the skins taken are in the British museum; the whereabouts of the rest are (to me) unknown.

Field, Clyde. Assistant to Griffing Bancroft in 1925.

Frazar, M. Abbott. (21). Working in the interests of William Brewster, Frazar collected at Guaymas from January 13 to 21, 1887, while awaiting a boat to Baja California. Specimens collected on these dates are not wrongly dated as stated by Griscom (1933). On his return from Baja California in 1888, he collected at Guaymas from January 17 to 27, at Alamos (Hacienda Mercedes) from February 2 to March 30, at Mina Abundancia from April 7 to 30, and at Hacienda de San Rafael from May 1 to 22. Almost all of the great collections made are in the Museum of Comparative Zoölogy. An uncertain number of specimens (probably very few) are not listed in the Brewster catalogue (van Rossem, 1934d) but 
were sent to the British Museum, and perhaps other places, before the entries were made. Except for the much later collections by J. T. Wright, Frazar's collections are by far the most valuable ever to come out of Sonora. Unfortunately, their usefulness is now greatly impaired by excessive postmortem color change induced, presumably, by the preservative used in their preparation.

Gallegos, José. Prior to his death a few years ago, Gallegos was a collector and observer for the Departmento de Forestal y de Caza y Pesca, with headquarters in the City of México. The only evidence of activity in Sonora is a Least Cliff Swallow taken at Hermosillo, June 19, 1922, and now in the University of Michigan Museum of Zoology.

Goldman, Edward A. (11). Made general and well-selected, though not extensive, collections in the southeast (mostly at Álamos and Camoa) in October, November, and December, 1898, and January, 1899. Specimens collected are in the Fish and Wildlife Service (Biological Survey) collection.

Goldman, Luther I. Collected for the Bureau of Biological Survey in the delta of the Colorado in May, 1915. His most important discovery there was the long-sought breeding ground of the Large-billed Sparrow.

Gorsuch, David $M$. Extensive and careful ecological studies of Masked Bob-white and other quail south as far as Tecoripa in October, 1931.

Goss, Nathaniel S. (2). Visited San Pedro Mártir Island in March, 1888. Observed and collected a few species including the types of Sula gossi and Sula brewsteri. Locations of specimens unknown to me.

Grayson, Andrew J. Casual observations (as recorded by Lawrence, 1874 ) in southern Sonora, presumably in the sixties or early seventies.

Green, I. Elton. As assistant to Griffing Bancroft, collected about 500 birds, mostly from coastal localities, in 1928, 1929, and 1930.

Hannum, Robert. (15 [van Rossem and Hannum]). Assistant to van Rossem in May and June, 1937.

Heermann, Adolpbus L. Visited Guaymas in April, 1851, when he noted the Cactus Wren, House Finch, and "Purple-throated Hummingbird" nesting commonly in the cactus desert near the town.

Holzner, Frank X. Assistant to Edgar A. Mearns, 1892 to 1894.

Huey, Laurence $M$. Coastal observations at Punta Peñascosa in February, 1934, and south to Puerto Libertad and Kino Bay in January and February, 1935. Boundary work in the northwestern desert from the vicinity of Quitovaquito eastward in the spring and winter of 1939. Specimens taken are in the Huey and San Diego Natural History Museum collections.

Jenkins, O. P. Observations (with B. W. Evermann) of birds seen between Nogales and Guaymas in July, 1887. 
Kellett, Captain Sir Henry. In command of H.M.S. "Herald" at Guaymas from December 25, 1849, to February 1, 1850. During this time the only birds collected were apparently an Eared Grebe and a Ring-billed Gull. These, the first birds known certainly to have been obtained in Sonora, are in the British Museum.

Kennerly, Caleb B. R. (1). Dr. Kennerly, medical officer and naturalist attached to various early western surveys, collected a few birds at Nogales ("Los Nogales") and Guadalupe Cañon in June, 1855. Among these was the type of Peucaea aestivalis, var. arizonae. All specimens are, or were, in the United States National Museum.

Kenyon, Karl $W$. Observation of Pigeon Hawks near Nogales in February, 1942.

Lamb, Chester C. From December, 1932, to April, 1933, collected about 200 birds at El Álamo, Hermosillo, Rancho Costa Rica, San José de Guaymas, Ures, and Agiabampo. All except those from Agiabampo (Moore collection) are in the Dickey collection.

Lloyd, William. (1). Traveled from the high mountains in the eastcentral part of the State, southward down the Rio Cedros to the Sierra de Alamos and thence into Sinaloa in April and May, 1888. His specimens went to Salvin and Godman and are now in the British Museum. Some are listed in the "Biologia Centrali-Americana" but without dates. From specimens examined at the British Museum his itinerary appears to be as follows. Since many of his specimens were migrants the dates are of some importance.

April 2 Tutuaca (in Chihuahua) "9500 feet."

April 4 Yepachic (now in Chihuahua).

April 11-16 Yecaera [= Yécora] "8500 ft."

April 17 Trinidad. "6000 ft."

April 18 Santa Ana.

April 19 Guadalupe and Realito.

April 20-23 Nuri.

April 25 (?) Santa Rosa.

April 26 Cedros.

April 27 La Cobriza.

April 28-30 Quiriego.

May 4 and 5 Río Mayo (near junction of Cedros and Mayo Rivers).

May 5-9. Agua Caliente.

May 10-14 Álamos.

May 15-19 Ysleta $\lceil=$ Isleta $]$.

May 23-25 Sierra de Álamos.

Loring, J. Alden. A few birds, incidental to mammal work, taken at Ortiz in May, 1892. Biological Survey collection.

Lumboltz, Carl. Chief of an archaeological expedition through the mountains of the northeast from September 9, 1890 to January 1, 1891. 
He observed the Imperial Ivory-bill east of Nácori but all specimens were collected by Robinette (q.v.).

Mathew, Gervase. Presumably a ship's officer on the "Herald"; at any rate he collected a Ring-billed Gull at Guaymas in December, 1849, when that vessel was at anchor there.

Mearns, Edgar A. Medical officer and naturalist with the International Boundary Commission. For comment on his historic collections made along the northern boundary see introductory remarks.

Moore, Robert T. (2). Collected about Guirocoba and the mountains to the eastward in May, 1933, and May, 1934. Presumably all specimens are in his collection, although only a few have been recorded and none (except a few specifically mentioned) have been examined in the preparation of this report.

Osburn, Pingree I. (1). Assistant on the "Albatross" expedition to the Gulf in March and April 1911. Collected on several islands including San Estéban and Tiburón. His specimens are in the American Museum of Natural History.

Owen, Vergil. Assistant on the California Academy of Sciences expedition to the Gulf in April, May and June, 1921. The eggs and the four or five skins collected are in the Academy collection.

Palmer, Edward. This famous botanist was at several mainland and insular points in Sonora at various times in the seventies, eighties, and nineties but the very few birds he collected scarcely warrant the time necessary to work out his exact dates. However, he was at Guaymas several times, at San Pedro Mártir Island in 1887, and in the Colorado delta at Colonia Lerdo in 1889. His specimens are in the United States National Museum.

Pbillips, Allan C. Observation trip from Sásabe to Puerto Libertad in February, 1932.

Price, William $W$. Observed many species in the delta of the Colorado in November and December, 1898. The whereabouts of the specimens taken (if any) is unknown.

Renardo, Juan. Minor observations at Guaymas some time prior to 1886.

Rhoads, Samuel N. Collected 258 specimens and noted numerous additional species (some of the latter highly questionable) in the Colorado delta in February, 1905. The specimens are presumably in the Academy of Natural Sciences of Philadelphia.

Robinette, F. Zoological collector for the Lumholtz expedition which was in Sonora territory from September 9, 1890, to January 1, 1891. Of the roughly 1000 birds collected, perhaps half were taken in Sonora. Unfortunately, all were poorly prepared, many are carelessly labeled, and 
a few are not labeled at all. The greater part, perhaps all, are now in the American Museum of Natural History.

Rowley, John. Collected perhaps 25 skins in April and May, 1903, at Cerro Blanco and the Providencia Mines in the central part of the State. They are now in the Chicago Natural History Museum.

Rowley, J. Stuart. A few specimens taken at Punta Peñascosa, January $21-23,1930$, are now in his collection.

Schofield, John. About 25 specimens taken at Hermosillo and Guaymas in June and July, 1932, are in the Max M. Peet and University of Michigan Museum of Zoology collections.

Sheffler, William J. Has collected perhaps 200 skins at Punta Peñascosa, El Alamo, and Magdalena, south to Guirocoba and Alamos from 1930 to 1944 . They are in his collection.

Sheldon, Charles. Collected the Sahuaro Screech Owl in the Sierra Seri, January 1, 1922.

Sibley, Charles G. Co-collector with Seth Benson.

Slevin, Joseph $R$. Made notes on many species of birds during the California Academy of Sciences expedition to the Gulf in April, May, and June, 1921 (see Mailliard, 1923).

Smith, [initials unknown]. Made a small collection of birds somewhere in the mountains of northeastern Sonora (exact locality unknown) in April, 1909. The specimens are in the Museum of Comparative Zoölogy.

Stephens, Frank. (1). Collected or noted 25 species of birds between Sásabe and Puerto Lobos in August, 1884. Most of the specimens are in the San Diego Natural History Museum. At least one, the type of Colinus ridgwayi, is in the British Museum.

Streets, Thomas. Medical officer and naturalist on the "Narragansett." Visited Tiburón Island, the mouth of the Río San Ignacio, and the mouth of the Colorado in April, 1875. The four or five bird skins taken are in the United States National Museum.

Townsend, Charles H. (1). Naturalist on the "Albatross." In March, 1899 , collected in Gulf waters, on George Island, and at one or two Sonora mainland points. Among the few birds taken (now in the United States National Museum) is the type of Otocoris alpestris pallida. In March and April, 1911, visited San Pedro Mártir, San Estéban and Tiburón Islands, at which time the type of Pipilo fuscus jamesi was taken (by Osburn). Specimens from this latter expedition seem to be wholly or at least in large part in the American Museum of Natural History.

van Rossem, A. J. (33 [15 with Hannum]). Gulf islands south to San Pedro Mártir in April, 1925. San Estéban and San Pedro Nolasco Islands 
and mainland coast from Guaymas south to Tóbari Bay in April, May, and June, 1930. Coast and islands from Guaymas north to Tepopa Bay and Tiburón Island in December, 1931, and January, 1932. Colorado River delta and the Pajaritos Mountains south to Agiabampo and east in the extreme south to the Chihuahua and Sinaloa boundaries in May and June, 1937. The several hundred specimens collected, except for a few dispersed through exchange, are in the Dickey collection.

Vorbies, Charles $T$. Short reconnaisance trips in the early thirties south as far as Hermosillo and Puerto Libertad.

Wakefield, E. S. Collected a specimen of the Green-backed Goldfinch (in the National Museum) at Arispe some time before 1874.

Woods, Ralph A. Co-collector with W. J. Sheffler.

$W$ right, John T. (24). From early January, 1929, to the summer of 1933, collected in the Colorado River delta and in the central and southeastern parts of the State south to the Guirocoba region. His collections totaling, probably, between 3000-4000 skins are widely dispersed. Most of them taken up to the fall of 1931 are in the Dickey collection; those taken subsequent to that time were disposed of to the Bishop, Conover, Moore, and Peet collections, the San Diego Natural History Museum, the Chicago Natural History Museum, and probably to various other destinations which I have not been able to determine. On the whole, the material undoubtedly outweighs in importance that collected by Frazar in 1888.

To date there have been 111 species and subspecies of birds described from within the limits of Sonora. This is truly a surprising number when it is remembered that the avian make-up of the State is largely a conglomerate of elements common to extra-territorial areas which have received a good deal of attention at the hands of systematists. Of these 111 forms, one is believed to be a hybrid, and 10 are considered to be synonyms because they are not distinguishable from other species or races. These forms have been originally described by 19 persons, as follows. The type localities and the collectors of the type specimens are included.

Sula gossi "Ridgway MS" Goss [=Sula nebouxii Milne-Edwards]. San Pedro Mártir Island by Goss.

Sula brewsteri Goss [=Sula leucogaster brewsteri Goss] San Pedro Mártir Island by Goss.

Phalacrocorax olivaceus chancho van Rossem and Hachisuka. Tesia by van Rossem and Hannum.

Heterocnus cabanist [sic] fremitus van Rossem and Hachisuka [ = Heterocnus mexicanus fremitus van Rossem and Hachisuka]. Guirocoba by van Rossem and Hannum. 
Ixobrychus exilis pullus van Rossem. Tóbari Bay by van Rossem.

Buteo rufescentior Salvin and Godman $[=$ Buteo jamaicensis calurus Cassin]. Hermosillo cotype by Ferrari-Perez.

Asturina plagiata maxima van Rossem $[=B$ Buteo nitidus maximus (van Rossem) ]. San Javier by Wright.

Geranospiza caerulescens livens Bangs and Penard [= Geranospiza nigra livens Bangs and Penard]. Álamos by Frazar.

Polyborus cheriway ammophilus van Rossem. Tesia by Wright.

Falco albigularis petrophilus van Rossem and Hachisuka. Guirocoba by van Rossem and Hannum.

Ortalis wagleri griseiceps van Rossem. Alamos by Frazar.

Callipepla gambeli fulvipectus Nelson [=Lophortyx gambelii fulvipectus (Nelson) ]. Camoa by E. A. Goldman.

Lophortyx gambelii pembertoni van Rossem. Tiburón Island by van Rossem.

Callipepla elegans bensoni Ridgway [=Lophortyx douglasii bensoni (Ridgway) ]. 18 miles N. of Cumpas by H. C. Benson.

Colinus ridgwayi Brewster [=Colinus virginianus ridgwayi Brewster $]$. 18 miles S.W. of Sásabe by Stephens.

Cyrtonyx montezumae morio van Rossem. Guirocoba by van Rossem.

Rallus obsoletus rhizophorae Dickey $[=$ Rallus elegans rbizophorae Dickey]. Tóbari Bay by van Rossem.

Sterna albifrons mexicanus van Rossem and Hachisuka $[=$ Sterna albifrons mexicana van Rossem and Hachisuka]. Tóbari Bay by van Rossem.

Columba flavirostris restricta van Rossem. Tecoripa by Wright.

Leptotila verreauxi santiago van Rossem and Hachisuka. Guirocoba by van Rossem and Hannum.

Ara militaris sheffleri van Rossem and Hachisuka. Guirocoba by van Rossem and Hannum.

Aratinga bolochlora brewsteri Nelson. Hacienda de San Rafael by Frazar.

Psittacula cyanopyga pallida Brewster $[=$ Forpus cyanopygius pallidus (Brewster) ]. Alamos by Frazar.

Amazona albifrons saltuensis Nelson. Camoa by E. A. Goldman.

Amazona finschi woodi Moore. Guirocoba by Wright.

Piaya cayana extima van Rossem. Guirocoba by Wright. 
Geococcyx velox melanchima Moore. Guirocoba by Wright.

Glaucidium brasilianum cactorum van Rossem. Between Guaymas and Empalme by van Rossem.

Cyanomyia salvini Brewster $[=$ Hybrid. Cynanthus latirostris magica $X$ Amazilia violiceps conjuncta]. Nacozari by Cahoon.

Amazilia violiceps conjuncta Griscom. Álamos by Frazar.

Amazilia florenceae van Rossem and Hachisuka. Rancho Santa Bárbara by van Rossem and Hannum.

Anthoscenus constantii surdus van Rossem $[=$ Heliomaster constantii surdus (van Rossem)]. Álamos by Frazar.

Trogon elegans canescens van Rossem. San Javier by Wright.

Chloroceryle americana leucosticta van Rossem and Hachisuka $[=$ Chlorocerjle americana hachisukai Laubmann (new name)]. Rancho La Arizona by van Rossem and Hannum.

Momotus mexicanus vanrossemi Moore. Chinobampo by Wright.

Colaptes chrysoides tenebrosus van Rossem. Ciudad Obregón by Wright. Centurus uropygialis fuscescens van Rossem. Chinobampo by Wright.

Centurus uropygialis tiburonensis van Rossem. Tiburón Island by van Rossem.

Piculus auricularis sonoriensis van Rossem and Hachisuka. Rancho Santa Bárbara by van Rossem and Hannum.

Ceophloeus lineatus obsoletus van Rossem [ $=$ Hylatomus lineatus obsoletus (van Rossem) ]. Álamos by Frazar.

Phloeoceastes guatemalensis dorsofasciatus Moore. Guirocoba by Wright.

Dryobates scalaris agnus Oberholser $[=$ Dendrocopos scalaris sinaloensis (Ridgway) ]. Camoa by E. A. Goldman.

Xiphorhynchus flavigaster tardus Bangs and Peters. Hacienda de San Rafael by Frazar.

Lepidocolaptes leucogaster umbrosus Moore. Between San José and Guirocoba by Moore.

Tityra semifasciata hannumi van Rossem and Hachisuka. San Francisco Cañon by van Rossem and Hannum.

Platypsaris aglaiae richmondi van Rossem. Rancho La Arizona by Wright. Tyrannus crassirostris sequestratus van Rossem. Rancho La Arizona by Wright. 
Tyrannus crassirostris pompalis Bangs and Peters. Alamos by Frazar. Myiozetetes similis primulus van Rossem. Tesia by Wright.

Pitangus sulfuratus [sic] palliatus van Rossem [=Pitangus sulphuratus palliatus van Rossem]. Álamos by Frazar.

Mitrephanes phaeocercus tenuirostris Brewster. "Mountains near Oposura" by Cahoon.

Otocoris alpestris pallida Dwight $[=$ Chionophilos alpestris dwighti Stresemann (new name); =Eremophila alpestris leucansiptila (Oberholser) ]. Direction Hill by Townsend.

Petrochelidon albifrons minima van Rossem and Hachisuka. "Pichicuate" [error, = Cuchujaqui] River, $7 \mathrm{mi}$. E. of Álamos by van Rossem and Hannum.

Stelgidopteryx rufucollis psammochrous Griscom. Oposura by Cahoon.

Iridoprocne albilinea rhizophorae van Rossem. Tóbari Bay by van Rossem.

Calocitta colliei arguta van Rossem. Chinobampo by Wright.

Auriparus flaviceps fraterculus van Rossem. Chinobampo by Wright.

Psaltriparus plumbeus cecaumenorum Thayer and Bangs $[=P$ saltriparus minimus cecaumenorum Thayer and Bangs]. La Chumata Mine by Brown.

Psaltriparus minimus dimorphicus van Rossem and Hachisuka. Rancho Santa Bárbara by van Rossem and Hannum.

Picolaptes brunneicapillus Lafresnaye $[=$ Campylorbynchus brunneicapillus brunneicapillus (Lafresnaye)]. Guaymas; collector unknown.

Heleodytes brunneicapillus seri van Rossem $[=$ Campylorbynchus brunneicapillus seri (van Rossem) ]. Tiburón Island by van Rossem.

Thryophilus sinaloa cinereus Brewster $[=$ Thryothorus sinaloa cinereus (Brewster) ]. Alamos by Frazar.

Pheugopedius felix sonorae van Rossem [ $=$ Thryothorus felix sonorae (van Rossem) ]. Guirocoba by Wright.

Troglodytes cabooni Brewster [=Troglodytes brunneicollis cabooni Brewster]. "Mountains near Oposura" by Cahoon.

Catherpes mexicanus meliphonus. Oberholser $[=$ Catherpes mexicanus mexicanus (Swainson)]. Alamos by Frazar.

Toxostoma bendirei candidum van Rossem. 10 miles N. of Guaymas by van Rossem.

Toxostoma bendirei rubricatum van Rossem. Tecoripa by Wright. 
Harporbynchus curvirostris maculatus Nelson $[=$ Toxostoma curvirostre maculatum (Nelson)]. Alamos by E. A. Goldman.

Toxostoma curvirostre insularum van Rossem. San Estéban Island by van Rossem.

Melanotis caerulescens effuticius Bangs and Penard. Hacienda de San Rafael by Frazar.

Turdus rufopalliatus grisior van Rossem $[=$ Turdus rufo-palliatus grisior van Rossem]. Guirocoba by Wright.

Turdus assimilis calliphthongus Moore. "Baromicon" [= Baromico $]$ by Moore.

Myadestes obscurus cinereus Nelson. "Mountains near Alamos" by E. A. Goldman.

Polioptila caerulea gracilis van Rossem and Hachisuka. Rancho Santa Bárbara by van Rossem and Hannum.

Polioptila nigriceps restricta Brewster. Álamos by Frazar.

Polioptila melanura lucida van Rossem. 10 miles N. of Guaymas by van Rossem.

Polioptila melanura curtata van Rossem. Tiburón Island by van Rossem.

Vireo bypochryseus nitidus van Rossem. Hacienda de San Rafael by Frazar.

Vireo virescens bypoleucus van Rossem and Hachisuka [ =Vireo olivaceus bypoleucus van Rossem and Hachisuka]. San Francisco Cañon by van Rossem and Hannum.

Compsothylpis pulchra Brewster [= Parula pitiayumi pulchra (Brewster)]. Hacienda de San Rafael by Frazar.

Dendroica aestiva sonorana Brewster $[=$ Dendroica aestiva sonorana Brewster]. Oposura by Cahoon.

Dendroica erithachorides rhizophorae van Rossem. Tóbari Bay by van Rossem.

Geothlypis trichas chryseola van Rossem. Rancho La Arizona by Wright.

Geothlypis trichas riparia van Rossem. Tesia by van Rossem and Hannum.

Icteria virens tropicalis van Rossem. Tesia by van Rossem.

Euthlypis lachrymosa tephra Ridgway $\Gamma=$ Euthlypis lachrymosa (Bonaparte) ]. Hacienda de San Rafael by Frazar.

Basileuterus rufifrons caudatus Nelson. Alamos by E. A. Goldman. 
Scaphidurus major nelsoni Ridgway [ = Cassidix mexicanus nelsoni (Ridgway) ]. Alamos by E. A. Goldman.

Icterus wagleri castaneopectus Brewster. "Mountains near Oposura" by Cahoon.

Icterus cucullatus restrictus van Rossem. Agiabampo by van Rossem and Hannum.

Icterus pustulatus microstictus Griscom. Guaymas by Brown.

Tanagra elegantissima viscivora van Rossem $[=$ Tanagra elegantissima rileyi van Rossem (new name)]. San Francisco Cañon by van Rossem and Hannum.

Piranga flava zimmeri van Rossem. Chinobampo by Wright.

Piranga erythrocephala candida Griscom. Hacienda de San Rafael by Frazar.

Richmondena cardinalis tounsendi van Rossem. Tiburón Island by van Rossem.

Cardinalis cardinalis affinis Nelson $[=$ Richmondena cardinalis affinis (Nelson) ]. Alamos by E. A. Goldman.

Passerina versicolor dickeyae van Rossem. Chinobampo by Wright.

Carpodacus mexicanus sonoriensis Ridgway. Alamos by E. A. Goldman.

Pipilo fuscus jamesi Townsend. Tiburón Island by Osburn.

Pipilo fuscus intermedius Nelson. Álamos by E. A. Goldman.

Melozone rubricatum grisior van Rossem $[=$ Melozone kieneri grisior van Rossem]. Hacienda de San Rafael by Frazar.

Passerculus sandwichensis atratus van Rossem. Tóbari Bay by van Rossem.

Aimophila quinquestriata septentrionalis van Rossem. Hacienda de San Rafael by Frazar.

Aimophila carpalis bangsi Moore [-Aimophila carpalis (Coues)]. Guirocoba by Wright.

Aimophila cahooni Brewster [= Aimophila rufescens mcleodii Brewster $]$. "Mountains near Oposura" by Cahoon.

Peucaea megarbyncha Salvin and Godman $[=$ Aimophila rufescens mcleodii Brewster]. Santa Ana by Lloyd.

Aimophila rufescens antonensis van Rossem. La Chumata Mine by Brown. Aimophila ruficeps simulans van Rossem. Mina Abundancia by Frazar. Peucaea aestivalis, var. arizonae Ridgway $[=$ Aimophila botterii botterii Sclater) ]. "Los Nogales" by Kennerly.

Amphispiza bilineata pacifica Nelson. Alamos by E. A. Goldman.

Amphispiza bilineata cana van Rossem. San Estéban Island by van Rossem. 


\section{Avifaunal Areas}

KNOWLEDGE of the climatic zones and the biota of Sonora has increased greatly since Hinds, in 1843, included the State in his "Chihuahua Region" of vegetation. But not even Baird, Allen, and Merriam were fully aware of the abrupt variations in climate, flora, and fauna which approximate in complexity those of California more nearly than is the case in any other Mexican state. Pioneers in the recognition of the diversity of these features were Mearns in the north and Goldman in the south, but even as late as 1910, the "Fourth Provisional Zone Map of North America" as published in the third edition of the American Ornithologists' Union Check-list failed to recognize that the arid division of the Lower Tropical zone covers a large part of southern Sonora. That it does so is now realized by most botanists and by zoologists generally. The most recent attempts to divide Sonora into biotic or zoological faunal areas or "provinces" have been made by van Rossem (1931c; 1936d), Burt (1938), Dice and Blossom (1937), and Dice (1939). Among these individuals there is reasonably close agreement (save unfortunately in terminology) as concerns the larger divisions. As to details there is considerable disunity, some of which may be due to disproportionate degrees of activity but more, I suspect, to the understandable tendency to put special emphasis on a particular field and to dismiss or gloss over contradictory evidence provided elsewhere. For that matter there is never likely to be complete harmony as to the limits of faunal areas or districts when different media are employed in their delineation, except in cases of insular or other sharply limited territory. These, perhaps trite, remarks are to stress the fact that the map here given (Frontispiece) is based on the distribution of bird life as it is known to me at this time. In other words it is an ornithological map, the boundaries of which in some details coincide and in others do not with a mammalian or other map of the same region. I believe it safe to say, however, that the boundaries here given agree more closely with climatic zones and their characteristic vegetations than do the boundaries for mammals, if one may judge by Burt's account.

Five major avifaunal land areas or "provinces" contribute in varying degree to the ornithological make-up of the State. For these areas I employ, tentatively, the names used by Burt, Dice, and Blossom, not because of agreement either as to appropriateness or significance in all cases but in the interest of concordance so far as is possible at this elementary stage in studies of the biota of northwestern Mexico. 
The Sonoran is the southern continuation of the desert avifauna of southwestern Arizona, southeastern California, and northeastern Baja California and lies wholly within the Lower Sonoran zone. Differentiation centers or districts now apparent are the Yuma District which is more or less the equivalent of the Western Desert Tract of Mearns (1907) and the Colorado River District of Grinnell (1928), and the Tucson District which, northerly, is the western part of Mearns' "Elevated Central Tract." The former centers mainly in the delta of the Colorado but extends eastward in dilute form to about longitude $113^{\circ}$ and around the head of the Gulf at least to Puerto Lobos and probably to Puerto Libertad. The latter covers the remainder, and by far the larger portion, of the Sonoran area within the State. Topographically, the whole of the Sonoran is undulating desert, broken frequently and irregularly by low, barren mountains of no particular directional trend. Aside from the Río Colorado no streams or rivers reach the sea except as seepages or for short periods following flash floods.

The Sinaloan is the northern extension of the Arid Lower Tropical avifauna of Sinaloa. Although by no means all of the members characteristic of that area or "province" reach Sonora, a large proportion of them do so and in families, genera, species, and races, this southern area is abundantly distinct from the Sonoran. As in the case of the Sonoran there are two known differentiation centers. The Allamos District (in part of van Rossem, 1931c) comprises all of the lowlands south of the Sonoran and projects northward as a narrow strip along the coast to Sargent Point and as tongues up the interior river valleys nearly to latitude $30^{\circ}$. It is probable that exploration will reveal more extensive interdigitation with the Apachian than has been ascertained to date. The Tiburón District is limited to Tiburón Island. Although Sonoran aspects predominate in other fields, ornithologically it is more properly a division of the Sinaloan and is here so considered. Physiographically the Sinaloan is not unlike the Sonoran but the climate is more humid and the vegetation infinitely more varied and abundant. Because of the narrower width of the coastal plain and the greater drainage from the interior mountains two major rivers, the Mayo and Yaqui, reach the sea at most periods of the year. Mergence with the Durangan occurs at about 2000 feet and with the Apachian at somewhat lower altitudes.

The Apachian, in part the "Elevated Central Tract" of Mearns, is the southward continuation of the avifauna of southeastern Arizona and extreme southwestern New Mexico. or rather it more properly may be said 
the designated portions of those states are the northern extension of what is primarily a Mexican faunal area or "province." It occupies practically the whole of the northeastern fourth of the State, is of high average elevation, and for the most part is broken and mountainous. Toward the north along the International Boundary the terrain consists of broad, level plains which are interrupted by short mountain ranges of a general northsouth trend. Upper Sonoran and Transition are the dominant zones, although the Canadian is present at the higher elevations. Mergence with the Tucson District of the Sonoran is abrupt and well defined northerly but specific information is not available for more southerly portions. There is considerable doubt as to the advisability of recognizing the Apachian and Durangan as major divisions, at least so far as concerns ornithology. They appear to me, rather, as well-defined differentiation centers or districts of the Sierra Madre Occidental and such, I believe, will be their eventual evaluation.

The Durangan, which has been presumed to center in the State of Durango in the Sierra Madre Occidental, occupies the relatively limited mountainous area above 2000 feet in southeastern Sonora south of the low ground along the east-west course of the Río Yaqui. It differs from the Apachian chiefly in being more continuously mountainous and the drainage consists, in the main, of cañons rather than of plains or river valleys. The climatic and plant zones represented are Upper Sonoran and Transition with some Canadian undoubtedly present in the region about Yécora. Part of the Upper Sonoran, southerly, should perhaps be referred to the Arid Upper Tropical since it is normally frostless. Gentry (1942) considers the plant life in the Rio Mayo basin to be "Subtropical" between about 1500 and 3000 feet and "Upper Sonoran" between 3000 and 5000 feet. It seems evident that botanically this region is of mixed characteristics zonally and the avifauna follows the same pattern rather closely.

The SAN LuCan, a term coined by Dice for the southern three-fourths of Baja California, is used with extreme reservation. If employed here it does not imply acceptance of the proposal to recognize Baja California as a separate "Biotic Province" but to emphasize the character of the avifauna of San Estéban Island. This island which lies almost exactly in mid-Gulf is a political accident so far as the present report is concerned for only one bird, a thrasher, belongs to the Sonoran mainland avifauna. So $\mathrm{far}$ as is known at this time all the other indicative resident races (except for an Amphispiza) are those of Baja California or more particularly of the San Ignacio District (of Grinnell, 1928). 
Maritime Species. The preceeding summary of land areas takes no account of the maritime species, the affinities of which must necessarily be considered on an oceanic basis. Although the greater number are of general west-Mexican distribution or are winter visitants or transients from other regions, it is readily apparent that the Gulf of California is a highly developed area of speciation which possesses a considerable number of differentiates of generic, specific, and subspecific rank. Some of these extend north along the Pacific coast of Baja California for varying distances but the majority are confined during the breeding season to islands lying in the Gulf, the southern limit of which is commonly considered to be between Cape San Lucas, Baja California and Cape Corrientes, Jalisco. I do not think it desirable to suggest a distinctive name at this time or until further studies of the area, now in progress, are completed. 


\section{DISTRIBUTIONAL SYNOPSES OF THE SPECIES}

The following accounts of the distributions of the 532 species and subspecies of birds which are known at present to occur in Sonora are summarized from existing literature, previously unrecorded specimens in certain collections, unpublished notes, and field observations contributed by various persons. First instances of record and the amount of attention a species has subsequently attracted, in a local sense, is evident from the included bibliography.

In many cases there is a lamentable lack of information from critical areas as regards endemics. A considerable additional number of regular migrants and winter visitants undoubtedly will be detected as knowledge of the bird life of the State increases, and the number of "accidentals" may be expected to increase materially. These last, though, cannot alter the basic existing ornithological make-up of the State and are distinctly of secondary interest.

Many of the forms included in the present report are beyond the scope of the American Ornithologists' Union "Check-list." In consequence it it has been desirable to follow the International code of nomenclature rather than that of the American Ornithologists' Union, a procedure which is in conformance with the practice of many American ornithologists when dealing with areas south of the United States. As a result, several generic names are at variance with those found in the "Checklist," such as Bucephala for the Bufflehead, Oxyura for the Ruddy Duck, Micrathene for the Elf Owl, Hylatomus for the Pileated Woodpecker, Dendrocopos for the Hairy and certain other woodpeckers, Contopus for the Wood Pewees, Eremophila for the Horned Larks, Campylorbynchus for the Cactus Wrens, Parula for the Parula Warblers, and Chlorura for the Green-tailed Towhee. Under the same rules the family name of the Wood Warblers becomes Parulidae.

The sequence of Wetmore's "A Systematic Classification for the Birds of the World" is followed for the higher groups. Generic and specific arrangements are those of Peters' "Check-list of Birds of the World" or Hellmayr's "Catalogue of Birds of the Americas"; but since neither of these is complete it is not possible to follow one exclusively. Departures from the nomenclature of these two works will be noticed but they are rare and reflect in most cases personal opinion only. 


\title{
ORDER GAVIIFORMES LOONS
}

Family GaviIDAE Loons

\section{GAVIA STELLATA (Pontoppidan) \\ RED-THROATED LOON}

\begin{abstract}
Colymbus Stellatus Pontoppidan, Danske Atlas, 1, 1763, 621 (No locality= Denmark).

Gavia stellata van Rossem, 1932, 128 (Tiburon* Island; Sargents Point).

An apparently uncommon midwinter visitant in the Gulf. There are but two records, respectively from Tiburón Island and Sargent Point, January 1 and 2, 1932. Contributory data from the Baja California side of the Gulf further indicate that the species is not common in these waters.
\end{abstract}

\section{GAVIA ARCTICA PACIFICA (LAWRENCE)}

\section{PACIFIC LOON}

Colymbus pacificus Lawrence, in Baird's Rep. Expl. and Surv. R. R. Pac., 9, 1858, 887, 889 ("San Diego, Cal. and Puget's Sound"=San Diego, California). Gavia pacifica Townsend, 1923, 5 (Tiburon Island).

Gavia arctica pacifica van Rossem, 1932, 128 (Tiburon Island).-van Rossem and Hachisuka, 1937a, 323 (San Esteban Island).-Abbott, 1941, 417 (Guaymas).

Common winter visitant and abundant spring migrant in the Gulf. Records specifically from Sonora waters are confined to a rather limited area in the vicinity of Guaymas, and Tiburón and San Estéban Islands but data from the Baja California side indicate a much more general distribution. Extreme dates of record for Sonora are December 28 and April 2, at which latter time strong northward flights have been noted. Migration overland from the head of the Gulf to the Pacific coast would seem almost certain (Grinnell, 1928, p. 55) though at present there is but slight positive evidence of such passage.

\section{GAVIA IMMER (BRÜNNICH) \\ COMMON LOON}

Colymbus Immer Brünnich, Orn. Borealis, 1764, 38 (E. Faeroa=Faroe Islands). Gavia immer subsp ? van Rossem, 1932, 128 (Tiburon Island).

* Accents have been omitted from place names in the synonymies, except in primary citations (i.e., type localities). 
One midwinter record; rather common in the vicinity of Tiburón Island, December 28, 1931. While there is at least one other sight record for the Gulf area ( $\mathrm{La} \mathrm{Paz}$ ), no specimens have been collected and the subspecies present is a matter of doubt.

\section{ORder COLYMBIFORMES GREBES}

\section{Family Colymbidae Grebes}

\section{ColymbUS DOMINICUS baNGSI VAN ROSSEM AND HaCHISUKa \\ BANGS LEAST GREBE}

Colymbus dominicus bangsi van Rossem and Hachisuka, Trans. San Diego Soc. Nat. Hist., 8, No. 23, June 15, 1937, 323 (Santiago, Baja California, México) ; ibid., in text (Agiabampo).-Wetmore, 1943, 231, in text (Sonora; crit.).-A.O.U. Comm., 1944, 442 (Sonora).

Status uncertain. The only two Sonora records to date are those of a specimen in breeding plumage taken at Agiabampo on April 21, 1933, and another taken by Seth Benson (Mus. Vert. Zool.) at Camoa on April 22, 1939. A supplementary occurrence is at Quitovaquita, just on the Arizona side of the boundary, April 28, 1939 (Huey, 1942, 363; exam. in Nat. Hist. Mus.).

\section{COLYMBUS NIGRICOLLIS CALIFORNICUS (HEFRMANN)}

\section{American Eared Grebe}

Podiceps Californicus Heermann, Proc. Acad. Nat. Sci. Phila., 7, October, 1854 [=April 12, 1855], 179 (California=San Pedro, Los Angeles County).

Podiceps californicus Grant, 1898, 535 (Guaymas).-Salvin and Godman, 1904, 442 (Guaymas).

Podiceps auritus var. californicus Lawrence, 1874, 319 (Guaymas). mas).

Dytes nigricollis Californicus Baird, Brewer, and Ridgway, 1884, 434 (Guay-

Colymbus nigricollis californicus Bent, 1919, 27 (Guaymas).-van Rossem, 1932, 128 (coastal localities in winter).- - Huey, 1935, 250 (Punta Peñascosa).- van Rossem and Hachisuka, 1937 a, 324 (coastal localities in spring).

Common winter visitant and abundant spring migrant along the coast and about off-shore islands from Guaymas north (numerous localities) to Punta Peñascosa near the head of the Gulf. The absence of records from south of Guaymas may or may not be significant; however, on the Baja California side also (Grinnell, 1928, p. 54), the species is obviously more common northerly. Extreme seasonal dates are December 23 and April 25, the locality for both dates being Guaymas. 


\section{AECHMOPHORUS OCCIDENTALIS (LAWRENCE) \\ Western Grebe}

Podiceps occidentalis Lawrence, in Baird's Rep. Expl. and Surv. R. R. Pac., 9, 1858, 892, 894 (Washington Territory to California=Fort Steilacoom, Washington).

Aechmophorus occidentalis Price, 1899, 90 (mouth of the Colorado River).van Rossem and Hachisuka, 1937 a, 324 (Guaymas).

Probably a rather common winter visitant in the Colorado delta, southward, sporadically at least, to Guaymas. Contributory data from the Baja California portion of the delta are relatively numerous and there is some seasonal evidence of breeding there. The latest record specifically from Sonora is March 27 (Guaymas).

\section{PODILYMBUS PODICEPS PODICEPS (LINNAEUS) \\ Pied-BILI.ED GRebe}

Colymbus Podiceps Linnaeus, Syst. Nat., ed. 10, 1, 1758, 136 (in America septentrionali=South Carolina).

Podilymbus podiceps Thayer and Bangs, 1906, 18 (Opodepe).

Detected only as a spring migrant. The two known specimens were taken, respectively, by Brown at Opodepe in late April, 1905 (exact date not published), and by Mearns and Holzner at Monument 204 on the Colorado River on March 24, 1894 (U. S. Nat. Mus. catl.). There are winter records for the Colorado delta, though for the Baja California side.

\section{Order PROCELLARIIFORMES Tube-NOSEd Swimmers}

\section{Family Procellariddae Shearwaters, Fulmars, and Petrels Puffinus griseus (GMelin)}

\section{SOOTY SHEARWATER}

Procellaria grisea Gmelin, Syst. Nat., 1, Pt. 2, 1789, 564 (in hemisphaerio australi-inter $35^{\circ}$ et $50^{\circ}=$ New Zealand)

Puffinus griseus van Rossem and Hachisuka, 1937 a, 324 (near Tiburon Island).

Uncommon spring and summer visitant in the Gulf. Records for the general area extend from April to August; those definitely from Sonora waters are April 19 [not 25], 1925, and a single bird seen by Dickey (notes) on June 2, 1928, both in the vicinity of Tiburón Island. 


\section{Puffinus opisthomelas Coues}

\section{Black-vented Shearwater}

Puffinus opistbomelas Coues, Proc. Acad. Nat. Sci. Phila., 1864 [June 30], 139 (Cape San Lucas, Baja California, México).-van Rossem, 1933 b, 199 (San Pedro Nolasco Island to Kino Bay).

Apparently decidedly uncommon in the Gulf at any season although there is fairly good evidence that a few may occasionally breed on suitable islands. The only definite record for the Sonora side is that of about a dozen individuals seen between San Pedro Nolasco Island and Kino Bay on December 26, 1931. Certain shearwaters noted by Dickey about Tiburón Island in June, 1928, were very probably this species. His notes, though, are not certain.

\section{Family Hydrobatidae Storm Petrels}

\section{LOOMELANIA MELANIA (BONAPARTE)}

\section{Black Petrel}

Procellaria melania Bonaparte, Comp. Rend. Acad. Sci. Paris, 38, No. 14, (for April 3), 1854, 662 (Coast of California $=$ San Francisco).

Oceanodroma melania Brewster, 1902, 32 (near Guaymas).-Townsend, 1923, 6 (Guaymas).-Bancroft, 1927 b, 191 (San Esteban Island).

Oceanodroma melania melania van Rossem and Hachisuka, 1937 a, 325 (Guaymas; San Esteban Island).

Cymochorea melania melania Mathews, 1934, 190 (San Esteban Island).

Oceanodroma townsendi Ridgway, 1893, 687 (off Guaymas).

Common summer visitant to the entire Gulf, although not (to date) found breeding on any island actually within Sonora waters. Probably present in limited numbers in winter, although there are no Sonora records for that season. Great numbers of Black Petrels have been seen between April 17 and May 5 in northward migration flight, a circumstance which indicates that many birds leave the Gulf in winter. The only known winter occurrence for the area seems to be that of nine specimens taken by Grenville Ashcraft near Consag Rock on the night of January 31, 1940, and which are now in the Hancock collection at the University of Southern California. This island, though, is properly within Baja California waters. ${ }^{1}$

1 Breeding birds from the Gulf seem to have slightly wider and deeper bills than those from the Pacific side of Baja California but I can detect no other differences and the Gulf series is too small to serve as a basis for definite conclusions. While there is some variation in wing length (males 167-178; females 174-185), I cannot discern any geographical tendencies in this respect among specimens examined. 


\title{
HALOCYPTENA MICROSOMA COUES
}

\section{LeAst PeTrel}

Halocyptena microsoma Coues, Proc. Acad. Nat. Sci. Phila., 1864, 79 (San José del Cabo, Baja California, México).-Bancroft, 1927 b, 191 (San Esteban Island). -Mathews, 1934, 188 (San Esteban Island)._-van Rossem and Hachisuka, 1937 a, 325 (San Esteban Island; Tiburon Island; Guaymas).

Summer visitant, breeding abundantly on many of the smaller islands and outlying rocks almost throughout the Gulf. As in the case of the Black Petrel, though, there are no actual breeding records for islands lying properly within Sonora waters. Between April 17 and 21, 1925, in the vicinity of Guaymas, San Estéban and Tiburón Islands, a tremendous migration flight was in progress and some of the resting rafts certainly contained several hundred individuals. No data relative to dates of departure are available.

\section{Order PELECANIFORMES Totipalmate Swimmers}

\author{
Family Phä̈Thontidae Tropic Birds \\ Phä̈thon aEthereus mesonauta Peters \\ RED-BILLED TROPIC-BIRD
}

Phaëthon aethereus mesonauta Peters, Occ. Papers Boston Soc. Nat. Hist., 5, April 15, 1930, 261 (Swan Key, Almirante Bay, Panamá).-van Rossem, 1932 a, 129 (Tiburon Island).- -van Rossem and Hachisuka, 1937 a, 325 (mouth of the Colorado River).

Phaëthon aethereus (not of Linnaeus) Goss, 1888, 240 (San Pedro Martir Island) ; 1889, 253 (ditto).-Brewster, 1902, 33 (ditto).-Bent, 1922, 187, part, (ditto).-Mailliard, 1923, 454 (Georges Island).-Bancroft, 1927 b, 191 (George Island; San Pedro Martir Island).-Grinnell, 1928, 69 (San Pedro Martir Island).

P.[baëthon] aetherus Coues, 1903, 972, part (San Pedro Martir Island).

Fairly common resident throughout the Gulf area, with breeding centers seemingly confined to the smaller and more precipitous islands. Within Sonora waters the only two known nesting localities are George and San Pedro Mártir Islands. There seems to be very little seasonal fluctuation in numbers since breeding evidently continues over the greater part of the year. Bancroft (1927 b) found fully grown young and also fresh eggs in early March, and Dickey (notes) observed the same condition in mid-June. 


\section{Family Pelecanidae Pelicans \\ PELECANUS ERYTHRORHYNCHOS GMELIN \\ White Pelican}

Pelecanus erythrorbynchos Gmelin, Syst. Nat., 1, Pt. 2, 1789, 571 (in America septentrionale $=$ Hudson Bay).-Price, 1899, 90 (lower Colorado River). - Stone and Rhoads, 1905, 687 (lower Colorado River)._-van Rossem, 1933 b, 199 (Tepopa Bay; Estrada de Tasiola; El Golfo).--van Rossem and Hachisuka, 1937 a, 325 (Guaymas).

Winter visitant, apparently in some numbers, from the lower Colorado River southward, in coastal lagoons and bays, at least to Guaymas. The earliest seasonal record is "November" (El Golfo); the latest is April 22 (Guaymas).

\section{PELECANUS OCCIDENTALIS CALIFORNICUS RIDGWAY}

\section{California Brown Pelican}

P.[elecanus] californicus Ridgway, in Baird, Brewer, and Ridgway, Water Birds of North America, 2, 1884, 132, 143 (Coast of California, [etc.] =La Paz, Baja California, México).

Pelecanus californicus Jouy, 1894, 788 (Guaymas).-Mailliard, 1923, 441 (San Pedro Nolasco Island).

Pelecanus occidentalis californicus van Rossem, 1932, 139 (Tiburon Island; San Pedro Nolasco Island).-Huey, 1935, 250 (Punta Peñascosa).-Abbott, 1941, 417 (Guaymas).

Pelecanus fuscus (not of Gmelin) Evermann and Jenkins, 1888, 69 (Guaymas). -Salvin and Godman, 1901, 142, part (Guaymas).

Extremely common resident of the entire Gulf. The main nesting colony on the Sonora coast is located on San Pedro Nolasco Island where, in April, 1930, and in December, 1931, there were several thousand pairs present. A few pairs are usually to be found nesting on the smaller sslands such as George, or even on off-shore rocks lying close to the mainland (van Rossem notes).

\section{Family Sulidae Boobies and Gannets}

\section{Sula NEBOUXII Milne-EdwardS}

\section{BLUE-FOOTED BOOBY}

Sula Nebouxii Milne-Edwards, Ann. Sci. Nat. (Zool.), sér. 6, 13, 1882, Art. 4, 37, pl. 14 (la coté pacifique de l'Amérique=Chile).

Sula nebouxii Nelson, 1899 b, 31 (San Pedro Martir Island).-Bent, 1922, 197 
(San Pedro Martir Island).-Grinnell, 1928, 69 (San Pedro Martir Island).-van Rossem, 1932, Guaymas; San Pedro Nolasco Island; Estrada de Tasiola; etc.).

S. [ula] nebouxii Brewster, 1902, 35 (San Pedro Martir, Georges, and Tiburon Islands).

Sula nebouxi Salvin and Godman, 1901, 148 (San Pedro Martir Island).Reed, 1904, (San Pedro Martir Island).-Bancroft, 1927 b, 193, in text (San Pedro Martir Island).-Abbott, 1941, 417 (Guaymas).

Sula gossi "Ridgway MS" Goss, 1888, 241 (San Pedro Martir Isle).-Shufeldt, 1889, 67 (San Pedro Martir Island).

Sula gossii Bryant, 1889, 253 (San Pedro Martir Island).--Ridgway, 1896, 584, footnote $(S$. gossii=S. nebouxii).

Common resident of Gulf waters, with concentrations about the more precipitous islands and off-shore rocks where breeding apparently is continuous throughout the year. Due to an absence of suitable islands there are no colonies, on the Sonora side of the Gulf, south of Guaymas and San Pedro Mártir Island. The basis of Brewster's statement of breeding on Tiburón Island is obscure and is possibly a lapsus.

\section{SULA LEUCOGASTER BREWSTERI GOSS}

\section{BREWSTFR BOOBY}

Sula brewsteri Goss, Auk, 5, No. 3, July, 1888, 242 (San Pedro Mártir Isle, [Sonora, México]).-Shufeldt, 1889, 67 (San Pedro Martir Island).-Townsend, 1890, 138 (Georges Island); 1923, 6 (Georges Island; San Pedro Martir Island). -A. O. U. Comm., 1895, 40 (Georges Island).-Brewster, 1902, 34 (San Pedro Martir Island: Georges Island).-Bent, 1922, 208 (ditto).-Mailliard, 1923, 454 (San Pedro Nolasco Island; Georges Island).-Grinnell, 1928, 70 (San Pedro Martir Island).- -van Rossem, 1932, 129 (Tiburon Island.)-Huey, 1935, 251 (Punta Peñascosa).-Abbott, 1941, 417 (Guaymas).

Sula leucogaster brewsteri Wetmore, 1939 b, 2 (nomen.; crit.).

Sula leucogaster (not Pelecanus leucogaster Boddaert) Streets, 1887, 22 (Tiburon Island).

Common, even abundant, resident throughout the Gulf, though with local concentrations about islands. Breeding apparently continues throughout the year. Although still very common, there has been a marked decrease in numbers in recent years, due, probably, to the heavy drain on food supply by commercial fishermen. Additional localities where noted are El Golfo and Estero de Tasiota (Anthony notes); mouth of the Colorado River; San Estéban Island; Tóbari Bay; Agiabampo (van Rossem notes).

\section{Family Phalacrocoracidae Cormorants}

\section{PHALACROCORAX AURITUS ALBOCILIATUS RIDGWAY}

\section{Farallón Cormorant}

Phalacrocorax dilophus albociliatus Ridgway, Proc. Biol. Soc. Wash., 2, April 10, 1884, 94 (Farallon Islands to Cape San Lucas, etc.=Farallón Islands, California). 
Phalacrocorax auritus albociliatus van Rossem, 1932, 129 (Tiburon Island; San Carlos Bay).-Huey, 1935, 251 (Punta Peñascosa).- -van Rossem and Hachisuka, 1937 a, 325 (Guaymas; San Pedro Martir Island).-Abbott, 1941, 417 (Guaymas).

Common resident of Gulf waters, at least from Guaymas northward. Breeds in considerable numbers in some years (but apparently not in others) on San Pedro Nolasco and George Islands, and occurs generally at insular and coastal points. Breeding data for the two islands above mentioned were supplied by Mr. Randolph Leigh who secured colored slides and motion pictures there in February, 1941, at which time most nests contained half-grown young. The cormorants seen by Price (1899, p. 90) on the lower Colorado River in the winter of 1898 and listed under "Phalacrocorax penicillatus (?)" seem most likely to have been of this species.

\section{Phalacrocorax olivaceus chancho van Rossem and Hachisuka}

\section{SONORA CORMORANT}

Phalacrocorax olivaceus chancho van Rossem and Hachisuka, Proc. Biol. Soc. Wash., 52, Feb. 4, 1939, 9 (Tesia, Sonora, México).

Phalacrocorax mexicanus (not Carbo mexicanus Brandt) Nelson, 1903, 139 (coastal lagoons of southern Sonora).

(?) Phalacrocorax vigua mexicanus Bent, 1922, 261, part (Guaymas).

Common in summer in extreme southern coastal lagoons and in the lower Mayo River valley. Has been observed at Tóbari Bay in late April, 1930, and at Agiabampo in mid-May, 1937 (van Rossem notes). Specimens have been collected at Camoa, in April, 1939 (Mus. Vert. Zool.), and at Tesia in late June, 1937 (Dickey collection). The bases of the Guaymas record of Bent and for the general statement of Nelson cannot be ascertained. According to F. C. Lincoln, the Biological Survey files provide no clues to either.

\section{Phalacrocorax penicillatus (BRANDt)}

\section{BRANDT CORMORANT}

Carbo penicillatus Brandt, Bull. Sci. Acad. Imp. Sci. St. Petersb., 3, 1837, col. 55 (type loc. unknown =Vancouver Island).

Phalacrocorax penicillatus van Rossem, 1932, 130 (Tiburon Island).- - van Rossem and Hachisuka, 1937 a, 325 (San Pedro Martir Island: San Esteban Island; San Pedro Nolasco Island; Guaymas).-Abbott, 1941, 417 (Guaymas).

Probably a fairly common resident about islands and along the mainland coast. Dates of record range from January 1 at Tiburón Island to 
April 21 at Guaymas and San Pedro Nolasco Island. In April, 1925, there was a fairly populous breeding colony on the west end of San Pedro Mártir Island, and in April, 1930, certain off-shore rocks near Guaymas gave fairly good evidence of having at one time been used as nesting sites by Brandt Cormorants. The questionable record by Price (1899, p. 90) for the Colorado River most likely pertains to another species.

\title{
Family Fregatidae Man-o'-war-birds
}

\section{FREGATA MAGNIFICENS ROTHSCHILDI MATHEWS}

\section{MEXICAN MAN-O'-WAR-BIRI)}

Fregata minor rothschildi Mathews, Birds Australia, 4, 1915, 280 (Aruba, Dutch West Indies).

Fregata magnificens rothschildi van Rossem and Hachisuka, 1937 a, 325 (Guaymas; Lobos Island).-Abbott, 1941, 417 (Guaymas).

Fregata magnificens (not Fregata minor magnificens Mathews) van Rossem, 1932, 130 (Tiburon Island).

Fregata aquila (not Pelecanus aquilus Linnaeus) Fvermann and Jenkins, 1888, 69 (Guaymas).-Bryant, 1889, 265, in text (San Pedro Martir Island).- Mailliard, 1923, 454 (Pelican lsland).

Present throughout the year in the entire Gulf area, although much more common southerly. There are no nesting colonies known within Sonora territory. Additional localities where observed are Estero de Tasiota; Kino Point (Anthony notes) ; San Pedro Nolasco Island; San Estéban Island; George Island; Tóbari Bay; Agiabampo (van Rossem notes).

\section{Order CiCONiIformes Herons, Storks, Ibises, and Allies}

\section{Family ARDEIDAE Herons and Bitterns}

\author{
ARDEA HERODIAS TREGANZAI COURT
}

\section{TrFganza Heron}

Ardea herodias treganzai Court, Auk, 25, No. 3, July, 1908, 291 (Egg Island, Great Salt Lake, Utah).-Oberholser, 1912, 545, part (Cajon Bonito Creek; Sonoyta River; Santa Cruz River: San Bernardino Ranch; Colorado River at Mon. 204).--Bailey, 1928, 87, part (Sonora).--van Rossem, 1932, 130 (Tiburon Island). - Huev, 1935, 251 (Punta Peñascosa).

Ardea herodias (not of Linnaeus) Price, 1899, 91 (lower Colorado River).Stone and Rhoads, 1905, 688 (lower Colorado River).

Common resident coastwise and on larger interior streams in the northern part of the State, where all definite records to date are from points on 
or near the Arizona boundary. In default of specimens, records from Punta Peñascosa and Tiburón Island are allocated provisionally and in conformance with known southward distribution in Baja California.

\section{ARDEA herodias sancti-luCAE THAYER AND BANGS}

\section{Espíritu Santo Heron}

Ardea herodias sancti-lucae Thayer and Bangs, Proc. New Engl. Zoöl. Club, 4, Feb. 23, 1912, 83 (Espíritu Santo Island, Baja California, México).

Ardea herodias treganzai (not of Court) Oberholser, 1912, 545, part (Guaymas ?).-Bent, 1926, 123, part (Guaymas).- -van Rossem and Hachisuka, 1937 a, 325 (Guaymas; San Pedro Nolasco Island; Tobari Bay).-Abbott, 1941, 417 (Guaymas).

Common resident of the Tropical zone coast, including Gulf and bay islands, from Guaymas and San Pedro Nolasco Island southward. Additional localities (sight records only) are Ciudad Obregón, Tesia, Agiabampo, and Masocari Island in May and June, 1937 (van Rossem) . ${ }^{2}$

\section{BUTORIDES VIRESCENS ANTHONYI (MEARNS)}

\section{ANTHONy GreEN Heron}

Ardea virescens anthonyi Mearns, Auk, 12, July, 1895, 257 (Seven Wells, Salton River, Baja California, México); ibid., in text (Monument 77; San Pedro River on boundary).

Butorides virescens anthonyi Oberholser, 1912 a, 543 (San Pedro River near U. S. boundary; San Bernardino River near U. S. boundary).-Bent, 1926, 195 (San Pedro River).-A. O. U. Comm., 1931, 30 (northern Sonora).-van Rossem, 1934 d, 427 (Alamos; Oposura).- -van Rossem and Hachisuka, 1937 a, 326 (Tecoripa; Saric; Pilares).

Fairly common summer visitant to suitable watercourses in Sonoran zones in the northern part of the State. Westernmost breeding station, Colonia Indepenencia on the Colorado River (May 3, 1937, van Rossem notes) ; easternmost, Pilares; southernmost, Magdalena (May 15, 1925, Dawson notes). Records from Tecoripa, March 1, 1929; 2 miles south of Magdalena, March 28, 1936 (Mus. Vert. Zool.) ; Oposura, April 15, 1887 , are most probably those of transients although the localities may be within the breeding range. There is one midwinter record, far to the south of the breeding range, from Álamos, February 7, 1888.

2 There appear to be no differences in color or size between Sonora specimens (Guaymas, 2; Tóbari Bay, 1) and topotypical sancti-lucae, in spite of the former positive (but erroneous) allocation of the former to treganzai (van Rossem and Hachisuka, 1937 a). How much further south along the coast the range of sanctilucae may extend is problematical. George Willett informs me that similarly light-colored birds were noted by him at various points south to Jalisco; however, no specimens were taken. 


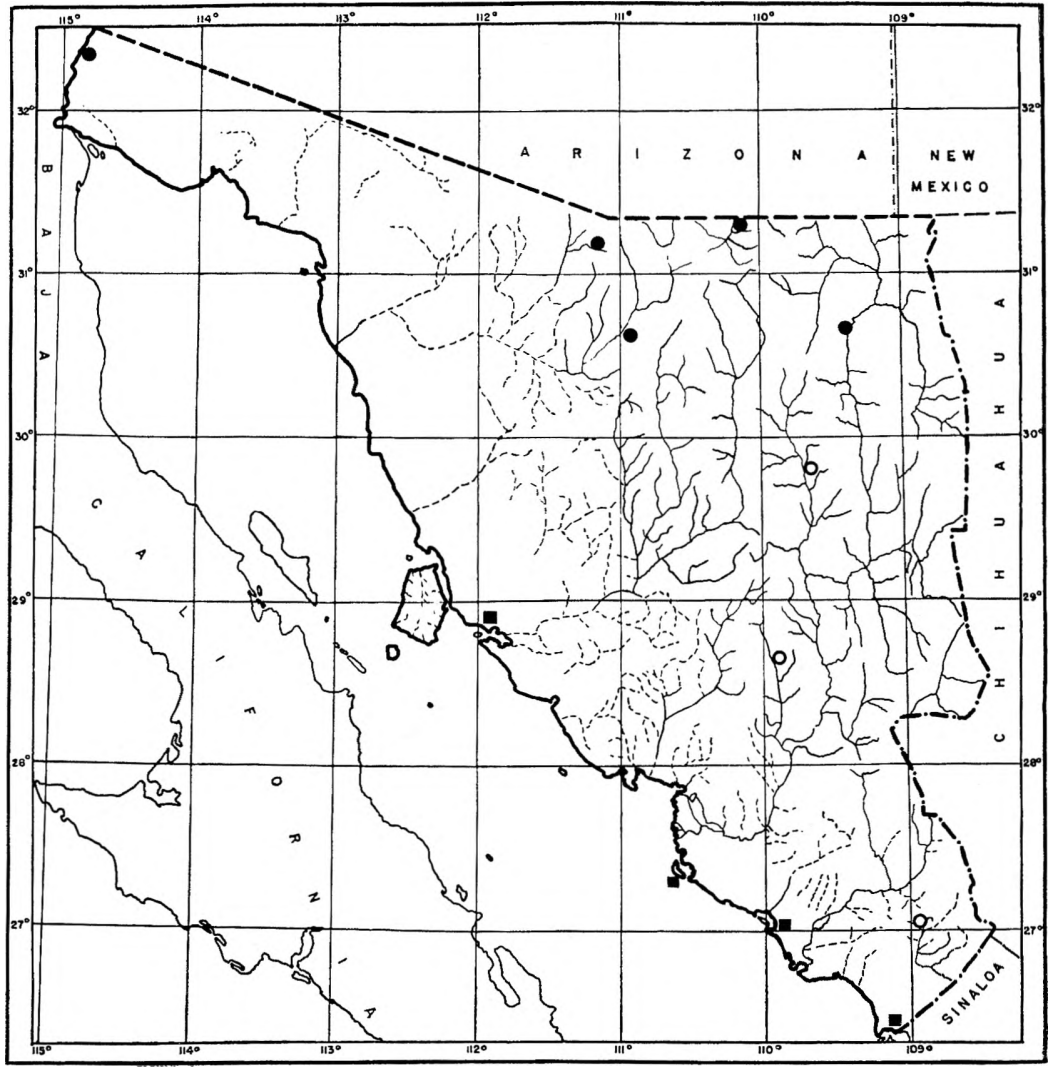

MAP 2. Distribution of Butorides virescens. Circles, B. v. anthonyi; hollow circles, winter or transient stations outside of established breeding range; squares, B. v. virescens.

\section{BUTORIDES VIRESCENS VIRESCENS (LINNAEUS) \\ EAstern Green Heron}

Ardea virescens Linnaeus, Syst. Nat., ed. 10, 1, 1758, 144 (in America $=$ South Carolina).

Butorides virescens virescens van Rossem and Hachisuka, 1937 a, 326 (Tobari Bay; Kino Bay; Lobos Island; crit.).

Fairly common summer visitant to Tropical zone mangrove lagoons north to Kino Bay. Although probably a permanent resident, present dates extend only from April 27 to June 12, all of them for breeding birds, 
however. Green Herons seen at Agiabampo in May, 1937 (van Rossem notes), were undoubtedly of this race.

\section{FLORIDA CAERULEA CAERULESCENS (LATHAM) Southern Little Blue Heron}

Ardea caerulescens Latham, Index Orn., 1790, 2, 690 (Cayenne).

Florida caerulea caerulescens van Rossem and Hachisuka, 1937 a, 326 (Lobos Island; Tobari Bay).

Florida caerulea (not Ardea caerulea Linnaeus) van Rossem, 1932, 130 (Tiburon Island).

Rather common, in summer at least, in the Tropical zone mangrove association north to the vicinity of Guaymas (Guásimas Lagoon). The single winter record from Tiburón Island, December 28, suggests a seasonal dispersal northward and is also confirmation that some part of the population is resident. An additional locality is Agiabampo, where noted May 13, 1937 (van Rossem notes).

\section{DICHROMANASSA RUFESCENS DICKEYI VAN ROSSEM}

\section{DICKEY EGRET}

Dichromanassa rufescens dickeyi van Rossem, Condor, 28, Sept., 1926, 246 (San Luís Island, Baja California, México) ; 1933 b, 199 (Tepopa Bay).-van Rossem and Hachisuka, 1937 a, 326 (Guaymas; Tobari Bay).-Abbott, 1941, 418 (Guaymas).

Dichromanassa rufescens (not Ardea rufescens Gmelin) Townsend, 1923, 10 (Guaymas).

Fairly common, although rather local, inhabitant of Tropical zone coastal lagoons. There are no breeding colonies actually on record, but specimens taken at Tóbari Bay on April 28, 1930, were in breeding condition. Dates of occurrence range from December 23 at Guaymas to May 13 at Agiabampo (van Rossem notes). ${ }^{3}$

\section{CASMERODIUS ALBUS EGRETTA (GMELIN)}

\section{AMERICAN EGRET}

Ardea Egretta Gmelin, Syst. Nat., 1, Pt. 2, 1789, 629 (Cayenne).

Casmerodius albus egretta van Rossem, 1933 b, 199 (Hermosillo; Guaymas; Tepopa Bay).-Huey, 1935, 251 (Punta Peñascosa).- -van Rossem and Hachisuka, 1937 a, 326 (Guaymas; Tobari Bay).

3 Peters (1931, p. 109) does not recognize this race. When skins not impregnated with fat are compared, the differences between rufescens of the southeastern United States and dickeyi are obvious, the latter being uniformly and decidedly darker. Wetmore (Proc. U. S. Nat. Mus., 40, 1941, p. 487) has made a similar observation in upholding the validity of Florida caerulea caerulescens, a race also rejected by Peters. 
Rather common resident coastwise and along suitable interior streams. Recorded as breeding at Tóbari Bay, and undoubtedly does so at other points. Further records, previously unpublished, are Colonia Independencia in the Colorado delta, May 3; Agiabampo, May 14; Tesia on the Mayo River, June 20, 1937 (van Rossem notes) ; Colorado River opposite mouth of the Hardy, March 28, 1894 (Mearns notes).

\section{LEUCOPHOYX THULA BREIWSTERI (THAYER AND BANGS)}

\section{BREWSTER EGRET}

Egretta candidissima brewsteri Thayer and Bangs, Proc. New Engl. Zoöl. Club, 4, April 29, 1909, 40 (San José Island, Baja California, México); ibid., in text (Guaymas).-Bent, 1926, 156 (Guaymas).

Egretta thula brewsteri van Rossem, 1932, 130 (Tiburon Island) ; 1933 d, 199 (Tepopa Bay).-Huey, 1935, 251 (Punta Peñascosa).-Abbott, 1941, 418 (Guaymas).

Leucophoyx thula brewsteri van Rossem, 1934 d, 427 (Guaymas).- -van Rossem and Hachisuka, 1937 a, 326 (Guaymas; Lobos Island).

Egretta candidissima (not Ardea candidissima Gmelin) Townsend, 1923, 9 (Tiburon Island).

Fairly common resident coastwise from Guaymas southward. The several records north of Guaymas are most probably for winter or post-breeding vagrants. An additional station is Agiabampo, May 12 to 14, 1937, where observed as rather common (van Rossem notes).

\section{HYDRANASSA TRICOLOR RUFICOLLIS (GOSSE)}

\section{LOUISIANA HERON}

Egretta ruficollis Gosse, Birds Jamaica, 1847, 338 (Burnt Savanna River, [Jamaica]).

Hydranassa tricolor ruficollis van Rossem, 1933 b, 199 (Guaymas).—van Rossem and Hachisuka, 1937 a, 327 (Tobari Bay).

Seemingly a rather uncommon resident of coastal lagoons from Guaymas southward to Agiabampo (May 12 to 14, 1937, van Rossem notes). There are two widely separated winter records from fresh water localities. The species was found commonly 9 miles S.W. of Cuidad Obregón, November 24, 1944 (Sheffler notes; 1 taken), and Mearns notes mention two flocks of 6 and 11 individuals seen, presumably along the Sonoyta River, between January 27 and February 7, 1894. 


\section{NyCTICORAX NYCTICORAX HOACTLI (GMELIN)}

\section{Black-Crowned Night Heron}

Ardea Hoactli Gmelin, Syst. Nat., 1, Pt. 2, 1789, 630 (In Novae Hispaniae lacubus $=$ Valley of México $)$.

Nycticorax nycticorax hoactli van Rossem and Hachisuka, 1937 a, 327 (Guaymas; Tobari Bay).

Nycticorax nycticorax naevius Price, 1899, 91 (lower Colorado River).-Stone and Rhoads, 1905, 681 ("Colony").

Resident in suitable Sonoran and Tropical zone localities almost everywhere in the State, although probably more generally distributed in winter and during post-breeding wanderings. Some additional localities are Colonia Independencia, Rancho La Arizona, and Agiabampo in May, 1937 (van Rossem notes) ; San Bernardino River on the boundary, July 31 and October 16, 1892; Colorado River at Monument 204, March 22 and 28, 1894 (U. S. Nat. Mus. catl.) ; San Pedro River on the boundary, October 11, 1892 (Mearns notes); Magdalena, April 20, 1925 (Dawson notes).

\section{NYCTANASSA VIOLACEA BANCROFTI HUEY}

\section{BANCROFT Night HrRON}

Nyctanassa violacea bancrofti Huey, Condor, 29, No. 3, May 15, 1927, 167 (Scammon Lagoon, Baja California, México).—van Rossem, 1933 b, 199 (Tepopa Bay).-van Rossem and Hachisuka, 1937 a, 327 (Tobari Bay).

Fairly common but apparently rather local resident of coastwise lagoons north to Tepopa Bay. Although detected at but three points, Tepopa Bay, Tóbari Bay, and Agiabampo (van Rossem notes), numbers were observed on each occasion.

\section{HETEROCNUS MEXICANUS FREMITUS VAN ROSSEM AND HaCHISUKA}

\section{Northwestern Tigfr HFron}

Heterocnus cabanist [sic] fremitus van Rossem and Hachisuka, Proc. Biol. Soc. Wash., 50, September 30, 1937, 161 (Guirocoba, Sonora, México).

Heterocnus mexicanus fremitus van Rossem, 1942 i, 572 (nomen.).

Heterocnus cabanisi (not of Heine) Peters, 1931, 119 (Sonora).- -van Rossem and Hachisuka, 1937 a, 327 (Tesia).-Moore, 1938, 24 (Guirocoba; Alamos). Heterocnus mexicanus (not Tigrisoma mexicana Swainson) Cooke, 1913, 67, part (Alamos).

Fairly common resident along fresh-water streams in Tropical zone lowlands and foothills. There are no records for salt, or even brackish, water. Unpublished data are from Guirocoba, where common in December, 
1941 (Sheffler notes); Cuchujaqui River near Ålamos; San Francisco Cañon, May, 1937 (van Rossem notes).

\section{IXOBRYCHUS EXILIS HESPERIS DICKEY AND VAN ROSSEM \\ WESTERN LEAST BitTERN}

Ixobrychus exilis hesperis Dickey and van Rossem, Bull. So. Calif. Acad. Sci., 23, Feb. 20, 1924, 11 (Buena Vista Lake, Kern Co., California).-van Rossem, 1930 j, 228, in text (Kino Bay).

Known only from two specimens taken, respectively, at Tóbari Bay, April 28, 1930, and at Kino Bay, May 16, 1930 (Natural History Museum). Although both of these males were in breeding condition, they may have been transients.

\section{IXOBRYCHUS EXILIS PULLUS VAN ROSSEM}

\section{SONORA LEAST BITTERN}

Ixobrychus exilis pullus van Rossem, Trans. San Diego Soc. Nat. Hist., 6, No. 15, Nov. 28, 1930, 227 (Tóbari Bay, Sonora, México); ibid., in text (Kino Bay; Miramar; Guasimas Lagoon; Lobos Island).--Peters, 1931, 132 (range in Sonora).

Fairly common summer visitant (possibly resident) in Tropical zone mangrove lagoons from Kino Bay south to Tóbari Bay. Dates of record (all breeding) cover only the limited time from April 28 to May 25.*

\section{Botaurus lentiginosus (Montague)}

\section{AMERICAN BITTERN}

Ardea lentiginosa Montague, Suppl. Orn. Dict., 1813, (not paged), (Piddletown, Dorsetshire, England).

Botaurus lentiginosus van Rossem and Hachisuka, 1937 a, 327 (El Doctor).

Detected as a winter visitant and migrant. There are four records: El Doctor in the Colorado delta, January 25, 1929 (Dickey coll.); San

\footnotetext{
4 The systematic status of pullus remains undecided. Two adult male besperis have been collected in breeding condition at places where pullus was definitely breeding at the time. These, of course, may have been transients, but so late a date as May 16 would almost rule out such a possibility. One of the Kino Bay pullus shows some evidence of hesperis coloration, but whether this is the result of hybridization, or is a normal variation, is pure speculation at this time. In May, 1937, I spent three days in the mangrove lagoons at Agiabampo with the principal object of determining this point but failed to find a trace of either form. Neither was the species encountered at Guaymas or Kino Bay in December, 1932. My impression at this time is that pullus will prove to be of specific value.
} 
Bernardino Ranch on the boundary [though cvidently on the Arizona side], August 28, 1892, and San Bernardino River on the boundary, October 5, 1893 (U. S. Nat. Mus.); two seen at Tóbari Bay, November 25, 1944 (Scheffler notes).

\section{Family Ciconirdae Storks and Wood Ibises \\ MYCTERIA AMERICANA LINNAEUS \\ WOOD IBIS}

Mycteria americana Linnaeus, Syst. Nat., ed 10, 1, 1758, 140 (in America calidiore = Brazil). - van Rossem and Hachisuka, 1937 a, 327 (Guaymas; Tobari Bay).

Tantalus loculator Stone and Rhoads, 1905, 688 (lower Colorado River).

Common in summer in Tropical zone coastal lagoons and river valleys from Guaymas southward. There is good, though not conclusive, evidence that breeding colonies exist at Guásimas Lagoon and perhaps other points. Sporadic occurrences have been noted in fall and winter at scveral northern localities such as the lower Colorado River in "February," the San Bernardino River, August 6, 1892 (U. S. Nat. Mus. catl.), and September 10, 1892 (Mearns notes), and the Sonoyta River where (Mearns notes) on an unspecified date Lieut. Gaillard "shot several." Other southern localities are Agiabampo in May, and Tesia on the lower Mayo River in June, 1937 ("common"; van Rossem notes).

\section{GUARA ALBA (LinNAEUS)}

\section{WHITE IBIS}

Scolopax alba Linnaeus, Syst. Nat. ed. 10, 1, 1758, 145 (Carolina).

Guara alba van Rossem, 1933 b, 199 (Tepopa Bay).- van Rossem and Hachisuka, 1937 a, 327 (Tobari Bay; Guasimas Lagoon).

Present, both in midwinter and summer, and presumably resident, in Tropical zone coastal lagoons. A winter record is from Tepopa Bay, where not uncommon on January 2, 1932. Spring and summer occurrences are Tóbari Bay, April 28 to June 12, 1930; Guásimas Lagoon, May 12, 1930; Agiabampo, May 12 to 14, 1937; (van Rossem notes).

\section{Plegadis mexicanus (GMflin) \\ WHITE-FACED GLOSSY IBIS}

Tantalus mexicanus Gmelin, Syst. Nat., 1, 1788, 652 (Novae Hispaniae= México).

Plegadis guarauna (not Scolopax guarauna Linnaeus) Allen, 1893 a, 33 (Cachuta).-Salvin and Godman, 1902, 194 (Cachuta). 
Ibis ordii (not of Bonaparte) Baird, 1858, 685 (Santa Cruza) ; 1859, 24 (Santa Cruza).-Brewer, 1844, 99, in text (Santa Cruz).

Status uncertain. Detected at widely separated fresh-water localities in spring, summer, and fall, but not so far found to breed. Recorded from Santa Cruz in June, 1855, and Cuchuta on October 5, 1890. Additional localities are Colonia Independencia in the Colorado delta, where common on May 5, 1937; Tesia on the lower Mayo River, common in late June, 1937 (van Rossem notes) ; in the U. S. National Museum catalogue are records of nine specimens taken by Mearns and Holzner on the San Bernardino River on the boundary line, August 2, 1892, and October 4 and 5, 1893; noted "by thousands" in the lower Yaqui River valley west of Cuidad Obregón, November 24, 1944 (Sheffler notes); Huey (1942, p. 363) noted several in migration at Quitovaquita on the boundary (though on the Arizona side) April 11 and 12, 1939.

\section{AJAIA AJAJA (LINNAEUS)}

\section{Roseate Spoonbill}

Platalea ajaja Linnaeus, Syst. Nat., ed. 10, 1, 1758, 140 (in America australi= Brazil).

Ajaia ajaja van Rossem and Hachisuka, 1937 a, 327 (Mayo River valley; Tobari Bay; Guaymas).

Ajaja [sic] ajaja Dawson, 1923, 1932 (Guaymas).

Fairly common in summer in coastal lagoons from Guaymas southward. Reported at one inland point, the lower Mayo River valley near Tesia. Additional localities are Agiabampo, where common in mid May, 1937 (van Rossem notes), and Kino Bay in "September" (Nat. Hist. Mus.) The latter instance is possibly that of a seasonal wanderer. The basis of the statement by Dawson that the Spoonbill breeds at Guaymas cannot be ascertained. Possibly it does so at some point or points along the Tropical zone coast, but no colonies have, to date, been definitely recorded from Sonora.

\section{Order ANSERIFORMES Swans, GEEse, ANd DuCKs \\ Family Anatidae Swans, Geese and Ducks Chen hyperborea (PALlas) \\ LESSER SNOW GOOSE}

Anser byperboreus Pallas, Spic. Zool., 1, Fasc. vi, 1769, 25 (in terris borealibus ad Orientem $130^{\circ}$ longitudinis ... = northeastern Siberia).

Chen byperborea van Rossem and Hachisuka, 1937 a, 328 (San Luis; El Doctor).

Common, perhaps even abundant, winter visitant in the Colorado River delta. Observed by Dickey (notes) as common all along the river from 
San Luis to El Doctor between December 5 and 9, 1925, and similarily noted by Wright in February, 1929. In the U. S. National Museum catalogue is the record of two specimens taken by Mearns and Holzner on the Sonora side of the river opposite the mouth of the Hardy, March 27, 1894. There are a number of supplementary records from the Baja California bank (Grinnell, 1928, p. 78). An extreme southern record, possibly that of a casual, is from Tóbari Bay, November 25, 1944, where a single individual was seen by W. J. Sheffler (notes).

\section{ANSER ALBIFRONS ALBIFRONS (SCOPOLI)}

\section{WHITE-FRONTED GOOSE}

Branta albifrons Scopoli, Annus 1, Historico-Naturalis, 1769, 69 (No locality).

Known only from the record by W. J. Sheffler, who found the species in great abundance at Tóbari Bay on November 25, 1944 (notes). One flight observed by him took two hours to pass. All birds shot were adults.

\section{BRANTA CANADENSIS (LINNAEUS) \\ Canada Goose}

Branta canadensis subsp., ? Stone and Rhoads, 1905, 688 (Colorado River delta).

Mearns' notes, under the name of "Branta canadensis occidentalis," mention "a small flock" seen at San Domingo sometime between January 9 and 25,1894 . While the record is interesting as showing the presence of some form of the Canada Goose, it is otherwise of no particular value. In spite of the several records of the Canada Goose for the Colorado River delta (Grinnell, 1928, p. 78), no specimens seem to have been collected and the race, or races, present in the region in winter cannot be identified at this time. Similarly, W. J. Sheffler, although he took no specimens, noted this species as "fairly common" near Tóbari Bay on November 25, 1944.

\section{Dendrocygna bicolor helva Wetmore and Peters}

\section{Fulvous TREE-DUCK}

Dendrocygna bicolor helva Wetmore and Peters, Proc. Biol. Soc. Wash., 35, March 20, 1922, 42 (Unlucky Lake, San Diego Co., California).-van Rossem and Hachisuka, 1937 a, 328 (Guaymas).

Dendrocygna fulva (not Anas fulva Gmelin) Lawrence, 1874, 313 (Mayo and Yaqui Rivers).--Sanford, Bishop, and Van Dyke, 1903, 257, part (Mayo and Yaqui Rivers). 
Dendrocycna fulva Baird, Brewer, and Ridgway, 1884 (1), 484, part (Mayo and Yaqui Rivers).- Salvin and Godman, 1902, part (ditto).

Dendrocygna bicolor (not Anas bicolor Vieillot) Phillips, 1922, 128, part (Sonora).-Bent, 1925, 273, part (Mayo and Yaqui Rivers).

Status uncertain. The only definite records are: a specimen listed in the U. S. National Muscum catalogue as taken by Mearns and Holzner at Monument 205 on the Colorado River, March 19, 1894; a flock of at least 100 birds seen at Guaymas on May 5, 1930; and three birds seen at Tóbari Bay on November 25, 1944 (Sheffler notes). The frequently repeated "Mayo and Yaqui Rivers" was based on nothing more substantial than reports of natives, as Grayson's notes specifically state, and which in part or in whole probably pertain to another specics.

\section{DENDROCYGNA AUTUMNALIS AUTUMNALIS (LiNNAFUS)}

\section{Black-BFllifD TRFF-I)UCK}

Anas autumnalis Linnaeus, Syst. Nat. ed. 10, 1, 1758, 127 (in America=West Indies).

Dendrocygna autumnalis Lawrence, 1874, 314 (toward Sonora).

Dendrocjona autumnali, Baird, Brewer, and Ridgway, 1884, 483 (Sonora).

Dendroc)gna autumnalis autumnalis van Rossem, 1933 b, 199 (Camoa)

Status uncertain. Known to be common in June in the lower Mayo River valley but not otherwise recorded definitely from the State. Flocks noted there (Tesia) in late June, 1937, appeared to be transient in character (van Rossem notes). As in the case of the preceeding species, Grayson's observation is not specific. He mercly stated that it migrated "toward Sonora."

\section{ANAS PLATYRHYNCHOS PLATYRHYNCHOS LINNAFUS}

\section{MALLARD}

Anas plat)rbjuchor L.innacus, Syst. Nat., ed. 10, 1, 1758, 125 (in Europae maritimis = Sweden ).

Anas borchas Baird, 1859, 26 (Rio San Pedro).--Baird, Brewer, and Ridgway, 1884, (1), 491, part (R:o San Pedro).-Salvadori, 1895, 189, part (Hermosillo). - Price, 1899, 90 (lower Colorado River).--Salvin and Godman, 1902, 207 part (Hermosillo).--Stone and Rhoads, 1905, 688 (lower Colorado River).- Phillips, 1923, 3, part (Sonora)

Breeds, formerly at least, on the San Bernardino River in the vicinity of the boundary but not otherwise known to do so within Sonora limits. Occurs widely and apparently rather commonly as a winter visitant in suitable localities south to the lower Yaqui River valley. Unpublished records are Sonoyta and the Sonoyta River, January 9 to February 28, 
1894; San Bernardino River, summer of 1892 (Mearns notes); Fronteras, January 20, 1943 (F. C. Lincoln MS); Noche Buena in the Colorado delta, December 6, 1925 (Dickey coll. and notes); Ciudad Obregón, December 10, 1941 (common; Sheffler notes).

\section{ANAS CYANOPTERA CYANOPTERA VIFILLOT \\ Cinnamon TFal}

Anas cyanoptera Vieillot, Nouv. Dict. d'Hist. Nat., nouv. éd., 5, 1816, 104 (dans l'Amérique méridionale sur la rivière de la Plate et à Buenos Ayres).-Phillips, 1923, 390, part (Sonora).

Querquedula cyanoptera cyanoptera Oberholser, 1906, 93 (Colorado River).van Rossem and Hachisuka, 1937 a, 328 (Nogales; El Ductor: Saric).

Anas discors (not of Linnaeus) Allen, 1893 a, 32 (Cachuta).--Phillips, 1923, 373 (Sonora).

Querquedula discors Salvin and Godman, 1902, 215 (Cachuta).

Occurs in fall, winter, and spring on fresh-water strcams and ponds throughout the Statc. Possibly breeds at some points, although not known certainly to do so. Unpublished records are from the San Bernardino River, August 13 and 31, 1892; October 5, 1893 ; San Luís Spring, "Chihuahua," September 3, 1893 (U. S. Nat. Mus.; Mearns notes) ; Hacienda la Casita, August 25, 1934 (F. C. Lincoln) ; Rancho La Arizona, May 7, 1937 (said to breed; van Rossem notes) ; common 9 miles S.W. of Cuidad Obregón, November 24, 1944 (Sheffler notes). A supplemental record is Quitovaquita on the boundary, March 6, 1939 (Arizona side; Hucy, 1942). Extreme dates, except for Rancho La Arizona, are August 13 (San Bernardino River) and March 30 (Las Carpas on the lower Colorado River).

\section{ANAS DisCors LinNafus \\ BLUF-WINGED TFAL}

Anas discors Linnaeus, Syst. Nat., ed. 12, 1, 1766, 205 (North America = Virginia or Carolina).

Known only as a winter visitant in the lower Yaqui River valley where found to be fairly common 9 miles S. W. of Ciudad (Obregón, November 24, 1944 (Sheffler notes). The only previous record for Sonora is erroncous (Allen, 1893a) as the female specimen taken at Cachuta is cyanoptera (fide Zimmer).

\section{ANAS CAROLINENSIS GMFLIN \\ GRFFN-W'INGFI) TFAL}

Anas carolinensis Gmelin, Syst. Nat., 1, Pt. 2, 1789, 533 (in America a Carolina ad sinum Hudsonis = South Carolina). - Allen, 1893 a, 32 (Nacory) - Price, 1899, 90 (lower Colorado River) - Stone and Rhoads, 1905, 688 (lower Colorado River).-Phillips, 1923, 231 (Sonora). 
Nettion carolinense Salvadori, 1895, 250 (Hermosillo).

Nettion crecca carolinense van Rossem, 1934 d, 428 (Fronteriza).-van Rossem and Hachisuka, 1937 a, 328 (El Doctor; Saric; Chinobampo).

Nettium carolinense Salvin and Godman, 1902, 212 (Hermosillo).

Common migrant and winter visitant in suitable fresh-water localities nearly everywhere. Additional records are Cajón Bonito Creek, September 27, 1893; San Bernardino River on the boundary, September 2, 1892; Sonoyta and Sonoyta River, January and February, 1894 (U. S. Nat. Mus.; Mearns notes) ; 9 miles S.W. of Ciudad Obregón, November 24; Tóbari Bay, November 25, 1944 (abundant; Sheffler notes). Extreme dates are August 17 (Rancho La Arizona ["Saric"]) and March 13 (Fronteras). The latest boundary date is April 28 at Quitovaquita (Huey, 1942), though this is technically just within Arizona territory.

\section{ANAS ACUTA TZITZIHOA VieILLOT}

\section{American Pintail}

Anas tzitziboa Vieillot, Nouv. Dict. d'Hist. Nat., nouv. éd., 5, 1816, 163 (Mexique).

Anas acuta tzitziboa Phillips, 1923, 306 (Cachuta).

Dafila acuta tzitzihoa Huey, 1935, 261 (Punta Peñascosa).-van Rossem and Hachisuka, 1937a, 328 (El Doctor).

Dafila acuta (not Anas acuta Linnaeus Allen, 1893a, 33 (Cachuta).-Salvin and Godman, 1902, 213, part (Cachuta).- Stone and Rhoads, 1905, 688 (lower Colorado River).

Very common migrant and winter visitant in suitable localities everywhere, both coastally and on fresh water streams and ponds in the interior. Indicating numerical abundance are 28 returns of banded birds taken at Ciudad Obregón, Guaymas, López Collado, Hermosillo, Pueblo Yaqui, and Huatabampo, between the seasonal dates of September 1 and April 25 (F. C. Lincoln MS). Other occurrences are San Bernardino River on the boundary, September 4, 1892 ; Sonoyta, January 18, 1894 (Mearns notes) ; Cuidad Obregón, December 10, 1941 (Sheffler notes).

\section{MARECA AMERICANA (GMELIN)}

\section{BALDPATE}

Anas americana Gmelin, Syst. Nat. 1, Pt. 2, 1789, 526 (in America [etc.] New York).-Allen, 1893 a, 32 (Cachuta).-Phillips, 1923, 189 (Cachuta; Hermosillo).

Mareca americana Salvadori, 1895, 233 (Hermosillo).-Salvin and Godman, 1902, 210 (Cachuta).- van Rossem and Hachisuka, 1937 a, 328 (San Jose de Guaymas). 
Migrant and winter visitant, probably in fair numbers. Additional occurrences are the San Bernardino River, August 2, 1892; San Pedro River, October 13, 1892; Sonoyta, January 13, 1894 (U. S. Nat. Mus. catl.) San Luís, September 15, 1938 (F. C. Lincoln, in litt.) ; 9 miles S.W. of Ciudad Obregón, November 24; Tóbari Bay, November 25, 1944 ("abundant"; Sheffler notes). El Doctor, December 7, 1925 (Dickey coll.). Extreme dates are August 2 (San Bernardino River) and March 22 (Hacienda Aranjuez).

\section{Chaulelasmus streperus (LinNaeus)}

\section{GADWALL}

Anas strepera Linnaeus, Syt. Nat., ed. 10, 1, 1758, 125 (in Europae=Sweden).

Rather uncommon winter visitant. Authentic instances of occurrence are a specimen in the U. S. National Museum taken by Mearns and Holzner on the San Pedro River, October 23, 1892; two killed and one seen 9 miles S.W. of Ciudad Obregón, November 24, 1944 (Sheffler notes); a skeleton in the Dickey collection, taken by Dickey near El Doctor in the Colorado delta, December 8, 1925; and Mearns' notes which mention the Gadwall "in flocks" at Sonoyta and along the Sonoyta River between January 9 and February 8, 1894. Previously published ascriptions to Sonora (Salvin and Godman, Phillips, etc.) are based on Allen (1893 a) who lists a specimen from San Diego, a Chihuahua locality.

\section{SPATULA CLYPEATA (LINNAEUS)}

\section{SHOVELLER}

Anas clypeata Linnaeus, Syst. Nat., ed. 10, 1, 1758, 124 (coasts of Europe = southern Sweden).

Spatula clypeata Lawrence, 1874, 314 (Guaymas).-Baird, Brewer, and Ridgway, 1884, 526 (Guaymas).-Price, 1899, 90 (lower Colorado River).- Salvin and Godman, 1902, 218 (Guaymas).-Stone and Rhoads, 1905, 688 (lower Colorado River).-Cooke, 1906, 36 (Guaymas).-Phillips, 1925, 10 (Sonora).-van Rossem and Hachisuka, 1937 a, 328 (Guaymas; El Doctor).

Common migrant and winter visitant to suitable localities both coastwise and in the interior. Additional localities are San Carlos Bay, December 24, 1931; San Pedro Bay, December 25, 1931 ; Tóbari Bay, April 29, 1930 (van Rossem notes) ; San Pedro River, October 13, 1892; Sonoyta, January 11, 1894 by Mearns and Holzner (U. S. Nat. Mus. catl.). Quitovaquita and Gray's Ranch [Arizona], March 4 to April 28, 1939 (Huey, 1942, p. 
363). Extreme dates are October 13 (San Pedro River) and April 29 (Tóbari Bay).

\author{
NYROCA AMERICANA (EYTON)
}

REIHFAI)

Fuligula americana Eyton, Monog. Anat., 1838, 155 (North America).

Nyroca americana van Rossem, 1933 b, 199 (San José de Guaymas).- Huey, 1935, 251 (Punta Peñascosa).—van Rossem and Hachisuka, 1937 a, 328 (Guaymas).-Williams, 1944, 255, map (Sonora locs.).

A seemingly rather common migrant and winter visitant, both coastally and in the interior. To the few published records are added those of two specimens entered in the National Muscum catalogue as taken by Mearns and Holzner on the Santa Cruz River, November 18, 1892, and October 20, 1893, respectively; Cananea, October 2 and November 9, 1930; Pueblo Yaqui, December 20, 1939; Empalme, March 13, 1934 (F. C. Lincoln, in litt.). Extreme dates are October 2 (Cananea) and March 13 (Empalme).

\title{
NYROCA COLLARIS (DONOVAN)
}

\section{RING-NFCKFD DUCK}

Anas collaris Donovan, Brit. Birds, 6, 1809, pl. 147 and text (Lincolnshire, England. Found in Leadenhall market, London).

Known, certainly, from Sonora only on the basis of a specimen in the National Museum, taken by Mearns and Holzner on the Santa Cruz River, October 20, 1893. Price has recorded the Ring-necked Duck as present at the head of the Gulf "in flocks," but as remarked by Grinnell (1928, p. 238), this is highly questionable.

\section{NYROCA AFFINIS (EYTON) \\ LESSFR SCAUP DUCK}

Fuligula affinis Eyton, Monogr. Anat., 1838, 157 (North America).

Aythya affinis Price, 1899, 90 (lower Colorado River).

Nyroca affinis van Rossem, 1932, 130 (Tiburon Island; San Carlos Bay; San Pedro Bay).-Huey, 1935, 251 (Punta Peñascosa).- -van Rossem and Hachisuka, 1937 a, 329 (Guaymas; San Jose de Guaymas; Kino Bay; Aranjuez).-Abbott, 1941, 417 (Guaymas).

Common, at times abundant, migrant and winter visitant coastwise. Fresh-water records in addition to that of Price for the lower Colorado River, are Ciudad Obregón, November 10, 1940, and February, 1941; 
Hermosillo, January 13,1941 (F. C. Lincoln, in litt.). Seasonally extreme dates are from November 10 (Ciudad Obregón) to April 25 (Guaymas). In the latter instance the individuals noted were possibly non-breeding birds which would not have migrated northward, although large flocks, presumably migrants, have been noted near Guaymas as late as April 14.

\section{BUCEPHALA ALBEOI.A (LinNaEUS)}

\section{BUFFLE-HEAD}

Anar Albeola Linnaeus, Syst. Nat., ed. 10, 1, 1758, 124 (America= Newfoundland).

Charitonetza albeola Price, 1899, 90 (lower Colorado River)-van Rossem and Hachisuka, 1937 a, 329 (Ciudad Obregon).

Rather rare winter visitant. There are four records, all but one from fresh-water localities; lower Colorado River in early December, 1898 (Price, 1899), which may not actually be within Sonora limits; specimen collected by Wright at Ciudad Obregón on November 17, 1930; observed in hunter's bag in the same locality on December 10, 1941: Punta Peñascosa, January 21 to 23, 1930 ("common"; 3 specimens taken; Sheffler coll. and notes).

\section{MEI.ANITI A PERSPICILLATA (LINNAEUS)}

\section{SuRF SCOTER}

Anas perspicillata Linnaeus, Syst. Nat., ed. 10, 1, 1758. 125 (Hudson Bay). Melanitta perspicillata van Rossem, 1932, 131 (San Pedro Bay; San Carlos Bay; Kino Bay; Tepopa Bay: San Esteban Island).--Huey, 1935, 251 (Punta Peñascosa).- van Rossem and Hachisuka, 1937 a, 329 (San Esteban Island).

Common in winter and spring in the Gulf and coastal bays from about latitude $28^{\circ}$ northward. Extreme dates of record are December 25 (San Pedro Bay) and April 19 (San Estéban Island). Scoters of some species (probably, in large part the present one) are said to winter "by the acre" at the head of the Gulf (Sanford, Bishop, and Van Dyke, 1924, p. 531).

\section{OXYURA JAMAICENSIS RUBIDA (WILSON)}

\section{RuDI)Y DUCK}

Anas rubidus Wilson, Amer. Orn., 8, 1814, 128, pl. 71, figs. 5, 6 (Delaware River, near Philadelphia).

Erismatura jamaicensis rubida van Rossem and Hachisuka, 1937 a, 329 (Guay. mas).

Erismatura jamaicensis (not Anas jamaicensis Gmelin) Stone and Rhoads, 1905, 688 (lower Colorado River). 
There are seemingly but three authentic records, those of a specimen in the Museum of Comparative Zoölogy taken by W. W. Brown, Jr., at Guayinas, March 10, 1905; 9 miles S.W. of Cuidad Obregón, November 24, 1944 (Sheffler notes; "very common") ; and another in the U. S. National Museum taken by Mearns and Holzner on the Colorado River at Monument 204, March 24, 1894. The "Pachico, Sonora" ascription of Salvin and Godman (1902) pertains to Chihuahua; that of Stone and Rhoads for the lower Colorado River is indefinite as to locality.

\section{MERGUS MERGANSER AIMERICANUS CASSIN}

\section{AMERICAN MERganSer}

Mergus americanur Cassin, Proc. Acad. Nat. Sci. Phila., 6, 1852, 187 (North America).-Stone and Rhoads, 1905, 687 (lower Colorado River).

Mergus merganser americanus Bent, 1925, 1 (Sonora).--van Rossem and Hachisuka, 1937 a, 329 (Guaymas; San Jose de Guaymas; San Esteban Island).

Seemingly a rather uncommon winter visitant. There is one record for the Colorado delta in "February," 1905. What may have been transients rather than winter visitants have been recorded as late as April 17 at San Estéban Island and April 22, 1930, at Guaymas. An unpublished record is Punta Peñascosa, January 21 to 23, 1930 ("fairly common," Sheffler notes).

\section{MERGUS SERRATOR LINNAEUS}

\section{RfiD-BREASTfiD Mfrgansfer}

Mergus Serrator Linnaeus, Syst. Nat., ed. 10, 1, 1758, 129 (Europe=Sweden).

Mergus serrator Townsend, 1923, 9 (Tiburon Island).-van Rossem, 1932, 131 (Guaymas; San Pedro, San Carlos, Kino, and Tepopa Bays; Tiburon Island).-. Huey, 1935, 251 (Punta Peñascosa).- -van Rossem and Hachisuka, 1937 a, 329 (Guaymas).-Abbott, 1941, 417 (Bocochibampo).

Merganser serrator Stone and Rhoads, 1905, 688 (lower Colorado River).

Common winter visitant coastwise from about Guaymas northward, where favoring sheltered lagoons rather than open water off shore. Aside from published data, Anthony (notes) found Red-breasted Mergansers common at El Golfo on November 24, 1930, and Allan Phillips (notes) observed 25 at Puerto Libertad on February 4, 1932. There is but one freshwater record-the Colorado delta in "February," 1905. Extreme dates are December 23 (Guaymas) and April 14 (Bocochibampo). 


\title{
Order FALCONIFORMES BiRdS OF PREY
}

\author{
Family Cathartidae American Vultures
}

CORAGYPS ATRATUS (BECHSTEIN)

\section{BLACK Vulture}

Vultur atratus Bechstein, in Latham, Allgem. Leb., Vögel, 1, 1793, Anh., 655 (Florida).

Coragyps atratus atratus van Rossem, 1931 c, 242 (Guaymas; Saric; Pesqueira Obregon; Tesia); 1934 d, 428 (Oposura).-Bent, 1937, 43, in text (Guaymas Tonichi).-Abbott, 1941, 417 (Guaymas).- Huey, 1942, 363 (boundary at Quitovaquita).

Cathartista atrata Belding, 1883, 344 (Guaymas).-Salvin and Godman, 1901, 133 (Guaymas).

Common, locally abundant, resident of Lower Sonoran and Tropical zones almost throughout the State, except that there are no records as yet from the deserts west of longitude $113^{\circ}$, nor from any of the islands. Concentration is most likely to occur in the vicinity of towns and ranches. A rather rapid extension of range to the northward seems to have taken place within a relatively few years for the species was not noted by earlier observers anywhere north of the limits of the Tropical zone (Guaymas and Oposura). It is now common nearly everywhere, a few modern records being Nogales and Rancho La Arizona southward to Agiabampo, with distribution almost continuous and with numbers rapidly increasing southerly, May and June, 1937 (van Rossem notes) ; Pilares, in the northeast, June 23, 1935 (Univ. Mich.) ; Altar, in the northwest, February 2, 1932 (Phillips notes); Magdalena, May, 1925 (Dawson notes; [not noted in that locality by Evermann and Jenkins in July, 1887]). The highest altitudes where observed to date are Rancho La Arizona, 3,200 feet; Nogales, 3,850 feet; Rancho Santa Bárbara, 5,000 feet, the last at the lower fringe of the Transition zone.

\section{CATHARTES AURA TETER FRIEDMANN}

\section{Western TuRKey Vulture}

Cathartes aura teter Friedmann, Proc. Biol. Soc. Wash., 46, Oct. 26, 1933, 188 (Riverside, California); ibid., in text (Guadalupe Cañon).-Huey, 1935, 251 (Punta Peñascosa).

Cathartes aura septentrionalis (not Cathartes septentrionalis Wied) van Rossem, 1931 c, 241 (Guaymas; Tobari Bay; El Doctor; Pesqueira; Saric; etc.) ; 1932, 131 (Tiburon Island).-Abbott, 1941, 417 (Guaymas).

Cathartes aura (not Vultur aura Linnaeus) Belding, 1883, 344 (Guaymas).Evermann and Jenkins, 1888, 68, 69 (Magdalena; Guaymas).-Allen, 1893 a, 34 
(Fronteras).-Salvin and Godman, 1901, 134, part (Guaymas; Fronteras).Stone and Rhoads, 1905, 689 (lower Colorado River).

Common resident throughout the State, apparently irrespective of zonal or associational considerations. It is usually decidedly less numerous than the Black Vulture in Tropical zone towns and lowlands, but outnumbers that species northerly and at higher elevations. Some additional localities are Cajón Bonito Creek; Sonoyta; common resident of all boundary localities (Mearns notes); El Alamo; Rancho Costa Rica (Lamb notes); Rancho Santa Bárbara; Agiabampo (van Rossem notes).$^{5}$

\section{Family Accipitridae Kites, Hawks, and Allies}

\section{ACCIPITER GENTILIS APACHE VAN ROSSEM}

\section{Sierra Madre GoshaWK}

Accipiter gentilis apache van Rossem, Proc. Biol. Soc. Wash., 51, May 19, 1938, 99 (Paradise, Cochise County, Arizona); ibid., in text (Yecora).

Astur atricapillus (not Falco atricapillus Wilson) Salvin and Godman, 1899, 45, part (Yecora).

Accipiter atricapillus striatulus (not Astur atricapillus striatulus Ridgway) van Rossem, 1936 d, 126 (Yecora; crit.).

The only known occurrence in Sonora is that of a single adult, taken by Lloyd at Yécora on April 13,1888, and now in the collection at the British Museum. The altitude given, "8,500 feet," is probably in excess of the actual elevation.

\section{ACCIPITER COOPERII MEXICANUS SWAINSON}

\section{Western COOPER HaWk}

Accipiter Mexicanus Swainson, Fauna Bor.-Amer., 2, 1831 [Feb., 1832], 45, footnote (Real del Monte, Hidalgo, México).

Accipiter cooperii mexicanus van Rossem, 1931 c, 242 (Saric; Chinobampo); 1932, 131 (Tiburon Island); 1934 d, 428 (Alamos; Oposura).

Accipiter cooperi mexicanus Thayer and Bangs, 1906, 18 (La Chumata).

Accipiter cooperi (not Falco cooperii Bonaparte) Salvin and Godman, 1899, 46, part (Hermosillo).-Stone and Rhoads, 1905, 689 (lower Colorado River).Bailey, 1928, 160, part (San Luis Mountains).

Accipiter cooperii cooperii Huey, 1942, 364 (Gray's Ranch; Quitovaquita, [Arizona]).

\footnotetext{
5 The only specimen of the Turkey Vulture collected in Sonora seems to be one from Guadalupe Cañon identified by Friedmann as teter. It is likely that all northern records belong under this name, but whether it applies also to Tropical zone resident birds remains to be determined.
} 
Fairly common resident of timbered localities northerly, chicfly in the Upper Sonoran zone although possibly breeding locally in Lower Sonoran areas westward to about longitude $113^{\circ}$. Definite or very probable breeding localities are the Pajaritos Mountains, San Luís Mountains, the Sierra de San Antonio, and the Sierra de Oposura. Much more common and widespread in fall, winter, and early spring, when occurring generally over the State and on Tiburón Island. Further stations are San José de Guaymas, January 20, 1933 (Lamb notes); Santa Cruz River on the boundary, August 20 and Scptember 4, 1892; San Pedro River, October 11, 1892; Hall's Ranch and Guadalupe Cañon, October 2, 1892; Sonoyta and Pozo de Luís, December 29, 1893 to January 25, 1894 (U. S. Nat. Mus.; Mearns notes) ${ }^{6}$

\section{ACCIPITER STRIATUS VEI.OX (WILSON)}

\section{NorthFrn Sharp-ShINNFi) HaWK}

Falco velox Wilson, Amer. ()rn., 1812, 116, pl. 45, fig. 1 (Banks of the Schuylkill River, near Philadelphia, Pennsylvania).

Accipiter velox Allen, 1893 a, 34 (Granados).... Price, 1899, 91 (lower Colorado River).-Stone and Rhoads, 1905, 681 (30 miles below Yuma).- van Rossem, 1931 c, 242 (Tecoripa; Saric, Tesia).

Accipiter striatus velox van Rossem, 1934 d, 428 (Alamos).

Common migrant and winter visitant in Sonoran and Tropical zones throughout the State, although most records are from northerly localities. Additional records are from 15 miles south of San Luis (Dickey coll.); Pozo de Luis and Sonoyta, December 29, 1893 to January 25, 1894; (Mearns notes). San José de Guaymas, January 20, 1933 (Lamb notes); San Pedro River, October 10, 1892; San José Mountains, October 5 and 6, 1892; Santa Cruz River, November 6, 1892; Colorado River at Monument 204, March 28, 1894; Cajón Bonito Creek, September 8 to 28, 1893 ; (U. S. Nat. Mus.; Mcarns notes). Extreme dates are September 8 (Cajón Bonito Creek) and March 28 (Monument 204). However, Huey (1942, p. 363) records a specimen from Quitovaquita, just on the Arizona side of the boundary as late as May 1, 1939.

6 While convinced that the Cooper Hawks of the Pacific coast and northwestern México constitute a recognizable race, the name mexicanus is of dubious applicability. The type locality favors the probability that mexicanus was based on a migratory individual of the nominate race, conperii. 


\section{ACCIPITER STRIATUS SUTTONI VAN ROSSEM}

\section{MEXICAN Sharp-SHINNFD HaWK}

Accipiter striatus suttoni van Rossem, Auk, 56, No. 2, April 7, 1939, 127 (Mesa del Chipinque, Nuevo León, México); ibid., in text (Tesia).-A. O. U. Comm., 1944, 444 (lowlands of Sonora).

Accipiter velox (not Falco velox Wilson) van Rossem, 1931 c, 242, part (Tesia).

Known only as a rare winter and early spring visitant in the lower Mayo River valley. The two specimens of record (Dickey coll.) were taken by Wright at Tesia on December 29, 1929, and March 23, 1930.

\section{BUTEO ALBICAUDATUS hYPOSPODIUS GURNEY}

\section{SENNETt White-TAILED HaWk}

Buteo hypospodius Gurney, Ibis, 1876, 73, pl. 3 (Medellín, Colombia).

Status uncertain. Three solitary individuals were seen (unmistakably) between Empalme and Potam in the Yaqui River valley on May 12, 1937, by van Rossem and Hannum. The date suggests that these might have been breeding birds. J. T. Wright states that he saw this species in summer (dates not recalled) in this same general region. He collected an adult male (examined in the Chicago Nat. Hist. Mus.) at Tres Marías near Allamos on October 21, 1934.

\section{Buteo jamaicensis calurus Cassin}

\section{Western Red-TAIled HaWk}

Buteo calurus Cassin, Proc. Acad. Nat. Sci. Phila., 7, 1855, 281 (near Fort Webster, Río Mimbres, New Mexico).

Buteo borealis calurus Belding, 1883, 344 (Guaymas).-Price, 1899, 91 (lower Colorado River).- Stone and Rhoads, 1905, 689 (lower Colorado River).-Thayer and Bangs, 1906, 18 (La Chumata).--van Rossem, 1931 c, 242 (El Doctor; Guaymas) ; 1932, 131 (Tiburon Island) ; 1934 d, 428 (Alamos).-Sheffler, 1931 a, 138 (Imuris).--Huey, 1935, 251 (Punta Peñascosa); 1942, 364 (Gray's Ranch, etc.).

Buteo borealis (not Falco borealis Gmelin) Salvin and Godman, 1900, 61, part (Guaymas).

Buteo borealis socorroensis (not of Nelson) Brewster, 1902, 85, part, in text (Alamos).

Buteo rufescentior Salvin and Godman, 1900, 61, part, in text (Sonora [Hermosillo, part]).

Fairly common resident throughout the State, irrespective of altitude or zonal considerations, except that records from the Tropical zone coastal plain south of Guaymas are lacking. Additional records are Nogales, May 6; Rancho La Arizona, May 9; Magdalena, May 10; Guirocoba in 
May and early June; and Rancho Santa Bárbara, June 8 to 17, 1937 (van Rossem notes) ; Pilares, July 15, 1935 (Univ. Mich.; juvenile just from nest, identified by Brodkorb and Van Tyne as "good calurus"); Cajón Bonito Creek and Guadalupe Cañon (common; breeding; July, 1892, Mearns notes); San Bernardino River on the boundary, August 15 and September 3, 1892; San Pedro River, October 10, 1892; Santo Domingo, January 15, 1894 (U. S. Nat. Mus. catl., and Mearns' notes).

\section{Buteo JAMAICENSIS fuertesi Sutton ANd Van TyNe}

\section{Fuertes Red-tailed Hawk}

Buteo jamaicensis fuertesi Sutton and Van Tyne, Occ. Pap. Mus. Zool., Univ. Michigan, No. 321, Sept. 23, 1935, 1 (Calamity Creek Bridge, 22 miles south of Alpine, Brewster County, Texas).- - van Rossem, 1942 f, 450 (Hermosillo).

Buteo borealis (not Falco borealis Gmelin) Salvin and Godman, 1900, 61, part (Hermosillo, part).

Rare winter visitant. One record, that of a typical adult female in the British Museum (90.4.26.140), taken at Hermosillo on November 23, 1887, by (or for) F. Ferrari-Perez. Examined by van Rossem in September, 1933, when identified as "kriderii"; re-examined in June, 1938, and August, 1939, when reidentified as fuertesi.

\section{Buteo albonotatus albonotatus Kaup}

\section{ZONE-TAILED HAWK}

Buteo albonotatus Kaup, Isis von Oken, 1847, Heft 5, [May], col. 329 (México).- -van Rossem, 1934 d, 429 (Alamos; Hacienda de San Rafael; Oposura).

Buteo albonotatus albonotatus van Rossem, 1931 c, 243 (Obregon).

Buteo abbreviatus (not of Cabanis) Salvin and Godman, 1900, 59, part (Hermosillo)

Fairly common summer visitant in the Upper Sonoran and lower parts of the Transition zones (chiefly oak or oak-pine associations) east of the western desert region; also occurs in winter in lower Sonoran and Tropical zone lowlands from about latitude $29^{\circ}$ southward. Further records are from Rancho La Arizona (the westernmost station), May 8, 1937; Rancho Santa Bárbara, June 12, 1937 (van Rossem notes) ; Rancho Costa Rica, December 16, 1932 (Lamb notes) ; 2 miles east of Guirocoba [no date], 1939 (Mus. Vert. Zool.) ; San Luís Mountains on the boundary, June 1 (eggs) and July 7, 1892 ; Cajón Bonito Creek, July 4, 1892, by Mearns and Holzner (U. S. Nat. Mus. catl.). The Hermosillo specimen in the British Museum was taken by, or for, Ferrari-Perez, in November 
or December, 1887. Price's observation (1899, 91) of "hundreds" seen in the Colorado delta on December 3, 1898, is obviously an error in identification. Huey (1942, p. 364) reports this hawk from Dowling Well and Gray's Ranch, Lower Sonoran localities on the Arizona boundary, on May 9 and 13, 1939. However, these occurrences may pertain to migrating or non-breeding individuals.

\section{BUteo nitidus maximus (VAN Rossem)}

\section{NORTHERN GRAY HaWk}

Asturina plagiata maxima van Rossem, Condor, 32, Nov., 1930, 103 (San Javier, Sonora, México) ; ibid., in text (Saric; Guirocoba; Chinobampo; Magdalena).-1931 c, 243 (same locs.).

Buteo nitida maxima A.O.U. Comm., 1944, 445 (San Javier).

Buteo plagiatus maximus van Rossem, 1934 d, 429 (Alamos; Hacienda de San Rafael; Nacozari; crit.).

Asturina plagiata (not of Schlegel) Allen, 1893 a, 34 (Fronteras; Oputo) Salvin and Godman, 1900, 74, part (Fronteras; Oputo).-Sheffler, 1931 a, 138 (Imuris).

Asturina plagiata plagiata Miller and Griscom, 1921, 4, part (Sonora; crit.).

Asturina nitida plagiata Peters, 1931, 240, part (San Javier).

Fairly common summer visitant to wooded areas (chiefly riparian associations) in Sonoran zones eastward from the longitude of the Pajaritos Mountains and Guaymas. Resident and more numerous in the Tropical zone in the extreme south, and there reaching the coastal plain where suitable timber occurs. The statement (van Rossem, $1931 \mathrm{c}$ ) that this hawk is a permanent resident throughout the State is not justified; there are no northerly winter records. Additional localities are Agiabampo, May 14; San Francisco Cañon, May 29; Rancho Santa Bárbara, June 10, breeding in Transition zone; Tesia, June 22, 1937 (van Rossem notes); Guirocoba, common in December, 1941 (Sheffler notes). Arrival and departure dates for northern localities are March 29 (Nacozari) and October 26 (Oputo).

\section{BUTEO SW AINSONI BONAPARTE}

\section{SWAINSON HAWK}

Buteo suainsoni Bonaparte, Geog. and Comp. List, 1838, 3 (Columbia River= Fort Vancouver, Washington).--Allen, 1893 a, 34 (Fronteras).- Salvin and Godman, 1900, 68 (Fronteras).-Thayer and Bangs, 1906, 18 (Opodepe).- - van Rossem, 1931 c, 243 (El Alamo)-Bent, 1937, 233 (Opodepe).

Common summer visitant to Sonoran zone river valleys and deserts south to about the latitude of Guaymas. There are no records for the 
Tropical zone, nor for the extreme northwest other than the almost impossible one of "several seen" in the Colorado delta in February (Stone and Rhoads, 1905, 689). Additional stations are Pesqueira, June 21, 1931 (Bishop coll.); Santa Ana, May 11, 1937 (Dickey coll.); Santa Ana to Guaymas, May 11 and 12, 1937 (common, nest building; van Rossem notes). Extreme dates are May 11 (Santa Ana) and September 23 (Fronteras).

\section{PARABUTEO UNICINCTUS SUPERIOR VAN ROSSEM}

\section{NORTHWFStFrn Harris HaWk}

Parabuteo unicinctus superior van Rossem, Trans. San Diego Soc. Nat. Hist., 9, no. 33, Feb. 17, 1942, 377 (Laguna Dam, Imperial Co., California); ibid., in text (Sonora).

Buteo harrisi (not of Audubon) Salvin and Godman, 1900, 56, part (Guaymas). Parabuteo unicinctus harrisi Belding, 1883, 344 (Guaymas).--van Rossem, 1931 c, 242 (Tesia; 10 miles N. of Guaymas).-Dickey and van Rossem, 1938, 119 (Sonora; crit.).-Abbott, 1941, 418 (Guaymas).

Parabuteo unicinctus harrissi [sic] Stone and Rhoads, 1905, 689 (lower Colorado River).

Common resident of Lower Sonoran and Tropical zones from the Colorado River eastward to the limits of the western desert area and south to the Sinaloa boundary. Easternmost stations to date are Pozo de Luís, Santa Ana, Cerro Blanco, and Guirocoba. Unpublished stations are Pozo de I.uís, January 4, 1892; Sonoyta, January 17, 1892 (U. S. Nat. Mus.) ; Cerro Blanco, April 15, 1903; Camoa, October 18, 1934 (Chicago Nat. Hist. Mus.) ; Rancho Costa Rica, December 13, 1932 (Lamb notes) ; Santa Ana to Agiabampo, pairs at frequent intervals, May 11 to 13, 1937; Guirocoba, May, 1937; Colonia Independencia, May 3, 1937, common (van Rossem notes). Mearns' field book lists a specimen taken on the Arizona side of the boundary at San Bernardino Ranch, August 3, 1892. Corresponding occurrences are to be expected in Sonora.

\section{HYPOMORPHNUS URUBITINGA RIIGGAY'I (GURNFY)}

\section{RIDGWAY BLACK HAWK}

Urubitinga ridgwayi Gurney, List. Diurn. Bds. Prey, 1884, 148 (Guatemala). H)pomorphnus urubitinga ridguayi Peters, 1931, 244 (Sonora).-van Rossem, 1934 d, 429 (Alamos).

Status uncertain. Known only from the two specimens taken by Frazar at Alamos on March 8, 1888. It is quite possible that this black hawk is really not so uncommon in Sonora as the single record might indicate. 


\section{BUteogallus aNTHRACINUS MICRONYX VAN ROSSEM AND HaCHISUKA}

\section{NORTHWESTERN BlaCK HAWK}

Buteogallus anthracinus micronyx van Rossem and Hachisuka, Trans. San Diego. Soc. Nat. Hist., 8, June 15, 1937, 361 (Arivaipa Creek, Graham Co., Arizona); ibid., in text (Alamos; Girocoba).

Urbitinga anthracina (not Falco antbracinus Lichtenstein) Thayer and Bangs, 1906, 18 (Opodepe or La Chumata).

Urubitinga anthracina antbracina Bent, 1937, 263, part, (Sonora).

Buteogallus anthracinus anthracinus van Rossem, 1934 d, 430 (Alamos).Aldrich and Bole, 1937, 47 (Cajon Bonito Creek).

Common summer visitant to riparian associations from the Pajaritos Mountains eastward to the San Luís Mountains and southward throughout the State. There are, however, no tide-water records. Absence from the northwestern deserts is due, in all probability, to the lack of permanent streams. Resident in the Tropical zone, at least in the vicinity of Alamos and Guirocoba. Further localities are Rancho La Arizona, nesting May 9; Rancho Santa Bárbara, nesting, 5,000 feet, June 9, 1937 (van Rossem notes) ; Pilares, June 25, 1935 (Univ. Mich.) ; Mayo River valley, October 17, 1930 (Wright notes) ; Guirocoba, December 3 to 5, 1941 (common; Sheffler notes). Seasonal dates for the northern part of the State are May 9 (Rancho La Arizona) and September 27 (Cajón Bonito Creek).

\section{AQUILA CHRYSAËTOS CANADENSIS (LINNAEUS)}

\section{GOLDEN EAGLE}

Falco canadensis Linnaeus, Syst. Nat., ed. 10, 1, 1758, 88 (in Canada $=$ Hudson Bay).

Aquila chrysaëtos canadensis Huey, 1935, 251 (Punta Peñascosa).-Bent, 1937, 313, in text (San Bernardino River).

Aquila chrysaëtos (not Falco chrysaëtos Linnaeus) Price, 1899, 91 (lower Colorado River).

Apparently a not uncommon resident across the northern part of the State. Records include mountains, plains and deserts and extend from the San Luis Mountains to the Colorado River. Additional stations are Cajón Bonito Creek and the San Luís Mountains, July, 1892; San Luís Springs at Monument 66, September 24, 1893; Pozo de Luís, December 29, 1893 to January 8, 1894; considered to be common throughout the boundary region (Mearns notes); Tiburón Island, April 5, 1935 (Mus. Vert. Zool.). The last named locality is the southernmost recorded to date. 


\section{CiRcus CyANEUS hudsonius (LinNaeus)}

\section{MARSH HAWK}

Falco budsonius Linnaeus, Syst. Nat., ed. 12, 1, 1766, 128 (ad fretum Hudsonis= Hudson Bay).

Circus budsonius Salvin and Godman, 1899, 43 (Hermosillo).- Stone and Rhoads, 1905, 689 (lower Colorado River).--van Rossem, 1931 c, 243 (Tccoripa); 1932, 131 (Tiburon Island; San Esteban Island; San Carlos, San Pedro, Kino, and Tepopa Bays).--Huey, 1942, 364 (Sonoita River).

Circus hudsonicus [sic.] Huey, 1935, 251 (Punta Peñascosa).

Common migrant and winter visitant, distributed probably over the whole of the lowlands, although all records to date are from about latitude $27^{\circ}$ northward. Further occurrences are from Colorado River opposite the mouth of the Hardy, March 26, 1894; Santa Cruz River, November 12 and 16,1892 (Mearns and Holzner in U. S. Mat. Mus. catl.) ; 9 miles southwest of Cuidad Obregón, November 24; Tóbari Bay, November 25, 1944 (Sheffler notes; "fairly common"); El Doctor, December 8, 1925 (Dickey coll.) ; El Álamo, December 5, 1932 (Lamb notes) ; Magdalena, April 20, 1925 (Dawson notes) Sonoyta, January 9 to 29, 1894 (Mearns notes). Extreme dates are November 12 (Santa Cruz River) and April 20 (Magdalena).

\section{Geranospiza nigra livins Bangs ani Penari)}

\section{SONORA BLACK HARRIFR}

Geranospiza cuerulescens livens Bangs and Penard, Proc. Biol. Soc. Whash., 34, June 30, 1921 (Alamos, Sonora, México).--Bangs, 1930, 187 (location of type).

Geranospiza nigra livens Peters, 1931, 268 (Alamos).-Swann, 1925, 157 (Alamos; crit.).- van Rossem, 1934 d, 430 (Alamos).

Geranospizias caerulescens livens Swann, 1922, 1, following 233 (Alamos).

Resident in Tropical zone riparian associations in the extreme southern part of the State. In addition to the original pair collected by Frazar at Alamos on February 9, 1888, there are two specimens in the Dickcy collection taken by van Rossem and Hannum. One of these, an adult male, was collected at Guirocoba on June 2, 1937; the other, an immature male, is from Tesia in the lower Mayo River valley, June 19, 1937. The only winter record is that of a specimen taken at Guirocoba on November 17, 1944 (Sheffler notes). At the McCarty ranch at Guirocoba the owncrs had preserved portions of two immature birds which were killed at that place in September or October, 1936. 


\section{Family Pandionidae Ospreys \\ PANDION HALIAETUS CAROLINENSIS (GMELIN)}

\section{OSPREY}

Falco Haliaetos $y$ carolinensis Gmelin, Syst. Nat., 1, Pt. i, 1788, 263 (in America $=$ South Carolina .

Pandion haliaëtus carolinensis Belding, 1883, 344 (Guaymas).-Mailliard, 1923, 455 (San Esteban Island; Tepopa Bay; Pelican Island).--van Rossem, 1931 c, 243 (San Pedro Nolasco Island; Guaymas; Tobari Bay); 1932, 131 (Tiburon Island). - Huey, 1935, 251 (Punta Peñascosa).

Pandion baliaetus (not Falco haliaetus Linnaeus) Salvin and Godman, 1897, 39, part (Guaymas).

Common resident of the entire Gulf area. There are three instances of inland occurrence: Rancho La Arizona, May 7, 1937 (van Rossem notes) ; Cajón Bonito Creek, September 27, 1893 (U. S. Nat. Mus. catl.) ; (northeastern) Sonora, April 23, 1909 (Mus. Comp. Zoöl.).

\section{Family Falconidae Caracaras and Falcons HERPETOTHERES CACHINNANS EXCUBITOR VAN ROSSEM}

\section{Northern LAUGHING Falcon}

Herpetotheres cacbinnans execubitor van Rossem, Trans. San Diego Soc. Nat. Hist., 9, Nov. 21, 1938, 10 (Volcán de Colima, Jalisco, México); ibid., in text, (extreme southern Sonora).

Herpetotheres cachinnans (not Falco cachinnans Linnaeus) Lawrence, 1874, 300 (western and southern Sonora).-Salvin and Godman, 1901, 112, part (west and south Sonora).- Sheffler and van Rossem, 1944, 140 (Guirocoba; nesting).

Resident in the Tropical zone foothills in the vicinity of Guirocoba. Known occurrences are as follows: single individual seen by van Rossem near Guirocoba, June 2, 1937; three pairs nesting in the same locality May 9 and 11, 1941 (two adults, one immature, one downy young, and two eggs in Sheffler collection); immature in post-juvenile molt, November 16, 1944. These data tend to verify the old Lawrence (1874) statement, made on the authority of Grayson, that the Laughing Falcon occurs in "southern and western Sonora." The specific localities of Grayson's observations are unknown. ${ }^{7}$

7 Wetmore (1944, pp. 35-38), has challenged the validity of excubitor on the ground that the paleness or buffiness in Mexican birds is a result of local relative humidity and because one specimen examined by him from eastern Guatemala exceeds in wing length the maximum of excubitor. Granted that he is correct on these two items (although neither is evident in the material examined by me), I do not see that they invalidate the race. He has shown no overlap whatever in tail length since there is actually a biatus between the largest chapmani $(232 \mathrm{~mm}$.) 


\section{POLYBORUS CHERIWAY AMMOPHILUS VAN ROSSEM Mexican Caracara}

Polyborus cheriway ammophilus van Rossem, Ann. and Mag. Nat. Hist., ser. 4, Oct. 1939, 441 (Tesia, Sonora, México).

Polyborus cheriway auduboni (not Polyborus audubonii Cassin) van Rossem, 1931 c, 243 (Tesia; Guaymas; Tobari Bay; Tecoripa; San Javier; Pesqueira; Guirocoba; 25 miles S. E. of Guaymas) ; 1934 d, 430 (Oposura).-Bent, 1937, 132, part, in text (Sonora).-Abbott, 1941, 417 (Guaymas).

Polyborus cheriway (not Falco cheriway Jacquin) Bclding, 1883, 344 (Guay. mas).-Bendire, 1892, (Sonora).- Salvin and Godman, 1901, 125, part (Guaymas).

Common resident of Lower Sonoran and Tropical zones from the Arizona border southward, though apparently absent from the extreme northwestern desert and from the northeastern valleys north of Moctezuma. Like the Black Vulture, and for the same reasons, the Caracara is most likely to be found in the vicinity of habitations. Some localities in addition to those published are Caborca, February 2, and Puerto Libcrtad, February 4, 1932 (Phillips notes); El Álamo, December 3, and Rancho Costa Rica, December 9, 1932 (Lamb notes) ; Sonoyta, January 9, 1894 (U. S. Nat. Mus.) ; Santo Domingo, in January or Fcbruary, 1894 (Mearns notes) ; Magdalena, March 27, 1936 (Benson notes); Rancho La Arizona; Hermosillo; Ciudad Obregón; Navojoa; Agiabampo, May, 1937; Kino Bay; Tepopa Bay, January, 1932 (van Rossem notes).

\section{FALCO MEXICANUS SCHLEgFL}

\section{PRAIRIE FALCON}

Falco mexicanus "Lichtenstein" Schlegel, Abh. Geb. Zool., heft 3, 1843, 15 (México)-Salvin and Godman, 1901, 115 (Hermosillo).-Huey, 1935, 251 (Punta Peñascosa) ; 1942, 364 (Gray's Ranch).

Fairly common winter visitant to Lower Sonoran deserts south at least to Hermosillo. Records to date, all of which are western except one, are San Pedro River on the boundary, October 14, 1892; Santo Domingo, January 15, 1894 (U. S. Nat. Mus. catl.) ; Pozo de Luís, December 29, 1893 to January 8, 1894 (Mearns notes) ; Hermosillo, November 28 and December 22, 1887. Gray's Ranch on the boundary, March 21 and 23, 1939.

and the smallest excubitor $(235 \mathrm{~mm}$.) examined by either of us and the average general size of excubitor (see also tarsus, middle toe, and bill measurements in the original description) is entirely too large to be ignored. Two recently taken Sonora specimens (Sheffler collection) measure: $\hat{o}$ wing, 295; tail, 248; $q$ wing, 295; tail, 252. 


\section{FALCO PEREGRINUS ANATUM BONAPARTE}

\section{Duck Hawk}

Falco Anatum Bonaparte, Geog. and Comp. List, 1838, 4 (Great Egg Harbor, New Jersey).

Falco peregrinus anatum Bancroft, 1927 b, 194 (San Esteban Island)-van Rossem, 1931 c, 244 (Tecoripa; San Pedro Martir Island; San Esteban Island); 1932, 132 (Tiburon Island).

Fairly common resident of suitable Gulf islands and probably of the mainland coast. Mainland records, most or all of which are probably those of transients or winter visitants, are San Bernardino River on the boundary, August 19, 1892 (U. S. Nat. Mus.) ; 9 miles S. W. of Ciudad Obregón, November 24; Tóbari Bay, November 25, 1944 ("actually abundant-as many as 6 in sight at once"; Sheffler notes); Tecoripa, March 2, 1929 (Dickey coll.).

\section{FALCO ALBIGULARIS PETROPHILUS VAN ROSSEM AND HaCHISUKA}

\section{NORTHWESTERN BAT FALCON}

Falco albigularis petrophilus van Rossem and Hachisuka, Proc. Biol. Soc. Wash., 50, Aug. 7, 1937, 107 (Guirocoba, Sonora, México).

Known in Sonora only from the vicinity of Guirocoba, where resident in limited numbers. To date, specimens have been collected as follows: breeding pair taken by van Rossem and Hannum on May 29 and June 1, 1937; breeding pair taken by Benson and Sibley, April 27, 1939 (Mus. Vert. Zool.) ; breeding female taken by Sheffler (with eggs), May 9, 1941; two specimens taken, three others seen by Sheffler, November 17 and 18, 1944.

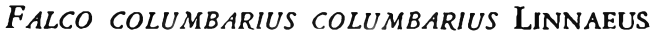

\section{EAstern Pigeon HaWk}

Falco columbarius Linnaeus, Syst. Nat., ed. 10, 1, 1758, 90 (in America $=$ South Carolina).- Salvin and Godman, 1901, 120, part (Hermosillo).

One casual or accidental midwinter record, an adult male taken by (or for) Ferrari-Perez at Hermosillo on December $28,1887 .{ }^{8}$

8 I have examined this specimen (in the British Museum) on several occasions and cannot escape the conclusion that it is in fact an example of the nominate race. 


\section{Falco columbarius bendirei Swann Western Pigeon Hawk}

Falco columbarius bendirei Swann, Bull. Brit. Orn. Club, 42, No. 265, Feb. 2, 1922, 66 (Fort Walla Walla, Washington).-Kenyon, 1942, 443 (south of Nogales).

Apparently a not uncommon winter visitant south at least to the Mayo River valley. Specimens have been examined as follows: San Pedro River, October 25, 1892; Colorado River at Monument 204, March 24, 1894 (Mearns and Holzner in U. S. Nat. Mus.) ; Camoa, October 16, 1934 (Wright in Chicago Nat. Hist. Mus.) ; 9 miles S.W. of Ciudad Obregón, November 24; seen at Tóbari Bay, November 25, 1944 ("fairly common at both places"; Shcffler coll. and notes). Six individuals seen by Kenyon in the Upper Sonoran Zone south of Nogales on February 2, 1942, must of course be allocated provisionally.

\section{FaLCO COLUMBARIUS RICHARDSONII RIDGWAY \\ Richardson Pigeon Hawk}

Falco (Hypotriorchis) richardsonii Ridgway, Proc. Acad. Nat. Sci. Phila., 1870 [Mch. 14, 1871], 145 (Interior of North America mouth of Vermilion River, South Dakota).

Falco columbarius richardsoni Dawson, 1923, 1634 (Sonora).

Falco richardsoni Salvin and Godman, 1901, 120 (Hermosillo; crit.).

Winter visitant. The three known occurrences are a specimen (examined) in the British Museum, taken by, or for, Ferrari-Perez at Hermosillo, November 21, 1887, and two specimens in the U. S. National Museum taken by Mearns and Holzner on the Santa Cruz River on the boundary, October 10 and November 6, 1892.

\section{FALCO SPARVERIUS SPARVERIUS LINNAFUS}

\section{AMERICAN SPaRrow HaWK}

Falco sparterius Linnaeus, Syst. Nat., ed. 10, 1, 1758, 90 (in America $=$ South Carolina).

Falco sparverius sparverius van Rossem, 1931 c, 244 (30 miles S.W. of Magdalena; Obregon; Tesia); 1934 d, 430 (Guaymas; Alamos; 35 miles S. of San Pedro).

(?) Falco sparterius subsp. van Rossem, 1932, 132 (Tiburon Island).

Falco sparterius phalaena van Rossem, 1931 c, 244, part (El Doctor, part; Tecorpia); 1934 d, 430, part (Alamos).

Common migrant and winter visitant nearly everywhere, although most common at lower levels. This is possibly the breeding race of the northern and eastern interior, but data are not available for decision. Further specimens have been examined from San José Mountains, August 11, 
1892; Santa Cruz River, October 23, 1892 (U. S. Nat. Mus.) ; Camoa, February 9, 1931 (Bishop coll.), October 11 and 15, 1934 (Chicago Nat. Hist. Mus.) ; Bonancita, December 17, 1905; Guaymas, March 4, 1905 (Mus. Comp. Zoöl.). Extreme dates are August 11 (San José Mountains) and April 24 (near Magdalena).

\section{Falco sparVERIUS peninsularis Mfarns}

\section{Mexican SPARRow Hawk}

Falco sparverius peninsularis Mearns, Auk, 9, No. 3, July, 1892, 267 (San José, Baja California, México)-Bond, 1943, 176 (Guaymas; range in Sonora).

Falco sparverius phalaena (not Tinnunculus phalaena Lesson) van Rossem, 1931 c, 244, part (El Doctor, part; Obregon; Guaymas; 12 miles W. of Magdalena; 15 miles S. of Nogales); 1934 d, 430, part (Cumpas).-Sheffler, 1931 a, 138 (Imuris).

(?) Falco sparterius deserticolus (not of Mearns) Allen, 1893 a, 34 (Granados; Nacori).-Price, 1899, 91 (lower Colorado River).

(?) Tinnunculus sparverius (not Falco sparverius Linnacus) Salvin and Godman, 1901, 121, part (Hermosillo; Granados; Nacori).

Fairly common resident of Lower Sonoran and Tropical zone deserts and river valleys throughout the State, although evidently decidedly less numerous southerly. Additional specimens have been examined from Agiabampo, April 19, 1933 (Lamb coll.) ; Presidio near Guaymas, March 28, 1905; Batamoti, November 27, 1905; San Marcial, November 20, 1905 (Mus. Comp. Zoöl.) ; Kino Bay, February 16, 1935; 4 miles south of International boundary, below San Miguel, Arizona, January 17, 1928 (Nat. Hist. Mus.) ${ }^{9}$

\section{Order GALLIFORMES Gallinaceous Birds}

\section{Family Cracidae Curassows and Guans \\ ORTALIS WAGLERI GRISEICEPS VAN ROSSEM \\ Sonora Chachat.aca}

Ortalis wagleri griseiceps van Rossem, Bull. Mus. Comp. Zoöl., 77, No. 7, Dec., 1934, 431 (Alamos, Sonora, México); ibid., in text (Hacienda de San Rafael). - Hellmayr and Conover, 1942, 167 (Guirocoba; Alamos; (hinobampo; crit.).Peters, 1943, 54 (re. type).

Ortalida uagleri (not of Gray) Lawrence, 1874, 306 (Sonora).

Ortalis uugleri van Rossem, 1931 c, 244 (Guirocoba; Chinobampo); 1942 e, 77 (Sonora; subgen.)-Peters, 1934, 18, part (southern Sonora).

${ }^{9}$ According to the careful studies of R. M. Bond, Sparrow Hawks from interior Sonora north of the Tropical zone come within the belt of intergradation between peninsularis and sparcerius. Until known breeding material becomes available for final determination the former name is used arbitrarily for the small, presumably resident birds of that area. 
Common resident of more densely grown chaparral and wooded areas in the foothills of the extreme southeast. Altitudes at which this Chachalaca has been detected range from 300 feet at Chinobampo at the base of the Sierra de Alamos to slightly over 2,000 feet near the headwaters of the Cuchujaqui and above Guirocoba, but even at the upper limits the distribution is confined to Tropical zone associations. An additional locality is San Francisco Cañon, May 30, 1937 (van Rossem notes).

\section{Family Phasianidae Pheasants and Quails \\ CALLIPEPLA SQUAMATA PALLIDA BREWSTER}

\section{Arizona Scaled Quail}

Callipepla squamata pallida Brewster, Bull. Nuttall Orn. Club, 6, April, 1881, 72, in text (San Pedro River, Arizona).-Bangs, 1914, 100 (northern Sonora).A.O.U. Comm., 1931, 89 (northern Sonora).-Bent, 1932, 51 (Sasabe; San Pedro).-Peters, 1934, 44 (northern Sonora).- van Rossem, 1936 d, 127 (range).Kelso, 1937, 2, in text (Sonora).-Hellmayr and Conover, 1942, 231 (northern Sonora).

Callipepla squamata (not Ortyx squamatus Vigors) Baird, 1859, 23, part (San Bernardino).-Brewer, in Baird, Brewer, and Ridgway, 1874 (3), 490, in text (San Bernardino).-Stephens, 1885, 228 (18 miles S. W. of Sasabe).-Allen, 1893 a, 34 (San Pedro).- Salvin and Godman, 1903, 290, part (San Pedro).

Common resident of extreme northern grass and mesquite plains east of about longitude $111^{\circ} 40^{\prime}$. The range of this quail in Sonora apparently consists of a narrow strip only a few miles in width near the International boundary, the southernmost definite record being that of a specimen taken by Bernard Bailey, 32 miles south of Nogales in November, 1932 (Mus. Comp Zoöl.). Two additional boundary localities are Cerro Gallardo ("Niggerhead Mountain") and the San José Mountains (Mearns notes). Audubon's (1906, p. 144) notation of the "Gambel's blue partridge" at Altar in September, 1849, most probably, though not certainly pertains to this species.

\section{LOPHORTYX GAMBELII GAMBELII GAMBEL}

\section{Gambel Quatl}

Lophortyx Gambelii "Nutt." Gambel, Proc. Acad. Nat. Sci. Phila., 1, Nos. 24-25, March-April [May 19], 1843, 260 (Some distance west [= east] of California [= southern Nevada]).

Lophortyx gambelii Baird, 1858, 645 (Sonora); 1859, 23 (San Bernardino).Stone and Rhoads, 1905, 681 (50 miles S. of Yuma).-Sheffler, 1931 a, 138 (Imuris) ; 1931 b, 164 (Santa Ana).

Lophortyx gambelii gambelii van Rossem, 1931 c, 245 (many locs. south to Guaymas and Tecoripa); 1932, 132, in text (Guaymas; crit.); 1934 d, 431 (Ba- 


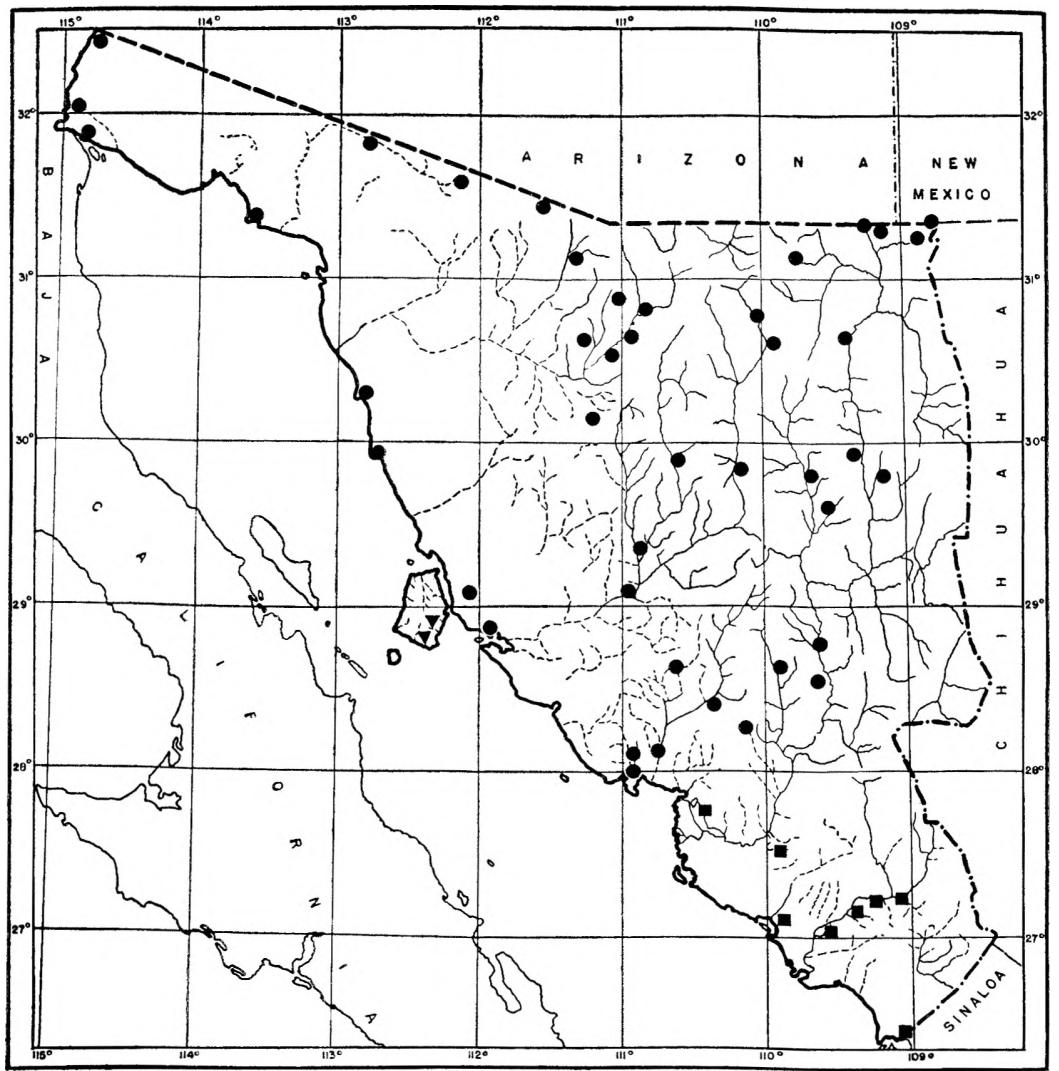

MaP 3. Distribution of Lophortyx gambelii. Circles, L. g. gambelii; squares, L. g. fulvipectus; triangles, L. g. pembertoni.

cuachi; 35 miles S. of San Pedro; Oposura; Granados); 1936 d, 128 (range in Sonora).-Peters, 1934, 45 (northern Sonora).-Burt, 1938, 13, in text (near Guaymas).-Hellmayr and Conover, 1942, 235, part (Cerro Blanco; Rancho Carrizo; Maytorena; Pesqueira).-Friedmann, 1943, 371, in text (Cajon Bonito Creek).

Lophortyx gambeli Belding, 1883, 344 (Guaymas).--Stephens, 1885, 228 (Sasabe; Port Lobos).-Ogilvie-Grant, 1902, 238, part (Hermosillo).- Salvin and Godman, 1903, 292 (Hermosillo; Guaymas; Santa Barbara).-A. O. U. Comm., 1910, 137 (Guaymas).

Lophortyx gambeli gambeli A.O.U. Comm., 1931, 90 (Guaymas).-Gorsuch, 1934, 13, 47 (Soyopa).- - Huey, 1935, 252 (Punta Peñascosa).

Callipepla gambeli Evermann and Jenkins, 1888, 68 (Magdalena).-Allen, 1893 a, 33 (Santa Barbara).-Price, 1899, 91 (lower Colorado River).-Nelson, 1902, 388 (Hermosillo; crit.). 
Lophortyx gambeli fulvipectus (not Callipepla gambeli fulvipectus Nelson) Thayer and Bangs, 1906, 18 (Opodepe).

Common, locally abundant, state-wide resident of Sonoran zones (mostly desert associations) south to about latitude $28^{\circ}$ coastwise and to about $28^{\circ} 30^{\prime}$ in the interior. Specimens from Guaymas eastward are all more or less intermediate toward the Tropical zone race fulvipectus, as are those from Tecoripa and San Javier. Unpublished localities for the Gambel Quail are so numerous that it is impractical to list all of them. Some are Puerto Libertad; Kino Bay (Nat. Hist. Mus.) ; Pilares (Univ. Mich.); San Bernardino Ranch; Sonoyta; Pozo de Luís (U. S. Nat. Mus. catl.); San Luís Mountains; Guadalupe Cañon (Mearns notes) ; Sierra Seri (Mus. Vert. Zool.).

\section{LOPHORTYX GAMBELII FULVIPECTUS (NELSON)}

\section{Mayo QuaIL}

Callipepla gambeli fulvipectus Nelson, Auk, 16, January, 1899, 26 (Camoa, Rio Mayo, Sonora, México).

Lophortyx gambeli fulvipectus Gorsuch, 1934, 13 (Navojoa).

Lophortyx gambelii fulvipectus van Rossem, 1931 c, 245 (Obregon; Tesia; Tobari Bay; 25 miles southeast of Guaymas; Agiabampo; crit.) ; 1932, 132, in text (southern Sonora; crit.).--Peters, 1934, 46 (southwestern Sonora).-Burt, 1938,13 , in text ("just south of Guaymas").

Lophortyx fulvipectus Sharpe, 1898, 44 (Sonora).

Lophortyx gambelii (not of Gambel) Lawrence, 1874, 307 (Sonora). crit.).

Lophortyx gambelii gambelii Hellmayr and Conover, 1942, 235, part (Camoa);

Lophortyx gambeli Salvin and Godman, 1903, 292, part (Rio Mayo).

Lophortyx gambeli gambeli Bent, 1932, 73, part (Camoa).

Common resident of Tropical zone lowlands from the lower Yaqui River valley southward to the Sinaloa boundary (Agiabampo and Masocari Island). There are no upland records, even for the lower foothills, and the race seems to be confined to the coastal plain and lower parts of the river valleys.

\section{LOPHORTYX GAMBELII PEMBERTONI VAN ROSSEM}

\section{Tiburón IsLand QuaIL}

Lophortyx gambelii pembertoni van Rossem, Trans. San Diego Soc. Nat. Hist., 7, No. 12, July 28, 1932, 132 (Petrel Bay, Tiburón Island, Sonora, México).Peters, 1934, 46 (Tiburon Island).-Hellmayr and Conover, 1942, 236 (Tiburon Island).

Lophortyx gambeli pembertoni Gorsuch, 1934, 13, in text (Tiburon Island).

Fairly common resident of brushy areas on Tiburón Island. 


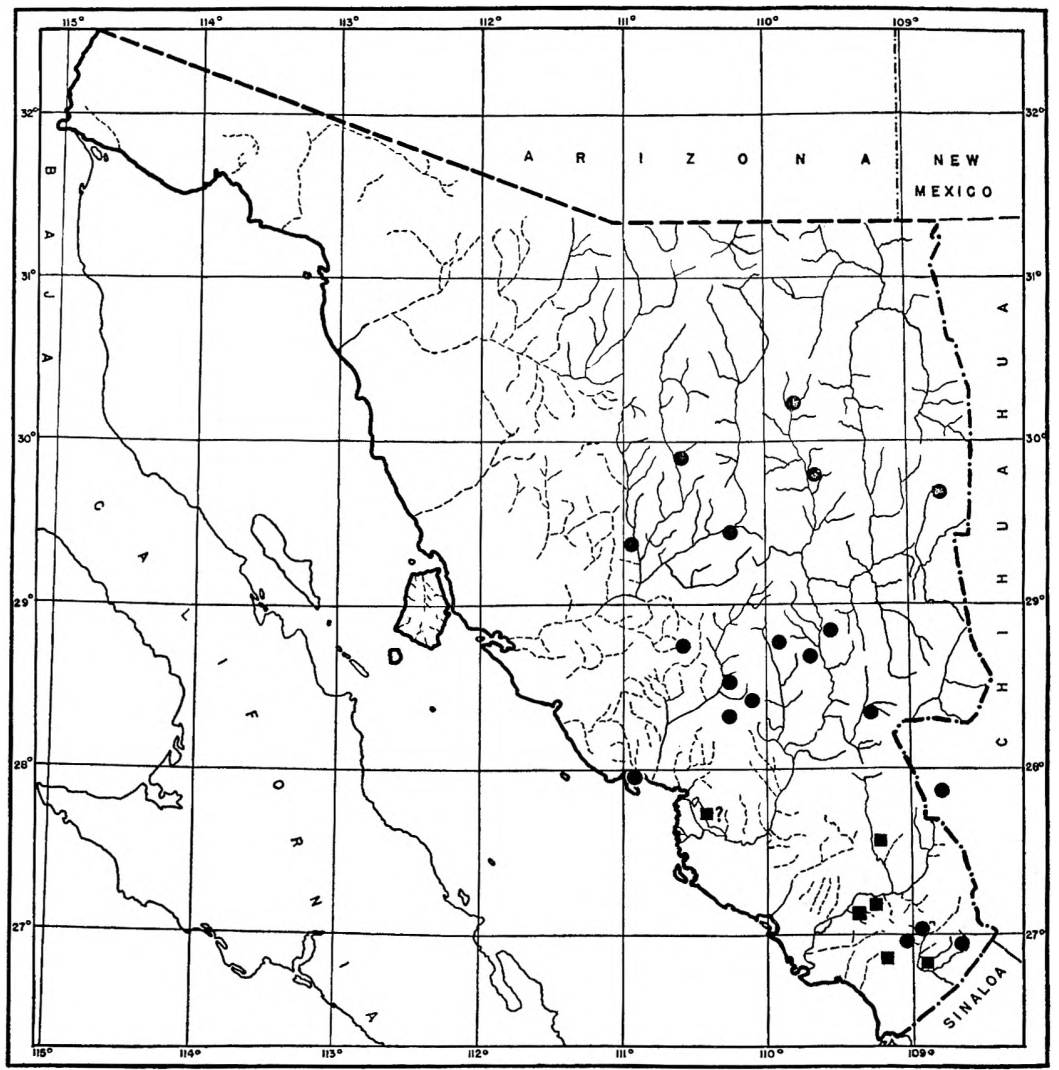

MaP 4. Distribution of Lophortyx douglasii. Circles, L. d. bensoni; squares, L. d. elegans.

\section{LOPHORTYX DOUGLASII BENSONI (RIDGWAY)}

\section{BENSON QUAIL}

Callipepla elegans bensoni Ridgway, Forest and Stream, 28, No. 6, March 3, 1887, 106 (Campos [ $=18$ miles north of Cumpas], Sonora, México); 1887c, 148 (redescription) ; 1887d, 585 (Campos); 1896, 589 (Campos).

Callipepla douglasi bensoni Nelson, 1902, 389 (Campos; crit..)

Lophortyx douglasi bensoni Thayer and Bangs, 1906, 18 (Opodepe).

Lophortyx douglasii bensoni van Rossem, 1931c, 246 (Pesqueira; Tecoripa; Guaymas; San Javier; 90 miles S.E. of Nogales; crit.); 1934d, 431 (Oposura; Alamos; Cumpas).-Peters, 1934, 46 (Sonora).-Burt, 1938, 13, in text (Guaymas).-Hellmayr and Conover, 1942, 236, part (Guirocoba; Tecoripa; Soyopa).Friedmann, 1943, 370, in text (Sonora). 
Lophortyx douglasi (not Ortyx douglasii Vigors) Ogilvie-Grant, 1893, 404, part Guadalupe; Sierra de Alamos).-Salvin and Godman, 1903, 293, part (Guadalupe; Sierra de Alamos; Nacory; Campos).

Lophortyx douglasii douglasii van Rossem, 1931 c, 245, (Guirocoba).

Callipepla elegans (not Ortyx elegans Lesson) Allen, 1893a, 33 (Nacory).

Common resident of Sonoran and the higher Tropical zone foothills and river valleys in the central, eastern, and southeastern parts of the State. Northernmost localities are Opodepe, and 18 miles north of Cumpas; westernmost are Pesqueira, Guaymas (which is also the only coastal locality), and the Sierra de Alamos. Intergradation with elegans is evident in some individuals from Tecoripa, Soyopa, San Javier, and the vicinity of Alamos. Additional stations from which specimens have been examined are San Marcial, Las Arenas, Chivata, and Las Chinchas (Mus. Comp. Zoöl.).

\section{LOPHORTYX DOUGLASII ELEGANS (LESSON)}

\section{LESSON QUAIL}

Ortyx elegans Lesson, Cent. Zool., pl. 61, 189 (la Californie=Mazatlán, Sinaloa, México).

Lophortyx douglasi (not Ortyx douglasii Vigors) Ogilvie-Grant, 1893, 404, part (Ysleta; Quiriego).-Salvin and Godman, 1903, 293, part (ditto).

Lophortyx douglasii douglasii van Rossem, 1931 c, 245, part (Tesia; Chinobampo).

Lophortyx douglasii bensoni (not Callipepla elegans bensoni Ridgway) van Rossem, 1934 d, 431, part (southern Sonora; crit.).--Hellmayr and Conover, 1942, 236, part (Camoa).

Common resident of Tropical zone lower foothills and river valleys in the extreme southwest, north to the lower Mayo and Cedros valleys, and probably in the lower Yaqui valley to about $28^{\circ} .{ }^{10}$

\footnotetext{
19 Unfortunately I am not able to follow Friedmann's recent (1943) review of the races of this quail, either in respect to names employed or in evaluation of some of the critical characters. My former comment (1934d) on Vigor's type of Ortyx douglasii and its characters must have been misinterpreted in some way, for on no other basis can I understand Friedmann's action in re-naming douglasii as "impedita" and assigning the name douglasii to the more or less intermediate race of Sinaloa. Equally perplexing is his argument that I might better have merged bensoni, the pale extreme, with douglasii and "described the dark, southern race," which is douglasii. I am agreeable to following him in recognizing an intermediate step between the dark southern, and pale northern extremes, but the name of this transitional form is most certainly not douglasii which, as I can only repeat again, applies to the dark southern extreme. Of the two names available for the Sinaloa race the earliest is Ortyx elegans Lesson, the type of which was collected by Botta, presumably in "la Californie," but actually at Mazatlán. This latter place was visited by the "Heros" in November and December, 1826, and again in May and June, 1827, and is the only port on the Mexican mainland touched by that vessel.
} 
In general, elegans is paler and grayer (less olivaceous) than douglasii and all the ventral markings are larger and more diffused. From bensoni it differs in slightly darker and more olivaceous dorsal coloration, and in the obsolescence or absence of rusty spotting on the breasts of the males. From both douglasii and (particularly) bensoni it differs in decidedly less reddish sides and flanks. As I pointed out some years ago (1931c), bensoni, while a pale, grayish race, very frequently has the pectoral region of the males marked with terminal spots of rusty red, and the flanks and sides are more extensively and more brightly red than in the Sinaloa race. On two specimens from La Trompa in extreme southwestern Chihuahua, Friedmann has named Lophortyx douglasii languens, the chief supposed character of which is rusty breast spotting. I have examined these specimens in the Museum of Comparative Zoölogy and fail to see any feature to distinguish them from bensoni except the very slightly more olivaceous coloration which reflects an approach to elegans. Friedmann correctly attaches no importance to the relative amounts of black and white in the throat patches of the males but he is in error in believing the (usually) uniformly dark crests of female bensoni to be of value as a distinguishing character. All three of the female douglasii from San Blas examined by me, two in the British Museum and one in the Dickey collection, have uniform, blackish brown (sepia) crests, a feature which would at once place them in bensoni in Friedmann's "Key." Individual variation in this respect is very marked in both bensoni and elegans. Age seemingly enters into the picture, somewhat, for one-year-old females appear to be more variegated than adults.

Appended here are the wing, tail, and wing-tip measurements of 10 fully adult males of bensoni from central Sonora, of 10 fully adult males of elegans from extreme southwestern Sonora, and of a male and three females of douglasii from San Blas. The short tail of douglasii appears to be a diagnostic character, but there seems to be not much difference in wing length between northern and southern populations. One-year-old birds (distinguished by the spotted primary coverts) average about $5 \mathrm{~mm}$. shorter.

bensoni

Wing.-117-111-115-120-118-113-116-114-115-116.

Tail.-96-81-84-87-95-79-90-87-86-83.

Tip.-8-9-21-25-16-9-5-20-5-15.

elegans

Wing.-116-111-109-111-110-114-115-121-110-112.

Tail.-88-85-78-84-89-91-86-99-86-99-74-82.

Tip.-6-0-5-7-0-8-11-3-0-11.

douglasii ô

Wing.-114.

Tail.-65 (badly abraded).

Tip.-14.

douglasii $\& \quad(\dagger=$ type $)$

Wing.-109†-108-109.

Tail.-missing $†-65-70$.

Tip.-not recorded $†-6$-not recorded. 


\section{COLINUS VIRGINIANUS RIDGWAYI BREWSTER}

\section{MASKed BOB-WHITE}

Colinus ridgwayi Brewster, Auk, 2, No. 2, April, 1885, 199 (18 miles southwest of Sásabe, Sonora, México) ; 1887, 159 (Cumpas; Bacuachi).--Stephens, 1885, 228 (near Sasabe).--Brown, 1885, 445 (between Baboquivari Mountains and the Gulf) ; 1904, 209 (Sonora).-Allen, 1886 a, 275 (Sonora) ; 1886 b, 274 (range in Sonora) ; 1886 c, 483 (re. type).-Scott, 1886, 387 (Sonora).-Ridgway, 1887 d, 189, 585 (Sonora); 1896, 189 (Sonora).-Beckham, 1888, 655 (status).Bendire, 1892, 10 (Campos; Bacuachi)-A. O. U. Comm., 1895, 107 (Sonora); 1910, 135 (north-central Sonora) ; 1931, 88 (northern Sonora).-Elliot, 1897, 38 (Barboquivari [sic] Mts. to the Gulf [!]; Plomosa).-Nelson, 1898 b, 121 (Sonora).--Sharpe, 1898, 46 (Sonora).-Coues, 1903, 755 (Sonora).--Sandys and Van Dyke, 1904, 89 (Sonora).-Bent, 1932, 36 (Sonora; range, life history, status).--Sheffler, 1931 a, 135 (vic. Magdalena) ; 1931 b, 164 (vic. Santa Ana).Cottam and Knappen, 1939, 152 ( 6 miles W. of Tecoripa; food).

Colinus virginianus ridgwayi van Rossem, 1931 c, 245 (90 miles S. of Nogales; Magdalena); 1934 d, 431 (Cumpas; Bacuachi).-Peters, 1934, 49 (range in Sonora).--Hellmayr and Conover, 1942, 242 (Rancho Carrizo; Tecoripa).-Brodkorb, 1942 b, 3, in text (Sonora; crit.).-A.O.U. Comm., 1944, 346 (nomen.).

Ortyx ridgwayi Ogilvie-Grant, 1893, 422 (south of Sasabe; type).--Salvin and Godman, 1903, 302 (Sasabe; Campos; Bacuachi).

Ortyx graysoni (not of Lawrence) Grinnell, 1884, 243 (range in Sonora).Ridgway, 1887 d, 189, part, 585 (Sonora).

Resident of grass plains, river valleys, and foothills (lower Sonoran zone) from the vicinity of Sásabe to a little east of longitude $110^{\circ}$, and south in the interior nearly to latitude $28^{\circ}$. This was evidently the former range; now rare and probably locally extinct in the extreme north and undoubtedly greatly reduced in numbers everywhere. Some actual or circumstantial instances of northerly occurrence within recent years are El Alamo where (in 1931) there was said to be a flock of nine near the ranch house. Numbers were trapped for local restaurants at Magdalena as late as 1929, and were said to be occasionally brought in for the same purpose in 1937. As late as 1931, Wright collected numbers at Tecoripa and Rancho Carrizo, the latter locality being the most southwesterly record to date. There are no northeasterly records since Lieutenant Benson found the species near Cumpas in 1886, and Cahoon found it in abundance about Cumpas and Bacuachi in 1887. At or near the southern limit of the range, W. W. Brown collected specimens (now in Mus. Comp. Zoöl.) at Las Arenas, Batamoti, San Marcial, and Las Capomas in 1905. By far the best recent account of the past and present status is to be found in Bent, 1932. 


\section{CYRTONYX MONTEZUMAE MEARNSI NELSON}

\section{MEARNS QUAIL}

Cyrtonyx montezumae mearnsi Nelson, Auk, 17, No. 3, July, 1900, 225 (Fort Huachuca, Arizona).- Thayer and Bangs, 1906, 18 (La Chumata).-A. O. U. Comm., 1910, 137 (eastern Sonora); 1931, 91 (eastern Sonora).-Bailey, 1928, 223 (eastern Sonora; San Luis Mts.).-van Rossem, 1931 c, 247 (Saric); 1934 d, 431, part (Cumpas; Nacozari; Oposura; crit.); $1942 \mathrm{c}, 378$, in text (northern Sonora).-Bent, 1932, 81 (L.a Chumata; Patagonia Mountains).-Peters, 1934, 57 (northern Sonora).-Wetmore, 1934, 30 (Sonora).--Hellmayr and Conover, 1942, 284 (Sonora).

Cyrtonyx montezumae (not Ortyx montezumae Vigors) Bendire, 1892, 35, part (Sierra Madre).-Allen, 1893 a, 33 (Los Pinitos; Los Vengos; Nacory; Huerachi). -Salvin and Godman, 1903, 305, part (Allen locs.).

Cyrtonyx massena (not Ortyx massena Lesson) Baird, 1859, 23 (Santa Cruz River).

Fairly common resident of the oak belt in Upper Sonoran and Transition zones from the Pajaritos Mountains eastward, and south in the central ranges at least to the Sicrra de San Antonio and the Sierra Madre ranges to about latitude $29^{\circ} 30^{\prime}$.

\section{CyRTONYX MONTEZUMAE MORIO VAN ROSSEM}

\section{Guirocoba QuaIL}

Cyrtonyx montezumae morio van Rossem, Trans. San Diego Soc. Nat. Hist., 9, Nu. 33, Feb. 17, 1942, 379 (Guirocoba, Sonora, México); ibid., in text (Rancho Santa Barbara; Hacienda de San Rafael; Mina Abundancia; Las Chinchas; Yecora).

Cyrtonyx montezumae (not Ortyx montezumae Vigors) Ogilvie-Grant, 1893. 425, part (Yecora).-Salvin and Godman, 1903, 305, part (Yecora).

Cyrtonyx montezumae montezumae van Rossem, 1931c, 246 (Guirocoba).Peters, 1934, 57, part (southern Sonora).

Cyrtonyx montezumae mearnsi (not of Nelson) van Rossem, 1934 d, 431, part (Mina Abundancia; Hacienda de San Rafael).

Fairly common resident in the Upper Sonoran and Transition zones of the southeastern foothills and mountains, north at least to latitude $28^{\circ} 30^{\prime}$ (Las Chinchas and Yécora). The meeting place of morio and mearnsi may be approximated at $29^{\circ}$; however, no specimens from that latitude have been examined.

\section{Family Meleagrididae Turkeys \\ Mfleagris gallopaVo mirriami Nflison \\ MFrRIAM TURKFY}

Meleagris gallopano merriami Nelson, Auk, 17, No. 2, April, 1900, 120 (47 miles south of Winslow, Arizona).-A.O.U. Comm., 1910, 145 (northern Sonora). - Bailey, 1928, 231 (northern Sonora).- Peters, 1934, 140 (northern Sonora).Hellmayr and Conover, 1942, 293 (northern Sonora). 
Meleagris gallopavo mexicana (not Meleagris mexicana Gould) Bendire, 1892, 116 (southeast of Sierra Azul).

Resident in the northeastern mountains, where once probably generally distributed but now undoubtedly much reduced in numbers and perhaps exterminated in some areas. Records or specimens are few in number; San Luís Mountains (west side), May 31 and June 1, 1892; San Luís Mountains near Cajón Bonito Creek, July 21, 1892, "common"; Cajón Bonito Creek, July, 1892, and September, 1893, "common" (U. S. Nat. Mus.; Mearns notes) ; [northeastern] Sonora, April, 1909 (2 specimens in Mus. Comp. Zoöl.) ; Herbert Brown's observation southeast of the Sierra Azul, probably in the eighties (Bendire, 1892). There are no recent data.

\section{MELEAGRIS GALLOPAVO ONUSTA MOORE}

\section{MOORE TURKEY}

Meleagris gallopavo onusta Moore, Auk, 55, January, 1938, 112 (2 miles southeast of Guayachi, Chihuahua, México) ; ibid., in text (Barromicon).-Hellmayr and Conover, 1942, 294 (Sonora-Chihuahuan border).-Leopold, 1944, 133 (Sonora; crit.).

Meleagris gallopavo subsp. (?) Moore, 1938 a, 24 (Mirasol; Baromicon).

Resident, apparently in rather limited numbers, in the Transition and Upper Sonoran zones on the west slope of the Sierra Madre in the extreme southeastern corner of the State. The area of the intergradation with merriami is at present unknown.

\section{Order GRUiformes Cranes, Rails, and Allies Family GruidaE Cranes}

\section{GRUS CANADENSIS CANADENSIS (LINNAEUS)}

\section{Little Brown Crane}

Ardea canadensis Linnaeus, Syst. Nat. ed. 10, 1, 1758, 141 (in America septentrionali=Hudson Bay).

Grus mexicana Price, 1899, 91 (lower Colorado River).- Stone and Rhoads, 1905, 688 (lower Colorado River).

Canada Crane Audubon, 1906, 146 (Rancho La Sone [Sonoyta]).

Evidently a common (formerly abundant) winter visitant in the Colotado River delta and probably in other river valleys also. Price, Rhoads, and Mearns, the last informally (1907, p. 128), report this species as abundant in the delta from November to late March, but no specimens seem actually to have been collected on the Sonora side of the river. Pos- 
sibly more than one subspecies winters in this region, but since the specimens taken on the Baja California side are canadensis (Grinnell, 1928, p. 86), all sight records from Sonora are tentatively considered to be of that race also. However, Audubon believed that he saw "sand-hill" as well as "Canada cranes" at Sonoyta, September 14, 1849. According to residents, cranes formerly wintered in abundance in the Mayo River valley but of late years have markedly decreased in numbers.

\section{Family Rallidae Rails, Gallinules, and Coots}

\section{RALLUS ELEGANS RHIZOPHORAE DICKEY}

\section{SONORA KING RAIL}

Rallus obsoletus rbizophorae Dickey, Trans. San Diego Soc. Nat. Hist., 6, No. 18, Dec. 24, 1930, 235 (Tóbari Bay, Sonora, México); ibid., in text (Guaymas to Sinaloa boundary).

Rallus elegans rhizophorae Peters, 1934, 159 (Guaymas, south to Sinaloa).Hellmayr and Conover, 1942, 334 (Guaymas to Sinaloa).

Rallus longirostris rhizophorae Oberholser, 1937, 342 (Guaymas; Tobari Bay; Viejo Yaqui Lagoon).-Friedmann, 1941, (same locs.).

Common resident of the tidal lagoons (mangrove and salicornia associations) in the Tropical zone. The northernmost locality known to date is Guaymas; however, some form of this species occurs at Kino Bay and zonal considerations indicate the present one. Further localities are Lobos Lagoon; Lobos Island (Nat. Hist. Mus.) ; Agiabampo; Masocari Island (Dickey coll.).

\section{RALLUS LIMICOLA ZETARIUS PETERS}

\section{PACIFIC Virginia RaIL}

Rallus limicola zetarius Peters, Check-list of Birds of the World, 2, 1934, 160 [new name for Rallus virginianus pacificus Dickey, pre-occ.] (5 miles west of Corona, Riverside County, California).

Rallus virginianus (not of Linnaeus) Cassin, in Baird, 1858, 748, part (Sonora).-Baird, 1859, 26 (Santa Cruz).-Baird, Brewer, and Ridgway, 1884 (1), 363, part (Sonora).

Rallus limicola limicola (not Rallus limicola Vieillot) Friedmann, 1941, 90, part (Santa Cruz).

Possibly a rare resident in the extreme northern part of the State. The only records are a specimen taken by Kennerly at Santa Cruz on the Santa Cruz River in June, 1855, and an entry in Mearns' notes which states that two were seen at Sonoyta between January 9 and 25, 1894. There are two spring records (Grinnell, 1928, p. 87) for the Baja California side of the Colorado River. 


\section{Porzana carolina (LinNaEUs)}

\section{SORA}

Rallus carolinus Linnaeus, Syst. Nat., ed. 10, 1, 1758, 153 (in America septentrionali $=$ Hudson Bay).

Porzana carolina van Rossem and Hachisuka, 1937 a, 329 (El Doctor).

Detected only in fall and winter in the extreme north. Wright found this rail to be fairly common at El Doctor in the Colorado delta and took three specimens on January 24,27 , and 31,1929 , respectively. In the National Museum catalogue and Mearns notes are records of specimens taken by Mearns at the San Bernardino Ranch, "Arizona," and San Bernardino River on the boundary, August 12 and 29, 1892, respectively.

\section{GALLINULA CHLOROPUS CACHINNANS BANGS}

\section{American Gallinule}

Gallinula chloropus cachinnans Bangs, Proc. New England Zoöl. Club, 5, May 17, 1915, 96 (Arbuckle Creek, De Soto Co., Florida).

Status uncertain. Probably a resident in limited numbers although the only records to date are those of three specimens entered in Mearns' field book as taken on the San Bernardino River on the boundary line October 4,1893 , and mention of legs and feathers, apparently of several individuals, found at Sonoyta between January 9 and 25, 1894. There are spring and summer records for the Colorado delta, though so far only from the Baja California side of the river (Grinnell, 1928, p. 88).

\section{FuLICA AMERICANA AMERICANA GMELIN}

\section{AMERICAN COOT}

Fulica americana Gmelin, Syst. Nat., 1, pt. 2, 1789, 704 (North America).Allen, 1893 a, 33 (Cachuta).-Price, 1899, 91 (lower Colorado River).- Salvin and Godman, 1903, 329, part (Cachuta).

Fulica americana americana van Rossem and Hachisuka, 1937 a, 329) (San Jose de Guaymas; Guaymas; El Doctor).

Common migrant and winter visitant from the Arizona boundary south at least to Tóbari Bay, and probably in other suitable localities throughout the State. Breeds in the Colorado delta, though to date reported only from the Baja California side, and possibly at other northern points. In addition to the above records, the species has been observed as abundant 9 miles S.W. of Ciudad Obregón, November 24 and at Tóbari Bay, November 25, 1944 (Sheffler notes); specimens are listed in the National Museum catalogue as taken by Mearns and Holzner at the San Bernardino Ranch, 
July 13, 1892, and on the Colorado River at Monument 204, March 25, 1894; Quitovaquita on the boundary (Arizona side), March and November, 1939 (Hucy, 1942, p. 364) ; Animas Valley on the boundary, September 8, 1893; Sonoyta, January 9 to 25, 1894 (Mearns notes).

\section{Order CHARADRIIFORMES SHORE Birds, Gulls, AuKs, AND Allies \\ Family HAEMATOPODIDAE Oyster-catchers HAEMATOPUS PALLIATUS FRAZARI BREWSTER}

\section{FraZAR OYSTER-CATCHER}

Haematopus frazari Brewster, Auk, 5, No. 1, January, 1888, 84 (Carmen Island, Baja California, México).-Townsend, 1923, 12 (San Esteban Island).-Mailliard, 1923, 454 (San Esteban Island).

Haematopus palliatus frazari Murphy, 1925, 9 (Quotla).-Bent, 1929, 316 (Quotla)._-van Rossem, 1932, 133 (Tiburon Island; San Esteban Island; San Pedro, San Carlos, Kino, and Tepopa Bays).-Abbott, 1941, 418 (Guaymas).Webster, 1943, 41, 45 (Sonora; descr. young).

Common resident of islands and beaches from the head of the Gulf south to the Sinaloa boundary. Unpublished localities are George Island; San Pedro Mártir Island; Masocari Island; Agiabampo; Tóbari Bay (van Rossem notes) ; Lobos Island (Nat. Hist. Mus.) ; Kino Point (Anthony notes).

\section{Family ChaRAdRIIDAE Plovers SQUATAROLA SQUATAROLA (LinNAFus) \\ Black-bellied Plover}

Tringa Squatarolo Linnaeus, Syst. Nat., ed. 10, 1, 1758, 149 (in Europa $=$ Sweden).

Squatarola squatarola Huey, 1935, 252 (Punta Peñascosa).- -van Rossem and Hachisuka, 1937 a, 329 (Tobari Bay).

Fairly common spring migrant coastwise. Detected also as a winter visitant. Noted in spring from April 26 to May 1 (Tóbari Bay) and in winter from February 8 to 29 (Punta Peñascosa).

\section{CHARADRIUS hiaticula SEMIPALMATUS BonapaRTE}

\section{Semipalmated Plover}

Charadrius semipalmatus Bonaparte, Journ. Acad. Nat. Sci. Phila., S, [Aug., 1825], 98 [New name for Tringa biaticula Wilson] (Coast of New Jersey).- -van Rossem, 1932, 133 (Tiburon Island). 
Charadrius biaticula semipalmatus van Rossem, 1934 d, 433 (Guaymas).-van Rossem and Hachisuka, 1937 a, 330 (Tobari Bay).

Aegialites [sic] semipalmata Townsend, 1923, 12 (Tiburon Island).

Fairly common spring migrant and, at least occasionally, a winter visitant. In the case of this as well as of the great majority of shore birds the absence of fall records is undoubtedly because of the lack of observation at that season. Spring dates are from March 29 (Las Carpas; Mearns and Holzner in U. S. Nat. Mus. catl.) to May 1 (Tóbari Bay). Winter records are January 13 and 14 (Guaymas).

\section{CharadRIUS alexandRINUS NIVOSUS (CASSIN)}

\section{Western SNowy Plover}

Aegialitis nivosa Cassin, in Baird's Rep. Expl. and Surv. R. R. Pac., 9, 1858, xlvi, 696 (Presidio=San Francisco, California).

Charadrius nivosus nivosus van Rossem, 1932, 133 (Tiburon Island).- Huey, 1935, 252 (Punta Peñascosa).

Charadrius alexandrinus nivosus van Rossem, 1934 d, 433 (Guaymas).

Common winter visitant coastwise, at least from Guaymas northward. Unpublished occurrences are Kino Bay, December 28, 1931 (Dickey coll.) ; Puerto Libertad, February 3 and 4, 1932 ("common," Phillips notes) ; Colorado River opposite mouth of Hardy, March 29, 1894 (U. S. Nat. Mus.). Extreme dates are December 28 (Kino Bay) and March 29 (Colorado River). Since the Snowy Plover is a common resident the fuli length of the Baja California peninsula, its apparent summer absence from the coast of Sonora is rather surprising.

\section{CHARADRIUS VOCIFERUS VOCIFERUS LINNAEUS}

\section{KILLDEER}

Charadrius vociferus Linnaeus, Syst. Nat., ed. 10, 1, 1758, 150 (in America septentrionali=South Carolina).

Charadrius vociferus vociferus van Rossem, 1934 d, 433 (Alamos; Oposura).

Oxyechus vociferus Sharpe, 1896, 242, part (Hermosillo).-Salvin and Godman, 1903, 356, part (Hermosillo).-Stone and Rhoads, 1905, 688 (lower Colorado River).

Oxyechus vociferus vociferus Huey, 1935, 252 (Punta Peñascosa).

Aegialitis vociferus Price, 1899, 91 (lower Colorado River).

Common resident everywhere in suitable territory, both insular and on the mainland. Even more numerous in winter, probably because of winter visitants from northern localities. Additional localities are El Doctor, January; Tecoripa, March (Dickey coll.); San Estéban Island, April; Guaymas; Tóbari Bay; Colonia Independencia; Rancho La Arizona; Agiabampo; Masocari Island, May (van Rossem notes); Guadalupe Cañon; 
San Bernardino River; San Pedro River, July and November ("common wherever there is water"; Mearns notes).

\section{CHARADRIUS WILSONIA BELDINGI (RIDGWAY) BELDING Plover}

Pagolla wilsonia beldingi Ridgway, Bull. U. S. Nat. Mus., 50, pt. 8, June 26, 1919, 108, 112 (La Paz, Baja California, México).- -van Rossem, 1932, 133 (Tiburón Island and mainland points [ = San Pedro, San Carlos, Kino, and Tepopa Bays; San Estéban Island; Guaymas]).-Bent, 1929, 257 (Guaymas).-Huey 1935, 252 (Punta Peñascosa).

Charadrius wilsonia beldingi van Rossem, 1934 d, 433 (Guaymas).- van Rossem and Hachisuka, 1937 a, 330 (Agiabampo).

Ocbthodromus wilsonius (not Charadrius wilsonia Ord) Mailliard, 1923, 454 (Pelican Island).

Common resident of sea beaches, both mainland and insular, from Kino Bay southward, a distribution which corresponds closely with the Tropical zone. By far the most northerly record is Punta Peñascosa (February 16) but whether this indicates a winter dispersal north from known breeding territory, or whether the species is resident so far north cannot be stated at this time.

\section{EUPODA MONTANA (TOWNSEND) \\ Mountain Plover}

Charadrius montanus J. K. Townsend, Journ. Acad. Nat. Sci. Phila., 7, Pt. 2 [Nov. 21], 1837, 192 (near Sweetwater River, Wyoming).

Podasocys montanus Sharpe, 1896, 242 (Hermosillo).-Ridgway, 1919, 105 (Hermosillo).-Bent, 1929, 263 (Santa Rosa; Hermosillo).

Eupoda montana Huey, 1935, 252 (Punta Peñascosa).

Midwinter visitant to Lower Sonoran deserts in the northwestern part of the State. There are three records; Hermosillo, "Dec." [1887], taken by Ferrari-Perez and now in the British Museum; four specimens taken by Mearns and Holzner at Santa Rosa, January 9, 1894; two specimens taken by Huey from a flock of "about three dozen" at Punta Peñascosa, February 19, 1934.

Family Scolopacidae Woodcock, Snipe, Sandpipers and Allies Numenius hudsonicus Latham

\section{Hudsonian Curlew}

Numenius budsonicus Latham, Ind. Orn., 2, 1790, 712 (in sinu Hudsonis= Hudson Bay).- -van Rossem and Hachisuka, 1937 a, 330 (Guaymas; Tobari Bay).

Detected only as a spring migrant along the coast. Dates range from March 25 (Guaymas) to May 1 (Tóbari Bay, "common"). Perhaps 
significantly, this curlew was not found anywhere along the Sonora coast in December, 1931, and January, 1932.11

\section{NUMENIUS AMERICANUS PARVUS BISHOP}

\section{NORTHERN CURLEW}

Numenius americanus parvus Bishop, Auk, 27, No. 1, Jan., 1910, 59 (Crane Lake, Saskatchewan ).

Numenius americanus occidentalis (not Numineus occidentalis Woodhouse) Oberholser, 1918 c, 191 (Monument 179; Naris).

There are no data upon which to base any estimate of the relative numbers of the two races of the Long-billed Curlew which occur in Sonora in winter. There are two specific records for the present race: Nariz Temporal, January 8, 1894, and Monument 179, February 9, 1894, by Mearns and Holzner.

\section{NUMENIUS AMERICANUS AMERICANUS BECHSTEIN}

\section{LoNG-BILled CuRlew}

Numenius americanus Bechstein, in Latham, Allgem. Ueb. Vög., 4, pt. 2, 1812, 432 (New York).

Numenius americanus americanus Oberholser, 1918 c, 188 (Naris).- -van Rossem, 1933 b, 199 (San Carlos, Kino, and Tepopa Bays; Querobabi; San Jose de Guaymas).- Huey, 1935, 252 (Punta Peñascosa).-van Rossem and Hachisuka, 1937 a, 330 (Tobari Bay).

Numenius longirostris Price, 1899, 91 (lower Colorado River).

Long-billed Curlew Audubon, 1906, 146 (Rancho La Sone [Sonoyta]).

Common winter visitant and migrant, probably in suitable localities throughout the State, although all records to date are westerly. In default of confirmatory data, all sight records of the Long-billed Curlew are included under the nominate race. Actual specimens are seemingly but two in number; Nariz Temporal, January 8, 1894 (U. S. Nat. Mus.), and Kino Bay, December 27, 1931 (Dickey coll.). Dates of record extend from September 14 (Sonoyta) to May 1 (Tóbari Bay).

\section{LIMOSA FEDOA (LINNAEUS) \\ MARBLED Godwit}

Scolopax Fedoa Linnaeus, Syst. Nat., ed. 10, 1, 1758, 146 (in America septentrionali=Hudson Bay).

Limosa fedoa Huey, 1935, 252 (Punta Peñascosa).- -van Rossem and Hachisuka, 1937 a, 330 (Tobari Bay).

11 It does not appear to me that Phaeopus is of more than subgeneric value in spite of the case presented by Wetmore (Proc. U. S. Nat. Mus., 90, 1941: 490). However, I believe him to be correct in keeping budsonicus as a species apart from the Old World Numenius phaeopus because of the difference in color pattern. 
A common, at times abundant, winter visitant and migrant coastwise. Extremely common at Tóbari Bay, April 26 to May 1, 1930, and observed as "common" at Agiabampo, May 13 to 16, 1937 (van Rossem notes). A specimen (Dickey coll.) taken on this latter occasion was a non-breeder of the previous year, and it seems probable that some individuals may remain through the summer. The only winter records are from Punta Peñascosa, "thousands," January 21 to 23, 1930 (Sheffler notes); "in limited numbers," February 8 to 28, 1934. The record of Price (1899) of "abundant" at the head of the Gulf in December, 1898, may pertain to the Baja California shore.

\section{TOTANUS FLAVIPES (GMELIN)}

\section{LESSER YELLOW-LEGS}

Scolopax flavipes Gmelin, Syst. Nat., 1, Pt. 2, 1789, 659 (auctumno in Noveboraco $=$ New York).

Tringa flavipes van Rossem and Hachisuka, 1937 a, 330 (Ciudad Obregon).

One satisfactory record, that of two specimens taken by Wright at Ciudad Obregón in the lower Yaqui River valley, November 14, 1929. It is possible that these were belated fall migrants rather than winter visitants. Mearns and Holzner collected a large series at the San Bernardino Ranch on the boundary, between August 2 and 27, 1892 (U. S. Nat. Mus.) but Mearns' notes definitely cite the specimens as taken in Arizona. This supplemental record indicates a degree of abundance in Sonora, at least during the fall migration. ${ }^{12}$

\section{TOTANUS MELANOLEUCUS (GMELIN)}

\section{GREATER YELLOW-LEGS}

Scolopax melanoleuca Gmelin, Syst. Nat., 1, pt. 2, 1789, 659 (Labrador= Chateaux Bay, Labrador).

Tringa melanoleuca van Rossem and Hachisuka, 1937 a, 330 (Guaymas; Hermosillo; Ciudad Obregon).

Probably a fairly common transient and winter visitant, although records are few and scattered. These are Ciudad Obregón, two specimens November 14, 1929; single bird noted by Lamb at Hermosillo, December 22, 1932; three taken by Brown at Guaymas, February 27, 1905; Animas Valley, "Chihuahua," at Monument 67, September 30, 1893 (Mearns

12 Peters' arrangement (1934) whereby he includes Totanus with Tringa does not seem to be justified. Wetmore (Bull. U. S. Nat. Mus., 133, 1926:150-152), has shown important structural differences between these two genera. 
notes); Quitovaquita on the boundary (Arizona side), March 6, 1939 (Huey, 1942). Incidentally, the old "Sonora" record of Salvin and Godman (1903, p. 373) probably was based on nothing more tangible than Allen (1893 a) who lists a specimen without date or locality.

\section{TRINGA SOLITARIA CINNAMOMEA (BREWSTER)}

\section{Western SOlitary SANDPIPER}

Totanus solitarius cinnamomeus Brewster, Auk, 7, No. 4, Oct., 1890, 377 (San José del Cabo, Baja California, México).-Allen, 1893 a, 33 (Cachuta).

Tringa solitaria cinnamomea van Rossem and Hachisuka, 1937 a, 330 (Saric).

Helodromas solitarius (not Tringa solitaria Wilson) Salvin and Godman, 1903, 375, part (Cachuta).

Fall and spring transient in the interior. Fall dates are as follows: San Bernardino Ranch, and San Pedro River on the boundary August 13 to October 10, 1892, by Mearns and Holzner (8 specimens in U. S. Nat. Mus. exam.) ; two specimens taken by Wright at Rancho La Arizona, September 14, 1929 (Dickey coll.); Cuchuta, October 8, 1890, by Robinette (Amer. Mus.). Spring records are those of two individuals seen (one taken but not preserved) by van Rossem and Hannum at Rancho La Arizona, May 7, 1937; Quitovaquita on the boundary (Arizona side), April 28 and 30, 1939 (Huey, 1942). Recorded also from "San Diego, Sonora" by Salvin and Godman (1903), citing Allen (1893 a), but this locality is in Chihuahua.

\section{ACTITIS MACULARIA (LiNNAEUS)}

\section{SPOTTED SANDPIPER}

Tringa macularia Linnaeus, Syst. Nat., ed. 12, 1, 1766, 249 (in Europa and America septentrionali=Pennsylvania $)$.

Actitis macularia Stone and Rhoads, 1905, 688 (lower Colorado River).-Bent, 1929, 78 (Alamos; Hermosillo).- -van Rossem, 1932, 133 (Tiburon Island); 1934 d, 433 (Alamos; Oposura).- - van Rossem and Hachisuka, 1937 a, 330 (Pilares; Saric; Tobari Bay; Guaymas; San Esteban, San Pedro Martir, and San Pedro No. lasco Islands).

Common winter visitant and transient, both coastwise (including islands) and on interior streams and ponds. Dates of record include every month in the year except June, October, and November; however, there are no breeding records. Additional localities are Colorado River at Monument 205, March 19, 1894; San Bernardino Ranch, July 31, 1892; Cajón Bonito Creek, September 27 and 28, 1893 (Mearns notes; U. S. Nat. Mus.). 


\section{CATOPTROPHORUS SEMIPALMATUS INORNATUS (BREWSTER) WESTERN WILLET}

Symphemia semipalmata inornata Brewster, Auk, 4, No. 2, April, 1887, 145 (Larimer County, Colorado).-Price, 1899, 91 (lower Colorado River).

Catoptrophorus semipalmatus inornatus van Rossem, 1932, 133 (San Pedro, San Carlos, Kino, and Tepopa Bays; Tiburon, San Pedro Nolasco, and San Esteban Islands) ; 1934 d, 433 (Guaymas).--Huey, 1935, 252 (Punta Peñascosa).- van Rossem and Hachisuka, 1937 a, 331 (El Doctor; Guaymas; Tobari Bay).

Common, even abundant, winter visitant and transient along the coast and on most Gulf islands. Numerous individuals seen at Agiabampo and Masocari Island, May 13 to 16, 1937, were not in breeding plumage and probably were birds which would have remained in the locality through the summer (van Rossem notes). There are no interior records except for the Colorado River delta, but Arizona boundary occurrences at Quitovaquita, April 28, 1939 (Huey, 1942), and San Bernardino Ranch, August 13, 1892 (U. S. Nat. Mus.), indicate plainly that this is due to lack of observation.

\section{HeTERosCELUS INCANUS (GMELIN) \\ WANDERING TATLER}

Scolopax incanus Gmelin, Syst. Nat., 1, pt. 2, 1789. 658 (Eimeo et Palmerston [= Moorea Island, Society Group, Pacific Ocean]).

Heteroscelus incanus van Rossem and Hachisuka, 1937 a, 331 (San Pedro Nolasco Island).

Detected only as a rare spring migrant or perhaps only as a casual. A single Wandering Tattler was seen by van Rossem on San Pedro Nolasco Island on April 21, 1930, under circumstances which allowed certain identification.

\section{APHRIZA VIRGATA (GMELIN)}

\section{SURF-BIRD}

Tringa virgata Gmelin, Syst. Nat., 1, pt. 2, 1789, 674 (in sinu Sandwich= Prince William Sound, Alaska).

Apbriza virgata Townsend, 1923, 12 (Tiburon Island).-van Rossem, 1932, 133 (Tiburon Island).

A winter visitant and spring transient. Townsend took one or more specimens at Tiburón Island on April 12, 1911, and J. S. Rowley took one at Punta Peñascosa, January 21, 1930 (Rowley coll.). The Surf-bird is at times an abundant spring migrant on the Baja California side of the Gulf and perhaps will be found to occur on the Sonora side more than casually. 


\section{ARENARIA INTERPRES INTERPRES (LINNAEUS) \\ COMMON TURNSTONE}

Tringa Interpres Linnaeus, Syst. Nat., ed. 10, 1, 1758, 148 (Europe and North America $=$ Gotland, Sweden .

Arenaria interpres morinella (not Tringa morinella Linnaeus) Huey, 1935, 252 (Punta Peñascosa).- van Rossem and Hachisuka, 1937 a, 331 (Agiabampo; San Pedro Nolasco Island; Tobari Bay).

A winter visitant and spring migrant coastwise. A single individual noted by Huey at Punta Peñascosa on February 15, 1934; specimen taken by Lamb at Agiabampo on April 18, 1933; one seen at San Pedro Nolasco Island, April 21, 1930 (van Rossem); two specimens taken at Tóbari Bay, April 29 and May 1, 1930, comprise the available data. ${ }^{13}$

\section{ARENARIA MELANOCEPHALA (VIGORS)}

\section{Black Turnstone}

Strepsilas melanocephalus Vigors, Zool. Journ., 4, 1828 [Jan., 1829], 356 (Northwest coast of [North] America).

Arenaria melanocephala Townsend, 1923, 12 (Tiburon Island).-van Rossem, 1932, 133 (Tiburon Island).- - Huey, 1935, 252 (Punta Peñascosa).- van Rossem and Hachisuka, 1937 a, 331 (San Esteban Island; San Pedro Nolasco Island).

Winter visitant coastwise from about latitude $28^{\circ}$ northward. Dates cxtend from December 31 (Tiburón Island) to April 21 (San Pedro Nolasco Island). The species is evidently fairly common at times, for Huey noted as many as "about 20" at one time at Punta Peñascosa and Townsend's party secured five on Tiburón Island.

\section{LIMNODROMUS SCOLOPACEUS (SAY)}

\section{LONG-BILLED DOWITCHER}

Limosa scolopacea Say, in Long's Exped. Rocky Mts., 1, 1823, 335 (near Boyer Creek = Council Bluffs, Iowa).

Limnodromus griseus scolopaceus van Rossem and Hachisuka, 1937 a, 331, part (Ciudad Obregon).

Winter visitant and transient, probably more common than the threc records might indicate. All of these are from fresh water localities: Ciu-

13 I agree with Peters (1934, p. 271 and footnote) that Pacific Coast turnstones are best referred to interpres (unless oabuensis be recognized). At least, in a series of some 40 specimens from various localities from Alaska south to Baja California I can find none which are exactly like morinella from the Atlantic coast. Certainly the two Sonora specimens now available for study (Tóbari Bay) are not morinella, though I once so recorded them. 
dad Obregón, where Wright took seven specimens on November 13, 1929, Ánimas Valley, "Chihuahua" at Monument 67, September 30, 1893 (Mearns notes); Las Carpas on the Lower Colorado River about 15 miles south of the boundary where Mearns and Holzner collected five on March 29,1894 . Dr. Friedmann states that three of the five listed in the National Museum catalogue from Las Carpas are still present in the collection and that they are definitely scolopaceus. Because of the behavior of the two species in migration in California it seems likely that the apparent preference of bendersoni for salt water and of scolopaceus for fresh water is more than coincidence. An old, erroneous record is "Espia, Sonora" (Ridgway, 1919, p. 201), probably taken from Baird (1859, p. 25). Espia is in Chihuahua.

\section{LIMNODROMUS GRISEUS HENDERSONI ROWAN}

\section{HENDERSON DOWITCHER}

Limnodromus griseus bendersoni Rowan, Auk, 49, Jan., 1932, 22 (Devil's Lake, Alberta, Canada).

Limnodromus griseus scolopaceus (not Limosa scolopacea Say) van Rossem and Hachisuka, 1937 a, 331, part (Tobari Bay).

Probably a common migrant and winter visitant along the coast, although detected to date only in summer. The only specific records are of two non-breeding specimens still in winter dress taken at Masocari Island on May 16, 1937 (Dickey coll.), and two in similar plumage from Agiabampo, June 7, 1930, and Tóbari Bay, June 27, 1930 (Nat. Hist. Mus.). It is possible that the numerous Dowitchers noted in migration at Tóbari Bay between April 26 and May 1, 1930, were chiefly, perhaps entirely, of this race. ${ }^{14}$

\section{Capella delicata (ORD)}

\section{WILSON SNIPE}

Scolopax delicata Ord, in reprint of Wilson, Amer. Orn., 9, 1825, 218 (Pennsylvania).

Gallinago delicata Cooke, 1910, 23 (San Bernardino River).

14 I follow Rowan (l. c.) and Conover (Auk, 58, July, 1941: 376-380) in considering scolopaceus specifically distinct from griseus. In addition to the darker tail, all the scolopaceus examined in winter plumage differ from griseus and bendersoni in their decidedly darker and much more extensively gray anterior underparts and flanks. There seems to be no certain means of distinguishing winter hendersoni from winter griseus. Sonora specimens are listed under hendersoni partly because of geographic probabilities and partly because they have the very slightly longer bill average given by Conover for that race. 
Capella delicata van Rossem, 1934 d, 433 (Granados).-Huey, 1935, 252 (Punta Peñascosa).

Capella gallinago delicata van Rossem and Hachisuka, 1937 a, 331 (El Ductor; Tecoripa; 15 miles south of Nogales).

Migrant and winter visitant in suitable localities, probably throughout the State, although noted so far only north of about latitude $28^{\circ} 30^{\prime}$. Record stations are widely scattered; San Bernardino River, August 19 and November 13; Santa Cruz River, October 20; San Pedro River, October 22 ; Sonoyta, January 19 and 20 (U. S. Nat. Mus. catl.) ; El Doctor, December 8; January 21 and 24 (Dickey coll.) ; Punta Peñacosca, February 17 ; 15 miles south of Nogales, February 25; Tecoripa, March 25; Magdalena, April 20 (Dawson notes); Quitovaquita on the boundary (Arizona side), March 4 to May 1 (Huey, 1942, 364) Granados, May 6. The Salvin and Godman records (1903, p. 392) for "Sonora" all pertain to Chihuahua.

\section{CALIDRIS CANUTUS RUFUS (WIISON)}

\section{AMERICAN KNOT}

Tringa rufa Wilson, Amer. (Orn., 1813, 43, pl. 57, fig. 5 (Middle Atlantic States = New Jersey).

Calidris canutus rufus van Rossem and Hachisuka, 1937 a, 331 (Tobari Bay).

Spring migrant on the coast. There is one record, Tóbari Bay from April 26 to May 1, 1930. At this time the Knot was the most abundant shore bird present in the locality and was swarming over the tide flats in flocks of hundreds.

\section{Crocethia alba (Pallas)}

\section{SANIDERI.ING}

Trynga albu Pallas in Vroeg's Cat., 1764, Adumbr., 7 (Coast of the North Sea). Crocethia alba Huey, 1935, 253 (Punta Peñascosa).--van Rossem and Hachisuka, 1937 a, 332 (Tobari Bay).

Calidris arenaria Streets, 1877, 18 (I.a L.ihertad).

Coastwise winter visitant and transient. The earliest date is Punta Peñascosa, February 8, 1934 ; the latest, May 16, 1937, when several small flocks, possibly in part composed of summer-lingering individuals, were seen at Agiabampo and Masocari Island (van Rossem notes).

\section{EREunetes MAURI CABANiS}

\section{WESTFRN SANDPIPI:R}

Ereunetes Mauri Cabanis, Journ. für Orn., 6, No. 24, Nov., 1856 [1857], 419 (Cuba). 
Ereunetes mauri van Rossem and Hachisuka, 1937 a, 332 (Guaymas; Tobari Bay).

Ereunetes maurii Huey, 1935, 252 (Punta Peñascosa).

Ereunetes orcidentalis Allen, 1893 a, 33 (Cachuta).

Ereunetes pusillus (not Tringa pusilla Linnaeus) Sharpe, 1896, 514, part (Hermosillo).-Salvin and Godman, 1903, 382, part (Hermosillo).-Bent, 1927, 244, part (Hermosillo).

Abundant transient and winter visitant coastwise and on interior streams and ponds. In common with various other shore birds it is not improbable that a certain proportion of non-breeding individuals remain through the summer. Unpublished records are San Bernardino Ranch, August 27, 1892; Las Carpas, March 29, 1894 (U. S. Nat. Mus.; Mearns notes); Agiabampo and Masocari Island, May 14 to 16, 1937 (common in nonbreeding plumage; van Rossem notes).

\section{EROLIA MINUTILLA (VIEILLOT)}

\section{LEAST SANDPIPER}

Tringa minutilla Vieillot, Nouv. Dict. Hist. Nat., 34, 1819, 466, (Amérique [etc.] = Halifax, Nova Scotia).-Allen, 1893 a, 33 (San Pedro).-Stone and Rhoads, 1905, 688 (lower Colorado River).

Limonites minutilla Sharpe, 1896, 548 (Hermosillo).-Salvin and Godman, 1903, 387 (Hermosillo; San Pedro).

Pisobia minutilla Huey, 1935, 252 (Punta Peñascosa).

Erolia minutilla van Rossem and Hachisuka, 1937 a, 332 (El Doctor; Guaymas; Tobari Bay).

Common, sometimes abundant, winter visitant and transient, both coastwise and on fresh-water streams and ponds in the interior. Non-breeding individuals seemingly may be found throughout the year. Additional occurrences are San Bernardino Ranch, August 3; San Pedro River on the boundary, October 15; La Noria, November 30, 1892 (Mearns and Holzner in U. S. Nat. Mus. catl.) ; Monument 204 and Las Carpas on the Colorado River, March 19 and 29, 1894 (Mearns notes); Quitovaquita on the boundary (Arizona side), March 4 to 7, 1939 (Huey, 1942, p. 365) ; Agiabampo, May 16; Tesia, June 22, 1937 (van Rossem notes).

\section{ERolia aLPINA SAKHALINA (VIEILLOT)}

\section{RED-BACKED SANDPIPER}

Scolopax sakhalina Vieillot, Nouv. Dict. Hist. Nat., 3, 1816, 359 (Russia = Sakhalin Island).

Erolia alpina sakbalina van Rossem and Hachisuka, 1937 a, 332 (Tobari Bay).

Spring migrant. One record, when found to be abundant at Tóbari Bay between the dates of April 26 and May 1, 1930. 


\section{Family Recurvirostridae Stilts and Avocets HIMANTOPUS MEXICANUS (MÜlLLER) \\ BLACK-NECKED STILT}

Charadrius Mexicanus P. L. S. Müller, Natursyst. Suppl., 1776, 117 (México). Himantopus mexicanus Allen, 1893 a, 33 (Cachuta).-Salvin and Godman, 1903, 361 (Cachuta).-Ridgway, 1919, 442 (Cachuta; Arizona-Sonora boundary).

Himantopus bimantopus mexicanus van Rossem, 1934 d, 434 (Oposura). - van Rossem and Hachisuka, 1937 a, 332 (Ciudad Obregon; Tobari Bay).

Transient and winter visitant to fresh-water streams and coastal marshes; possibly resident locally, though there is no direct evidence. Additional data are from the San Bernardino River on the boundary, August 27, 1892, and October 4, 1893 (U. S. Nat. Mus.; Mearns notes) ; Magdalena, May 8; Rio Mayo, May 18, 1925 (Dawson notes); Quitovaquita on the boundary (Arizona side), April 28 to May 1, 1939 (Huey, 1942, p. 365). Extreme dates are August 27 (San Bernardino River) and May 18 (Río Mayo).

\section{RECURVIROSTRA AMERICANA GMELIN}

\section{AvOceT}

Recurvirostra americana Gmelin, Syst. Nat., 1, pt. 2, 1789, 693 (in America septentrionali et Nova Hollandia=North America).-Allen, 1893 a, 33 (Oputo) .Salvin and Godman, 1903, 363 (Oputo).--Ridgway, 1919, 437 (Oputo).- van Rossem and Hachisuka, 1937 a, 332 (Guaymas; Aranjuez; Ciudad Obregon; Tobari Bay).

American Avoset [sic] Audubon, 1906, 146 (Rancho La Sone [Sonoyta]).

Transient and winter visitant of uncertain abundance, though probably not uncommon. Two additional localities are Colorado River opposite mouth of the Hardy, March 28, 1894 (U. S. Nat. Mus.) ; Rancho La Arizona, May 7, 1937. Extreme dates are September 14 (Sonoyta) and May 7 (Rancho La Arizona).

\section{Family Phalaropodidae Phalaropes \\ Phalaropus fulicarius (LinNaeus)}

\section{Red Phalarope}

Tringa Fulicaria Linnaeus, Syst. Nat., ed. 10, 1, 1758, 148 (in America $=$ Hudson Bay).

Phalaropus fulicarius van Rossem, 1933 b, 199 (San Pedro Nolasco Island to Kino Bay).

Probably not uncommon, at times at least, on open water in the Gulf. The only Sonora record to date is that of "small flocks noted at frequent 
intervals" between San Pedro Nolasco Island and Kino Bay, December 26, 1931. There are records of transients from the Baja California side (Grinnell, 1928).

\section{STEGANOPUS TRICOLOR VIEILLOT}

\section{Wilson Phalarope}

Steganopus tricolor Vieillot, Nouv. Dict. Hist. Nat., 38, 1819, 136 (Paraguay). -van Rossem and Hachisuka, 1937 a, 332 (Saric; off Tiburon Island).

Fall and spring transient. Detected in fall at Rancho La Arizona ("Saric"), September 10, 1929, and at the San Bernardino Ranch and San Bernardino River on or near the boundary from July 31 to October 3, 1892, by Mearns and Holzner (13 specimens catalogued; some examined in U. S. Nat. Mus.). There is one spring record, when seen migrating abundantly off Tiburón Island, April 19, 1925.

\section{LOBIPES LOBATUS (LINNAEUS)}

\section{Northern Phalarope}

Tringa tobata Linnaeus, Syst. Nat., ed. 10, 1, 1758, 148, 824 [Lobata; emend.], (Hudson Bay).

Lobipes lobatus van Rossem and Hachisuka, 1937 a, 332 (Saric; San Esteban Island; Tiburon Island).

Fall and spring migrant. Wright collected a single specimen at Rancho La Arizona on September 10, 1929. Observed in the Gulf off San Estéban Island, April 17, and off Tiburón Island, April 19, 1925, migrating northward in immense numbers.

\section{Family LARIDAE Gulls and Terns \\ LaRUS hEERMANNI CASSIN \\ HEERMANN Gull}

Larus Heermanni Cassin, Proc. Acad. Nat. Sci. Phila., 6, 1852, 187 (San Diego, California).

Larus heermanni Townsend, 1923, 5 (Tiburon Island).-.Mailliard, 1923, 453 (Georges Island).-Bancroft, 1927 b, 189 (George Island).- van Rossem, 1932, 134 (Tiburon Island).--Huey, 1935, 253 (Punta Peñascosa).-Abbott, 1941, 417 (Guaymas).

Common resident of the Gulf, where found the entire length of the coast and about all islands. Although resident in the sense that numerous individuals can be found throughout the year, the only nesting colony on 
the islands lying within Sonora waters seems to be that on George Island in the northern part of the Gulf. There are curiously few published records considering the universal distribution. Some localities where noted (other than above) are San Pedro Mártir Island, and San Estéban Island, January and April; Guaymas in December, April, and May; Kino Bay, December; Tóbari Bay, April; Agiabampo, May (van Rossem notes). Rhoads' (1905, p. 687) sight record of the species for the lower Colorado River has already been rejected (by Grinnell, 1928).

\section{LARUS DELAW ARENSIS ORD}

\section{RING-BILLED GULL}

Larus Delawarensis Ord, in Guthrie's Geogr., 2nd Amer. ed., 1815, 319 (Delaware River, below Philadelphia).

Larus delawarensis Saunders, 1896, 273 (Guaymas).-Salvin and Godman, 1903, 424 (Guaymas).-Cooke, 1915, 43 (Guaymas).-Ridgway, 1919, 623 (Guaymas). - van Rossem, 1932, 134 (Tiburon Island [etc.] = San Pedro, San Carlos, Kino, and Tepopa Bays; San Esteban Island); 1934 d, 434 (Guaymas).- Huey, 1935, 253 (Punta Peñascosa). - van Rossem and Hachisuka, 1937 a, 332 (Guaymas).

Common winter visitant to maritime localities, at least from Guaymas northward. The absence of southern records is probably of no significance. Occurs also, probably not uncommonly, at suitable fresh water localities, such as the Colorado River (U. S. Nat. Mus., March 27 and 28, 1894). Extreme dates are "Dec." and May 14, both records being from Guaymas. The presence of many individuals in immature plumage at the latter date indicates that some, at least, may remain through the summer.

\section{LARUS ARGENTATUS SMITHSONIANUS COUES}

\section{Herring Gull}

Larus Smithsonianus Coues, Proc. Acad. Nat. Sci. Phila., [14], No. 6, June [Aug. 1], 1862, 296 (Eastern and Western coasts of North America).

Larus argentatus smithsonianus van Rossem, 1932, 134 (Tiburon Island).

Larus argentatus (not of Pontoppidan) Stone and Rhoads, 1905, 687 (lower Colorado River).

Apparently a rather uncommon winter visitant northerly in the Gulf area. Occurrences known to date are El Golfo, "a few," November 24, 1930 (Anthony notes) ; Tiburón Island, December 28, 1931; lower Colorado River, "a few" in February, 1905; Colorado River opposite mouth of the Hardy, March 27, 1894 (U. S. Nat. Mus.). Contributory data from the Baja California side are equally rare. 


\section{LARUS CALIFORNICUS LAWRENCE}

\section{California Gull}

Larus Californicus Lawrence, Ann. Lyc. Nat. Hist. N. Y., 6, 1854, 79 (near Stockton, California).

Larus californicus Stone and Rhoads, 1905, 687 (lower Colorado River).- van Rossem, 1932, 134 (Tiburon Island; coast; etc.).-Huey, 1935 (Punta Peñascosa). —van Rossem and Hachisuka, 1937 a (San Esteban Island; Guaymas; Tobari Bay).

Common, often abundant, winter visitant and migrant coastwise and about all islands. One fresh-water record; "a few seen" along the lower Colorado River in February, 1905, by Rhoads. Some maritime and coastal occurrences are El Golfo, November 24, 1930 ("extremely common"; Anthony notes); Punta Peñascosa, February 8 to 28, 1934, "abundant"; Tiburón Island and all along the coast between Guaymas and Tepopa Bay in late December, 1931, and early January, 1932; migrating northward in large flocks at San Estéban Island, April 17 to 19, 1930, and at Tóbari Bay, April 26 to May 1, 1930; common in Guaymas Harbor as late as May 14,1930 , although in this last instance most individuals seen were immature.

\section{LARUS OCCIDENTALIS WYMANI DICKEY AND VAN ROSSEM \\ WyMAN GULL}

Larus occidentalis wymani Dickey and van Rossem, Condor, 27, July, 1925, 163 (Santa Catalina Island, California).-van Rossem, 1933 b, 199 (San Pedro Bay).

One record, that of an adult seen at San Pedro Bay on December 25, 1931, under circumstances which permitted satisfactory identification. Winter occurrences of wymani in the Gulf are probably not unusual since they have been observed as "fairly common" at Cape San Lucas at that season (February 2 and 3, 1938; George Willett, in litt.).

\section{LARUS OCCIDENTALIS LIVENS DWIGHT}

\section{YeLLOW-FOOTED GULL}

Larus occidentalis livens Dwight, Proc. Biol. Soc. Wash., 32, No. 5, Feb. 14, 11 (San José Island, Baja California, México).-Dickey and van Rossem, 1925, 163 (San Pedro Martir and George Islands).-Bancroft, 1927 b, 189 (George Island).- -van Rossem, 1932, 134 (Tiburon Island; coast, etc.).-Huey, 1935, 253 (Punta Peñascosa).-Abbott, 1941, 417 (Guaymas).

Larus occidentalis (not of Audubon) Goss, 1888, 240 (San Pedro Martir Isle).Bryant, 1889, 251 (San Pedro Martir Island).- Townsend, 1890, 138 (Georges Island).-Bent, 1921, 89, part (San Pedro Martir Island).-Mailliard, 1923, 453 (San Esteban Island; Georges Island). 
Common resident of the entire Gulf area with brecding apparently confined, so far as Sonora is concerned, to islands from San Pedro Nolasco northward. A few unpublished localities are Tóbari Bay in late April and early May, 1930; Agiabampo and Masocari Island, May, 1937; mouth of the Colorado River, April, 1925 (van Rossem notes). Colorado River records for this strictly maritime gull (Price, 1899); Stone and Rhoads, 1905) almost certainly pertain to some other species.

\section{LARUS GLAUCESCENS NAUMANN \\ GlauCous-winged Gull}

Larus glaucescens Naumann, Naturg. Vög. Deutschl., 10, 1840, 35 (North America).- van Rossem, 1933 b, 199 (San Pedro Bay).--Huey, 1935, 253 (Punta Peñascosa).

Winter visitant coastwise. Two records; adult seen by van Rossem at San Pedro Bay on December 25, 1931; immature birds noted as "not uncommon" by Huey at Punta Peñascosa, February 8 to 28, 1934 .

\section{LARUS ATRICILLA LINNAEUS}

\section{LAUGHiNG GULL}

Larus Atricilla Linnaeus, Syst. Nat., ed. 10, 1, 1758, 136 (In America=Bahamas).

Larus atricilla van Rossem and Hachisuka, 1937 a, 333 (Guaymas; Tobari Bay).

Common in late spring and carly summer in coastal lagoons from Guaymas southward. Observed to date at Guaymas, April 22 to May 14, 1930; Tóbari Bay (where apparently preparing to breed), April 26 to May 1, 1930 ; Médanos, May 10, 1939 (Mus. Vert. Zool.) ; Agiabampo, May 13 to 15, 1937 (van Rossem notes).

\section{LARUS PHILADELPHIA (ORD)}

\section{Bonaparte Gull}

Sterna Philadelphia Ord, in Guthrie's Geogr., 2nd Amer. ed., 1815, 315 (No locality mentioned $=$ near Philadelphia, Penna.).

Larus philadelphia Townsend, 1890, 137 (Upper Gulf); 1923, 5 (Tiburon Island).-Stone and Rhoads, 1905, 681 (30 miles S. of Yuma).- van Rossem, 1932, 134 (Tiburon Island).- - Huey, 1935, 253 (Punta Peñascosa).- van Rossem and Hachisuka, 1937 a, 333 (Guaymas).-Abbott, 1941, 417 (Guaymas).

Common, sometimes abundant, winter visitant and migrant coastwise. There is but one fresh-water record, that of Stone and Rhoads for the 
lower Colorado River. Additional occurrences are El Golfo, November 24, 1930, "common"; Tiburón Island, December 5, 1930, "thousands" (Anthony notes) ; Puerto Libertad, February 8, 1935 (Nat. Hist. Mus.). Extreme dates are November 24 (El Golfo) and May 4 (Guaymas).

\section{GELOCHELIDON NILOTICA VANROSSEMI BANCROFT}

\section{Western Gull-Billed TerN}

Gelochelidon nilotica vanrossemi Bancroft, Trans. San Diego Soc. Nat. Hist., 5, 1929, 284 (Salton Sca, Imperial County, California).- van Rossem and Hachisuka, 1937 a, 333 (Tobari Bay).

Status uncertain. One record, that at Tóbari Bay between April 26 and May 1, 1930, when van Rossem noted the species as not uncommon and evidently preparing to nest. In default of specimens it is presumed that the race is the same as that which breeds on Salton Sea.

\section{HYDROPROGNE TSCHEGRAVA TSCHEGRAVA (LEPECHIN) \\ Caspian Tern}

Sterna Tschegrai'a Leepechin, Novi Comm. Acad. Sci. Petropol., 14, pt. 1, 1770, 500, pl. 13 (Caspian Sea).

Hydroprogne caspia Ridgway, 1919, 461 (Colorado River). mas).

Hydroprogne caspia imperator van Rossem and Hachisuka, 1937 a, 333 Guay-

Detected only as a spring migrant. There are but two records, those of a specimen taken on the lower Colorado River opposite the mouth of the Hardy, March 28, 1894 (U. S. Nat. Mus.), and one or more individuals scen daily at Guaymas between April 21 and 23, 1930.

\section{STERNA FORSTERI NUTTALI.}

\section{FORSTER TERN}

Sterna Forteri Nuttall, Man. Orn. U. S. and Canada, 2, 1834, 274, note (Banks of Saskatchewan River between Cumberland House and I.ake Winnipeg).

Sterna forsteri van Rossem and Hachisuka, 1937 a, 333 (Guaymas: Tobari Bay; Guasimas Lagoon; mouth of the Colorado River).

A winter visitant and spring migrant, evidently in limited numbers. Observed at follows: fairly common at Punta Peñascosa, January 21 to 23, 1930 (Sheffler coll. and notes) ; noted at mouth of the Colorado near Montague Island, April 23, 1925; at Tóbari Bay, April 26 to May 1, 1930 ; at Guaymas, April 21 to May 4, 1930; at Guásimas Lagoon, May 
1, 1930 (spec. in Dickey collection), and at Agiabampo, May 13 to 15, 1937 (van Rossem notes). The fact that by far the majority of those observed were immature and that these were present as late as the middle of May suggests summer (but non-breeding) residence by some individuals. Price (1899) saw some species of tern "about the size of $S$. forsteri" at the mouth of the Colorado near Montague Island in early December, 1898, which may or may not have been that species.

\section{STERNA ALBIFRONS MEXICANA VAN ROSSEM AND HaCHISUKA}

\section{Mexican Least Tern}

Sterna albitrons mexicanus [sic] van Rossem and Hachisuka, Trans. San Diego Soc. Nat. Hist., 8, No. 23, June 15, 1937, 333 (Tóbari Bay, Sonora, México) ; ibid., in text (Guaymas south to Sinaloa).

Sterna albifrons mexicana Brodkorb, 1940, 542 (Sonora; crit.).--Burleigh and Lowery, 1942, 173, in text (Masocari Island; Tobari Bay; crit.).

Summer visitant to the Tropical zone seacoast southward from Guaymas. Present dates (breeding or about to do so) cover only the short interval between April 26 to May 16. Some race of the Least Tern winters in the northern part of the Gulf but its identity has not been determined (Punta Peñascosa, January 21 to 23, 1930; specimens taken lost en route) (Sheffler and Rowley notes).

\section{ThaLASSEUS maXIMUS MAXIMUS (BODDAERT)}

\section{ROYAL TERN}

Sterna maxima Boddaert, Table Pl. Enlum., 1783, 58 (Cayenne).-Lawrence, 1874, 318 (Guaymas).--Salvin and Godman, 1903, 406, part (Guaymas).Mailliard, 1923, 453 (Georges Island).- -van Rossem, 1932, 135 (Tiburon Island). Huey, 1935, 253 (Punta Peñascosa).- - van Rossem and Hachisuka, 1937 a, 334 (Estrada de Tasiota; mouth of the Colorado River; Guaymas; Tobari Bay; Lobos Island; George Island).

Royal Tern Bancroft, 1927 a, 34 (George Island).-Vorhies, 1936, 248, in text (Puerto Libertad).

Common resident of the seacoast and islands from the mouth of the Colorado southward. The only positive breeding station for Sonora seems to be George Island, whence reported by Mailliard, Bancroft, and others; however, numerous pairs seen on a small sand island in Tóbari Bay on May 1, 1930, gave every indication of preparing to nest. Van Rossem and Hannum noted numerous pairs in breeding plumage at Agiabampo and Masocari Island on May 16, 1937. 


\section{THALASSEUS ELEGANS (GAMBEL)}

\section{ELEgant Tern}

Sterna elegans Gambel, Proc. Acad. Nat. Sci. Phila., 4, No. 6, Dec., 1848 [June 16, 1849], 129 (Mazatlán, [Sinaloa], Pacific coast of México).-Baird, Brewer, and Ridgway, 1884 (2), 287 (Guaymas).-Brewster, 1902, 24 (Guaymas).-Salvin and Godman, 1903, 407 (Guaymas).-Bent, 1921, 219 (Guaymas; San Pedro Martir Island).- Townsend, 1923, 6 (San Esteban Island; Guaymas).-Mailliard, 1923, 454 (Georges Island).-Bancroft, 1927 a, 36 (George Island).

Thalasseus elegans Ridgway, 1919, 472 (Guaymas).- van Rossem, 1932, 135 (Tiburon Island).-Huey, 1935, 253 (Punta Peñascosa).

Common resident throughout the Gulf area; breeding, though, is confined to a few islands of which only one, George Island, is properly within Sonora waters. The northward migration of this species along the Pacific coast indicates the seasonal departure from the Gulf of a part of the population; however, it is common at all seasons. Some further localities are the mouth of the Colorado River at Montague Island; Tóbari Bay; Agiabampo; Masocari Island (van Rossem notes). A good part of the bibliography above concerns an egg in the U. S. National Museum, supposed to have been taken at "Guaymas, west of Sonora." Guaymas has been the chief market for Raza Island eggers from time immemorial, but doubtless will continue to be cited as a breeding locality of the Elegant Tern for the duration of ornithological literature.

\section{Family RYNCHOPIDAE Skimmers \\ RYNCHOPS NIGRA OBLITA GRISCOM}

\section{Western Black Skimmer}

Rynchops nigra oblita Griscom, Ibis, July, 1935, 545 (Acapam Lagoon, Pacific Coast of Guatemala).- van Rossem and Hachisuka, 1937 a, 334 (Guasimas Lagoon; Algodones Lagoon).

Known only as an early summer visitant to lagoons between the mouth of the Yaqui River and Guaymas. Six specimens in the Dickey collection, taken at Algodones Lagoon, May 1, 1930, and Guásimas Lagoon, May 12, 1930, were just finishing the prenuptial moult and were apparently nearly ready to breed on the above dates..$^{15}$

15 The name oblita is used provisionally, pending a review of the American Skimmers by Dr. Wetmore. 


\title{
Family Alcidae Auks, Murres, and Puffins \\ BRACHYRAMPHUS hYPOLEUCUS CRAVERI (SALVADORI)
}

\section{Craveri Murrelet}

Uria Craveri Salvadori, Atti Soc. Ital. Sci. Nat., 8, 1865, 387 ("Golfo della California" = Raza Island, Gulf of California, México ).

Endomychura craveri Bancroft, 1927 b, 188 (George Island; San Esteban Island).-van Rossem, 1932, 135 (Tiburon Island; off Kino Bay).

Brachyramphus bypoleucus craveri van Rossem, 1939 f, 441 (nomen.; crit.).

Brachyramphus craverii Townsend, 1923, 5 (Tiburon Island).-van Rossem, 1926 a, 82 (George Island; 5 miles west of Tiburon Island).

Common resident of the Gulf; on the Sonora side from San Pedro Nolasco Island north to George Island. The proportion of the population which leaves the Gulf to winter north along the Pacific coast cannot even be estimated; however, numbers have been seen in midwinter at San Pedro Nolasco Island, December 26, 1931 ; San Pedro Mártir Island, January 10, 1932 (where breeding in April, 1925) ; San Estéban Island, January 11, 1932, Kino Bay, and Tiburón Island, December 28, 1931, and January 1, 1932. Due to the absence of rocky islands south of San Pedro Nolasco, the breeding range abruptly stops at that point,-this in contrast to the almost continuous distribution on the Baja California side. ${ }^{16}$

\section{Order COLUMBIFORMES Pigeon-Like BiRdS}

\section{Family Columbidae Pigeons and Doves \\ COLUMBA FLAVIROSTRIS FLAVIROSTRIS WAGLER}

\section{Eastern Red-Billed Pigeon}

\author{
Columba flavirostris Wagler, Isis von Oken, 1831, col. 519 (México=Vera \\ Cruz). \\ Columba flavirostris flavirostris Peters, 1937, 65 (Southeastern Sonora). \\ Columba flavirostris restricta (not of van Rossem, 1930) van Rossem, 1934 d, \\ 434, part (Alamos, part).
}

${ }^{16}$ In curious error, Cooke (Auk, 1916, p. 80) states that the latitude as given by Salvadori is not that of Natividad Island (which it is), but is that of Raza Island (which it is not). It seems clear from Salvadori's remarks that the latitude and longitude given were intended to be that of Natividad Island, where Craveri also (italics mine) saw, or thought he saw, murrelets. However, since San Pedro Mártir and Raza were the only two guano islands of any former importance in the Gulf, and since Salvadori specifically places his type locality in the Gulf area, Raza will do well enough. The longitude as given by Salvadori is surely a typographical error: " $110^{\circ}$ " instead of $115^{\circ} .110^{\circ}$ is in the desert east of Guaymas! 
One record, that of a specimen taken by Frazar at Alamos on February 2, 1888, and now in the Museum of Comparative Zoölogy. This individ. ual, undoubtedly a vagrant from east of the mountains, is the basis upon which Peters (1937) included southeastern Sonora in the range of flavirostris. The other specimen taken by Frazar at Alamos (March 22, 1888) is the resident race restricta, as are all other specimens examined from Sonora.

\section{COLUMBA FLAVIROSTRIS RESTRICTA VAN ROSSEM}

\section{Western Red-Billed Pigeon}

Columba flavirostris restricta van Rossem, Trans. San Diego Soc. Nat. Hist., 6, No. 8, Aug. 30, 1930, 197 (Tecoripa, Sonora, México) ; ibid., in text (Chinobampo; Guirocoba); 1931 c, 248 (Tecoripa; Chinobampo; Guirocoba; Agiabampo) ; 1934 d, 434, part (Alamos; part ).-Peters, 1937, 65 (west-central Sonora to Sinaloa).Hellmayr and Conover, 1942, 451 (Chinobampo; Guirocoba; crit.).

Columba flavirostris (not of Wagler) Cooper, 1870, 508, part (northern Sonora).-Salvadori, 1893, 285, part (Sierra de Alamos).--Salvin and Godman, 1902, 234, part (Sierra de Alamos).

Columba flavirostris flavirostris Bent, 1932, 365, part (Sierra de Alamos).

Chloroenas flavirostris flavirostris Ridgway, 1916, 300, part (Sierra de Alamos).

Fairly common resident in the Tropical zone, north, locally, to about latitude $29^{\circ}$. The northernmost localities known to date are Rancho Costa Rica, December 15, 1932 (Lamb notes), Tecoripa, March 5, 1929, and Las Arenas, January 7, 1906 (Mus. Comp. Zoöl.). Other localities not listed above are San Francisco Cañon, Navojoa, and Tesia in June, 1937 (van Rossem notes). The basis for Cooper's statement of "northern Sonora" has not been ascertained.

\section{COLUMBA FASCIATA FASCIATA SAY}

\section{BAND-TAILED PigEON}

Columba fasciata Say, in Long's Exped. Rocky Mts., Phila. ed., 2, 1823, 10, note (small tributary of the Platte=Plum Creek, near Castle Rock, Douglas County, Colorado).-Baird, 1858, 597 (Los Nogales); 1859, 21 (Los Nogales; Santa Cruz River).--Brewer in Baird, Brewer, and Ridgway, 1874, (3), 362, part, in text (Los Nogales; Santa Cruz River).--Jouy, 1894, 789 (32 miles south of Nogales).-Salvin and Godman, 1902, 237, part (Nogales).

Columba fasciata fasciata van Rossem, 1931 c, 247 (Saric; San Javier); 1934 d, 434 (Oposura).

Chloroenas fasciata fasciata Ridgway, 1916, 288, part (Quijano; San Jose Mts.; 32 miles south of Nogales).

Fairly common in spring, summer, and fall in Upper Sonoran and Tran. sition oak associations from the vicinity of Nogales eastward, and south through the mountainous eastern part of the State. Occurs irregularly or 
perhaps seasonally at lower levels such as Tecoripa in early April (Wright notes) and Guirocoba in the fall months (fide residents). Unpublished localities are Rancho Santa Bárbara, June, 1937 (van Rossem notes); San Luís Mountains, July and September, 1892; Cajón Bonito Creek, September, 1892 (Mearns notes). Although existing records fall between "early April" and October 21, the Band-tailed Pigeon is undoubtedly a permanent resident.

\section{ZENAIDURA MACROURA MARGINELLA (WOODHOUSE) Western MOURNING Dove}

Ectopistes marginellus Woodhouse, Proc. Acad. Nat. Sci. Phila., 6, No. 3, MayJune [Aug. 20], 1852, 104 (Cross Timbers, north fork of the Canadian River, Oklahoma).

Zenaidura macroura marginella Ridgway, 1916, 347 (Guaymas; Huerachi; Hermosillo; Ysleta; Opodepe; La Chumata).-Townsend, 1923, 13 (Tiburon Island).—van Rossem, 1931 c, 248 (Tecoripa; San Pedro Martir Island; 15 miles south of Nogales; Tobari Bay) ; 1932, 135 (Tiburon Island); 1934 d, 434 (Alamos; Oposura).- Hellmayr and Conover, 1942, 479 (Tecoripa).

Zenaidura macroura (not Columba macroura Linn.) Evermann and Jenkins, 1888, 68 (Magdalena).-Goss, 1891, 241, part (San Pedro Martir Island).-Allen, 1893, a, 34 (Huerachi).- Stone and Rhoads, 1905, 688 (Colony=Colonia Lerdo).

Zenaidura macrura Evermann and Jenkins, 1888, 65 (Nogales; Hermosillo).

Zenaidura carolinensis (not Columba carolinensis Linn.) Baird, 1859, 21, part (Santa Cruz).--Brewer, 1874, 383, part (Santa Cruz).--Belding, 1883, 344 (Guaymas).-Salvadori, 1893, 374, part (Ysleta).-Salvin and Godman, 1902, 242, part (Ysleta; Huerachi; Guaymas).

Zenaidura carolinensis carolinensis Thayer and Bangs, 1906, 18 (Opodepe; La Chumata ).

A common, often abundant, resident of Sonoran and Tropical zones everywhere, including islands in the Gulf, although occurring in greatest numbers in river valleys and cultivated areas. Some additional unpublished localities are El Álamo and Rancho Costa Rica, December, 1932; Ures, January, 1933 (Lamb notes); San Estéban Island, January, 1932; Colonia Independencia, May, 1937; Rancho Santa Bárbara, June, 1937; Guirocoba, May and June, 1937 (van Rossem notes) ; Cajón Bonito Creek, Guadalupe Cañon, and San Bernardino, July to September, 1892-93 Mearns notes).

\section{ZENAIDA ASIATICA MEARNSI (RIDGWAY)}

\section{WESTERN WHITE-WINGED DOVE}

Melopelia asiatica mearnsi Ridgway, Proc. Biol. Soc. Wash., 28, No. 18, May 27, 1915, 107 (five miles north of Nogales, Arizona); 1916, 382 (Hermosillo; Guaymas; Alamos).-Townsend, 1923, 13 (Tiburon Island).-Bailey, 1928, 303 (Guadalupe Cañon).--van Rossem, 1931 c, 248 (Pesqueira; Guaymas; El Alamo; 
Miramar; Empalme; Tobari Bay; San Esteban Island); 1932, 135 (Tiburon Island); 1934 d, 434 (Guaymas; Alamos; Oposura).-Bent, 1932, 422 (Guaymas).-Friedmann, 1933 a, 189 (Guirocoba).

Zenaida asiatica mearnsi Hellmayr and Conover, 1942, 499 (Tecoripa).

Columba leucoptera (not of Linnaeus) Heermann, 1853, 271 (Guaymas).

Melopelia leucoptera Lawrence, 1874, 30 s (Sonora).--Belding, 1883, 344 (Guaymas).-Stephens, 1885, 229 (Caborca).-Evermann and Jenkins, 1888, 68 (Magdalena).-Salvadori, 1893, 292, part (Alamos; Nuri).-Salvin and Godman, 1902, 245, part Alamos; Guaymas).- Thayer and Bangs, 1906, 18 (Opodepe; La Chumata).-Sheffler, 1931 b, 165 (Santa Ana; Magdalena).

Common resident nearly everywhere in Sonoran and Tropical zones (including the larger islands), except that there is an almost total withdrawal in winter north of about latitude $29^{\circ}$. The northernmost winter locality at present known is Puerto Libertad, February 5, 1935 (Nat. Hist. Mus.) ; however, small numbers winter in southern Arizona and may be expected to do so in northern Sonora. Additional localities are Cajón Bonito Creek, July, 1892 (Mearns notes) ; Rancho La Arizona, migration flights May 7 to 9; Agiabampo, May 13; San Francisco Cañon, May 31 ; Rancho Santa Bárbara, June, 1937 (van Rossem notes).

\section{SCARDAFELLA INCA (LESSON)}

\section{INCA DOVE}

Chamaepelia inca Lesson, Descr. Mamm. et Ois. recémm. decouv., 1847, 211 (México [probably west coast]).

Scardafella inca Belding, 1883, 344 (Guaymas).-Stephens, 1885, 228 (Pedroquito).-Allen, 1893 a, 34 (Granados).-Salvadori, 1893, 465 (Guaymas; Nacozari; Rio Mayo).-Salvin and Godman, 1902, 248 (Guaymas; Nacozari; Rio Mayo; Granados; Rio Yaqui).-Ridgway, 1916, 390 (Opodepe; La Chumata; et supra).van Rossem, 1931 c, 249 (Tecoripa; Saric; San Jose de Guaymas; Obregon; San Javier) ; 1934 d, 435 (Guaymas; Alamos; Nacozari; Oposura).-Sheffler, 1931 a, 137 (27 miles S. of Nogales); 1931 b, 164 (between Magdalena and Santa Ana).Bent, 1932, 444 (Opodepe).-Dickey and van Rossem, 1938, 195 (Sonora; crit.).

Scardafella incu inca Thayer and Bangs, 1906, 18 (Opodepe).

Scardafella squammata inca Hellmayr and Conover, 1942, 508 (Alamos; Tecoripa).

Common mainland resident of Lower Sonoran and Tropical zones nearly everywhere except in the extreme northeast and northwest, from which regions there are as yet no records. There is local penctration to 4,500 fect in the Upper Sonoran. Numbers decline rapidly toward the northern boundary and distribution tends to become "spotty" and to localize even more definitely than usual in the vicinity of towns and ranches. Some localities not cited above are Rancho Costa Rica, Deccmber 9 to 14, 1932 (Lamb notes) ; Hermosillo; Navojoa; Guirocoba; Agiabampo, in May, 1937; Rancho Santa Bárbara; Tesia, in June, 1937 (van Rosscm notes). 


\section{Columbigalilina passerina paLLescens (BAIRD)}

\section{Mexican Ground Dove}

Chamaepelia passerina? var. pallescens Baird, Proc. Acad. Nat. Sci. Phila., [11], 1859, sig. 21-23, Oct.-Nov., [Jan. 12, 1860], 305 (Cape San Lucas, Baja California, México).

Chamaepelia passerina pallescens Bancroft, 193026 (southern Sonora).

Chaemepelia passerina pallescens Todd, 1913, 534, 595 (Alamos; Hermosillo; Guaymas; Bacoachi; monog.).--Ridgway, 1916, 402 (Alamos; Hermosillo; Guaymas: Bacoachi; Santa Rosa; Opodepe).

Columbigallina passerina pallescens Thayer and Bangs, 1906, 18 (Opodepe).van Rossem, 1931 c, 248 (many locs.); 1934 d, 434 (Guaymas; Alamos; Bacoachi; Oposura).-Dickey and van Rossem, 1938, 189 (Sonora; crit.).-Hellmayr and Conover, 1942, 514 (Rancho Carrizo; Soyopa; Tecoripa).

Chamaepelia passerina (not Columba passerina Linnaeus) Belding, 1883, 344 (Guaymas).-Stephens, 1885, 229 (Pedroquito).-Salvadori, 1893, 473, part (Santa Rosa).- Salvin and Godman, 1902, 250, part (Guaymas).

Columbigallina passerina Evermann and Jenkins, 1888, 68 (Magdalena).

Common resident of Iower Sonoran and Tropical zones nearly every. where, except that there are no records from any of the islands nor from the extreme northeast. Associational preferences are riparian shrubbery. about human habitations, and cultivated areas generally. Further occurrences are Caborca, February 2, 1932 (Phillips notes); San Luís; San Francisco Cañon; Agiabampo, in May, 1937 (van Rossem notes).

\section{LEPTOTILA VERREAUXI SANTIAGO VAN ROSSEM ANI) HaCHISUKA}

\section{WFSTFRN WHITE-FR(ONTEI) DOVE}

Leptotila verreauxi santiago van Rossem and Hachisuka, Proc. Biol. Soc. Wash., 50. Nov. 26, 1937, 199 (Guirocoba, Sonora, México).- Hellmayr and Conover, 1942, 570, footnote (Chinobampo); Guirocoba; Tecoripa).

Leptoptila brachyptera (not of Salvadori, p. 545) Salvadori, 1893, 547, in text (Sonora).-Salvin and Godman, 1902, 257, part (Sonora).

Leptotila fulviventris brachyptera Ridgway, 1916, 453, part (Alamos).

Leptotila fulviventris angelica (not of Bangs and Penard, p. 29) Bangs and Penard, 1922, 30, in text (Alamos; Hacienda de San Rafael).-van Rossem, 1931 c, 249 (San Javier); 1934 d, 435 (Alamos; Hacienda de San Rafael).-Peters, 1937, 122, part (southern Sonora).

Fairly common resident of foothill areas in the southeastern part of the State. While the life zone occupied is almost entirely Tropical (arid deciduous forest), small numbers occur as high as 5,000 feet in an Upper Sonoran oak association (Rancho Santa Bárbara, June, 1937). North. ernmost localities are San Javier and Tecoripa at about latitude $28^{\circ} 30^{\prime}$. An additional locality is San Francisco Cañon (breeding May 31, 1937; van Rossem notes). 


\title{
Order PSITTACIFORMES Macaws ANd PARrots
}

\author{
Family Psittacidae Macaws and Parrots \\ ARA MILITARIS SHEFFIERI VAN ROSSEM AND HACHISUKA
}

Northern Military Macaw

Ara militaris sheffleri van Rossem and Hachisuka, Proc. Biol. Soc. Wash., 52, Feb. 4, 1939, 13 (Guirocoba, Sonora, México) ; ibid., in text (Chinobampo; Alamos; Quiriego; Soyopa; San Francisco Cañon ["Chihuahua"-lapsus]).

Ara militaris (not Psittacus militaris Linn.) Salvadori, 1891, 158, part (Quiriego).-Salvin and Godman, 1897, 556, part (Quiriego).

Ara militaris mexicana (not of Ridgway, 1915) Ridgway, 1916, 132, part (Quiriego).-van Rossem, 1931 c, 247 (Chinobampo; Guirocoba); 1934 d, 435 (Alamos).-Peters, 1937, 181 (Sonora).

Common resident of the foothills and mountains in the southeastern part of the State, where tending to localize in the vicinity of large timber. Although most of the records are from Tropical zone localities, this species was noted as not uncommon as high as 5,500 feet in the oak-pine association of the Transition zone at Rancho Santa Bárbara in June, 1937 (van Rossem notes). Soyopa, at $28^{\circ} 45^{\prime}$ where noted by Wright on October 14, 1931, is by far the most northerly point at which the military macaw has been detected.

\section{ARATINGA HOLOCHLORA BREIUSTERI NELSON \\ Brewster Green Paroquet}

Aratinga bolochlora brewsteri Nelson, Proc. Biol. Soc. Wash., 41, Oct. 15, 1928, 154 (Hacienda de San Rafael, "Chihuahua" [=Sonora], México).- Bangs, 1930, 202 (location of type).- van Rossem, 1934 d, 435 (Hacienda de San Rafael).Peters, 1937, 186 (Hacienda de San Rafael).

Aratinga bolochlora bolocblora (not Conurus bolochlorus Sclater) Ridgway, 1916, 157, part (Hacienda de San Rafael).

Status uncertain. The race brewsteri is known only from the eight specimens collected by Frazar at Hacienda de San Rafael between May 5 and 7,1888 . Since the general region in which they were collected has been intensively worked by several experienced collectors, without the discovery of further evidence, it would seem likely that Frazar's birds were vagrants and that the real center of distribution lies outside of Sonora.

\section{RHYNCHOPSITTA PACHYRHYNCHA (SWAINSON) \\ THICK-BILled Parrot}

Macrocercus pacbyrbynchus Swainson, Philos. Mag., new ser., 1, No. 6, June, 1827, 439 (Table land [of México]).

Rbynchopsitta pacbyrbyncha Lusk, 1900, 129 (Sonora [?]).-Sheffler, 1931 b, 166, in text (Madera Mountains). 
Although the Thick-billed Parrot is probably present in various Transition zone ranges in eastern Sonora, the only definite record is that of Sheffler who cites the species from the "Madera Mountains." This name (Sierra de Madera) is synonymous with El Tigre Mountains, the north. western portion of the Sierra de Nácori.

Photographic evidence of the occurrence has been examined (van Rossem) and is satisfactory. ${ }^{17}$

\section{FORPUS CYANOPYGIUS PALLIDUS (BREWSTER)}

\section{SONORA PARROTLET}

Psittacula cyanopyga pallida Brewster, Auk, 6, No. 2, April, 1899 [separates issued Jan. 31], 85 (Álamos, Sonora, México).

Psittacula cyanopygia pallida Ridgway, 1916, 193 (Alamos; Sierra de Alamos).Cory, 1918, 75 (Sonora).- -van Rossem, 1931, c, 247 (Guirocoba; Chinobampo).

Psittacula pallida Sharpe, 1900, 19 (Sonora).-Dubois, 1903, 1053 (Sonora).Salvadori, 1906 a, 464 (Sonora; crit.).

Forpus cyanopygia pallida van Rossem, 1934 d, 435 (Alamos).

Forpus cyanopygius pallidus Bangs, 1930, 203 (cotypes).-Peters, 1937, 203 (Sonora).

Psittacula cyanopygia (not of Souancé) Salvadori, 1891, 249, part (Sierra de Alamos; crit.).-Salvin and Godman, 1897, 581, part (Alamos; Sierra de Alamos).

Psittacula cyanopyga Salvin and Godman, 1889 b, 242, in text (Alamos).

Resident and rather common in the Tropical zone foothills in the

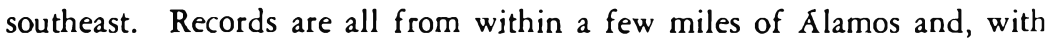
one exception, in the narrow altitudinal range of 1,200 to 1,500 feet. Wright (notes) believed a few individuals seen at Chinobampo (altitude 300 feet), in February, 1929, and March, 1930, to be seasonal vagrants in the locality. Further seasonal and locality records are Alamos, October 26, 1898, to January 9, 1899 (Biol. Surv.) ; Guirocoba, late May to late June, 1937 (van Rossem notes) ; Agua Marín, May 4 to 6, 1939 (Mus. Vert. Zool.).

17 Southern specimens (Cofre de Perote and south central México) have longer tails than those from northwestern localities but I am unable to detect significant color differences. Five from the former area (Brit. Mus.; sex not indicated) have tails measuring 190-192 mm., while 17 from Durango, Chihuahua, and Arizona measure 157 (worn)-182 mm. Subspecific separation of the northwestern population may prove to be desirable if larger series confirm the differences. All available names, including Psittacus strenuus Lichtenstein (type from Angangueo, extreme east-central Michoacán) apply to southern birds. 


\section{AMAZONA ALBIFRONS SALTUENSIS NELSON}

\section{SONORA WHITE-FRONTED PARROT}

Amazona albifrons saltuensis Nelson, Proc. Biol. Soc. Wash., 13, May 29, 1899, 28 (Camoa, Sonora, México).-Ridgway, 1916, 259 (Camoa; Alamos; Sierra de Alamos; Quiriego; Batamotal).-Cory, 1918, 89 (Sonora).-Kuroda, 1930, 131 (Sonora).- van Rossem, 1931 c, 247 (Tesia, Chinobampo, Guirocoba; Guaymas; Ciudad Obregon) ; 1934 d, 346 (Alamos).-Peters, 1937, 217 (Sonora).

A.[mazona] a.[lbifrons] saltuensis Miller, 1905, 348, in 'text (Sonora; crit.). Chrysotis saltuensis Salvadori, 1906 b, 648 (Sonora; crit.).

A.[mazona] albifrons (not Psittacus albifrons Sparrman) Ridgway, 1896, 595 (Alamos).

Chrysotis albifrons Salvin and Godman, 1889 a, 242, part, in text (Alamos); 1897, 593, part (Queriego; Sierra de Alamos).-Salvadori, 1891, 311, part (Quiriego; Sierra de Alamos).

Common resident of the lowlands, foothills, and lower mountains from latitude $28^{\circ}$ southward; apparently breeding throughout its range. North. ernmost records are from the vicinity of Guaymas, coastwise, and Quiriego in the interior. South of these points stations of occurrence are numerous: some not previously cited are Cocorit, common in June, 1930; Navojoa, and Hacienda de San Rafael, common at all seasons (Wright notes) ; Agiabampo, common in carly May, 1937; San Francisco Cañon, fairly com. mon May 31, 1937; Rancho Santa Bárbara, occasionally noted in pines at 5,000 feet in early June, 1937 (van Rossem notes). Although associations of wide diversity are occupied (chiefly giant cactus northerly, and wooded areas southerly) all records are from the Tropical zone except the one from Rancho Santa Bárbara.

\section{AMAZONA FINSCHI WOODI MOORE}

\section{WoOd Red-Fronted Parrot}

Amazona finschi woodi Moore, Auk, 54, October, 1937, 528 (Guirocoba, Sonora, México); ibid.. in text (Alamos).

Chrysotis finschi (not of Sclater) Lawrence, 1874, 296, part (southern Sonora).Salvin and Godman, 1889 a, 242, part, in text (Alamos); 1897, 589, part (southern Sonora).

Amazona finschi Ridgway, 1896, 595, part (Alamos); 1916, 244, part (Alamos; Mina Abundancia).- van Rossem, 1931 c, 247 (Guirocoba); 1934 d, 346 (Alamos; Mina Abundancia).-Peters, 1937, 219, part (Sonora).

Fairly common, but rather local, resident of foothills and mountains in the extreme southeastern corner of the State. Available data indicate that the vertical range begins at about 1,200 feet altitude in the Tropical zone (Álamos; Guirocoba, breeding; San Francisco Cañon, breeding) and extends upward through the Upper Sonoran to the Transition (El Cobre; 
Rancho Santa Bárbara, breeding). Data additional to that cited in the synonymy above are Hacienda de San Rafael where observed by Wright (notes) "from January to May"; San Francisco Cañon, May 29, 1937, common; Rancho Santa Bárbara in pine and oak-pine associations to 5,500 feet in early June, 1937 (van Rossem notes).

\section{Order CUCULIFORMES CucKoo-Like BirdS}

\section{Family Cuculidae Cuckoos, Roadrunners, and Anis}

\section{COCCYZUS AMERICANUS OCCIDENTALIS RIDGWAY}

\section{California Cuckoo}

C.[occyzus] americanus occidentalis Ridgway, Man. No. Amer. Birds, 1887, 273 (western United States $=$ Santa Rita Mountains, Arizona).

Coccyzus americanus occidentalis van Rossem, 1931 c, 249 (Saric; Guaymas; Agiabampo).-Bent, 1940, 64, in text (Guaymas).

Coccjzus americanus (not Cuculus americanus Linnaeus) Evermann and Jenkins, 1888, 68 (Magdalena).-Salvin and Godman, 1896, 525, part (Moctezuma).Shelley, 1891, 308, part (Moctezuma).

Summer visitant to riparian woodland over most of the State. The few records are well scattered zonally and geographically and with alti. tude extremes of sea level and 4,500 feet. Additional localities are Pilares, June 22, 1935 (Univ. Mich.) ; Rancho Carrizo, July 6, 1931 (Bishop coll.) ; Guirocoba, June 16 and 17, 1937; Rancho Santa Bárbara, June 11, 1937 (van Rossem notes). Dates extend from June 9 (Agiabampo) to September 22 (Rancho La Arizona). ${ }^{18}$

18 The validity of the race occidentalis has several times been questioned, most recently by Swarth (Proc. Calif. Acad. Sci., 4th ser., 13, 1929: 297-299), and it is true that a proportion of the smaller individuals are indistinguishable from americanus. Measurements of specimens of occidentalis in the Dickey collection are as follows:

8 breeding males from Rancho La Arizona (only a few miles from the Santa Rita Mountains).

Wing, 139-148 (144.8)

6 breeding males from southern California.

Wing, $143-152$ (148.3)

Tail, 141-153 (148.0)

breeding male from Bellingham, Washington.

Wing, 155

5 breeding females from Rancho La Arizona.

Wing, 149-154 (152.0)

Tail, 140-155 (148.0)

6 breeding females from southern California.

Wing, 148-155 (151.5)

1 breeding female from Seattle, Washington.

Wing, 159

Tail, 167

Tail, 149-155 (152.0)

Tail, 152-161 (155.8)

Tail, 159 


\section{PIAYA CAYANA EXTIMA VAN ROSSEM}

\section{SONORA SQUirRel-Cuckoo}

Piaya cayana extima van Rossem, Trans. San Diego Soc. Nat. Hist., 6, No. 12 , Sept. 30, 1930, 210 (Guirocoba, Sonora, México).-1931 c, 249 (Guirocoba); 1934 d, 436, in text (Guirocoba; Hacienda de San Rafael; Questa del Tigre).Peters, 1940, 45 (southern Sonora).-Wetmore, 1944, 44, in text (southern Sonora; crit.).

Status uncertain. Presumably resident in the Tropical zone foothills of the extreme southeastern part of the State. The nine specimens collected to date have been taken in April, May, and June.

\section{Crotophaga sulcirostris pallidula Bangs and Penard}

\section{NORTHWESTERN ANI}

Crotophaga sulcirostris pallidula Bangs and Penard, Bull. Mus. Comp. Zoöl., 64, No. 4, Jan., 1921, 365 (San José del Cabo, Baja California, México).- van Rossem, 1938 b, 91 (Sonora; crit.).

Crotophaga sulcirostris sulcirostris (not Crotophaga sulcirostris Swainson) van Rossem, 1931 c, 249 (Guirocoba).-Peters, 1940, 58, part (southern Sonora).

Common, though seemingly very local, summer visitant to the Tropical zone. This Ani is definitely migratory in Sonora, the first arrivals appearing at Guirocoba on May 6 in 1930, May 24 in 1931, and June 16 in 1937. Numbers vary considerably from year to year according to local testimony. The only other station to date is Tesia in the Mayo River valley, where common and evidently breeding June 19 to 22, 1937 (van Rossem notes). There are no data relative to fall departure.

\section{GEOCOCCYX CALIFORNIANUS (LESSON)}

\section{ROADRUNNER}

Saurothera californiana Lesson, Compl. Oeuvres Buffon, 6, 1829, 420 (La Californie $=$ San Diego .

Geococcyx californianus Belding, 1883, 344 (Guaymas).-Salvin and Godman, 1896, 534 (Guaymas).-Price, 1899, 92 (lower Colorado River).-Ridgway, 1916, 75 (Sonora).-Cory, 1919, 348 (Sonora).- -van Rossem, 1931 c, 249 (San Javier; Saric; Obregon; Tesia; 40 miles south of San Luis); 1934 d, 436 (Alamos).Sheffler, 1931 a, 138 (Imuris).

Common resident of desert and semi-desert associations throughout the State. Most numerous in the Lower Sonoran and Tropical zone lowlands but penetrating locally to grasslands and cleared areas to at least 5,000 feet altitude. Additional localities are Guirocoba; Camoa (Bishop coll.) ; Pilares (Univ. Mich.) ; Agiabampo; San Francisco Cañon; Rancho Santa 
Bárbara (van Rosscm notes); Magdalena (Dawson notes); San Pedro River on the boundary; Sonoyta; Colorado River at Monument 204 (Mearns notes); Cerro Blanco (Chicago Nat. Hist. Mus.).

\section{GEOCOCCYX VELOX MELANCHIMA MOORE}

\section{SONORA LESSER ROADRUNNER}

Geococcyx velox melanchima Moore, Trans. San Diego Soc. Nat. Hist., 7, May 31, 1934, 459 (Guirocoba, Sonora, México; alt. 2,500 feet); 1938 a, 24 (Guirocoba).-Peters, 1940, 61 (southern Sonora).

Geococcyx affinis (not of Hartlaub) Shelley, 1891, 421, part (Sierra de Alamos). - Salvin and Godman, 1896, 536, part (Sierra de Alamos).-Ridgway, 1916, 81, part (Sierra de Alamos).

Rare inhabitant of the lower mountains in the extreme southeastern corner of the State. The only two individuals collected to date are one taken by Lloyd in the Sierra de Alamos, May 23, 1888 (examined in Brit. Mus.) and the type which was taken by Wright ncar Guirocoba on March 25, 1931.

\section{ORDER STRIGIFORMES OWLS \\ Family Tytonidae Barn Owls \\ TYTO ALBA PRATINCOLA (BONAPARTE) \\ BARN OWL}

Strix Pratincola Bonaparte, Geog. and Comp. List, 1838, 7 [New name for Strix flammea Wilson] (northern parts [of America] = Pennsylvania).-Stonc and Rhoads, 1905, 689 (Colony).

Tyto perlata pratincola Ridgway, 1914, 605 (Sonora).

Tyto alba pratincola van Rossem, 1931 c, 250 (Tecoripa; Saric; crit.) ; 1934 d, 436 (Alamos).

Probably a fairly common resident of Sonoran and Tropical zones, al. though recorded from but few localitics. Noted at Colonia Lerdo in the Colorado delta by Rhoads in the winter of 1905; observed in the same region at San Luís on May 2, 1937 (van Rossem notes); not uncommon about Rancho La Arizona ["Saric"] in carly May, 1937, and July, 1929; Tecoripa, March 14, 1929; Alamos, February 23, 1888; heard occasionally at Guirocoba in May and June, 1937 (van Rosscm notes); San Bcrna. dino Ranch, September 4, 1892 (Mearns notes)..$^{19}$

19 As previously mentioned (van Rossem, 1931c), the Tecoripa specimen is indistinguishable from Tyto alba guatemalae of Central America. 


\title{
Family Strigidae Typical Owls
}

\section{OtUS ASIO CINERACEUS (RIDGWAY)}

\section{MeXICAN SCREECH OWL}

\begin{abstract}
Megascops asio cineraceus Ridgway, Auk, 12, No. 4, Oct., 1895, 390 (Fort Huachuca, Arizona).

Otus asio cineraceus Ridgway, 1914, 702, part ("probably northern Sonora").Cory, 1918, 30, part (northern Sonora).-A.O.U. Comm., 1931, 163 (Sonora).van Rossem, 1931 c, 250 (El Alamo).-Bent, 1938, 274, part, in text (Sonora).Moore and Peters, 1939, 40 (Sonora).

Status uncertain, though probably a resident in the northeastern and north central foothills and mountains. This distribution is predicated by the distribution in the mountains of extreme southern Arizona. There is one definite record, that of a specimen taken July 1, 1928, by Bancroft at El Alamo in the Lower Sonoran zone, though in a locality closely adjacent to the Upper Sonoran. This specimen (Nat. Hist. Mus.) is unquestionably cineraceus. Screech owls heard at Rancho La Arizona on June 7, 1937, (van Rossem notes) almost certainly belonged to this subspecies, since the locality lies between El Alamo and the Arizona boundary. There appears to be no basis, other than supposition, for "Sonora" records of cineraceus previous to 1931 .
\end{abstract}

\section{OTUS ASIO GILMANI SWARTH}

\section{SAHUARO SCREECH OWL}

Otus asio gilmani Swarth, Univ. Calif. Pub. Zool., 7, No. 1, May 26, 1910, 1 (Blackwater, Pinal Co., Arizona).-Moore, 1937 b, 65, in text (northern Sonora).-Moore and Peters, 1939, 40 (Sierra Seri).-Peters, 1940, 102 (extreme northern Sonora).

Megascops asio cineraceus (not of Ridgway) Stone and Rhoads, 1905, 689 lower Colorado River).

Otus asio cineraceus Huey, 1931a, 430, in text (Sonora side of Gulf at lat. $\left.29^{\circ} 46^{\prime}\right)$.

Otus asio trichopsis ? (not Scops trichopsis Wagler) Price, 1899, 92 (lower Colorado River).

Probably a resident of Lower Sonoran deserts in the northwest. Screech Owls heard by Price along the lower Colorado in early January, 1898, by Rhoads in early February, 1905, and by van Rossem at San Luís in early May, 1937, were undoubtedly gilmani, since this race occurs in immediately adjacent parts of Baja California and Arizona. As in the case of the northeastern cineraceus, though, there is but one specimen on record, that taken by Charles Sheldon in the Sierra Seri on January 1, 1922, and which is now in the collection of the Biological Survey. This individual seems 
to be the basis of Huey's statement that "cineraceus" occurs on the Sonora side of the Gulf at the above-given latitude.

\section{Otus ASIO SINALOENSIS MOORE}

\section{Sinaloa SCREech OWl}

Otus asio sinaloensis Moore, Proc. Biol. Soc. Wash., 50, April 21, 1937, 64 (Guamuchil, northwestern Sinaloa, México); ibid., in text (Guirocoba).-Moore and Peters, 1939, 42 (Guirocoba).-Peters, 1940, 103 (southwestern Sonora).

Otus vinaceus sinaloensis Moore, 1941 b, 158, in text (Guirocoba; Agiabampo).

Probably a not uncommon resident of the Tropical zone lowlands and foothills from the latitude of Guaymas southward. According to Moore (1937 a), specimens from the foothill region (Guirocoba) are interme. diate toward vinacens of the higher zones east of the Sonora-Chihuahua boundary. Additional specimens of this race have been examined from 10 miles north of Guaymas, May 11 (breeding) and June 27, 1937 (Dickey coll.).

\section{OTUS TRICHOPSIS ASPERSUS (BREWSTER)}

\section{SPOTted SCREeCh OWL}

Megascops aspersus Brewster, Auk, 5, No. 1, Jan., 1888, 87 (El Carmen, Chihuahua, México).

Otus trichopsis aspersus Moore and Peters, 1939, 44, in text (San Luis Mountains, "Chihuahua"; crit.).

Probably not uncommon, at least in summer, in the high Upper Sonoran and Transition zones in the northern and eastern mountains. Definite records are but two in number; specimen taken near El Tigre Mine by Berry Campbell, July 26, 1935 (Univ. Mich.), and two adults and two juveniles taken by Mearns on the west side of the San Luís Mountains, July 13, 1892 (U. S. Nat. Mus.; Mearns notes). Known occurrences in Arizona (west to the Pajaritos Mountains) and Chihuahua (El Carmen near the Sonora-Chihuahua boundary) indicate a more extensive distribu. tion in Sonora than is at present known. ${ }^{20}$

20 The validity of the race aspersus is by no means proven, as Moore and Peters freely admit, and my own investigation which goes considerably beyond "sending two specimens to the British Museum" fully bears out their doubts. However, after correspondence with Peters I have decided to use the name tentatively and without endorsement of the ascribed characters, my doubts concerning which are further heightened by seven recently collected October specimens from the Para. ritos Mountains in Arizona. 


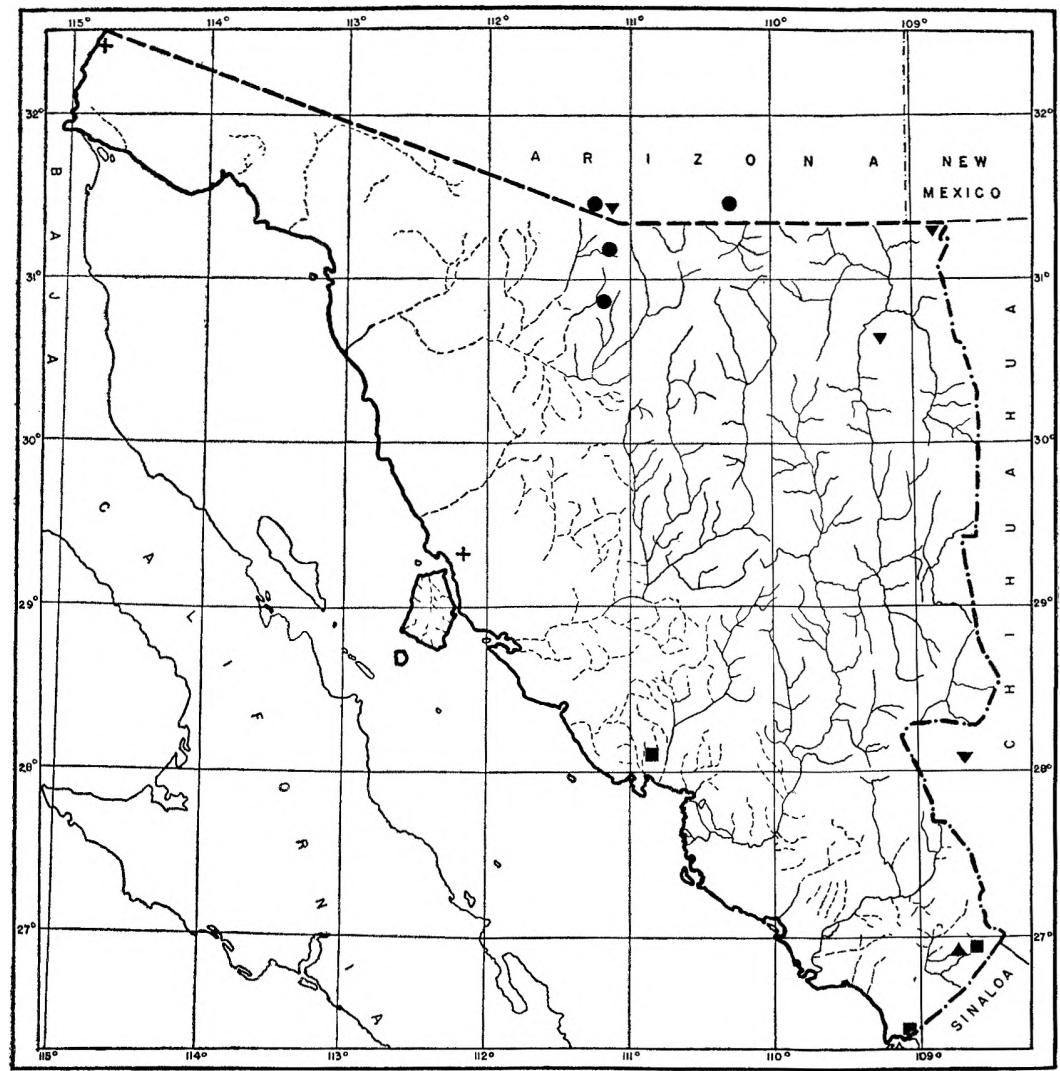

MAP 5. Distribution of the genus Otus. Circles, $O$. asio cineraceus; crosses, $O$. a. gilmani; squares, $O$. a. sinaloensis; inverted triangles, $O$. trichopsis aspersus; triangle, $O$. guatemalae bastatus.

\section{OTUS GUATEMALAE HASTATUS (RIDGWAY) \\ MAZATLÁN SCREECH OWL}

Megascops bastatus Ridgway, Proc. U. S. Nat. Mus., 10, sig. 17, Aug. 1, 1887, 268 ("La Paz, Lower California"= Mazatlán, Sinaloa, México).

Otus bastatus hastatus van Rossem, 1934 d, 436 (Guirocoba).

Otus guatemalae tomlini Moore, 1937 a, 63 (Guirocoba).-Moore and Peters, 1939, 49 (Guirocoba).-Peters, 1940, 104 (southeastern Sonora).

Otus vinaceus [!] (not Megascops vinaceus Brewster) van Rossem, 1931 c, 250 (Guirocoba).

Uncommon inhabitant (probably resident) in the Tropical zone foothills in the extreme southeast. The two specimens so far taken in Sonora 
were collected by J. T. Wright at Guirocoba, respectively, on April 22, 1930 (Dickey coll.) and at an unknown (to me) date (Moore coll.). ${ }^{21}$

\section{BUBO VIRGINIANUS PALLESCENS STONE}

\section{WESTERN HORNED OWL}

Bubo virginianus pallescens Stone, Amer. Nat., 31, No. 363, Mch. 1, 1897, 237 (Watson Ranch, 18 miles southwest of San Antonio, Texas).-Ridgway, 1914, 742 (Hermosillo; Oberholser locs.).—van Rossem, 1931 c, 251, part (El Doctor) ; 1934 d, 437, part (35 miles south of San Pedro; crit.).-A. O. U. Comm., 1931, (Sonora).-Sheffler, 1931 b, 165 (between Magdalena and Santa Ana).-Huey, 1935, 253 (Punta Peñascosa).-Bent, 1938, 321, in text (Sonora).-Peters, 1940, 111 (Sonora).

Bubo magellanicus pallescens Oberholser, 1904 a, 182 (Colorado River at Mon. 204; San Bernardino Ranch; San Luis Mountains).

Bubo virginianus (not Strix virginiana Gmelin) Salvin and Godman, 1897, 12, part (Hermosillo).

Bubo virginianus subarticus [sic.] (not Bubo subarcticus Hoy) Price, 1899, 92 (lower Colorado River).

Common resident of Sonoran zones south at least to Punta Peñascosa coastwise and to Hermosillo in the interior (specimen in Brit. Mus. examined). The zone of intergradation between pallescens and mayensis is not known, but may be roughly anticipated, by analogies provided by other species, as at no great distance north of Guaymas on the coast and north of latitude $29^{\circ}$ in the eastern interior. Additional localities are Ca. jón Bonita Creek; Guadalupe Cañon; Niggerhead Mountain at Monument 82 (Mearns notes).

\section{BUbO VIRGINIANUS MAYENSIS NELSON}

\section{Mexican Horned OWL}

Bubo virginianus mayensis Nelson, Proc. Biol. Soc. Wash., 14, Sept. 25, 1901, 170 (Chichén Itzá, Yucatán, México).

Bubo virginianus pallescens (not of Stone) van Rossem, 1931 c, 251, part (Obregon; Tesia); 1934 d, 437, part (Guaymas; Alamos).

Resident in the Tropical zone foothills and lowlands north to Guaymas. Specimens have been examined from Guaymas, January 13, 1887; Álamos, February 14, 1888 (Mus. Comp. Zoöl.) ; Ciudad Obregón, No-

21 I agree thoroughly that hastatus is a race of guatemalae, but am unable to appreciate the characters which are supposed to distinguish "tomlini" from bastatus. 
vember 17, 1929; Tesia, December 16, 1929 (Dickey coll.) ; Guirocoba, May 10, 1931 (Bishop coll.) $^{22}$

\section{GLAUCIDIUM BRASILIANUM CACTORUM VAN ROSSEM}

\section{Cactus Pygmy OWL}

Glaucidium brasilianum cactorum van Rossem, Proc. Biol. Soc. Wash., 50, Feb. 23, 1937, 27 (between Guaymas and Empalme, Sonora, México).-Peters, 1940, 130 (Sonora).-Brodkorb, 1941, 2, in text (nomen; crit.).-A. O. U. Comm., 1944,450 (between Guaymas and Empalme).

Glaucidium brasilianum ridgwayi (not Glaucidium ridgwayi Sharpe) Ridgway, 1914, 798, part (Alamos; Sonoyta; Caborca).—van Rossem, 1931 c, 251 (Magdalena; Obregon; Guaymas; Miramar; San Jose de Guaymas; Agiabampo; Caborca); 1934 d, 437 (Alamos).-Bent, 1938, 438, part, in text (Sonoyta; Caborca).

Glaucidium phalaenoides (not Strix ploalaenoides Daudin) Stephens, 1885, 231 (20 miles southwest of Caborca).

Fairly common resident of Lower Sonoran and Tropical zones, chiefly in giant cactus associations, in the western part of the State. Records extend from Sonoyta, Caborca, and Magdalena in the north, southward to the Sinaloa boundary. There are no records from the Colorado River region, nor from northern interior points east of Magdalena. Additional stations are 35 miles northwest of Magdalena, December 4, 1932; Guiro. coba, May 25, 1937 (Dickey coll.).

\section{MICRATHENE WHITNEYI WHITNEYI (COOPER)}

\section{Whitney ElF OWL}

Athene whitneyi Cooper, Proc. Calif. Acad. Sci., [ser. 1] 2, sig. 8, [before Dec.] 1861, 118 (Fort Mojave, Arizona).

Micrathene whitneyi Evermann and Jenkins, 1888, 69 (Querobabi).

Micrathene whitneyi whitneyi Peters, 1940, 135 (northern Sonora).

Micropallas whitneyi whitneyi Ridgway, 1914, 807 (Cerro Blanco).- Cory, 1918, 47 (Sonora).-Dawson, 1923, 1133 (Sonora).- van Rossem, 1931 c, 251

22 I am inclined to believe that Griscom (Ibis, 1935, pp. 546-7) and Peters (1940, p. 112) are correct in recognizing but one race of the Great Horned Owl from the territory formerly assigned to mayensis, melancerus, and mesembrinus, especially as all were originally described on utterly inadequate material. The Sonora series of five specimens is not distinguishable in color from an El Salvador specimen of "mesembrinus"; for that matter about the only way any of the lot can be separated from pacificus is by the slightly smaller size. Wings of three females from Sonora measure $343.343 .357 \mathrm{~mm}$., the two smallest being from the lowlands, the largest from 1,500 feet altitude at Guirocoba. The Tesia and Ciudad Obregón specimens I once stated (1931 c) were "exactly" like pallescens of southeastern Arizona. This was because of two pacificus which were labeled by the collector (though not on original field tags) as from that region. The locality may be correct, but it seems more likely a mixup in labels has occurred. 
(Magdalena).-A. O. U. Comm., 1931, 168 (Sonora).-Moore, 1938 a, 24, (Guirocoba).-Bent, 1938, 443, in text (Querobabi; Magdalena).

A fairly common summer visitant in suitable localities in Sonoran and Tropical zones from the Arizona boundary southward. While the easternmost northern stations are Rancho La Arizona and Magdalena, the distribution in Arizona and southwestern New Mexico indicates a corresponding longitudinal range in Sonora. Concentrations of population favor the giant cactus association where available; in the absence of cactus any timber large enough to provide nesting sites is likely to be inhabited. Records beyond those cited above are Rancho La Arizona (both in Lower and Upper Sonoran zones), May 7 to 9, heard commonly; Guay. mas, May 11, 1937, heard commonly (van Rossem notes) ; Agua Marín, 8 miles northwest of Álamos, May 4, 1939 (Mus. Vert. Zool.) ; noted in the Pinacate region by Lumholtz (1912). Sonora records cover only the period from March 5 (Guirocoba) to "June" (Querobabi).

\section{SPEOTYTO CUNICULARIA HYPUGAEA (BONAPARTE)}

\section{WESTERN BURROWING OWL}

Strix bypugaea Bonaparte, Amer. Orn., 1, 1825, 72 note (Western United States = Plains of the River Platte).

Speotyto cunicularia hypugaea van Rossem, 1931 c, 251 (Obregon; Tesia) ; 1932, 135 (Tiburon Island); $1934 \mathrm{~d}, 437$ (Bacuachi).

Speotyto cunicularia bypogaea Allen, 1893 a, 34 (San Pedro).-Ridgway, 1914, 814 (San Pedro; Bacuachi).

Speotyto cunicularia (not Strix cunicularia Molina) Salvin and Godman, 1897, 31, part (San Pedro).

Common winter visitant to deserts and plains areas nearly everywhere, including Tiburón, San Estéban, and probably other islands. Breeds commonly in farming areas in the lower Colorado River valley, the Animas Valley and Guadalupe Cañon, and without much doubt at many other suitable points in the extreme northern part of the State. Additional rec. ords are Ánimas Valley; Guadalupe Cañon, July, 1892; San Luís Springs, "Chihuahua," September 3, 1892 (Mearns notes) ; Bonancita, November 20; Las Arenas, December 15, 1905 (Mus. Comp. Zoöl.) ; San José de Guaymas, January 9, 1933 (Lamb notes) ; San Estéban Island, January 11, 1932 (Dickey coll.) ; Kino Bay, February 20, 1935 (Nat. Hist. Mus.) ; San Luís to Colonia Independencia, May 1 to 3, 1937 (van Rossem notes). Extreme dates which most likely pertain to migrants or winter visitants are September 3 (San Luis Springs) and February 20 (Kino Bay). 


\section{CICCABA VIRGATA SQUAMULATA (BONAPARTE) \\ SQuamulated OWL}

Syrnium squamulatum Bonaparte, Consp. Gen. Ávium, 1, 1850, 53 ("México"). Ciccaba virgata amplonota [sic] van Rossem, 1934 d, 437 (Hacienda de San Rafael; Alamos).

Ciccaba virgata squamulata Peters, 1940, 153 (Sonora).

Probably resident in the southeastern mountains, though known only through the four specimens taken by Frazar at Allamos and Hacienda de San Rafael between March 16 and May 18, 1888. A specimen by McLeod at Durazno, Chihuahua, a locality close to the Sonora boundary, on December 2, 1884, indicates permanent residence in the region. No recent collectors seem to have encountered the species in Sonora. ${ }^{23}$

\section{STRIX OCCIDENTALIS LUCIDA (NELSON) \\ MeXican SpotTed OwL}

Syinium occidentale lucidum Nelson, Proc. Biol. Soc. Wash., 16, No. 40, Nov. 30, 1903, 152 (Mt. Tancítaro, Michoacán, México).

Strix occidentalis lucida van Rossem, 1934 d, 438 (Oposura).

Known only from the single specimen taken by Cahoon near Oposura (almost certainly the Sierra de Oposura) on June 11, 1887 (Mus. Comp. Zoöl.). The distribution of the Spotted Owl in closely adjacent localities in Arizona and Chihuahua indicates that it may be expected to occur as a resident in the mountains of eastern Sonora.

\section{ASIO OTUS WILSONIANUS (LESSON)}

\section{LONG-EARED OWL}

Otus Wilsonianus Lesson, Traité d'Orn., Livr. 2, May 8, 1830, 110 (États-Unis . . Pennsylvanie $=$ Pennsylvania $)$.

Asio wilsonianus Bent, 1938, 167, in text (Tiburon Island).

Asio otus wilsonianus van Rossem, 1932, 135 (Tiburon Island).

One record, when found in some numbers on Tiburón Island, December 28 and 29, 1931. Mearns (notes) saw or collected individuals at various

\footnotetext{
${ }^{23}$ Bonaparte's type came to Leiden from the Berlin Museum and is undoubtedly one of the co-types of Lichtenstein's manuscript name of Strix squamulata. While this name applies without question to the light-colored, large-spotted race of western México there is no necessity to fix a type locality at this time. Lichtenstein's other co-type or co-types, if they are still in existence, may provide a locality, assuming of course that the name is not a composite. I have examined Bonaparte's type at Leiden and agree with Dr. Junge (see also Peters, 1940) that it belongs to the race recently named amplonotata by Kelso.
} 
points along the northern boundary, all of them apparently on the Arizona side. The status of this owl is probably that of a not uncommon winter visitant in the northern part of the State.

\section{Asio flammeus flammeus (Pontoppidan)}

\section{SHORT-EARED OWL}

Strix flammea Pontoppidan, Danske Atlas, 1, 1763, 617, pl. 25 (Sweden).

Asio flammeus flammeus van Rossem, 1932, 135 (Tiburon Island).

Asio accipitrinus Price, 1899, 92 (lower Colorado River).

A winter visitant in the northern part of the State. There are three records; single individual seen on the lower Colorado River, December 4, 1898 (at which date Price was on the Sonora side of the river); one seen on Tiburón Island, January 1, 1932; one taken on the Santa Cruz River, November 11, 1892 (U. S. Nat. Mus.).

\section{Order CAPRIMULGIFORMES Goatsuckers ANd Allies}

\section{Family CAPRimulgidae Goatsuckers}

\section{CHORDEILES ACUTIPENNIS TEXENSIS LAWRENCE}

\section{Texas NighthawK}

Chordeiles texensis Lawrence, Ann. Lyc. Nat. Hist. N. Y., 6, 1857, 167 (Texas [= Ringgold Barracks, near Río Grande]).

Chordeiles acutipennis texensis Ridgway, 1914, 581 (Sonora).-Oberholser, 1914, 103 (Colorado River opp. mouth of Hardy; San Marcial; San Bernardino Ranch; San Bernardino River; Mon. 204.).- van Rossem, 1931 c, 252, part (Saric; El Alamo; Tesia, part) ; 1934 d, 438 (Oposura; Granados; Alamos); 1942 d, 73 (Rancho La Arizona; El Alamo; Pilares; Hermosillo; crit).-Brodkorb, 1940, 543, part (El Alamo; Hermosillo; Pilares).

Common summer visitant to Lower Sonoran deserts south to about latitude $29^{\circ}$, penetrating locally into the Upper Sonoran. Occurs occasionally in winter in the Tropical zone southerly and possibly at more northerly points. Migratory and summer dates not so far published are from Cajón Bonito Creek and Guadalupe Cañon, July 2, 1892 (Mearns notes) ; Hermosillo, June 24 and 25, 1932; Pilares, July 3, 1935 (Univ. Mich.); Rancho La Arizona, May 9, 1937; San Luís, May 2 and 3, 1937 (van Rossem notes) ; Magdalena, May 13, 1925 (Dawson notes). Winter dates are San Marcial, November 10, 1905 (Mus. Comp. Zoöl.); Tesia, January 28, 1930 (Univ. Mich.). A definite migratory date is from Tesia, March 15, 1930, a locality where micromeris is the breeding form (Dickey 
coll.). The March 2, Álamos specimen (van Rossem, 1934 d) has not been examined in the present connection.

\section{CHORdeILES ACUTIPENNIS MICROMERIS OBERHOLSER}

\section{Mexican Nighthawk}

Chordeiles acutipennis micromeris Oberholser, Bull. U. S. Nat. Mus., 86, April 6, 1914, 100 (Xbac, Yucatán, México).—van Rossem, 1942 d, 73 (Guaymas; Obregon; Tecoripa; Tesia; Camoa; crit.).

Chordeiles acutipennis (not of Lawrence) Hartert, 1892, 616, part (Sierra de Alamos).-Salvin and Godman, 1894, 397, part (Sierra de Alamos).

Chordeiles acutipennis texensis van Rossem, 1931 c, 252, part (Tecoripa; Obregon: Tesia; Guaymas; Agiabampo).-Brodkorb, 1940, 543, part (Tesia; Cajeme; Guaymas).

Common resident in the Tropical zone, from about Guaymas and Tecoripa southward to the Sinaloa boundary. Specimens have been examined from the following localities: Guaymas, June 28, 1928; Tecoripa, March 8 to 29, 1929 (intergrades toward texensis); Ciudad Obegón, November 1, 1929; June 20, 1928; Tesia, March 15 and 16; February 3, 1930; Camoa, June 10, 1931; Agiabampo, June 8, 1930. There is a specimen in the Museum of Vertebrate Zoology taken at Buenos Aires, 13 miles N. W. of Navojoa, May 7, 1939. The three specimens recorded by Hartert from the Sierra de Álamos are most likely to be placed under micromeris since Lloyd was in that locality from May 23 to 25, 1888.

\section{Chordeiles minor henRYi CASSIN}

\section{WESTERN NighTHAWK}

Chordeiles Henryi Cassin, Illustr. Birds Calif., Texas [etc.], 1, pt. 8, [March 13], 1855, 239 (Fort Webster, New Mexico).

Chordeiles henryi Baird, 1859, 7 (Los Nogales).

Chordeiles popetue, var. henryi Brewer, 1874, 404, in text (Los Nogales).

Chordeiles tirginianus benryi Ridgway, 1914, 272 (Nogales).-Oberholser, 1914, 65 (Nogales).

Chordenles minor henryi Bailey, 1928, 342 (Sonora).-van Rossem, 1931 c, 252 (Saric); 1934 d, 438 ([Sierra de] Oposura).-A.O.L. Comm. 1931, 176 (Sonora).-Peters, 1940, 188 (northern Sonora).-Bent, 1940, 231, in text (Oposura: Los Nogales);

Chordeiles popetue (not Caprimulgus popetue Vieillot) Baird, 1858, 151, part (Los Nogales).

Probably a fairly common summer visitant in the Transition and Upper Sonoran zones of the higher ranges in the eastern part of the State; nesting, as in most other localities, probably confined to the Transition. Recorded as "very common" about Nogales in June, 1855; specimen taken 
by Cahoon at Oposura (undoubtedly the Sierra de Oposura), June 10, 1887; observed as common in the Transition zone at Rancho Santa Bárbara, June 9 to 15, 1937, but no specimens taken (van Rossem notes).

\section{PhaLAENoptilus NUTt ALLII NUTTALLII (Audubon)}

\section{NutTall POOR-WILL}

Caprimulgus Nuttallii Audubon, Birds Amer., 7, 1844 (oct. ed.) 350, pl. 495 (Upper Missouri=between Fort Pierre and mouth of Cheyenne River, South Dakota).

Phalaenoptilus nuttallii nuttallii Ridgway, 1914, 548, part (Sonora).-Cory, 1918, 126, part (Sonora).—van Rossem, 1931 c, 252, part (Saric) ; 1941 a, 247 (Rancho La Arizona; crit.).-Peters, 1940, 194 (Sonora).

Antrostomus nuttalli Baird, 1859, 6, in text (Santa Cruz).

Rather common summer visitant to the Upper Sonoran zone in the northern part of the State from the Pajaritos Mountains eastward. Occurs in winter on Tiburón Island (Mus. Vert. Zool., November 3 and 4, $1941)$ and probably at mainland localities in the western deserts. Mearns' notes record what is almost certainly this subspecies from Guadalupe Cañon in early July, 1892, and September 27, 1893. Specimens from the Pajaritos Mountains are not typical and incline toward adustus.

\section{PhaLAENoptilus NUTTALLII ADUSTUS VAN ROSSEM}

\section{SONORA POOR-WILL}

Phalaenoptilus nuttallii adustus van Rossem, Condor, 43, No. 5, Sept. 18, 1941, 247 (Bate's Well, Pima County, Arizona, alt. 1,500 feet) ; ibid., in text (El Alamo; Providencia Mines; Moctezuma).-Huey, 1942, 366 (International boundary at Gray's Ranch).

Phalaenoptilus nuttallii nuttallii (not Caprimulgus nuttallii Audubon) Ridgway, 1914, 548, part (Providencia Mines).-Cory, 1918, 128, part ("Sonora" [ = Providencia Mines]).-Dickey, 1928, 153, in text (Sonora = [Oposura]).-van Rossem, 1931 c, 252, part (El Alamo) ; 1934 d, 438 (Oposura).-Bent, 1940, 193, part, in text (Alamos=error for Fi Alamo).

Summer visitant to Lower Sonoran deserts from about longitude $113^{\circ}$ (Quitovaquita and Gray's Ranch) southeast (El Alamo and Providencia Mines) to the Moctezuma River valley (Oposura). Whether this race is resident or migratory is unknown; present dates extend only from late April to early July. Some race of the Poor-will, most probably the present one, occurs in summer in the Tropical zone (Guaymas, May 11, and Agiabampo, May 15 and 16, 1937 (van Rossem notes), but its status has not been determined. 


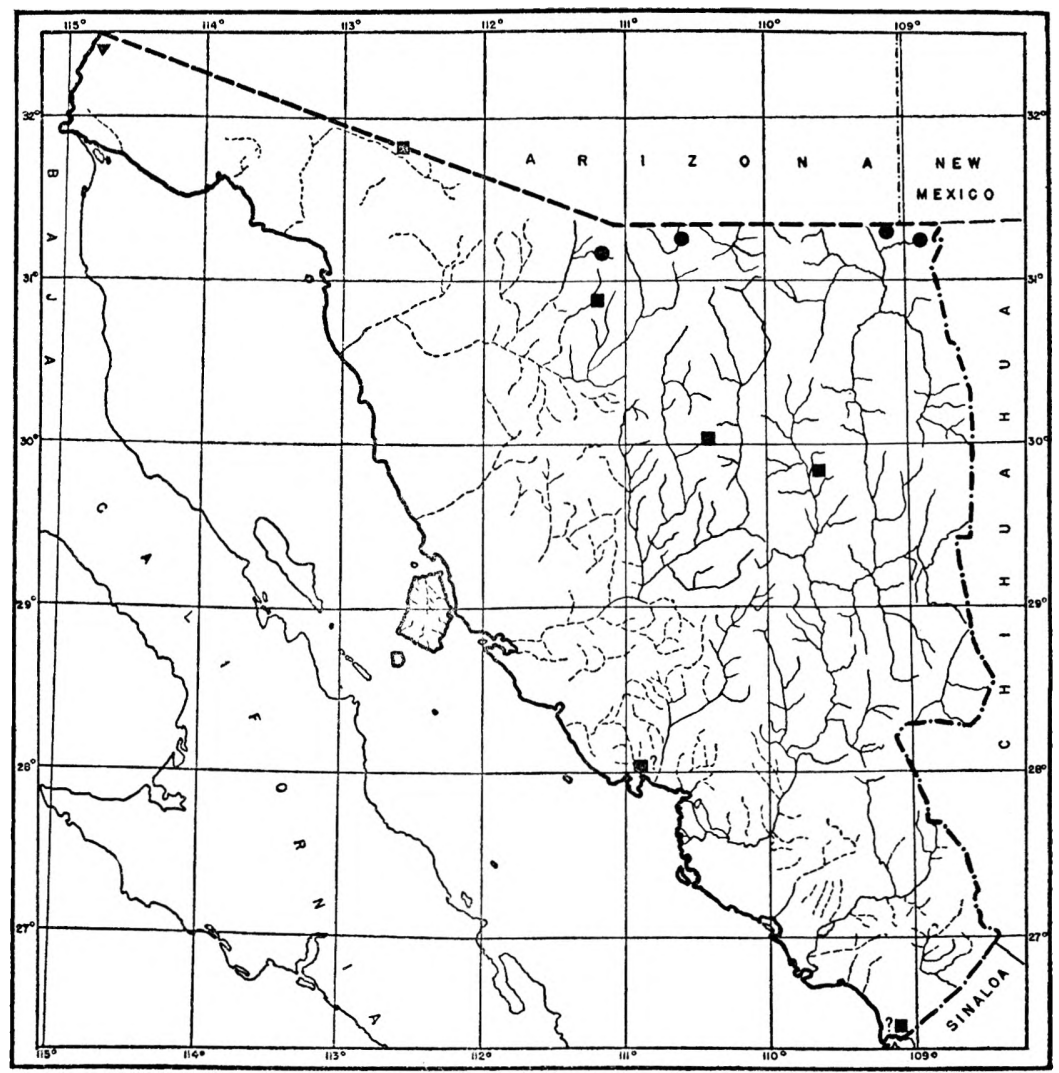

Map 6. Distribution of Phalaenoptilus nuttallii. Circles, $P . n$. nuttallii; inverted triangle, $P$. n. hueyi; squares, $P$. n. adustus.

\section{Phalaenoptilus nutTalli hueyi Dickey}

\section{DESERT POOR-WILL}

Phalaenoptilus nuttallii bueyi Dickey, Condor, 30, No. 2, Mch. 15, 1928, 152 (Bard, Imperial County, California).

Phalaenoptilus nuttalli nitidus ? Price, 1899, 92 (lower Colorado River).

Poor-wills were frequently heard in early May, 1937, at San Luís on the Sonora side of the Colorado River (van Rossem notes). Price records seeing an individual in the same locality on December 2, 1898. The occurrence of bueyi as the resident race in immediately adjacent localities in Arizona and Baja California presupposes almost to a certainty the 
similar status of the Poor-wills of the lower Colorado River Valley in Sonora. No specimens, though, have been collected to date.

\section{CAPRIMULGUS RIDGWAYI RIDGH'AYI (NeI.SON)}

\section{RIDGWAY WHIP-POOR-WILL} ico).

Antrostomus ridgwayi Nelson, Auk, 14, Jan., 1897, 50 (Tlakisla, Guerrero, Méx-

Antrostomus ridguayi ridgwayi van Rossem, 1931 c, 251 (Chinobampo; Guiro. coba; crit.).

Caprimulgus ridgu'ayi ridgu'ayi Peters, 1940, 198 (Sonora).

Common, occasionally abundant, summer visitant to the Tropical, Upper Sonoran, and even the lower fringe of the Transition zones from Agiabampo and the lower Mayo River valley east to the Chihuahua and Sinaloa boundaries. The earliest arrival date is February 18 (possibly wintering individual), but there are no data relative to fall departure. Breeding begins with the advent of the rains about the last of June. Extremes of altitude range from sea level to at least 5,500 feet, with little or no association preference shown. Besides the two previously published occurrences, the Ridgway Whip-poor-will was heard at Agiabampo, May 13; near Alamos (commonly), May 19; San Francisco Cañon, May 31 ; Rancho Santa Bárbara, in early June; Guirocoba, (abundant), May 20 to June 16; Tesia (common), June 21 to 24, 1937 (van Rossem notes; Dickey coll.; Sheffler coll.). ${ }^{24}$

\section{CAPRIMUlgus Vociferus arizonaE (BREWSTER)}

STIPHENS WHIP-POOR-WILL

Antrostomus vociferus arizonae Brewster, Bull. Nuttall Orn. Club, 5, No. 2, April, 1881, 69 (Chiricahua Mountains, Arizona).-Bent, 1940, 182, in text (Alamos).

Caprimulgus vociferus arizonae van Rossem, 1934 d, 438 (Alamos; Mina Abundancia).

Antrostomus vociferus macromystax (not Caprimulgus macromystax Wagler) Ridgway, 1914, 520, part (Alamos; Mina Abundancia).

21 I am quite unable to follow Griscom (1932, p. 192) in his suggesticn that ridguayi is possibly a race of salvini. It differs radically from salvini in the pattern of the tail spotting and the only cluse resemblance is in the consp:cuous buffy collar. Actually, ridguayi is a small. bleached out, distinct species must closely allied to "ociferus. It aerees with rociferus in tail pattern and plumage markings in general, and the buffy collar, while wide and conspicuous in most cases, is occesionally broken up and not so very different from some vociferus. This is particularly true in the darkest individuals. 
Summer visitant to the Transition zone in the more easterly part of the State. Occurs at lower elevations in migration (Mina Abundancia, April 25 ) and even in the Tropical zone in winter (Alamos, February 27). Mid. summer records are from the Pajaritos Mountains (Arizona side of the boundary), June 17, 1931 (L. Miller coll.); the San Luis Mountains, July 5 to 13, 1892 (U. S. Nat. Mus.; Mearns notes), and El Tigre Mountains, July 27 and 28, 1935 (Univ. Mich.). The record of Evermann and Jen. kins (1888, p. 67) of this species heard at Nogales in July is most un. likely and doubtless pertains to the Poor-will. ${ }^{25}$

\title{
Order APODIFORMES SwifTS ANd Hummingbirds
}

\author{
Family Apodidae Swifts \\ ChaETURA VAUXI VAUXI (TOWNSEND) \\ VAUX SWIFT
}

Cypcelus Vauxi J. K. Townsend, Nar. Journ. Rocky Mts., April, 1839, 348 (Columbia River=-Fort Vancouver, Washington).

Chaetura rauxi van Rossem, 1931 C, 252 ( 10 miles N. of Guaymas).

Detected as a late spring migrant at two widely separated points. Noted as migrating "in flocks" at Magdalena on April 20, and May 14 and 15, 1925 (Dawson notes); specimen taken from a small flock 10 miles north of Guaymas, May 9, 1930 (Dickey coll.).

\section{AËRONAUTES SAXATALIS SAXATALIS (WOODHOUSE)}

\section{WhITE-THROATED SWIFT}

Acanthylis saxatalis Woodhouse, Rep. Sitreaves' Expl. Zuni and Colorado Rivers, 1853, 64 (Inscription Rock, New Mexico).

Aëronautes saxatalis saxatalis Rogers, 1939, 465 (Sonora; crit.).-Twomey, 1942,403 , in text (Sonora; crit.).

[Chaetura] saxatilis Giebel, 1872, 628 (Sonora).

Aëronautes melanoleucus Allen, 1893 a, 36 (Granados).-Ridgway, 1911, 687, part (Senoyita, "etc.").

Seemingly a resident throughout the eastern and central part of the State, except that there are no records from any locality within the Tropi-

2.5 Whether vociferus and ridgwayi ever come into direct contact at the edges of their respective zonal habitats during the breeding season is problematical. Vociferus is present in southwestern Chihuahua very close to the Sonora boundary but only ridgu'uji was found at Rancho Santa Bárbara in June, 1937. The call notes are utterly different and were the two species ever to occupy the same locality the fact could be ascertained by ear alone. 
cal zone. Localities where observed are the San Pedro River, October 21, 1892 ; Sonoyta, January 21, 1894 (U. S. Nat. Mus.) ; Cajón Bonito Creek and Guadalupe Cañon, "common; breeding," in early July, 1892 (Mearns notes) ; Magdalena, April 22 and May 17, 1925 (Dawson notes); Rancho Santa Bárbara, common in early June, 1937 (van Rossem notes); Granados, November 16, 1890.

\section{Family Trochilidae Hummingbirds Cynanthus latirostris magica (MUlsant and Verreaux)}

\section{BROAD-BILLED HUMMINGBIRD}

Hylocharis magica Mulsant and Verreaux, Ann. Soc. Linn. Lyon, 18, Jan. 31, 1872, 110 (Mazatlan, Basse California [ - Mazatlán, Sinaloa, México]).

Cynantbus latirostris magica Moore, 1939 a, 58, in text (Camoa; Yaqui River; Agiabampo; Masocari Island; Guirocoba; etc.; crit; nomen.); 1939 c, 31 j (Guirocoba; nesting).

Cynanthus latirostris (not of Swainson) Ridgway, 1911, 371, part (Dist. of Moctezuma; Nuri; Ysleta; Guaymas; Opodepe; La Chumata).-Cory, 1918, 195, part (Oposura).- - van Rossem, 1931 c, 254 (Magdalena; Pesqueira; Tecoripa; San Javier; Saric; Tesia; vic. Guaymas; vic. Obregon); 1934 d, 441 (Guaymas; Alamos; Hacienda de San Rafael; Nacozari; Oposura).-Bent, 1940, 465 (Guirocoba; Tesia; San Javier; Moctezuma; Saric; life history).

Iache latirostris Belding, 1883, 344 (Guaymas).-Salvin, 1892, 60, part (Dist. of Moctezuma; Nuri; Ysleta).-Salvin and Godman, 1892, 256, part (same locs.).-Sheffler, 1931 a, (Imuris; Rancho Los Alamos [=El Alamo]); 1931 b, 165 (Santa Ana).

Pbaeoptila latirostris Thayer and Bangs, 1906, 18 (Opodepe; La Chumata).

Common, generally distributed, summer visitant in Tropical, Sonoran, and lower Transition zones throughout the State eastward from about the longitudes of the Pajaritos Mountains and Guaymas; westernmost records are from El Álamo and San Carlos Bay. There are no records for any of the islands, nor from the western deserts northwest of Guaymas. Common permanent resident in the Tropical zone, north, coastwise, to the vicinity of Guaymas, and in the interior to the vicinity of Moctezuma. In spite of the abundance of summer records there are little data to indicate the migratory movements north of the Tropical zone. The species was noted as common at Magdalena from March 25 forward (Dawson notes). The latest recorded northern date is Cajón Bonito Creek, September 27, 1893 (common; Mearns notes). Localities not cited above are Pilares, EJ Tigre Mine, and El Tigre Mountains in July, 1935 (Univ. Mich.), and Rancho Santa Bárbara in June, 1937 (van Rossem notes); Guadalupe Cañon, August 31, 1893 (U. S. Nat. Mus.). 


\section{HyLOCHARIS LEUCOTIS BOREALIS GRISCOM}

\section{NORTHERN WhITE-EARED HUMMINGBIRD}

Hylocharis leucotis borealis Griscom, Amer. Mus. Novit., No. 379, Oct. 17, 1929, 10 (Pinos Altos, Chihuahua, México) ; ibid., in text (Sonora).- van Rossem, 1934 d, 441 (Mina Abundancia; [Sierra de] Oposura).

Hylocharis leucotis leucotis (not Trochilus leucotis Vieillot) A. O. L. Comm. 1931, 184, part (Sonora).-Bent, 1940, 464 (Oposura).

Common summer visitant to the Transition zone (oak-pine associations above about 5,500 feet) of the Sierra Madre and adjacent spur ranges nearly the full length of the State. Midwinter occurrences in nearby Chihuahua localities presuppose permanent residence in Sonora, at least southerly. In the University of Michigan Museum of Zoology there are eight specimens taken by Campbell in El Tigre Mountains [Sierra de Madera] between July 26 and August 3, 1935; the species was also found to be common at Rancho Santa Bárbara in early June, 1937, at which time breeding activity had waned and young of the year were in evidence (van Rossem notes). Incidentally, the "Sonora" citations of Salvin, 1892; Salvin and Godman, 1892 ; and Ridgway, 1911, are based on the erroneous placing, by the first author, of Tutuaca in Sonora instead of Chihuahua.

\section{AMAZILIA VIOLICEPS CONJUNCTA GRISCOM}

\section{SONORA AZURE-CROWNED HUMMINGBIRD}

Amazilia violiceps conjuncta Griscom, Bull. Mus. Comp. Zoöl., 75, No. 10, Jan., 1934, 377 (Âlamos; Sonora, México).-van Rossem, 1934 d, 440 (Alamos; Hacienda de San Rafael).--Peters, 1943, 69 (re type).

Uranomitra violiceps conjuncta Berlioz, 1938, (Sonora; crit.).

Amizilis verticalis (not Trochilus verticalis Licht.) Ridgway, 1911, 422, part (Alamos).

Amazilis verticalis van Rossem, 1931 c, 253 (Guirocoba; crit.).

Amazilis ellioti (not of Berlepsch) Hellmayr, 1913, 252 (Sonora).

Uranomitra ellioti Simon, 1921, 325, part (Sonora).

Common resident in the extreme southeast, north, perhaps only as a summer visitant, to Pilares and El Tigre Mountains. Most numerous in the Tropical zone foothills above 1,000 feet but penetrating to about 6,000 feet altitude in the Transition zone in summer. Records for the low. lands are Tesia, June 20, 1937 (Dickey coll.), and Chinobampo, March and April, 1931 (Bishop coll.). Additional stations from which specimens have been examined are San Francisco Cañon, May 31, 1937; Ran. cho Santa Bárbara, common in June, 1937, in Upper Sonoran and Transition zones (Dickey coll.; van Rossem notes) ; Pilares, June 27 and July 19, 1935; El Tigre Mine, July 11, 1935 (Univ. Mich.). 


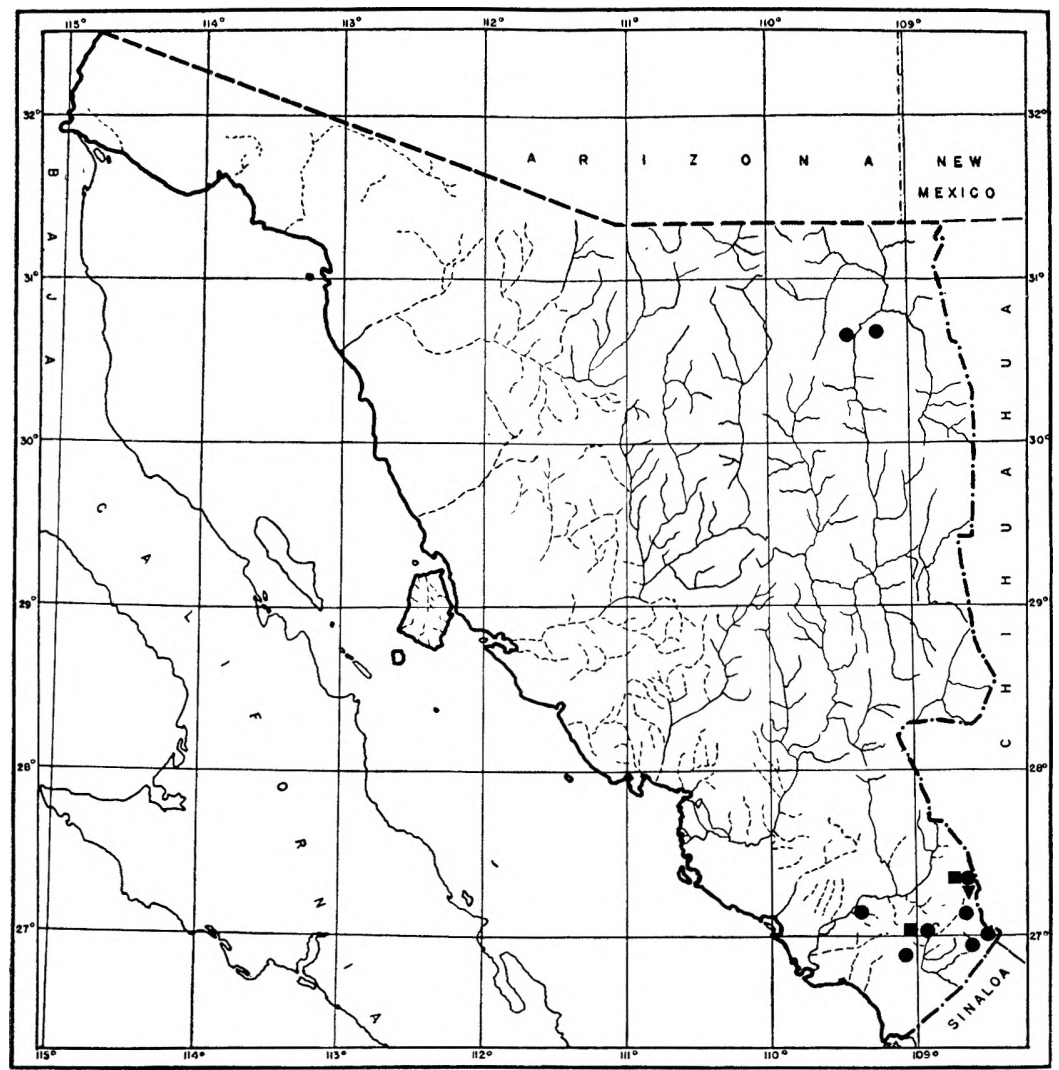

Map 7. Distribution of the genus Amazilia. Circles, A. violiceps conjuncta; squares, $A$. beryllina viola; inverted triangle, $A$. florenceae.

\section{AMAZILIA BERYLLINA VIOLA MilleR}

\section{ViolaceOUS HUMmingBiRD}

Amizilis beryllina viola Miller, Bull. Amer. Mus. Nat. Hist., 21, Nov. 24, 1905, 353 (Jalpa, Sinaloa, México).

Saucerottia beryllina viola van Rossem, 1934 d, 440 (Alamos; Hacienda de San Rafael).

Summer visitant, apparently in some numbers, in the mountains of the extreme southeast. Found to be abundant in early June, 1937, at 5,000 to 5,500 feet in the oak-pine association at Rancho Santa Bárbara (Dickey and Sheffler colls.; van Rossem notes). The fact that Frazar failed to find 
the species at Mina Abundancia in April strongly indicates only a summer residence in the mountains. Three specimens taken by him at Allamos on February 20, and on March 14 and 30,1888, are of uncertain status. They were possibly seasonal visitants in the locality.

\section{AmAZILIA FLORENCEAE (VAN RosSem and Hachisuka)}

\section{FLoRenCE HummingBird}

Saucerottia florenceae van Rossem and Hachisuka, Trans. San Diego Soc. Nat. Hist., 8, Jan. 18, 1938, 408 (Rancho Santa Bárbara, alt. 5000 ft., extreme southeastern Sonora, México).

Saucerottia (ocai) florenceae Zimmer, in Zimmer and Mayr, 1943, 252, 261 (crit.).

Known only from the unique type collected by van Rossem and Hannum at Rancho Santa Bárbara on June 9, 1937. Its characters cannot be ac. counted for by hybridization between any of the species known to inhabit the region.

\section{LAMPORNIS CLEMENCIAE BESSOPHILUS (OBERHOLSER)}

\section{Arizona Blue-throated Hummingbird}

Cyanolaemus clemenciae bessophilus Oberholser, Condor, 20, No. 5, Sept. 27, 1918, 121 (Fly Park, Chiricahua Mountains, Arizona).

Lampornis clemenciae bessophilus van Rossem, 1934 d, 439 ([Sierra de] Oposura).-Bent, 1940, 330, in text (Oposura).

Lampornis clemenciae clemenciae (not Ornismya clemenciae Lesson ?) Moore, 1938 a, 25 (Baromicon).

Occurs in summer, probably never very commonly, in the Transition zone in the eastern mountains. There are five known localities: San Luis Mountains on the boundary, July 11, 12 and 13, 1892 (Mearns notes) ; El Tigre Mountains [Sierra de Madera], July 26 to August 2, 1935 (Univ. Mich.) ; Sierra de Oposura, June 10, 1887; Baromico, May 18, 1933; Rancho Santa Bárbara, June 11, 1937, (Sheffler coll.). Contrib. utory data from near-by Chihuahua localities show the Blue-throated Hum. mingbird to be present in the region as late as September $11 .{ }^{26}$

20 Moore records from Baromico an intermediate between bessopbilus and clemenciae as, in his opinion, closer to the nominate race. In this region of intermediates I naturally hesitate to accept a single specimen as clemenciae, especially since the Santa Bárbara specimen is typical bessophilus and Oberholser cites intermediates closer to bessophilus from the adjacent portiort of southwestern Chihuahua. 


\section{EUGENES FULGENS AUREOVIRIDIS VAN ROSSEM}

\section{NORTHERN RivOLI HUMMingBiRd}

Eugenes fulgens aureoviridis van Rossem, Proc. Biol. Soc. Wash., 52, Feb. 4, 1939, 7 (Chiricahua Mountains, Cochise Co., Arizona); ibid., in text (Sonora).

Eugenes fulgens (not Trochilus fulgens Swainson) van Rossem, 1934 d, 439 (Mina Abundancia; Oposura).--Moore, 1938 a, 25 (Baromicon).-Bent, 1940, 325 (Oposura).

Summer visitant in the Transition zone of the Sierra Madre and adjacent ranges and probably, in accord with the distribution in Arizona, in more westerly ranges as well. Additional localities are El Tigre Mountains, August 3, 1935 (Univ. Mich.) and San Luís Mountains, July 19 and 23, 1892 (Mearns notes). Dates range only from April 13 (Mina Abundan. cia) to August 3 (San Luís Mountains).

\section{HELIOMASTER CONSTANTII SURDUS (VAN ROSSEM)}

\section{SONORA STAR-THROATED HumMingBiRd}

Anthoscenus constantii surdus van Rossem, Bull. Mus. Comp. Zoöl., 77, No. 7, Dec., 1934, 439 (Álamos, Sonora, México); ibid., in text (Sierra de Alamos; Guirocoba).-Peters, 1943, 70 (re type).

Floricola leocadiae (not Trochilus leocadiae Bourcier and Mulsant).-Salvin and Godman, 1892, 306, part (Sierra de Alamos).

Anthoscenus constantii leocadiae Ridgway, 1911, 353, part (Sierra de Alamos). Floricola leocardiae Salvin, 1892, 232, part (Sierra de Alamos).

Resident in the Tropical zone foothills (chiefly riparian associations) in the extreme southeast. Known, however, only from three closely adjacent localities, Álamos, Sierra de Álamos, and Guirocoba. The fact that Frazar took but one specimen at Alamos in February (date not recorded) suggests that there may be a partial exodus during the winter months. Guirocoba dates range from March 25 (Bishop coll.) to June 17 (Dickey coll.), with young of the year on the wing as early as the middle of May.

\section{ARCHILOCHUS ALEXANDRI (BOURCIER AND MULSANT)}

\section{BLACK-CHINNED HUMMINGBIRD}

Trocbilus Alexandri Bourcier and Mulsant, Ann. Soc. Agric. Lyon, 9, 1846, 330 (Sierra Madre, México).

Trochilus alexandri Salvin, 1892, 402 (Nuri).-Salvin and Godman, 1892, 359 (Nuri).

Archilochus alexandri Ridgway, 1911, 633 (Nuri).-Bailey, 1928, 354 (central Sonora).-A. O. U. Comm., 1931, 180 (Sonora).- van Rossem, 1931 c, 253 (San Javier; Saric) ; 1934 d, 439 (Alamos; Nacozari).-Wetmore, 1932, 74 (Sonora).Bent, 1940, 361, in text (San Javier and Guaymas in breeding range [!]). 
Summer visitant to foothills and mountains (chiefly Upper Sonoran and lower parts of the Transition zones) from the Pajaritos Mountains eastward. Occurs as a migrant, probably rather generally, over the eastern half of the State. Certain or probable breeding localities are Rancho La Arizona, May 8, 1937 (van Rossem notes), and May 29, 1929; west side of the San Luis Mountains, Cajón Bonito Creek, and Guadalupe Cañon, July, 1892 (Mearns notes) ; Nogales, May 10; Magdalena, dates in midMay, 1925 (Dawson notes). Extreme arrival and departure dates are March 26 (Álamos) and September 8 (Cajón Bonito Creek). The many citations of the Black-chinned Hummingbird as nesting at Guaymas (Heerman, 1853, et seq.) are erroneous and pertain to Calypte costae.

\section{Calypte anNa (Lesson)}

\section{ANNA HUMmingBiRd}

Ornismya Anna Lesson, Hist. Nat. Ois.-Mouch., 1839, xxxi, 205, pl. 74 (La Californie = San Francisco).

Calypte anna Ridgway, 1911, 619 (San Jose Mountains).-Cory, 1919, 298 (Sonora).-A. O. U. Comm., 1931, 180 (Sonora).-Huey, 1935, 254 (Punta Peñascosa).-Bent, 1940, 387, in text (Punta Peñascosa).

Z.[ephyritis] Annae Simon, 1921, 401 (San Jose Mts.).

Calypte costae (not Ornismya costae Bourcier) Allen, 1893 a, 36 (El Pinita [= Los Pinitos]).

Fall and winter visitant. There are three records, all northerly: San José Mountains, August 19, 1893, taken by Mearns and Holzner (U. S. Nat. Mus.) ; Los Pinitos, October 14, 1890, taken by Robinette (Amer. Mus.) ; Punta Peñascosa, February 21, 1934, taken by Huey (Nat. Hist. Mus.).

\section{CALYPTE COSTAE (BOURCIER)}

\section{COSTA Hummingbird}

Ornismya Cortae Bourcier, Revue Zool., 2, No. 8, Oct., 1839, 294 (la Californie [ = Magdalena Bay, Baja California México]).

Calypte costae Cooper, 1870, 360 (Guaymas).-Brewer, 1874, 457, in text (Guaymas).--Belding, 1883, 343 (Guaymas).-Stephens, 1885, 230 (Port Lobos). -Salvin and Godman, 1892, 359 (Guaymas).-Bailey, 1928, 355 (Sonora).- - van Rossem, 1931 c, 253 (Tesia; Port Lobos; San Esteban Island; Guaymas); 1932, 136 (Tiburon Island); 1934 d, 439 (Nacozari; Oposura).-Bent. 1940, 370, in text (Tiburon Island; Tesia).-Huey, 1942, 366 (Arizona-Sonora boundary).

Trochilus alexandri (not of Bourcier and Mulsant) Heermann, 1853, 269 (Guaymas; breeding) ; 1859, 56 (Guaymas).-Cassin, 1856, 141 (Guaymas).-Cooper. 1870, 354 (Guaymas).-De Oca, 1875 (Guaymas).--Ridgway, 1892, 331 (Guaymas).

Common resident of western deserts south at least to Guaymas and San Estéban Island coastwise and to Moctezuma in the interior. During the 
summer there is occasional penetration into the Upper Sonoran zone (Ran. cho La Arizona), and probably in the fall to still higher levels. However, the species is essentially characteristic of Lower Sonoran deserts. Near the southern part of the range there is notable winter concentration, indi. cating a partial withdrawal from northern areas. The southernmost record at any season is that of a possible casual taken at Tesia in the Mayo River valley, November 29, 1929. Unpublished localities are Kino Bay, December 31, 1931; Hermosillo, May 10, 1937 (van Rossem notes); Pozo de Luís; Nariz, and Sonoyta, December, 1893, and January, 1894 (Mearns notes).

\section{Stellula CALLIOPE CALLIOPE (Gould)}

\section{Calliope HummingBird}

Trochilus (Calothorax) calliope Gould, Proc. Zool., Soc. London, 1847, No. 168 [March 29], 11 (México=Real del Monte, Hidalgo).

Stellula calliope calliope van Rossem, 1934 d, 439 (Oposura).

Evidently a not uncommon migrant in the eastern part of the State, although all records save one are from northern boundary localities. Known occurrences are from west side of San Luís Mountains on the boundary, July 13, 1892 and October 1, 1893; San Bernardino Ranch, August 30, September 6 and 14, 1892; Johnson's Ranch, September 25, 1892 (U. S. Nat. Mus.; Mearns notes); Oposura $[=$ Moctezuma $]$, April 8, 1887 (Mus. Comp. Zoöl.).

\section{SELASPHORUS PLATYCERCUS PLATYCERCUS (SWAINSON)}

\section{BROAD-TAILED HUMMINGBIRD}

Trochilus platycercus Swainson, Philos. Mag., n. s. 1, No. 6, June, 1827, 441 (no locality given $=$ México ).

Selasphorus platycercus Salvin, 1892, 396, part (Micoba).-Salvin and Godman, 1892, 355, part (Micoba).-Ridgway, 1911, 597, part (Micoba).

Selasphorus platycercus platycercus van Rossem, 1931 c, 253 (Saric): 1934 d, 439 ([Sierra de] Oposura); 1936 c, 26 (Sonora; crit.).-Bent, 1940, 395, in text (Oposura).

Migrant and summer visitant to higher mountains, probably throughout the eastern part of the State. Specific records are, however, few in number. They are: Maicoba, on or about April 4, 1888 (Brit. Mus.); Rancho La Arizona, May 12, 1929 (transient; Dickey coll.) ; Sierra de Oposura, May 27, June 8 and 10, 1887 (Mus. Comp. Zoöl.) ; San José Mountains, August 9, 1892 (Univ. Mich.), August 10, 1892 (U. S. Nat. 
Mus.) ; El Tigre Mountains, August 3, 1935 (Univ. Mich.) ; San Luís Mountains, September 6, 1893 (Mearns notes).

\section{SELASPHORUS RUFUS (GMELIN)}

\section{Rufous HummingBiRD}

Trochilus rufus Gmelin, Syst. Nat., 1, i, 1788, 497 (Nootka Sound, Vancouver Island).

Seiasphorus rufus Ridgway, 1911, 612 (San Jose Mountains).-van Rossem, 1931 c, 253 (Tesia; San Esteban Island); 1934 d, 439 Alamos; Nacozari; Oposura).

Selctsphorus alleni (not of Henshaw) Allen, 1893 a, 36 (Santa Barbara).

A fairly common fall and spring migrant. Record stations are well scattered geographically and zonally, and indicate that the species may be expected almost anywhere at these seasons. Fall dates are from the north eastern part of the State; San José Mountains, August 6 and 9, and October 7; San Bernardino Ranch, September 6; Cajón Bonito Creek, September 8 (Mearns notes; U. S. Nat. Mus.) ; Santa Bárbara, September 21. Spring dates range from March 8 at Alamos to April 18 at San Estéban Island. There is a specimen in the Bishop collection taken at Guirocoba, March 28, 1931.

\section{ORDER TROGONIFORMES TROGONS}

\section{Family Trogonidae Trogons \\ EUPTILOTIS NEOXENUS (GOULD)}

\section{EARED TROGon}

Trogon neoxenus Gould, Monog. Trogonidae, ed. 1, 1838, pl. 35, and text (México = Sierra de Nayarit, Jalisco).

Euptilotis neoxenus Allen, 1893 a, 34 ("El Pinita" [=El Puerto]).-Salvin and Godman, 1896, 485 (El Pinita).

Leptuas neoxenus Ridgway, 1911, 471 (La Pinita).

Presumably resident in the Transition zone of the Sierra Madre. Al. though there are numerous records from Chihuahua localities close to the Chihuahua-Sonora boundary, the only Sonora locality known to date is El Puerto (alt. about 6,300 feet) where Robinette collected a specimen on December 16, 1890. It was erroneously recorded by Allen from "El Pi. nita" (= Los Pinitos), a locality far to the northwest and in a lower life zone. 


\title{
TROGON ELEGANS CANESCENS VAN ROSSEM
}

\section{NORTHERN COPPERY-TAILED TROGON}

Trogon elegans canescens van Rossem, Bull. Mus. Comp. Zoöl., 77, No. 7, December 29, 1934, 441 (San Javier, Sonora, México); ibid., in text (Alamos; Hacienda de San Rafael; [Sierra de] Oposura).-A. O. U. Comm., 1944, 451 (San Javier).

Trogon ambiguus (not of Gould) Ogilvie-Grant, 1892, 451, part (Ysleta; Sierra de Alamos).-Salvin and Godman, 1896, 490, part (Ysleta; Sierra de Alamos).

Trogon ambiguus ambiguus Ridgway, 1911, 768, part (Alamos; Ysleta).Cottam and Knappen, 1939, 162 (Tecoripa; food).

Trogon elegans ambiguus van Rossem, 1931 c, 254 (San Javier; Chinobampo; Guirocoba ).

Common resident of the Tropical zone foothills and lower moun. tains in the southern part of the State, north to about latitude $28^{\circ} 30^{\prime}$. Occurs, apparently as a summer visitant only, at higher elevations in the mountains, north nearly or quite to the Arizona boundary. Additional record stations are Rancho Santa Bárbara, where found as high as 5,500 feet in the Transition zone in early June, 1937; San Francisco Cañon, May 30, 1937 (van Rossem, notes) ; 8 miles N. W. of Alamos, May 5, 1939 (Mus. Vert. Zool.) ; El Tigre Mountains, July 29 to August 3, 1935 (5 specimens at Univ. Mich.).

\section{Order CORACIIFORMES Kingfishers, Motmots, [ETC.]}

\author{
Family AlCEDinidae Kingfishers \\ MEGACERYLE ALCYON CAURINA (GRINNELL) \\ WESTERN BELTED KINGFisher
}

Ceryle alcyon caurina Grinnell, Univ. Calif. Pub. Zool., 5, No. 12, Mch. S, 1910, 388 (Montague Island, Prince William Sound, Alaska).

Streptoceryle alcyon caurina Ridgway, 1914, 420 (Sonora).

Megaceryle alcyon caurina A. O. U. Comm., 1931, 185 (Sonora).-van Rossem, 1931 c, 254 (Chinobampo; Saric; Tesia) ; 1934 d, 442 (Alamos; Guaymas; Bacuachi).-Huey, 1935, 254 (Punta Peñascosa).

Ceryle alcyon (not Alcedo alcyon Linn.) Price, 1899, 92 (lower Colorado River).

Common migrant and winter visitant, both coastwise and in the interior. The earliest date seasonally is "August" at Rancho La Arizona; the latest is May 9 at the same locality (van Rossem notes). Some additional records are San José de Guaymas, January 6, 1933 (Lamb notes) ; San Bernardino River on the boundary, September 1 and 2, October 4 
and 10, 1893 (Mearns and Holzner in U. S. Nat. Mus. catl.) ; Magdalena, April 23, 1925 (Dawson notes); Quitovaquita on the boundary (Arizona side), April 28, 1939 (Huey, 1942, p. 366) ; Cajón Bonito Creek, September 27, 1893 (Mearns notes).

\section{ChLoroceryle americana hachisukal (LAUBMANN)}

\section{NORTHERN GREEN KINGFISHER}

Chloroceryle americana leucosticta van Rossem and Hachisuka, Condor, 40, No. 5, Sept. 15, 1938, 227 (Rancho La Arizona, Sonora, México).-Brodkorb, 1940, 544 (Sonora; crit.).-A. O. U. Comm., 1944, 451 (Rancho La Arizona).

Ceryle americana hachisukai Laubmann, Verh. Orn. Ges. Bayern, 22, Jan. 25, 1942, 165 (new name for $C$. a. leucosticta van Rossem and Hachisuka [preoccupied by Chloroceryle leucosticta Reichenbach, 1851]).

Ceryle cabanisi (not Alcedo cabanisi Tschudi) Evermann and Jenkins, 1888, 88 (Magdalena).

Ceryle americana, subsp. b Ceryle septentrionalis (not of Sharpe!) Sharpe, 1892, 134, part (Hermosillo; Ysleta).

Ceryle septentrionalis Savin and Godman, 1895, 476, part (Hermosillo; Ysleta).

Chloroceryle americana septentrionalis Ridgway, 1914, 431, part (Hermosillo; Ysleta).--van Rossem, 1931 c, 254 (Tecoripa; Saric; Guirocoba; $15 \mathrm{mi}$. S. of Nogales; Agiabampo); 1934 d, 443 (Alamos; Oposura).-Bent, 1940, 146, part, in text (Cajon Bonito Creek).

Texas Kingfisher Mearns, 1907, 93, in text (Cajon Bonito Creek).

Rather common resident of streams and river valleys in the Tropical zone southerly; less common in the Lower Sonoran zone (east of about longitude $111^{\circ} \mathrm{W}$.) almost to the Arizona boundary. There is local penetration into the Upper Sonoran zone, as at Rancho La Arizona, and Ca. jón Bonito Creek. There are no records for the northwest, and but one for the seacoast north of Agiabampo, that of a specimen taken at Tepopa Bay, January 2, 1932 (Dickey coll.). Probably there is a recession of part of the population from more northerly localities during the winter; however, it has been taken in the extreme north (near Nogales) in February. Specimens or records other than those given are from Magdalena, common in April and May (Dawson and Canterbury notes) ; Camoa, in June (Bishop coll.); Tesia, common in June (Dickey coll.).

\section{Family Momotidae Motmots}

\section{Momotus mexicanus Vanrossemi Moore}

\section{SONORA MOTMOT}

Momotus mexicanus vaniossemi Moore, Proc. Biol. Soc. Wash., 45, July 19, 1932, 109 (Chinobampo, Sonora, México); ibid., in text (Guirocoba; San Rafael; San Francisco Cañon). 
Momotus mexicanus (not of Swainson) van Rossem, 1931 c, 254 (Chinobampo; crit.).

Probably resident in the Tropical zone foothills of the Alamos Sierra, and eastward to the Sinaloa and Chihuahua boundaries; however, all records fall between March 6 and June 18, the latter at the height of the nesting season. The altitudinal range secms not to extend beyond the limits of 300 and 2,000 fect. Two specimens were taken by Benson at Agua Marín, near Álamos on May 5, 1939); (Mus. Vert. Zool.) ; noted as fairly common along the trail from Guirocoba to San Francisco Cañon, May 30, and as uncommon on the road from Guirocoba to Alamos on June 18, 1937 (van Rossem notes). It is remarkable that none of the early collectors found this species; Frazar and Lloyd in particular were in suitable territory at a favorable season.

\section{ORder PICIFORMES WOODPECKERS, [ETC.].}

Family PICIDAE Woodpeckers

COLAPTES CAFER COLLARIS Vigors

\section{RED)-SHAFTID FLICKER}

Colaptes collaris Vigors, Zool. Journ., 4, no. 15, (Jct., 1828 [Jan., 1829], 354 (N. W. coast of America Monterery, California).

Colaptes cafer collaris Ridgway, 1914, 33, part (Hermosillo).- van Rossem, 1931 c, 255 (El Doctor: Tecoripa; San Javier; 15 miles S. W. of Nogales) ; 1934 d, 4.43 ([Sierra de] Oposura).-Griscom, 193.4, 381 (Sonora).

Colaptes cafer (not Picus cafer Gmelin) Evermann and Jenkins, 1888, 67 (Nogales).-Allen, 1892, 25 (eastern Sonora); 1893 a, 36 (Las Trincheras; El Pinita).-Price, 1899, 92 (lower Colorado River).

Colapter mexicanus (not of Swainson) Hargitt, 1890, 17, part (Hermosillo).Salvin and Godman, 1895, 402, part (Hermosillo).

Resident in high Upper Sonoran and Transition zones in the mountains along the eastern boundary. There are two summer stations of record; breeding at Cajón Bonito Creck, in early July, 1892 (Mearns notes) and the Sierra de Oposura where Cahoon took two specimens May 26 and June 2, 1887. Common and widespread in fall, winter, and spring, when occurring almost everywhere south to about latitude $28^{\circ} 30^{\prime}$. The great majority of individuals at these seasons are almost certainly winter visitants from the north. There are no records from the Tropical zone at any season. Additional stations are Guadalupe Cañon, October 2, 1893 ; Nogales, October 25, 1893 ; Sonoyta, January 17, 1894 (U. S. Nat. Mus.) ; El Âlamo, December 3, 1932 (Lamb notes). 


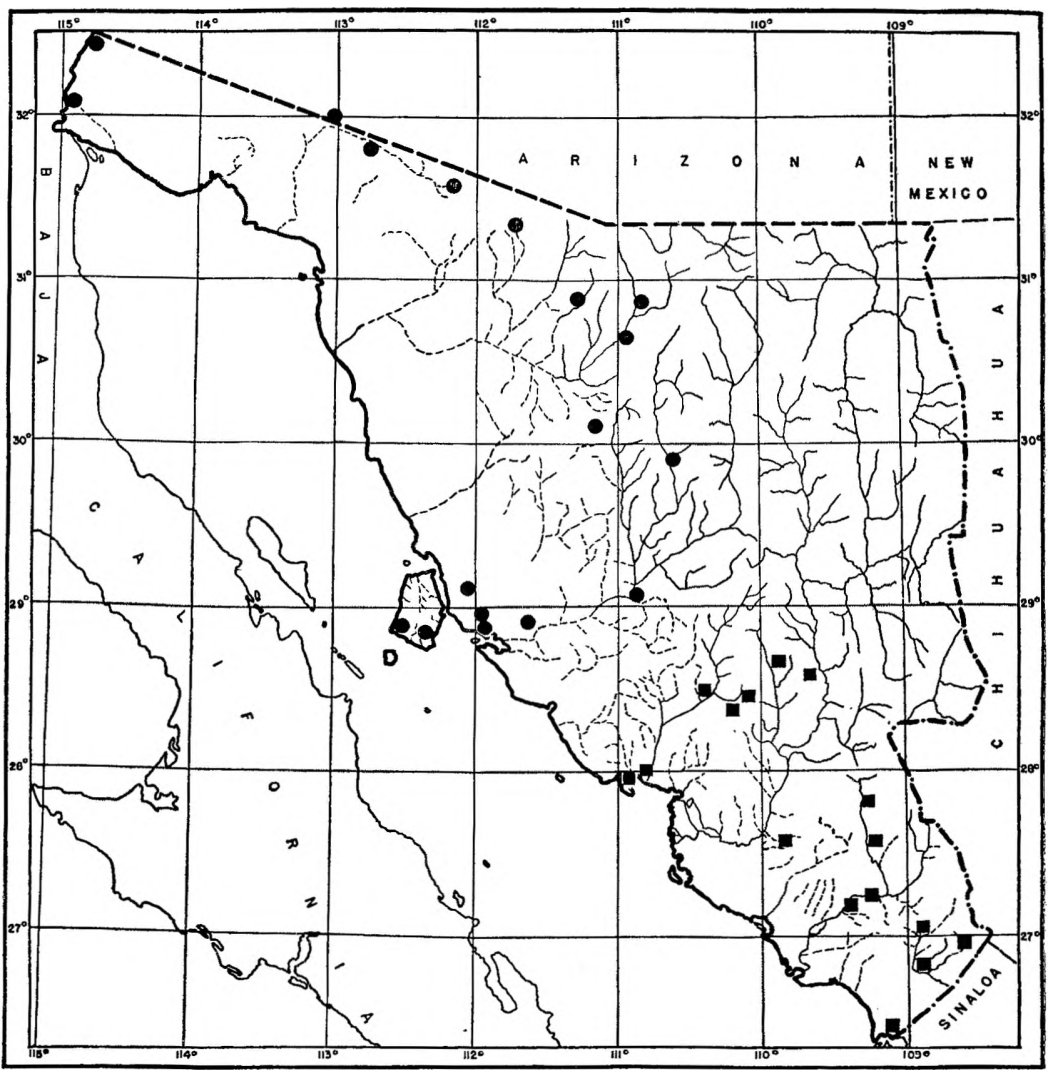

MaP 8. Distribution of Colaptes chrysoides. Circles, C. c. mearnsi; squares, C. c. tenebrosus.

\section{COLAPTES CHRYSOIDES MEARNSI RIDGWAY}

\section{MEARNS GILDED FLICKER}

Colaptes chrysoides mearnsi Ridgway, Proc. Biol. Soc. Wash., 24, Feb. 24, 1911, 32 (Quitovaquito, [Pima County], Arizona); 1914, 28, part (locs. in northern Sonora).-Townsend, 1923, 16 (Tiburon Island).-A.O.U. Comm., 1931, 188, part ([northern] Sonora).- van Rossem, 1932, 136 (Tiburon Island).-Bent, 1939, 300, part, in text (Magdalena; Opodepe; Hermosillo).

Colaptes chrysoides (not Geopicus chrysoides Malherbe) Stephens, 1885, 228 (southwest of Sasabe).-Ridgway, 1887, 295, part (Sonora).-Hargitt, 1890, 16, part (Hermosillo).-Allen, 1892, 26, in text (Sonora).-Bendire, 1895, 138, part (Sonora).- Salvin and Godman, 1895, 405, part (Hermosillo).-Dubois, 1899, 63 part (Sonora).-Brewster, 1902, 108, part (northern Sonora).- Thayer and Bangs, 1906, 18 (Opodepe).

C.[olaptes] chrysoides Coues, 1903, 601, part (Sonora). 
Common resident of Lower Sonoran deserts (giant cactus and riparian timber) in the northwestern part of the State from the Arizona-Sonora boundary south to about latitude $28^{\circ} 30^{\prime}$. Easternmost occurrences are $32 \mathrm{klms}$. south of Nogales (Mus. Comp. Zoöl.), Opodepe, and Hermosillo; southernmost are Sicrra Seri and Mina Las Afanes (Mus. Vert. Zool.); Kino Bay (Nat. Hist. Mus.), Tiburón Island, and Hermosillo.

\section{COLAPTES CHRYSOIDES TENEBROSUS VAN ROSSEM}

\section{Brewster Gilded Fuicker}

Colaptes chrysoides tenebrosus van Rossem, Trans. San Diego Soc. Nat. Hist., 6, July 12, 1930, 171 ([Ciudad] Obregón, Sonora, México); ibid., in text (Tecoripa, San Javier; Guaymas: Tesia); 1931 c, 255 (locs. north to Tecoripa and Guaymas); 1934 d, 443 (Alamos; Guaymas).

Colaptes chrysoides (not Geopicus chrysoides Malherbe) Belding, 1883, 344 (Guaymas).-Hargitt, 1890, 16, part (Ysleta).- Salvin and Godman, 1895, 405, part (Guaymas; Cedros; La Cobriza; Ysleta).-A. O. U. Comm., 1895, 167, part (southern Sonora); 1910, 195, part (southern Sonora).-Dubois, 1899, 63, part (Sonora).-Brewster, 1902, 108, part (Alamos; crit.).

Colaptes chrysoides mearnsi (not of Ridgway) A.O.U. Comm., 1912, 384, part (southern Sonora).-Ridgway, 1914, 28, part (Camoa; Guaymas; etc.).-Cory, 1919. 112, part (southern Sonora).-Bent, 1939, 300, part, in text (Cedros; Camoa).

Common resident of riparian timber and giant cactus associations of the Tropical zone from the Sinaloa-Sonora boundary northward to about latitude $28^{\circ} 30^{\prime}$ coastwise and $28^{\circ} 50^{\prime}$ in the interior. Specimens from latitude $28^{\circ}$ northward are varyingly intermediate toward Colaptes chry. soides mearnsi. Some localitics whence specimens have been examined, but which have not been published, are San Marcial; Las Chinchas; La Bonancita (Mus. Comp. Zoöl.).

\section{Centurus uROPygialis UROPYGIALIS BAIRD}

\section{GILA WOODPECKER}

Centurus uropygialis Baird, Proc. Acad. Nat. Sci. Phila., 7, June, 1854, 120 (Bill Williams Fork of Colorado River, New Mexico=Junction of Bill Williams and Santa María Rivers, Arizona).- Stephens, 1885, 228 (southwest of Sasabe).

Centurus uropygialis uropygialis Ridgway, 1914, 93, part (Senoyta; Fronteras; Rio Santa Cruz; Hermosillo; Pozo de Luis).-Cory, 1919, 425, part (Sonora).- -van Rossem, 1931 C, 255, part (Saric: Pesqueira; 15 miles S. W. of Nogales; 12 miles W. of Magdalena; Sasabe Valley); 1934 d, 411 (Hermosillo; range; crit.); ibid., 443 (Ranken's Ranch; 25 miles S. of San Pedro; Nacozari); 1942 b, 22, in text (nothern Sonora).-Bent, 1939, 256, part, in text (Fronteras).

Melanerpes uropygialis Evermann and Jenkins, 1888, 69, part (Querobabi; Carbo; Hermosillo).-Hargitt, 1890, 182, part (Hermosillo).-Allen, 1893 a, 36, 


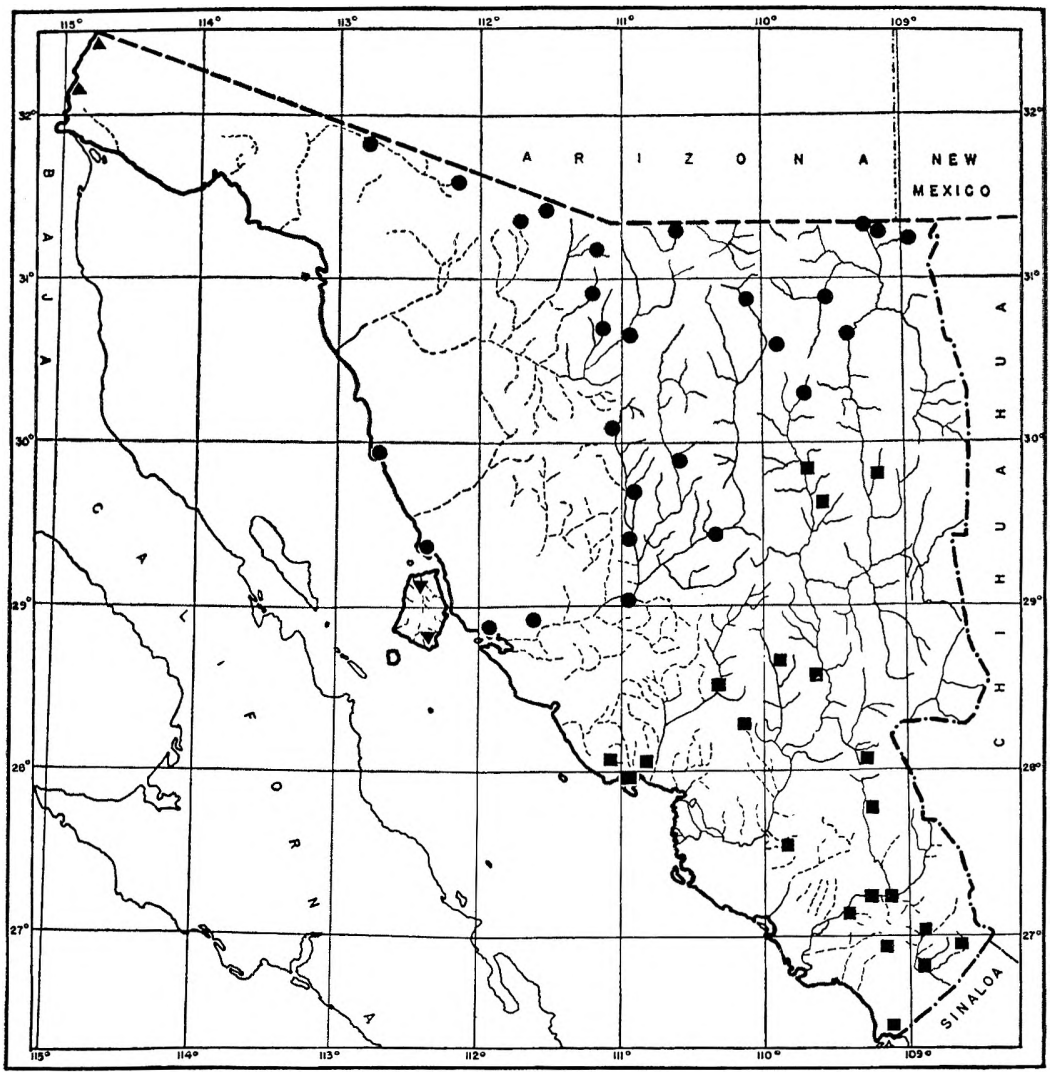

Map 9. Distribution of Centurus uropygialis. Circles, C. u. uropygialis; squares, C. u. fuscescens; triangles, $C$. $u$. albescens; inverted triangles, C. u. tiburonensis.

part (Fronteras).-Salvin and Godman, 1895, 423, part (Hermosillo).-Thayer and Bangs, 1906, 19 (Opodepe).

Common resident of Sonoran zones (chiefly giant cactus and riparian associations in the Lower Sonoran) from the Arizona boundary (except the Colorado River delta) south, coastwise and centrally, to about latitude $29^{\circ}$, and in the east to about $30^{\circ}$. However, most specimens from these latitudes are so variously intermediate toward the Tropical zone race fuscescens that their allocation to one race or the other is more or less arbitrary. Some additional stations are El Álamo (Lamb notes) ; Ures (Dickey coll.); Pilares (Univ. Mich.) ; San Bernardino River; Guadalupe Cañon (U. S. Nat. Mus.) ; Hall's Ranch; Cajón Bonito Creek (Mearns notes). 


\section{Centurus uropy gialis albescens van Rossem}

\section{DFITA WOODPECKER}

Centurus uropygialis albescens van Rossem, Condor, 44, No. 1, Jan. 15, 1942, 22 (Laguna Dam, lower Colorado River, Imperial County, California); ibid., in text (extreme northwestern Sonora).

Centurus uropygialis (not of Baird) Stone and Rhoads, 1905, 681 ("Colony"). Centurus uropygialis uropjgialis Ridgway, 1914, 93, part (Colonia Lerdo).

Melanerpes uropigialis Price, 1899, 92 (lower Colorado River).

Common resident of riparian growth along the Colorado River. Has been reported from various localities, those of Price (1899) indefinite. Observed as common at San Luís and Colonia Independencia by van Rossem and Hannum in May, 1937; Colorado River at Monument 205. March 19, 1894 (U. S. Nat. Mus.).

\section{Centurus uropygiatis fuscescens van Rossem}

\section{ÁLAMOS WOODPECKER}

Centurus uropjgialis fuscescens van Rossem, Bull. Mus. Comp. Zoöl., 77, No. 7 Dec., 1934, 410 (Chinobampo, Sonora, México); ibid., 443 (Guaymas; Alamos). Censurus uropygialis (not of Baird) Belding, 1883, 344 (Guaymas).

Centurus uropygialis uropygialis Ridgway, 1914, 93, part (Alamos; Batomotal; Camoa; Guaymas: Ysleta; Rio Mayo; Nuri, Cedros; Moctezuma; Cerro Blanco; Bacadehuachy).-Kuroda, 1930, 130, part (Sonora).-Bent, 1939, 256, part, in text (Boca de Huachy; Nuri).

Melanerpes uropjgialis Evermann and Jenkins, 1888, 69, part (Guaymas).Hargitt, 1890, 182, part (Ysleta; Rio Mayo; Moctezuma).-Allen, 1893 a, 36, part (Bacadehuachy).- Salvin and (jodman, 1895, 423, part (Guaymas; Rio Mayo; Moctezuma; Nuri).

Centurus uropygialis sulfuriventer (not Centurus sulfuriventer Reichenbach) van Rossem, 1930 a. 172, in text (southern Sonora): 1931 c, 256 (Tecoripa; San Javier; Tesia; Obregon; Chinobampo; Guaymas; Guirocoba; crit.).

Common resident of the Tropical zone coastal plain and interior foothills and valleys, from the Sinaloa boundary north to about latitude $28^{\circ}$ $30^{\prime}$ coastwise and to about $30^{\circ}$ in the Moctezuma River valley. Specimens from Guaymas and from points north of latitude $28^{\circ}$ are varyingly inter. mediate toward uropygialis. Further localities not recorded above are I.as Chinchas; San Marcial (Mus. Comp. Zoöl.) ; Agiabampo (Dickey coll.) ; 10 miles N. W. of Guaymas (Mus. Vert. Zool.).

\section{CENTURIJS UROPY'GIAIIS TIBURONENSIS VAN ROSSEM}

\section{Tiburón WoODPECKer}

Centurus uropjgialis tiburonensis van Rossem. Condor, 44, No. 1, Jan. 15, 1942, 22 (Petrel Bay, Tiburón Island, Sonora, México).

Centurus uropygialis uropygialis (not Centurus uropygialis Baird) Townsend, 
1923, 16 (Tiburon Island).-van Rossem, 1931 c, 255, part (Tiburon Island); 1932, 136 (Tiburon Island; crit.); 1934 d, 411, part (Tiburon Island; crit.).

Common resident of the giant cactus association on Tiburón Island.

\section{BALANOSPHYRA FORMICIVORA FORMICIVORA (SWAINSON)}

\section{ANT-EATING WOODPECKER}

Picus formicivorus Swainson, Philos. Mag., new ser., 1, June, 1827, 439 (Temascáltepec, México).

Melanerpes formicivorus Baird, 1858, 114 (Los Nogales) ; 1859, 6 (Los Nogales; Santa Cruz).-Salvin and Godman, 1895, 412, part (Santa Rosa; Yecora).

Melanerpes formicivorus, var. formicivorus Baird, Brewer, and Ridgway, 1874.

(2) 566 part (Los Nogales; crit.).

Balanosphyra formicivora formicinora van Rossem, 1934 d, 444 (Mina Abundancia; Hacienda de San Rafael; Oposura; crit.).

Melanerpes melanopogon Hargitt, 1890, 151, part (Sonora).

Melanerpes formicivorus melanopogon Thayer and Bangs, 1906, 19 (La Chumata; crit.).

Balenorphra formicivora aculeata Ridgway, 1914, 105 (San Jose Mts.) ; Cerro Blanco; other locs. as above).-Cory, 1919, 427 (Sonora).- van Rossem, 1931 C, 256 (Saric: 15 mi. S. W. of Nogales).-Bent, 1939, 212, in text (Sonora).

Melanerpes formicivorus bairdi (not of Ridgway) Allen, 1893 a, 36 (Cachuta; El Pinita).

Common resident of oak and oak-pine regions (Upper Sonoran and Transition zones) throughout the mountainous eastern part of the State. Westernmost stations, northerly, are the Pajaritos Mountains and the Sierra de San Antonio. Some unrecorded localities are 2,000 feet near Guirocoba; Rancho Santa Bárbara (Dickey coll.) ; Pilares (Univ. Mich.); Cibuta (Bishop coll.) ; San Luís Mountains; Cajón Bonito Creek; Guadalupe Cañon (Mearns notes). ${ }^{27}$

\section{ASYNDESMUS LEW'IS (GRAY)}

\section{LEWIS WOODPECKER}

Picus Leuis "Drap[iez]" Gray, Gen. Birds, 3, 1849, app., 22. Substitute name for Picus torquatus Wilson [nec. Boddaert]. (Montana, about lat. $46^{\circ} \mathrm{N}$. = Clearwater River, 2 miles north of Kamiah, Idaho).

Asyndermus lewisi van Rossem, 1931 c, 256 (15 miles S.W. of Nogales).

Aryndermur leu is Bent, 1939, 226 (southwest of Nogales).

Winter visitant in the north. To date the only specimen of record is one taken by Bancroft 15 miles southwest of Nogales on January 13, 1928.

27 As previously stated (1934 d) I can see no reason for the recognition of aculeata Mearns as distinct from formicivora. Not only are the measurements practically identical but the supposed character of a more solidly black (less streaked) chest is evident in only a very small proportion of "aculeata." 
This locality is close to, or actually, Rancho La Arizona. Mearns (notes) observed this species in considerable numbers at Warsaw Mills in the same mountains, although on the Arizona side of the boundary, in early December, 1893.

\section{Piculus aURICUlaris sonoriensis Van Rossem and Hachisuka}

\section{SONORA GREEN WOODPECKER}

Piculus auricularis sonoriensis van Rossem and Hachisuka, Proc. Biol. Soc. Wash., 50 Nov. 26, 1937, 195 (Rancho Santa Bárbara, Sonora, México; alt. $5000 \mathrm{ft}$.).

Known only in summer (though probably a permanent resident) in the high Upper Sonoran and extreme lower part of the Transition zones (pineoak association) in the mountains of the southeastern part of the State. The three specimens of record were collected by van Rossem and Hannum on June 8 and 13, 1937, at Rancho Santa Bárbara.

\section{HyLatomus lineatus obsoletus (VAN ROSSEM)}

\section{Sonora Pileaten Woodpecker}

Ceophloeus lineatus obsoletus van Rossem, Trans. San Diego Soc. Nat. Hist., 8, Aug. 10, 1934, 12 (Álamos, Sonora, México); 1934 d, 443 (Alamos).-Peters, 1943, 75 (re type).

Ceophloeus scapularis (not Picus scapularis Vigors) Hargitt, 1890, 510, part (Sierra de Alamos).-Salvin and Godman, 1895, 450, part (Sierra de Alamos).

Ceopbloeus lineatus scapularis Ridgway, 1914, 152, part (Sierra de Alamos).Cory, 1919, 458, part (Sonora).--Peters, 1930, 318 (Alamos).

Rather uncommon resident of Tropical zone foothills and lower mountains in the extreme southeast. Localities to date are Guirocoba, May, 1937 (van Rossem notes) and December, 1941 (Sheffler notes); San Francisco Cañon, May 30, 1937 (van Rossem notes); Álamos, March 16 and 21, 1888 ; Sierra de Álamos, May 25, 1888.

\section{CAMPEPHILUS IMPERIALIS (GOULD)}

\section{IMPERIAL IVORY-BILLED WOODPECKER}

Picus imperialis Gould, Proc. Zool. Soc. Lond., 2, 1832, 140 ("California"= Bolaños, Jalisco, México).

Campephilus imperialis Ridgway, 1887 b, 161 (50 miles from Arizona boundary) ; 1914, 166 (Rio Bavispe; Sierra Madre; 50 miles S. of Arizona boundary).Allen, 1893 a, 35 (Bavispee River).-Bendire, 1895, 45 ("15" miles S. of Arizona boundary in Sonora).-Lumholtz, 1902, 36 (Sierra de Nacori; Bavispe River).- 
Cory, 1919, 461 (Sonora).-Nelson, 1898 d, 218, in text (50 miles S. of Arizona boundary; habits; nesting).

Campophilus imperialis Salvin and Godman, 1895, 444 (Sierra Madre of Sonora ).

Resident in the Transition zone of the Sierra Madre and closely adjacent ranges. The three Sonora record stations are all from north of latitude $29^{\circ}$, a circumstance doubtless due to the fact that the Sonora-Chihuahua boundary leaves the main ridge of the Sierra Madre south of that point.

\section{PhLoeoceastes guatemalensis dorsofasciatus Moore}

\section{SONORA IVORY-BILLED WOODPECKER}

Phloeoceastes guatemalensis dorsofasciatus Moore, Proc. Biol. Soc. Wash., 48, May 3, 1935, 113 (Guirocoba, Sonora, México).

Pbloeocaestes [sic] guatemalensis nelsoni (not Scapaneus guatemalensis nelsoni (Ridgway) van Rossem, 1934 d, 445 (Alamos; crit.).

Uncommon resident of the foothills in the Tropical zone in the extreme southeastern portion of the State. A locality additional to the two which previously have been published is San Francisco Cañon, where the species was taken in a giant cactus association in open gallery forest at 1,500 feet altitude on May 30, 1937. It was also taken in a precisely similar environment near Guirocoba on May 24, 1937 (Dickey coll.).

\section{DENDROCOPOS VILLOSUS ICASTUS (OBERHOLSER)}

\section{Chinuahua Hairy Woodpecker}

Dryobates rillosus icastus Oberholser, Proc. U. S. Nat. Mus., 40, June 3, 1911, 612 (El Salto, Durango, México) ; ibid., in text (El Puerto; west side of San Luis Mountains).-Ridgway, 1914, 222 (El Puerto).-Cory, 1919, 487 (eastern Sonora).-van Rossem, 1934 d, 445 ([Sierra de] Oposura).

Dryobates villosus byloscopus (not Dryobates byloscopus Cabanis and Heine) Allen, 1893 a, 35 (El Puerto).

Probably a not uncommon resident in the Transition zone of the high mountains near the Chihuahua boundary with occasional descent to lower levels in winter. There are but three record stations, El Puerto, 6,300 feet, December 7, 1890; "Oposura" (but undoubtedly the Sierra de Oposura), May 31 and June 10, 1887; west side of San Luís Mountains, September 29, 1893. A specimen recorded in Mearns' field book as taken on the San Pedro River, October 21, 1892, was most probably of this subspecies. It cannot now be located. 


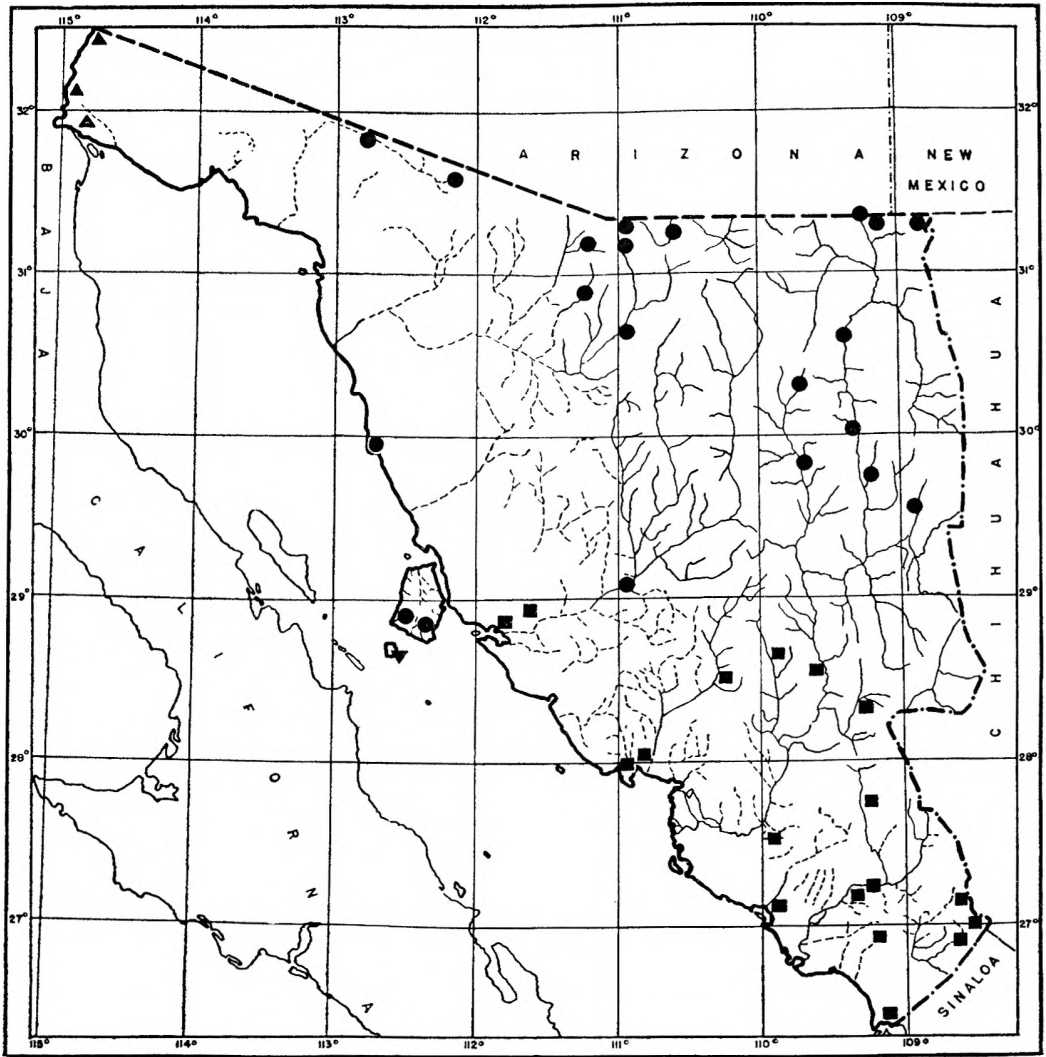

MAP 10. Distribution of Dendrocopos scalaris. Circles, D. s. cactophilus; squares, D. s. sinaloensis; triangles, D. s. yumanensis; inverted triangle, $D . s$. lucasanus.

\section{DENDROCOPOS SCALARIS CACTOPHILUS (OBERHOLSER) \\ CACTUS WOODPECKER}

Dryobates scalaris cactophilus Oberholser, Proc. U. S. Nat. Mus., 41, June 30, 1911, 152 (Tucson, Arizona); ibid., part (many locs. in northern Sonora),Ridgway, 1914, 254 part (Nogales; Santa Cruz, etc.).-Cory, 1919, 494 (northern and middle Sonora).- - Townsend, 1923, 15 (Tiburon Island).- -van Rossem, 1931 c, 257, part (Saric; etc.) ; 1932, 136 (Tiburon Island); 134 d, 445 (Nacozari; Oposura).

Dendrocopus scalaris (not Picus scalaris Wagler) Hargitt, 1890, 246, part (Hermosillo; Moctezuma).-Salvin and Godman, 1895, 435, part (ditto).

Dryobates scalaris Allen, 1893 a, 35 (Oputo; Bacadehuachy). 
Common resident, essentially of riparian and cactus associations in the Lower Sonoran zone, from the Arizona-Sonora boundary south, both coastwise (except the Colorado delta) and in the interior, to about latitude $29^{\circ}$. Many specimens from latitute $30^{\circ}$ southward show variable evidences of intergradation with the Tropical zone race sinaloensis. Some unpublished localities from which specimens have been examined are Puerto Libertad (Nat. Hist. Mus.) ; Pilares (Univ. Mich.); San Bernardino Ranch (U. S. Nat. Mus.). Lamb (notes) also observed the species at El Álamo. Noted by Mearns at almost every Sonoran zone boundary locality from the San Luís Mountains and Guadalupe Cañon westward.

\section{DENDROCOPOS SCALARIS YUMANENSIS (VAN ROSSEM)}

\section{YUMA WOODPECKER}

Dryobates scalaris yumanensis van Rossem, Condor, 44, No. 1, Jan. 15, 1942, 22 (Laguna Dam, lower Colorado River, Imperial County, California); ibid, in text (Colorado delta, Sonora).

Dryobates scalaris bairdi (not Picus bairdi Malherbe) Price, 1899, 92 (lower Colorado River).

Dryobates scalaris lucasanus (not Picus lucasanus Xantus) Stone and Rhoads, 1905, 681 ("Colony"=Colonia Lerdo).

Dryobates scalaris cactophilus (not of Oberholser p. 152) Oberholser, 1911 b, 153, 154, 155, in text (Colony: Colorado River at Mon. 204; Colorado River below Colonia Diaz).--Ridgway, 1914, 254, part (Colony; Colonia Diaz).-van Rossem, 1931 c, 257, part (El Doctor).

Confined to the Colorado River delta, where apparently a common resident.

\section{DENDROCOPOS SCALARIS SINALOENSIS (RIDGWAY)}

\section{MAZATLÁN WOODPECKER}

D.[ryobates] scalaris sinaloensis Ridgway, Man. No. Amer. Birds, 1887, 285 (Mazatlán, Sinaloa, México).

Picus scalaris (not of Wagler) Grayson, 1871, 273, part (Sonora).-Belding, 1883, 344 (Guaymas).

Dendrocopus scalaris Hargitt, 1890, 246, part (Sonora; [ =Cedros; Guadalupe]).- Salvin and Godman, 1895, 435, part (Guaymas; Cedros; Guadalupe).

Dryobates scalaris cactophilus (not of Oberholser, p. 152!) Oberholser, 1911 b, 150, part (Guaymas).-Ridgway, 1914, 254, part (Guadalupe; Guaymas).-van Rossem, 1932, 136, part (Kino Bay).

Dryobates scalaris agnus Oberholser, 1911 b, 150 (Camoa; Batamotal).-Ridgway, 1914, 252 (Camoa; Batamotal).-Cory, 1919; 493 (southern Sunora).--van Rossem, 1930 a, 172, in text (southern Sonora); 1931 c, 257 (locs. north to Guaymas and Tecoripa); 1934 d, 445 (Guaymas; Alamos; Hacienda de San Rafael ).

Common resident of the Tropical zone lowlands and foothills northward along the coast to Kino Bay and in the interior to Tecoripa and San Javier. 
Additional localities are San Marcial (Mus. Comp. Zoöl) ; Rancho Costa Rica, Agiabampo, and San Francisco Cañon (Dickey coll.; van Rossem notes). While few Sonora specimens examined are absolutely typical of this race, the population from the range outlined is certainly much closer to sinaloensis than to cactophilus. ${ }^{28}$

\section{DENDROCOPOS SCALARIS LUCASANUS (XANTUS)}

\section{SAN LUCAS WOODPECKer}

Picus lucasanur Xantus, Proc. Acad. Nat. Sci. Phila., 11, 1859, sig, 21.23, Oct.Nov. [Jan. 12, 1860], 298 (Cape San Lucas, Baja California, México).

Dryobates scalaris lucasanus van Rossem, $1942 \mathrm{~g}, 184$ (San Estchan Island).

Dryobates rcalaris cactophilus (not of Oberholser) van Rossem, 1931 c, 257, part (San Esteban Island).

Resident on San Estéban Island. There are two specimens of record, taken respectively on April 18, 1930, and January 11, 1932.

\section{DENIROCOPOS ARIZONAE ARIZONAE (HARGITT)}

\section{ARIZONA WOODPECKER}

Picus arizonae Hargitt, Ibis, April, 1886, 115 (Santa Rita Mountains, Arizona).

Dendrocopus arizonae Hargitt, 1890, 228, part ("New Oposura").- Salvin and Godman, 1895, 434, part (Oposura).- Thayer and Bangs, 1906, 19 (La Chumata ).

Dryobates arizonae arizonae Ridgway, 1914, 261 (La Chumata; Oposura).Cory, 1919, 495 (Sonora).- -van Rossem, 1931 c, 257 (Saric); 1934 d, 445, part (Oposura).-Bent, 1939, 91 (La Chumata; Saric).

Probably a fairly common resident of Upper Sonoran and Transition zone oak regions in the northeastern part of the State, though to date recorded from but few localities. Westernmost stations are Rancho La Arizona and La Chumata: the southernmost is Oposura, or rather the Sierra de Oposura. Further localities are Cajón Bonito Creek; Guadalupe Cañon; San Luís Mountains; San Pedro River (Mearns notes).

${ }^{28}$ After examination of 32 specimens of "agnus" I am unable to recognize this proposed race, since it is clearly an unstable intermediate between the smaller, darker sinaloensis and the larger, paler cactophilus. Although there is a progressive increase in average size northerly from the metropolis of the former race to that of the latter, individual variation is such that certain northern sinaloensis-cactophilus intergrades are almost as small as typical sinaloensis. Robert T. Moore, to whom I am indebted for the loan of a series of 7 typical sinaloensir, informs me that some of his specimens from northern Sinaloa are almost as large as cactophilus. In the matter of color, the 7 rinaloensis are completely lost in the series of "agnus." 


\section{DENDROCOPOS ARIZONAE FRATERCULUS (RIDGWAY)}

\section{COLIMA WOODPECKER}

D. [ryobates] arizonae fraterculus Ridgway, Man. No. Amer. Birds, 1887, 286 (Sierra Madre, Colima, México).

Dryobates arizonae arizonae (not Picus arizonae Hargitt) van Rossem, 1934 d, 445, part (Mina Abundancia).

Dryocopus arizonae Salvin and Godman, 1895, 434, part (Yecaera).

Fairly common resident of the oak-pine regions in the mountains of the southeast, north probably to about latitude $29^{\circ}$. The northernmost station of record to date is Yécora at about $28^{\circ} 15^{\prime}$. Fairly common in the oakpine regions at Rancho Santa Bárbara in June, 1937 (van Rossem notes).$^{29}$

\section{SPHRYAPICUS VARIUS NUCHALIS BAIRD}

\section{REI)-NAPI:D SAPSUCKFR}

Sphyapicur variu, var. nuchalis Baird, Rep. Expl. and Surv. R. R. Pac., 9, 1858, 103 (Mimbres River, New Mexico).

Sphyrapicus varius nuchali, Allen, 1893 a, 35 (El Pinita; Los Cuevas; El Puerto; Bavispee River).-Ridgway, 1914, 279 (same locs.).--van Rossem, 1931 c, 257 (Saric: Tesia; 15 miles S.W. of Nogales); 1934 d, 444 (Alamos; Miller Ranch; 25 miles S.E. of San Pedro).--Huey, 1942, 367 (Quitovaquita [Arizona]).

Fairly common winter visitant and migrant over most of the State, including Tropical zone lowlands. The earliest fall record is September 19 (Rancho I.a Arizona) ; the latest in spring is March 23 (Álamos). Additional localities are San Pedro River, October 12, 1892 ; Santa Cruz River, October 24, 1893; Nogales, November 27, 1893 (U. S. Nat. Mus.) ; San Luís Mountains, October 1, 1893 (Mearns notes).

\section{SPHYRAPICUS THYROIDEUS NATALIAE (MALHERBE)}

\section{NATALIF. SAPSUCKER}

Picus Natuliae Malherbe, Journ. für Orn., 2, No. 8, March, 1854, 171 (Mexique ex Darmstadt Mus. $=[$ probably] Zacatecas, México).

Sphyrapicus thyroideus (not Picus thyroideus Cassin) Allen, 1893 a, 35 (Bavispee River).-Ridgway, 1914, 287, part (Rio Bavispe).

\footnotetext{
29 Specimens from southeastern Sonora are so intermediate in character between arizonae and fraterculus that their assignment to one race or the other is largely a matter of opinion. At one time (1934 d) I listed the Mina Abundancia series in the Museum of Comparative Zoölogy as arizonae, but 6 specimens from Rancho Santa Bárbara (Dickey and Sheffler collections) and one from Yécora (British Museum) have caused a reversal of opinion.
} 
Known only from a single specimen taken by the Lumholtz expedition on the upper Río Bavispe, December "12," [=22] 1890. The status is most likely that of a winter visitant.

\title{
ORder PASSERIFORMES PERCHING BIRDS
}

\author{
Family Dendrocolaptidae Woodhewers \\ Xiphorhynchus flavigaster tardus Bangs and Peters
}

\section{SONORA WOODHEWER}

Xiphorhynchus flavigaster tardus Bangs and Peters, Bull. Mus. Comp. Zoöl., 68, Oct., 1928, 393 (Hacienda de San Rafael, "Chihuahua" [=Sonora], México).Bangs, 1930, 257 (loc. of type).-van Rossem, 1931 c, 257 (Guirocoba) ; 1934 d, 446 (Hacienda de San Rafael).

Fairly common in summer (breeding) in the extreme southeastern Tropical zone foothills. Although previously reported from but two localities, this woodhewer is not uncommon. Specimens were taken and others noted at San Francisco Cañon, May 29 and 30, at Guirocoba between May 24 and June 16, and seen near Álamos on June 18, 1937 (Dickey coll.; van Rossem notes). Permanent residence seems likely, although the species has been observed to date only in May and June.

\section{LEPIDOCOLAPTES LEUCOGASTER UMBROSUS MOORE}

\section{NORTHERN WHITE-STRIPED WOODHEWER}

Lepidocolaptes leucogaster umbrosus Moore, Proc. Biol. Soc. Wash., 47, April 2, 1934, 87 (between San José and Guirocoba, Sonora, México); ibid., in text (Mina Abundancia; Hacienda de San Rafael).

Picolaptes leucogaster (not Xiphorbynchus leucogaster Swainson) Salvin and Godman, 1891, 185, part (Nuri).-Ridgway, 1911, 259, part (Nuri).- van Rossem, 1934 d, 446 (Mina Abundancia; Hacienda de San Rafael).

Lepidocolaptes leucogaster Hellmayr, 1925, 319, part (Sonora).

Fairly common in spring and summer in the Tropical and Upper Sonoran zone foothills and lower mountains in the extreme southeastern corner of the State. The northernmost record to date is from Nuri on the Rio Chico. Extremes of altitude at which detected are from approximately 1,500 feet at Nuri and Guirocoba to 5,500 feet at Rancho Santa Bárbara (Dickey coll.). Although Sonora records cover only the period from early April to mid-June, the fact that the species has been found in im- 
mediately adjacent portions of Chihuahua in midwinter indicates permanent residence in Sonora also.

\section{Family Cotingidae Cotingas}

\section{TITYRA SEMIFASCIATA HANNUMI VAN ROSSEM AND HACHISUKA}

\section{NORTHWESTERN TITYRA}

Tityra semifasciata bannumi van Rossem and Hachisuka, Proc. Biol. Soc. Wash., 50. Nov. 26, 1937, 197 (San Francisco Cañon, extreme southeastern Sonora, México).

Known only from the type locality, where two specimens, a pair in breeding condition, were taken and four other individuals seen on May 29, 1937. All were in semi-deciduous woodland in the Tropical zone at altitudes of from 1,400 to 2,000 feet.

\section{PLATYPSARIS AGLAIAE RICHMONDI VAN ROSSEM}

\section{RICHMOND BECARD}

Platypsaris aglaiae richmondi van Rossem, Proc. Biol. Soc. Wash., 43, July 18, 1930, 130 ("Saric" [ = Rancho La Arizona], Sonora, México); ibid., in text (Tesia; Chinobampo; Guirocoba); 1931 c, 258 (same locs.); 1934 d, 446 (Alamos; Hacienda de San Rafael).-Bent, 1942, 7, in text (Sonora; crit.)-A.O.U. Comm., 1944, 452 (Saric).

Platypsaris aglaiae albiventris (not Hadrostomus albiventris Lawrence) Ridgway, 1907, 856, part (Alamos; Hacienda de San Rafael; Ysleta).-Hellmayr, 1929, 201, part (Sonora).

Hadrostomus aglaiae (not Pachyrbynchus aglaiae Lafresnaye) Salvin and Godman, 1890, 121, part (Ysleta).

Fairly common resident in the foothills and mountains in the extreme southeast, where occasionally reaching an altitude of 5,500 feet in the Transition zone. There are four records for the lowlands: Tesia, December 21, 1929, and Chinobampo, February 21 and 30, 1930; Isleta, May 16, 1888. A colony, apparently completely isolated by some 300 miles, exists at Rancho La Arizona in the extreme northcentral part of the State where Wright took six specimens between May 14 and June 24, 1929. Additional records are San Francisco Cañon where seen commonly on May 30, and Rancho Santa Bárbara in early June, 1937, where found to penetrate the Transition zone up to 5,500 feet (van Rossem notes; Dickey coll.)..$^{30}$

30 This northern colony is apparently migratory for although nests of the previous year were found between May 6 and 10, 1937, no birds had appeared as yet. 


\section{Family TyRannidae Tyrant Flycatchers SAYORNIS NIGRICANS SEMIATRA (VIGORS) \\ Western Black Phofbe}

Muscicapa semiatra Vigors, Zool. Voy. Blossom, 1839, 17(Monterey, California). Sayornis nigricans semiatra van Rossem, 1931 c, 262 (El Doctor; Pesqueira; Tecoripa; Saric; Obregon; Tesia; Chinobampo; San Jose de Guaymas; 15 mi. S. W. of Nogales; San Luis); 1934 d, 448 (Guaymas; Alamos; Nacozari; Oposura).

Sayornis nigricans (not Tyrannula nigricans Swainson) Allen, 1893 a, 37 (Granados).-Price, 1899, 92 (lower Colorado River).

Sayornis nigricans nigricans Ridgway, 1907, 597, part (Hermosillo).-Huey, 1935, 254 (Punta Peñascosa).

Common resident of the entire State (except that there is no record from any of the islands) below an altitude of 5,500 feet, with concentration on ponds, reservoirs, and streams. Numbers secm to be fairly stable throughout the year and the great bulk of the population is probably resident. Locality records in addition to those given are almost too numerous to site; some of them are Guirocoba, March (Bishop coll.); El Alamo, and Rancho Costa Rica, December (Lamb notes); Guaymas, February and March (Mus. Comp. Zoöl.), Kino Bay, December; Rancho Santa Bárbara, June (Dickey coll.); San Pedro River, October and July; San Bernardino Ranch, August; Sonoyta, January; Colorado River at Monument 204, March (U. S. Nat. Mus.); Magdalena, May (Dawson notes); Cajón Bonito Creek, July (Mcarns notes).

\section{SAYORNIS SAYA SAYA (BONAPARTE)}

\section{SAY Phofbe}

Muscicapa saya Bonaparte, Amer. Orn., 1825, 20, pl. 11, fig. 3 (Arkansas River, about 20 miles from the Rocky Mountains [ $=$ near Pueblo, Colorado]).

Sayornis saya Evermann and Jenkins, 1888, 67 (Nogales).-Allen 1893 a, 37 (San Pedro).--Ridgway, 1907, 602, part (Sonora).

Sayornis saya saya A.O.U. Comm., 1931, 207, part (Sonora).-van Rossem, 1931 c, 262 (El Doctor; Saric; Obregon; Tesia; 15 mi. S. of Nogales; San Luis); 1934 d, 448 (Guaymas; Alamos; Cumpas).

Evidently rather uncommon in summer in the northcentral portion of the State, where known to brced in the vicinity of Rancho La Arizona, Nogales, and Magdalena. Distribution of the subspecies saya in southern Arizona suggests summer residence eastward from Nogales; however, there are no Sonora records for that season other than those given above. In winter, commonly and widely distributed in Sonoran and Tropical zones nearly everywhere. Unpublished records are San Carlos Bay, De- 
cember 24 (Dickey coll.) ; boundary south of Bisbee, September 23 (U. S. Nat. Mus.) ; Nogales, breeding, May 10; Magdalena, breeding, May 13 (Dawson notes); Rancho La Arizona, breeding, May 7 (van Rossem notes) ; El Álamo, December 2; Rancho Costa Rica, December 11 (Lamb notes); San Marcial, November 8 (Mus. Comp. Zoöl.); Cajón Bonito Creek, September 27; San Pedro River, October 11 (Mearns notes).

\section{SAYORNIS SAYA QUIESCENS GRINNELL}

\section{Desert Phoebe}

Sayornis sayus quiescens Grinnell, Condor, 28, No. 4, July 15, 1926, 180 (San José, about 45 miles northeast of San Quentín, Baja California, México).

Sayornis saya quiescens van Rossem, 1931 c, 262 (El Doctor).

Sayornis saya saya (not Muscicapa saya Bonaparte) Huey, 1935, 254 (Punta Peñascosa); 1942, 367 (Quitovaquita; Dowling Well).

(?) Sayornis saya Price, 1899, 92 (lower Colorado River).

Fairly common and generally distributed midwinter visitant in the northwest desert region, south, coastwise, to the vicinity of Guaymas and (casually?) to the lower Mayo River valley. Specimens of quiescens have been examined from El Doctor, January 24 to 30, 1929; San José de Guaymas, January 7, 1933 (Dickey coll.) ; Punta Peñascosa, February 27, 1934; Puerto Libertad, February 2, 1935; Kino Bay, February 14 to 27, 1935 (Nat. Hist. Mus.) ; Camoa, February 20, 1931 (Bishop coll.). In default of specimens the midwinter record of Price can be allocated only provisionally. ${ }^{31}$

\section{PyRocephaLUS RUBINUS FLAMMEUS VAN ROSSEM}

\section{Western Vermilion Flycatcher}

Pyrocephalus rubinus flammeus van Rossem, Trans. San Diego Soc. Nat. Hist., 7, No. 30, May 31, 1934, 353 (Brawley, Imperial County, California) ; 1934 d, 451 (Guaymas; Alamos; Fronteriza; Nacozari).

Pyrocephalus rubineus (not Muscicapa rubinus Boddaert) Baird, 1858, 201, part (San Bernardino); 1859, 9, part (San Bernardino).-Salvin and Godman, 1889, 60, part (Realito).

Pyrocephalus rubineus, var. mexicanus (not Pyrocephalus mexicanus Sclater) Brewer, 1874, 387 (Los Nogales).

31 The range of quiescens covers a great deal more territory than that originally accorded it by Grinnell. It is the breeding race of southeastern California and southwestern Arizona, north at least to extreme southeastern Clark County, Nevada. In central Baja California quiescens has been found breeding as early as February 22 (van Rossem, $1931 \mathrm{c}$ ). Because of this, as well as from the appearance of some of the specimens examined. I suspect that quiescens is the resident race in northwestern Sonora. 
Pyrocephalus rubineus mexicanus Evermann and Jenkins, 1888, 68 (Querobabi; Carbo).-Allen, 1893 a, 37 (San Pedro; Nacory; Granados).- Thayer and Bangs, 1906, 19 (Opodepe).

Pyrocephalus rubinus mexicanus Hellmayr, 1927, 22, part (Sonora).-van Rossem, 1931 c, 266 (El Doctor; Pesqueira; Tecoripa; San Javier, Saric; Obregon; Tesia; Tobari Bay; Guaymas; El Alamo; Agiabampo; San Luis).-Griscom, 1934, 385, part (Sonora; crit.).

Common resident of Sonoran and Tropical zones everywhere on the mainland although there is probably a recession during the winter months of part of the population from more northern locallities. Additional localities are Rancho Costa Rica, December; Ures, January (Lamb notes); Pilares, June (Univ. Mich.) ; Guirocoba, June (Dickey coll.) ; Sonoyta, January; Colorado River at Monument 204, March (U. S. Nat. Mus.); Cerro Blanco, March (Field Mus.); Magdalena, May (Dawson notes); San Luís Mountains on the boundary, July; San Pedro River, July; Guadalupe Cañon, July (Mearns notes).

\section{TYRANNUS VOCIFERANS VOCIFERANS SWAINSON}

\section{CASSIN KINGBIRD}

Tyrannus vociferans Swainson, Quart. Journ. Sci., 20, 1826, 273 (Temascáltepec, México).-Baird, 1858, 174 (Los Nogales); 1859, 8 (Los Nogales).Sclater, 1862, 235 (Los Nogales) ; 1888, 269 (Los Nogales).-Brewer, 1874, 327, in text (Los Nogales).-Salvin and Godman, 1889, 99, part (Santa Rosa; Trinidad; Micoba; Los Nogales).-Allen, 1893 a, 36 (Leoncita; Fronteras).- Thayer and Bangs, 1906, 19 (Opodepe; La Chumata).-Ridgway, 1907, 694, part (Sonora).van Rossem, 1931 c, 258 (Tecoripa; Saric; Obregon; Tesia; Chinobampo).

Tyrannus vociferans vociferans van Rossem, 1934 d, 446 (Alamos; Nacozari; Oposura).

Common summer visitant to Sonoran and Tropical zones nearly everywhere, principally in the vicinity of streams and about habitations, except that there are no records for the desert regions north of Guaymas, nor from any of the islands. Winter records are all from Guaymas and Hermosillo southward and the species is evidently more or less restricted at that season to the Tropical zone. Records additional to those published are Camoa, February 9; Guirocoba, April 14 (Bishop coll.) ; Hermosillo, December 31 (Lamb notes); Guaymas, February 2 to 27 (Mus. Comp. Zoöl.) ; Magdalena, May 12; Nogales, May 10 (Dawson notes) ; Cajón Bonito Creek, July 3 and September 8 (Mearns notes); San Pedro River, July 29; Guadalupe Cañon, October 4; Santa Cruz River, October 22 and 23 (U. S. Nat. Mus. catl.). The last named date is the latest for the northern part of the State. The earliest seems to be March 24 at Nacozari. 


\section{TYRANNUS VERTICALIS SAY \\ WESTERN KINGBIRD}

Tyrannus verticalis Say, in Long's Exped. Rocky Mts., 2, 1823, 60, note (Ash River, near Rocky Mts. [= La Junta, Colorado]).- Thayer and Bangs, 1906, 19 (Opodepe).-Ridgway, 1907, 697 (Sonora).--van Rossem, 1931 c, 258 (San Javier; Saric; Guirocoba) ; 1934 d, 446 (Oposura).

Common summer visitant to Sonoran and Tropical zones south to the Mayo River valley. There are no records from any of the islands. Further locality records are San Luís and Colonia Independencia, May 3 ; Hermosillo, May 10; Tesia, June 22, 1937, breeding (van Rossem notes) ; San Bernardino Ranch, August 13, 1892; Colorado River at Monument 204, March 31, 1894 (U. S. Nat. Mus. catl.) ; Gray's Ranch on the boundary, April and May, 1939 (Huey, 1942). The earliest date of arrival is March 31 (Colorado River at Monument 204) ; the latest fall date is September 8 (Rancho La Arizona).

\section{Ty'RANNUS melancholicus occidentalis HaRtert AND GoOdson Western Tropical Kingbird}

Tyrannus melancholicus occidentalis Hartert and Goodson, Novit. Zool., 24, Aug. 31, 1917, 412 (San Blas, Tepic [-Nayarit], México)--van Rossem, 1931 c, 258 (Tobari Bay; Guaymas; Agiabampo) ; 1934 d, 447, in text (southern Sonora). -Dickey and van Rossem, 1938, 352, in text (Sonora).-Phillips, 1940, 117 (Guaymas).

A common summer visitant to the Tropical zone coastal plain, north to the vicinity of Guaymas. In spite of extensive observation there is but one locality of record away from the vicinity of the seacoast and lower river valleys,--Guirocoba in the foothills at 1,450 feet, where the species is rather common. Additional localities are Camoa, June 5, 1931 (Bishop coll.) ; Masocari Island, May 15, and Tesia, June 20, 1937 (Dickey coll.). Actually, by personal observation, the distribution of this kingbird is practically continuous in the lowlands from the Sinaloa boundary north to Guaymas. The earliest date of arrival recorded is April 26 (Tóbari Bay). There are no data concerning fall departure.

\section{TYRANNUS CRASSIROSTRIS SEQUESTRATUS VAN ROSSEM}

\section{NORTHERN THICK-BILled KINGBiRD}

Tyrannus crassirostris sequestratus van Rossem, Condor, 43, No. 5, Sept. 18, 1941, 250 (Rancho La Arizona, Sonora, México).

Tyrannus crassirostris pompalis (not of Bangs and Peters) van Rossem, 1931 c, 259, part (Saric). 
Known only as a fairly common summer visitant in the vicinity of Rancho La Arizona, where seemingly confined to riparian timber associations. Dates of record extend from May 7 to September 11.

\section{Tyrannus crassirostris pompalis Bangs and Peters}

\section{Álamos THICK-BILled KINGBird}

Tyrannus crassirostris pompalis Bangs and Peters, Bull. Mus. Comp. Zoöl., 68 No. 8, Oct. 1928, 396 (Hacienda de San Rafael, Chihuahua [=Sonora], México); ibid., in text (Alamos).-Bangs, 1930, 268 (data on type).-van Rossem, 1931 c, 259, part (Tesia; Agiabampo); 1934 d, 446 (Alamos; Hacienda de San Rafael); 1941 b, 250, in text (southern Sonora; crit.).

Tyrannus crassirostris (not of Swainson) Salvin and Godman, 1889, 103, part (western Sonora).

Fairly common resident in the Tropical zone lowlands and foothills, chiefly in riparian associations, north to about $27^{\circ} 10^{\prime}$. This race is thus separated from sequestratus by almost the entire length of the State. The northernmost records to date are Tesia in the lower Mayo River valley and Hacienda de San Rafael in the extreme eastern foothill region. Dates range from December 21 through June; the July-November hiatus most likely reflects lack of collecting or observation during that period. Although first recorded from Sonora by Salvin and Godman (1889), the basis is obscure. There are no specimens taken in Sonora in the British Museum, but Lloyd may have noted the species there in the spring of 1888. In addition to the records cited above, there are two specimens in the Museum of Vertebrate Zoology taken by Benson at Agua Marín, 8 miles northwest of Álamos on May 2, 1939.

\section{MYIODYNASTES LUTEIVENTRIS SW ARTHI VAN ROSSEM}

\section{Arizona Sulphur-bellied Flycatcher}

Myiodynastes luteiventris swarthi van Rossem, Condor, 29, No. 2, March 15, 1927, 126 (Huachuca Mountains; Arizona); 1931 c, 259 (Saric; Guirocoba); 1934 d, 477 (Hacienda de San Rafael); 1940, 79 (nomen.).--Bangs and Peters, 1928, 394 (Hacienda de San Rafael).-Bent, 1942, 106, in text (San Rafael).

Myiodynastes luteiventris (not of Sclater) Salvin and Godman, 1889, 48, part (Ysleta).-Ridgway, 1907, 657 (Hacienda de San Rafael; Cajon Bonito Creek).

Myiodynastes luteiventris vicinior (not of Cory) Zimmer, 1937, 26, in text (nomen.; crit.).

Summer visitant to the mountainous eastern area; possibly of general distribution although detected so far only in the extreme north and the extreme south. The chief associational requirement is relatively large timber along cañon streams. Zonal distribution extends from Tropical 
into Transition in the south, and from low Upper Sonoran into Transition in the north. Additional records arc from San Francisco Cañon (ncst building; also migrating abundantly), May 29 and 30; Guirocoba, migrating abundantly after May 15, brecding June 2; Rancho Santa Bárbara, fairly common, brceding, Junc 6 to 15, 1937 (Dickey coll.; van Rossem notes). The carliest arrival date is May 2 (Guirocoba); the latest for fall is Scptember 10 (Rancho La Arizona).$^{32}$

\section{MYIOZETETES SIMILIS IPRIMIII.US VAN ROSSEM}

\section{MAYO FLyC.ATCHFR}

Mjiozctetcs similis primulus van Rossem, Trans. San Diego Soc. Niat. Hist., 6, No. 8, Aug. 30, 1930, 198 (Tcsia, Sonorat, México); 1931 c, 259 (Tesia).Griscom, 1934, 385 (Sonora).

Common resident in the lower Mayo River valley. The extreme localness of many Tropical zone specics is well cxemplified by this flycatcher. Carcful personal scarch in other, apparcntly equally suitable Tropical zone localities, has failed to produce a single specimen, nor has it been cncountcred elsewhere in Sonora by any of the scveral collectors who have inrestigated the region.

\section{MIIOTHETES SIMIIIS TEXINSIS (GIRAUI))}

\section{Giraui) Flycatcher}

Muscicapa texensis Giraud, Sixtcen Specics Texas Birds, 1841, pl. I (Texas= [probably] Vera Cruz. Méxicu).

A single specimen, scemingly typical of this race, was taken by W. J. Shefler at Guirocoba on December 5, 19.41, and is now in his collection. Its status is almost ccrtainly that of a casual, in all probability from east of the Sicrra Madre by way of onc of the great cast-west cañons.

32 Birds from southeastern Sonora by no means represent typical suarthi, for although they arc pale colored and have narrow streaking below there is a pronounced ycllowish flush dorsally. The apparent gap in the range of this species hetoeen latitudes $28^{\circ}$ (Bravo, Chihuahua) and $31^{\circ}$ (Cajón Bonito Crcek) may he significant in this conncetion. It is diffcult to helieve that such a gap actually exists, but on the other hand no Sulphur-bellicd Flycatchers were taken hy Camphell in F:I Tigre Mountains, by Calhoon in the Sicrra de Oposura, by Brown in the Sierra de San Antonio. nor, so far as can be determined, by any of the scveral col. lectors who have w'orked the Chihuahua side of the boundary hetrecn the above given latitudes. If this proves to be the casc, suarthi in typical form occupies a rather limited and isolated range. 


\section{Pitangus sulphuratus palliatus van Rossem}

\section{Western Derby Flycatcher}

Pitangus sulfuratus (sic) palliatus van Rossem, Proc. Biol. Soc. Wash., 50, Feb. 23, 1937, 25 (Álamos, Sonora, México); ibid., in text (Agiabampo; Basacori [= Masocari $]$ Island).

Pitangus sulphuratus palliatus van Rossem, 1940, 84 (Sonora; monog.).Peters, 1943, 77 (re. type).-Wetmore, 1943, 288, in text (southern Sonora; crit.).

Pitangus sulphuratus derbianus (not Saurophagus derbianus Kaup) Peters, 1929 b, 448, in text (Sonora).- van Rossem, 1931 c, 259 (Agiabampo); 1934 d, 447 (Alamos).-Zimmer, 1937, 26, part (Sonora).-Bent, 1942, 98, in text (Agiabampo; Alamos).

Summer visitant in the extreme south, where virtually confined to the Tropical zone coastal plain. The earliest date of arrival is March 8 (Alamos); there are no data on fall departure. In addition to the cited Jocalities, the species was found at Camoa, April 19, 1939 (Mus. Vert. Zool.) and at Tesia (commonly) in late June, 1937 (Dickey coll.). Possibly the Derby Flycatcher is resident, since W. J. Sheffler is certain (notes) that four individuals were seen by him at Guirocoba between November 13 and 20, 1944.

\section{MYIARCHUS CINERASCENS CINERASCENS (LAWRENCE)}

\section{ASH-THROATED FLYCATCHER}

T'yrannula cinerascens I.awrence, Ann. Lyc. Nat. Hist. Ncw York, S, 1851, 121 ([Bctween San Antonio and the Rio Grande] Western Texas).

Myiarchus cinerascens Evcrmann and Jenkins, 1888, 67 (Nogales).-Salvin and Godman, 1889, 91, part (Yecera).-Nelson, 1904 b, 33 (Central Sonora).

Myiarchus cinerascens cinerascens Thayer and Bangs, 1906, 19 (La Chumata; Opodepe).--Ridgway, 1907, 625, part (I.a Chumata; Opodepe).-[?] Mailliard, 1923, 455 (San Pedro Nolasco Island).-Hellmayr, 1927, 160, part (Cerro Blanco Mines).-van Rossem, 1931 c, 260, part (San Javier; Saric; El Alamo; Tesia; 10 miles W. of Magdalena) ; 1932, 136, part (Tiburon Island, part [winter]); 1934 d, 447 part (Oposura; Nacozari).-Griscom, 1934, 388, part (Oposura; La Chumata; Nacozari; Guaymas, part; Opodepe).-Bent, 1942, 128, part (Sonoyta; Tesia; Pozo de Luís).-Huey, 1942, 367 (Gray's Ranch; Dowling Well).

Myiarchus crinitur, var. cinerascens Brewer, in Baird, Brewer, and Ridgway, 1874 (2), 337, in text (Los Nogales).

Myiarchus cinereus Stone and Rhoads, 1905, 682 (Colony).

Myiarchus mexicanus (not Tyrannula mexicana Kaup) Baird, 1858, 179 (Los Nogales).

Myiarchus nuttingi inquietus (not Myiarchus inquietus Salvin and Godman) Nelson, 1904 b, 38, part (Nacozari).

Common summer visitant to Sonoran zones the width of the State northerly, and south in the central-eastern interior at lcast to latitude $29^{\circ} 30^{\prime}$. Occurs as a winter visitant over the Lower Sonoran and Tropical 
deserts south at least to the Mayo River valley. As a transient, the distribution is general. Some stations not listed above are San Marcial, November 5, 1905 (Mus. Comp. Zoöl.) ; Kino Bay, February 16 to 27, 1935; Puerto Libertad, January 28 to February 3, 1935 (Nat. Hist. Mus.) ; San Pedro River, July 29, 1893; Monument 205, March 19, 1894; Cajón Bonito Creek, July 3, 1892; San Luís Mountains, July 12, 1893 (U. S. Nat. Mus.; Mearns notes) ; San Luís, May 3, 1937 (van Rossem notes).

\section{MYIARCHUS CINERASCENS MEXICANUS (KAUP)}

\section{KAUP FlyCATCHER}

Tyrannula mexicana Kaup., Proc. Zool. Soc. Lond., 19, [Oct.], 1852, 51 (México $=$ State of Zacatecas $)$.

Myiarchus cinerascens cinerascens (not Tyrannula cinerascens Lawrence) Ridgway, 1907, 625, part (Batamotal).-[?] Townsend, 1917, 17, part (Tiburon Island).-van Rossem, 1931 c, 260, part (Pesqueira; 10 miles N. of Guaymas; Guirocoba; Guaymas; Kino Bay; Tiburon Island); 1932, 136 (Tiburon Island, part; Kino Bay; Guaymas; crit.); 1934 d, (Guaymas).-Griscom, 1934, 388, part (Guaymas, part).-Bent, 1942, 128, part (Guaymas).

(?) Myiarchus cinerescens Belding, 1883, 343 (Guaymas).

Fairly common resident of Lower Sonoran and Tropical zones from Tiburón Island and Kino Bay southward. Two winter records north of the established breeding range, Puerto Libertad, January 28, 1935 (3 specimens in Nat. Hist. Mus.), and Pesqueira, February 24, 1929 (Dickey coll.), may be within the breeding range, the northern and eastern limits of which are unknown at this time. ${ }^{33}$

\section{MYIARCHUS CINERASCENS PERTINAX BAIRD \\ Lower California Flycatcher}

M.[yiarchus] pertinax Baird, Proc. Acad. Nat. Sci. Phila., [11], 1859, Sigs. 2123, Oct.-Nov. [Jan. 12, 1860], 303 (Cape San Lucas, Baja California, México).

33 While seemingly identical with cinerascens in coloration, birds from the range outlined above differ in slightly smaller size, proportionately slightly longer tail, and more rounded wing in which the tenth (outer) primary is about equal to the third instead of to the fourth or the fifth. Kaup's type, which I examined at Darmstadt in August, 1933, was obtained from Wollweber; hence, the State of Zacatecas is almost certainly the type locality. It is not marked as to sex but the rather indistinct character of the markings on the outer rectrices and the small size led me to believe it to be a female. Osgood (Auk, 24, 1907: 219-220), has long ago examined this type and commented on the post-mortem fading. The measurements of wing and tail are 91.5 and $87.0 \mathrm{~mm}$., respectively. Since these are very close indeed to the measurements of the 13 Sonora females, I see no objection to using Kaup's name tentatively. Unfortunately, I did not take the wing formula. Griscom (1934 p. 388) has previously segregated this race (under Groups 2 and 3) so far as his Sonora material would permit, but applied no name. 
Myiarchus cinerascens pertinax van Rossem, 1942 g, 184 (San Esteban Island). Myiarchus cinerascens cinerascens (not Tyrannula cinerascens Lawrence) Townsend, 1923, 17, part (San Esteban Island).--van Rossem, 1931 c, 260, part (San Esteban Island).

Breeds on San Estéban Island, where presumably resident, although specimens have been taken only on April 17 and 18, 1930 (Dickey and Nat. Hist. Mus. colls.).

\section{MyiaRchus NUTTINGI INQUiETUS SALVIN AND Godman}

\section{Guerrero Flycatcher}

Myiarchus inquietus Salvin and Godman, Biol. Centr.-Amer., Aves, 2, March, 1889, 88 (Acaguisotla [=Acahuizotla], Guerrero, México).-Allen, 1893 a, 36 (Oputa [Nov. 9, not "Sept." 9]; Bacadehuachy, [Nov. 20, not "Dec." 20]).

Myiarchus nuttingi inquietus Nelson, 1904 b, 38, part (Alamos; Hacienda de San Rafael).-Ridgway, 1907, 631, part (Alamos; Oputa; Bacahehuachy).-Hellmayr, 1927, 161 (Sonora).

Myiarchus cinerascens inquietus van Rossem, 1931 c, 260 (Pesqueira; San Javier; Tesia, Chinobampo; Guirocoba); 1932, 137, in text (Alamos District; crit.); 1934 d, 447 (Hacienda de San Rafael; Alamos); 1936 b, 117 (Sonora).

Myiardius [sic.] inquietus Ridgway, 1894 a, 66 (Oputo; Bacadehuachy; crit.).

Myiarchus nuttingi (not of Ridgway) Griscom, 1932 a, 253, part (Sonora; crit.).

Seemingly a fairly common resident of the Tropical zone north, in the interior at least, to about $28^{\circ} 30^{\prime}$. Definite breeding stations are Agiabampo on the coast and Guirocoba in the extreme southeastern foothills. A very probable breeding locality is San Javier. Whether fall and winter occurrences north and west of the breeding range, as known, are due to seasonal dispersal or represent resident localities cannot be determined at this time. Unrecorded specimens are from Camoa, February 10, 1931 (Bishop coll.) ; Rancho Costa Rica, December 15, 1932; Agiabampo, May 17, 1937; Guirocoba, May 22 to 31, 1937 (Dickey coll.) ; Agua Marín, May 5, 1939 (Mus. Vert. Zool.). ${ }^{34}$

34 I once presented evidence (1931 C and 1932) that inquietus was conspecific with cinerascens, and on the basis of the material then available it seemed a logical conclusion. More recent data, particularly that presented by Griscom (1934) concerning the situation in Guerrero, seem to indicate strongly that two closely related but distinct species are involved and that the truly impressive number of intermediates are the result of hybridization on a mass scale. Personal field work during the breeding season supports this latter view, for at Guirocoba in 1937 I found both present in typical form, though connected by intermediates showing various combinations of characters. Additionally, intergradation in a geographic sense over the area from Sonora to Guerrero is out of the question, except as zonal distribution might be a factor. This obviously is not the case in Guerrero. On present data the breeding ranges of cinerascens and inquietus in Sonora appear to be complementary with overlap along a narrow belt, but future field work may well prove such segregation to be non-existent. 


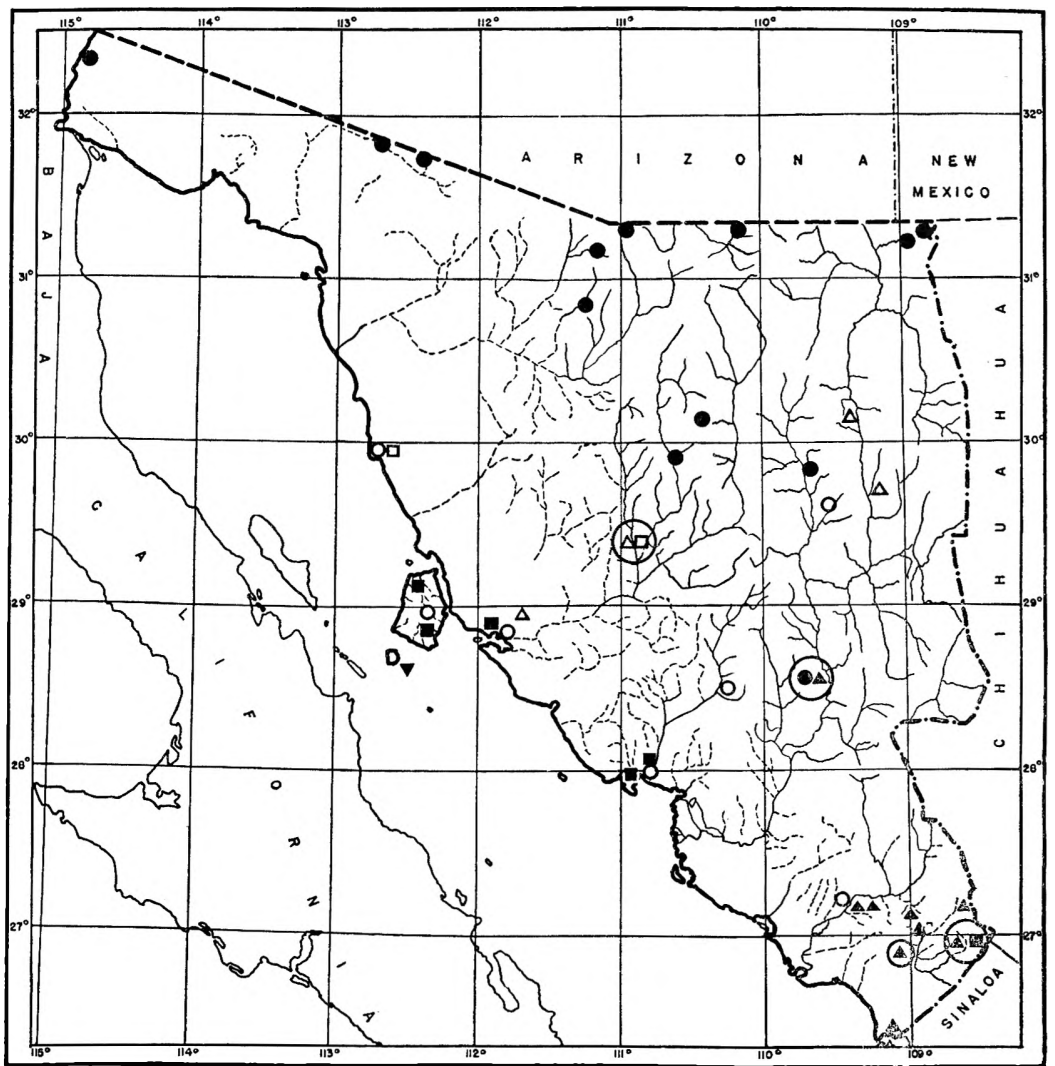

Map 11. Distribution of two species of the genus Myiarchus. Circles, M. cinerascens cinerascens; squares, $M$. c. mexicanus; triangles, $M$. nuttingi inquietus; hollow figures, transient or winter stations outside of established breeding range; large circles, evidence of hybridism present.

\section{MYIARCHUS TYRANNULUS MAGISTER RIDGWAY \\ Arizona CRested Flycatcher}

Myiarcbus mexicanus magister Ridgway, Proc. Biol. Soc. Wash., 2, April 10, 1884, 90 (Camp Lowell, Arizona); 1907, 623 (Ortiz; Ysleta).-Thayer and Bangs, 1906, 19 (La Chumata).

Myiarchus tyrannulus magister Hellmayr, 1927, 162 (Sonora).- -van Rossem, 1931 c, 260 (Saric; Guaymas; Guirocoba; 1934 d, 447 (Hacienda de San Rafael).Bent, 1942, 123 (Ortiz; Nogales).--Huey, 1942, 367 (Gray's Ranch on the boundary).

Myiarchus magister Salvin and Godman, 1889, 89, part (Ysleta).

Common summer visitant and transient almost everywhere up to and including the lower fringe of the Transition zone. Most common, how- 
ever, in giant cactus areas in Lower Sonoran and Tropical zone deserts. There are no records as yet for any of the islands, nor for the Sonora side of the Colorado River. Additional stations are Alamos, April 25, 1939 (Mus. Vert. Zool.); Magdalena, May 12, 1925 (Dawson notes); Agiabampo, May 17; San Francisco Cañon, May 30; Rancho Santa Bárbara, June 11, 1937 (Dickey coll.; van Rossem notes). The earliest arrival date is April 25 (Álamos). There are no dates for fall departure.

\section{MYIARCHUS TUBERCULIFER OIIVASCENS RIDGWAY}

\section{OlivaceOUS FLyCATCHER}

Myiarchus lawrencei olivascens Ridgway, Proc. Biol. Soc. Wash., 2, April 10 , 1884, 91 (Santa Efigenia, Oaxaca, México); Thayer and Bangs, 1906, 19 (I.a Chumata).

Myiarchus lawrenceii olivascens Ridgway, 1907, (Alamos; Yecera; Realito; Guadalupe; Hacienda de San Rafael).

Myiarchus tuberculifer olivascens Hellmayr, 1927, 186 (Sonora).--van Rossem, 1931 c, 261 (San Javier; Saric; Tesia; Chinobampo; Magdalena; Guirocoba; Agiabampo); 1934 d, 448 (Alamos; Mina Abundancia; Hacienda de San Rafael) ; 1936 d, 137 (Sonora; range).-Bent, 1942 (Cajon Bonito Creek; Saric; Guaymas; Agiabampo; Oposura).

Myiarchus lawrencii (not Muscicapa lawrencii Giraud) Salvin and Godman, 1889, 94, part (Yecera; Realito; Guadalupe).

Common summer visitant to Tropical, Sonoran, and Transition zones in the southern part of the State north, chiefly or entircly in the Upper Sonoran zone of the mountainous eastern part, to the Arizona boundary. Winters, apparently in fair numbers, north at least to the Mayo River valley. Some additional record stations are Ysleta, May 16, 1888 (Brit. Mus.) ; Cerro Blanco Mines, April 4, 1903 (Chicago Nat. Hist. Mus.) : Cajón Bonito Creek, July 3, 1892 ; San José Mountains, August 8, 1893 (Mearns notes) ; San Francisco Cañon, May 30, 1937 (van Rossem notes) ; Rancho Santa Bárbara, June 6 and 9, 1937 (Dickey coll.). Numerous March and early April records may pertain either to migrating or wintering individuals; the earliest date for northern localitics is April 4 (Cerro Blanco Mines). As is all too frequently the case there is a scarcity of fall departure data. The latest record at present is August 19 (Rancho La Arizona). ${ }^{35}$

35 The apparent indifference of tuberculifer to zonal or associational considera. tions over most of its Central American and Mexican range is truly surprising. Equally so is the restriction of habitat in the extreme northwest. Southern Sonora apparently marks the northern limit of general distribution: north of that region the zonal range narrows abruptly and is practically restricted to timbered localities in the Upper Sonoran zone. 


\section{NUTTALLORNIS BOREALIS (SWAINSON)}

\section{Olive-SIDEd Flycatcher}

Tyrannus borealis Swainson, Fauna Bor.-Am., 2, 1831 [Feb., 1832], 141, pl. 35 (Cumberland House [ $=$ Carleton House], Saskatchewan).

Nuttallornis borealis cooperi Moore, 1938 a, 25 (Guirocoba).

Spring and fall migrant at lower elevations; probably more common than the few known occurrences might suggest. Noted by Dawson at Magdalena several times between April 22 and May 15, and at Nogales, May 10, 1925 (notes) ; specimen in the Dickey collection taken at Agiabampo, May 17, 1937. Instances of fall occurrence are San Bernardino River on the boundary, August 15 and September 4, 1892 (U. S. Nat. Mus. catl.); Guirocoba, September 25, 1933.36

\section{CONTOPUS VIRENS RICHARDSONII (SWAINSON)}

\section{Western WoOd PeWee}

Tyrannula richardsonii Swainson, Fauna, Bor.-Amer., 2, 1831 [Feb., 1832], 146, pl. 46, lower fig. (Cumberland House, [Saskatchewan], Canada).

Myiochanes richardsonii richardsonii van Rossem, 1931 c, 265, part (Guirocoba; Saric, part).

Breeds in the San Luís Mountains in the extreme northeast and possibly at high altitudes at other points southward. Specimens nearest to this race, though not typical, have been examined from "San Luís Mountains, Mexican Boundary Line," June 17, 1892, and Cajón Bonito Creek, "Chihuahua," 10 miles south of Monument 66, July 6, 1892 (U. S. Nat. Mus.). Occurs also as a spring and fall transient, probably in some numbers in spite of the few specimens so far collected. Spring records are from Guirocoba, May 2, 1931 (Bishop coll.) ; May 6, 1930; Rancho La Arizona ["Saric"], May 29, 1929. Fall records are all from Rancho La Arizona between August 11 and 29, 1929.

\section{CONTOPUS VIRENS SATURATUS Bishop}

\section{NORTHWESTERN WOOD PEWeE}

Contopus richardsonii saturatus Bishop, Auk, 17, No. 2, April, 1900, 116 (Haines, Alaska).

${ }^{36}$ After some consideration and the examination of a large number of western specimens, I have concluded that the recognition of two races of the Olive-sided Flycatcher is not practical, at least on the basis of the ranges now allocated respectively to borealis and cooperi. This course has already been advocated by Wetmore (Proc. U. S. Nat. Mus., 86, 1939: 200-201). There is the possibility that two races exist, but a large number of breeding birds are necessary in order to test this. The great majority now available are migrants. 
Myiochanes richardsonii richardsonii (not Tyrannula richardsonii Swainson) van Rossem, 1931 c, 265, part (Saric, part; Guasimas Lagoon).

Evidently a rather common spring and fall transient. Specimens have been examined as follows: Agiabampo, May 17, 1937; Guirocoba, May 27, 1937; Guásimas Lagoon, May 12, 1930; Rancho La Arizona, 5 specimens August 16 to September 16, 1929 (Dickey coll.) ; Guirocoba, April 27, 1931 (Bishop coll.).

\section{CONTOPUS VIRENS PLACENS (VAN ROSSEM)}

\section{Pallid WoOd PeWEe}

Myiochanes virens placens van Rossem, Trans. San Diego Soc. Nat. Hist., 9, No. 17, April 30, 1940, 84 (Madera Cañon, alt. 6000 feet, Santa Rita Mountains, Arizona): ibid., in text (central and eastern Sonora).

Myiochanes richardsonii richardsonii (not Tyrannula richardsonii Swainson) Ridgway, 1907, 521, part (Sonora).-Hellmayr, 1927, 191, part (Sonora).-van Rossem, 1931 c, 265, part (Saric, part); 1934 d, 450 (Hacienda de San Rafael; Oposura; La Chumata; crit.)

Myiochanes richardsoni richardsoni A.O.U. Comm., 1910, 214, part (Sonora); 1931, 210, part (Sonora).

Horizopus richardsoni Thayer and Bangs, 1906, 19 (La Chumata).

Common summer visitant to lower mountains and foothills in the extreme southeast, north (Sierra de Oposura and Sierra de San Antonio) to the Arizona boundary. Arboreal associations rather than climatic zones seem largely to govern distribution in the southern part of the range at least, for the race occurs from Tropical to the lower fringe of the Transition; northerly it seems to favor the Upper Sonoran. There are no records for the coastal plain, even during migrations. Unpublished localities are San José Mountains, August 7, 1893 and October 3, 1892 (U. S. Nat. Mus.) ; Rancho Santa Bárbara, breeding in mid-June, 1937; Guirocoba, breeding, mid-May to late June, 1937 (Dickey coll.). The earliest date of arrival is May 7 (Hacienda de San Rafael); the latest fall date is October 3 (San José Mountains). ${ }^{37}$

${ }^{37}$ As previously remarked (van Rossem, 1940), specimens from the mountains in the vicinity of the boundary from the Huachuca Mountains eastward are not typical. Generally speaking they tend toward the darker coloration of richardsonii but possess the small size of placens. The two specimens examined from the San Jose Mountains are in this category and their assignment is necessarily arbitrary. In listing the several Wood Pewees as races of virens, I do not believe that the difference in call notes (advanced as an argument) is a valid reason for regarding eastern and western birds as different species. 


\section{CONTOPUS PERTINAX PALLIDIVENTRIS ChapmaN}

\section{COUES Flycatcher}

Contopus pertinax pallidiventris Chapman, Auk, 14, No. 3, July, 1897, 310 (Pima County, Arizona).

Myiochanes pertinax pallidiventris Ridgway, 1907, 515 (Yecera; Alamos; San Jose Mts.).-A.O.U. Comm., 1910, 213 (Sonora); 1931, 210 (Sonora).-Hellmayr, 1927, 203 (Sonora).-Bailey, 1928, 442 (Sonora).- van Rossem, 1931 c, 265 (Saric; Chinobampo) ; 1934 d, 450 (Alamos; Mina Abundancia; Oposura).Phillips, 1911, 78 (Sonora).-Bent, 1942, 266, in text (Oposura; Saric).

Contopus musicus (not Tyrannula musica Swainson?) Salvin and Godman, 1889, 82, part (Sierra Madre of Sonora; Yecera).

A fairly common summer visitant in the Transition zone of the eastern mountains the full length of the State. Detected in summer in the San José Mountains, [Sierra de] Oposura, Yécora, and at Rancho Santa Bárbara. A migratory record is Rancho La Arizona ("Saric") in the Upper Sonoran zone, August 25, 1929. Winters, apparently in some numbers, in the Tropical zone foothills in the extreme south (Álamos, 13 specimens February 4 to March 28, 1888; Chinobampo, 3 specimens February 15 to March 4, 1930). The migrations of this flycatcher are obviously much less extensive than is the case with other local members of the genus, and are, to some extent at least, merely in the nature of an altitudinal shift.

\section{EMPIDONAX TRAILLII BREWSTERI OBERHOLSER}

\section{BREWSTER Flycatcher}

Empidonax traillii brewsteri Oberholser, Ohio Journ. Sci., 18, No. 3, Jan., 1918, 93 (Cloverdale, Nye County, Nevada) ; ibid., in text (Nogales).-Hellmayr, 1927, 209 (northern Sonora).- - van Rossem, 1931 c, 264 (Saric; Guirocoba; Tiburon Island); 1932, 137 (Tiburon Island).-Bent, 1942, 211, part in text (Nogales).

Empidonax trailli brewsteri Bailey, 1928, 437 (northern Sonora).-Moore, 1940, 352 (Cocorit; Guirocoba).

Empidonax pusillus (not Tyrannula pusilla Swainson ?) Baird, 1858, 194 (Los Nogales).--Sclater, 1859, 411 (Los Nogales).

Known to date as a fairly common fall and spring migrant in Sonoran and Tropical zones. Fall dates are from August 3 (Guirocoba) to October 6 (San José Mountains). Spring dates are from May 10 (Magdalena) to June 7 (Guirocoba), or possibly even later ("June," Nogales; Baird, 1858). The extreme late spring migration of brewsteri has led to speculation as to possible breeding south of the United States boundary; however, there are no data to support this. Further stations are San José Mountains, October 6, 1892; San Bernardino Ranch on the boundary, August 17, 1893 (U. S. Nat. Mus.) ; Masocari Island, May 15 and 16, 
1937; Guirocoba, May 26, 1937; migrating commonly but not breeding at cither point (van Rossem notes); Magdalena, May 10, 1925 (Dawson notes).

\section{EMPIDONAX MINIMUS (BAIRD ANI) BAIRD)}

\section{LEAST Flycatcher}

Tyrannula minima W. M. and S. F. Baird, Proc. Acad. Nat. Sci. Phila., 1, No. 28-29, July-Aug., 1843 [Sept. 18], 284 (Cumberland County [=Carlisle], Penna.)

Empidonax minimus van Rossem, 1934 d, 448 (Alamos).-Moore, 1940, 354 (Alamos).

Accidental or casual visitant or spring migrant. Known only from the single specimen in the Museum of Comparative Zoölogy, taken by Frazar at Álamos on March 7, 1888.

\section{EMPIIDONAX HAMMONDII (XANTUS)}

\section{HAMMOND FLYCATCHER}

Tyrannula hammondii De Vesey [=Xantus], Proc. Acad. Nat. Sci. Phila., 10, 1858 [after April 19], 117 (Fort Tejón, California).

Empidonax hammondii Ridgway, 1907, 565 (San Jose Mountains).--van Rossem, 1934 d, 448 (Mina Abundancia; Nacozari; Oposura).

Empidonax hammondi Allen, 1893 a, 37 (Los Cuervos).-Moore, 1940, 360, in text (El Cobre).

Empidonax obscurus (not Tyrannula obscura Swainson ?) Salvin and Godman, 1889, 77, part (Micoba; exam. in Brit. Mus.).

Fairly common fall and spring transient through the mountainous eastern part of the State. Dates for the fall migration extend from August 11 (San José Mountains) to October 15 (Las Cuevas); those for spring from April 4 (Maicoba) to May 21 [Sicrra de] Oposura, the latter possibly a summering non-breeder. Unpublished record stations are San José Mountains, October 3, 1892, and August 11, 1893 (U. S. Nat. Mus.); Rancho I.a Arizona, migrating May 8, 1937 (van Rossem notes) ; Cajón Bonito Creek, September 8 and 27, 1893 (Mearns notes).

\section{EMPIDONAX W'RIGHTII BAIRI) \\ WRIGHT FlyCATCHER}

E.[mpidonax] urightii Baird, Rep. Expl. and Surv. R. R. Pac., 9, 1858, 200 (El Paso, Texas).

Empidonax wrightii Allen, 1893 a, 37 (Oputo).-Ridgway, 1907, 567 (Micoba).- -van Rossem, 1931 c, 264 (Tecoripa; San Javier; Saric; Obregon; Tesia; 15 miles S. of Nogales); 1932, 137 (Tiburon Island); 1934 d, 449 (Alamos).

Empidonax u'righti Moore, 1940, 357 (Guirojaqui; Guirocoba; Tesia; Alamos).-Bent, 1942, 233 (Tiburon Island; $15 \mathrm{mi}$. S. W. of Nogales). 
Transient and winter visitant, practically throughout the State. Occurs in all zones although most of the records are from sea level to about 1,500 feet. Additional to the above localities are Rancho Costa Rica, December 15, 1932 (Dickey coll.); San José Mountains, August 8, 1893; San Bernardino Ranch, August 23, 1893 (U. S. Nat. Mus.) ; Chinobampo, February 4 and March 4, 1931 (Bishop coll.). Extreme dates are August 8 (San José Mountains) and April 17 (San Javier).

\section{EMPIDONAX GRISEUS BREWSTER}

\section{GRAY FLyCATCHER}

Empidonax griseus Brewster, Auk, 6, No. 2, April, 1889 [separates issued January 31], 87 (La Paz, Baja California, México); ibid., in text (Alamos).A.O.U. Comm. 1890, 62 (Sonora).-Bendire, 1895, 320 (Alamos).- Sharpe, 1901, 140 (Sonora).-Ridgway, 1907, 570 (Alamos; San Bernardino Ranch).-van Rossem, 1931 c, 265 (Tecoripa; San Javier; Obregon; Tesia; Chinobampo); 1934 d, 449 (Alamos; Cumpas; Oposura).-Moore, 1940, 362 (Soyopa; Agiabampo; Guirocoba).

Empidonax canescens Nelson, 1904 a, 80 (southern Sonora).

Common winter visitant and transient in Sonoran and Tropical zones nearly everywhere, except that there are no records for the extreme northwestern deserts. Fxtreme dates are September 18 (Guirocoba) and April 20 (Agiabampo). Unrecorded specimens are from Tiburón Island, November 4, and Sierra Seri, November 16, 1941 (Mus. Vert. Zool.); Ures, January 28, 1933 (Dickey coll.).

\section{EMPIDONAX DIFFICILIS DIFFICILIS BAIRD}

\section{WESTERN FLYCATCHER}

Empidonax difficilis Baird, Rep. Expl. and Surv., R. R. Pac., 9, 1858, xxx, 198 (West coast; Fort Steilacuom; Ft. Tejon [ = Fort Tejón, California]).-Allen, 1893 a, 37 (Las Cuevas).- Thayer and Bangs, 1906, 19 (La Chumata).

Empidonax diffrcilis diffcilis Ridgway, 1907, 577, part (Sonora).- Townsend, 1923, 17 (Tiburon Island).- -van Rossem, 1931 c, 263, part (Tecoripa; San Javier; Saric, part; Tesia, part); 1932, 137 (Tiburon Island); 1934 d, 449 (Alamos; Hacienda de San Rafael; Mina Abundancia; Oposura).-Brodkorb, 1935, 3 (Sonora).--Moore, 1940, 369 (Soyopa; Guirocoba; Saric; Tecoripa; San Javier; Tesia, part).-Bent, 1942, 252, part, in text (Tesia; Alamos).-Huey, 1942, 367 ("April 24 to May 12" [=Dowling Well; Gray's Ranch]).

A fairly common resident, in the sense of year-around occurrence, of almost the entire State from sea level to the upper limits of the Upper Sonoran zone, although there are no summer records from the northwestern desert region. Most numerous during spring and fall migra- 
tions, which occur chiefly in April-May and September-Octobcr, but midsummer and midwinter records cover most of the territory from the Arizona boundary southward, particularly (in the former case) in the foothills and lower mountains. There are no authentic breeding records, and, what is most significant, no summer juveniles have been collected. Unpublished records not covered in the bibliography above are Guaymas, March 1 to 25, 1905 (Mus. Comp. Zoöl.); Masocari Island, May 15, 1937 (Dickey coll.) ; Pozo de Luís, December 30, 1893; San José Mountains, August 8, 1893; October 2 and 3, 1892; San Luís Mountains on the boundary, October 1, 1893 (U. S. Nat. Mus.).$^{38}$

\section{EMPIDONAX DIFFICILIS HELLMAYRI BRODKORB}

\section{Hellmayr Flycatcher}

Empidonax difficilis hellmayri Brodkorb, Occ. Papers Mus. Zool. Univ. Mich., 306, Jan. 30, 1935, 1 (Boot Spring, Chisos Mountains, Texas).

Empidonax diffrilis difficilis (not Empidonax diffcilis Baird) van Rossem, 1931 c, 263, part (Saric, part).

Empidonax bairdi (not of Sclater) Salvin and Godman, 1889, 74, part (Yecora).

Summer visitant, probably, throughout higher mountains in the northern and castern parts of the State. This conjecture is based in large part on the summer distribution in immediatcly adjacent portions of Arizona and Chihuahua. Specific records are from the San José Mountains August 8 and 10, 1893, and October 6, 1892 (4 specimens in U. S. Nat. Mus.) ; Rancho La Arizona, August 15 to September 18, 1929 (4 specimens in I)ickey coll.) ; Yécora, April 15, 1888 (Brit. Mus.).

\section{EMPIDONAX DIFFICILIS CULIACANI MOORE}

\section{Culiać́n Flycatcher}

Empidonax difficilis culiacani Moore, Auk, 57, July, 1940, 370 (Culiacán, Sinaloa, México) ; ibid., in text (Chinobampo; Guirocoba).

Empidonax difficilis difficilis (not Empidonax difficilis Baird) van Rossem, 1931 c, 263, part (Guirocoba; Chinobampo; Tesia, part).-Bent, 1942, 252, part, in text (Chinobampo).

38 The "breeding" record for Saric [= Rancho La Arizona] is erroneous, Moore (1940) having been misled by my previous statement (1931 c) to that effect. It would indeed be remarkable if a breeding population of difficilis existed within twenty miles of the breeding grounds of "immodulatus" [bellmayri] and at the same time be isolated from difficilis of California by 300 miles of desert. The evidence at this time, supported by personal observation, is that the summer diffcilis found in Sonora are chiefly young, non-breeding individuals of the previous year which have remained on their wintering grounds instead of migrating northward. 
Resident, in the same sense as difficilis, in the foothills and lower mountains in the extreme southeast. Dates of occurrence (specimens chiefly in Dickey coll.) are as follows: Guirocoba, January 15, 1930 and June 4, 1937; Chinobampo, February 26 to March 5, 1929; San Francisco Cañon, May 30, 1937; Rancho Santa Bárbara, June 12, 1937; Tesia, December 15 and 29, 1930. Not one of the summer birds (personally collected) showed the slightest trace of breeding activity and the nesting territory of culiacani is still hypothetical.

\section{EMPIDONAX FULVIFRons PYgmaEus CoUfs}

\section{Buff-BREASTED FlyCatCher}

Empidonax pygmaeus Coues, Ibis, n. s. [=ser. 2], Oct., 1865, 537 (Fort Whipple, Arizona).

Empidonax fulvifrons pygmaeus Ridgway, 1907, 589 (Alamos; Nacozari).van Rossem, 1931 c, 265 (Tesia); 1934 d, 450 (Alamos; Nacozari).-Moore, 1940, 383 (Guirocoba).-Bent, 1942, 259, in text (Tesia, Guirocoba).

Uncommon winter visitant in the Tropical zone foothills and lowlands in the extreme southern part of the State. The few records to date are Alamos, February 6, 1900 (Biological Surv. coll.) ; February 9, 13, and March 12, 1888 (Mus. Comp. Zoöl.) ; Guirocoba, September 25 and January 27 [year not stated] (Moore coll.); Tesia, December 28, 1930 (Dickey coll.). There is one record for the northeast, Nacozari, March 24, 1887 (Mus. Comp. Zoöl.), which probably pertains to a migrant. While there is every reason to expect this species to be a common summer visitant in the Transition zone of the eastern mountain area, it has not so far been detected.

\section{MITREPHANES PHAEOCERCUS TENUIROSTRIS BREWSTER}

\section{Brewster Tufted Flycatcher}

Mitrephanes phaeocercus tenuirostris Brewster, Auk, 5, April, 1888, 137 (Oposura [-Sierra de Oposura], Sonora, México).-Ridgway, 1907, 500 (Oposura; Mina Abundancia; Alamos).--Hellmayr, 1927, 227 (Sonora).-Bangs, 1930, 273 (type).- -van Rossem, 1934 d, 450 (Alamos; Mina Abundancia; Oposura).Sutton and Burleigh, 1940, 30 (Sonora).

Mitrephanes phaeocercus (not Mitrephorus phaeocercus Sclater) Salvin and Godman, 1889, 66, part (Oposura).

Status uncertain; known to have been rather common in the winter and spring of 1888 , when Frazar took fifteen specimens at $\overline{\text { lamos be- }}$ tween February 2 and March 8, and seven at Mina Abundancia April 7 and 21 . The original specimen, the type of the subspecies tenuirostris, was 
taken in the Sierra de Oposura by Cahoon on June 7, 1887. Since that time, over 50 years ago, the only occasion when the species has been found in Sonora was when Sheffler encountered it at Guirocoba between November 13 and 20, 1944 ("common"; specimen taken November 15; Sheffler notes).

\section{CAMPTOSTOMA IMBERBE RIDGWAYI (BREWSTER)}

\section{WESTERN BEARDLESS FLyCATCHER}

Ornithion imberbe ridgwayi Brewster, Bull. Nuttall Orn. Club, 7, October 1882, 208 (Tucson, Arizona).

Camptostoma imberbe ridguayi van Russem, 1930 b, 129 (Sonora; crit.); 1931 c, 266 (San Javier; Saric; Chinobampo; Guirocoba); 1934 d, 451 (Alamos; Hacienda de San Rafael; crit.).-A.O.U. Comm., 1944, 452 (Sonora).

Camptostoma imberbe (not of Sclater) Ridgway, 1907, 414, part (Alamos; Hacienda de San Rafael).-Griscom, 1934, 384, part (Sonora; crit.).-Bent, 1942, 308, part (San Javier; Saric; Alamos).

Fairly common summer visitant to Lower Sonoran and Tropical zones over most of the State except the northwestern desert region. Northerly, the westernmost locality of record is Rancho La Arizona ("Saric"); the easternmost is Pilares. Occurrences at Alamos, February 6, and Chinobampo, March 4, indicate residence in the Tropical zone in the extreme south. For northern localities there are no data by which to estimate arrival and departure, since May 9 and August 27 (both from Rancho La Arizona) are the earliest and latest dates of record. Unpublished stations are Pilares, June 19 and 22, 1935 (Univ. Mich.), and Tesia, June 21, 1937 (Dickey coll.).

Family Alaudidae Larks

EREMophiLA ALPESTRIS LEUCOLAEMA COUES

\section{Desert Horned Lark}

Eremophila alpestris var. leucolaema Coues, Birds Northwest, 1874, 38, 39 (Fort Randall [South Dakota]).

Otocoris alpestris leucolaema Oberholser, 1902, 820 (Animas Valley).-Ridgway, 1907, 309 (Sonora).-A.O.U. Comm., 1910, 219 (Sonora); 1931, 213 (Sonora).-Bailey, 1928, 448 (Sonora).-Huey, 1935, 254 (Punta Peñascosa).

Chionophilos alpestris leucolaema Hellmayr, 1935, 4 (Sonora).

Winter visitant, seemingly in limited numbers, in the extreme north. Recorded so far from but two localities, respectively at the northeast and northwest corners of the State; Ánimas Valley, October 2, 1893, and Punta Peñascosa, February 3 and 28, 1934. 


\section{EREMOPHILA ALPESTRIS OCCIDENTALIS (MCCAIL)}

\section{MONTEZUMa HORNed LARK}

Otocoris? occidentalis McCall, Proc. Acad. Nat. Sci. Phila., 5, No. 9, MayJune [Dec. 31] , 1851, 218 (Near Santa Fé, New Mexico).

Otocoris alpestris occidentalis Oberholser, 1902, 855 (La Noria; San Luis Spring, Animas Valley, "Chihuahua").-Ridgway, 1907, 324 (La Noria).-A.O.U. Comm., 1903, 344 (Sonora) ; 1931, 214 (Sonora).-Bailey, 1928, 452 (northern Sonora).-Behle, 1942, 285 (Sonora).

Winter visitant. There are two records actually within Sonora territory: La Noria, in the extreme northcentral part of the State, October 19, 1893, and San Luís Spring, "Chihuahua," September 3, 1893 (U. S. Nat. Mus.). The numerous fall and winter records from localities immediately adjacent to or actually on the boundary (La Ventana Ranch; Buenos Aires; Lochicl; San Pedro River) are indicative of equally common occurrence on the Sonora side.

\section{EREMOPHILA ALPESTRIS ADUSTA (DWIGHT)}

\section{SCORCHFI) HORNED LARK}

Otocoris alpestris adusta Dwight, Auk, 7, No. 2. April, 1890, 148 (Fort Huachuca, Arizona).-Oberholser, 1902, 858 (Santa Cruz River; San Pedro River on the boundary).-Ridgway, 1907, 325 (Santa Cruz River).-A.O.U. Comm., 1931, 214 (Sonora)._van Rossem, 1931c, 266 (15 miles S.W. of Nogales); 1936d, 139 (Nogales).-Behle. 1942, 282 (boundary locs.).

Chionopbilor alpestris adustus Hellmayr, 1935, 8 (Sonora).

Common resident of Sonoran zone plains and foothills from the Sásabe Valley eastward across the extreme northern part of the State. While there are numerous boundary records for all seasons, these are with few exceptions from the Arizona side. The southward limit in the vicinity of Nogales appears to be about 10 miles south of the boundary; the southward limits in other areas remain to be determined. So far as is known at present, no resident race of Horned Lark occurs along the boundary between the ranges of adusta and leucansiptila, a distance of some 150 miles.

\section{EREMOPHILA ALPESTRIS AMMOPHILA (OBERHOLSER)}

\section{MOHAve Horned LaRK}

Otocoris alpestris ammophila Oberholser, Proc. U. S. Nat. Mus., 24, No. 1271, June 9, 1902, 849 (Coso Valley, [Inyo County], California).--Huey, 1935, 254 (Punta Peñascosa).

Apparently a fairly common winter visitant to the northwestern portion of the Colorado desert region. Although there is but one locality 
of record, Punta Peñascosa, the fact that nine specimens were taken between February 8 and 28, 1934, indicates rather frequent winter occurrence in the region.

\section{EREMOPHILA ALPESTRIS LEUCANSIPTILA (OBFRHOLSER)}

\section{SONORA HORNED LARK}

Otocoris alpestris leucansiptila Oberholser, Proc. U. S. Nat. Mus., 24, No. 1271, June 9, 1902, 864 (Yuma, Arizona); ibid., in text, (Colorado River at Monument 204).-Grinnell, 1928, 145 (re. status of "pallida").-Huey, 1935, 254 (Punta Peñascosa; crit.).

Otocoris alpestris pallida (not Pbileremos pallidus Brehm) Dwight, 1890, 154 (Lower California and Sonora=Direction Hill, between Adair Bay and mouth of Rio Colorado, northwestern Sonora, Mexico).- Townsend, 1890, 138 (Direction Hill).-A.O.U. Comm., 1891, 85, part (Sonora); 1897, 127, part (auth.); 1910, 220, part (Direction Hill); 1931, 215 ("Mexican"=Sonora).-Bendire, 1895, 247, part (western Sonora).-Oberholser, 1902, 863 (Direction Hill; crit.).-Ridgway, 1907, 326 (Direction Hill).-Grinnell, 1928, 146, in text (crit.).-Behle, 1942, 277, in text (re. type).

Chionophilus alpestris duighti Stresemann, 1922, 88 (new name for pallida Dwight).-Hellmayr, 1935, 9 (northwestern Sonora).

Otocoris alpestris arenicola? (not of Henshaw) Price, 1899, 92 (lower Colorado River).

Common resident of the lower Colorado River valley from the Arizona boundary south around the head of the Gulf to Punta Peñascosa. ${ }^{39}$

\section{Family Hirundinidar: Swallows}

\section{Progne subIS hesperia BRIE'STFR}

\section{WESTERN MARTIN}

Progne subis hesperia Brewster, Auk, 6, No. 2, April, 1889, 92 [separates published January 31] (Sierra de La Laguna, Baja California, México).-van Rossem, 1931c, 269 (Saric; Tobari Bay; El Alamo; Tiburon Island; crit.); 1932, 137 (Tiburon Island).- - Hellmayr, 1935,13 (Sonora; crit.).

Progne subis (not Hirundo subis Linnaeus) Stephens, 1885, 228 (Altar).

Common summer visitant to western Lower Sonoran and Tropical zone deserts the full length of the State, including Tiburón Island. In the absence of suitable nesting sites (almost exclusivcly giant cactus) there are no breeding, or even transient, records for the extreme northwest. Ex-

39 The status of the Horned Larks resident on the coast of extreme northwestern Sonora would appear to be settled by the series collected by Huey at Punta Peñascosa. Incidentally, Oberholser (1902) cites Monument 204 as in Baja California, an error repeated by Grinnell (1928). It is on the Arizona-Sonora boundary about three miles east of the Colorado River. 
treme dates are April 26 (Tóbari Bay) and August 13 (Altar). Additional localities are Rancho Carrizo, July 2, 1931 (Bishop coll.) ; Magdalena, May 12 to 15,1925 (Dawson notes)..$^{40}$

\section{PETROCHELIDON PYRRHONOTA PYRRHONOTA (VIEILLOT)}

\section{American Cliff Swallow}

Hirundo pyrrbonota Vieillot, Nouv. Dict. Hist. Nat., nouv. éd., 14, 1817, 519 (Paraguay).

Petrochelidon albifrons albifrons van Rossem, 1931c, 269 (Tesia).

Known only as a spring migrant. The single Sonora specimen collected to date was taken by J. T. Wright at Tesia in the lower Mayo River valley on March 14, 1930. Recorded by Huey (1942, 368) as "abundant" and possibly breeding at Quitovaquita and Gray's Ranch on the boundary (Arizona side) in late April and early May, 1939.

\section{PETROCHELIDON PYRRHONOTA MINIMA VAN ROSSEM AND HACHISUKA}

\section{Least Cliff Swallow}

Petrocbelidon albifrons minima van Rossem and Hachisuka, Trans. San Diego Soc. Nat. Hist., 9, No. 2, Nov. 21, 1938, 5 ("Pichicuate"=Cucujaqui River, 7 miles E. of Álamos, Sonora, México).

Petrochelidon melanogaster (not Hirundo melanogaster Swainson) Mearns, 1901, 178, in text (San Bernardino River; Santa Cruz River); 1920a, 73, footnote (San Luis Mountains to Nogales).

Petrocbelidon lunifrons melanogaster Ridgway, 1904, 51, part (Sonora).A.O.U. Comm., 1910, 292, part (Sonora).

Petrochelidon albifrons melanogaster A.O.U. Comm., 1931, 218, part (Sonora). - van Rossem, 1934d, 452 (Granados).

Petrochelidon pyrrbonota melanogaster Hellmayr, 1935, 32, part (San Luis Mts. to Nogales).- Van Tyne and Sutton, 1937, 59 (Pilares).

Petrochelidon lunifrons (not Hirundo lunifrons Say) Evermann and Jenkins, 1888, 68 (Magdalena).

Common, though irregularly distributed, summer visitant from the Pajaritos Mountains eastward to the San Luís Mountains, and southward

40 All Sonora specimens taken to date, save for a single exception, seem to be indistinguishable from Baja California besperia in both size and color. The exception is a male in breeding condition taken at Agiabampo, May 18, 1937 (Dickey coll.), which perhaps offers evidence of intergradation with sinaloae. Although apparently fully adult, the extremely small size (wing, 137; tail, 71) is combined with conspicuously white-margined under tail coverts and an occasional concealed white feather on the abdominal region. Incidentally, the nominate race, subis, may be expected in the higher zones of the eastern mountains since it occurs in contiguous parts of Arizona and Chihuahua. 
seemingly throughout the State. Unpublished records are Rancho La Arizona; Magdalena, May 13, 1925 (Dawson notes); Hermosillo, June 19, 1922 (Univ. Mich.); Cajón Bonito Creek and Guadalupe Cañon, early July, 1892 (Mearns notes). There are no migration data. ${ }^{41}$

\section{STELGIDOPTERYX RUFICOLLIS SERRIPENNIS (AUDUBON)}

\section{NorThern ROUgh-WINGed SWALLOW}

Hirundo serripennis Audubon, Orn. Biog., 4, 1838, 593 (Charleston, South Carolina).

Stelgidopteryx ruficollis serripennis van Rossem, 1931c, 268, part (Tesia, part). -Brodkorb, 1942a, 214 (Tesia).

One record, that of a spring migrant taken at Tesia, March 14, 1930.

\section{STELGIDOPTERYX RUFICOLLIS PSAMMOCHROUS GRISCOM}

\section{Desert Rough-winged Swallow}

Stelgidopterjx ruficollis psammochrous Griscom, Proc. New England Zoöl. Club, 11, Dec. 14, 1929, 72 (near Oposura, Sonora, México); ibid., in text (Alamos; Hacienda de San Rafael).-Bangs, 1930, 292 (re. type).-Oberholser, 1932, 5 (Sonora; crit.).-Wetmore, 1939a, 202 (Sonora; crit.).-Brodkorb, 1942a, 215 (Sonora; crit.).

Stelgidopteryx rufcollis serripennis (not Hirundo serripennis Audubon) Thayer and Bangs, 1906, 21 (Opodepe).- van Rossem, 1931c, 268 part (Tesia, part; Saric; Guaymas; San Jose de Guaymas; crit.).-Hellmayr, 1935, 47 (Sonora; crit.).-Huey, 1942, 358 (Gray's Well; Sonoita River).-Bent, 1942, 424, part (Alamos).

? Clivicola riparia (not Hirundo riparia Linnaeus) Evermann and Jenkins, 1888, 68 (Magdalena).

Common summer visitant throughout the Tropical, Sonoran and, locally, even in the lower fringes of the Transition zones. There is but one winter record, Álamos, February 23, 1888; however, the species winters occasionally in Arizona and southern California and may be expected to do so rather regularly in Sonora. The earliest spring record is March 14 (Tesia). There are no data as to fall departure, save September 8 (Cajón Bonito Creek). Additional records are Camoa, June 7, 1931 (Bishop

41 The Rancho La Arizona record is not conclusive, though extremely probable. This colony was not occupied on May 7, 1937, but the ranch owner insisted that the birds which irregularly used the many nests were definitely not white on the forehead. In company with Van Tyne and Sutton (1937), I am far from convinced that the common and Mexican Cliff Swallows are conspecific. 
coll.) ; Pilares, June 24, 1935 (Univ. Mich.) ; San Bernardino Ranch on the boundary, August 1, 1892 (U. S. Nat. Mus.) ; Magdalena, May 15, 1925 (Dawson notes) ; Rancho Santa Bárbara, 5,500 feet, June 11, 1937 (Dickey coll.) ; Hermosillo; Agiabampo, breeding May 13; Guirocoba, breeding, May and June, 1937 (van Rossem notes); Cajón Bonito Creck, July 31, 1892 and September 8, 1893 (Mearns notes).

\section{HIRUNDO RUSTICA ERYTHROGASTER BODDAERT}

\section{Barn Swallow}

Hirundo erythrogaster Boddaert, Tab. Pl. Enl., 1783, 45 (Cayenne).- van Rossem, 1931c, 268 (Guaymas; Tobari Bay).-Huey, 1942, 368 (Gray's Ranch; Quitovaquita [Arizona side of boundary]).

Chelidon erythrogaster Evermann and Jenkins, 1888, 68 (Magdalena).

Hirundo erytbrogastra Thayer and Bangs, 1906, 21 (Opodepe).

Breeds in the northcentral foothill region south at least to Magdalena and Opodepe, and possibly to Hermosillo. Occurs as a common migrant, probably at lower elevations throughout the State, although recorded from but a few, widely-scattered points. Additional records are Nogales to Hermosillo, May 11; Magdalena to Nogales, June 24, 1937 (van Rossem notes) ; Magdalena, April 20 to May 15, 1925 (Dawson notes); San Pedro River, October 10 to 13, 1892 (U. S. Nat. Mus.) ; San Bernardino Ranch, September 8, 1892. Extreme dates are April 20 (Magdalena) and October 13 (San Pedro River).

\section{IRIDOPROCNE BICOLOR (VIEILLOT)}

\section{Tree Swallow}

Hirundo bicolor Vieillot, Ois. Amér. Sept., 1, 1807, [1808], 61, pl. 31 (Centre des Etats-Unis = New York).

Tacbycineta bïcolor Belding, 1883, 343 (Guaymas).-Sharpe and Wyatt, 1889, 155 (Guaymas).

Iridoprocne bicolor van Rossem, 1931C, 268 (El Doctor).-Huey, 1935, 254 (Punta Peñascosa).

Probably rather generally distributed as a migrant and winter visitant in the lowlands; however, specific records are all from the northwest coastal region. These are Guaymas, "April"; Kino Bay, February [16?], 1935 (Nat. Hist. Mus.) ; and El Doctor, February 10, 1929. Records from the Arizona side of the boundary, such as San Bernardino Ranch, August 2, 1892 (U. S. Nat. Mus.), and Quitovaquita, March 6, 1939 (Huey, 1942, p. 368), indicate, as above stated, a much wider dispersal. 


\section{IRIDOPROCNE ALBILINEA RHIZOPHORAE VAN ROSSEM}

\section{Northern Mangrove SWallow}

Iridoprocne albilinea rbizophorae van Rossem, Proc. Biol. Soc. Wash., 52, Oct. 11, 1939, 155 (Tóbari Bay, Sonora, México); ibid. in text, (Guasimas; Lobos Island; Agiabampo).

Iridoprocne albilinea (not Petrochelidon albilinea Lawrence) van Rossem, 1931c, 268 (locs. cited above).

Iridoprocne albilinea albilinea Hellmayr, 1935, 69, part (Sonora).

Fairly common summer visitant from Guásimas Lagoon (Lat. $27^{\circ} 50^{\prime}$ ) southward. To date the species has been found only in the Tropical zone mangrove association during the months of April, May, and June.

\section{TACHYCINET A T'HALASSINA LEPIDA MEARNS}

\section{Western Violet-GReen Swallow}

Tacbycineta lepida Mearns, Proc. Biol. Soc. Wash., 15, March 5, 1902, 31 (Campbell's Ranch, Laguna Mountains, San Diego County, California).

Tachycineta thalassina lepida van Rossem, 1931c, 267 (El Doctor; Tesia; Tecoripa; Guirocoba); 1934d, 452 (Oposura; Nacozari).-Hellmayr, 1935, 79 (Sonora).

Tachycineta thalassina (not Hirundo thalassinus Swainson) Allen, 1893a, 40 (San Pedro).--Stone and Rhoads, 1905, 690 (lower Colorado River).

Summer visitant in the eastern mountains. Occurs widely and commonly as a migrant; less commonly as a winter visitant in the Colorado delta, and probably elsewhere. Probable breeding localities are Cajón Bonito Creek, July 23, 1892 (Mearns notes), and Oposura, May 26, 1887. Specimens from this latter point suggest intergradation with the Tropical zone race brachyptera. Additional records are from Guaymas, March 5 and 12, 1905 (Mus. Comp. Zoöl.) ; San Bernardino River on the boundary, October 15, 1892 (U. S. Nat. Mus.) ; Cajón Bonito Creek, September 28, 1893; San Pedro River, October 11, 1892 (Mearns notes) ; Magdalena, May 12 to 15, 1925 (Dawson notes).

\section{TACHYCINETA THALASSINA THALASSINA (SWAINSON)}

\section{Mexican Violet-green Swallow}

Hirundo thalassinus Swainson, Philos. Mag., n. s. 1, May, 1827, 366 (Table land. Real del Monte [Hidalgo, México]).

Tachycineta thalassina thalassina van Rossem, 1931c, 266 (Tesia; Tecoripa; crit.).-Hellmayr, 1935, 78 (Sonora; crit.).

Occurs in early spring in the Tropical zone lowlands. Stations of record are Tesia, March 16, 1930, and Tecoripa, March 26, 1929. It 
seems likely that these individuals represent a seasonal descent from certain parts of the high mountains to the eastward.

\section{TACHYCINETA THALASSINA BRACHYPTERA BREWSTER}

\section{Tropical Violet-green Swallow}

Tachycineta thalassina brachyptera Brewster, Bull. Mus. Comp. Zoöl., 41, No. 1, Sept., 1902, 167 (Sierra de La Laguna, Baja California, México).-van Rossem, 1931c, 267 (Tesia; Guaymas).-Hellmayr, 1935, 79 (Guaymas).

Present as a rather common summer visitant in the vicinity of Guaymas (breeding) and very probably at other points southward over the coastal plain. Additional to the two published occurrences, individuals (presumably of this race) were seen at Tesia on June 21, 1937 (van Rossem notes); two specimens taken at San Carlos Bay, April 7, 1939 (Mus. Vert. Zool.). That brachyptera is resident in southern Sonora, as in Baja California, is to be supposed; however, no winter specimens have been taken.

\section{Family CORvidaE Crows and Jays \\ CORVUS CORAX SINUATUS WAGLER \\ Mexican Raven}

Corvus sinuatus Wagler, Isis von Oken, 22. Heft 7 (July), col. 748 (México= Ixmiquilpán, Hidalgo).

Corvus corax sinuatus Ridgway, 1904, 263 (Sonora).-Thayer and Bangs, 1907, 79, in text (Sonora).-Oberholser, 1918b, 219 (Guaymas)--Bruner, 1926, 235 (Tubatama).- -van Rossem, 1931c, 271, part (Tesia; Tecoripa; Guaymas; Chinobampo; Guirocoba; San Javier, Obregon) ; 1934d, 454 (Guaymas; Oposura) ; Hellmayr, 1934, 2 (Cerro Blanco).-Huey, 1935, 254 (Punta Peñascosa).

Corvus corax carnivorus Belding, 1883, 343 (Guaymas).

Common, sometimes in fall and winter extremely common, resident throughout the State from sea level to at least 6,000 feet, except that during the breeding season there is a withdrawal from the plains to the mountains in the region from Nogales eastward. Some of the many unpublished localities where the Raven has been taken or observed are Camoa, February (Bishop coll.); San Marcial, November (Mus. Comp. Zoöl.); many boundary localities from the San Luís Mountains across the State to the Colorado delta, in fall, winter, and spring (Mearns notes and spec. in U. S. Nat. Mus.) ; Magdalena, April (Dawson notes) ; Rancho La Arizona; Rancho Santa Bárbara; Nogales south to Agiabampo in May and June, 1937 (van Rossem notes). 


\section{Corvus corax cLARIONENSIS RothsCHILd AND HaRTERT}

\section{WESTERN RAVEN}

Corvus corax clarionensis Rothschild and Hartert, Novit, Zool., 9, July 25, 1902, 381 (Clarion Island, Revillagigedo Group, México).-van Rossem, 1932, 137 (Tiburon Island; San Esteban Island).

Corius corax sinuatus (not Corvus sinuatus Wagler) Goss, 1888, 241 (San Pedro Martir Isle).-Townsend, 1923, 18 (Tiburon Island).-Mailliard, 1923, 455 (San Esteban Island; San Pedro Nolasco Island).-van Rossem, 1931c, 271, part (San Pedro Martir, San Pedro Nolasco, and San Esteban Islands).

Common resident of islands in the Gulf. It is possible that the Tiburón Island Ravens should be referred to sinuatus but to date no specimens from that locality have been collected and the records are assigned provisionally. ${ }^{42}$

\section{CoRVus CRYPTOLEucus COUCH}

\section{WHITE-NECKED RAVEN}

Cori'us cryptoleucus Couch, Proc. Acad. Nat. Sci. Phila., 7, No. 2, March-April [May 20], 1854, 66 (State of Tamaulipas [Charco Escondido], México).-Allen, 1893a, 37 (San Pedro).-Clark, 1899, 78 (El Plomo).- Bruner, 1926, 235 (Tubatama).- van Rossem, 1931c, 271 (15 miles S. W. of Nogales; Saric).-Sheffler, 1931a, 138 (Imuris).-Worhies, 1934, 119 (between Magdalena and Hermosillo).

Common resident of Sonoran zone deserts and plains in the northern part of the State from about longitude $112^{\circ}$ eastward to the Chihuahua boundary. The southern limits of the range are indefinite but in the western desert region extend about to Hermosillo. It scems likely that there is a marked recession from more northerly localitics during the winter months. Unpublished records are San Pedro River on the boundary, October 12 and 13 (U. S. Nat. Mus. catl.) ; Cajón Bonito Creek, "July," 1892 (Mearns notes) ; numerous at many points between Nogales and Hermosillo in May and June, 1937 (van Rossem notes).

\section{CORVUS BRACHYRHYNCHOS HESPERIS RIDGWAY}

\section{WESTERN CROW}

Corvus americanus hesperis Ridgway, Man. No. Amer. Birds, 1887, 362 (Western United States [etc.] $=$ Fort Klamath, Oregon).

42 Thayer and Bangs (1907) believe that Sonora mainland Ravens are more or less intermediate toward clarionensis and in this $I$ am inclined to concur, with the stipulation, however, that they are distinctly closer to sinuatus. For measurements of the few available island birds see van Rossem, 1932, p. 138, and for size averages of western Ravens from critical areas see particularly Willett, Auk, 1941, pp. 246-249. 
Known from a single specimen taken by Mearns and Holzner at Monument 204 on the lower Colorado River on March 14, 1894 (U. S. Nat. Mus.). The Crow may be more than a casual in the region since Rhoads (1905, p. 690) believed that he saw some in the delta in February.

\section{Corvus imparatus Peters}

\section{Mexican Crow}

Corvus imparatus Peters, Proc. Biol. Soc. Wash., 25, 1929, 123 (Río La Cruz, Tamaulipas, México).--van Rossem, 1931c, 270 (Tesia; Guirocoba; Chinobampo; Agiabampo); 1934d, 454 (Alamos).

Corvus ossifragus imparatus Hellmayr, 1934, 5 (Tesia; Agiabampo).

Conuus mexicanus (not of Gmelin) Ridgrvay, 1904, 275 (Alamos; Camoa).Sharpe, 1909, 598 (Sonora).

Corvus mexicanus mexicanus Meinertzhagen, 1926, 87 (Sonora).-Meise, 1928, 26 (Camoa).

Common, locally abundant, resident of the Tropical zone from the lower Yaqui River valley southward. Distribution tends to be concentrated in river valleys and farming districts, with avoidance of deserts and maritime associations. Unpublished localities are Agua Caliente, May 7, 1888 (Brit. Mus.) ; Navojoa and Ciudad Obregón, May and June, 1937 (van Rossem notes).

\section{Calocitta colliel arguta van Rossem}

Frazar MagPie-Jay

Calocitta colliei arguta van Rossem, Trans. San Diego Soc. Nat. Hist., 9, No. 33, Feb. 17, 1942, 379 (Chinobampo, Sonora, México).

Calocitta colliei (not Pica colliei Vigors) Ridgway, 1904, 294, part (Alamos; Camoa; Plomosas; "etc.").--Sharpe, 1909, 610, part (Sonora).

Callocitta [sic] colliei van Rossem, 1931c, 270 (San Javier; Guirocoba; Chinobampo) ; 1934d, 454 (Alamos).

Calocitta formosa colliei Hellmayr, 1934, 11, part (southern Sonora).

Common resident of deciduous woods and riparian timber in the southeastern Tropical zone foothills, north at least to San Javier at about $28^{\circ} 30^{\prime}$. Apparently rather definitely confined (in Sonora) to altitudes between 300 and 2,000 feet, and therefore not reaching the coast, nor, save locally, the Upper Sonoran zone. Noted at frequent intervals between Álamos and Guirocoba, between Guirocoba and San Francisco Cañon, and between Guirocoba and Rancho Santa Bárbara (below 2,000 feet) in May and June, 1937 (Dickey coll.; van Rossem notes) ; Agua Marín, May 5, 1939 (Mus. Vert. Zool.). 


\section{CISSILOPHA BEECHEII (VIGORS)}

\section{BEECHEY JAY}

Pica Beecheii Vigors, Zool. Journ., 4, Jan., 1829, 353 (Montereale=Mazatlán, Sinaloa, or San Blas, Nayarit, México).

Cissilopha beecheii Ridgway, 1904, 316 (southern Sonora; Alamos; crit.).van Rossem, 1931c, 270 (Chinobampo; Guirocoba; crit.); 1934d, 454 (Alamos).Hellmayr, 1934, 38 (Alamos).

Cissilopha beecheyi Sharpe, 1909, 622 (southern Sonora).

Fairly common resident in the Tropical zone foothills in the southeast. All known Sonora specimens have been taken at altitudes between 300 and 1,500 feet in a limited area bounded roughly by Chinobampo, Álamos, Agua Marín (Mus. Vert. Zool.) and Guirocoba. It has not been observed beyond these limits by any of the several collectors who have worked in this region. An isolated colony thus is indicated, although not as yet conclusively demonstrated.

\section{APHELOCOMA CALIFORNICA WOODHOUSEII (BAIRD) \\ WOODHOUSE JAY}

Cyanocitta woodhouseii Baird, Rep. Expl. and Surv. R. R. Pac., 9, 1858, 584, 585, [woodbousii p. "xli" =xliii, nomen nudem], (central Rocky Mountains $=$ Fort Thorn, New Mexico).

Probably a not uncommon resident of the Upper Sonoran zone of the northeastern mountains. There are two definite records; two specimens taken by Mearns (field book) in the San José Mountains, October 4 and 7, 1892, the first of which (fide Friedmann) is still in the National Museum collection; "several seen" at Cajón Bonito Creek in early July [dates not definite], 1892 (Mearns notes).

\section{APHELOCOMA ULTRAMARINA ARIZONAE (BAIRD AND RidgWay) ARIZONA JAY}

Cyanocitta ultramarina var. Arizonae Baird and Ridgway, Bull. Essex Inst., 5, No. 12, Dec., 1873, 199 (Ft. Buchanan and Copper Mines=Old Fort Buchanan, near Crittenden, Pima Co., Arizona).

Aphelocoma sieberii arizonae Bendire, 1895, 380 (Sonora).-A.O.U. Comm., 1895, 198 (Sonora).-Ridgway, 1904, 340 (northern Sonora).- Thayer and Bangs, 1906, 20 (La Chumata).--van Rossem, 1931c, 269 (Saric; Nogales); 1934d, 454 (Nacozari; Oposura).

Aphelocoma sieberi arizonae Allen, 1893a, 37 (Cachuta; Bavispee River).A.O.U. Comm., 1910, 225 (Sonora); 1931, 224 (Sonora).-Bailey, 1928, 479 (Sonora).

A.[phelocoma] sieberi arizonae Coues, 1903, 499 (Sonora).

Aphelocoma siberii [sic] arizonae Evermann and Jenkins, 1888, 69 (Nogales).

Aphelocoma sordida arizonae Hellmayr, 1934, 55 (northern Sonora). 
Common resident in the Upper Sonoran zone (chiefly oak associations) from the Pajaritos Mountains eastward; south in the western mountains to the Sierra de San Antonio and in the east to the Sierra de Oposura. Intergradation between arizonae and wollweberi doubtless occurs between latitudes $28^{\circ}$ and $29^{\circ} 30^{\prime}$, an area from which no specimens have been examined. Additional stations are Cibuta (Bishop coll.) ; San José Mountains; Guadalupe Cañon (U. S. Nat. Mus.); Cajón Bonito Creek; San Luís Mountains; San Pedro River on the boundary (Mearns notes)

\section{APHELOCOMA ULTRAMARINA WOLLWEBERI KAUP ZaCATECAS JaY}

Aphelocoma Wollweberi Kaup, Journ. für Orn., 2, Erinnerungsschrift Jahresvers. 1855, LV, footnote (Zacatecas, México).

Aphelocoma sieberii wollweberi van Rossem, 1934d, 453 (Mina Abundancia).

Fairly common resident of high Upper Sonoran oak associations in the extreme southeast. There are but two localities of record, Mina Abundancia on the Chihuahua boundary (April 9 to 25, 1888) and Rancho Santa Bárbara, where fairly common in June, 1937 (Dickey and Sheffler colls.; van Rossem notes).

\section{CYANOCITTA STELLERI MACROLOPHA BAIRD}

\section{LONG-CRESTED JAY}

Cyanocitta macrolopha Baird, Proc. Acad. Nat. Sci. Phila., 7, No. 3, May-June, [July 3], 1854, 118 (100 miles west of Albuquerque, New Mexico).

Cyanocitta stelleri macrolopha Allen, 1893a, 37 (El Pinita).-Jouy, 1894, 781 (mountains 32 miles S. of Nogales).-van Rossem, 1934d, 453 (Nacozari; Oposura ).

Cyanocitta stelleri diademata (not Cyanogarrulus diadematus Bonaparte) Ridgway, 1904, 558, part ([northern] Sonora).-A.O.U. Comm., 1910, 223, part ([northern] Sonora).- van Rossem, 1931c, 269 (Saric; 15 miles S. of Nogales).Hellmayr, 1934, 63, part ([northern] Sonora).

Resident of high Upper Sonoran and Transition zones from the Pajaritos Mountains (Sierra de Huacomea) eastward to the Chihuahua boundary, and south along the Sierra Madre and adjacent ranges at least to the Sierra de Oposura. Casuals occur in winter in the Lower Sonoran deserts to the west and probably at other points. Additional localities are the San José Mountains, October 3, 1892, and August 11, 1893; Sonoyta, January 18, 1894 (U. S. Nat. Mus. catl. ; Mearns nọtes) ; San Luís Mountains, July 19, 1892; San Pedro River, October 15, 1892 (Mearns notes). 


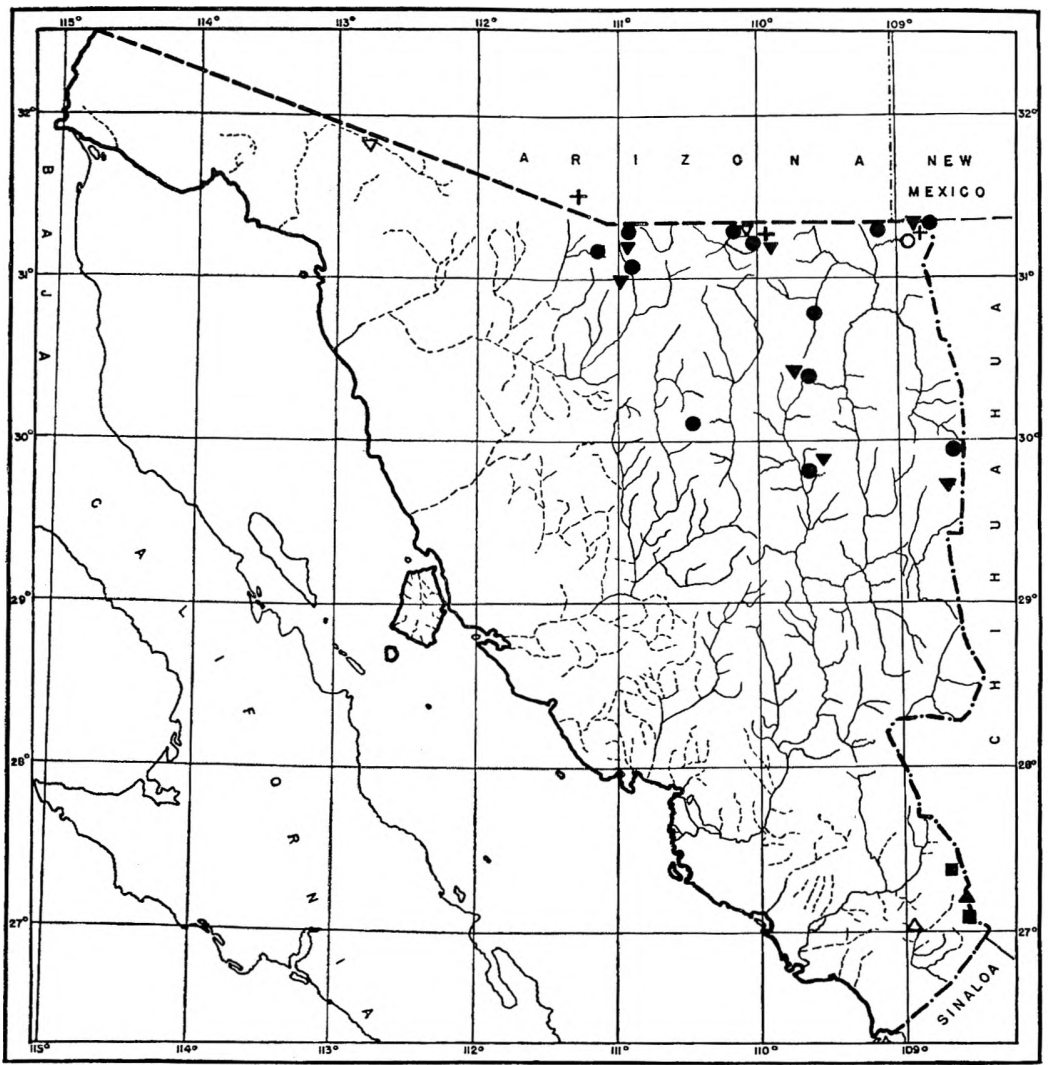

MaP 12. Distribution of the genera Aphelocoma and Cyanocitta. Crosses, $A$. californica woodhouseii; circles, $A$. ultramariana arizonae; squares, $A$. u. wollweberi; inverted triangles, $C$. stelleri macrolopba; triangles, C. s. diademata; hollow figures, winter stations outside breeding range.

\section{CyANocitTA STELleRI DiADEMATA (Bonaparte)}

\section{Sierra Madre Jay}

C.[yanogarrulus] diadematus Bonaparte, Consp. Gen. Avium, 1, sig. 48, May 6, 1850, [Feb. 3, 1851], 377 (Ex Mexico mer. Zacatecas=Zacatecas, México). Cyanocitta stelleri diademata Ridgway, 1904, 558, part ([southern] Sonora).van Rossem, 1934d, 453 (Alamos; Mina Abundancia; crit.).-Hellmayr, 1934, 63, part ([southern] Sonora).

Probably a rather common resident of the Transition zone in the southeastern mountains. The northern limits have not as yet been precisely ascertained; however, distribution in closely adjacent Chihuahua localities 
indicates approximately latitude $29^{\circ}$. Four specimens from Álamos taken by Frazar March 6 to 14, 1888 (Mus. Comp. Zoöl.) were undoubtedly seasonal visitors in the locality.

\section{Family Paridae Titmice, Verdins, and Bush-Tits PARUS SCLATERI EIDOS (PETERS)}

\section{Northern Mexican ChickadeE}

Penthestes sclateri eidos Peters, Proc. New Eng. Zoöl. Club, 9, June 24, 1927, 113 (Chiricahua Mountains, Arizona).

Known certainly only from the San Luís Mountains, where resident and apparently rather common in the Transition zone. Mearns' specimens came from various parts of the range on both sides of the international boundary. Those taken on July 19, 1892, are listed in his field book as "on the boundary"; those from "Chihuahua," September 4, 1892, are certainly from the west slope in Sonora, as are those taken on the west slope September 29, 1893, since he was on Cajón Bonito Creek well within Sonora territory on September 28. Numerous records from Chihuahua localities very close to the Sonora boundary indicate a Sonora range extending far south of the San Luís Mountains; however, no further specimens have been collected to date.

\section{Parus wOLLWEBERI anNeXus Cassin}

\section{Western BRidled Titmouse}

Parus annexus Cassin, Proc. Acad. Nat. Sci. Philadelphia, 5, 1850, 103 (Texas, upon the Rio Grande=southern Arizona).

Parus wollueberi annexus Hellmayr, 1911, 28 (Sonora); 1934, 85 (Providencia Mines).

Baeolopbus wollweberi annexus Ridgway, 1904, 393 (Oposura; Hacienda de San Rafael; Mina Abundancia; Napolera; Puerto de Los Pinitos).- - Thayer and Bangs, 1906, 20 (La Chumata).--Oberholser, 1917, 323 (Sonora).-Bailey, 1928, 513 (Sonora).-A.O.U. Comm., 1931, 325 (Sonora).--van Rossem, 1931c, 271 (Saric; 15 miles S. W. of Nogales); 1934d, 454 (Mina Abundancia; Hacienda de San Rafael; Oposura; crit.).

Lophophanes u'ollweberi (not of Bonaparte) Coues, 1866, 79, part (Sonora).

Parus wollweberi Jouy, 1894, 766 (32 miles S. of Nogales).-Allen, 1893a, 41 (Puerto de Los Pinitos; Napolera).

Common resident of the oak and oak-pine associations in the Upper Sonoran and lower parts of the Transition zones of mountainous regions throughout the State. It has been recorded from various points along the western slope of the Sierra Madre and less frequently from lower ranges 
in the interior. Some western stations are Cibuta (Bishop coll.), Rancho La Arizona, and Opodepe. Localities not previously published are Rancho Santa Bárbara (Dickey coll.); San José Mountains and Nogales (U. S. Nat. Mus. catl.); San Pedro River on the boundary; Terrenate Creek; west side of San Luís Mountains; Cajón Bonito Creek; Guadalupe Cañon (Mearns notes). This species is apparently strictly resident and very seldom descends below the oak beit, even in midwinter.

\section{AURIPARUS FLAVICEPS ORNATUS (LAWRENCE) \\ TEXAS VERDIN}

Conirostrum ornatum Lawrence, Ann. Lyc. Nat. Hist. New York, 5, 1852, 112, pl. 5, fig 1 (Río Grande, Texas).

Auriparus flaviceps ornatus van Rossem, 1930d, 201 (Saric; Pesqueira); 1931c, 271 (Saric; Pesqueira); 1936d, 139 (Saric; crit.).-Hellmayr, 1934, 88 (Sonora).

Auriparus flaviceps (not Aegithalus flaviceps Sundevall) Evermann and Jenkins, 1888, 68 (Querobabi; Carbo).-Sheffler, 1931b, 165 (between Magdalena and Santa Ana).

Auriparus flaviceps flaviceps Ridgway, 1904, 420, part (Sonora).-Thayer and Bangs, 1906, 20 (Opodepe).-A.O.U. Comm., 1910, 354, part (northern Sonora); 1931, 235, part (northern Sonora).-Dawson, 1923, 623, part (northern Sonora). -Bailey, 1928, 514, part (northern Sonora).

Resident in Sonoran zones (chiefly in mesquite associations) from the western foothills of the Pajaritos Mountains eastward across the State, and south in the central interior to about latitude $29^{\circ}$. An extreme northeastern station is San Bernardino Ranch on the boundry (U. S. Nat. Mus.).

\section{AURIPARUS FLAVICEPS ACACIARUM GRINNELL \\ California Verdin}

Auriparus flaviceps acaciarum Grinnell, Condor, 33, No. 4, 1931, 168 (Palm Springs, Riverside County, California).-Hellmayr, 1934, 87 (northwestern Sonora).-Huey, 1935, 254 (Punta Peñascosa).

Auriparus flaviceps (not Aegithalus flaviceps Sundevall) Stephens, 1885, 229 (San Felix Mine).-Price, 1899, 93 (lower Colorado River).

Auriparus flaviceps flaviceps Ridgway, 1904, 420, part (northwestern locs.; crit.).-A.O.U. Comm., 1910, 354, part (northern Sonora); 1931, 235, part (northern Sonora).- -van Rossem, 1930d, 200 (F.l Doctor; San Felix Mine); 1931c, 271 (same locs.).

Rather common resident of the northwestern deserts from the Colorado River eastward, and south at least to Puerto Libertad. Intergradation with ornatus occurs rather abruptly at about longitude $111^{\circ} 30^{\prime}$, and with fraterculus in more gradual fashion between latitudes $28^{\circ} 30^{\prime}$ and $29^{\circ} 30^{\circ}$ coastwise. Additional record stations are Puerto Libertad (Nat. Hist. Mus.) ; Sonoyta ; Pozo de Luís (U. S. Nat. Mus.). 


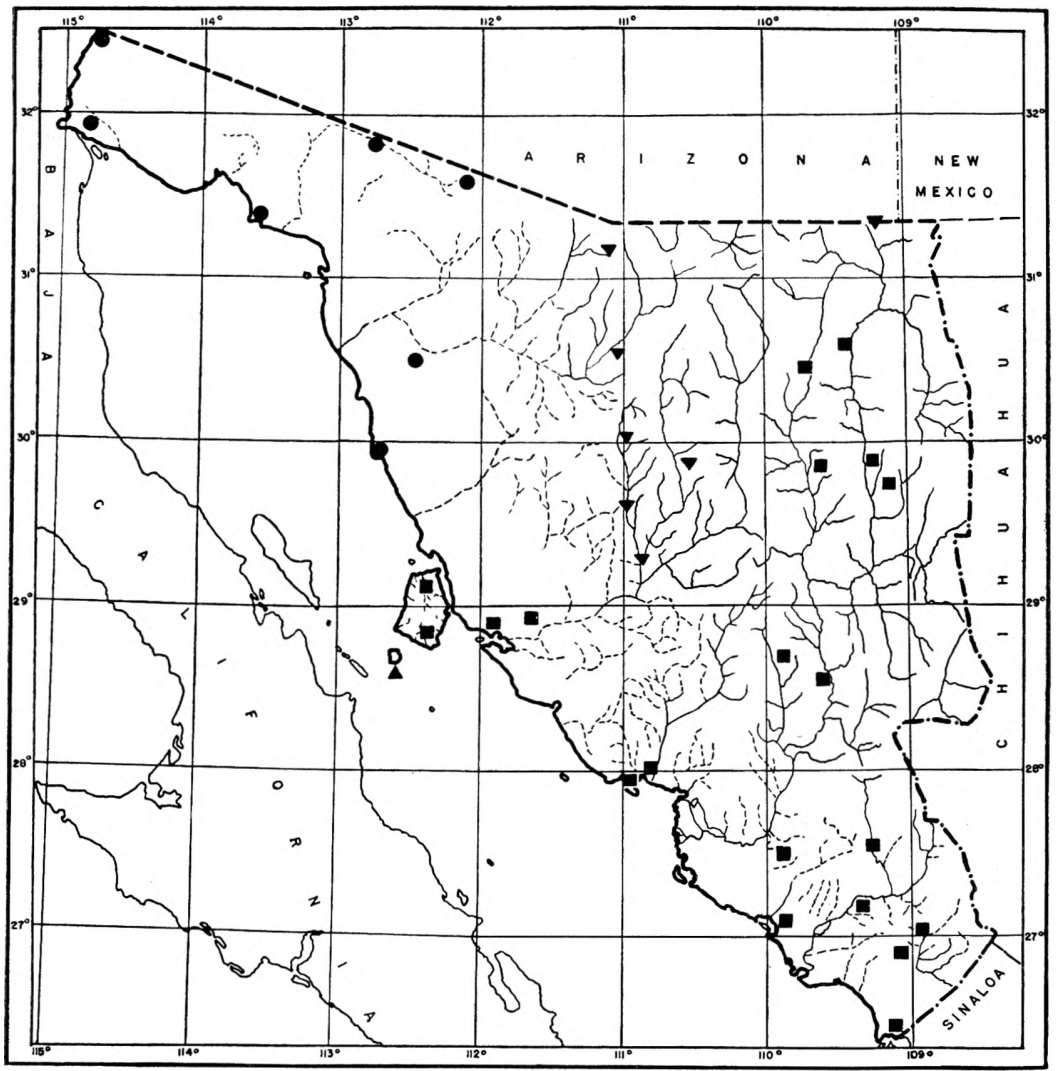

Map 13. Distribution of Auriparus flaviceps. Circles, A. f. acaciarum; inverted triangles, $A$. f. ornatus; squares, $A$. f. fraterculus; triangle, $A$. $f$. flaviceps.

\section{AURIPARUS FLAVICEPS FLAVICEPS (SUNDEVALL)}

\section{Baja California Verdin}

Aegitbalus flaviceps Sundevall, Öfv. Vet.-Akad. Förh., 7, 1850, 129, note (e Sitka in America bor. occid. vel e California=Loreto, central Baja California).

Auriparus flaviceps flaviceps van Rossem, 1942g, 184 (San Esteban Island).

Auriparus flaviceps fraterculus (not of van Rossem, p. 201) van Rossem, 1930d, 202, in text (San Esteban Island; crit.) ; 1931c, 272, part (San Esteban Island); 1932, 138, part (San Esteban Island).

Common resident on San Estéban Island. 


\section{AURIPARUS FLAVICEPS FRATERCUIUS VAN ROSSEM}

\section{SONORA Verdin}

Auriparus flaviceps fraterculus van Rossem, Trans. San Diego Soc. Nat. Hist., 6, No. 9, August 30, 1930, 201 (Chinobampo, Sonora, México) ; 1931c, 272 part (Tecoripa; San Javier; Tesia; Chinobampo; Obregon; Guaymas; Tobari Bay; Tiburon Island); 1932, 138 (Tiburon Island); 1934d, 455 (Guaymas; Alamos; Oposura; Nacozari; Granados).-Hellmayr, 1934, 87 (central and southern Sonora).

Auriparus flaviceps (not Aegithalus flaviceps Sundevall) Belding, 1883, 343 (Guaymas).--Salvin and Godman, 1889b, 236, part (Quiriego)-Allen, 1893a, 41, part (Granados; Bacadehuachy).

Auriparus flaviceps lamprocephalus (not of Oberholser) Ridgway, 1904, 422, part (Guaymas; Alamos; Batamotal).-A.O.U. Comm., 1910, 354, part (southern Sonora); 1931, 235, part (southern Sonora).-Hellmayr, 1911, 64, part (Guaymas; Alamos).- Townsend, 1923, 24, part (Tiburon Island).

Common resident of Tropical zone valleys and foothills north, coastwise, to Kino Bay and Tiburón Island, and in the Yaqui River valley and its tributaries to about $30^{\circ} 30^{\prime}$. Specimens from the northern part of the range, coastwise, are intermediate toward acaciarum; those from the northern interior toward ornatus. Additional stations are Camoa (Bishop coll.); San José de Guaymas; Kino Bay; Agiabampo (Dickey coll.); Rancho Costa Rica [presumably this form] (Lamb notes); Pilares [perhaps nearer ornatus] (Univ. Mich.).

\section{Psattriparus minimus plumbeus (BAird)}

\section{LEAD-COLORED BUSH-TIT}

Psaltria plumbea Baird, Proc. Acad. Nat. Sci. Phila., 7, No. 3, May-June [July 3], 1854, 118 (I.ittle Colorado, N. M. [near long. $111^{\circ} \mathrm{W} .$, Arizona]).

Psaltriparus plumbeus Ridgway, 1904, 430, part (Oposura).-A.O.U. Comm., 1910, 353, part (northern Sonora).-Bailey, 1928, 517, part (northern Sonora).-

Psaltriparus minimus plumbeus A.O.U. Comm., 1931, 236, part (northern Sonora).- van Rossem, 1934d, 455 (Oposura; crit.).

Probably a resident of the Upper Sonoran zone from the Patagonia Mountains eastward across the northern portion of the State and south in the eastern mountains to the Sierra de Oposura. This distribution is hypothecated by the known distribution along the Arizona side of the boundary. The ranges of the four races of Bush-tits which occur in Sonora cannot be more than vaguely outlined at this time. Such data as there are may be found on the accompanying map (Figure 14). 


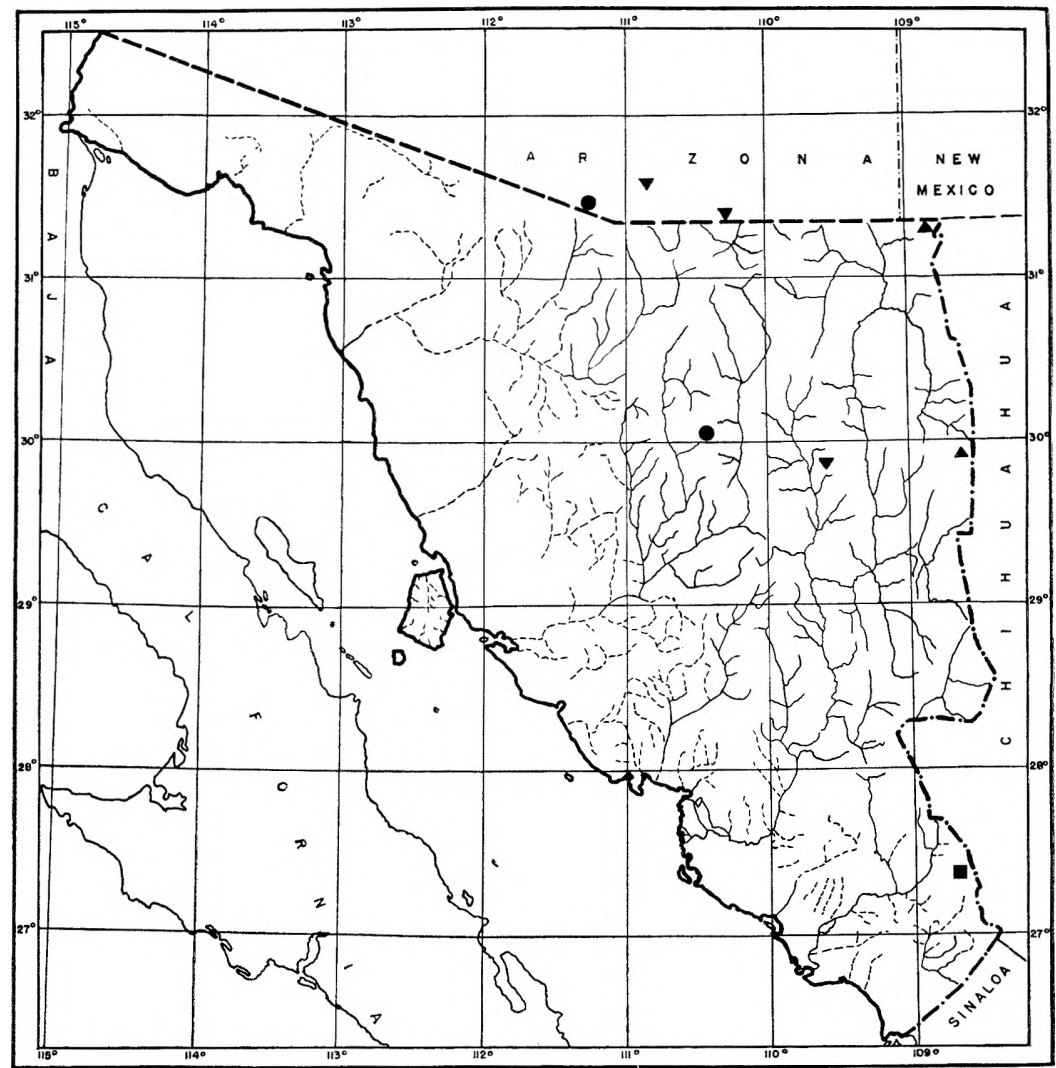

Map 14. Distribution of Psaltriparus minimus. Circles, $P . m$. cecaumenorum; inverted triangles, $P . m$. plumbeus; triangles, $P$. m. lloydi; squares, $P$. m. dimorphicus.

\section{Psaltriparus minimus cecaumenorum THAYer and Bangs}

\section{Ashy Bush-Tit}

Psaltriparus plumbeus cecaumenorum Thayer and Bangs, Proc. Biol. Soc. Wash., 19, Feb. 26, 1906, 20 (La Chumata Mine [Sierra de San Antonio], north central Sonora, México, 4500 feet altitude).-Hellmayr 1911, 55 (Sierra de Antonez).

Psaltriparus minimus ceceaumenorum Hellmayr, 1934, 91 (Sierra de Antonez).van Rossem, 1934d, 455 (central Sonora) ; 1936a, 85 (Sonora; crit.) ; 1936b, 37 (Sonora).-Arvey, 1941, 74 (Sonora; crit.).

Probably resident in the Upper Sonoran and low Transition zones in the northcentral part of the State from the Sierra de San Antonio north- 
west to the Pajaritos Mountains, at which latter locality it has been taken just over the boundary in Arizona (Dickcy coll.).

\section{Psaltriparus minimus Lloyd SENNETt}

\section{LLOYD BUSH-TIT}

Psaltriparus lloydi Sennett, Auk, 5, No. 1, Jan., 1888, 43 (Limpia Cañon, near Fort Davis, Presidio [=Jeff Davis] Co., Texas).-Allen, 1893a, 41 (Bavispee River).-A.O.U. Comm., 1895, 312 (eastern Sonora).-Coues, 1905, 275 (Sonora).

Psaltriparus melanotis lloydi Ridgway, 1904, 429, part (Puerto de Los Pinitos [error]; Bavispe River).-A.O.U. Comm., 1910, 353 (Sonora).-Hellmayr, 1911, 54 (northern Sonora).-Bailey, 1928, 520 (northern Sonora).

Psaltriparus minimus lloydi A.O.U. Comm., 1931, 236 (Sonora).-Hellmayr, 1934, 91, (northeastern Sonora).

Resident in the higher mountains in the northeast. Known at present only from the San Luís Mountains (specimen in the U. S. Nat. Mus. exam.) and from the headwaters of the Bavispe River near the Chihuahua boundary at about latitude $30^{\circ}$ ( $5 \mathrm{spec}$. in Amer. Mus. exam.).

\section{Psaltriparus minimus dimorphicus Van Rossem and Hachisuka}

\section{BI-COLORED BUSH-TIT}

Psaleriparus minimus dimorphicus van Rossem and Hachisuka, Trans. San Diego Soc. Nat. Hist., 9, Nov. 21, 1938, 8 (Rancho Santa Bárbara, alt. 5500 feet, southeastern Sonora, México).

Common in summer (probably resident) in the high Upper Sonoran and Transition zones (oak-pine association) in the vicinity of Rancho Santa Bárbara. This race is seemingly confined to the western drainage but its north-south limits cannot be defined at this time.

\section{Family SitTidaE Nuthatches}

\section{SitTA CAROLINENSIS NELSONI MEARNS}

\section{Rocky Mountain Nuthatch}

Sitta carolinensis nelsoni Mearns, Proc. U. S. Nat. Mus., 24, No. 1274, June 2, 1902, 923 (Huachuca Mountains, Arizona); ibid., in text (San Jose Mountains; Santa Cruz River at Monument 118).-A.O.U. Comm., 1903, 357 (Sonora); 1910, 346, part (Sonora).-Ridgway, 1904, 447, part (Sonora).- Thayer and Bangs, 1906, 20 (La Chumata).-Hellmayr, 1903, 188 (Sonora) ; 1911, 11 (Sonora) ; 1934, 94, part (Sonora).-Bailey, 1928, 521, part (Sonora).--van Rossem, 1931c, 272 (15 mi. S.W. of Nogales); 1934d, 456 (Oposura).-Aldrich, 1944, 597 (centralnorthern Sonora; monog.). 
Sitta nelsoni Sharpe, 1903, 349 (northern Sonora).-Pycraft, 1915, 769 (Sonora). Sitta carolinensis aculeata (not Sitta aculeata Cassin) Allen, 1893a, 41, part (Napolera).-Jouy, 1894, 776 (mountains 32 miles S. of Nogales).

Apparently a rather uncommon resident of Upper Sonoran and Transition zones (chiefly oak and pine associations) from the Pajaritos Mountains eastward across the State, and south in the ranges west of the Sierra Madre proper to the Sierra de San Antonio and Sierra de Oposura. Two additional stations are Cibuta, July 17, 1931 (Bishop coll.) and Rancho La Arizona, May 7, 1937 (van Rossem notes). Individuals of transient or winter status, which resemble Rocky Mountain rather than southern Arizona nelsoni, are occasionally encountered. One such is a specimen taken by the Lumholtz expedition at Nopalera on November " 21 " [Nov'. 27], 1890.

\section{SITTA CAROLINEN'SIS UMBROSA VAN ROSSEM}

\section{Sierra Maidre Nuthatch}

Sitta carolinensis umbrosa van Rossem, Proc. Biol. Soc. Wash., 52, Feb. 4, 1939, 4 (Sierra Madre, near Guadalupe y Calvo, Chihuahua, México); ibid., in text (Mina Abundancia).-Aldrich, 1944, 598 (central Sonora; monog.).

Sitta carolinensis mexicana (not of Nelson and Palmer) van Rossem, 1934d, 456 (Mina Abundancia).

Sitta carolinensis aculeata (not Sitta aculeata Cassin) Allen, 1893a, 41, part (El Pinita; Bavispee River).

Uncommon resident in the Transition zone in the extreme southeast, north along the Sierra Madre to at least latitude $29^{\circ} 30^{\prime}$, and probably to somewhat above latitude $30^{\circ}$. This race appears to be restricted to the main cordillera and immediately adjacent spurs; hence the Sonora distribution is necessarily interrupted. Sonora records to date are Rancho Santa Bárbara (Dickey coll.); Mina Abundancia (Mus. Comp. Zoöl.), and the Bavispe River near its headwaters (Amer. Mus.). A specimen from Los Pinitos ["El Pinita"], "Sept. 10" (October 12), 1890 (Amer. Mus.) is very close to umbrosa but may well be a fall wanderer and not a representative of the breeding population of that locality.

\section{SITTA PYGMAEA MELANOTIS VAN ROSSEM}

\section{BLACK-EARED NuthatCH}

Sitta pygmaea melanotis van Rossem, Proc. Biol. Soc. Wash., 42 June 25, 1929, 176 (Chiricahua Mountains, Arizona).

Sitta pygmaea pygmaea (not Sitta pygmaea Vigors) Ridgway, 1904, 456, part (northern Sonora). 
Probably a not uncommon resident in the Transition zone in the northeastern mountains. To date, however, the only specimens taken in Sonora seem to be five in the U. S. National Museum from the San José Mountains, collected by Mearns between August 7 and 11, 1893. These appear to be typical of the Rocky Mountain race. Mearns' field book lists a specimen as taken on the San Pedro River on the boundary line, October 15,1892 , but this cannot now be located. If there is no error, the locality is, zonally speaking, an abnormal one.

\section{SITTA PYGMAEA CHIHUAHUAE VAN ROSSEM}

\section{Chinuahua Nuthatch}

Sitta pygmaea chibuabuae van Rossem, Proc. Biol. Soc. Wash., 42, June 25, 1929, 177 (Mound Valley, Chihuahua, México).-Hellmayr, 1934, 99, part (crit.).

Sitta pygmaea (not of Vigors) Allen, 1893a, 41 (Bavispee River).

Sitta pygmaea pygmaea Ridgway, 1904, 456, part (Bavispee River).

Known from a single specimen taken by the Lumholtz expedition on the upper Bavispe River, "Jan. 15" [=December 15], 1890, and now in the American Museum of Natural History. The distribution of this race in Chihuahua strongly indicates that it should also occur in the Transition zone on the Sonora side of the boundary from about latitude $30^{\circ}$ southward.

\section{Family CERTHIIDAE Creepers}

\section{CERTHIA FAMILIARIS ALBESCENS BERLEPSCH}

\section{Sierra Madre Creeper}

Certhia mexicana albescens Berlepsch, Auk, 5, No. 4, Oct., 1888, 450 (Ciudad, Durango, México).

Certhia familiaris albescens Oberholser, 1896, 315 (Nopalera).-Ridgway, 1904, 472 (32 mi. S. of Nogales).-Miller and Griscom, 1925, 7 (Sonora).van Rossem, 1934d, 456 (Mina Abundancia; [Sierra de] Oposura).

Certbia brachydactyla albescens Hellmayr, 1911, 8 (Sonora).

Certhia americana albescens Hellmayr, 1934, 102 (Oposura).

Certhia familiaris mexicana (not Certhia mexicana Gloger) Allen, 1893a, 41 (Napolera).-Jouy, 1894, 766 (mountains $32 \mathrm{mi}$. S. of Nogales).

Fairly common resident in the Transition zone from the Pajaritos Mountains (Sierra de Huacomea) eastward, and south along the higher eastern ranges the full length of the State. Further stations are El Tigre Mountains (Univ. Mich.); San José Mountains (U. S. Nat. Mus.); San Luís Mountains on the boundary (Mearns notes); Rancho Santa Bárbara (Dickey coll.). 


\section{Family Troglodytidae Wrens \\ TELMatodytes palustris plesius (OBerholser) \\ WESTERN MARSH WREN}

Cistotborus palustris plesius Oberholser, Auk, 14, April, 1897, 188 (Fort Wingate, New Mexico); ibid., in text (Sonoyta; San Bernardino River at Monument 77; La Noria).

Telmatodytes palustris plesius Ridgway, 1904, 494, part (Senoyta; Santa Cruz River; San Bernardino River).-van Rossem, 1934d, 458 (Nacozari).

Migrant and winter visitant. Fall and winter specimens examined are as follows, all taken by Mearns and Holzner in 1892: San Bernardino River, October 7: Santa Cruz River (4), November 6 and 7; Sonoyta, January 13, 1894 (U. S. Nat. Mus.). The single spring record was taken by Cahoon at Nacozari on March 23, 1887. The winter range of plesius extends to Sinaloa (A.O.U. Comm., 1931, p. 249), and it is also common at that season in the Colorado River valley in California and Arizona. It may, therefore, be expected in many suitable localities in Sonora; however, all records to date are from the northern interior.

\section{TELMATODYTES PALUSTRIS PALUDICOLA (BAIRI)}

\section{TULE WREN}

Cistothorus palustris, var. paludicola Baird, Rev. Amer. Birds, Sept., 1864, 148 (Shoalwater Bay, Washington).

Telmatodytes palustris paludicola Mailliard, 1923, 455 (Patos Island).

Telmatodytes palustris aestuarinus (not of Swarth) van Rossem, 1931c, 273 (El Doctor).

Cistothorus palustris aestuarinus Hellmayr, 1934, 127, part (El Doctor).

Rare, perhaps only casual, in winter and spring in the desert region northwesterly. Two records: El Doctor on January 27, 1929, and Patos Island, April 23, 1921. This latter specimen (Calif. Acad. Sci.) has been verified as to previous identification by James Moffitt and R. T. Orr.

\section{TELMATODYTES PALUSTRIS AESTUARINUS SWARTH}

\section{SUISUN MARSH WREN}

Telmatodjtes palustris aestuarinus Swarth, Auk, 34, July [June 30], 1917, 310 (Grizzly Island, Solano County, California.).

Cistothorus palustris paludicola (not of Baird) Oberholser, 1897, 193, part (Colorado River, opposite mouth of Rio Hardy).-Hellmayr, 1934, 127, part (northwestern Sonora).

Telmatodytes palustris paludicola Ridgway, 1904, 496, part (mouth of Colorado River).-A.O.L. Comm., 1910, 343 (northwestern Sonora); 1931, 249, part (northwestern Sonora).-Dawson, 1923, 657, part (Sonora). 
Presumably a resident of marshes along the Colorado River. The only three specimens actually collected in Sonora seem to be those taken by Mearns and Holzner opposite the mouth of the Hardy on March 25 and 26, 1894. These are now in the United States National Museum, where they have been personally examined and identified as aestuarinus. ${ }^{43}$

\section{CAMPYlorhy'NCHUS bRUNNEICAPILlus COUESI SHARPE}

\section{NORTHERN CACTUS WREN}

Campylorbynchus couesi Sharpe, Catl. Birds Brit. Mus., 6, 1881, 196 [New name for Picolaptes brunneicapillus of Lawrence and other American authors, but not of Lafresnaye] (Ringgold Barracks, near Río Grande, Texas).

Heleodytes brunneicapillus couesi van Rossem, 1931c, 273, part (Saric; 12 miles W. of Magdalena; Sasabe Valley; San Felix Mine).--Hellmayr, 1934, 147 (Sonora).-Huey, 1935, 254 (Punta Peñascosa).

Campylorhynchus brunneicapillus (not Picolaptes brunneicapillus Lafresnaye) Stephens, 1885, 229 (San Felix mine).

Heleodytes brunneicapillus Anthony, 1894, 211 (Sonora).-Nelson, 1898a, 58, part (Sonora).--Price, 1899, 93 (lower Colorado River).

Heleodytes brunneicapillus anthonyi Mearns, 1902b, 143, part (northern Sonora).-Sheffler, 1931b, 165 (between Magdalena and Santa Ana).

Heleodytes anthonyi Sharpe, 1903, 75 (Sonora).

Common resident of Lower Sonoran cactus and mesquite deserts south at least to Puerto Libertad coastwise, to about lat. $30^{\circ} 30^{\prime}$ in the central interior, and to an undetermined point in the northeast. Intergradation with brunneicapillus takes place over a relatively broad belt and individual specimens from within this belt may closely resemble either race. Larger series may very possibly alter somewhat the range outlines as drawn here. ${ }^{44}$

43 It seems remarkable that aestuarinus should occur as the breeding form in two such isolated and climatically diverse areas as central interior California and the lower Colorado River valley (see also Grinnell, 1928, p. 219), but such is the case. A series of seven definitely breeding males from the Salton Sea (Dickey coll.), seven from Bard, California, taken in the breeding season (Natural History Museum), and an adult and juvenile from St. Thomas, Clark County, Nevada (Dickey coll.), are apparently inseparable from topotypical aestuarinus. The Colorado Valley colony breeds very early, for complete sets of eggs were found at Salton Sea on March 24.

44 John T. Zimmer agrees with me that Sharpe simply proposed a new name for the Picolaptes brunneicapillus of Lawrence and other early American authors (but not of Lafresnaye, which Sharpe mistakenly applied to affinis) and that he did not intend to describe a new species. The authorities he cites make the name an inclusive one for all Cactus Wrens of this species except the Cape San Lucas affinis. Even his description is a composite of a specimen of unstated locality in the Salvin and Godman collection, plus quotations from Coues. In order to prevent 


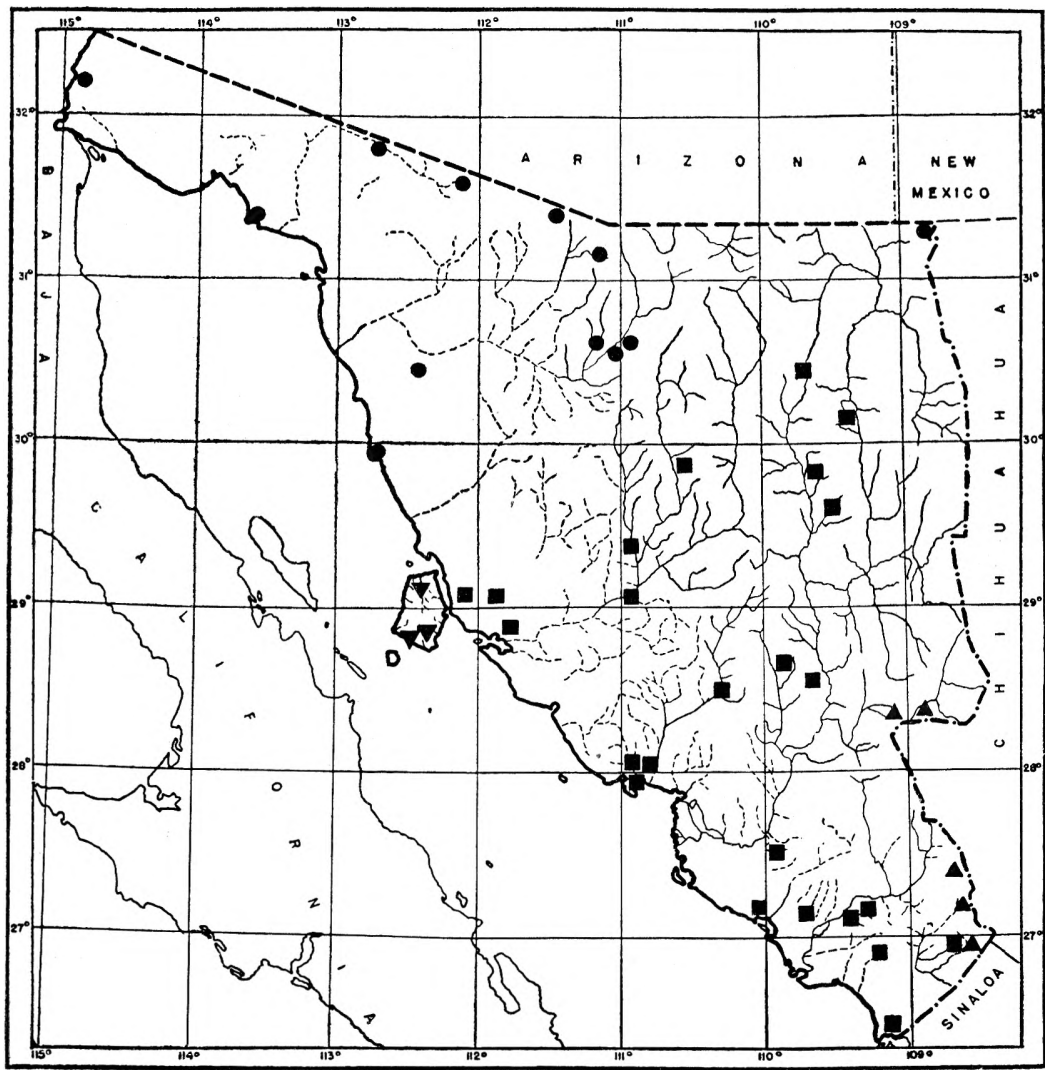

MaP 15. Distribution of the genus Campylorbynchus. Circles, C. brunneicapillus couesi; squares, $C$. b. brunneicapillus; inverted triangles, C. b. seri; triangles, C. gularis.

\section{CAMPYLORHYNCHUS BRUNNEICAPILLUS BRUNNEICAPILLUS (LAFRESNAYE)}

\section{Guaymas Cactus Wren}

Picolaptes brunneicapillus Lafresnaye, Mag. de Zool., 5, 1835, [61], pl. 47 (Californie ou Perou=Guaymas, Sonora, México).-Heermann, 1853, 263 (Guaymas).-Cassin, 1856, 156, part (Guaymas).

Campylorbynchus brunneicapillus Brewer, 1874 (1), 132, part (Guaymas).-Coues, 1878, 156, part (Guaymas).-Salvin and Godman, 1880, 67, part (Guay-

the possibility of future name shifting, I suggest that the locality first cited by an American author, "on the Rio Grande in Texas," or more specifically Ringgold Barracks, be accepted as the type locality (Lawrence, Ann. Lyc. Nat. Hist. New York, 5, 1852: 114). 
mas).-Belding, 1883, 343, part (Guaymas).--Herrera, 1898, 228, part (Guaymas; hot regions of Sonora).-Allen, 1893a, (Oputo).

C.[ampylorbynchus] brunneicapillus Ridgway, 1887d, 547, part (Guaymas).-

Heleodytes brunneicapillus Ridgway, 1896, 547, part (Guaymas).-Sharpe, 1903, 74, part (Sonora).

H.[eleodytes] brunneicapillus Anthony, 1894, 214, in text (Guaymas).

Heleod)tes brunneicapillus brunneicapillus Mearns, 1902b, 141 (type loc.; crit.).-Ridgway, 1904, 518 (Alamos; Batamotal; Camoa; Guaymas; type loc.; crit.).- Thayer and Bangs, 1906, 19 (Opodepe).-Bangs, 1930, 313 (re. type).van Rossem, 1931c, 273, part (many locs.); 1934d, 457 (Guaymas; Alamos; Nacozari; Oposura).-Grinnell, 1932, 321 (re. type and type loc.).-Hellmayr, 1934, 148 (coastal district of southern Sonora).

Heleodytes brunneicapillus couesi (not Campjlorbynchus couesi Sharpe) Ridg. way, 1904, 522, part (Hermosillo; Oposura).-van Rossem, 1931c, 273, part (Pesqueira).

Common resident of Tropical and Lower Sonoran desert and semidesert areas from the Sinaloa boundary north to the Sierra Seri coastwise, to Opodepe in the central interior, and in the Bavispe and Moctezuma river valleys to about latitude $30^{\circ} 30^{\prime}$. Specimens from north of about latitude $29^{\circ}$ are variously intermediate toward couesi. Some unpublished localities are San Marcial (Mus. Comp. Zoöl.); Moctezuma (Brit. Mus.) ; Kino Bay (Dickey and Nat. Hist. Mus.) ; Pilares (Univ. Mich.) ; Cerro Blanco (Chicago Nat. Hist. Mus.); Guirocoba (Dickey coll.); Sierra Seri and Rancho San José (Mus. Vert. Zool.).

\section{CAMPYLORHYNCHUS BRUNNEICAPILILUS SERI (VAN ROSSEM)}

\section{Tiburón Islani) (actus Wren}

Heleodytes brunneicapillus seri van Rossem, Trans. San Diego Soc. Nat. Hist., 7, No. 19, July 28, 1932, 138 (Tíburón Island, Sonora, México)-- Hellmayr, 1934, 149 (Tiburon Island).

Heleodytes brunneicapillus brunneicapillus (not Picolaptes brunneicapillus Lafresnaye) Townsend, 1923, 24 (Tiburon Island).- van Rossem, 1931c, 273, part (Tiburon Island; crit.).

Common resident of cactus and chaparral associations on Tiburón Island. ${ }^{45}$

\section{Campylorhynchus gularis SClater}

\section{Spottei) Cactus Wren}

Campylorbynchus gularis Sclater, Proc. Zool. Soc. Lond., 1860, 462 (México= Bolaños, Jalisco).- Salvin and Godman, 1889b., 235 (western slope of Sierra Madre in Sonora $[=$ Yecora and Santa Ana $])$.

45 Some form of Cactus Wren occurs on San Estéban Island, as attested by the presence of nests. However, in two visits to that island I failed to see any birds. 
Heleodytes gularis Ridgway, 1904, 527 (w. slope of Sierra Madre; Mina Abundancia).- van Rossem, 1931c, 273 (Guirocoba): 1938d, 11 (sp. char.; crit.). Heleodytes capistratus gularis van Rossem, 1934d, 457 (Mina Aundancia).

Heleodytes jocosus gularis Hellmayr, 1934, 151 (Guirocoba).

Heleodytes stridulus Nelson, 1899c, 30 (Sonora).-Sharpe, 1903, 74 (Sonora).

Uncommon resident of undergrowth in mountain cañons between the altitudes of 1,400 and 5,500 feet in the southeastern part of the State. The northernmost records are from Yécora and Santa Ana at about latitude $28^{\circ} 15^{\circ}$. Found at Rancho Santa Bárbara in June, 1937 (undergrowth in Upper Sonoran oak association). The only winter record is from Guirocoba in early December, 1941 (Sheffler notes). This wren has been recorded between 1,450 (Tropical) and 5,500 feet (high Upper Sonoran or Transition), but apparently there is no contact with the Guaymas Cactus Wren even though both species may occur in the same general locality, as at Guirocoba.

\section{THRYOTHORUS SINALOA CINEREUS (BREWSTER)}

\section{ASHY WREN}

Thryophilus sinaloa cinereus Brewster, Auk, 6, April, 1889, 96 (Âlamos, Sonora, México).-Ridgway, 1904, 636 (Alamos; Hacienda de San Rafael; Ysleta).Bangs, 1930, 316 (location of co-types).

Thryophilus cinereus Sharpe, 1903, 79 (Sonora).

Pheugopedius sinaloa cinereus van Rossem, 1931c, 272 (San Javier; Guirocoba); 1934d, 457 (Alamos; Hacienda de San Rafael).

Thryothorus sinaloa cinereus Hellmayr, 1934, 171 (Ysleta).

Thryophilus sinaloa Var. Cinerea Dubois, 1901, 422 (Sonora).

Rather common resident of Tropical zone foothills in the southeast, north, perhaps rarely, to San Javier. From available data this wren is normally found in a rather narrow altitudinal belt of from about 1,000 to 2,000 feet, and tends further to localize in shrubbery along small streams. Besides the recorded localities there is a specimen in the Dickey collection from San Francisco Cañon.

\section{THRYOTHORUS FELIX SONORAE (VAN ROSSEM) SONORA WREN}

Pheugopedius felix sonorae van Rossem, Trans. San Diego Soc. Nat. Hist., 6, No. 11, Sept. 30, 1930, 208 (Guirocoba, Sonora, México); 1931c, 272 (Chinobampo; Guirocoba).

Thryothorus felix sonorae Hellmayr, 1934, 200 (southern Sonora).

Uncommon resident of Tropical zone foothills and coastal plain, north to the delta of the Yaqui River. The seven specimens known to date were 


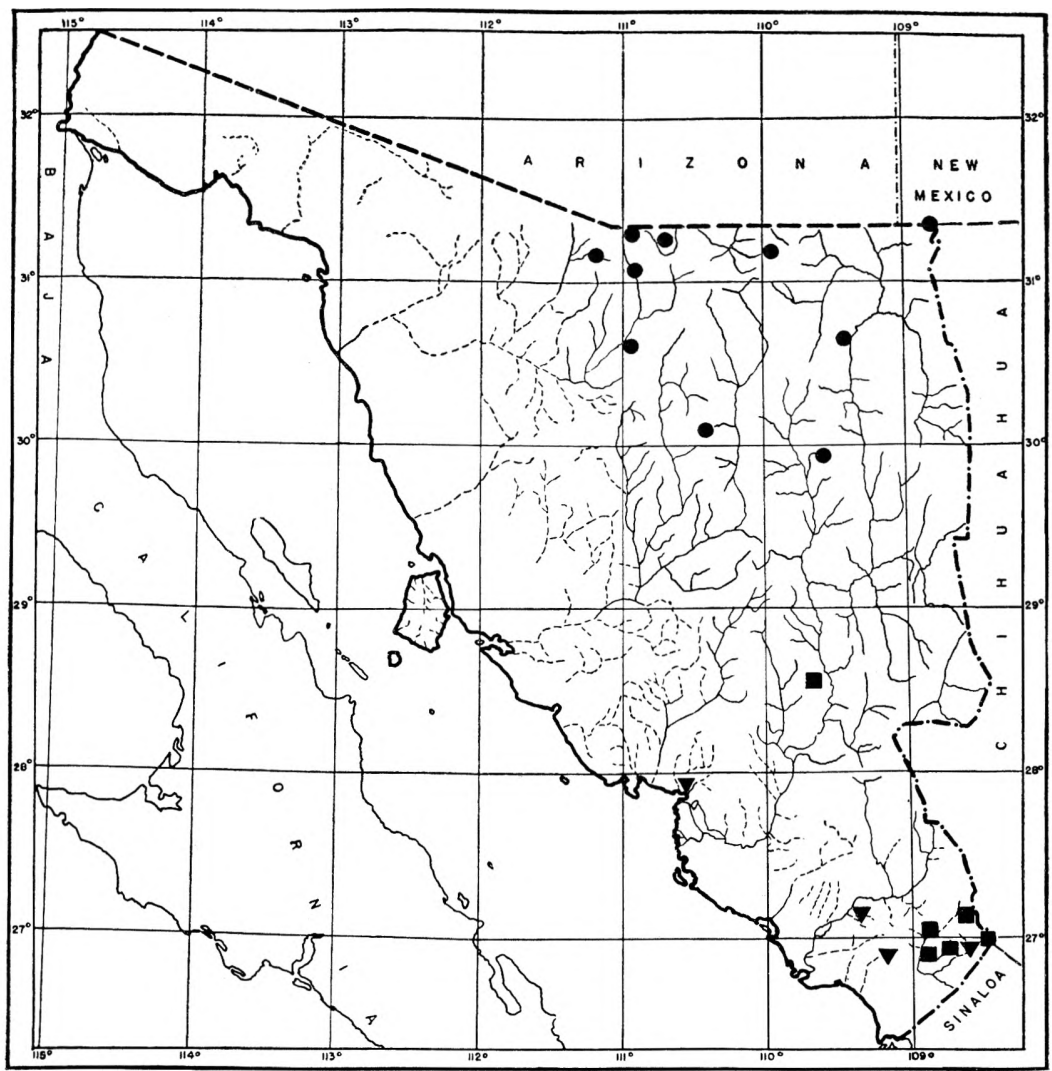

Map 16. Distribution of the genera Thryothorus and Thryomanes. Squares, Thryothorus sinaloa cinereus; inverted triangles, T. felix sonorae; circles, Thryomanes bewickii eremophilus.

taken at Chinobampo, February 10, 1930; Guirocoba, May 3, 1930; Tesia, June 20, 1937 (Dickey and Sheffler colls.) ; Guásimas, April 13, 1939 (Mus. Vert. Zool.). The preferred habitat seems to be dense riparian shrubbery.

\section{THRYOMANES BEWICKII EREMOPHILUS OBERHOLSER DESERT WREN}

Thryomanes bewickii eremopbilus Oberholser, Proc. U. S. Nat. Mus., 21, Nov. 19, 1898, 427 (Big Hatchet Mts., New Mexico); ibid., in text (San Jose Mts.; Patagone Mts.; Los Nogales; San Luis Mountains); 1920, 20 (central Sonora). - Thayer and Bangs, 1906, 20 (La Chumata).- -van Rossem, 1931c, 272 (Saric; 15 mi. S. of Nogales); 1934d, 457 (Oposura). 
Throthorus bewickii (not Troglodytes bewickii Audubon) Baird, 1858, 363, part (Los Nogales).

Thryothorus bewickii Baird, 1859, 13 (Los Nogales).

Thryothorus bewickii bairdi (not Thryothorus bairdi Salvin and Godman). Evermann and Jenkins, 1888, 68 (Magdalena).

Thryomanes bewicki bairdi A.O.U. Comm. 1910, 399, part (Sonora).

Thryothorus bewickii, var. spilurus (not Troglodytes spilurus Vigors) Baird, 1864, 126, part (Los Nogales).

A rather common resident of Sonoran zones in the northcentral and northeastern foothills. There are no records for the northwestern deserts (the westernmost being Rancho La Arizona), nor from south of Moctezuma and La Chumata. Besides the localities cited above, specimens have been examined from Cibuta (Bishop coll.) and Pilares (Univ. Mich.).

\section{Troglodytes ä̈DON PARKMANII AUDUBON}

\section{WESTERN HOUSE WREN}

Troglodytes Parkmanii Audubon, Orn. Biog., 5, 1839, 310 (Columbia River [near Fort Vancouver, Washington]).

Troglodytes aëdon parkmanii van Rossem, 1931c, 272 (Tecoripa; Obregon; Tesia; Chinobampo); 1932, 138 (Tiburon Island).

Troglodytes domesticus parkmanii Oberholser, 1934, 96 (Alamos).-van Rossem, 1934d, 456 (Alamos; Mina Abundancia; Nacozari; Oposura).

Troglodytes aëdon aztecus Allen, 1893a, 41 (Bavispee River; El Puerto).

Common migrant and winter visitant everywhere. Records include the mountains (6,300 feet at El Puerto), seacoast (Puerto Libertad and Tiburón Island), and all zones from Transition downward. The earliest fall date is October 6 (San José Mts.); the latest in spring, April 20 (Mina Abundancia). Even though the House Wren is known to breed in the mountains of southeastern Arizona very close to the boundary, there are no known instances of breeding within Sonora borders. Specimens examined or noted in addition to those recorded are from Puerto Libertad, January 30, 1935 (Nat. Hist. Mus.) ; San José Mountains, October 6, 1892; Sonoyta, January 12 and 22, 1894; Colorado River at Monument 204, March 21, 1894 (U. S. Nat. Mus.).

\section{TROGLODITES BRUNNEICOLLIS CAHOONI BREWSTER}

\section{CAHOON WREN}

Troglodytes cabooni Brewster, Auk, 5, No. 1, Jan., 1888, 94 (Mountains near Oposura, [ = Sierra de Oposura] Sonora, México).

Troglodytes brunneicollis cabooni Oberholser, 1904, 200 (Sonora),-Ridgway. 1904, 588 (Oposura).-Bangs, 1930, 318 (re. cotypes).-Griscom, 1934, 395, 
in text (Sonora; crit.).-Hellmayr, 1934, 243 (Sonora).-van Rossem, 1934d, 457 (Oposura); 1938d, 14, in text (Sonora).

Hemiura cabooni Sharpe, 1903, 94 (Sonora).

Known only as a summer visitant in the Sierra de Oposura in the east central part of the State. Existing records from adjacent areas in Chihuahua indicate that this is a high Transition zone species; therefore it is unlikely to occur in Sonora except locally in limited areas near the eastern boundary.

\section{SALPINCTES OBSOLETUS OBSOLETUS (SAY)}

\section{NORTHERN ROCK WREN}

Troglodytes obsoleta Say, in Long, Exped. Rocky Mts., 2, 1823, 4, note (Northern part of Douglas Co., Colorado near junction of Plum Creek with South Platte River).

Salpinctes obsoletus Belding, 1883, 343 (Guaymas).--Renardo, 1886, 118 (Guaymas).-Allen, 1893a, 41 (Fronteras; Bavispee River).

Salpinctes obsoletus obsoletus Ridgway, 1904, 645 (middle Sonora).-A.O.U. Comm., 1910, 336 (central Sunura).-van Russem, 1931c, 274 (El Doctor; 15 miles S.W. of Nogales); 1932, 139 (Tiburon Island); 1934d, 459 (Guaymas; Alamos; Miller Ranch; Nacozari).-Hellmayr, 1934, 273 (Cerro Blanco).Huey, 1935, 255 (Punta Peñascosa).-Moore, 1941a, 41, in text (Guirocoba).

Salpinctes obsoletus notius Ridgway, 1904, 648, part (Alamos).--Hellmayr, 1934, 274, part (Alamos).

Common, widely distributed resident of desert and rupestrine associations nearly everywhere, including all rocky islands in the Gulf. There are, however, no records for the Tropical zone coastal plain south of Guaymas. Some unpublished localities are San Estéban, George, and San Pedro Mártir Islands; Rancho Santa Bárbara (van Rossem notes); Puerto Libertad; Kino Bay (Nat. Hist. Mus.) ; Nogales; Sonoyta; Pozo de Luís (U. S. Nat. Mus. catl.); Magdalena (Dawson notes) ; Cajón Bonito Creek; Guadalupe Cañon; Toronato Creek (Mearns notes).

\section{CATHERPES MEXICANUS CONSPERSUS RiIdGWY}

\section{WESTERN CAÑON WREN}

Catherpes Mexicanus var. conspersus Ridgway, Amer. Nat., 7, No. 10, Oct., 1873, 603 (Fort Churchill [Washoe Mountains], Nevada).

Catherpes mexicanus conspersus Belding, 1883, 343 (Guaymas).-A.O.U. Comm., 1910, 337 (Sonora).-Bailey, 1928, 545 (Sonora).-van Rossem, 1931c, 274 (San Javier); 1934d, 458 (Oposura).

Catherpres [sic] mexicanus conspersus Evermann and Jenkins, 1888, 67 (Nogales).

Catherpes mexicanus polioptilus Ridgway, 1904, 660, part (Oposura).-Thayer and Bangs, 1906, 20 (La Chumata). 
Resident, locally, in broken or mountainous terrain in the northern part of the State, south to Guaymas coastwise and to about latitude $28^{\circ} 30^{\prime}$ in the eastern interior, - at which latter point intergradation with mexicanus occurs. There are no records for the western deserts north of Tiburón Island and west of the Pajaritos Mountains. Unpublished record stations are Rancho La Arizona, May 7, 1937, breeding (van Rossem notes) ; Tiburón Island, April 4, 1936 (Mus. Vert. Zool.); Hermosillo, December 27, 1932 (Lamb notes); Cajón Bonito Creek, early July, 1892 (Mearns notes).

\section{CATHERPES MEXICANUS MEXICANUS (SWAINSON)}

\section{Mexic.an Cañon Wren}

Thryothorus mexicanus Swainson, Zool. Illustr., 2nd. ser., 1, 1829, pl. 11 (Real del Monte, Hidalgo, México).

Catherpes mexicanus mexicanus van Rossem, 1931c, 273 (Chinobampo) ; 1934d, 458 (Alamos; Mina Abundancia; Hacienda de San Rafael; crit.).

Catherpes mexicanus polioptilus Ridgway, 1904, 660, part (Alamos).

Catherpes mexicanus meliphonus Oberholser, 1930, 95 (Alamos).- Hellmayr, 1934, 277 (Sonora; crit.).

Rather uncommon resident in the southeastern foothills and mountains. Though known only from a relatively restricted area, the appearance of specimens from latitude $28^{\circ} 30^{\circ}$ (see under conspersus) indicates a distribution north nearly to that point. Additional stations are San Francisco Cañon, May 31; Guirocoba in May and June; Rancho Santa Bárbara, June, 1937 (Dickey coll.; van Rossem notes). Records include the Tropical, Sonoran, and Transition zones; however, there are no records for the coastal plain. ${ }^{46}$

\section{Family Mimidae Mockingbirds and Thrashers}

\section{TOXOSTOMA BENDIREI BENDIREI (COUES)}

\section{BendiRe THRASHER}

Harporbynchus Bendirei Coues, Amer. Nat., 7, No. 6, June, 1873, 330 (Tucson, Arizona).

Harporbynchus bendirei Belding, 1883, 343 (Guaymas).-A.O.U. Comm., 1886, 323 (Guaymas) ; 1895, 293 (Guaymas).

${ }^{46}$ Although southern Sonora specimens average smaller and perhaps a little puler than typical mexicanus (in these respects showing an approach to conspersus), I cannot endorse their recognition under a distinctive name. Cañon Wrens vary individually far more than is generally appreciated and because of that circumstance various intermediate "races" which have been proposed seem to exist as transitional averages rather than as definable entities. 
H.[arporbynchus] bendirei Ridgway, 1887d, 545 (Guaymas).-Coues, 1903, 287 (Sonora).

Toxostoma bendirei Sharpe, 1903, 107 (Sonora).-Ridgway, 1907, 197, part (Guaymas; Camoa; Alamos, part).-A.O.U. Comm., 1910, 333 (northern Sonora) ; 1931, 253 (northern Sonora).-Dawson, 1923, 697 (northern Sonora).Bailey, 1928, 557 (northern Sonora).-Sheffler, 1931b, 164 (between Magdalena and Santa Ana).- van Rossem, 1931c, 276, part (Tesia, part; 12 miles W. of Magdalena); 1934d, 460, part (Guaymas).-Hellmayr, 1934, 298 (northern Sonora).

[Toxostoma bendirei] bendirei van Rossem, 1942c, 382, in text (Nogales; Mayo River valley; Alamos).

Fairly common winter visitant to desert associations from the Arizona boundary (centrally) southward over the State. The summer range has yet to be determined. Presumably it is this race which breeds as far south as Magdalena (Sheffler, 1931b) but until specimens have been collected the matter must remain in doubt.

\section{TOXOSTOMA BENDIREI CANDIDUM VAN ROSSEM \\ Guaymas Thrasher}

Toxostoma bendirei candidum van Rossem, Trans. San Diego Soc. Nat. Hist., 9, No. 33, Feb. 17, 1942, 381 (10 miles north of Guaymas, Sonora, México).

Toxostoma bendirei (not Harporbynchus bendirei Coues).- van Rossem, 1931c, 276, part (Guaymas; 8 miles N. of Guaymas).

Rather uncommon resident in the Lower Sonoran desert in the vicinity of Guaymas. Specimens have been examined from Guaymas, San José de Guaymas, and 8 and 10 miles north of Guaymas. The range is extremely limited, for a specimen from Ortiz (Biol. Surv. coll., May 14, 1892), only about 25 miles north of Guaymas, seems to be exactly intermediate between candidum and rubricatum, and therefore not distinguishable from bendirei.

\section{TOXOSTOMA BENDIREI RUBRICATUM VAN ROSSEM \\ RUSTY THRASHER}

Toxostoma bendirei rubricatum van Rossem, Trans. San Diego Soc. Nat. Hist., 9, No. 33, Feb. 17, 1942, 381 (Tecoripa, southeastern Sonora, México); ibid., in text (Pesqueira; Tiburon Island; San Carlos Bay; San Pedro Bay; Hermosillo; Obregon; Tesia).

Toxostoma bendirei (not Harporbynchus bendirei Coues) Ridgway, 1907, 197, part (Ortiz; Alamos, part).-van Rossem, 1931c, 276, part (Pesqueira; Tecoripa; Obregon; Tesia, part); 1932, 139 (Tiburon Island); 1934d, 460, part (Alamos).

Occurs rather generally in winter (except in the Guaymas area) over southern and central deserts north to Tiburón Island, Pesqueira, and Tecoripa. Whether the race is resident over this range is uncertain at this time. At present Tecoripa is the only definite breeding locality. 


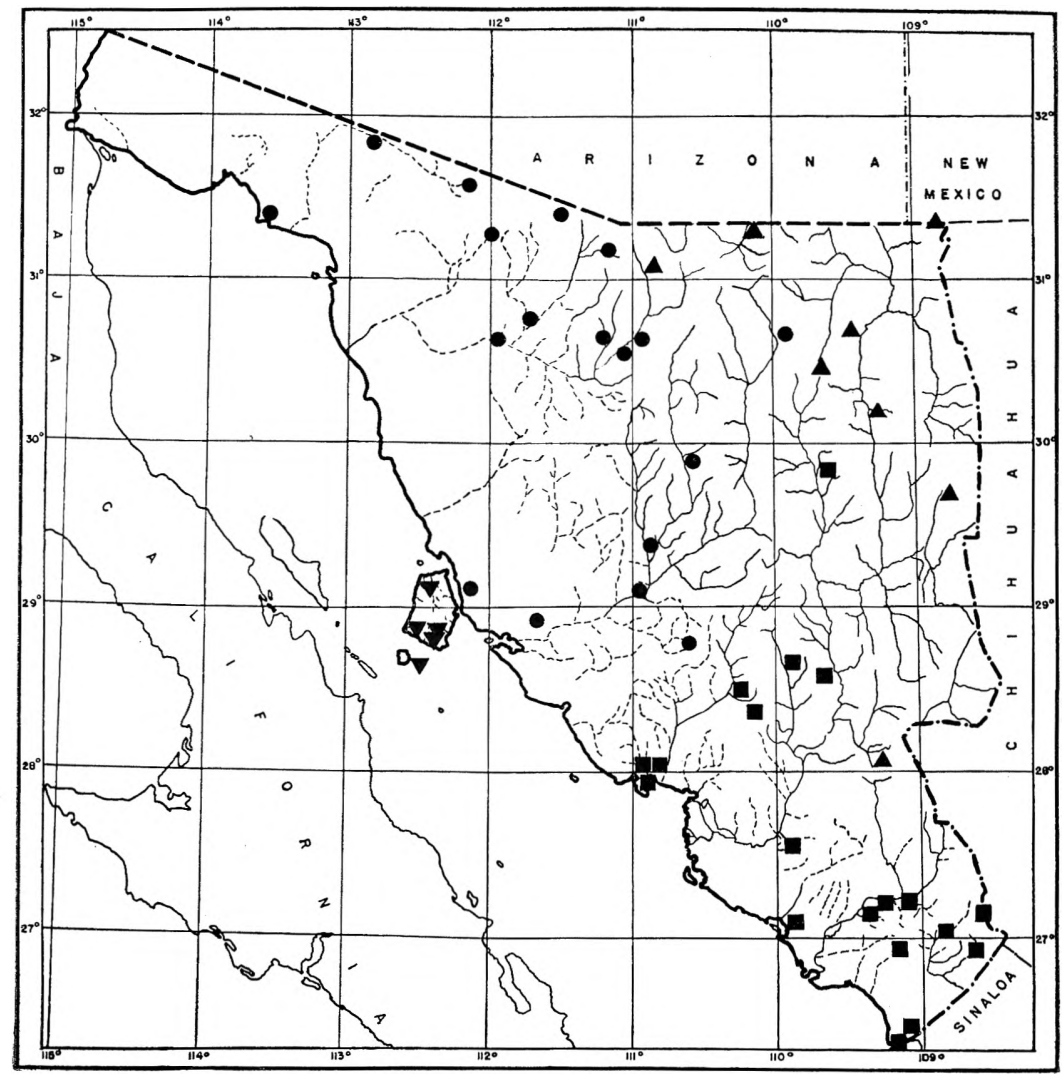

Map 17. Distribution of Toxostoma curvirostre. Circles, T. c. palmeri; squares, $T$. c. maculatum; triangles, T. c. celsum; inverted triangles, T. c. insularum.

\section{Toxostoma CURVIROSTRE CELSUM MOORE}

\section{UPLAND THRASHER}

Toxostoma curvirostre celsum Moore, Proc. Biol. Soc. Wash., 54, Dec. 8, 1941, 212 (Laguna Juanota, southwestern Chihuahua, México).

Harporbyncbus curvirostris (not Orpheus curvirostris Swainson) Allen, 1893a, 41 (Oputo; Nacori).

Toxostoma curvirostre curvirostre van Rossem, 1934d, 460 (Nacozari); 1936d, 142, map (range in northern Sonora).

Common resident along the northern boundary from about Nogales eastward, and south along the Sonoran levels of the eastern mountains to about latitude $28^{\circ}$. Specimens have been examined as follows: $32 \mathrm{klms}$. 
south of Nogales (Mus. Comp. Zoöl.); Pilares (Univ. Mich.); Nacori; Oputo; Arroyo Hondo (Amer. Mus.); San Pedro River on the boundary (U. S. Nat. Mus.); Nuri (Brit. Mus.); west side of San Luís Mountains (Mearns notes).

\section{TOXOSTOMA CURVIROSTRE PALMERI (COUES)}

\section{PALMER THRASHER}

Harporbynchus curvirostris var. palmeri "Ridg. Ms." Coues, Key No. Amer. Birds, 1872, 351 (Tucson, Arizona).

Harporhynchus curvirostris palmeri Brewster, 1885, 196 (Altar).-Stephens, 1885, 228 (Altar).--Parker, 1887, 72 (Sonora).-Clark, 1898, 272 (El Plomo); 1904, 214 (El Plomo).

Toxostoma curvirostre palmeri Thayer and Bangs, 1906, 19, part (Opodepe; crit.).-Ridgway, 1907, 202, part (El Plomo; Magdalena; Poso de Luis; Sonoyta; Altar).-A.O.U. Comm., 1931, 333 (Sonora).-Dawson, 1923, 694 (Sonora).- - van Rossem, 1931c, 275, part (Saric; 12 miles W. of Magdalena; 15 miles W. of Nogales; Sasabe Valley; Pesqueira; Altar; Pitiquito; crit.); 1934d, 460, part (Bacuachi); 1936, 140 (southwest of Nogales; range map in northern Sonora; crit.).-Sheffler, 1931b, 164 (between Magdalena and Santa Ana).Hellmayr, 1934, 298 (northern Sonora).-Huey, 1935, 255 (Punta Peñascosa). -Moore, 1941b, 215, in text (Saric).

Toxostoma palmeri Sharpe, 1903, 107 (Sonora).

Common resident, chiefly of cactus and mesquite associations in the Lower Sonoran zone, from about Nogales westward; south to about latitude $28^{\circ} 30^{\prime}$, and east in the northcentral part of the State to about longitude $110^{\circ}$. Specimens from the northeastern part of the range are variously intermediate toward celsum, those from the south and southeast toward maculalum. Additional localities are Hermosillo (Univ. Mich.) ; Chivata (Mus. Comp. Zoöl.); Rancho Costa Rica (Lamb notes); Sierra Seri (Mus. Vert. Zool.).

\section{TOXOSTOMA CURVIROSTRE MACULATUM NELSON}

\section{ÁLAMOS THRASHER}

Harporhynchus curvirostris maculatus Nelson, Auk, 17, July, 1900, 269 (Álamos, Sonora, México).

Toxostoma curvirostre maculatum Ridgway, 1907, 202, part (Alamos; Guaymas; Camoa).- -van Rossem, 1931c, 274 (Tecoripa; Obregon; Tesia; Chinobampo; Tobari Bay; Guirocoba; crit.) : 1934, 460 (Alamos; Mina Abundancia; Oposura).-Hellmayr, 1934, 299 (southern Sonora).-Moore, 1941b, 215, in text (Tecoripa; Agiabampo; Guirocoba).

Harporbynchus curvirostris palmert (not of Coues) Ridgway, 1887d, 545, part (Guaymas).-A.O.U. Comm., 1886, 323, part (Guaymas).

Toxostoma curvirostre palmeri Thayer and Bangs, 1906, 19, part (Guaymas; 
crit.).-Ridgway, 1907, 202, part (Batamotal).--van Rossem, 1931 c, 275, part (San Javier; Guaymas; San Jose de Guaymas) ; 1934d, 460, part (Guaymas).

Harporbynchus palmeri Belding, 1883, 343 (Guaymas).

Common resident of Tropical zone lowlands and foothills from about Guaymas, coastwise, and Moctezuma in the interior, south to the Chihuahua and Sinaloa boundaries. Specimens from the foothill regions easterly often show tendencies toward celsum, while in the northwest many incline toward palmeri. Specimens from localities not recorded above have been examined from San Marcial; Las Chinchas (Mus. Comp. Zoöl.); Río Mayo; Agua Caliente (Brit. Mus.); Masocari Island (Dickecy coll.). ${ }^{47}$

\section{TOXOSTOMA CURVIROSTRE INSULARUM VAN ROSSEM}

\section{ISLANI) THRASHER}

Toxostoma curvirostre insularum van Rossem, Trans. San. Diego Soc. Nat. Hist., 6, Sept. 30, 1930, 207 (San Estéban Island, Sonora, México); ibid. in text, (Tiburon Island) ; 1931c, 275 (San Esteban Island; Tiburon Island); 1932, 140 (Tiburon Island; San Esteban Island).--Hellmayr, 1934, 300 (San Esteban Island; Tiburon Island).

Toxostoma bendiret (not Harporbynchus bendirei Coues) Townsend, 1923, 24 (Tiburon Island).

Uncommon resident, almost entirely of cactus associations, on San Estéban and Tiburón 1slands. It is now possibly extinct on San Estéban, for suitable associations are of limited area and investigations subsequent to 1930 have failed to find it. Seven specimens are now known from Tiburon; in addition to the five recorded in the synonymy above, there are two in the collection of the Muscum of Vertebrate Zoology, taken by Bensen and Sibley, November 4 and 8, 1941.

\footnotetext{
4i Intergradation between maculatum. palmeri, and celsum occurs over such broad bands and is so irregular in individual specimens that there was the inclination to discard the name maculatum altogether, and to consider birds from the range of that race as intergrades connecting palmeri, celsum, and occidentale. However, the combined series in the Moore and Dickey collections, both of which are of relatively recent origin and which retain the original color values, show that maculatum may be recognized. It is somewhat darker below, and has darker brown posterior under parts than any of the surrounding forms. Ventral spotting averages about intermediate between palmeri and occidentale. There is very little difference in size between maculatum and palmeri, the former having a very slightly shorter wing and slightly longer tail. Twenty-one fully adult males of palmeri from southern Arizona average: wing, 106.4; tail, 117.5. Fifteen fully adult male maculatum from southern Sonora average: wing, 105.0; tail, 119.1. One-year-old birds (distinguishable by the primary coverts) average considerably smaller, a fact not generally appreciated.
} 


\section{TOXOSTOMA LECONTEI LECONTEI LAWRENCE}

\section{LECONTE THRASHER}

Toxostoma Le Contei Lawrence, Ann. Lyc. Nat. Hist. New York, 1852 [pub. Sept., 1851], 121 (California, near the junction of the Gila and Colorado rivers $=$ Fort Yuma, California $)$.

Toxostoma lecontei lecontei Ridgway, 1907, 205 (south to "Cape" [=Point] Lobos).-Chapman, 1917, 39 (northern Sonora).-Dawson, 1923, 705 "Cape" Lobos).- -van Rossem, 1931c, 276 (Port Lobos).-Hellmayr, 1934, 301 (Puerto de Lobos).--Huey, 1935, 255 (Punta Peñascosa).

Harporbynchus lecontei Stephens, 1885, 229 (Port Lobos and vicinity).Mearns, 1886, 299 (15 miles inland from Point Lobos).-Merriam, 1895, 58, part ("Cape" Lobos).-A.O.U. Comm., 1895, 294, part (Lat. 30, Sonora).Anthony, 1897, 168 (15 miles inland from Point Lobos).

H. [arporbynchus] lecontei Ridgway, 1887d, 546, part (Sonora).-Coues, 1903, 288 , part (N.W. Sonora).

Harporbynchus lecontii Brewster, 1885, 196 (Point Lobos).

Rather common in the sandy, Lower Sonoran coastwise deserts in the northwest, although reported to date only in February and August. Recorded as common at Port Lobos and inland for some "ten to twenty miles," in August, 1884, and as common and breeding at Punta Peñascosa in February, 1934. In all likelihood, the species is resident and of continuous distribution on the sandy deserts near the coast from about latitude $30^{\circ}$ northward to the Colorado River region, where found commonly on the Baja California side.

\section{TOXOSTOMA DORSALE DORSALE HENRY}

\section{Crissal Thrasher}

Toxostoma dorsalis Henry, Proc. Acad. Nat. Sci. Phila., [10], 1858, No. 7-9, April-May [after April 19], 117 (Fort Thorn [Donna Anna Co., New Mexico]). Toxostoma dorsale dorsale A.O.U. Comm., 1931, 254 (Sonora).-Hellmayr, 1934, 302 (Sonora).

Toxostoma crissale Ridgway, 1907, 207, part (Senoyta).-A.O.U. Comm., 1910, 334, part (northern Sonora).-Chapman, 1917, 39, part (northern Sonora). -Dawson, 1923, 710, part (Sonora).-Bailey, 1928, 558, part (northern Sonora).

Toxostoma crissale crissale van Rossem, 1931c, 276 (Pesqueira; Guaymas).

Toxostoma crissalis Sheffler, 1931b, 164 (between Magdalena and Santa Ana).

Harporbynchus crissalis Mearns, 1886, 292, part (Sonora).

Fairly common resident of the Lower Sonoran zone across the State northerly, and south in the western deserts at least to Guaymas. Distribution is not general but tends to localize in areas of relatively dense cover such as watercourse shrubbery and mesquite thickets. Record stations additional to the above are Cienega Well, 25 miles south of Monu- 
ment 205 on the Colorado River, March 23, 1894 ; San Bernardino Ranch, September 9, 1892 and October 7, 1893 (U. S. Nat. Mus. catl.); Guadalupe Cañon, in early July, 1892 (Mearns notes) ; Kino Bay, February 23, 1935 (Nat. Hist. Mus.); San José de Guaymas, January 19, 1933 (Dickey coll.); Magdalena, April 17 to May 23, 1925 (Dawson notes); Mina Los Afanes, January 19, 1942 (Mus. Vert. Zool.).

\section{Melanotis caerulescens effuticius Bangs and Penard}

\section{Western BLUe MOCKINGBird}

Melanotis caerulescens effuticius Bangs and Penard, Proc. Biol. Soc. Wash., 34, June 30, 1921, 91 (Hacienda de San Rafael, "Chihuahua" [=Sonora], México); ibid., in text (Alamos).-Bangs, 1930, 324 (location of type).-van Rossem, 1931c, 274 (Chinobampo); 1934d, 459 (Alamos; Hacienda de San Rafael).-Hellmayr, 1934, 303 (Sonora).

Probably a fairly common resident of brushy areas in the extreme southeastern Tropical zone foothills. Specimens have been taken at Álamos and Hacienda de San Rafael between February 16 and May 19, 1888 (Mus. Comp. Zoöl.), and at Chinobampo, February 28, 1930 (Dickey coll.) : noted as present at Guirocoba in May and June and at San Francisco Cañon, May 30, 1937 (van Rossem notes)..$^{48}$

\section{MIMUS POLYGLOTTOS LEUCOPTERUS (Vigors)}

\section{WESTERN MOCKINGBIRD}

Orpheus leucopterus Vigors, in Zool. Beechey's Voy., 1839, 17 (West coast of America $=$ Monterey, California .

Mimus polyglottos leucopterus Thayer and Bangs, 1906, 19 (Opodepe).Ridgway, 1907, 228 (Sonora).- Townsend, 1923, 23 (Tiburon Island).-van Rossem, 1931c, 274 (Pesqueira; Tecoripa; San Javier; Saric; Obregon; Tesia; Chinobampo; Guirocoba; El Alamo; Sasabe); 1934d, 459 (Guaymas; Alamos; Nacozari).-Huey, 1935, 255 (Punta Peñascosa).

Mimus polyglottos (not Turdus polyglottos Linn.) Evermann and Jenkins, 1888, 67 (Nogales; Magdalena; Guaymas).-Allen, 1893a, 41 (Oputo; Nacory).-Price, 1899, 93 (lower Colorado River).

Mimus polyglottus Belding, 1883, 343 (Guaymas).

${ }^{48}$ It is possible that the name effuticius is a synonym of caerulescens Swainson. Bangs and Penard evidently considered Swainson's name to apply to the eastern form, but this allocation is doubtful. The type of caerulescens was taken by Bullock at "Upper Themascaltepec," a village about four miles above Temascáltepec, and it will require new material to determine what race is present there. In case a shift of names becomes necessary, the first available one for the eastern bird is Turdus melanotis Temminck, the type of which I have examined at Leiden. 
Common, generally distributed resident of Sonoran and Tropical zones, including some, and probably all, of the suitable islands. Records practically blanket the State, nor does there seem to be the concentration in cultivated areas as is the case further north. Some unpublished occurrences are Camoa, February (Bishop coll.) ; Rancho Costa Rica, December (Lamb notes); Puerto Libertad, January and February (Nat. Hist. Mus.); Agiabampo and Masocari Island, May; San Estéban Island, January (van Rossem notes); Pozo de Luís, December and January; lower Colorado River, March (U. S. Nat. Mus.).

\section{OREOSCOPTES MONTANUS (TOWNSEND)}

\section{SAgE THRASHER}

Orpheus montanus J. K. Townsend, Journ. Acad. Nat. Sci. Phila., 7, Pt. 2, [Nov. 21, 1837], 192 (Plains of the Rocky Mountains=Sandy Creek, $42^{\circ} \mathrm{N}$, $109^{\circ} 30^{\circ}$ W., Wyoming).

Oroscoptes montanus Price, 1899, 93 (lower Colorado River).-Ridgway, 1907, 259 (Sonora).-van Rossem, 1931c, 276 (El Doctor).

Oreoscoptes montanus Huey, 1935, 255 (Punta Peñascosa); 1942, 269 (Gray's Ranch) [Arizona].

Evidently a not uncommon winter visitant to deserts and plains across the northern part of the State. Unpublished occurrences are Sonoyta, January 12, 1894 (U. S. Nat. Mus. catl.), and Johnson's Ranch [Arizona], at Monument 90, September 15, 1892 (Mearn's notes). Extreme dates are September 15 (Johnson's Ranch) and March 22 (Gray's Ranch).

Family Turdidae Thrushes

TURDUS MIGRATORIUS PROPINQUUS RIDGWAY

\section{WESTERN ROBIN}

Turdus propinquus Ridgway, Bull. Nuttall Orn. Club, 2, No. 1, Jan., 1877, 9 (Western region [etc.] = Laramie Peak, Wyoming).

Turdus migratorius propinquus van Rossem, 1931c, 277 (El Doctor; 15 miles W. of Nogales); 1934d, 460 (Alamos; Mina Abundancia; Hacienda de San Rafael; Oposura; crit.) ; 1936c, 41 (Colorado delta; crit.).

Summer visitant in the Transition zone in the Sierra de Oposura and probably at other points along the eastern boundary. Common and widespread at lower elevations in winter and during migrations, the majority of birds present at those seasons being most probably from regions north of México. Unpublished records are San José de Guaymas, January 15, 1933 (Lamb notes); San Pedro River on the boundary, October 15 and 26, 1892; Sonoyta, January 14 and 21, 1894; Colorado River at Monu- 
ment 205, March 19, 1894; San Luís Mountains, September 4, 1893; Cajón Bonito Creek, September 8 to 27, 1893 (U. S. Nat. Mus.; Mearns notes).

\section{TURDUS RUFO-PALLIATUS GRISIOR VAN ROSSEM}

\section{SONORA ROBIN}

Turdus rufopalliatus grisior van Rossem, Bull. Mus. Comp. Zoöl., 77, No. 7, Dec., 1934, 461 (Guirocoba, Sonora, México); ibid., in text (Alamos; Hacienda de San Rafael; Chinobampo).

Turdus rufo-palliatus (not of Lafresnaye) van Rossem, 1931c, 277 (Chinobampo; Guirocoba).

Turdus rufo-palliatus rufo-palliatus Hellmayr, 1934, 355, part (Sierra de Alamos; southern Sonora locs.).

Turdus flavirostris (not of Horsfield) Sharp, in Seebohm, 1899, 299, part (Sierra de Alamos).

Common resident in the southeastern foothills, where it is the Tropical zone representative of the genus. There seems to be little or no penetration into the Upper Sonoran and the range is apparently pretty well confined to riparian growth between the altitudes of 300 and 2,000 feet. Observed to be very common at Guirocoba, San Francisco Cañon, and intervening points in May and June, 1937 (Dickey coll. ; van Rossem notes). The northernmost locality to date is Hacienda de San Rafael.

\section{TURDUS ASSIMILIS CALLIPHTHONGUS MOORE}

\section{WHITE-THROATED ROBIN}

Turdus assimilis calliphtbongus Moore, Proc. Biol. Soc. Wash., 50, Nov. 30, 1937, 204 (Baromicon [ = Baromico, extreme southeastern], Sonora, [México], alt. $3000 \mathrm{ft}$ ) ; ibid., in text (San Rafael: Hacienda de San Rafael; Guirojaqui).

Turdus assimilis renominatus (not of Miller and Griscom) van Rossem, 1934d, 461 (Hacienda de San Rafael; crit.).

Present in summer (May and June) in the Upper Sonoran and lower parts of the Transition zones in the mountains of the extreme southeast. Supplementing the little data available is the occurrence at Rancho Santa Bárbara, where observed as very rare in the oaks and pines at elevations of from 5,000 to 5,500 feet in mid-June, 1937 (van Rossem notes).

\section{MyAdestes TOWNSENDI (AUDUBON) \\ TOWNSEnd SOlitaire}

Ptilogony's [sic] Townsendi Audubon, Birds Amer., (folio), 4, pl. 419, fig. 2, 1838 (Columbia River=near Astoria, Oregon).

Myadestes tounsendi Ridgway, 1907, 163 (Sonora?).- -van Rossem, 1931c, 278 (15 miles S.W. of Nogales).

Myiadestes townsendi Salvin and Godman, 1889c, 381 (Sonora; crit.). 
Detected to date only as an uncommon transient and winter visitant. The following seem to be the only records: two specimens taken by Mearns and Holzner in the San José Mountains, October 5 and 7, 1892 (U. S. Nat. Mus. catl.); specimen taken by Bancroft 15 miles southwest of Nogales, February 17, 1929) (Dickey coll.); specimen or specimens taken by Lloyd somewhere in southeastern Sonora between April 4 and May 25, 1888 (Salvin and Godman, 1889b). The first two records are from the Upper Sonoran (or higher) zone, the last is uncertain.

\section{MYADESTES OBSCURUS CINEREUS NEI.SON}

\section{Ashy Sol.tTAire}

Mradestes obscurus cinereus Nelson, Proc. Biol. Soc. Wash., 13, May 29, 1899, 30 (mountains near Álamos, Sonora, México).-Griscom, 1932, 303, in text (Sonora).-van Rossem, 1934d, 463 (Alamos; Mina Abundancia; Hacienda de San Rafael).

Myadestes obscurus occidentalis (not of Stejneger) Ridgway, 1907, 168, part (Alamos; Hacienda de San Rafael; Mina Abundancia).-Hellmayr, 1934, 435, part (Sonora).

Seemingly, in some years at least, a fairly common winter visitant in the Tropical zone foothills and lower mountains in the southeastern corner of the State. Dates range from January 3 to May 15 . No specimens have been collected anywhere in Sonora during the midsummer months in spite of careful search in a variety of zones and associations ranging up to 5,500 feet. The breeding range apparently is in the Transition zone of the higher Sierras east of the Sonora-Chihuahua boundary. ${ }^{49}$

\section{Hylocichla guttata guttata (Pallas)}

\section{Alaska Hermit Thrush}

Muscicapa guttata Pallas, Zoogr. Rosso-Asiatica, 1, 1811, 465 (in insulis . . Kadiak=Kodiak Island, Alaska $)$.

Hylocichla guttata guttata Ridgway, 1907, 39, part (Nacozari; Alamos):A.O.U. Comm., 1910, 361 (Sonora); 1931, 258 (Sonora).-Bailey, 1928, 570 (Sonora).- van Rossem, 1931c, 277 (El Doctor; Tecoripa; Chinobampo) ; 1934d, 462 (Alamos; Nacozari).-Hellmayr, 1934, 453 (Sonora).

Winter visitant to Sonoran and Tropical zones. Probably generally distributed since the none-too-numerous records are scattered over most of the State. There is one additional record, Tepopa Bay, January 2, 1932 (Dickey coll.). The latest spring date is March 29 (Nacozari).

49 I agree with Griscom (l.c.) that cinereus is an excellent race, with characters as originally described by Nelson, and cannot understand the reluctance of Ridgway and Hellmayr to recognise it. 
This and other races of the Hermit Thrush are represented by such small series that estimates of relative abundance are not to be considered at this time.

\section{HYLOCICHLA GUTTATA SLEVINI GRINNELL}

\section{MONTEREY HeRmit Thrush}

Hylocicbla aonalaschkae slevini Grinnell, Auk, 18, No. 3 July, 1901, 258 (Vicinity of Point Sur, Monterey County, California).

Hylocichla guttata slevini A.O.U. Comm., 1910, 362 (Sonora); 1931, 258 (Sonora).-van Rossem, 1931c, 277 (Chinobampo); 1934d, 462 (Alamos).Hellmayr, 1934, 454 (Sonora).

Hylocicbla guttata sleveni [sic] Ridgway, 1907, 44 ("Campos").

Hylocichla guttata oromela Bishop, 1933, 203 (Chinobampo).

A winter visitant, apparently in some numbers and chiefly in the southern part of the State. Specimens have been examined from San José de Guaymas, January 15, 1933 (Dickey coll.) ; Chinobampo, February 28, 1931 (Bishop coll.) and March 2 and 9, 1930 (Dickey coll.); Álamos, February 3 and 23; March 1, 1888; Cumpas, February 3, 1887 (Mus. Comp. Zoöl.). ${ }^{50}$

\section{Hylocichla guttata sequoiensis (Belding)}

\section{SiERra Hermit Thrush}

Turdus sequoiensis Belding, Proc. Calif. Acad. Sci., ser. 2, 2, June 11, 1889, 18 (Big Trees [Calaveras County, California]).

Hylocichla guttata sequoiensis Ridgway, 1907, 44 (Alamos).-Dawson, 1923, 748 (Sonora).- -van Rossem, 1934d, 462 (Alamos).

Turdus aonalaschkae (not of Gmelin) Allen, 1893a, 42 (Bacadehuachy).

Hylocichla guttata guttata (not Muscicapa guttata Pallas) Ridgway, 1907, 39, part (Baradehuachy).

Winter visitant in the eastern foothill region. Has been taken at Bacadéhuachi, November 21, 1890 (not November 11 as published) and Alamos (four specimens), between February 4 and March 13, 1888.

\section{HyLOCICHLA GUTTATA POLIONOTA GRINNELL}

\section{Great Basin Hermit Thrush}

Hylocicbla guttata polionota Grinnell, Condor, 20, No. 2, March 20, 1918, 89 (White Mountains, Inyo County, California).-van Rossem, 1934d, 462 (Mina Abundancia ).

50If the subspecies oromela is recognized, the Chinobampo specimen from the Bishop collection belongs there. According to Alden Miller (Condor, 1941, p. 262 ), oromela is an unstable intergrade in which three currently recognized forms are involved. 
Spring migrant in the castern mountains. There is but one record; taken by Frazar at Mina Abundancia, April 11, 1888, (Mus. Comp. Zoöl.).

\section{HyLOCICHLA GUTTATA AUDUBONI (BAIRD)}

\section{Alidubon Hermit Thrush}

Turdus auduboni Baird, Review Amer. Birds, sig. 1, June, 1864, 16 (Ft. Bridger [Wyoming]).-Sharpe, in Secbohm, 1898, 197, part (Yecora).

Turdus aonalaschkae auduboni Allen, 1893a, 42 (Bavispee River).

Hylocichla guttata auduboni van Rossem, 1934d, 462 (Mina Abundancia).

Winter visitant, possibly only as a casual, and a transient in the eastern mountains. There is one fall record, that of a specimen taken by Mearns and Holzner in the San José Mountains, October 5, 1892 (U. S. Nat. Mus.). Spring records are from Mina Abundancia, April 11 to 20, 1888 (Mus. Comp. Zoöl.), and Yécora, "April" [between 11 and 16], 1888 (Brit. Mus.). The specimen recorded by Allen has also been examined. It was taken January 1, 1891 on the upper Bavispe near the Chihuahua boundary.

\section{HyLocichla ustulata USTULATA (NutTALL)}

\section{RUSSET-BACKed THRUSH}

Turdus cestulatus [ = ustulatus] Nuttall, Manual Orn. U. S. and Canada, 1, ed. 2, 1840, 400, 830; errata, p. vi (Forests of Oregon=Fort Vancouver, Washington).-Sharpe, in Seebohm, 1898, 175 (Ysleta).

Hylocicbla ustulata ustulata van Rossem, 1931c, 277 (Saric; Guirocoba); 1934d, 462 (Hacienda de San Rafael; Mina Abundancia; Oposura).

Fairly common transient, chiefly through the easterly foothills. Fall dates are from San Bernardino River on the boundary, September 4, 1892 ; San José Mountains, October 6, 1892 (U. S. Nat. Mus.). Spring records are more numerous, the earliest being April 20 (Mina Abundancia) and the latest May 24 (Oposura). Further spring data are from Magdalena, May 13 to 15, 1925 (Dawson notes); Colonia Independencia in the Colorado delta, May 3, 1937 (van Rossem notes.).

\section{SIALIA SIALIS FULVA BREWSTER}

\section{AZURE BLUEBIRD}

Sialia sialis fulva Brewster, Auk, 2, Jan., 1885, 85 (Santa Rita Mountains, Arizona).-Ridgway, 1907, 146, part (Mina Abundancia; Bavispe River).-Griscom, 1932, 313, in text (Sonora; crit.).--van Rossem, 1934d, 463 (Mina Abundancia) .

Sialia sialis (not Motacilla sialis Linn.) Allen, 1893a, 42 (Bavispee River).

Sialia sialis azurea (not Sialia azurea Swainson) Thayer and Bangs, 1906, 19 (La Chumata).-Ridgway, 1907, 887 (La Chumata). 
Common in summer in the Upper Sonoran and Transition zones (oakpine association) along the west slope of the Sierra Madre, although apparently in greatly decreasing numbers northerly. Occurs also in some, at least, of the northcentral ranges such as the Parjaritos Mountains (specimen from Arizona side in Miller coll.) and the Sierra de San Antonio. Observed so far at four points: Rancho Santa Bárbara, where common in June, 1937 (van Rossem notes); Mina Abundancia, apparently common in April, 1888 (series by Frazar in Mus. Comp. Zoöl.); La Chumata in May or June, 1905; Bavispe River, December 30, 1890. This last record indicates year-around residence, at least in part.

\section{SIALIA MEXICANA BAIRDI RIDGWAY}

\section{Chestnut-Backed Bluebird}

Sialia mexicana bairdi Ridgway, Auk, 11, No. 2, April, 1894, 148, in text (Camp 110, New Mexico=Cactus Pass, 20 miles east of Kingman, Mohave Co., Arizona) ; 1907, 152 (Alamos).-Bailey, 1928, 573 (Sonora).-van Rossem, 1931c, 277 (Nogales); 1934d, 463 (Alamos).-Moore, 1939d, 126 (Alamos).

Sialia mexicana occidentalis (not Sialia occidentalis Townsend) Ridgway, 1894b, 154 (Sonora).

Sialia mexicana (not of Swainson) Allen, 1893a, 42 (Nacory).

Seemingly breeds in the San Luís Mountains; elsewhere a winter visitant, when probably fairly common in spite of the scarcity of definite records. These are: Santa Cruz River on the boundary, November 6, 1892; west side of the San Luís Mountains, September 29, 1893 (Mearns notes); Nogales, February 17, 1929; Nácori, November 24, 1890 ; Álamos, February 8 to March 27,1888 . Bluebirds reported as seen commonly by Price (1899) and Rhoads (1905) in the Colorado delta may have belonged to any or all of three races. Lamb observed bluebirds near Hermosillo in December, 1932, but collected no specimens. Mearns' notes list a " $\sigma$ " juv" taken on the west side of the San Luis Mountains on July 5, 1892, at which date he was on the Mexican side of the boundary.

\section{SiALIA CURRUCOIDES (BECHSTEIN)}

\section{MOUNTAIN BLuEBIRD}

Motacilla s. Sylvia Currucoides "Borkh." Bechstein, in Latham, Allgem. Ueb. Vögel, 3, pt. ii, 1798, 546, pl. 121 (Virginien=Western America).

Sialia currucoides A.O.U. Comm., 1910, 367 (Sonora); 1931, 262 (Sonora). -Dawson, 1923, 781 (Sonora).-Bailey, 1928, 576 (Sonora).-van Rossem, 1931c, 278 (El Doctor; 12 miles W. of Magdalena; 15 miles W. of Nogales); 1934d, 463 (Alamos; Bacuachi). 
Sialia arctica Allen, 1893a, 42 (Nacory).-Price, 1899, 93 (lower Colorado River).-Ridgway, 1907, 156 (Nacory).

Winter visitant in Sonoran and Tropical zones, though apparently in rather limited numbers and chiefly in the northern part of the State. Records extend from the Colorado delta in the northwest to Bacuachi in the northeast and south to Álamos. The earliest seasonal record is that of a specimen taken by Mearns and Holzner on the Santa Cruz River, November 7, 1892 (U. S. Nat. Mus. catl.); the latest is that of three specimens taken 12 miles west of Magdalena, February 25, 1929. Additional localities are Sonoyta, January 13, 1894 (U. S. Nat. Mus.) ; Pozo de Luís, December 29, 1893 to January 8, 1894 ("scarce," Mearns notes).

\section{Family SYLVIIDAE Old-World Warblers}

\section{Poliop'tilla caERULEa amoenissima Grinnell}

\section{WESTERN GNATCATCHER}

Polioptila caerulea amoenissima Grinnell, Proc. Calif. Acad. Sci., ser. 4, 15, No. 16, Sept. 15, 1926, 494 (Pleasant Valley, Mariposa Co., California).-A.O.U. Comm., 1931, 265 (Sonora).- -van Rossem, 1931c, 278, part (El Doctor; Saric; Pesqueira; Tecoripa, part; Tesia, part; Chinobampo, part; Obregon, part); 1934d, 463, part (Guaymas; Alamos; Nacozari; Oposura).-Hellmayr, 1934, 487 (Sonora).- - Huey, 1935, 255 (Punta Peñascosa).- -van Rossem and Hachisuka, 1937d, 109 (La Chumata; "Opodepe" [-Oposura]).

Polioptila caerulea obscura (not of Ridgway) Allen, 1893a, 42 (Oputo; Bacadehuachy).-Jouy, 1894, 775 (Guaymas).-Ridgway, 1904, 720, part (Sonora).-Thayer and Bangs, 1906, 19 (La Chumata):- Hellmayr, 1911, 14 (Sonora).

Polioptila caerulea (not Motacilla caerulea Linnaeus) Belding, 1883, 343 (Guaymas).

Fairly common summer visitant in the Upper Sonoran zone (chicfly oak associations) from the Pajaritos Mountains eastward; south at least to latitude $30^{\circ}$ (Sierra de Oposura and Sierra de San Antonio) and probably for some distance further in the eastern mountains. Occurs commonly in winter and as a transicnt over lowlands and foothills throughout the State, except that there are no winter records from the northeast. Additional stations are Camoa, February 8 (Bishop coll.); El Álamo, December 3 (Lamb notes); Kino Bay, February 17 (Nat. Hist. Mus.) ; San Pedro River, October 13; San José Mountains, August 8; Pozo de Luís, January 3; Sonoyta, January 14 (U. S. Nat. Mus.; Mearns notes); Colonia Independencia, May 3 (van Rossem notes). 


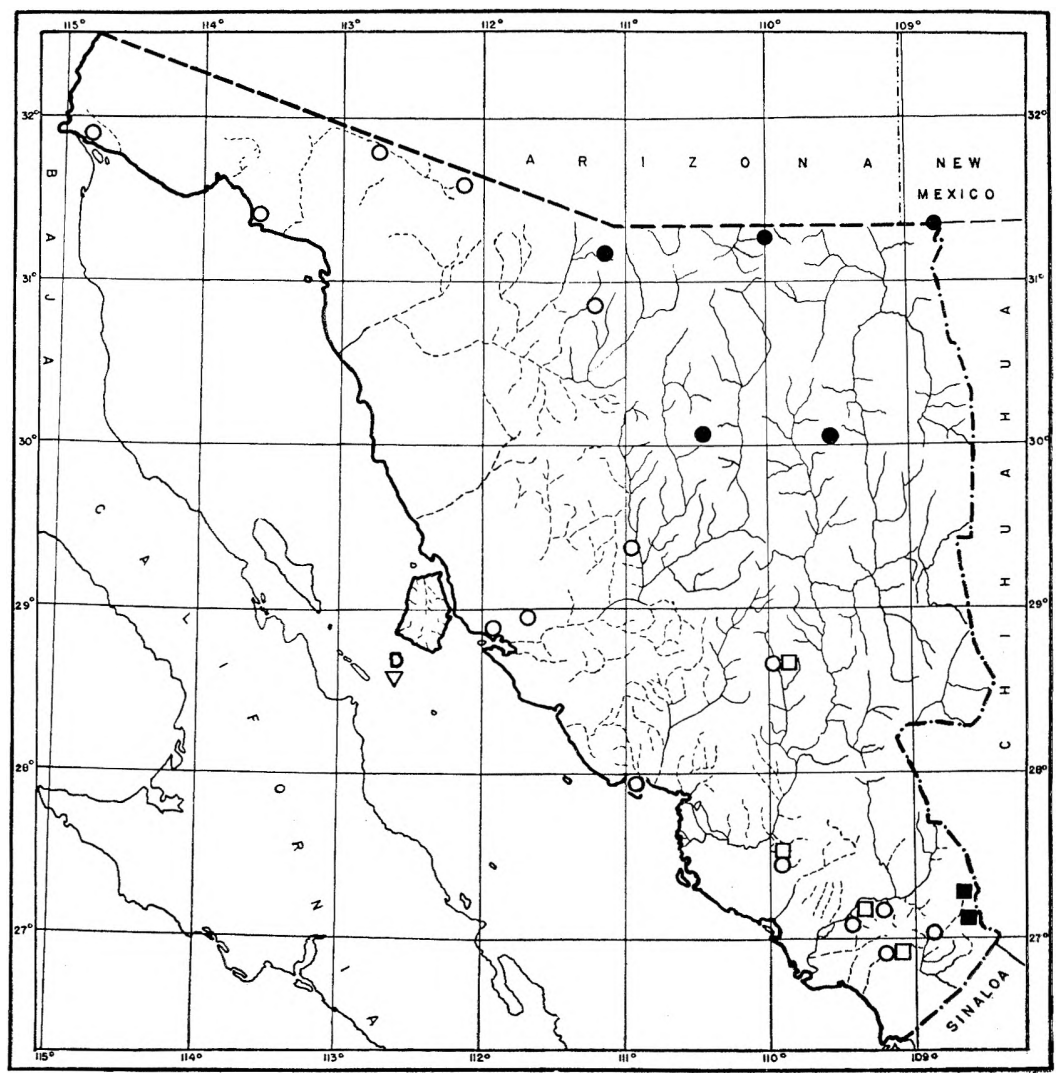

Map 18. Distribution of Polioptila caerulea. Circles, P.c. amoenissima; squares, $P$. c. gracilis; inverted triangle, P. c. obscura; hollow figures, winter stations outside established breeding ranges.

\section{Polioptila caERULEa GRACILIS van Rossem and Hachisuka}

\section{Sierra Madre Gnatcatcher}

Polioptila caerulea gracilis van Rossem and Hachisuka, Proc. Biol. Soc. Wash., 50, Aug. 7, 1937, 109 (Rancho Santa Bárbara, altitude 5000 feet, southeastern Sonora, México); ibid., in text (Tesia).

Polioptila caerulea amoenissima (not of Grinnell) van Rossem, 1931c, 278, part (Tesia, part; Obregon, part; Chinobampo, part; Tecoripa, part); 1934d, 463, part (Mina Abundancia [?]).

Common summer visitant in the high Upper Sonoran zone (oak association at 4,500-5,000 feet) in the mountains in the extreme southeastern 
part of the State. Although known in summer only from the general vicinity of the type locality, a more general distribution is to be supposed since it winters commonly in the Tropical zone lowlands west of the breeding area. Records for this latter region are Ciudad Obregón, November 3 to 11, 1929; Tesia, December 4 and 27, 1929, March 20, 1930; Chinobampo, February 18 and March 5, 1930; Tecoripa, March 10 and 23, 1929 (Dickey coll.).

\section{Polioptila CAERULEA ObSCURA RiDgway}

\section{San LuCas Gnatcatcher}

Polioptila caerulea obscura Ridgway, Proc. U. S. Nat. Mus., 5, 1882, 535, note (San José [del Cabo, Baja California, México]).

Polioptila caerulea gracilis (not of page 109!) van Rossem and Hachisuka, 1937d, 110, part (San Esteban Island).

Detected in midwinter on San Estéban Island (two specimens taken January 12,1932) where probably resident. Gnatcatchers observed on April 17 and 18,1930, were most likely of this race, but unfortunately no specimens were collected. ${ }^{51}$

\section{PolioptILA NIGRICEPS RESTRICTA BREWSTER}

\section{BLACK-CROWNED GNATCATCHER}

Polioptila nigriceps restricta Brewster, Auk, 6, No. 2, April, 1889 [separates issued January 31], 97 (Âlamos, Sonora, México).-van Rossem, 1931a, 37 (Tecoripa; San Javier; crit.); 1931c, 278 (Tecoripa; San Javier; Tesia; Chinobampo; Obregon; Tobari Bay; 10 miles N. of Guaymas; Guirocoba); 1934d, 464 (Alamos).-Hellmayr, 1901, 358 (southern Sonora); 1903, 25 (southern Sonora); 1934, 507 (Sonora).

Polioptila restricta Sharpe, 1901, 241 (Sonora).

Polioptila nigriceps (not of Baird) Ridgway, 1904, 729, part (Alamos).Bangs, 1930, 242 (re. type).

Polioptila nigriceps nigriceps Hellmayr, 1911, 17, part (Alamos).

Polioptila bilineata albiloris (not Polioptila albiloris Sclater and Salvin) Griscom, 1930, 7, part (Sonora).

Fairly common resident in the Tropical zone foothills and lowlands, north, coastwise, to about latitude $28^{\circ}$, and in interior river valleys to about $28^{\circ} 40^{\prime}$. Additional stations are Agiabampo and Masocari Island. ${ }^{.52}$

51 Although I once stated that the San Estéban specimens were "unmistakably" gracilis they had not, at that time, been compared with obscura. The two races are of equally small size and while easily distinguishable in the case of summer males, winter specimens require closer discrimination. Dorsally, gracilis is paler and more ashy gray, and purer (less creamy) white below.

52 The black summer cap of the males is sometimes, in specimens from ex- 


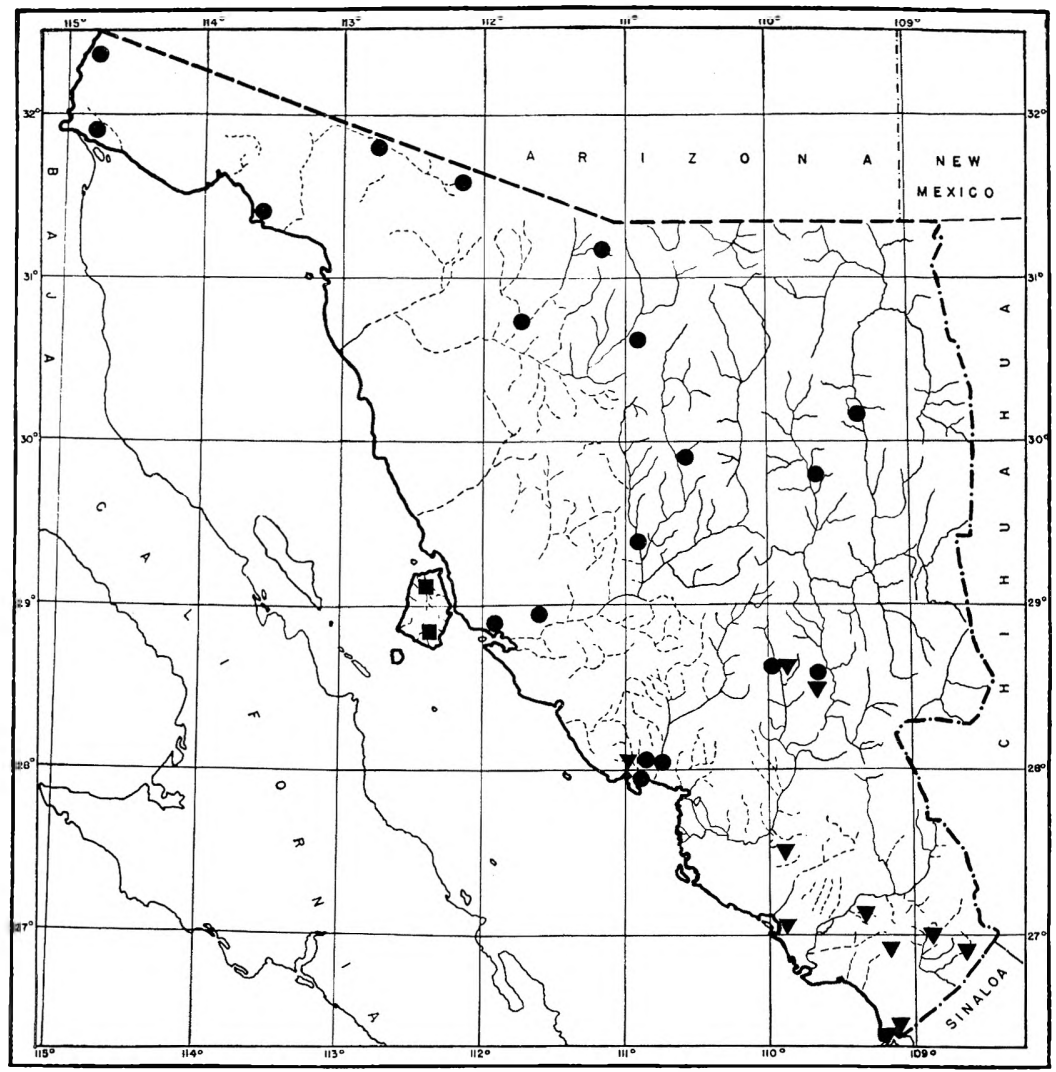

MAP 19. Distribution of Polioptila nigriceps and Polioptila melanura. Triagles, $P$. $n$. restricta; circles, $P . m$. lucida; squares, $P$. $m$. curtata.

\section{Polioptill melanuRa LUCIDA VAN ROSSEM}

\section{Plumbeous Gnatcatcher}

Polioptila melanura lucida van Rossem, Condor, 33, No. 1, Jan., 1931, 36 (10 miles N. of Guaymas, Sonora, México) ; 1931c, 278 (El Doctor; Pesqueira; Tecoripa; San Javier; Saric; Guaymas); 1934d, 464 (Guaymas; Oposura).Hellmayr, 1934, 508 (Sonora).- - Huey, 1935, 255 (Punta Peñascosa).

Polioptila plumbea (not Todus plumbeus Gmelin) Belding, 1883, 343 (Guaymas).-Stephens, 1885, 228 (Altar).-Allen, 1893a, 42 (Oputo).-Price, 1899,

treme southern Sonora, almost as extensive as in nigriceps. The characters of restricted black cap, darker and less purely gray upper parts, and grayer, less purely white under parts are best accentuated in the northern part of the range. The differences in body coloration are slight and I had previously (1931a) overlooked them. 
93 (south of Yuma).-Ridgway, 1904, 731, part (Batamotal; Senoyta).-Thayer and Bangs, 1906, 19 (Opodepe).-A.O.U. Comm., 1910, 358, part (Sonora).

Polioptila plumbea plumbea Hellmayr, 1911, 13, part (Sonora).-Bailey, 1928, 584, part (Sonora).

Polioptila melanura melanura (not Polioptila melanura Lawrence) A.O.U. Comm., 1931, 265, part (Sonora).-Friedmann, 1934, 33 (Guaymas).

Fairly common resident of Lower Sonoran and Tropical zone desert associations from the Arizona boundary southward to about latitude $28^{\circ}$ coastwise and to about $28^{\circ} 40^{\prime}$ in the interior. Additional stations are Rancho Costa Rica (Lamb notes); Puerto Libertad (Nat. Hist. Mus.) ; near Magdalena (Mus. Vert. Zool.); Kino and Tepopa Bays (Dickcy coll.); Pozo de Luís (Mearns' notes).

\section{Polioptila melanura curtata VAN ROSSEM \\ TiBuróN ISLAND GNATCATCHER}

Polioptila melanura curtata van Rossem, Trans. San. Diego Soc. Nat. Hist., 7, No. 12, July 28, 1932, 140 (Tiburón Island, Sonora, México).-Hellmayr, 1934, 508, footnote (Tiburon Island).

Polioptila plumbea (not Todus plumbeus Gmelin) Townsend, 1923, 25, part (Tiburon Island).

Fairly common resident of brushy areas on Tiburón Island.

\section{Family Regulidae Kinglets \\ REGULUS CALENDULA CALENDULA (LiNNAEUS)}

\section{EASTERN RUBY-CROWNED Kinglet}

Motacilla calendula Linnacus, Syst. Nat., ed. 12, 1, 1766, 337 (in Pennsylvania $=$ Philadelphia.)

Corthylio calendula calendula van Rossem, 1934d, 464 (Nacozari).

Corthylio calendula cineraceus (not Regulus calendula cineraceus Grinnell) van Rossem, 1931c, 279, part (El Doctor; Tesia, part).

A winter visitant, probably fairly common though greatly outnumbered by cineraceus. The four specimens recorded above (El Doctor, February 1, 1929; Tesia, March 18, 1930; Nacozari, March 21, 1887), seemingly are like eastern calendula. Whether thcy actually are that race or grinnellicineraceus intergrades is purely speculative.

\section{REGULUS CALENDULA CINERACEUS GRINNELL}

\section{Western RUBY-CROWNED KINGLET}

Regulus calendula cineraceus Grinnell, Condor, 6, No. 1, Jan., 1904, 25 (Strain's Camp, Mount Wilson, Los Angeles Co., California).

Cortbylio calendula cineraceus van Rossem, 1931 c, 279, part (Nogales; San 
Javier; Pesqueira; Tesia, part); 1932, 141 (Tiburon Island); 1934d, 464 (Alamos; Mina Abundancia).

[?] Regulus calendula (not Motacilla calendula Linnaeus) Allen, 1893a, 41 (Los Cuevos; Bacadehuachy; Nacory; Napolera).-Price, 1899, 93 (lower Colorado River).- Stone and Rhoads, 1905, 686 (lower Colorado River).

Regulus calendula calendula Ridgway, 1904, 705, part (Sonora; crit.).

Common winter visitant throughout the State from sea level to at least the lower parts of the Transition zone. Further records are El Álamo, December 4, 1932 (Lamb notes); Guaymas, March 24 and 25, 1905 (Mus. Comp. Zoöl.) ; San José Mountains, October 2, 1892 ; Sonoyta, January 19, 1894; Colorado River at Monument 204, March 14, 1894 (U. S. Nat. Mus.). Extreme dates are September 15 (Los Cuevos) and April 13 (Mina Abundancia).

\section{Family Motacillidae Pipits \\ ANTHUS SPINOLETTA PACIFICUS TODD \\ Western PIPIT}

Antbus rubescens pacificus Todd, Proc. Biol. Wash., 48, May 3, 1935, 63 (Red Pass, 6000 feet, British Columbia).

Anthus spinoletta rubescens (not Alauda rubescens Tunstall) van Rossem, 1931c, 279 (El Doctor); 1934d, 464 (Alamos; Oposura; Granados).

Anthus pensilvanicus (not Alauda pensilvanica Latham) Price, 1899, 93 (lower Colorado River).

Common winter visitant to river valleys throughout the State. Unpublished records are San Pedro River, October 17 and 21, 1892; Santa Cruz River, November 6 to 13, 1892; Sonoyta, January 12, 1894; Colorado River at Monument 205, March 19, 1894 (U. S. Nat. Mus.; Mearns notes). Extreme dates are October 17 (San Pedro River) and May 6 (Granados).

\section{Family Bombycillidae Waxwings \\ BOMBYCILLA CEDRORUM VIEILLOT}

\section{CEDAR WAXWING}

Bombycilla cedrorum Vieillot, Ois. Amér. Septen., 1, 1807 [1808], 80, pl. 57 (castern North America).--van Rossem, 1931c, 279 (Saric; Guirocoba); 1934d, 464 (Oposura; Hacienda de San Rafael).

Common spring migrant, likely to appear almost anywhere at lower elevations though there are no records from the northwestern deserts. There is, however, the record of a vagrant from Quitovaquita on the Arizona side of the boundary, November 30, 1939 (Huey, 1942, p. 370). 
Additional records are from Rancho La Arizona, where common in flocks from May 5 to 9, 1937 (van Rossem notes); Magdalena, in flocks between April 20 and May 12, 1925 (Dawson notes); Guaymas, March 1 and 19, 1905 (Mus. Comp. Zoöl.). Extreme dates are March 1 (Guaymas) and May 23 (Rancho La Arizona). Absence of fall and winter records are, in all probability, due simply to lack of observation at these seasons.

\section{Family Ptilogonatidaf: Silky Flycatchers \\ Phainopepla nitens lepida VAN Tyne}

\section{Northern Phiainopepi.a}

Phainopepla nitens lepida Van Tyne, Occ. Papers Bost. Soc. Nat. Hist., 5, May 22, 1925, 149 (Riverside, California); ibid., in text (Sonora).- -van Rossem, 1931c, 279 (Saric; Obregon; Tesia; Chinobampo; El Alamo; 10 miles W. of Magdalena; 15 miles S.W. of Nogales; Guaymas); 1932, 141 (Tiburon Island); 1934d, 464 (Ranken's Ranch; Cumpas: Nacozari; Oposura).--Hellmayr, 1935, 108 (Cerro Blanco).

Phainopepla nitens (not Ptilogonys nitens Swainson) Baird, 1859, 11 (Los Nogales).--Belding, 1883, 343 (Guaymas).-Stephens, 1885, 228 (Altar).Allen, 1893a, 40 (Oputo; Nacory).- Stone and Rhoads, 1905, 685 ( 50 miles below Yuma).- Thayer and Bangs, 1906, 20 (Opodepe).-Townsend, 1923, 22 (Tiburon Island).-Sheffler, 1931a, 137 (25 miles S. of Nogales).

Cichlopsis nitens Baird, 1858, 320 (I.os Nogales).

Common resident of Sonoran and Tropical zones throughout the State, with emphasis on mesquite associations in the Tropical and Lower Sonoran, and oak associations in the Upper Sonoran. Some additional localitics are La Noria, December 4; Sulphur Spring Valley on the boundary, October 7; Sonoyta, January 14; San José Mountains, October 8 (U. S. Nat. Mus. catl.); Camoa, February 18 (Bishop coll.); Rancho Costa Rica, December 15 (Lamb notes); Agiabampo; Hermosillo; San Luís; Colonia Independencia; Guirocoba, all in early May (van Rossem notes).

\section{Family LANIIDAE Shrikes \\ LANIUS LUDOVICIANUS GAMBELI RIDGWAY}

\section{C.ALIFORnia SHrike}

Lanius ludovicianus gambeli Ridgway, Man. No. Amer. Birds, 1887, 467 (California, especially coast district = Calaveras County); 1904, 250, part (Alamos). -Brewster, 1902, 172, part (Alamos).-van Rossem, 1931c, 280 (Obregon; Tesia; Tecoripa; $15 \mathrm{mi}$. S. of Nogales); 1934d, 465 (Alamos; Oposura).Miller, 1931, 81 (Sonora distr. in winter; map).-- Huey, 1935, 256 (Punta Peñascosa).-Hellmayr, 1935, 216 (Obregon, etc.).

Lanius ludovicianus nevadensis Miller, 1931, 74, part (Sonora; winter). 
Common winter visitant to deserts and river valleys throughout the State; more numerous, however, westwardly. Additional stations are Camoa, Fcbruary 14, 1931 (Bishop); San José de Guaymas, January 18, 1933; Kino Bay. December 28, 1931 (Dickey); and February 18, 1935 (Nat. Hist. Mus.). Extreme seasonal dates are October 31 (Ciudad Obregón) and April 9) (Oposura).

\section{L.aniUs ludovicianus sonoriensis Miller}

\section{SONORA SHRIKE}

Laniur ludoricianus ronoriensis A. H. Miller, Condor, 32, No. 3, May, 1930, 155 (White-tail Cañon. Chiricahua Mountains, Cochise County, Arizona); ibid.. in text (Sonora); 1931, 67 (Sonora; many locs. on maps pp. 66 and 75). - van Rossem, 1931c, 279 (Tesia; Tecoripa; $12 \mathrm{mi}$. W. of Magdalena; San Luis: El Doctor; Saric; $15 \mathrm{mi}$. W. of Nogales) : 1932, 141 (Tiburon Island) : 1934d, 465 (Guaymas; Alamos: Bacuachi).--Huey, 1935, 256 (Punta Peñascosa).--Hellmayr, 1935, 215 (Sonora).

Lanius ludoricianus excubitorides (not Lanius excubitorides Swainson) Belding, 1883, 343 (Guaymas).- Townsend, 1890, 138 (near mouth of Rio Colorado).-Jouy, 1894, 778 (Nogales).-Brewster, 1902, 172, part (Guaymas; Alamos).--Ridgway, 1904, 246 (Sonora).- Thayer and Bangs, 1906, 20 (Opodepe).

Lanius ludoricianus excubitoroides Allen, 1893a, 40 (Cachuta; San Pedro).

[?] Lanius ludovicianus gambeli (not of Ridgway) Townsend, 1923, 22, part (Tiburon Island).

Lanius ludoricianus neradensis Miller, 1931, 74, part (Sonora; winter).

Fairly common resident of Sonoran and Tropical zone deserts and river valleys. Both summcr and winter records of sonoriensis in typical form pretty well cover the State and the race is probably resident. During the winter the resident population is augmented by variously non-typical individuals. most likely seasonal visitants from north of the boundary. Additional stations are Guirocoba, April 5, 1931 (Bishop coll.) ; Ures, January 31, 1933 (Dickey coll.) ; Santa Cruz River, November 8 and 12 , 1892; San Pedro River, October 12, 1892; Pozo de I.uís, January 4, 1894 (U. S. Nat. Mus.).

\section{Family Vireonidae Vireos \\ VIREO PALI.ENS PALUSTER MOORE}

\section{Mangirove Virfo}

Vireo pallens paluster Moore, Proc. Biol. Soc. Wash., 51, May 19, 1938, 69 (Isla Las Tunas, Gulf coast of northwestern Sinaloa, México).

Rare summer visitant (possibly resident) in the Tropical zone mangrove association in the extreme southwest. There is one specimen of 
record, taken by van Rossem (Dickey coll.) on Masocari Island, May 14, 1937. It is a male which was in full breeding condition.

\section{VIREO HUTTONI STEPHENSI BREWSTER}

\section{STEPHENS ViREO}

Vireo huttoni stephensi Brewster, Bull. Nuttall Orn. Club, 7, July, 1882, 142 (Chiricahua Mountains, Arizona).-Allen, 1893a, 40 (Bacadehuachy).-Rhoads, 1893, 241 (Bacadehuachu; Mina Abundancia).- Thayer and Bangs, 1906, 20 (La Chumata).- -van Rossem, 1931c, 280 (15 miles S. W. of Nogales).1934d, 465 (Mina Abundancia; Oposura).-Hellmayr, 1935, 120 (Cerro Blanco).

Resident in Upper Sonoran and Transition zones from the Pajaritos Mountains eastward; south to the Sierra de San Antonio in the west, and along the eastern ranges the full length of the State. Altitudes range from about 500 feet (Quiriego) to well over 6,000 feet (Yécora) but the distribution of this species here, as elsewhere, seems to be governed largely by oak associations rather than by climatic zones. Further specimens (taken by Lloyd in 1888) have been examined in the British Museum as follows: Yécora, April 11; Quiriego, May 1, 1888.

\section{VIREO HYPOCHRYSEUS NITIDUS VAN ROSSEM}

\section{Northern Golden Vireo}

Vireo hypochryseus nitidus van Rossem, Bull. Mus. Comp. Zoöl., 77, No. 7, Dec., 1934, 465 (Hacienda de San Rafael, Sonora, México).-Peters, 1943, 88 (re. type).

Vireo bypochryseus bypocbryseus (not Vireo bypochryseus Sclater) Hellmayr, 1935, 122, part (Hacienda de San Rafael).

Evidently a rare summer visitant to the Tropical zone foothills in the extreme southeast. The only Sonora-taken specimen, aside from the original series of seven taken by Frazar at Hacienda de San Rafael between May 2 and 10, 1888, seems to be a male in breeding condition taken by van Rossem at San Francisco Cañon (willow-cottonwood association) on May 29, $1937 .{ }^{53}$

${ }^{53}$ The systematic position of this peculiar vireo is obscure. On the arbitrary basis of wing formula it must, of course, be placed in the subgenus Vireo. But the pattern of coloration (prominent superciliary stripe and obsolete wing bars) is so typically "Vireosylva" that one may easily suspect affinities in that direction. 


\section{VIREO VICINIOR COUES}

\section{GRAY VIREO}

Vireo vicinior Coues, Proc. Acad. Nat. Sci. Phila., [18], No. 1, Jan.-March [June 11], 1866, 75 (Fort Whipple, Arizona).-Belding, 1883, 343 (Guaymas) ; 1890, 204 (Guaymas).-Brewster, 1902, 177 (Guaymas).-Ridgway, 1904, 203 Guaymas).-A.O.U. Comm., 1910, 303 (Sonora); 1931, 276 (Sonora).-Dawson, 1923, 583 (Sonora).- -van Rossem, 1931c, 281 (Saric) ; 1932, 141 (Tiburon Island; San Esteban Island; San Carlos Bay); 1934d, 466 (Guaymas).-Hellmayr, 1935, 123 (Guaymas; Saric).

Fairly common winter visitant in a limited area from San Estéban and Tiburón Islands south to Guaymas. It has been detected also as a transient at Rancho La Arizona ["Saric"], September 15, 1929. Extreme dates are September 15 (Rancho La Arizona) and "April" (Guaymas).

\section{VIREO BELLII ARIZONAE RIDGWAY}

\section{ARIZONA Vireo}

Vireo bellii arizonae Ridgway, Proc. Biol. Soc. Wash., 16, No. 28, Sept. 30, 1903, 108 (Tucson, Arizona); ibid., 1904, 207 (Sonora).-Thayer and Bangs, 1906, 20 (Opodepe).-Oberholser, 1917, 322 (Sonora).- -van Rossem, 1931c, 280 (San Javier; Saric; Obregon; Tesia; Chinobampo; Guaymas; Tobari Bay); 1934d, 466 (Oposura; Guaymas).-Hellmayr, 1935, 124 (Sonora).-Huey, 1942, 370 (Dowling Well).

Vireo belli arizonae Bailey, 1928, 601 (Sonora).

Vireo pusillus (not of Coues) Belding, 1883, 343 (Guaymas).-Brewster, 1902, 176 (Oposura).

Summer visitant in Lower Sonoran and Tropical zones practically everywhere. The westernmost recorded northern locality is Dowling Well on the boundary May 10, 1939, although this is, technically, "50 yards" within Arizona territory. Resident in the Tropical zone in the southern part of the State, or even (casually?) as far north as Ures in the Sonora River valley (January 31, 1933; Dickey coll.). An unpublished summer locality in the northeast is Pilares, June 24 and July 1, 1935 (Univ. Mich.). Arrival and departure dates for northern localities are April 16 (Magdalena; Dawson notes) and September 16 (Rancho La Arizona).

\section{Vireo solit arius plumbeus Coues}

\section{Plumbeous Virfo}

Vireo plumbeus Coues, Proc. Acad. Nat. Sci. Phila., 1866, 74 (Fort Whipple, Arizona).

Vireo solitarius plumbeus van Rossem, 1931c, 281 (Tesia; Chinobampo); 1934d, 467 (Alamos; Nacozari). 
In all probability a summer visitor to the Transition zone in the mountains of the northeastern part of the State. The single record for that season was taken in the San Luís Mountains by Mcarns. Winter visitant, apparently not uncommon, on the Tropical zone coastal plain and adjacent foothills from the Mayo River valley southward. Detected but once as a transient north of the winter area; Nacozari, March 24, 1887, a circumstance which indicates the mountains rather than lower levels as the main migration route. Additional localities are Camoa, February 29; Chinobampo, March 4, 1931 (Bishop coll.); Agiabampo, April 20, 1933 (Lamb coll.); San Luís Mountains, July 5, 1892, on which date Mearns was definitely on the Mexican side of the boundary.

\section{VIREO SOLITARIUS PINICOLUS VAN ROSSEM}

\section{Sierra Maitre Virfo}

Vireo solitarius pinicolus van Rossem, Bull. Mus. Comp. Zoöl., 77, No. 7, Dec., 1934, 467 (Mound Valley, Chihuahua, México); ibid.. in text (Mina Abundancia).

Common summer visitant in high Upper Sonoran and Transition zones in the southeastern mountains, north at least to latitude $28^{\circ} 30^{\prime}$. In addition to the initial series from Mina Abundancia, specimens have been examined from Trinidad, April 17, 1888 (Brit Mus.), and Rancho Santa Bárbara, June 7 to 11, 1937, where breeding commonly in oak-pinesycamore associations above 4,500 feet (Dickey coll.; van Rossem notes). Presumably this race is migratory; at any rate no fall or winter specimens have been collected in Sonora, nor in adjacent areas in Chihuahua after early September. The earliest spring record is April 13 (Mina Abundancia).

\section{Vireo solitarius cassinil Xantus}

\section{CASSIN Virfo}

Vireo cassinii Xantus, Proc. Acad. Nat. Sci. Phila., 1858, sig. 7-9, April-May [May 8], 117 (Fort Tejón, California).

Vireo solitarius cassinii van Rossem, 1931c, 281 (Tecoripa; Saric; Chinobampo); 1934d, 466 (Alamos: Mina Abundancia; Nacozari; Oposura).

Vireo solitarius cassini Allen, 1893a, 40 (Cachuta).-Bailey, 1928, 602 (San Luis Mountains).

Common spring and fall transient through the eastern foothills and mountains; scemingly, also, a winter visitant in small numbers in the Tropical zone southerly. Additional stations are San Bernardino Ranch, 
September 2, 1892; Cajón Bonito Creek, September 27, 1893 (Mearns' notes). Fall dates are from August 24 (Rancho La Arizona) to September 27 (Cajón Bonito Creek); spring dates are from March 9 (Camoa; Bishop coll.) to May 30 (Oposura), the latter almost certainly belated migrants. Winter dates, which probably come in that category rather than that of early migrants, are February 13 (Álamos) and February 21 (Chinobampo).

\section{ViREo oliVACEUS hypoleucus VAN ROSSEM and Hachisuka}

\section{NORTHERN Yellow-GREFN Vireo}

Vireo virescens bypoleucus van Rossem and Hachisuka, Proc. Biol. Soc. Wash., 50, Sept. 30, 1937, 159 (San Francisco Cañon, eastern boundary of Sonora at lat. $27^{\circ}$ N., México); ibid., in text (Oposura; Rancho Santa Barbara; Guirocoba; Tesia).

Vireo olivaceus bypoleucus Zimmer, 1941, 4 (crit.).

Vireo flavovividis hypoleucus Wetmore, 1943, 308, in text (char.; crit.).

Vireosylua flavoviridis flavoviridis (not Vireosylvia flavoviridis Cassin) Peters, 1931a, 576 (Sonora).

Vireo olivaceus flavoviridis van Rossem, 1934d, 467 (Oposura).-Moore, 1938a, Sonora; crit.).

Common summer visitant in Tropical, Sonoran, and even, locally, in lower parts of the Transition zones in the southern part of the State, north, perhaps only casually, to Oposura or the Sierra de Oposura. Although not uncommon to an altitude of 5,500 feet, the metropolis seems to be the Tropical zone foothills below about 1,500 feet. The earliest arrival date is May 29 (San Francisco Cañon). There are no fall departure data. ${ }^{54}$

\section{VIREO GILI'US SW AINSONII BAIRD}

\section{WESTERN WARBLING VIREO}

Vireo suainsonii Baird, Rep. Expl. and Surv. R. R. Pac., 9, 1858, xxxxv [=xxxv], 336 (Petaluma, Cal.[ifornia]).

Vireo gili'us su'ainsonii van Rossem, 1931c, 228 (Tecoripa; Saric; San Javier; Tesia; Guirocoba; San Jose de Guaymas); 1934d, 467 (Alamos; Nacozari; Oposura).-Hellmayr, 1935, 151 (northern Sonora).

Vireo gilv'us surainsoni A.O.U. Comm., 1931, 279 (northern Sonora).-Huey, 1942, 370 ("April 22 and May 14" [=Quitovaquito; Gray's Ranch; Dowling Well]).

${ }^{54}$ The late spring migration of bypoleucus takes it in breeding condition through the range of flavoviridis. a factor not generally appreciated. The differences between the two are considerable when knou'n breeding series from Central America and Sonora are compared. 
Vireo gilva surainsoni Bailey, 1928, 605 (northern Sonora).

Vireosylva gilva swainsoni A.O.U. Comm., 1910, 299 (northern Sonora).

Common migrant everywhere at lower levels. Winters, apparently rarely, in the extreme south. Some specimens or records not cited above are Guaymas, March 5 to 27, 1905 (Mus. Comp. Zoöl.); San José Mountains, August 9, 1893, and October 2, 1892 (U. S. Nat. Mus. catl.); boundary at Monument 90, September 14, 1892; Cajón Bonito Creek, September 8, 1893 (Mearns' notes) ; Agiabampo, May 18, 1937 (Dickey coll.). Extreme fall dates are August 9 and October 2 (San José Mountains). Spring extremes are March 5 (Guaymas) and June 11 (Oposura). The single winter record is from Âlamos, February 9, 1888.55

\section{VIREO GILVUS BREWSTERI (RIDGWAY)}

\section{Chinuahua Warbling Vireo}

Vireosylu'a gilva brewsteri Ridgway, Proc. Biol. Soc. Wash., 16, Sept. 30, 1903, 108 (Bravo, Chihuahua, México); 1904, 158 (Mina Abundancia).

Vireo gilvus brewsteri van Rossem, 1934d, 468 (Mina Abundancia).

Summer visitant in the high Upper Sonoran and Transition zones in the southeastern mountains. The northern limits of the range are unknown; however, it extends north to $28^{\circ}$ in adjacent Chihuahua (Bravo). Aside from Mina Abundancia, the only Sonora locality seems to be Rancho Santa Bárbara, where brewsteri was found to be breeding uncommonly in the oak-pine association above 5,000 feet in early June, 1937 (Dickey coll.: van Rossem notes). The earliest arrival date is April 9 (Mina Abundancia); there are no fall departure data for Sonora.

\section{Family Parulidae Wood Warblers VERMIVORA CELATA CELATA (SAY)}

\section{EASTERN ORANGE-CROWNEI) WARBLER}

Sylvia celata Say, in Long, Exped. Rocky Mts., 1, 1823, 169, note (Engineet Cantonment near Council Bluff=Omaha, Nebraska).

Vermivora celata celata van Rossem, 1931c, 282 (San Javier; Obregon; Tesia; Chinobampo; Guirocoba); 1934d, 468 (Alamos; Oposura).

Fairly common winter visitant southerly; probably occurs generally as a transient. Dates range from November 7 to April 22.

\footnotetext{
${ }^{55}$ Although northern Sonora is generally considered to be within the breeding range of suitinsonii, such may not be the case. June 11 seems a very late date for transients; however, specimens taken at Rancho La Arizona as late as
} 


\section{VERMIVORA CELATA ORESTERA OBERHOLSER}

\section{Rocky Mountain Orange-Crowned Warbler}

Vermivora celata orestera Oberholser, Auk, 22, No. 2, April, 1905, 243 (Willis, New Mexico).—van Rossem, 1931c; 282 (Tesia; Tecoripa; San Javier); 1934d, 468 (Oposura; Nacozari; Granados).

Winter visitant in the southern part of the State. Detected as a transient at but one northern point,-Nacozari, March 29, 1887. However, distribution during migrations is probably general, particularly in the central and eastern areas. Two additional stations are Kino Bay, December 28, 1931 (Dickey coll.), and Camoa, February 16 and 18, 1931 (Bishop coll.). There are no records for fall; the latest spring record is May 6 (Oposura).

\section{VERMIVORA CELATA LUTESCENS (RIDGWAY)}

\section{LUTESCENT WARBLER}

Helminthophaga celata var. lutescens Ridgway, Amer. Journ. Sci., ser. 3, 4, No. 23, Nov. [Dec.], 1872, 457 (Pacific Coast from Kadiak to Cape San Lucas $=$ Fort Kenai, Alaska).

Vermivora celata lutescens van Rossem, 1931c, 282 (Tecoripa; San Javier; Saric; Obregon; Tesia; Chinobampo); 1932, 142 (Tiburon Island); 1934d, 486 (Guaymas; Alamos; Nacozari).-Huey, 1935, 256 (Punta Peñascosa).

Common winter visitant from near the head of the Gulf (Punta Peñascosa) southward, though apparently most numerous in the Tropical zone lowlands. During migrations it occurs generally over most of the State. Additional records are from Kino Bay, February 18, 1935 (Nat. Hist. Mus.); 2 miles south of Magdalena, March 26, 1936; Tiburón Island, April 3, 1936 (Mus. Vert. Zool.) ; San Pedro River on the boundary, October 11, 1892 (U. S. Nat. Mus.). Extreme dates are September 16 (Rancho La Arizona) and April 16 (Oposura). ${ }^{56}$

May 31 were definitely (fide Wright) in this category. In view of the endorsement of Vireo gilvus leucopolius (Oberholser) by Sibley (Condor, 1940, pp. 255-258), Miller (Condor, 1942, pp. 262-264), and most recently by the A.O.L' Committee (1944), I have re-examined all the material in local collections in an attempt to distinguish this proposed race and to identify the Sonora transients accordingly. Great Basin birds in summer plumage perhaps average very slightly paler, but there is so much variation that attempts to identify individual migrant specimens are not (to me) feasible.

56These three races of the Orange-crowned Warbler seemingly occur in much the same manner and proportionate numbers as on the Baja California peninsula. Of the three, lutescens is by far the commonest and approximates orestera and celata combined, the number of each examined being 30,19, and 13, respectively. 


\section{VERMIVORA RUFICAPILLA RIDGWAYI VAN ROSSEM}

\section{Calaveras Warbler}

Vermivora ruficapilla ridgwayi van Rossem, Proc. Biol. Soc. Wash., 42, June 25, 1929, 179 [new name for $V$. r. gutturalis (Ridgway), pre-occupied] (East Humboldt Mountains, Nevada); 1931c, 281 (San Javier; Saric; Chinobampo); 1934d, 469 (Nacozari; Alamos; Oposura).

Fairly common migrant through the central and castern foothills. Fall dates range from August 17 to September 16 (Rancho La Arizona): detected more frequently in spring, at which season extreme dates are March 10 (Álamos) and May 13 (Oposura). There is one winter record, possibly that of an early migrant, from Chinobampo in the southern part of the State, February 19, 1930 (Dickey coll.).

\section{VERMIVORA VIRGINIAE (BAIRI))}

\section{VIRGINIA WARBIF:R}

Helminthophaga virginiae Baird, Birds No. Amer., Atlas, 1860, vii, note, pl. 79, fig. 1 (Fort Burgwyn, New Mexico).

Vermivora virginiae van Rossem, 1931c, 281 (Guirocoba); 1934d, 469 (Oposura ).

Detected as a decidedly uncommon migrant through the eastern foothills. The three localities of record are Guadalupe Cañon, August 31, 1893 (U. S. Nat. Mus.) ; Oposura, four specimens April 12 to May 10, 1887 (Mus. Comp. Zoöl) ; Guirocoba, May 7, 1930 (Dickey coll.).

\section{VERMIVORA LUCIAE (COOPER)}

\section{LUCY WARBI.ER}

Helminthophaga luciae J. G. Cooper, Proc. Calif. Acad. Sci., 2, sig. 8 [before Dec.], 1861, 120 (near Fort Mojave, in the Colorado Valley, [Arizona]).A.O.U. Comm., 1895, 270 (Sonora).

Helminthophila luciae Jones, 1900, 49 (Sonora).-Ridgway, 1902, 473 (Sonora).

H. [elminthophila] luciat Ridgway, 1887d, 490 (Sonora).-Coues, 1903, 313 (Sonora).

Verminora luciae Sharpe, 1909, 99 (Sonora).- van Rossem, 1931c, 281 (Saric; Tecoripa; Tesia); 1934d, 469 (Alamos; Nacozari; Oposura).-Huey, 1942, 370 (Gray's Ranch on the boundary [Arizona side]).

Common summer visitant in the Lower Sonoran zone in the northern part of the State, south at least to latitude $29^{\circ} 45^{\prime}$ in the Moctezuma River valley; also occurs as a transient through more southerly localities. Some unpublished records are Magdalena, March 26, 1936 (Mus. Vert. 
Zoöl.) ; Colorado River at Monument 204, March 14, 1894 (U. S. Nat. Mus.) ; Guadalupe Cañon at Monument 72, August 26, 1893 (Mearns' notes), the two last being, probably, the basis of earlicr citations for Sonora. The earliest arrival date is March 10 (Alamos); the latest fall date is August 29 (Rancho La Arizona).

\section{VERMIVORA SUPERCILIOSA PALLIATA VAN ROSSEM}

\section{JALISCO WARBLER}

Vermivora superciliosa palliata van Rossem, Proc. Biol. Soc. Wash., 52, February 4, 1939, 12 (Sierra Nevada de Colima, Jalisco, México).

Vermivora superciliosa mexicana (not Parula mexicana Bonaparte or Compsothlypis mexicana Cabanis) van Rossem, 1931d, 469 (Mina Abundancia; crit.).

Known from a single specimen taken by Frazar at Mina Abundancia on April 9, 1888. The species is common in the Transition zone in Chihuahua at various localities very close to the Sonora boundary.

\section{PARUI.A PITIAYUMI PULCHRA (BREWSTER) \\ NORThern Olive-Backen) Warbler}

Compsotblypis pulchra Brewster, Auk, 6, No. 2, April, 1889 [separates issued Jan. 31], 93 (Hacienda de San Rafael, Chihuahua [=Sonora), México).

Compsotblypis pitiayumi pulchra Ridgway, 1902, 491 (Hacienda de San Rafael).- Thayer and Bangs, 1906, 21 (l.a Chumata).-Chapman, 1925, 198 (Sonora).—van Rossem, 1931c, 282 (Guirocuba); 1934d, 470 (Hacienda de San Rafael; Mina Abundancia).-Hellmayr, 1935, 350 (Hacienda de San Rafael).

Common summer visitant in the foothills and mountains in the extreme southeast. Also occurs, apparently as an isolated colony, in the Sierra de San Antonio in the northcentral part of the State. An oak association rather than zonal considerations seems to be the factor governing distribution, at least in the southeast. Altitudinal limits so far determined are 1,500 feet (near Guirocoba) and 5,500 feet at Rancho Santa Bárbara. The earliest spring date is April 20 (Guirocoba and San Rafacl). There are no fall departure data for Sonora, nor even for adjacent localities in Chihuahua. ${ }^{57}$

${ }^{57}$ The presence of this warbler at a spot so distant from the normal range as the Sierra de San Antonio seems extraordinary and perhaps is a case of isolation paralleling those of Plutypsaris aglaiae and Tyrannus crassirostris. It is to be remarked that Cahoon did not encounter the species in his extensive work in all zones about "Oposura," nor did Lloyd in his route through the southeast from latitude $28^{\circ} 30^{\circ}$ southward. The single specimen collected by Brown at La Chumata (May 26, 1905) is not typical of pulcbra and probably is representative of an undescribed race. 


\section{Peucedramus olivaceus arizonae Miller AND Griscom}

\section{Arizona Olive Warbler}

Peucedramus olivaceus arizonae Miller and Griscom, Amer. Mus. Novitates, No. 183, July 18, 1925, 10 (Paradise, Chiricahua Mts., Arizona).-van Rossem, 1934d, 470 (Mina Abundancia).

Presumably resident in the Transition zone of the mountains along the eastern boundary. The few specimens taken within Sonora limits, however, represent only April and June. Three taken by Frazar at Mina Abundancia, April 18 and 23, 1888; one taken by Lloyd at Yécora, "8500 ft.," April 16, 1888; one taken by van Rossem (not preserved) at Rancho Santa Bárbara, 5,500 feet, June 9 (others seen June 7 and 16), 1937, are the only records.

\section{Dendroica aestiva RUbiginosa (Pallas)}

\section{Alaska Yellow Warbler}

Motacilla rubiginosa Pallas, Zoogr. Rosso-Asiatica, 1, 1811, 496 (Kodiak Island [Alaska]).

Dendroica aestiva rubiginosa van Rossem, 1931c, 282 (Guaymas; San Jose de Guaymas); 1934d, 470 (Mina Abundancia).-Hellmayr, 1935, 365 (Guaymas).

Probably a fairly common transient at lower levels throughout the State, although the scattered records to date are all for the spring migration. Further specimens have been examined from Gray's Well on the boundary May 12, 1939 (Nat. Hist. Mus.) ; Masocari Island, May 15, 1937; Agiabampo, May 18, 1937 (Dickey coll.) ; Guirocoba, June 8, 1941 (Sheffler coll.), and June 30, 1931 (Bishop coll.). The last seems an extremely late date but there is no doubt as to the identity. Extreme dates are April 16 (Mina Abundancia) and June 30 (Guirocoba).

\section{DENDROICA AESTIVA MORCOMI COALE}

\section{WESTERN Yellow WARBLER}

Dendroica aestiva morcomi Coale, Bull. Ridgway Orn. Club, No. 2, April, 1887, 82 (Fort Bridger, Wyoming).-Brewster, 1888b, 139, in text (Sonora).van Rossem, 1931c, 283 (Saric; Guirocoba; San Jose de Guaymas); 1934d, 470 (Oposura).

Fairly common transient, probably generally distributed since the four localities of record are widely scattered geographically. Spring dates are from April 30 (Oposura) to May 25 (Rancho La Arizona ["Saric"]). Fall dates are from July 31 to September 9 (Rancho La Arizona). 


\section{DENDROICA AESTIVA BREWSTERI GRINNELL}

\section{CaLifornia Yellow WarbleR}

Dendroica aestiva brewsteri Grinnell, Condor, 5, No. 3, May 14, 1903, 72 (Palo Alto, California).- van Rossem, 1931c, 283 (Guirocoba).-Hellmayr, 1935, 366 (Guirocoba).

Detected only as a spring transient at Guirocoba, May 7 and 9, 1930.

\section{DENDROICA AESTIVA SONORANA BREWSTER}

\section{SONORA YeLLOW WARBLER}

Dendroica aestiva sonorana Brewster, Auk, 5, No. 2, April, 1888, [separates published Feb. 10], 137 (Oposura, Sonora, México); 1902, 180 (Alamos).Chapman, 1888, 400 (Sonora).-Ridgway, 1896, 608 (Sonora); 1902, 512 (Oposura).-A.O.U. Comm., 1910, 311 (Sonora); 1931, 286 (Sonora).-Dawson, 1923, 460 (Sonora).-Bailey, 1928, 614 (Sonora).-Kuroda, 1930, 121, in text (Sonora).--van Rossem, 1931c, 283 (Saric; Tesia); 1934d, 470 (Alamos; Nacozari; Oposura).-Hellmayr, 1935, 366 (Sonora).

Dendroeca sonorana Sharpe, 1909, 102 (Sonora).

D. [endroeca] ae.[stiva] sonorana Coues, 1903, 319 (Sonora).

Dendrioca [sic] aestiva sonorana Bangs, 1930, 357 (Oposura; type).

Dendroica petecbia sonorana Aldrich, 1942, 449 (nomencl.).

Fairly common summer visitant in suitable Sonoran zone localities (chiefly willow-cottonwood association) across the State northerly. Southern breeding limits at present known are the Colorado River delta in the extreme west, Magdalena centrally, and Oposura in the east. Occurs as a transient in more southern localities. Further specimens have been examined from Cajón Bonito Creek, July 3, 1822; San Bernardino Ranch on the boundary, August 21, 1892 and August 23, 1893 (U. S. Nat. Mus.) ; Guaymas, March 10, 1905 (Mus. Comp. Zoöl.) ; Pilares, June 24 and July 11, 1935 (Univ. Mich.). Found breeding at Colonia Independencia, May 3, 1937 (van Rossem), and at Magdalena, May 6, 1925 (Dawson notes). The earliest arrival date is March 9 (Alamos); the latest for fall is August 24 (Rancho La Arizona).

\section{DENDROICA ERITHACHORIDES RHIZOPHORAE VAN ROSSEM}

\section{Sonora Mangrove Warbler}

Dendroica erithachorides rbizophorae van Rossem, Trans. San Diego Soc. Nat. Hist., 8, No. 10, Aug. 24, 1935, 67 (Tóbari Bay, Sonora, México); ibid., in text (Tepopa Bay; Kino Bay; Guaymas; Agiabampo).

Dendroica erithachorides castaneiceps (not Dendroica bryanti castaneiceps Ridgway) van Rossem, 1931, 282 (Tobari Bay; Guaymas; Kino Bay; Tepopa Bay).

Dendroica petechia castaneiceps Hellmayr, 1935, 380, part (Tobari Bay, etc.). 
Common summer visitant to the Tropical zone coast from the Sinaloa boundary north of Tepopa Bay. Here, as elsewhere, the range of this warbler is rigidly confined to the mangrove association and therefore stops abruptly at Tepopa Bay, the northern limit of mangroves on the Sonora coast. Additional specimens have been examined from Agiabampo and Masocari Island, where breeding commonly May 14 to 16, 1937 (Dickey coll.). There are no winter records in spite of extensive collecting at that season from Guaymas northward. Permanent residence at more southerly points is to be assumed but is not yet demonstrated.

\section{DENDROICA MAGNOLIA (WILSON)}

\section{MAGNOLIA WarbLeR}

Sylvia magnolia Wilson, Amer. Orn., 3, 1811, 63, pl. 23, fig. 2 (Fort Adams, Mississippi).

Dendroica magnolia van Rossem, 1934d, 470 (Alamos).

One record, that of a specimen taken by Frazar at Álamos on February 27,1888 , and now in the Museum of Comparative Zoölogy.

\section{DENDROICA CORONATA HOOVERI MCGREGOR}

\section{Alaska Myrtle Warbler}

Dendroica coronata hooveri McGregor, Bull. Cooper Orn. Club, 1, No. 2, March, 1899, 32 (Palo Alto, California).--van Rossem, 1931c, 283 (El Doctor; Tecoripa).

Winter visitant in the Lower Sonoran zone; probably not uncommon in spite of the scarcity of records. One specimen taken by Wright at El Doctor in the Colorado delta, February 3, 1929, and two taken by the same collector at Tecoripa on March 30, 1929, are the only certain occurences. Lamb (notes) observed the species as "common" at San José de Guaymas on January 10, 1933, but took no specimens. ${ }^{58}$

${ }^{58}$ The race hooveri appears to me to be easily recognized. In winter plumage it is decidedly grayer dorsally; ventrally it is much whiter and lacks much of the yellowish or pale buffy suffusion of coronata. In fact hooveri is so close to auduboni at this season that some specimens can be distinguished from the whiter throated examples of the latter species only with difficulty. The specific character of the number of tail spots is not infallible, for hooveri frequently has traces of a fourth spot and auduboni occasionally has only three. The supposed slightly larger size of hooveri as compared with coronata is evident in series but is not reliable for determining individual specimens. The above remarks concerning the auduboni-booveri similarity in the general coloration of the winter plumages are not to be construed as an argument of specific identity; they concern solely the subspecific distinctness of hooveri as compared with coronata. 


\section{DENDROICA AUDUBONI AUDUBONI (TOWNSEND)}

\section{AUdubon Warbler}

Sylvia Auduboni J. K. Townsend, Journ. Acad. Nat. Sci. Phila., 7, Pt. 2, [Nov. 21, 1837], 191 (forests of the Columbia River=Fort Vancouver, Washington).

Dendroica auduboni Brewer, 1874, 229, part, in text (Sonora).-Allen, 1893a, 40 (Los Cuevas; Oputo).-Price, 1899, 93 (lower Colorado River).-Stone and Rhoads, 1905, 685 (Colony).

Dendroica auduboni auduboni Oberholser, 1921, 240 (Sonoyta; Guaymas; Taronato Creek).--van Rossem, 1931c, 283 (El Doctor, part; Tecoripa, part; Obregon, part; Tesia, part; Chinobampo, part; 15 miles S. of Nogales); 1934d, 471 (Alamos; Mina Abundancia; Nacozari; Oposura).-Huey, 1935, 256 (Punta Peñascosa).

Dendroica audubonii Baird, 1858, 273, part (San Bernardino); 1859, 10, part (San Bernardino).

A common winter visitant nearly everywhere in Sonoran and Tropical zones, although, oddly enough, not yet reported from any of the islands. The earliest fall date is September 3 (Las Cuevas); the latest departure date is May 23 (Oposura). Three record stations not cited above from which specimens have been examined are Kino Bay, February 18, 1935; Agiabampo, May 16, 1937 (Dickey coll.) ; Camoa, February, 1930 (Bishop coll.).

\section{DENDROICA AUDUBONI MEMORABILIS OBERHOLSER}

\section{ROCKY MOUNTAIN WARBLER}

Dendroica auduboni memorabilis Oberholser, Ohio Journ. Sci., 21, No. 7, June 6, 1921, 243 (Ward, Boulder County, Colorado) ; ibid., in text (mouth of Colorado River; Mon. 89).- van Rossem, 1931c, 284 (San Javier); 1934d, 471 (Guaymas; Alamos; Oposura).

Dendroica auduboni auduboni (not Sylvia auduboni Townsend) van Rossem, 1931c, 283, part (El Doctor, part; Tecoripa, part; Pesqueira; Obregon, part; Tesia, part; Chinobampo, part).

Common winter visitant throughout the Sonoran and Tropical zones, in much the same manner and numbers as the nominate race. The earliest fall record is September 24 (Monument 89). The latest date in spring is May 23 (Oposura).$^{59}$

\footnotetext{
${ }^{59} \mathrm{~A}$ re-appraisal of the series in the Dickey and other collections previously recorded as auduboni shows that approximately half are memorabilis. It is not unlikely that some, at least, of the specimens listed by other authors are memorabilis, but it has not been practicable to examine every individual so recorded. However, the lapse is not vitally important since the two races occur commonly and in approximately equal numbers over the same local territory.
} 


\section{DENDROICA NIGRESCENS (TOWNSEND)}

\section{BLACK-THROATED GRAY WARBLFR}

Sylvia nigrescens J. K. Townsend, Journ. Acad. Nat. Sci. Phila., 7, Pt. 2, [Nov. 21, 1837], 191 (Vicinity of the Columbia River=near Fort William [Portland], Oregon).

Dendroica nigrescens Bailey, 1928, 622 (San Luis Mountains); van Rossem, 1931c, 284 (San Javier; Tesia; Saric; Chinobampo; Guirocoba); 1934d, 471 (Alamos; Mina Abundancia; Nacozari; Oposura).-Hellmayr, 1935, 392 (Sonora).

Summer visitant in the San Luís Mountains in the extreme northeast and a common migrant through the foothill region in the eastern half of the State. Winters sparingly in the Tropical zone in the extreme south; Tesia in the Mayo River valley, December 4 and 9, 1929, and Alamos, February 4, 1888. Fall data are limited to the San José Mountains, August 9, 1893 (U. S. Nat. Mus.) ; Cajón Bonito C.reek, September 8, 1892 (Mearns notes) ; Rancho La Arizona, August 28 to September 13, 1929. Spring occurrences are much more common, the earliest being March 3 at Chinobampo, the latest May 17 at Magdalena where also observed rather frequently by Dawson (notes) in late April and early May, 1925. It is obvious that the main migration route avoids the northwestern desert region, although contributory data from adjacent areas in Baja California and Arizona suggest that limited numbers almost certainly occur there. ${ }^{60}$

\section{DENDROICA TOWNSENDI (TOWNSENI))}

\section{TOWNSEND WARBLER}

Sylvia Tounsendi "Nuttall" J. K. Townsend, Journ. Acad. Nat. Sci. Phila., 7, Pt. 2 [Nov. 21, 1837], 191 (forests of the Columbia River=Fort Vancouver, Washington ).

Dendroica tounsendi van Rossem, 1931c, 284 (San Javier; San Jose de Guaymas); 1934d, 471 (Mina Abundancia; Oposura).

Detected only as a rather uncommon spring migrant. Frazar took eight specimens at Mina Abundancia between April 11 and 27, 1888; Wright, three at San Javier, April 23 to 25, 1929; Bancroft, two at San José de Guaymas, May 8, 1930; Cahoon, one at Oposura, May 31, 1881. There are no fall records, and it is possible that the main flight at that

\footnotetext{
61)After careful consideration, I am unable to endorse Obcrholser's (1930b, 101) proposal to restrict the name nigrescens to the northwest coast, and therefore follow Hellmayr $(1935,392)$ and others in rejecting balseii as a recognisable race.
} 
season (perhaps in the spring also) passes along the higher mountains. This is indicated by the fact that Frazar collected forty-six specimens at Jesus María, Chihuahua, between August 31 and September 12.

\section{DENDROICA OCCIDENTALIS (TOWNSEND)}

\section{HERMIT WARBLER}

Sylvia occidentalis J. K. Townsend, Journ. Acad. Nat. Sci. Phila., 7, Pt. 2 [Nov. 21, 1837], 190 (forests of the Columbia=Fort Vancouver, Washington).

Dendroica occidentalis van Rossem, 1931c, 284 (Saric; San Javier); 1934d, 472 (Mina Abundancia).

Apparently a rather uncommon spring migrant through the central and eastern foothills. Detected in but three localities: eleven specimens taken by Frazar at Mina Abundancia between April 9 and 27, 1888; one taken by Wright at San Javier, April 21, 1929; one taken by Wright at Rancho La Arizona, May 8, 1929. As in the case of Dendroica townsendi there are no records for the fall migration, and again, as in that species, the vast majority probably travel south along the higher mountains. Frazar, for example, collected forty-nine at Jesus María, Chihuahua, between August 23 and September 8. An Arizona record from the boundary at Gray's Ranch, May 13, 1939 (Huey, 1942, p. 371), indicates that casuals may be expected almost anywhere.

\section{DENDROICA GRACIAE GRACIAE BAIRD}

\section{GRACE WARBLER}

Dendroica graciae "Coues MSS." Baird, Rev. Am. Birds, April, 1865, 210 (Fort Whipple, Arizona).-Jouy, 1894, 777 (32 miles S. of Nogales).-A.O.U. Comm., 1895, 278, part (Sonora).-Bailey, 1928, 621 (Sonora).-Dawson, 1923, 2098 (Sonora).

Dendroica graciae graciae Ridgway, 1902, 584 (32 miles S. of Nogales).A.O.U. Comm., 1931, 291 (Sonora).- van Rossem, 1934d, 472 (Mina Abundancia; Oposura).-Hellmayr, 1935, 400 (Sonora).

Summer visitant from the Pajaritos Mountains (Sierra de Huacomea) eastward, and south along the eastern ranges the full length of the State. Further stations are the San José Mountains, August 7, 1892, and August 9, 1893 (Mearns notes) ; Trinidad, April 17, 1888 (Brit. Mus.); Rancho Santa Bárbara, June 9, 1937 (Dickey coll.). The earliest arrival date is April 11 (Mina Abundancia). 


\section{SEIURUS MOTACILLA (VIEILLOT)}

\section{LOUISIANA WATER-THRUSH}

Turdus motacilla Vieillot, Ois. Amer. Sept., 2, 1807 [1808?], 9, pl. 65 (Kentucky).

Seiurus motacilla van Rossem, 1933b, 199 (Guirocoba); 1934d, 472 (Alamos).

Uncommon in winter and early spring in the Tropical zone foothills in the extreme southeast. Four records: three taken by Frazar at Alamos, February 7, March 8 and 28, 1888 (Mus. Comp. Zoöl.); one taken by Wright at Guirocoba, March 23, 1931 (Bishop coll.).

\section{SEIURUS NOVEBORACENSIS NOTABILIS RIDGWAY}

\section{GRINNELL WATER-THRUSH}

Siurus [sic] naevius notabilis Ridgway, Proc. U. S. Nat. Mus., 3, March 27, 1880, 12 (Black Hills [= shores of Como Lake, Carbon Co.], Wyoming).

Seiurus noveboracensis notabilis van Rossem, 1931c, 284 (Tobari Bay).-McCabe and Miller, 1933, 197 (San Bernardino River).

Spring and fall migrant of uncertain abundance. One specimen was taken at Tóbari Bay, April 26, 1930; several others, however, were seen the same day (Dickey coll.; van Rossem notes). The single fall record is that of three specimens taken by Mearns and Holzner on the San Bernardino River, September 4, 1892. ${ }^{61}$

\section{OPORORNIS FORMOSUS (WILSON)}

\section{KENTUCKY WARBLER}

Sylvia formosa Wilson, Amer. Orn., 3, 1811, 85, pl. 25, fig. 3 (Kentucky).

One casual record, that of a non-breeding male of the previous year taken by van Rossem at Rancho Santa Bárbara on June 12, 1937 (Dickey coll.).

\section{OPORORNIS TOLMIEI (TOWNSEND)}

\section{MACGILLIVRAY WARBLER}

Sylvia tolmiei J. K. Townsend, Narr. Journ. Rocky Mts., April, 1839, 343 (Columbia River=Fort Vancouver, Washington).

Oporornis tolmiei van Rossem, 1931c, 284 (San Javier; Saric; Chinobampo; Guirocoba; Guaymas); 1934d, 472 (Alamos; Mina Abundancia; Nacozari; Oposura).-Huey, 1942, 371 (Dowling Well).

61It is probable that the earliest name for this race is Seiurus tenuirostris Swainson. While the original description (Philos. Mag., n. s., 1, 1827: 360) is 
Common, rather generally distributed migrant. Winters, apparently rarely, in the southern part of the State. Additional records are from Cerro Gallardo, August 14, 1893; Cajón Bonito Creck, September 8 and 28, 1893; San Iuís Mountains, September 6 and 25, 1893 (Mearns notes). Fall migration dates extend from August 14 (Cerro Gallardo) to September 28 (Cajón Bonito Creck). Extreme spring dates are March 7 (Chinobampo) and May 22 (Rancho La Arizona). The only two winter records are from Álamos, February 7, 1888, and San José de Guaymas, January 9, 1933 (Lamb notes).

\section{GEOTHLYPIS TRICHAS OCCIDENTAIIIS BRFWSTER}

\section{WESTERN YFILIOW-THROAT}

Geothlypis trichas occidentalis Brewster, Bull. Nuttall Orn. Club, 8, No. 3, July, 1883, 159 (Truckee River, Nevada).- van Rossem, 1931c, 285 (Tecoripa; Tesia; Guirocoba); 1934d, 472 (Guaymas; Alamos; Hacienda de San Rafael; Nacozari; Oposura; Granados).

Geotblypir trichas modesta (not of Nelson) Ridgway, 1902, 672, part (Ortiz [fide J. W. Aldrich]).

Geothlypir trichas arizela Brewster, 1902, 186, part (Oposura; Guaymas).

Common migrant and winter visitant to Sonoran and Tropical zones throughout the State. Recorded from many localitics, to which may be added Rancho La Arizona, May 9, 1937 (Dickey coll.) ; Nuri, April 28, 1888 (Brit. Mus.) ; San Bernardino Ranch, August 26 to September 8, 1892; San Pedro River, October 7 to 15, 1892 (U. S. Nat. Mus.) ; Quitovaquita on the boundary (Arizona side), April 28 to 30, 1929 (Huey, 1942, p. 371). Extreme dates of arrival and departure as so far detected are August 26 (San Pedro River) and May 10 (Ortiz). Some kind of yellow-throat was observed in winter in the Colorado delta by Price (1899, p. 93) but the subspecics (recorded as occidentalis) is in doubt.

\section{GEOTHLYPIS TRICHAS SCIRPICOLA GRINNELL}

\section{Tule Yellow-throat}

Geothlypis trichas scirpicola Grinnell, Condor, 3, No. 3, May 15, 1901, 65 (F.1 Monte, I.os Angeles County, California).

Probably a resident in suitable localities along the Colorado River. where not uncommon on the Baja California side of the stream. The only

not identifiable as to subspecies, Swainson in a later publication (Fauna Bor.-Am., 2, 229) affirms the identity of his Mexican and Carleton House specimens and at the same time calls attention to the pale coloration of the under parts as compared with the description of Wilson's aquaticus. 


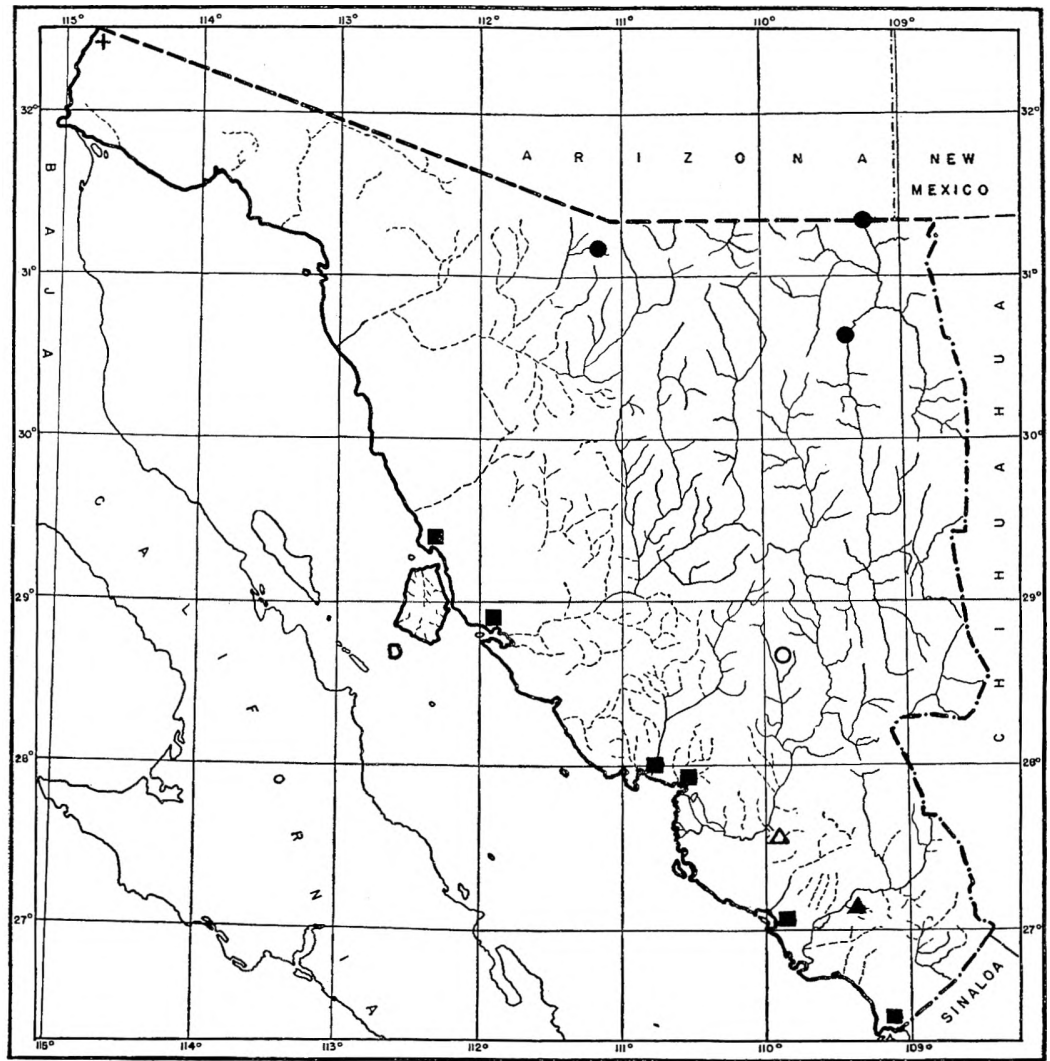

Map 20. Distribution of Geotblypis trichas. Circles, G. t. chryseola; cross, G. t. scirpicola; squares, G. t. modesta; triangles, $G$. t. riparia; hollow figures, winter stations outside established breeding ranges.

specimen collected on the Sonora side seems to be one taken by Mearns and Holzner at Monument 204, March 25, 1894. It is now in the collection of the U. S. National Museum, where examined in July, 1938.

\section{GEOTHLYPIS TRICHAS CHRYSEOLA VAN ROSSEM}

\section{GOLDEN YeLLOW-THROAT}

Geothlypis trichas chryseola van Rossem, Condor, 32, No. 6, Nov. 22, 1930, 298 (Saric [= Rancho La Arizona], Sonora, México); ibid., in text, (Tecoripa); 1931c, 285 (Saric; Tecoripa); 1936, 142 (Sonora); 1941d, 291 (San Bernardino Ranch; Pilares; range).-Hellmayr, 1935, 430 (northcentral Sonora).-A.O.U. Comm., 1944, 459 (Saric). 
Geothlypis trichas occidentalis (not of Brewster) Evermann and Jenkins, 1888, 68 (Magdalena).

Geotblypis trichas scirpicola (not of Grinnell) Dawson, 1923, 505, part (northern Sonora).

Evidently a fairly common resident in suitable localities along fresh water streams from the vicinity of Rancho La Arizona (and very probably from the Altar River valley) eastward across the northern part of the State nearly or quite to the Chihuahua boundary. The southernmost breeding station known at the present time is Pilares in the Bavispe River valley. Yellow-throats seen by Evermann and Jenkins (1888) at Magdalena in June, 1887, most probably were of this subspecies. One specimen taken at Tecoripa, March 3, 1929, (van Rossem, 1931c) indicates a seasonal movement by part, at least, of the population.

\section{GEOTHLYPIS TRICHAS RIPARIA VAN ROSSEM}

\section{Mayo Yellow-THROAT}

Geothlypis trichas riparia van Rossem, Condor, 43, No. 6, Nov. 17, 1941, 292 (Tesia, Mayo River, Sonora, México); ibid., in text (Yaqui River valley).

Geothlypis trichas modesta (not of Nelson) van Rossem, 1931c, 285, part (Tesia; Obregon).

Resident of fresh-water marsh associations in the lower Mayo River valley (Tropical zone) in the extreme southern end of the State; occurs in winter in the lower Yaqui River valley (Ciudad Obregón, November 12, 1929), where also probably resident.

\section{GEOTHLYPIS TRICHAS MODESTA NELSON}

\section{SAN Blas Yellow-THRoat}

Geotblypis trichas modestus Nelson, Auk, 17, July, 1900, 269 (San Blas, Tepic [= Nayarit], México).

Geothylpis trichas modesta van Rossem, 1930g, 289, in text (Agiabampo; Empalme; crit.) ; 1931c, 285, part (Guasimas Lagoon; Empalme; Tobari Bay; Agiabampo); 1941d, 292, in text (Kino Bay; Tepopa Bay; range).-Hellmayr, 1935, 431 (Guaymas).

Geothlypis modesta Sharpe, 1909, 114 (Sonora).

Resident in the narrow strip of Tropical zone salt water associations from the Sinaloa boundary north to Tepopa Bay. Additional specimens have been examined from Agiabampo, April, 1933 (Lamb coll.) ; Kino Bay, December 27, 1931; Tepopa Bay, January 2, 1932 (Dickey coll.). 
What yellow-throat, if any, breeds in tide-marsh associations at the mouth of the Colorado River is unknown.

\section{ICTERIA VIRENS AURICOLLIS (LICHTENSTEIN)}

\section{LONG-TAILED ChAT}

Tanagra auricollis Lichtenstein, Preis-Verz. der . . Vögel . . Mexico . . ., Sept. 1, 1830, 2 (México=City of México $)$.

Icteria virens auricollis van Rossem, 1939d, 156, in text (northern Sonora; Guaymas).

Icteria virens longicauda Renardo, 1886, 118 (Guaymas).-Evermann and Jenkins, 1888, 68 (Magdalena).- van Rossem, 1931c, 285, part (Tecoripa; Guaymas; Saric).

Common summer visitant in Sonoran zone riparian associations in the northern part of the State, south to Guaymas coastwise and at least to Magdalena in the interior. Distribution is, of course, extremely local and largely dependent upon the presence of summer streams. Probably rather generally distributed during migrations, although there is but one southerly record,-Tecoripa, March 28, 1929. Further localities are San Luís and Colonia Independencia in the Colorado delta, May 3, 1937 (van Rossem notes); San Bernardino Ranch, September 4, 1892; San Pedro River, October 15, 1892 (U. S. Nat. Mus. catl.) ; Cajón Bonito Creek, July 1, 1892 ("breeding"; Mearns notes). Arrival and departure dates are March 28 (Tecoripa) and October 15 (San Pedro River).

\section{ICTERIA VIRENS TROPICALIS VAN ROSSEM}

\section{Sonora Chat}

Icteria virens tropicalis van Rossem, Wilson Bull., 51, No. 3, Sept., 1939, 156 (Tesia, Sonora, México); ibid., in text (Agiabampo; Pilares; Mayo River valley [Camoa]).

Icteria virens longicauda (not Icteria longicauda Lawrence) van Rossem, 1931c, 285, part (Agiabampo).

[?] Icteria virens auricollis (not Tanagra auricollis Lichtenstein) van Rossem, 1934d, 472 (Hacienda de San Rafael).

Fairly common summer visitant along permanent streams in the Tropical zone, north in the Moctezuma and Bavispe valleys to Moctezuma and Pilares, and probably to the lower Yaqui River coastwise. Additional specimens have been examined from Moctezuma, September 24 and 26, 1887; Quiriego, April 28, 1888; Río Mayo [near Agua Caliente], May 5, 1888 (Brit. Mus.). This race is possibly resident, although existing dates extend only from April 28 to September 26. 


\section{WILSONIA PUSILLA PUSILLA (WILSON)}

\section{WILSON WARBLER}

Muscicapa pusilla Wilson, Amer. Orn., 3, 1811, 103, pl. 26, fig. 4 (Southern New Jersey).

Wilsonia pusilla pusilla van Rossem, 1934d, 473 (Oposura).

A spring migrant. Five specimens taken by Cahoon at Oposura between the dates of April 28 and May 27, 1887, would seem to place this warbler somewhat out of the casual class. No other examples of pusilla have since been collected in Sonora, in spite of the accumulation of large series of the two western races, though there is a recent record (Oberholser, 1930b, p. 100) for southeastern Arizona.

\section{Wilsonia pusilla pileolata (PAllas)}

\section{Northern Pileolated Warbler}

Motacilla pileolata Pallas, Zoogr. Rosso-Asiatica, 1, 1811, 497 (In insula Kadiak = Kodiak Island, Alaska $)$.

Wilsonia pusilla pileolata van Rossem, 1931c, 286 (Tecoripa; San Javier; Saric; Guirocoba); 1934d, 473 (Alamos; Mina Abundancia; Nacozari; Oposura).

Fairly common spring and fall transient through the mountainous eastern part of the State. Fall dates are August 16 (Rancho La Arizona) to September 5 (San Bernardino Ranch) [U. S. Nat. Mus.]). Spring dates are March 28 (Alamos and Tecoripa) to May 25 (Rancho La Arizona).

\section{WILSONIA PUSILLA CHRYSEOLA RIDGWAY}

\section{Golden Pileolated Warbler}

Wilsonia pusilla chryseola Ridgway, Bull. U. S. Nat. Mus., 50, Pt. 2, 1902, 714 (Pacific Coast district $=$ Red Bluff, California); ibid., in text (San Jose Mts.). -Cooke, 1904, 129 (Sonora).-Chapman, 1907, 279 (San Jose Mts.).-A.O.U. Comm., 1910, 325 (Sonora) ; 1931, 299 (Sonora).-Dawson, 1923, 514 (Sonora). -van Rossem, 1931c, 286 (Tecoripa; San Javier; Saric; Tesia; Chinobampo; Guirocoba) ; 1934d, 473 (Alamos; Mina Abundancia; Nacozari; Oposura).-Hellmayr, 1935, 454 (Sonora).

Common transient through the central and eastern foothills and lower mountains. Western desert records are lacking, though this is probably not significant. Winters in small numbers in the Tropical zone at the extreme southern part of the State from where there are three records: Álamos, February 4, 1888; Tesia, November 30, 1929; Chinobampo, March 2, 1930. Fall migration dates extend from August 21 (Rancho 
La Arizona) to October 25 (San José Mountains). Spring dates are from March 15 (Tecoripa [possibly a wintering individual]) to April 24 (San Javier).

\section{CARDELLINA RUBRIFrons (GiraUd)}

\section{RED-FACED WARBLER}

Muscicapa rubrifrons Giraud, Sixteen Species Texas Birds, 1841, [15], pl. vii, fig. 1 ( Texas=México $)$.

Cardellina rubrifrons Ridgway, 1902, 720 (Sonora).

Status uncertain, although in all probability a summer visitant in the Transition zone in the eastern mountains. The basis of Ridgway's inclusion of Sonora in the range of the Red-faced Warbler is most likely the three specimens in the U. S. National Museum which were taken by Mearns in the San José Mountains on August 7 and 11, 1892. The dates would suggest these individuals to have been summer visitants in the locality. The same comment applies to a specimen in the University of Michigan, taken by Campbell in El Tigre Mountains on July 28, 1935.

\section{SeTophaga RUTicilla (LiNNAEUS)}

\section{AMERICAN ReDSTART}

Motacilla Ruticilla Linnaeus, Syst. Nat. ed. 10, 1, 1758, 186 (in America= Virginia).

Setophaga ruticilla van Rossem, 1931c, 286 (Tobạri Bay).

Spring transient, perhaps more than casual. The only specimen taken to date is one from Tóbari Bay, April 27, 1930; however, at least one other was seen in the same locality on April 26 (van Rossem notes). A supplementary record is San Bernardino Ranch on the boundary ("Arizona," Mearns notes), August 31, 1892.

\section{SETophaga PICTA PICTA (SWAINSON) \\ Painted Redstart}

Setophaga picta Swainson, Zool. Illust., ser. 2, 1, 1829, pl. 3 and text (Real del Monte [Hidalgo], México).-Allen, 1893a, 40 (Huerachi).-Bailey, 1928, 634, part (San Luis Mountains).

Setophaga picta picta Ridgway, 1902, 738 (Huerachi).- Thayer and Bangs, 1906, 21 (La Cliumata).- - van Rossem, 1934d, 473 (Alamos; Mina Abundancia; Nacozari; Oposura). 
Common summer visitant to high Upper Sonoran and Transition zones throughout the mountainous eastern portion of the State, west to the Pajaritos Mountains and the Sierra de San Antonio. Winters, apparently in some numbers, in Tropical zone foothills and occasionally further north (Huerachi, at about $29^{\circ} 30^{\prime}$ ). Unpublished localities are San José Mountains, September 26 and October 6, 1892, and August 9 and 19, 1893 (Mearns notes); El Tigre Mountains, August 3, 1935 (Univ. Mich.) ; Rancho Santa Bárbara, June 10, 1937 (Dickey coll.) ; Guirocoba, December 8, 1941 ("abundant"); Pajaritos Mountains, May, 1942 ("breeding near boundary fence"; Sheffler notes).

\section{MYIOBORUS MINIATUS MINIATUS (SWAINSON)}

\section{RED-BELLIED REDSTART}

Setophaga miniata Swainson, Philos. Mag., n. ser., 1, No. 5, May, 1827, 368 (Valladolid, México).

Myioborus miniatus miniatus van Rossem, 1931c, 286 (Chinobampo).- Hellmayr, 1935, 459 (Chinobampo).

A winter visitant in the Tropical zone foothills in the extreme south. Two specimens have so far been taken, both at Chinobampo on February 12, 1930 (Dickey coll.), and March 9, 1931 (Bishop coll.). Although very common in the Transition zone in adjacent Chihuahua localities in summer, none have so far been detected in Sonora at that season.

\section{EUTHLYPIS LACHRYMOSA (BONAPARTE)}

\section{FAN-TAILED WARBLER}

Basileuterus lachrymosa "Licht." Bonaparte, Consp. Gen. Avium, 1, 1850, [Feb. 3, 1851] 314 (México=Lagunas [Oaxaca]).

Eutblypis lachrymosa van Rossem, 1934d, 474 (Hacienda de San Rafael; crit.). Euthlypis lacbrymosa tephra Ridgway, 1902, 738 (Hacienda de San Rafael).Dickey and van Rossem, 1926, 270 (Hacienda de San Rafael).-van Rossern, 1931c, 286 (Guirocoba).-Hellmayr, 1935, 473 (Hacienda de San Rafael; crit.).

Rather common summer visitant to the Tropical zone foothills in the extreme southeast. The first date of arrival is May 4 (Guirocoba); the departure date is unknown. ${ }^{62}$

${ }^{62} \mathrm{My}$ reasons for not recognising tephra have been summarized (1934d) previously, and additional freshly collected material examined tends to confirm the views then expressed. Some, perhaps the majority, of the northwestern birds attain a degree of pallor apparently never seen in the south and southeast; on the other hand the darker northwestern individuals are indistinguishable from southern specimens by any means I can devise. 


\section{BASILEUTERUS RUFIFRONS CAUDATUS NeLSON}

\section{NeLSON WarbleR}

Basileuterus rufifrons caudatus Nelson, Proc. Biol. Soc. Wash., 13, May 29, 1899, 29 (Álamos, Sonora, México).-Ridgway, 1902, 748 (Alamos; Napolera). -van Rossem, 1931c, 287 (Guirocoba); 1934d, 475 (Alamos; Mina Abundancia; Hacienda de San Rafael; Oposura).-Hellmayr, 1935, 510 (Sonora).

Idiotes rufifrons caudatus Todd, 1929, 94, (Oposura; Alamos; Napolera).

Basileuterus caudatus Sharpe, 1909, 126 (Sonora).

Basileuterus rufitrons (not Setophaga rufifrons Swainson) Allen, 1893a, 41 (Napolera).

Rather uncommon resident of the eastern foothill and lower mountain region, north nearly to latitude $30^{\circ}$. Environment (shrubbery along mountain streams) rather than life zones seems to govern the distribution of this warbler. Record stations range from 1,200 to about 4,000 feet in altitude. An additional locality is San Francisco Cañon (Dickey coll.).

\section{Family Plocerdae Weaver-finches \\ PASSER DOMESTICUS DOMESTICUS LinNaEUS}

\section{ENGiLISH SPARROW}

Fringilla domestica Linnaeus, Syst. Nat., ed. 10, 1, 1758, 183 (in Europa $=$ Sweden).

Passer domesticus domesticus van Rossem, 1931c, 287 (Guaymas; Saric).

Apparently well established in towns and about ranches from Nogales and San Luis in the extreme north, south to the Sinaloa boundary. Has been observed to date at Nogales, Rancho La Arizona, San I.uís, Santa Ana, Hermosillo, Guaymas, Navojoa, Alamos, Tesia, Agiabampo (van Rossem), and Rancho Costa Rica (Lamb notes).

\section{Family ICTERIDAE Blackbirds and Troupials \\ CASSiCUlus mELANICTERUS (BONAPARTE)}

\section{Mexican Cacique}

Icterus melanicterus Bonaparte, Journ. Acad. Nat. Sci. Phila., 4, May, 1825, 389 (México=Temascáltepec).

Known to have nested near Álamos in the summer of 1931, but not found in the State before or since that time. In carly September of that year W. J. Sheffler photographed this (then abandoned) colony which contained over thirty nests in a single trec. With native "sling-shot" 
assistance he secured one bird, apparently a fully grown male of the year, which is now in his collection.

\section{TANGAVIUS AENEUS MILLERI VAN ROSSEM}

\section{BRONZED COWBIRD}

Tangavius aeneus milleri van Rossem, Trans. San Diego Soc. Nat. Hist., 7, No. 30, May 31, 1934, 355 (Tucson, Arizona); ibid., in text, (Sonora); 1934d, 476, (Hacienda de San Rafael).- Hellmayr, 1937, 51 (Sonora).

Tangavius aeneus aeneus (not Psarocolius aeneus Wagler) Thayer and Bangs, 1906, 21 (Opodepe).-Friedmann, 1927, 507 (Sonora) ; 1929, 320 (Hermosillo; Opodepe); 1933a, 190 (Guirocoba; Guaymas; El Alamo).

Callothrus aeneus aeneus Ridgway, 1902, 203 (Hermosillo).

Common, sometimes abundant, summer visitant to Sonoran, Tropical and, locally, Transition zones from the longitude of $\mathrm{El}$ Alamo and Guaymas eastward throughout the State. Resident in seemingly limited numbers in the Tropical zone from the lower Yaqui River southward. Local concentration is usually evident about ranches and other inhabited areas. Further stations are Agiabampo, May 15 and 16, 1937; Rancho Santa Bárbara to 5,500 feet in June, 1937 (Dickey coll.; van Rossem notes) ; Pilares, July, 1935 (Univ. Mich.) ; Isleta, May 17, 1888 (Brit. Mus.). Dates of arrival and departure for northern localities are inconclusive. They are May 7 ("abundant") and August 18, both from Rancho La Arizona. Huey (1942, p. 371) reports Bronzed Cowbirds May 14, 1939, from Gray's Ranch, a boundary locality far to the west of the (present) normal range, but technically, this is "50 yards" within Arizona territory.

\section{Molothrus ater aRtemisiaE Grinneli.}

\section{Nevada COWBIRd}

Molothrus ater artemisiae Grinnell, Univ. Calif. Pub. Zool., 5, No. 5, Dec. 31, 1909, 276 (Quinn River Crossing, Humbolt Co., Nevada).- van Rossem, 1931c, 290 (Saric).

Detected only as a fall migrant at Rancho La Arizona in the extreme northcentral part of the State on August 10, 1929.

\section{MOLOTHRUS ATER OBSCURUS (GMELIN) \\ DWARF COWBIRD}

Sturnus obscurus Gmelin, Syst. Nat., 1, pt. 2, 1789, 804 (In Nova Hispania= México).

Molothrus ater obscurus Belding, 1883, 343 (Guaymas); 1890, 118 (Guaymas). -Evermann and Jenkins, 1888, 68 (Magdalena).-Ridgway, 1902, 210, part (Guaymas).--Stone and Rhoads, 1905, 683 (Colony).-Thayer and Bangs, 1906, 
21 (Opodepe; La Chumata).—van Rossem, 1931c, 290 (Saric; Tesia; Obregon; Guirocoba; Guaymas); 1934d, 476 (Hacienda de San Rafael; Oposura; Granados).-Friedmann, 1934, 107 (Guaymas).

Molothrus pecoris (not Fringilla pecoris Gmelin) Baird, 1858, 524, part (Los Nogales); 1859, 18, part (Los Nogales).-Salvin and Godman, 1887, 450, part (Los Nogales).

Common, locally abundant, resident almost anywhere below the Transition zone, though most numerous about ranches and cultivated areas at low altitudes. Further stations are Hermosillo, October and November; Quiriego, April (Brit. Mus.); Pilares, July (Univ. Mich.); Rancho Santa Bárbara to 5,000 feet, June; Agiabampo; Navojoa; Alamos, May and June; Kino Bay, December (van Rossem notes); Quitovaquita on the boundary [Arizona side], April (Huey, 1942, p. 371) ; Sonoyta, January (Mearns notes).

\section{CASSIDIX MEXICANUS NELSONI (RIDGWAY)}

\section{Sonora Boat-Tailed Grackle}

Scaphidurus major nelsoni Ridgway, Proc. Wash. Acad. Sci., 3, April 15, 1901, 151 (Âlamos, Sonora, México).

Megaquiscalus major nelsoni Ridgway, 1902, 242 (Alamos; Camoa; Guaymas).

Cassidix mexicanus nelsoni van Rossem, 1931c, 289 (Obregon; Tesia; San Jose de Guaymas; Tobari Bay; Guirocoba; Guaymas); 1934d, 476 (Alamos).Hellmayr, 1937, 88 (coast of Sonora).-A. Phillips, 1940, 117 (Guaymas).

Quiscalus palustris (not Scapbidurus palustris Swainson) Belding, 1883, 343 (Guaymas).

Common resident of the Tropical zone coastal plain, with concentrations about towns, ranches, and cultivated areas: Locally, there is penetration into the southeastern foothills as at Alamos and Guirocoba. The northermost Sonora station to date is Rancho Costa Rica, where observed as common by Lamb in December, 1932. Some unpublished localities are Camoa, Navojoa, and Agiabampo (Dickey coll.; van Rossem notes). ${ }^{63}$

\section{EUPHAGUS CYANOCEPHALUS (WAGLER)}

\section{BREWER BLACKBIRD}

Psarocolius cyanocephalus Wagler, Isis von Oken, 22, Heft 7 [July], 1829, col. 758 (Mexico=Temascáltepec, México).

${ }^{63}$ This race varies in measurements far beyond the limits set by Ridgway (1902), and in addition the tail is frequently decidedly longer than the wing. Certain large individuals (tails of adult males approximately $180 \mathrm{~mm}$.) taken in midwinter had been thought to represent some other race until the same size variability was subsequently found among breeding birds. The most diagnostic character seems to be the pallid coloration of the females. 
Scolecophagus cyanocephalus Belding, 1883, 343 (Guaymas).-Allen, 1893a, 38 (San Pedro; Cachuta).-Price, 1899, 92 (lower Colorado River).- Thayer and Bangs, 1906, 21 (Opodepe).

Euphagus cyanocephalus Ridgway, 1902, 248 (Guaymas).

Euphagus cyanocephalus cyanocephalus van Rossem, 1931c, 290 (El Doctor; Tesia; Técoripa; $12 \mathrm{mi}$. W. of Magdalena).-Moore, 1938a, 26 (Soyopa).

A common, even abundant, winter visitant to lower level river valleys and cultivated areas everywhere. Additional localities are Camoa, February 16, 1931 (Bishop coll.) ; Ures, "abundant in flocks," January 31, 1933 (Lamb notes); La Noria, November 30, 1892; San Pedro River, October 22, 1892; Sonoyta, January 20, 1894 (U. S. Nat. Mus. catl.). Extreme dates are September 15 (San Pedro) and the "very end of April" (Opodepe).

\section{ICTERUS BULI.OCKII BULLOCKII (SWAINSON)}

\section{Bullock ORIOLE}

Xantbornus Bullorkit Swainson, Philos. Mag., n. s., 1, No. 6, June, 1827, 436 (Tableland [of México]-Temascáltepec).

Icterus bullockii Baird, 1858, 549, part (Guadalupe Cañon); 1859, 20, part (Guadalupe Cañon).--Ridgway, 1902, 314, part (Sonora).

Icterus bullockii bullockii van Rossem, 1931c, 289, part (San Javier, part; Guaymas; Saric; Guirocoba, part) ; 1934d, 476 (Nacozari).-Hellmayr, 1937, 104, part (Sonora).

Icterus bullocki Brewer, in Baird, Brewer, and Ridgway, 1874, (2), 199, part (Guadalupe Cañon).-A.O.U. Comm., 1910, 238, part (Sonora): 1931, 307, part (Sonora).-Hucy, 19.42, 371 (Quitovaquita, Gray's Ranch, and Dowling Well on the boundary).

Icterus bullocki bullocki Bailey, 1928, 654, part (Sonora).

Rather common summer visitant in suitable localities (chiefly cottonwood and willow associations) across the extreme northern part of the State from about longitude $113^{\circ}$ eastward. Has been found breeding at various other points east to Pilares (July 2, 1935; Univ. Mich.), which is the southernmost as well as the easternmost definite breeding locality of record. Occurs widely and commonly as a migrant. Spring migration dates are from March 22 (Nacozari) to May 12 (Guirocoba; possibly breeding). The only available fall date is that from Rancho I.a Arizona, September 8 .

\section{ICIFRUS BULLOCKII PARVUS VAN ROSSEM}

\section{RIIJWAY ORIOLF.}

Icterus bullockil bullockil (not Xanthornus bullockii Swainson) van Rossem, 1931c, 289, part (San Javier, part; Guirocoba, part; Tesia). 
Detected only a spring migrant in the southern part of the State. Record stations to date are Tesia, March 19, 1930; San Javier, April 13 and 15, 1929; Guirocoba, April 25, 1930. Observed breeding (almost certainly this race) at San Luís and Colonia Independencia in the Colorado River delta, May 3, 1937 (van Rossem). ${ }^{64}$

${ }^{64}$ Icterus bullockii parvus new subspecies. Type, fully adult male, number J-464, Dickey collection; Jacumba, San Diego County, California, April 1, 1921; collected by May Canfield.

Subspecific characters.-Similar in color to Icterus bullockii bullockii (Swainson) of western North America in general. Size distinctly smaller. Measurements of the type are: wing, 97; tail, 76; culmen, 18.4; tarsus, 23.2; middle toe minus claw, 16.7. The corresponding measurements of Swainson's type of Xantbornus bullockii (examined at Cambridge, England, in 1933, and again on July 4, 1938), are 105, 83, 20.0, 24.5, and $17.8 \mathrm{~mm}$.

Range.-Coastal slope of California from the San Francisco Bay region south to northern Baja California, and eastward in the extreme southern part of the range to the lower Colorado River valley. Winter range undetermined but occurs in southeastern Arizona and southern Sonora in migration.

Remarks.-Swainson's type of Xanthornus bullockii is a fully adult male collected by Bullock but with no locality other than "Mexico" indicated on the label. The present designation of "Real del Monte" in the 1931 edition of the A.O.U. Check-list cannot stand, for Bullock, so far as can be determined, was never at the Real del Monte mines. Swainson's "Tableland" is indefinite and I therefore substitute Temascáltepec as the most likely place where the type might have been collected.

More than forty years ago Ridgway (1902, p. 316, footnote), on the basis of twelve specimens from each area, stated that "specimens from California are smaller than those from the interior" but seemingly no one has been inclined to follow up the matter with adequate series of breeding birds. My own interest was stimulated by the Sonora series which fell into two size groups. In the present investigation I have assembled 130 specimens from the range of the species (no Canadian specimens examined), 74 of which are adult males, 23 one-year-old males, and the remainder females of uncertain age or specimens of uncertain sex. About 20 additional adult males, too worn to be of value for measurement purposes, have been examined for variations in color and markings.

Purely on the basis of size it is apparent that the nominate race breeds south at least to southern Oregon on the coast, to the southern end of the San Joaquin Valley in California, to extreme southern Nevada (save possibly in the Nevada portion of the lower Colorado River Valley), to southeastern and eastern Arizona, and to northcentral and northeastern Sonora. It occurs commonly in migration over the whole range of parvus, a circumstance naturally to be expected but which probably is in large part responsible for previous failure to recognize that race.

Not the least interesting part of the present study has been the observation of the individual variation in color and markings among adult males. In fact it may be truly said that no two of the nearly 100 specimens of that age examined are exactly alike in all respects. George Sutton (Auk, 55, 1938: 1-6) has recently pictured some plumage variations in specimens taken in western Oklahoma, a region where the breeding ranges of bullockii and galbula meet. Figure 6 of his plate illustrates what he considers to represent "typical bullockii." In this figure the yellow superciliary stripe is confluent with the yellow of the side of head, a 
condition perhaps usual in the eastern parts of the range but relatively rare in the west where the superciliary is normally shorter and completely isolated by a prominent, black, post-ocular stripe (of a maximum width of $5 \mathrm{~mm}$.) which is confluent with the black of the nape. Some specimens have the feathers of the nape so broadly yellow sub-basally that moderate abrasion, or no abrasion at all, results in a mottled yellow and black collar (in one case completely yellow) around the normally black nape. Lesser wing coverts vary from black with gray bases to yellow with a few minute flecks of black posteriorly. Greater coverts are normally pure white on the outer webs but occasionally there are indications of black streaking as in Sutton's Figure 5. Tail markings vary from as shown in Figure 3, or between 2 and 3, to Figure 6. Coloration of the under parts varies a good deal, and although summer specimens average yellower and fresh ones more orange, individual variation includes the color range regardless of season.

It is evident that bullockii is far less stabilized in characters than the intimately related galbula and abeillei, and that although the above noted plumage variations are at present co-extensive with the range of the species there are tendencies for some of them to be emphasized in certain geographic areas. It is not at all difficult to visualize the eventual emergence of a fourth "species" of the galbulabullockii-abeillei complex in Sonora, characterized by yellow lesser coverts, a yellow collar around the hindneck, lemon-yellow under parts, and a relatively long slender bill, and in the northwest of another with wholly black lesser coverts, a short superciliary stripe, extensively black-tipped lateral rectrices, and a thicker bill.

The following comparative measurements are based chiefly on males. Young females (like young males) are considerably smaller than adults but I cannot devise any reasonably certain means of separating the ages of most specimens of that sex.

Comparative Measurements

\begin{tabular}{l|c|c|c}
\hline & wing & tail & culmen \\
\hline \hline $\begin{array}{l}26 \text { adult male } \\
\text { bullockii }\end{array}$ & $\begin{array}{c}99-105 \\
(101.2)\end{array}$ & $\begin{array}{c}77-83 \\
(80.3)\end{array}$ & $\begin{array}{c}19.1-22.0 \\
(21.0)\end{array}$ \\
\hline $\begin{array}{l}42 \text { adult male } \\
\text { parvus }\end{array}$ & $\begin{array}{c}94-99 \\
(96.3)\end{array}$ & $\begin{array}{c}72-79 \\
(75.5)\end{array}$ & $\begin{array}{c}17.3-20.4 \\
(19.5)\end{array}$ \\
\hline $\begin{array}{l}16 \text { one-year-old } \\
\text { bullockii }\end{array}$ & $\begin{array}{l}95-101 \\
(97.0)\end{array}$ & $\begin{array}{c}76-81 \\
(78.2)\end{array}$ & $\begin{array}{c}20.3-22.0 \\
(21.1)\end{array}$ \\
\hline $\begin{array}{l}7 \text { one-year-old } \\
\text { parvus }\end{array}$ & $\begin{array}{c}88-92 \\
(90.8)\end{array}$ & $\begin{array}{c}70-75 \\
(72.5)\end{array}$ & $\begin{array}{c}18.2-20.8 \\
(19.5)\end{array}$ \\
\hline $\begin{array}{l}14 \text { female } \\
\text { bullockii }\end{array}$ & $\begin{array}{l}90-95 \\
(93.7)\end{array}$ & $\begin{array}{c}73-79 \\
(77.3)\end{array}$ & $\begin{array}{c}18.7-21.0 \\
(19.2)\end{array}$ \\
\hline $\begin{array}{l}15 \text { female } \\
\text { parvus }\end{array}$ & $\begin{array}{c}85-93 \\
(90.6)\end{array}$ & $\begin{array}{l}68-76 \\
(72.6)\end{array}$ & $\begin{array}{c}17.6-19.0 \\
(18.3)\end{array}$ \\
\hline \hline
\end{tabular}




\section{ICTERUS PARISORUM BONAPARTE}

\section{SCOTT ORIOLE}

Icterus parisorum Bonaparte, Proc. Zool. Soc. Lond., 1837 [June, 1838], 110 (México).-Thayer and Bangs, 1906, 21 (La Chumata).-Townsend, 1923, 18 (Tiburon Island).-Bailey, 1928, 649 (Sonora).- van Rossem, 1932, 142 (Tiburon Island) ; 1934d, 476 (Mina Abundancia; Nacozari; Oposura).

Seemingly a fairly common summer visitant to Upper Sonoran oak regions in the central and eastern foothills. Known or probable breeding localities are Nogales (July); Cibuta, July (Bishop coll.); Sierra de Oposura, May; La Chumata, June; Cajón Bonito Creek, July (Mearns notes); Rancho Santa Bárbara, June (Dickey coll.). A few individuals winter in the Tropical zone lowlands, known occurrences at that season being San José de Guaymas, January 14 and 15, 1933 (Dickey coll.; Lamb notes) and Camoa, January 20, 1899 (Biol. Surv.). Lowland appearances during migrations are also to be expected, as on Tiburón Island, April 11, 1911.

\section{ICTERUS W'AGLERI CASTANEOPECTUS BREWSTER}

\section{Chestnut-breasted Oriole}

Icterus wagleri castaneopectus Brewster, Auk, 5, No. 1, January, 1888, 91 ([Sierra de] Oposura, Sonora, México).-Bangs, 1930, 419 (re type).-van Rossem, 1931c, 288 (San Javier; Chinobampo; Guirocoba; Agiabampo); 1934d, 475 (Alamos; Mina Abundancia; Hacienda de San Rafael; Oposura).-Griscom, 1932a, 393, in text (Sonora; crit.).-Hellmayr, 1937, 122 (Sonora).

Pendulinus Wagleri Var. Castaneopectus Dubois, 1901, 557 (mountains of Sonora).

Icterus wagleri (not of Sclater) Ridgway, 1902, 267, part (Alamos; Oposura). -Thayer and Bangs, 1906, 21 (Opodepe).

Common resident of the foothills and lower mountains in the southern part of the State. north in the interior to Opodepe and Moctezuma. Although found breeding on two occasions at Agiabampo (July, 1930, and May, 1937), this seacoast locality appears to be exceptional. Records include the Tropical, Sonoran, and the lower fringe of the Transition zones to at least 5,500 feet, where found to be breeding commonly in the oak-pine association at Rancho Santa Bárbara in June, 1937 (van Rossem notes; Dickey coll.).

\section{ICIERUS CUCULLATUS NELSONI RIDGWAY}

\section{Arizona Hooded Oriole}

Icterus cucullatus nelsoni Ridgway, Proc. U. S. Nat. Mus., 8, No. 2, "April 20" [May 6], 1885, 19 (Tucson, Arizona); 1902, 290, part (Sonora, part).- 


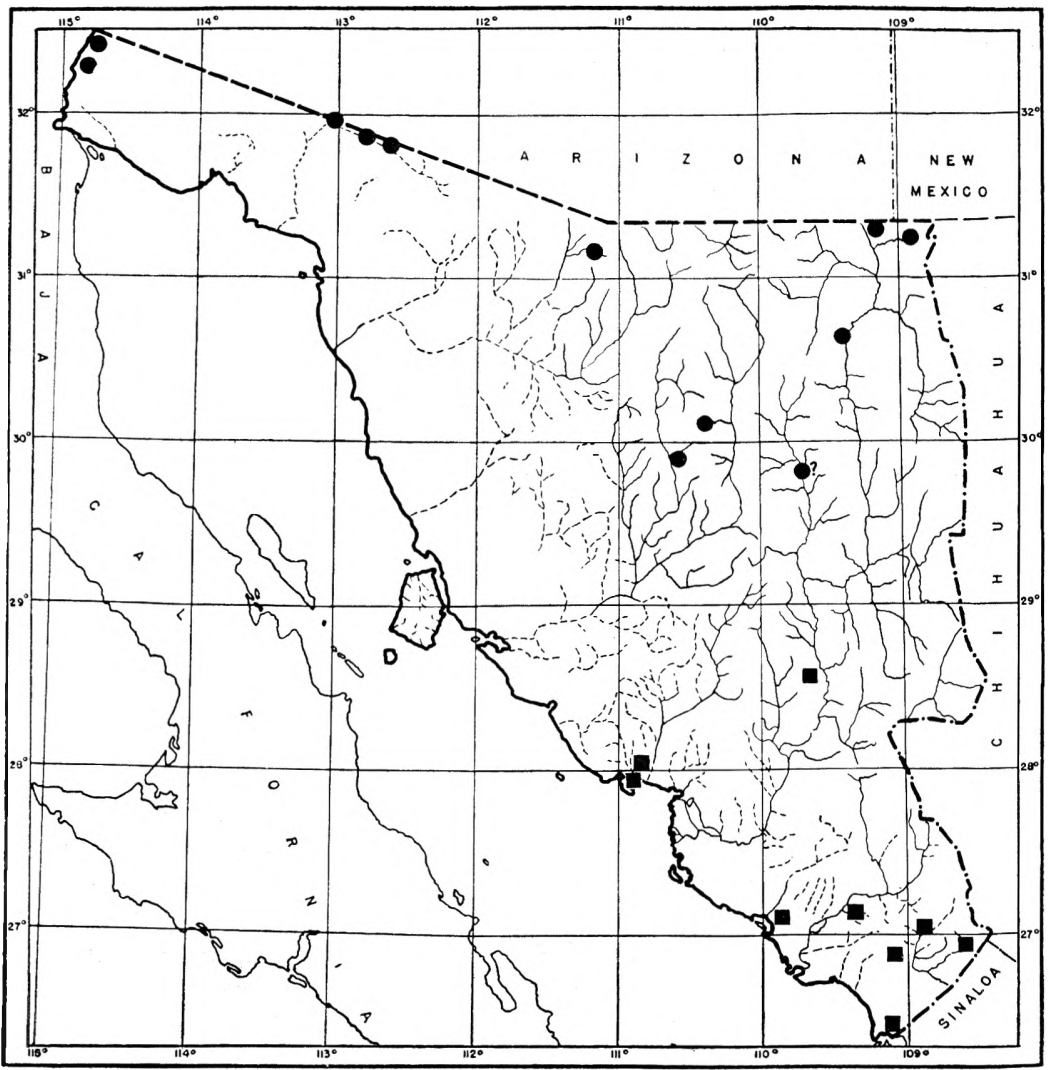

Map 21. Distribution of Icterus cucullatus. Circles, I. c. nelsoni; squares, I. c. restrictus.

Thayer and Bangs, 1906, 21 (Opodepe; La Chumata).- van Rossem, 1931c, 289, part (San Javier, part; Saric; Tesia, part; Guirocoba, part).

Icterus cucullatus californicus (not Pendulinus californicus Lesson) van Rossem, 1934d, 475, part (Nacozari; Oposura).-Hellmayr, 1937, 150, part (northern locs.).-Huey, 1942, 371 (Gray's Ranch; Dowling Well; Quitovaquita [Arizona]).

Common summer visitant, chiefly in the Lower Sonoran zone, in the northern part of the State south to Opodepe and [probably to] Moctezuma. Occurs as a transient elsewhere in the spring (Tesia (3), March 21 and 25; Guirocoba, April 20, May 20; San Javier, April 21), and doubtless in the fall, although there are no records for this latter season. Additional breeding localities are San Luís and Colonia Independencia, May 3, 1937 (van Rossem notes); Pilares, June 21 to July 24, 1935 
(Univ. Mich.) ; Guadalupe Cañon, "carly July," 1892; Cajoñ Bonito Crcek, July 1 to 4, 1892 (Mearns notes). The earliest spring record for northern localities is March 23 (Gray's Ranch), the latest for fall is October 4 (Guadalupe Cañon; Mearns notes). An individual seen at Hermosillo, December 22, 1932 (Lamb notes) possibly belonged to this race. If so, it is the only mid-winter record. ${ }^{65}$

\section{ICTERUS CUCULLATUS RESTRICTUS VAN ROSSEM}

\section{SONORA HOOded Oriole}

Icterus cucullatus (not of Swainson) Belding, 1883, 343 (Guaymas).

Icterus cucullatus nelsoni (not of Ridgway) van Rossem, 1931c, 289, part (San Javier, part; Tesia, part; Chinobampo; Guirocoba, part; Guaymas; 6 miles N. of Guaymas; Tobari Bay; Agiabampo).

Icterus cucullatus californicus (not Pendulinus californicus Lesson) van Rossem, 1943d, 475, part (Alamos).- Hellmayr, 1937, 150, part (southern Sonora locs.).

Common resident in the Tropical zone from the Sinaloa boundary north to about $28^{\circ}$ (Guaymas) coastwise, and to at least $28^{\circ} 30^{\prime}$ (San Javier) in the interior. ${ }^{66}$

65 The status of the breeding birds from Oposura [Moctezuma] remains in doubt, since they have not been re-examined in the present connection. It is likely that some of them, regardless of the identity of the breeding race, are migratory nelsoni.

${ }^{66}$ Icterus cucullatus restrictus new subspecies. Type, breeding male adult, number 31,998 Dickey collection; Agiabampo, extreme southern Sonora, México, May 19, 1937; collected by A. J. van Rossem and Robert Hannum.

Subspecific characters.- Not distinguishable in general coloration from Icterus cucullatus nelsoni of southern Arizona but black throat patch of fully adult males more restricted laterally and with its posterior outline reaching only to the anterior half of the lower eyelid instead of to the pusterior corner of the eye. Size slightly smaller.

Measurements.-10 restrictus from Sonora: wing, 84-88 (86.3); tail, 82-90 (88.2). 21 nelsoni from Arizona: wing, 86-91 (89.4); tail, 88-95 (92.0).

Remarks.-It is evident that the old "Arizona Hooded Oriole" was in reality a composite of four races which occupy as many distinct geographic and faunal areas. In brief, these races are Icterus cucullatus californicus (Lesson) of southern California and northwestern Baja California, Icterus cucullatus trochiloides Grinnell of southern Baja California, Icterus cucullatus nelsoni Ridgway of extreme southeastern California, southeastern Nevada, and southwestern Utah, eastward to southwestern New Mexico, and south into northern Sonora and northwestern Chihuahua, and Icterus cucullatus restrictus van Rossem of southern Sonora and (in all probability) Sinaloa. I have not recently examined west-Mexican specimens from south of the Sonora-Sinaloa boundary, however.

In the matter of coloration, both nelsoni and restrictus are lighter colored than californicus and trochiloides, the adult males are brighter and more golden (less greenish or ochraceous) yellow. The females and young males are paler and more 


\section{ICTERUS PUSTULATUS MICROSTICTUS GRISCOM}

\section{Northern SCarlet-headed Oriole}

Icterus pustulatus microstictus Griscom, Bull. Mus. Comp. Zoöl., 75, No. 30, Jan., 1934, 408 (Guaymas, Sonora, México).-van Rossem, 1934d, 476 (Alamos; Oposura).-Hellmayr, 1937, 134 (Sonora).-Peters, 1943, 103 (re. type).

Icterus pustulatus (not Psarocolius pustulatus Wagler) Ridgway, 1902, 295, part (Alamos).- -van Rossem, 1927, 76, in text (Sonora); 1931c, 289 (Tecoripa; San Javier; Tesia; Chinobampo; Guaymas; San Jose de Guaymas; Guirocoba).-Huey, 1931b, 606 (north to Tecoripa).-Friedmann, 1933a, 190 (Guaymas).

Common resident of wooded areas throughout the Tropical zone, north in interior river valleys at least to Hermosillo and Moctezuma. Localities previously unpublished are Hermosillo, December 8, 1887; Moctezuma, September 27 and December 18, 1887 (Brit. Mus.) ; Navojoa, May and June: Agiabampo, May; Ciudad Obregón, May and June, 1937. Marked daily fluctuation in numbers noted at Guaymas during late April, 1930, suggests that part of the population is migratory (van Rossem notes).

\section{AgELAIUS PHOENICEUS SONORIENSIS RIDGWAY}

\section{SONORA RED-WING}

A.[gelaius] phoeniceus sonoriensis Ridgway, Man. N. Amer. Birds, 1887, 370 (Northwestern Mexico ... and Arizona; south to Mazatlán=Camp Grant, Arizona ).

Agelaius phoeniceus sonoriensis Allen, 1893a, 37 (Nacory).-Ridgway, 1902, 337, part (Sonora, part).-A.O.U. Comm., 1910, 223, part (Sonora) ; 1931, 305,

grayish (less olive) on the interscapular region, lighter and more yellowish green elsewhere, and the one-year-old males rarely possess the solidly black throat so frequently seen in californicus and trochiloides at that age. A great many, perhaps all, males of this species require three years to attain full maturity. One-year-old birds are of course immediately recognizable by their greenish plumage. The second stage resembles the adult but the plumage is usually duller, the tail shorter, the outermost rectrices possess varying amounts of greenish mottling, and the black throat mask is more restricted and reaches only to the center or the anterior part of the lower eyelid. In the third year the longer, immaculate black (except for edgings) tail and full throat mask is acquired, the outline of which reaches to the posterior corner of the eye in californicus, trochiloides, and nelsoni, but which reaches only to the center of the lower eyelid in restrictus.

I can appreciate no significant size differences between californicus, trochiloides, and nelsoni. Restrictus compares with the last named in wing and tail length as recorded. The measurements are for fully adult males and excessively abraded birds are not included.

In conclusion it may be observed that among the many specimens examined from Arizona and northwestern México not one can be assigned to californicus and I can only conclude, therefore, that the main winter range of that race is in Baja California. 
part (Sonora).-van Rossem, 1926b, 226, part (Sonora); 1931c, 288 (Tecoripa; Obregon; Tesia).-Hellmayr, 1937, 163, part (Cerro Blanco).

Agelaius phoeniceus nevadensis (not of Grinnell) van Rossem, 1934d, 475 (Alamos).

Common migrant and winter visitant to suitable lowland localities almost everywhere except in the Colorado delta region. Further specimens have been examined from Ures, January 31 and February 4, 1933 ("common in flocks," Lamb notes) ; Guaymas, February 24 to March 11, 1905 (Mus. Comp. Zoöl.) ; Quitovaquita and Gray's Ranch on the boundary, March 4 and May 1, 1939 (Nat. Hist. Mus., not breeding); Hermosillo, October 22 to November 15, 1887 (Brit. Mus.). Dates extend from October 22 (Hermosillo) to April 5 (Tesia) [May 1 at Quitovaquita]. ${ }^{67}$

\section{AGELAIUS PHOENICEUS THERMOPHILUS VAN ROSSEM}

\section{Colorado River ReI)-Wing}

Agelaius phoeniceus thermophilus van Rossem, Trans. San Diego Soc. Nat. Hist., 9. No. 33, Feb. 17, 1942, 383 (3 miles N. of Calexico, Imperial Co., California); ibid., in text (Colorado River valley in Sonora).

Agelaius phoeniceus sonoriensis (not of Ridgway, 1887) Ridgway, 1902, 337, part (lower Colorado Valley).-Stone and Rhoads, 1905, 683 (Colony).-van Rossem, 1926b, 226, part (lower Colorado Valley); 1934d, 475 (Oposura).Hellmayr, 1937, 163, part (lower Colorado Valley).

Agelaius phoeniceus longirostris (not Agelaius longirostris Salvadori) Price, 1899, 92 (lower Colorado River).

Common, locally abundant, resident of marshes and cultivated areas along the Colorado River. Specimens have been examined from San Luís and Colonia Independencia (Dickey coll.), May 3, 1937; Colorado River opposite mouth of the Hardy, March 26, 1894; Colorado River at Monument 204, March 14, 1894 (U. S. Nat. Mus.). While this race is essentially resident, non-breeding casuals may be expected to occur in localities outside of the established breeding range. In this category, apparently, are three specimens from Oposura, April 4 and 5, 1887 (Mus. Comp. Zoöl.); Quitovaquita and Gray's Ranch on the boundary [Arizona side], in late April and early May, 1939 (Huey, 1942, p. 371; spec. exam.).

${ }^{67}$ This race breeds at several points in southeastern Arizona from the Altar Valley eastward, and although there is every probability that colonies exist on the Sonora side of the boundary, none have been noted to date. 


\section{XANTHOCEPHALUS XANTHOCEPHALUS (BONAPARTE)}

\section{YELLOW-HEADED BLACKBIRD}

Icterus xanthocephalus Bonaparte, Journ. Acad. Nat. Sci. Phila., S, [Feb., 1826], 223 (Pawnee villages on the river Platte $=$ Nebraska).

Xanthocephalus xanthocephalus Allen, 1893a, 37 (San Pedro).- van Rossem, 1931c, 288 (Obregon)._1934d, 475 (Fronteriza).- Hellmayr, 1937, 186 (Sonora).

Xanthocephalus icterocephalus Baird, 1859, 19, in text (Santa Cruz).-Brewer, 1874, (1), 167, in text (Santa Cruz).

Common migrant and winter visitant in Sonoran and Tropical zones, with occasional non-breeding individuals possibly remaining through the summer. Probably breeds in the Colorado delta, where noted on May 3, 1937 (van Rossem notes; see also Grinnell, 1928, p. 149). Further occurrences are San Bernardino Ranch on the boundary, August 17 to September 4, 1892 (U. S. Nat. Mus. catl.) ; Ures, January 28, 1933 (Lamb notes): Hermosillo, October 22 to 25, 1887 (Brit. Mus.) and February 27, 1929 (Wright notes); Cerro Blanco, April 16 and 17, 1903 (Field Mus.); Guaymas, March 11 to 21, 1905 (Mus. Comp. Zoöl.) ; Guirocoba, May 10, 1931 (not breeding; Bishop coll.) ; Quitovaquita on the boundary [Arizona side], April 28, 1939 (Huey, 1942, p. 371). Extreme dates are August 17 (San Bernardino Ranch) and May 10 (Guirocoba).

\section{STURNELLA MAGNA LILIANAE OBERHOLSER}

\section{Arizona Meadowlark}

Sturnella magna lilianae Oberholser, Sci. Pub. Cleveland Mus. Nat. Hist., 1, no. 4, Dec. 31, 1930, 103, pl. xviii (Huachuca Mountains, Arizona); ibid., in text (Sonora).-Saunders, 1934, 42 (Sonora; crit.)-Hellmayr, 1937, 211 (northern Sonora).-A.O.U. Comm., 1944, 459 (northern Sonora).

Sturnella magna hoopesi (not of Stone) Ridgway, 1902, 361, part (San Pedro; Cachuta; Nacory; Santa Cruz River).-A.O.U. Comm., 1910, 235, part (Sonora); 1931, 302, part (Sonora).-Bailey, 1928, 638, part (Sonora).

Sturnella hoopesi Sharpe, 1909, 497, part (Sonora).

Sturnella magna mexicana (not Sturnella mexicana Sclater) Allen, 1893a, 37 (San Pedro; Cachuta; Nacory).

Probably a fairly common resident of the northern plains and river valleys from about the vicinity of Sásabe eastward to the Chihuahua boundary and south, in winter at least, to the Mayo River valley. The extreme western limit of the range is hypothecated by the known distribution in Arizona. A specimen taken at Gray's Ranch on the boundary [Arizona side], March 21, 1939 (Huey, 1942, p. 371), seems to be 
that of a casual. The southern limits of the breeding range are not known, since all specimens from south of the boundary have been taken in fall and winter. Specimens have been examined as follows: nine from San Bernardino Ranch on the boundary, August 3 to 24; one from the San Pedro River, October 14; four from the Santa Cruz River, November 8 to 12, 1892 (U. S. Nat. Mus.); Llano, December 2, 1932 (Mus. Comp. Zoöl.); Camoa, February 20, 1931 (Bishop coll.).

\section{StURNeli.A NEGLECTA AuDubon}

\section{Western Meadowlark}

Sturnella neglecta Audubon, Birds Amer., oct. ed., 7, 1843, 339, pl. 489 (Missouri River above Fort Croghan=Old Fort Union, North Dakota).- -van Rossem, 1931c, 287 (El Doctor; Pesqueira; Tecoripa; Tesia; 12 miles W. of Magdalena; 15 miles E. of Nogales; Sasabe Valley; crit.).; 1934d, 475 (Alamos; Cumpas; Oposura); 1936c, 49 (El Doctor; crit).-Huey, 1935, 256 (Punta Peñascosa).

Common resident along the lower Colorado River and, without much doubt, at many points along the northern boundary. However, the only definite breeding record is that from San Luís. Common, sometimes abundant, migrant and winter visitant in Sonoran and Tropical zones throughout the state, except that there are no island records. Extreme dates are October 20 (Hermosillo) and April 4 (Oposura). Spccimens have been examined from localitics, other than those published, as follows: Camoa, February 4 (Bishop coll.); San José de Guaymas, January 22; San Luís, May 3, breeding (Dickey coll.); Hermosillo, October 20 and December 4 (Brit. Mus.); San Marcial and othẹr southcentral localities, many dates in October and November (Mus. Comp. Zoöl.); Sonoyta, January 18; Colorado River near the Gulf, March 27 (U. S. Nat. Mus.); Quitovaquita and Gray's Ranch on the boundary, November and March (Huey, 1942, p. 371).

\section{ramily Thraupidae Tanagers \\ TANAGRA ELEGANTISSIMA RILEYI VAN ROSSFM}

\section{RILEY EUPHONIA}

Tanagra elegantissima viscivora van Rossem, Occ. Papers Mus. Zool. Univ. Mich., No. 449, Oct. 9, 1911, 1 (San Francisco Cañon, extreme southeastern Sonora, México); ibid.. in text (Rancho Santa Barbara).

Tanagra elegantissima rileyi van Rossem, Trans. San Diego Soc. Nat. Hist., 9, No. 33, Feb. 17, 1942, 384 (new name for Tanagra elegantissima viscivora, preoccupied). 
Known only as a spring and summer visitant to the foothills and mountains in the extreme southeast. As elsewhere, the movements of this euphonia are probably erratic and governed in part by the supply of mistletoe berries. However, the oak-pine association in the higher mountains is obviously the preferred zonal level,-in other words, high Upper Sonoran and Transition. An additional record station is Alamos, April 24, 1939 (Mus. Vert. Zool.).

\section{TANAGRA GODMANI (BREWSTER)}

\section{GODMAN EUPHONIA}

Euphonia godmani Brewster, Auk, 6, No. 2, April [separates publ. Jan. 31], 1889, 90 (Mazatlán, Sinaloa, México) ; ibid., in text (Alamos).-Ridgway, 1902, 24 (Alamos).-Berlepsch, 1911, 1016 (Alamos).

Tanagra godmani van Rossem, 1934d, 477 (Alamos).-Hellmayr, 1936, 34 (Alamos; crit.).

The single record from Sonora was collected by Frazar at Alamos on March 16, 1888. Extensive search by several experienced collectors has failed to produce any further data.

\section{PIRANGA RUBRA RUBRA (LINNAEUS)}

\section{SUMmer TANAger}

Fringilla rubra Linnaeus, Syst. Nat., ed. 10, 1, 1758, 181 (in America=South Carolina).

Piranga rubra cooperi (not Pyranga cooperi Ridgway) van Rossem, 1931c, 291 part (Saric, part).

Casual migrant. Known from a single specimen taken by J. T. Wright at Rancho La Arizona, May 23, 1929 and now in the Dickey collection. Two other specimens from the same locality (May 9 and 11) are intermediate in characters between rubra and cooperi.

\section{PIRANGA RUBRA COOPERI RIDGWAY \\ COOPER TANAger}

Pyranga cooperi Ridgway, Proc. Acad. Nat. Sci. Phila., [21], 1869, No. 2, Apr.-July [July 30], 130 (Los Pinos, New Mexico).

Pyranga rubra cooperi Berlepsch, 1911, 1063 (Sonora).

Piranga rubra cooperi Evermann and Jenkins, 1888, 68 (Magdalena).-Allen, 1893a, 40 (Fronteras).-Ridgway, 1902, 776, part (Fronteras).--Thayer and Bangs, 1906, 21 (Opodepe; La Chumata).-van Rossem, 1931c, 291, part (Guirocoba; Saric; part); 1934d, 477 (Oposura: Granados; 1938f, 13, in text (central and eastern Sonora).-Friedmann, 1933, 190 (Saric); Moore, 1938a, 27 (Guirocoba). 
Common summer visitant in the foothills and mountains from the Pajaritos Mountains castward, and south to the Sinaloa boundary. Occurs in Tropical, Sonoran, and even in low Transition zones, but tends, though, to localize in riparian growth between about 1,400 and 5,500 feet altitude. Additional localities are Pilares, July 19, 1935 (Univ. Mich.); Magdalena, April 19; Nogales, May 10, 1925 (I)awson notes); Guadalupe Cañon, August 31; San Pcido River, July 29, 1893 (U. S. Nat .Mus. catl.): Rancho Santa Bárbara, June, 1937, breeding to 5,500 feet; San Francisco Cañon, May 30, 1937 (Dickey coll.; van Rossem notes); Cajón Bonito Creck and Guadalupe Cañon ("breeding"), early July, 1892; San Pedro River, October 5, 1893 (Mearns notes). Extreme dates are Apri! 19) (Magdalena) and October 5 (San Pedro River).

\section{Pirangia FLAVA zimMERI VAN ROSSEM}

\section{ZiMMER TANAGER}

Piranga flava zimmeri van Rossem, Auk, 59, No. 1, Jan., 1942, 87 (Chinobampo, southern Sonora, México).

Piranga hepatica (not Pyranga bepatica Swainson), Allen, 1893a, 40 (El Pinita).- Thayer and Bangs, 1906, 21 (La Chumata).

Piranga flava bepatica Zimmer, 1929, 213 part (Alamos).-A.O.U. Comm., 1931, 311, part (Sonora).-Hellmayr, 1936, 283, part (Sonora).

Piranga hepatica oreophasma (not of Oberholser, p. 74) Oberholser, 1919a, 78, in text (Alamos).

Piranga flaia oreophasma Oberholser, 1930b, 105 (Sonora).- -van Rossem, 1931c, 290 (San Javier; Saric; Chinobampo)) 1934d, 477 (Alamos; Mina Abundancia; Nacozari; Oposura).-Griscom, 1934, 409, part (Sonora).

Fairly common summer visitant in the oak-pine association (high Upper Sonoran and Transition zones) in the mountains of the northcentral and castern part of the State, from the Arizona boundary southward. Occurs in winter in the Tropical zone lowlands and foothills (and probably at higher elevations also) from Guaymas southward. Additional record stations are San José de Guaymas, January 14 and 15, 1933 (Dickey coll.; Lamb notes); Camoa, Fcbruary 16, 1931 (Bishop coll.); Rancho Santa Bárbara, June, 1937 (common; brecding; Dickey coll.; van Rossem notes); Cajón Bonito Creek, early July, 1892 ("brceding"); San Luís Mountains, July 13, 1892 and Scptember 4, 1893 (Mearns notes).

\section{Piranga ludoviciana (Wilson)}

\section{WFSTERN TANAGER}

Tanagra Ludoviciana Wilson, Amer. Orn., 3, 1811, 27, pl. 20, fig. 1 (Prairies of the Missouri=mouth of Lolo Creek Fork of Clearwater River, Idaho). 
Piranga ludoviciana van Rossem, 1931c, 290 (Saric; San Jose de Guaymas; Guirocoba) ; 1934d, 477 (Alamos; Hacienda de San Rafael; Oposura).-Huey, 1942, 372 ("April 21 to May 14" [= Quitovaquita; Gray's Ranch; Dowling Well]).

Summer visitant to Upper Sonoran and Transition zones in the mountains along the northern boundary. Definite breeding localities are the Pajaritos Mountains (Rancho La Arizona) and Cajón Bonito Creek, and possibly also the San José Mountains. Occurs as a transient throughout the State. Unpublished localities are San Bernardino Ranch, August 28, 1892 ; San José Mountains, August 11, 1893; San Luís Mountains, September 6, 1893: Guadalupe Cañon, October 4, 1893; Cajón Bonito Creek, breeding early July, 1892 (Mearns notes); Agua Marín, May 5, 1939 (Mus. Vert. Zool) ; Magdalena, May 12 to 14, 1925 (Dawson notes). Fall migration dates are August 28 (San Bernardino Ranch) to October 4 (Guadalupe Cañon). Spring dates are from March 30 (Álamos) to May 18 (Hacienda de San Rafael).

\section{PIRANGA BIDENTATA BIDENTATA SWAINSON}

\section{SwAINSON TANAGER}

Pjranga bidentata Swainson, Philos. Mag., new ser., 1, No. 6, June, 1827, 438 (Temascáltepec, México).

Piranga bidentata bidentata van Rossem, 1934d, 477 (Alamos).

Known from Sonora only by a specimen taken by Frazar at $\AA$ lamos on March 30, 1888.

\section{PIRANGA ERYTHROCEPHALA CAN'DIDA GRISCOM}

\section{Northern Red-headed TANager}

Piranga erytbrocephala candida Griscom, Bull. Mus. Comp. Zoöl., 75, No. 10, Jan., 1934, 410 (Hacienda de San Rafael, Chihuahua [=Sonora], México).van Rossem, 1934d, 477 (Hacienda de San Rafael).-Hellmayr, 1936, 295 (Hacienda de San Rafael).-Peters, 1934, 102 (re type).

Seemingly a rare resident in the lower mountains in the extreme southeast. The only Sonora records are those of four birds taken by Frazar at Hacienda de San Rafael between May 8 and 15, 1888, but midwinter records from adjacent Chihuahua localities indicate, in part at least, permanent residence in the region. 


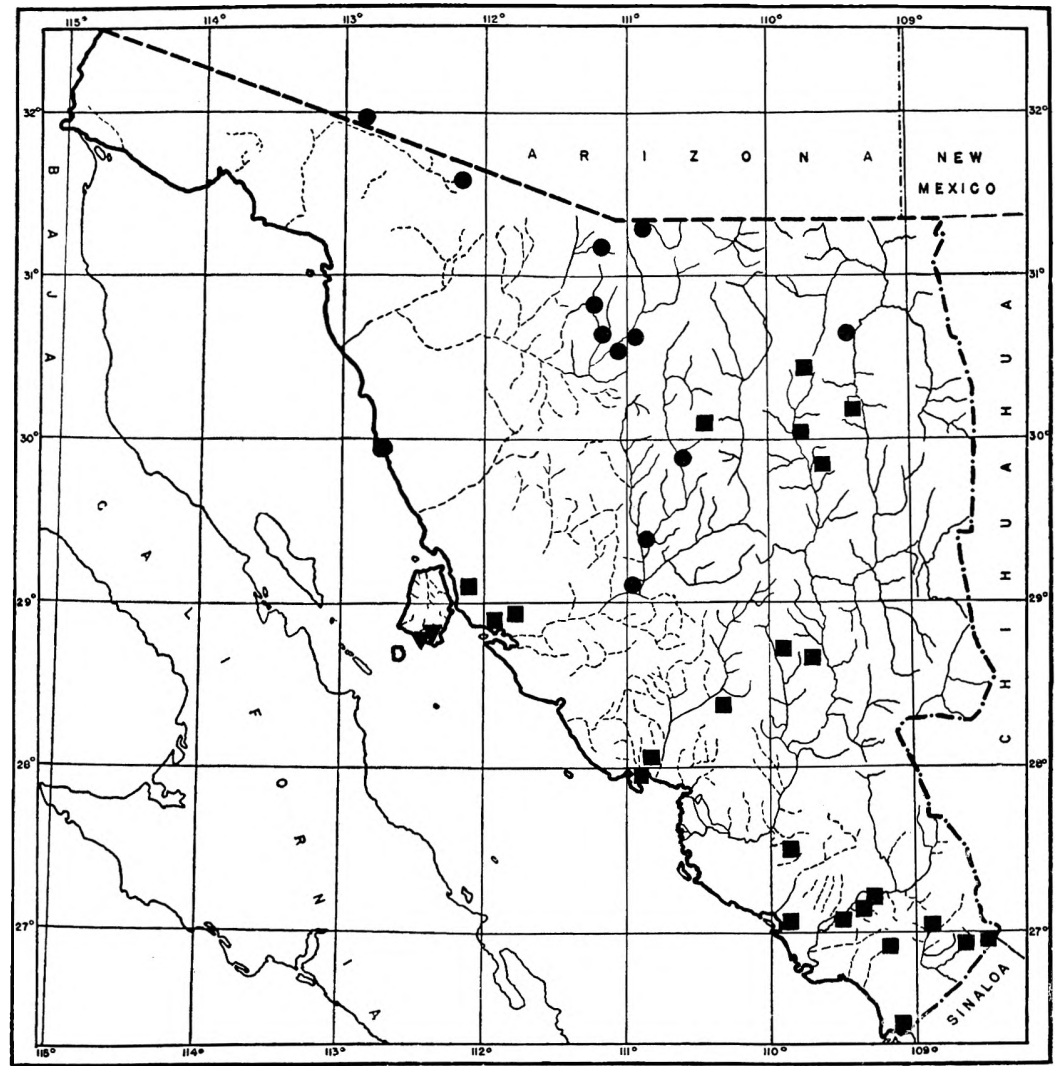

Map 22. Distribution of Richmondena cardinalis. Circles, R. c. superba; squares, $R$. c. affinis; triangles, R. c. townsendi.

\section{Family Fringillidae Grosbeaks, Finches, Buntings}

\section{RICHMONDENA CARDINALIS SUPERBA (RIDGWAY)}

\section{Arizona Cardinal}

Cardinalis cardinalis superbus Ridgway, Auk, 2, No. 4, Oct., 1885, 344 (Fuller's Ranch, a few miles east of Camp Lowell, Arizona) ; 1901, 645, part (Magdalena).-Evermann and Jenkins, 1888, 68 (Magdalena).-Brewster, 1902, 156, in text (northern Sonora).-A.O.U. Comm., 1910, 282 (northern Sonora).-Sheffler, 1931a, 137 (Magdalena Valley; Alamos [=El Alamo]); 1931b, 165 (between Magdalena and Santa Ana).

Richmondena cardinalis superbus Bailey, 1928, 670 (northern Sonora).

Richmondena cardinalis superba A.O.U. Comm., 1931, 313 (northern Sonora).- 
van Rosscm, 1931c, 291 (Saric; Pesqucira; 15 miles S.W. of Nogales; 12 miles W. of Magdalena).-Hellmayr, 1938, 71 (northern Sunora).

Cardinalis cardinalis affinis (not of Nelson) Thaycr and Bangs, 1906, 22, part (Opodepe).

Cardinalis virginianus, var. igneur (not Cardinalis igneus Baird) Baird, Brewer, and Ridgway, 1874, 2, 103, part (Sonora).

Fairly common resident of Sonoran deserts (chicfly mesquite and riparian associations) from about longitude $113^{\circ}$ eastward along the Arizona boundary; southward constwisc at lcast to latitude $30^{\circ}$, in the central interior to about $29^{\circ}$, and in the northeast to about $30^{\circ} 30^{\prime}$. Some unpublished stations are Puerto Libertad (Nat. Hist. Mus.); Pilares; Hermosillo (Univ. Mich.); Nogales (Dawson notes); Pozo de Luis ("common," Mearns notes). Intergradation between this race and affinis scems to be relatively abrupt where their respective ranges come into contact.

\section{RIGHMONDENA CARDINALIS TOHNNENDI VAN ROSSFM}

\section{Tiburón Islani) Cardinal}

Richmondena cardinalis sournsendi van Rosscm, Trans. San Diego Soc. Nat. Hist., 7, No. 12, July 28, 1932, 142 (Tiburón Island, Sonora, México).-Hellmayr, 1938, 72 (Tiburon Island).

Cardinalis curdinalis affinis (not of Nelson) Townsend, 1923, 21 (Tiburon Island; crit.).

Apparently a rather uncommon resident on Tiburón Island.

\section{RICHMONDENA GARDINAIIIS AFHINIS (NELSON)}

\section{Ai.amos Cardinal}

Cardinulis cardinalis affinis Nelson. Proc. Biol. Soc. Wash., 13. May 29, 1899, 28 (Álamos, Sonora, Méxicu).-Ridgway, 1901, 6.18 (Alamos; Ortiz; Batamotal; Guaymas; "etc.").-Brewster, 1902, 156, in text (southern Sonora).-Thayer and Bangs, 1906, 22, part (Lat Chumata).

Curdinalis affinis Sharpe, 1909, 220 (coast of southern Sonora).

Richmondena cardinalis affinis van Rosscm, 1931c, 291 (Tecoripa; San Javicr; Obregon; Tesia; Chinobampo: Guirocoba; Guaymas; Tobari Bay; Kino Bay); 1932, 142, in text (southern Sonora) : 1931d, 178 (Guaymas; Alamos; Oposura; Nacozari; Cumpas).- - Hellmayr, 1938. 72 (range in Sonora).

Cardinalis igneus (not of Baird) Salvin and Godman, 1881, 311, part (Guaymas).

Cardinalir virginianus var. igneus Baird, Brewer, and Ridgway, 1874, (2), 103, part (Sonora).

Cardinalis virginianus igneus Bclding, 1883, 343 (Guaymas).

Cardinalis curdinalis superbus (not of Ridgway) Allen, 1893a, 39 (Oputo).Ridgway, 1901, 615, part (Oputo). 
Common resident of the Tropical zone from the Sinaloa boundary, north, coastwise, at least to Kino Bay and the Sierra Seri, and in the eastern interior to somewhat north of latitude $30^{\circ}$. Further stations in the general range are Camoa (Bishop coll.); Agiabampo; Navojoa; San Francisco Cañon (van Rossem notes); Sierra Seri (Mus. Vert. Zool.); Ures; Rancho Costa Rica (Lamb notes).

\section{PyrRhuloxia sinUATA FULVESCENS VAN ROSSEM}

\section{ARIZONA PyrRHULOXIA}

Pyrrbuloxia sinuata fulvescens van Rossem, Trans. San Diego Soc. Nat. Hist., 7, No. 30, May 31, 1934, 356 (Fort Lowell, Arizona); 1934d, 478 (Guaymas; Alamos; Oposura).- -Hellmayr, 1938, 76 (Sonora; crit.).

Pyrrbuloxia sinuata (not Cardinalis sinuatus Bonaparte) Belding, 1883, 343 (Guaymas).--Salvin and Godman, 1884, 343, part (Guaymas).-Stephens, 1885, 228 (Sasabe).-Sheffler, 1931a, 138 (Imuris; Rancho Los Alamos); 1931b, 165 (between Magdalena and Santa Ana).

Pyrrbuloxia sinuata sinuata Ridgway, 1901, 625, part (Sonora).-Thayer and Bangs, 1906, 22 (Opodepe).--van Rossem, 1931c, 292 (Tecoripa; San Javier; Saric; Tesia; Chinobampo; Guaymas; Tobari Bay; Guirocoba; Sasabe).-Friedmann, 1934, 107 (Guaymas).

Pyrrbuloxia sinuata beckbami (not of Ridgway) Allen, 1893a, 40 (Granados).

Common resident of Sonoran and Tropical zones from Sásabe (probably from about longitude $113^{\circ}$ ) east to the San Bernardino River valley and south throughout the State. Further stations of occurrence are 35 miles W. of Magdalena; Ures; San Carlos Bay; San Pedro Bay; Masocari Island (Dickey coll.) ; Hermosillo (Lamb notes) ; Pilares (Univ. Mich.) ; Dutch Charley's Ranch at Monument 88 (Mearns notes); San Bernardino Ranch (U. S. Nat. Mus. catl.) ; Agua Caliente (Brit. Mus.).

\section{Phencticus CHRYSOPEPLUS DILUTUS VAN ROSSEM}

\section{SONORA Yellow Grosbeak}

Pheucticus chrysopeplus dilutus van Rossem, Bull. Mus. Comp. Zoöl., 77, No. 7, Dec., 1934, 479 (La Trompa, Chihuahua, México); ibid., in text (Hacienda de San Rafael; Alamos; Guirocoba; Ysleta).-Hellmayr, 1938, 77 (Sonora).-Meise, 1938, 4 (southern Sonora; crit.).

Pbeuticus [sic] chrysopeplus (not Coccothraustes chrysopeplus Vigors) van Rossem, 1931c, 293 (Guirocoba).

Common summer visitant to Tropical zone foothills in the extreme southwest, where practically all records fall between about 1,200 and 2,000 feet altitude. The association most favored is larger growth along 
streams. An additional station is San Francisco Cañon, where observed commonly May 30 and 31, 1937 (van Rossem notes). The earliest known date of arrival is April 30 (Guirocoba). There are no data as to fall departure. ${ }^{\text {is }}$

\section{Pheucticus melanocephalus melanocephatus (SWainson)}

\section{Rocky Mountain Grosbeak}

Guiraca melanocephala Swainson, Philos. Mag., n. s., 1, No. 6, June, 1827, 438 (Table land. Temiscaltipec $=$ Temascáltepec, México).

Zamelodia melunocephala Brewster, 1902, 158 (Álamos).- Thayer and Bangs, 1906, 22, part (I.a Chumata).

Zanzelodia melanocepbula melanocephala van Rossem, 1931c, 292 (Tecoripa; San Javier: Chinobampo; Guirocoba).

Hed.meler melanocephalur melanocephalus Griscom, 1934, 411, in text (Alamos: mountains of northern Sonora).--van Rossem, 1934d, 478 (Alamos; Mina Abundancia: Oposura; La Chumata).

Hedymeler melanocephalus papago Oberholser, 1919c, 412 (La Chumata; west side of San l.uis Mountains on Mexican boundary line; Patagone Mountains [Arizona side]).

Probably a fairly common summer visitant to Upper Sonoran and Transition zones in the northeastern mountainous area. What appear to be definite breeding localities are the Patagonia Mountains (Arizona side of the boundary), the Sierra de San Antonio, the San Luís Mountains and (Mearns notes) Guadalupe Cañon and Cajón Bonito Creek. A specimen taken at Oposura (more probably the Sierra de Oposura) on May 13, 1887, was possibly a belated migrant. No form of the Black-headed Grosbeak has been found in summer in the Transition (or any other) zone in southeastern Sonora, although the present race occurs at some closely adjacent localities in the higher mountains of Chihuahua. Three specimens respectively from Chinobampo, February 12 and 25, 1930, and Álamos, February 13, 1888, indicate that a limited number of individuals winter in the Tropical zone in the extreme southern part of the State. Spring migration records extend from March 4 (Tecoripa) to May 2 (Guirocoba) or even May 13 (Oposura).

68 It is evident that this species is migratory, at least in the northern part of the range. None of the experienced collectors who have visited southern Sonora in winter have encountered it at that season, and so common and conspicuous a bird could hardly have escaped notice. At Guirocoba in May, 1937, none were seen before the 20th, after which date it became common. Winter taken specimens from localities south of Sonora should be carefully determined. 


\section{Pheucticus melanocephalus maculatus (Audubon)}

\section{Black-HEAIED Grosbeak}

Fringilla maculuta Audubon, Birds Amer., folio, 4, 1837, pl. 373, figs. 2, 3, 4 (Columbia River, Oregon).

Zamelodia melanocephala maculata van Rossem, 1931c, 292 (Saric; Tecoripa; San Javier; Tesia; Chinobampo; Guaymas; Guirocoba).

Hed)meles melanocephalus maculatus Griscom, 1934, 410 (Oposura; Alamos; Opendepe; crit.).- -van Rossem, 1934d, 478 (Alamos; Oposura; Saric; crit.).Hellmayr, 1938, 87, footnote (Sonora).

[?] Habia melanocepbala (not Guiraca melanocephala Swainson) Evermann and Jenkins, 1888, 68 (Magdalena).

Zamelodia melunocephala Thayer and Bangs, 1906, 22, part (Opodepe).

Hedymeles melanocephalus melanorephalus Oberholser, 1919c, 408 (Opodepe).

Occurs widely and commonly as a migrant and, apparently very rarely, as a winter visitant in the south (Tesia, December 17). The breeding range is at present obscure, but present evidence indicates a lower level (Lower Sonoran) than that of melanocephalus. Known brecding localities are Rancho La Arizona (Saric) at the edge of the western desert and Moctezuma (Oposura) at about 1,800 feet altitude. The July record of Evermann and Jenkins for Magdalena most likcly belongs here. March 3 (Chinobampo) and March 9 (Tecoripa) are possibly dates for early migrants rather than for winter visitants). ${ }^{\text {ig }}$

\section{GUIRACA CAERULEA INTERFUSA DWight ANI) Griscom}

\section{Arizona Blue Grosbeak}

Guiraca caerulea interfusa Dwight and Griscom, Amer. Mus. Novit., 257, March 14, 1927, 4 (Fort Lowell, Arizona).-Bailey, 1928, 677 (southern Sonora). van Rossem, 1931c, 293 (Saric; El Alamo; Guirocoba); 1934d, 480 (Alamos; Hacienda de San Rafael; Oposura).

69 An intensive search in Tropical, Sonoran, and Transition zone localities in southeastern Sonora in late May and June, 1937, failed to disclose the presence of any race of the Black-headed Grosbeak and all records for that region may safely be considered those of winter visitants or transients. This region (below 2,000 feet) is occupied in summer by considerable numbers of the closely related yellow and black grosbeak, a circumstance which may prohibit the presence of melanocephalus. Incidentally, I do not see how Hedymeles can possibly be maintained as a genus distinct from Pheucticus in view of the intimate relationship shown in almost every particular. The bill characters given by Ridgway (1901) to distinguish the two genera break down completely through individual variation in the largest-billed examples of melanocephalus, though they are maintained as an average. A sub-generic rank seems more than sufficient to cover the situation. It may further be remarked that the songs of melanocephalus and chrysopeplus are remarkably similar, as are also the alarm notes, and differ chiefly in the vastly greater volume of the latter species. 
Guiraca caerulea deltarbyncha (not of van Rossem!) van Rossem, 1938c, 133, part (Guirocoba).

Guiraca caerulea lazula (not Pitylus lazulus Lesson) Brewster, 1902, 159, part (Alamos, part; Oposura).

Guiraca caerulea (not Loxia caerulea Linnaeus) Baird, 1858, 499, part (Los Nogales) ; 1859, 16, part (Los Nogales).-Evermann and Jenkins, 1888, 68 (Magdalena).

Fairly common summer visitant in Tropical and Sonoran zones almost throughout the State, though there are no records for the extreme northwest, nor from the coastal plain except in migration. There are no winter records, and it seems likely that the winter range lies south of Sonora. Further localities are Pilares, July 11 and 20, 1935 (Univ. Mich.) ; San Bernardino Ranch on the boundary, August 26 to 31, 1892 (U. S. Nat. Mus. catl.); Quitovaquita on the boundary (Arizona side), April 30 (Huey, 1942, p. 372) ; boundary south of Bisbee (Monument 90), September 20, 1892 (Mearns notes); Guaymas, March 9, 1905 (Mus. Comp. Zoöl.) ; Rancho Santa Bárbara, June 9 to 12, 1937 (Dickey and Sheffler coll.). Extreme dates are March 9 (Guaymas) and September 24 (Rancho La Arizona). ${ }^{70}$

\section{GUIRACA CAERULEA SALICARIA GRINNELL}

\section{California Blue Grosbeak}

Guiraca caerulea salicarius Grinnell, Proc. Biol. Soc. Wash., 24, June 16, 1911, 163 (near Colton, Riverside County, California).- -van Rossem, 1934d, 480 (Alamos).

Guiraca caerulea salicaria van Rossem, 1931c, 293 (Obregon; Tesia).-

Guiraca caerulea lazula (not Pitylus lazulus Lesson) Brewster, 1902, 159, part (Alamos).

Apparently a rather common winter visitant in the Tropical zone lowlands and foothills from the lower Yaqui River southward. Further specimens have been examined from Camoa, February 18, and Guiro-

${ }^{70}$ Breeding Blue Grosbeaks from the tropical zone of southern Sonora in some respects are not typical of interfusa. The posterior wing bar is slightly darker and the bills wider and deeper at the base. Two of the seven, however, seem to be exactly like Arizona birds in these respects, and all are similar to interfusa in general coloration. Presumably the differences mentioned are in the direction of deltarbyncha of westcentral Mexico; indeed I once erroneously listed the largestbilled Guirocoba specimen as that race before adequate material was available. Four breeding specimens taken at altitudes of 5,000 to 5,500 feet in undergrowth in. the oak-pine association at Rancho Santa Bárbara, June 9 to 12, 1937 (a strange environment surely for Guiraca!), are typical interfusa. 
coba, April 6, 1931 (Bishop coll.). Extreme dates are November 19 (Ciudad Obregón) and April 6 (Guirocoba).$^{71}$

\section{PASSERINA AMOENA (SAY)}

\section{LAZULI BUNTING}

Emberiza amoena Say, in Long, Exped. Rocky Mts., 2, 1823, 47, note (Rocky Mts., source of the Arkansas = Cañon City, Colorado ).

Passerina amoena Townsend, 1923, 21 (Tiburon Island).--van Rossem, 1931c, 294 (Tecoripa; San Javier; Saric; Tesia; Chinobampo; Guirocoba); 1934d, 480 (Alamos; Mina Abundancia; Nacozari; Oposura; Granados).--Hellmayr, 1938, 108 (northern Sonora).

Common spring and fall transient at Sonoran and Tropical zone levels nearly everywhere, and a winter visitant in the Tropical zone southerly. Summer residence in the north is indicated, but not proven, by the presence of full grown juveniles at Rancho La Arizona in late summer (August 23), and by the presence of apparently resident pairs in the same locality May 9 (van Rossem notes); however, actual breeding records are lacking. Additional stations are Magdalena, April 20 to May 12, 1925 (Dawson notes); Quitovaquita on the boundary [Arizona side], April 30, 1939 (Huey, 1942, p. 372); San Bernardino Ranch on the boundary, August 9 and 30, 1892 (Mearns notes); extreme dates are August 9 (San Bernardino Ranch) and May 12 (Oposura and Magdalena).

\section{PASSERINA VERSICOLOR VERSICOLOR (BONAPARTE)}

\section{EASTERN VARIEI) BUNTING}

Spiza versicolor Bonaparte, Proc. Zool. Soc. Lond., 5, 1837, No. 59 [June 14, 1838], 120 (near Temascáltepec [México]).

Passerina versicolor versicolor van Rossem, 1934b, 370, in text (Chinobampo).Hellmayr, 1938, 108 (Chinobampo).

Passerina versicolor pulchra (not of Ridgway) van Rossem, 1931c, 293, part (Chinobampo, part).

Occasional midwinter visitant to the Tropical zone in the extreme south. The two specimens (adult male and female) known to date were taken by Wright at Chinobampo, February 14 and 15, 1930, and are now in the Dickey collection. Southern Sonora offers numerous examples of seasonal intrusion from eastern and interior areas and the present case, while interesting, is not extraordinary.

71 This race of the Blue Grosbeak almost certainly breeds in Sonora along the Colorado River, since it does so on the Baja California side (Grinnell, 1928, p. 185, under "interfusa"), and also in the adjacent part of Arizona. 


\section{PASSERINA VERSICOLOR PULCHRA RIDGWAY \\ Baja California Varied Bunting}

Passerina versicolor pulchra Ridgway, Man. N. A. Birds, 1887, 448 (Miraflores, Baja California, México).--van Rossem, 1931c, 293, part (Chinobampo, part; 1934b, 370 (Chinobampo).--Hellmayr, 1938, 109 (Chinobampo).

Winter visitant to the Tropical zone; probably not uncommon, though only four specimens have been taken to date. These individuals (all females) which are seemingly typical of pulchra, were taken by Wright at Chinobampo on March 2, 4, and 9, 1930. It is probable that some of the numerous adult males taken in Sonora in winter and included under the resident race dickejae are actually pulchra, but since there seems to be no reasonably certain method of distinguishing adult males of the two races, all are included under the former name.

\section{PASSERINA VERSICOLOR DICKEYAE VAN ROSSEM}

\section{SONORA VARIEd BUNTING}

Passerina versicolor dickeyae van Rossem, Trans. San Diego Soc. Nat. Hist., 7, No. 33, May 31, 1934, 369 (Chinobampo, Sonora, México) ; 1934d, 480 (Alamos; Hacienda de San Rafael; Oposura).--Hellmayr, 1938, 109 (Sonora).-A.O.U. Comm., 1944, 460 (northern Sonora).

Passerina versicolor pulchia (not of Ridgway) van Rossem, 1931c, 293, part (Saric; Tesia; Guirocoba; Chinobampo, part).

Cyanospiza zersicolor pulchra Brewster, 1902, 161, part (Alamos; Oposura).

Cyanospiza versicolor (not Spiza iersicolor Bonaparte) Cooper, 1870, 234, part Sonora).

Fairly common summer visitant to Sonoran and Tropical zones from the vicinity of the Pajaritos Mountains eastward, and south along the eastern foothills the full length of the State. Apparently resident in the Tropical zone, where also found on the coastal plain in winter. Additional stations from which specimens have been examined are El Tigre Mountains, July 11, 1935 (Univ. Mich.) ; Quiriego, April 30; Guadalupe, April 19; Nuri, April 21, 1888 (Brit. Mus.) ; San Francisco Cañon, May 29 and 30, 1937 (Dickey coll.).

\section{SPIZA AMERICANA (GMELIN)}

\section{DiCKCISSEL}

Emberiza americana Gmelin, Syst. Nat., 1, pt. 2, 1789, 872 (in Noveboraco= New York).

Apparently, in former years, a sporadic late summer and fall visitant in the extreme northeast. Mearns' notes record an individual (appar- 
ently not preserved) carried by a Richardson Pigeon Hawk when the latter was collected on the San Pedro River "on the boundary," October 10, 1892. Other specimens were collected at the San Bernardino Ranch on July 18 and 24, and August 27, 1892, but these appear, from Mearns' field book, to have been taken on the Arizona side of the line. The last cited specimen seems to have disappeared from the National Museum collection.

\section{Carpodacus mexicanus frontalis (Say)}

\section{NORTHERN HOUSE FinCH}

Fringilla frontalis Say, in Long, Exped. Rocky Mts., 2, 1823, 40, note (Arkansas River near the mountains = near Pueblo, Colorado) .

Carpodacus frontalis Sharpe, 1909, 265 (northern Sonora).

Carpodacus mexicanus frontalis Evermann and Jenkins, 1888, 67, 69 (Nogales; Magdalena).-Allen, 1893a, 38 (Oputo; Granados; Nacory).-Price, 1899, 92 (lower Colorado River).-Ridgway, 1901, 137 (northern Sonora).-A.O.U. Comm., 1910, 244 (Sonora); 1931, 321 (northern Sonora).-Townsend, 1923, 18, part (Tiburon Island).--van Rossem, 1931c, 295, part (many locs., excl., San Esteban Island); 1932, 142 (Tiburon Island); 1934d, 481 (Guaymas; Ranken's Ranch; Nacozari; Oposura; crit.).--Moore, 1936, 203 (northern and central locs.; crit.); 1939e, 188 (Sonora).-Hellmayr, 1938, 153 (northern Sonora).

Carpodacus mexicanus solitudinis Moore, 1939b, 107 (El Doctor; Saric); 1939e, 191 (N.W. Sonora).

Carpodacus mexicanus ruberrimus (not of Ridgway) Maillard, 1923, 455, part (San Pedro Martir Island).

Common resident from the Arizona boundary south, coastwise, to Kino Bay, Tiburón and San Pedro Mártir Islands, and in the eastern interior to about latitude $29^{\circ}$. Winter dispersal extends southward over the range of sonoriensis, specific localities being Guaymas, San Carlos Bay, Ciudad Obregón, San Estéban Island, Tesia, and Chinobampo between the dates of November 9 and February 19.

\section{CARPODACUS MEXICANUS SONORIENSIS RIDGWAY}

\section{SONORA HOUSE FINCH}

Carpodacus mexicanus sonoriensis Ridgway, Bull. U. S. Nat. Mus., 50, Pt. 1, 1901, 135 (southern Sonora north to Guaymas=Álamos, Sonora, México) ; ibid., in text (Batamotal).-van Rossem, 1931c, 294 (locs. north to Guaymas, Pesqueira, and Tecoripa); 1934d, 481 (Guaymas; Alamos); 1937a, 38 (Sonora; nomen.).Moore, 1936, 203-208, in text (southern Sonora; crit.); 1937b, 205, in text (re type).--Hellmayr, 1938, 157 (Sonora; crit.).

Carpodacus sonoriensis Sharpe, 1909, 265 (southern Sonora).

Erythrina mexicana sonoriensis Kuroda, 1930, 117 (southern Sonora).

Carpodacus familiaris (not of McCall) Heermann, 1853, 267, part (Guaymas.Cassin, 1856, 73, part (Guaymas). 


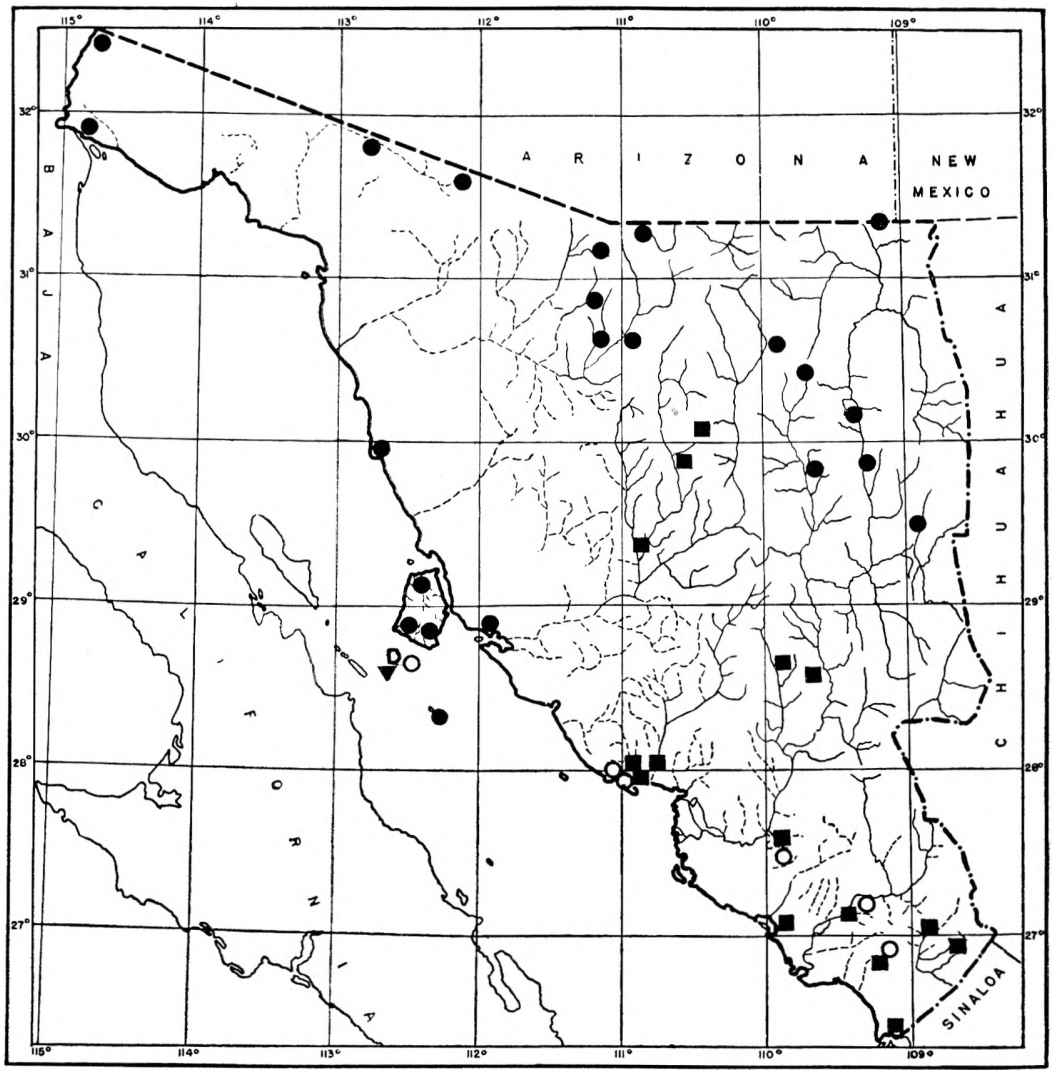

MAP 23. Distribution of Carpodacus mexicanus. Circles, C. m. frontalis; squares, $C . m$. sonoriensis; inverted triangles, $C . m$. ruberrimus; hollow figures, winter stations outside established breeding ranges.

Carpodacus frontalis (not Fringilla frontalis Say) Salvin and Godman, 1886, 421, part (Guaymas).

Carpodacus mexicanus frontalis Evermann and Jenkins, 1888, 69 (Guaymas).

Carpodacus mexicanus rbodocolpus (not Carpodacus rhodocolpus Cabanis) Belding, 1883, 343 (Guaymas).

Carpodacus mexicanus ruberrimus (not of Ridgway) A.O.U. Comm., 1895, 214, part (Guaymas).-Brewster, 1902, 133, part (Alamos; Guaymas; crit.).- Thayer and Bangs, 1906, 21 (Opodepe; La Chumata; crit.).-Moore, 1937d, 205-206, in text (Sonora; crit.); 1939e, 199, part (southern Sonora; monog.).

Common resident of the Tropical zone from the Sinaloa boundary north, coastwise, to about latitude $28^{\circ}$ and in the central interior to about latitude $30^{\circ}$. Most of the specimens from localities north of the lower 
Yaqui River valley are variously intermediate toward frontalis with resultant characters which closely approximate the Lower California race ruberrimus. ${ }^{i 2}$

\section{CARPODACUS MEXICANUS RUBERRIMUS RIIDGW}

\section{SAN Lucas House Finch}

Carpodacus mexicanus ruberrimus Ridgway, Manual No. Amer. Birds, 1887, 391, nute (Cape San Lucas = La Paz, Baja California, México).

Carpodacus mexicanus frontalis (not Fringilla frontalis Say) Townsend, 1923, 18. part (San Esteban Island).--van Rossem, 1931c, 295, part (San Esteban Island).

Fairly common resident on San Estéban Island. ${ }^{i 3}$

VOLATINIA JACARINA DILU'TA VAN ROSSEM

\section{Westrern Blue-Black Grassquit}

Volatinia jacarini diluta van Rossem, Bull. Brit. Orn. Club, 58, July, 1938, 130 (San Blas, Nayarit, México).

Volatinia jacarini atronitens (not of Todd) Moore, 1938a, 27 (Guirocoba; Baromicon).

Known only from two specimens in the Moore coilection, taken at Guirocoba on August 2 and 3, 1933, and one seen at Baromico on May 17, 1933. The two localities are, respectively, in the Tropical and Transition zones.

\section{SPINUS PINUS PINUS (WILSON)}

\section{Northern PINE Siskin}

Fringillu pinus Wilson, Amer. Orn., 2, 1810, 133, pl. 17, fig. 1 (Bush Hill near Philadelphia, Pennsylvania).

Spinus pinus pinur van Rossem, 1934d, 481 (Nacozari; Oposura).-Hellmayr, 1938, 270) (northern Sunora).

72 It has been urged that sonoriensis is synonymous with ruberrimus, initially by Brewster (1902), later by Bangs (1906), and finally by Moore (1936 et seq.) chiefly, in the first two cases, because of the appearance of specimens from such areas (occupied by frontalis-sonoriensis intergrades) as Guaymas, Opodepe, and La Chumata. However, House Finches from the lower Yaqui River southward are distinct from ruberrimus in certain color details, the slight Sinaloa accentuation of which, and a wing length averaging $2.6 \mathrm{~mm}$. shorter, has been named rhodopnus.

${ }^{73}$ Although the single male is paler in coloration than Cape San Lucas ruberri$m u s$, the five females are quite typical. All six San Estéban specimens are equally small and exhibit very strongly the tendency of larger and more swollen bills frequently seen in this race. An additional factor to be considered in this determi. nation (although not in itself conclusive) is the presence of other Baja California races on San Fstéban Island. 
Status uncertain. Four specimens in the Museum of Comparative Zoölogy, taken by Cahoon at Nacozari, March 25, 1887, and at Oposura [more probably the Sierra de Oposura], May 9 and June 2, 1887, are certainly to be referred only to pinzus. Whether the Oposura birds were resident or vagrants in the locality is unknown. Dawson (notes) observed numbers of Pine Siskins at Magdalena between May 7 and 15, 1925, and collected a specimen, the whereabouts of which is unknown and the subspecies therefore in doubt.

\section{SPINUS PINUS MACROPTERUS (DU BUS)}

\section{MeXican PINe Siskin}

Chrysomitris macropterus Du Bus, Esq. Orn., livr., 5, 1849, pl. 23, (no locality= Jalapa, Vera Cruz, México).

Spinus pinus macropterus van Rossem, 1931c, 295 (Saric).--Hellmayr, 1938, 271 (Saric).

Known only from eleven specimens shot from a vagrant flock at Rancho La Arizona ("Saric") on May 15, 1929. Certain minor peculiarities in coloration suggest the San Pedro Mártir Mountains in Baja California as the locality of origin, rather than the Mexican plateau.

\section{SPINUS NOTATUS FORRERI (SALVIN AND GODMAN)}

\section{FORRER SISKIN}

Chrysomitris forreri Salvin and Godman, Biol. Centr.-Am., Aves, 1, Nov. 1886, 429 (Ciudad, Durango, México).

Spinus notatus forreri van Rossem, 1934d, 482 (Mina Abundancia); 1938c, 136, in text (Sonora; crit.).-Hellmayr, 1938, 288 (northeastern [ $=$ southeastern] Sonora).

Common in spring and summer in the Transition zone in the mountains of the southeast, where breeding and probably resident. In addition to the single published Sonora locality (Mina Abundancia), there are specimens in the Dickey and Sheffler collections from Rancho Santa Bárbara taken between June 6 and 13, 1937.

\section{SPINUS PSALTRIA HESPEROPHILUS (OBERHOLSER)}

\section{GREEN-BACKED GOLDFINCH}

Astragalinus psaltria hesperopbilus Oberholser, Proc. Biol. Soc. Wash., 16, Sept. 30, 1903, 116 (San Bernardino, California).-Thayer and Bangs, 1906, 21 (Opodepe; La Chumata).-A.O.U. Comm., 1910, 249 (Sonora).-Dawson, 1923, 191 (Sonora). 
Spinus psaltria hesperophilus Bailey, 1928, 704 (Sonora).-A.O.U. Comm., 1931, 327 (Sonora).--van Rossem, 1931c, 296 (El Doctor; Pesqueira; San Javier; Saric; Chinobampo; Guirocoba; 15 miles S.W. of Nogales); 1934d, 482 (Hacienda de San Rafael; Nacozari; Oposura).-Hellmayr, 1938, 297 (northern Sonora). Astragalinus arizonae (not Chrysomitris mexicanus Var. arizonae Coues) Sharpe, 1909, 234 (Sonora).

Astragalinus psaltria arizonae Ridgway, 1901, 115, part (Sonora).

Spinus psaltria arizonae Evermann and Jenkins, 1888, 68 (Magdalena).

Spinus psaltria (not Fringilla psaltria Say) A.O.U. Comm., 1886, 261, part (Sonora).-Allen, 1893a, 38 (Los Cuevos).

S.[pinus] psaltria Ridgway, 1887d, 399, part (Sonora).

Chrysomitris psaltria, var. psaltria Baird, Brewer, and Ridgway, 1874 (1), 474 , part (Arispe).

Astargalinus [sic] psaltria mexicanus (not Carduelis mexicana Swainson) Sheffler, 1931a, 137 (27 mi. S. of Nogales).

Common resident of Sonoran zone levels from the Pajaritos Mountains eastward, and south through the central and eastern foothills the full length of the State. Also occurs generally over western deserts and lowlands in winter. Additional specimens have been examined from Guirocoba, May 1, 1931 (Bishop coll.); Guaymas, March 6 to 14, 1905 (Mus. Comp. Zoöl.) ; Guadalupe Cañon, early July, 1892; Cajón Bonito Creek, September 8, 1893 (Mearns notes).

\section{SPINUS LAW'RENCEI (CASSIN)}

\section{LAWRENCE GOLDFINCH}

Carduelis Lawrencei Cassin, Proc. Acad. Nat. Sci. Phila., 5, No. 5, Sept.-Oct. [Dec. 7], 1850, 105, pl. v (Sonoma and San Diego, California=Sonoma, Sonoma Co.).

Astragalinus lawrencei Price, 1899, 92 (lower Colorado River).

Spinus lawrencei van Rossem, 1931c, 296 (Tecoripa; 12 miles west of Magdalena).-Hellmayr, 1938, 301 (Sonora).

Winter visitant, probably appearing sporadically south at least as far as Tecoripa (lat. 28 40 ). Although Price (1899) observed "immense flocks" in the Colorado delta in December, he is not specific as to which side of the river he refers.

\section{Chlorura chlorura (AUdubon)}

\section{GrFen-TAILfD TOWHEE}

Fringilla chlorura Audubon, Orn. Biog., 5, 1839, 336 (Ross Creek=about 20 miles southwest of Blackfoot, Idaho).

Oreospiza chlorura Townsend, 1923, 20 (Tiburon Island).-Sheffler, 1931a, 138 (Imuris); 1931b, 164 (Between Magdalena and Santa Ana). 
Oberbolseria chlorura van Rossem, 1931c, 296 (Pesqueira; Tecoripa; Saric Obregon; Tesia; Chinobampo; Guaymas); 1932, 144 (Tihuron Island); 1934d 482 (Alamos; Cumpas; Nacozari; Oposura).-Hellmayr, 1938, 451 (southern Sonora).

Pipilo chlorurus Allen, 1893a, 39 (Fronteras; Bacadelhuachy).

Oberbolseria chlorura zapolia Oberholser, 1932, 10 (southern Sonora).

Common, sometimes abundant, state-wide winter visitant almost everywhere below Transition levels. Some additional stations are Camoa, Fcbruary 6 to 9 (Bishop coll.) ; EI Álamo, December 5; Costa Rica, December 11 ; Ures, January 29 (Dickcy coll.; Lamb notes) ; Kino Bay, February 19 (Nat. Hist. Mus.) ; Sonoyta, January 15 to 22; Colorado River at Monument 204, March 17 to 24 (U. S. Nat. Mus.); Magdalena, April 16 to May 12 (Dawson notes); San Luís Mountains, September 26; Cajón Bonito (reck, September 24; Boundary at Monument 90, September 14 (Mearns notes); Extreme dates are September 14 (Boundary at Mon. 90) and May 12 (Oposura and Magdalena).

\section{Pipilo maculatus montanus Swarth \\ SPurred TowheE}

Pipilo maculatus montunus Swarth, Condor, 7, No. 6, November 22, 1905, 172 (Miller Cañon, Huachuca Mountains, Arizona).-A.O.U. Comm., 1910, 280 (Sonora).--Bailey, 1928, 712 (Sonora).-van Rossem, 1931c, 296 (15 miles S. [W.] of Nogales=Rancho La Arizona) ; 1934d, 482 (Nacozari).-Hellmayr, 1938,455 (Sonora).

Pipilo maculatus megalonyx (not Pipilo megalonyx Baird) Allen, 1893a, 39 (Los Pinitos).-Ridgway, 1901, 415, part (Sonora).

Resident in Upper Sonoran and probably the lower parts of the Transition zones from the Pajaritos Mountains east to the Chihuahua boundary. The southern limits have not been determined; the farthest south to date is Nacozari. Additional specimens have been examined from the San José Mountains, August 8, 1893; Nogales, October 26, 1893; San Luís Mountains on the boundary, July 19, 1892 (U. S. Nat. Mus.).$^{74}$

\section{Pipilo macui.atus curtatus Grinnell}

\section{Neval)a TOWhFF}

Pipilo maculatus curtatus Grinnell, Univ. Calif. Pub. Zool., 7, No. 8, Aug. 24, 1911, 309 (Big Creek Ranch, base of Pine Forest Mountains, Humboldt Co., Nevada).

${ }^{74}$ Present evidence is that the species Pipilo maculatus trends southeast from northeastern Sonora and does not occur in apparently suitable mountains in central and southern Sonora. At least it was not detected by Brown in the Sierra de San Antonio, by Cahoon in the Sierra de Oposura, by Frazar at Mina Abundancia, nor by van Rossem in the Upper Sonoran and Transition zones at Rancho Santa Bárbara. 


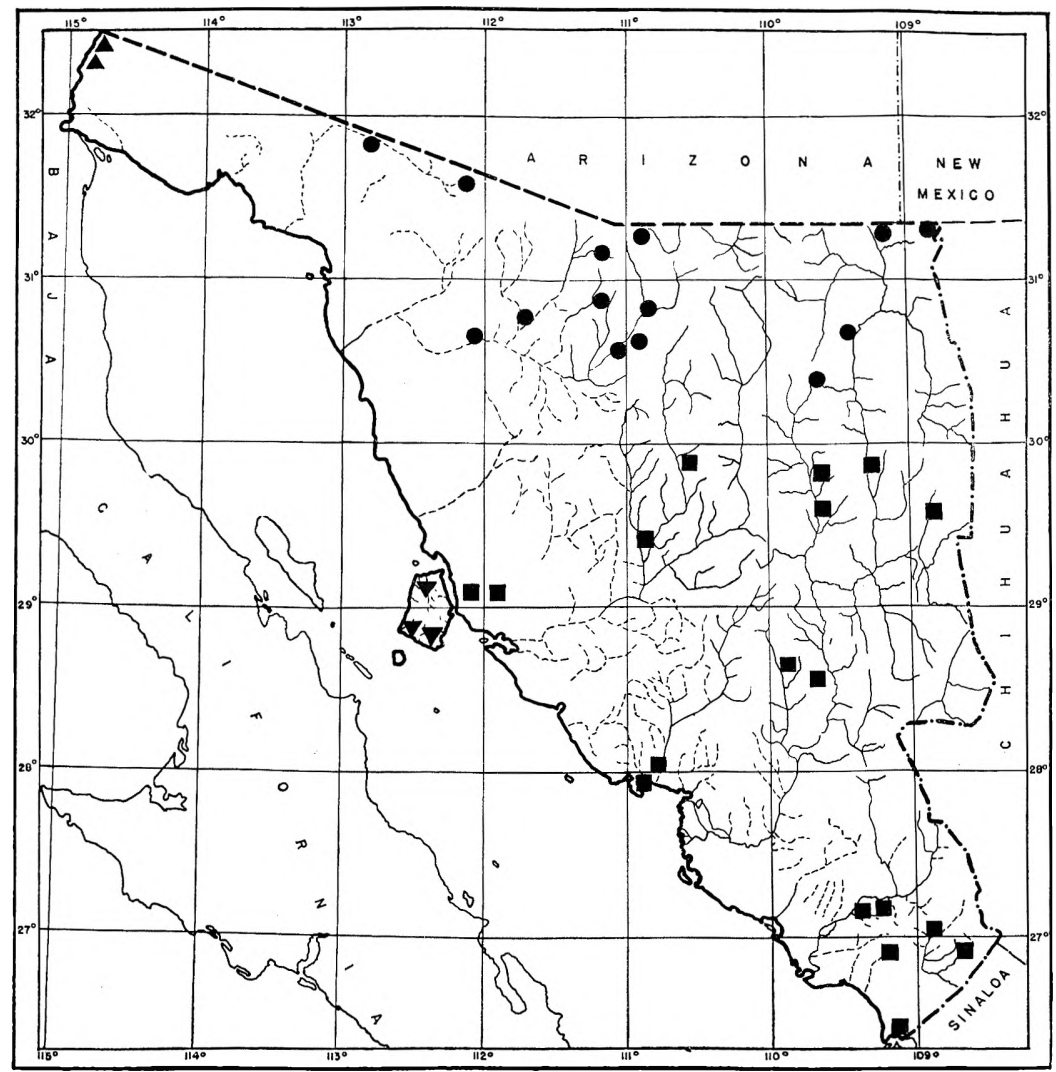

Map 24. Distribution of two species of Pipilo. Circles, $P$. fuscus mesoleucus; squares, $P$. $f$. intermedius; inverted triangles, $P . f$. james $i$; triangles, $P$. alberti.

Rare midwinter visitant in the extreme north. But one specimen has been examined,- - that taken by Mearns and Holzner at Sonoyta, January 16, 1894, and now in the United States National Museum.

\section{Pipilo FUSCUS MESOlEUCUS BAIRD}

\section{CAÑON TOWHEE}

Pipilo mesoleucus Baird, Proc. Acad. Nat. Sci. Phila., 7, No. 3, June [July 3], 1854, 119 (Bill Williams Fork=Big Sandy, just south of lat. $35^{\circ}$, Arizona) ; 1858, 518 (Los Nogales); 1859, 18 (Los Nogales).-Sharpe, 1909, 320 (northeastern Sonora).

Pipilo fuscus, var. mesoleucus Baird, Brewer, and Ridgway, 1874, (2), 127, in text (Los Nogales). 
Pipilo fuscus mesoleucus Stephens, 1885, 228 (Altar).-A.O.U. Comm., 1895, 247 (Sonora) ; 1910, 281 (northeastern Sonora) ; 1931, 333 (northeastern Sonora). -Coues, 1903, 461 (northern Sonora).-Bailey, 1928, 714 (northeastern Sonora). -van Rossem, 1931c, 297 (Saric; El Alamo; 15 miles S. W. of Nogales; Altar; Caborca) ; 1934d, 483 (Nacozari).- Sheffler, 1931a, 138 (Imuris) ; 1931b, 164 (between Magdalena and Santa Ana).-Hellmayr, 1938, 465, part (northern Sonora locs.).

Pipilo fuscus (not of Swainson) Salvin and Godman, 1886, 409, part (Los Nogales).

Pipilo fuscus intermedius (not of Nelson) Ridgway, 1901, 432, part (Magdalena).

Common resident of the Lower Sonoran zone (chiefly mesquite and stream-bed shrubbery associations), from about longitude $113^{\circ}$ eastward along the northern boundary and south at least to latitude $30^{\circ} 30^{\prime}$. Unpublished localities from which specimens have been examined are Pilares, July 11, 1935 (Univ. Mich.); Cajón Bonito Creck on the boundary, September 28, 1893; Guadalupe Cañon, July 28, 1892 ; Sonoyta, January 20, 1894 ; Pozo de Luís, January 1 and 3, 1894 (U. S. Nat. Mus.).

\section{PIPII.o fuscus JAMESI TOWNSENI)}

\section{Tiburón IsLÁNI) TowheE}

Pipilo fuscus jamesi Townsend, Bull. Am. Mus. Nat. Hist., 48, March 9, 1923, 20 (Tiburón Island, Sonora, México).- -van Rossem, 1932, 144 (Tiburon Island; crit.).-Hellmayr, 1938, 466 (Tiburon Island).

A fairly common resident of chaparral areas on Tiburón Island.

\section{Pipilo fuscus INTERMEDIUS Nelson}

\section{Álamos TowheE}

Pipilo fuscus intermedius Nelson, Proc. Biol. Soc. Wash., 13, May 29, 1899, 27 (Álamos, Sonora, México).--Ridgway, 1901, 432, part (Guaymas; Alamos; Batamotal).-Thayer and Bangs, 1906, 22 (Opodepe; Guaymas; crit.).-van Rossem, 1931c, 296 (Pesqueira; Tecoripa; San Javier; Tesia; Chinobampo; Guirocoba; Agiabampo); 1932, 143. 1.44, in text (Guaymas: Pesqueira); 1934d, 483 (Alamos: Oposura).-Hellmayr, 1938. 467 (Sonora locs.).--Moore, 1942, 47, in text (Guirocoba; crit.).

P.[ipilo] f.[uscus] internedius Townsend, 1923, 20 (Guaymas).

Pipilo intermedius Sharpe, 1909, 319 (coast district of southern Sonora).

Pipilo fuscus (not of Swainson) Ridgway, 1886, 148, part (Guaymas).-Salvin and Godman, 1886, 409, part (Guaymas).

Pipilo fuscus mesolencus (not Pipilo mesoleucus Baird) Belding. 1883, 343 (Guaymas).--Ridgway, 1886, 148, part, in text (Guaymas) ; 1901, 432, part (Granados: Nacory).-Allen, 1893a, 39, part (Nacory: Granados).-Hellmayr, 1938, 465, part (Cerro Blanco). 
Common resident of the Tropical zone, north, coastwise, at least to latitude $29^{\circ} 08^{\prime}$ (Sierra Seri) and in interior valleys to about latitude $30^{\circ}$. Most specimens between latitudes $29^{\circ}$ and $30^{\circ}$, particularly in the eastern part of the State, are varyingly intermediate toward mesoleucus. Although previously unknown to occur north of Guaymas along the coast, specimens have been collected by Benson and Sibley (Mus. Vert. Zool) in the Sierra Seri, November 15 to 17, 1941, and at Mina Los Afanes, January 19 and 20, 1942.

\section{PIPILO ABERTI BAIRD}

\section{Abert TowheE}

Pipilo aberti Baird, in Stansbury, Rep. Exped. Utah, 1852, 325 (New Mexico).Price, 1899, 93 (lower Colorado River).-A.O.U. Comm., 1910, 281 (northwestern Sonora).-1931, 333 (northwestern Sonora).-Bailey, 1928, 718 (Sonora).-Hellmayr, 1938, 468 (northwestern Sonora).

Common resident of the Colorado River delta, probably throughout its length though definitely known only from near the Arizona boundary. Noted as common at San Luís and Colonia Independencia on May 3, 1937 (van Rossem notes); specimens taken near the former locality by Mearns and Holzner between March 14 and 24, 1894 (U. S. Nat. Mus.). ${ }^{75}$

\section{MELOZONE KIENERI GRISIOR VAN ROSSEM}

\section{Northern Ground Sparrow}

Melozone rubricatum grisior van Rossem, Trans: San Diego Soc. Nat. Hist., 7, No. 23, March 31, 1933, 283 (Hacienda de San Rafael, Sonora, México).Peters, 1943, 94 (re. type).

Melozone kieneri grisior van Rossem, 1934d, 423, 484 (nomen.; Hacienda de San Rafael).-Hellmayr, 1938, 470 (Hacienda de San Rafael).

Melozone rubricatum xantusii (not Pyrgisoma xantusii Lawrence) Ridgway, 1901, 441, part (San Rafael).-Griscom, 1934, 421, part (Sonora; crit.).

Presumably resident in the Tropical zone foothills in the extreme southeast. Known, however, from but three localities, Hacienda de San Rafael, where Frazar took 28 specimens between May 3 and 19, 1888; San Fran-

${ }^{75}$ The notes of the late W. Leon Dawson contain specific references to the Abert Towhee at Nogales on May 10, and at Magdalena on May 15 and 17, 1925. This is a species with which Dawson was perfectly familiar and which he could scarcely have confused with Pipilo fuscus (which he frequently mentions also). Mearns (notes) believed he saw one at the San Bernardino Ranch in early July, 1892. In the absence of specimens it seems better for the present to accord these records hypothetical status. 
cisco Cañon, where taken by van Rossem on May 30, 1937 (Dickey coll.) ; one scen at Guirocoba on June 3, 1937 (van Rossem notes).

\section{ORITURUS SUPERCILIOSUS PALLIATUS (VAN ROSSFM)}

\section{Northern Striped Sparrow}

Plagiospiza superciliosa palliata van Rossem, Bull. Brit. Orn. Club, 58, July, 1938, 127 (Near Tutuaca, Chihuahua, México, alt. 9500 ft.); ibid., in text (Bavispe River).

Aimophila superciliosa (not of Swainson) Allen, 1893a, 39 (Bavispee River).

Plagiospiza superciliosa Ridgway, 1901, 229, part (northeastern Sonora).Hellmayr, 1938, 475 (northeastern Sonora).

The only record for Sonora is that by Allen of specimens (examined in Amer. Mus. N. H.) taken by Robinette of the I.umholtz Expedition on the upper Bavispe River, December 21 and 26, 1890. It appears probable, judging from the distribution in Chihuahua, that the Striped Sparrow will be found at other high Transition points in the Sierra Madre of eastern Sonora. ${ }^{\text {i6 }}$

\section{CaLAmospiza mei.anocoris Stejnegir}

\section{LARK BUNTING}

Calamospiza melanocorys Stejneger, Auk, 2, No. 1, Jan., 1885, 49 [New name for Fringilla bicolor Townsend nec Linnaeus] (Plains of the Platte River [Nebraska]).--Allen, 1893a, 40 (Oputo).-Ridgway, 1901, 168 (Sonora).-Brewster, 1902, 163 (Guaymas).-A.O.U. Comm., 1910, 288 (Sonora).-Townsend, 1923, 48 (Tiburon Island).--Bailey, 1928, 719 (Sonora).- van Rossem, 1931c, 297 (Obregon; Tesia): 1932, 144 (Tiburon Island); 1934d, 484 (Guaymas; Bacuachi).- - Huey, 1935, 256 (Punta Peñascosa).

Calamospiza bicolor (not Fringilla bicolor Linnaeus) Baird, 1858, 492 (Sonora).--Cooper, 1870, 225 (Sonora).-Baird, Brewer, and Ridgway, 1874 (2), 61 (Sonora).-Belding, 1883, 343 (Guaymas).- Salvin and Godman, 1886, 417 (Guaymas).

Common, often abundant, winter visitant to lowlands and foothills, probably throughout the State though not as yet recorded from the Colorado delta or south of the Mayo River valley. Additional localities are San Bernardino Ranch. August 6, 1892 ; Cerro (iallardo, August 14, 1893 , "hundreds" (U. S. Nat. Mus.; Mearns' notes); between Altar and Caborca, February 2, 1932 (Phillips notes); Santa Ana, March 1, 1934 (Nat. Hist. Mus.) : Kino Bay, December 27, 1931 (van Rossem notes).

${ }^{76}$ For change of generic name from Plagiospiza to Oriturus, see van Rossem, Auk, 39, 1942: 449. 
Seasonally, the earliest date is August 6 (San Bernardino Ranch), the latest is April 12 or 13 (Tiburón Island).

\section{Passerculus sandwilhensis anthinus Bonaparte \\ WEStern Savanna Sparrow}

Passerculus anthinus Bonaparte, Comptes Rendus Acad. Sci. (Paris), 37, No. 25, for Dec. 19, 1853, 920 (Kadiak-Kodiak Island, Alaska).

Passerculus sandu'ichenis alaudinus (not Passerculus alaudinus Bonaparte) van Rossem, 1931c, 298 (Tesia).-Huey, 1935. 256 (Punta Peñascosa).

Passerculus satanna aluudinu, Streets. 1877, 9 (Rio San Ignacio).

Passerculus sanduichenszi subsp. Hellmayr, 1938, 488, part (Tesia).

Probably not uncommon as a winter visitant, though but few specimens so far have been collected. Additional to the few published records are two specimens taken by Mearns and Holzner on the lower Colorado River, March 25, 1894 (examined at the U. S. National Museum). The relative abundance of anthimus and nevadensis in Sonora in winter is impossible to estimate at this time.

\section{Passerculus sandwichensis crassus Peters and Griscom \\ Northwestern Savanna Sparrow'}

Passerculus sandwichensis crasıus Peters and Griscom, Bull. Mus. Comp. Zoöl., 80, January, 1938, 459 (Sitka, Alaska).

Passerculus sanduichensis anthinus (not Passerculus anthinus Bonaparte) van Rossem, 1931c, 297 (Tesia).-Hellmayr, 1938, 485 (Tesia).

One midwinter record, possibly that of a casual, from Tesia in the lower Mayo River Valley, February 4, 1930, taken by J. T. Wright. Parenthetically, another record of this race from San Luís. Island, Baja California (Grinnell, 1928, p. 161) suggests that the Gulf area may be part of the normal winter range.

\section{PASSERCULUS SANDWICHENSIS NEVADENSIS GRINNFIL \\ Nevai)a Savanna Sparrow}

Passerculus sandwichensis nevadensis Grinnell, Lniv. Calif. Publ. Zool., 5, No. 9, Feb. 21, 1910, 312 (Soldier Meadows, Humboldt County, Nevada).--van Rossem, 1931c, 298 (Tesia).

Winter visitant, probably in some numbers, to grasslands and river valleys south at least to the Mayo River valley. Further specimens have been examined from Sulphur Spring Valley on the boundary, October 7, 1893; Santa Cruz River, Novcmber 6 and October 20, 1892 ; Sonoyta, January 14 and 15, 1894 (U. S. Nat. Mus.); Quitovaquita on the boundary, November 29, 1939) (Huey, 1942, p. 372). Dates extend from October 7 (Santa Cruz River) to March 24 (Tesia). 


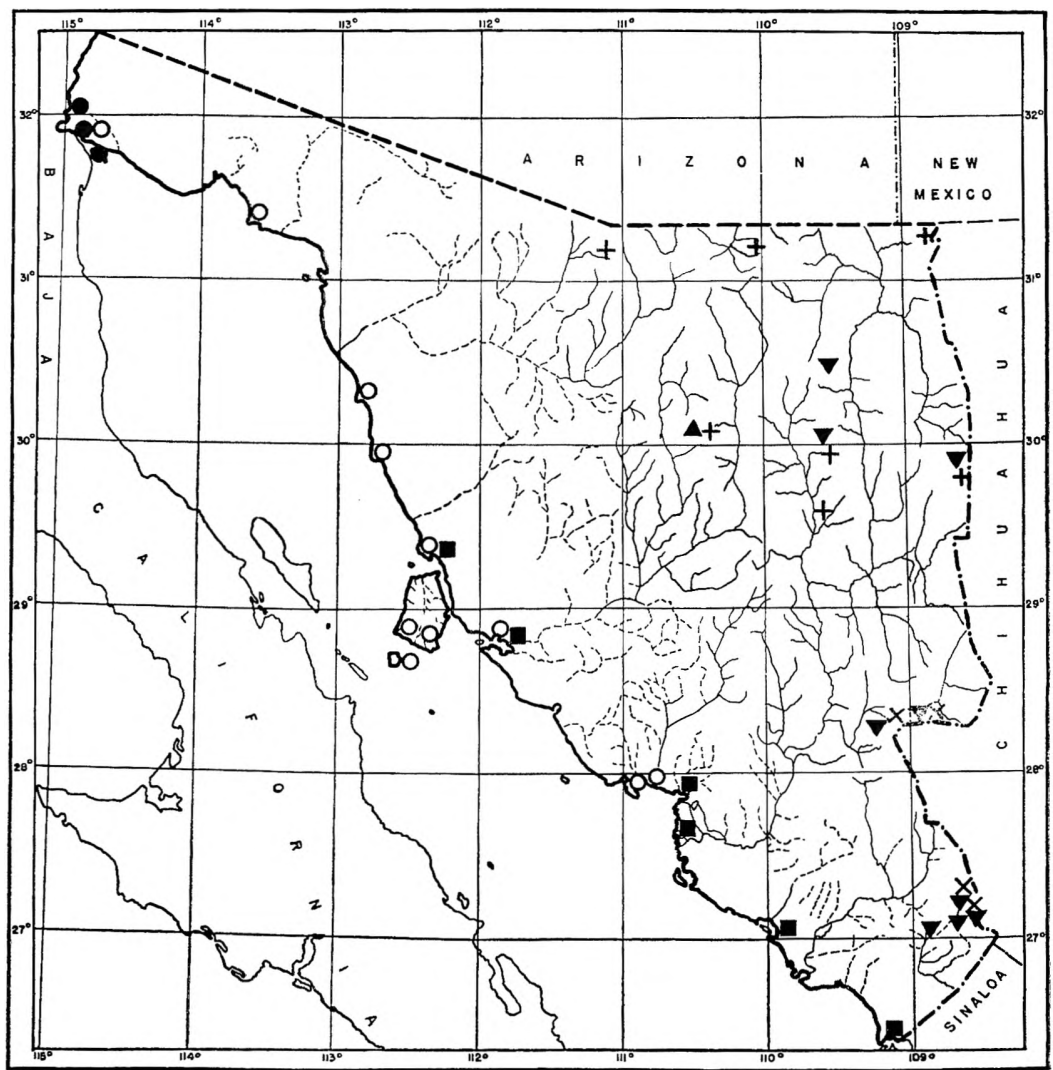

Map 25. Distribution of Passerculus sandwichensis and two species of Aimophila. Circles, $P$. s. rostratus; squares, $P$. s. atratus; inverted triangles, $A$. rufescens mcleodii; triangle, $A$. $r$. antonensis; vertical crosses, $A$. ruficeps scottii; diagonal crosses, $A$. r. simulans.

\section{PASSERCULUS SANDWICHENSIS ROSTRATUS (CASSIN)}

\section{LARGE-BILlED SPARROW}

Emberiza rostrata Cassin, Proc. Acad. Nat. Sci. Phila., 6, No. 5, Sept.-Oct. [Dec. 31] , 1852, 184 (San Diego, California).

Ammodramus rostratus Belding, 1890, 145 (Guaymas).--Brewster, 1902, 138 (Guaymas).

A.[mmodramus] rostratus Ridgway, $1887 \mathrm{~d}, 410$ (Sonora).

Passerculus rostratus Baird, Brewer, and Ridgway, 1874, (1), 542 (mouth of Colorado River).-Belding, 1883, 343 (Guaymas).-Brewster, 1885, 198 (Port Lobos).--Stephens, 1885, 230 (Port Lobos).-Salvin and Godman, 1886, 382 (Guaymas).-Sharpe, 1909, 291 (Sonora s. to Guaymas). 
Passerculus rostratus rostratus Ridgway, 1901, 199 (coast south to Guaymas).Grinnell, 1905, 16 (Sonora) ; 1939, 119 (nomen.; crit.). A.O.U. Comm., 1910, 255 (coast s. to Guaymas) ; 1931, 335 (head of Gulf; So. Sonora in winter).Oberholser, 1919b, 346 (Colorado River, opp. mouth of Hardy; Montague Island; Tiburon Island; Point Lobos; Guaymas).- Townsend, 1923, 19 (Tiburon Island).-Dawson, 1923, 259 (head of the Gulf).-Bancroft, 1927a, 56 (mouth of Colorado River; breeding).-Huey, 1930, 206 (Punta Lobos).

Passerculus sandwichensis rostratus van Rossem, 1930i, 215-219 (range in Sonora; crit.).; 1931c, 298 (El Doctor; mouth of Colorado River; Port Lobos) ; 1932, 145 (Tiburon Island); 1934d, 484 (Guaymas).--Huey, 1935, 256 (Punta Peñascosa).-Peters and Griscom, 1938, 476 (range in Sonora; crit.).- Hellmayr, 1938, 493 range in Sonora; crit.).

Passerculus rostratus guttatus?: Price, 1899, 92 (mouth of Colorado River).

Abundant resident of tidewater marshes at the mouth of the Colorado River. Abundant and generally distributed along the coast in fall, winter, and spring south as far as Guaymas at least and on Tiburón Island. Specimens intermediate toward the Tropical coast race atratus occur in winter at Puerto Libertad, but whether these represent a breeding population in that locality is not known. Many additional winter or early spring specimens have been examined from San José de Guaymas, Kino Bay, Tepopa Bay (Dickey coll.); Puerto Libertad and Punta Peñascosa (Nat. Hist. Mus.) ; Colorado River, opposite mouth of the Hardy (U. S. Nat. Mus.) ; observed at San Estéban Island, January 12, 1932 (van Rossem.) ${ }^{7 \pi}$

\section{PASSERCULUS SANDW'ICHENSIS ATRATUS VAN ROSSEM}

\section{SONORA MARSh SPARrow}

Passerculus sandwichensis atratus van Rossem, Trans. San Diego. Soc. Nat. Hist., 6, No. 14, Nov. 28, 1930, 218 (Tóbari Bay, Sonora, México); ibid., in text (Guasimas Lagoon; Kino Bay; mainland opposite Tiburon Island); 1931c, 298 (same locs.).-Peters and Griscom, 1938, 476 (coast of central and southern Sonora).-Hellmayr, 1938, 494 (range in Sonora).

Passerculus rostratus atratus Grinnell, 1939, 119 (nomen.; crit.).

Common resident of tidewater marsh associations from the Sinaloa boundary north to Tepopa Bay. Specimens from extreme northern points

7ז As Peters and Griscom (1938) have remarked, a great deal of collecting is necessary in summer and early fall, prior to dispersal from the breeding grounds, before the status of the type of Passerculus guttatus Lawrence can be disposed of with any degree of finality. Indeed the great degree of individual variation apparent in several races may prevent any definite and final allocation of the type,unless of course some as yet undiscovered breeding range solves the question. It is difficult to believe that the swarms of Large-billed Sparrows which occur over the extensive winter range are all, or even in major part, from the limited breeding grounds at the mouth of the Colorado. 
(Kino and Tepopa Bays) are somewhat intermediate toward rostratus. Additional specimens have been examined from Agiabampo, May 18, 1937; Kino Bay, December 27, 1931 (Dickey coll.); Médano, May 10, 1939 (Mus. Vert. Zool.).

\section{AMMODRAMUS SAVANNARUM PERPALLIDUS (COUES)}

\section{Western Grasshopper Sparrow}

Coturniculus passerinus var. perpallidus "Ridgway" Coues, Key N. A. Birds, 1872,137 , in text (dry western regions=Antelope Island, Great Salt Lake, Utah).

Ammodramus savannarum perpallidus van Rossem, 1934d, 484 (Alamos).

Coturniculus savannarum bimaculatus (not Ammodramus bimaculatus Swainson) Mearns, 1902, 917, in text (Guadalupe Cañon).

Ammodramus savannarum bimaculatus van Rossem, 1931c, 298, part (Obregon; Tesia; part; Chinobampo; Guirocoba).

[?] Coturniculus passerinus (not Fringilla passerina Wilson) Baird, 1858, 450, part (Los Nogales); 1859, 15, part (Los Nogales).

Common winter visitant in Tropical zone valleys and grasslands. Occurs as a transient, and probably as a winter visitant also, at more northern points. Extreme dates of arrival and departure are October 4 (Guadalupe Cañon) and April 17 (Guirocoba). Possibly some race of the Grasshopper Sparrow breeds in the vicinity of Nogales, where taken in "June," 1855; however, Dr. Kennerly's appended remark (Baird, 1859) of "generally in small flocks of four or five" sounds, rather, as though the specimen taken might have been a belated migrant.

\section{AMMODRAMUS SAVANNARUM AMMOLEGUS OBERHOLSER}

\section{Arizona Grasshopper Sparrow}

Ammodramus savannarum ammolegus Oberholser, Proc. Biol. Soc. Wash., 55, May 12, 1942, 15 ( 6 miles southeast of Fort Huachuca, Arizona, alt. $5000 \mathrm{ft}$.).

Ammodramus savannarum bimaculatus (not Ammodramus bimaculatus Swainson) van Rossem, 1931c, 298, part (Tesia, part).

A winter visitant and transient, probably at various suitable points south of the known breeding range in southeastern Arizona. There are two records, both from Tesia, December 27, 1929) and March 14, 1930, respectively. It is to be suspected that the breeding range of ammolegus includes northeastern Sonora; however, this remains to be demonstrated. It is obviously greatly outnumbered by perpallidus as a winter visitant and migrant. 


\section{AMMODRAMUS BAIRDII (AUDUBON)}

\section{BAIRD SPARROW}

Emberiza Bairdii Audubon, Birds Amer., oct. ed., 7, 1844, 359, pl. 500 (Prairie of the upper Missouri=near Old Fort Union, North Dakota).

[Centronyx bairdii Ridgway, 1901, 203 ("10 miles S. of Sasabe; Nuevencha Plain, etc.")]

[Ammodramus bairdi A.O.U. Comm., 1910, 256 (northern Sonora) ; 1931, 337 (northern Sonora).-Bailey, 1928, 723 (northern Sonora).]

The above records of the Baird Sparrow are erroneous. The Nuevencha Plain record goes back to Allen (1893a) and is from Chihuahua. That of Ridgway is a misquotation of Brewster's (1885) record which is from southern Arizona. However, there are two specimens in the U. S. National Museum (three in Mearns' field notes) taken by Mearns in the Ánimas Valley on the boundary, October 2, 1893, which may be considered sufficient ground for formal admission. There is obvious reason to suppose winter residence in some numbers on the grass plains of extreme northern Sonora.

\section{Pooecetes gramineus CONFINIS BAIRD}

\section{Western Vesper Sparrow}

Poocaeles gramineus var. confinis Baird, Rep. Expl. and Surv. R. R. Pac., 9, 1858, 448 (Western U. S. =Loup Fork of the Platte River, Nebraska).

Pooecetes gramineus confinis Price, 1899, 92 (south of Yuma).-van Rossem, 1931c, 298 (Tecoripa; Tesia; Obregon; Chinobampo; Guirocoba; $12 \mathrm{mi}$. W. of Magdalena; Sasabe Valley; San Luis); 1934d, 485 (Alamos).

Pooecetes gramineus definitus Oberholser, 1932, 11 (Alamos).

Common winter visitant and transient in Sonoran and Tropical zont valleys and deserts throughout the State. The earliest fall date is October 7 (Sulphur Spring Valley); the latest in spring is April 16 (Guirocoba). Some unpublished localities with dates between the above extremes are Camoa (Bishop coll.) ; Ures; El Álamo (Dickey coll.; Lamb notes) ; San Pedro River; Sulphur Spring Valley (October 7, 1893) ; Nogales; Colorado River at Monument 205 (U. S. Nat. Mus.) ; Quitovaquita and Grays' Ranch on the boundary (Huey, 1942, p. 373).

\section{Chondestes grammacus strigatus Swainson}

\section{WeSTERN LARK SPARROW}

Chondestes strigatus Swainson, Philos. Mag., n.s., 1, No. 6, June, 1827, 435 (Table land. Temiscaltepec. $=$ Temascáltepec, México' -Salvin and Godman, 1886, 375 (Guaymas). 
Chondestes grammacus rtrigatus Price, 1899, 92 (lower Colorado River).Ridgway, 1901, 178 (northern Sonora).-Allen, 1893a, 38 (Nacory).- van Rossem, 1931c, ?)9 (Saric; Obregon; Tesia; $15 \mathrm{mi}$. S. W. of Nogales; Guirocoba); 1934d, 485 (Guaymas; Alamos: Bacuachi; Oposura; Granados).-Shcffler, 1931b, 165 (between Magdalena and Santa Ana).-Hellmayr, 1938, 515, footnote (Sonora; crit.).

Chondestes grammica strigata Belding, 1883, 343 (Guaymas).

Summer visitant to Sonoran zones in the northern part of the State, from about Quitovaquita eastward. Southern limits of the breeding range are indefinite since there is a tendency for some individuals to linger until late spring on the winter range. Probable breeding localities are Rancho La Arizona, Cibuta, Nogales, San Pedro River, Guadalupe Cañon; Cajón Bonito Creek, and San Bernardino Ranch. Common and widespread in fall, winter, and spring over deserts and river valleys practically everywhere, and exceptinnally lingering as late as May 2 (Guirocoba) and May 10 (Oposura). Further occurrences are Camoa, February 4; Chinobampo, March 12: Cibuta, July 20, 1931 (Bishop coll.); El Alamo, December 2, 1932 (Lamb notes); Nogales, May 10, 1925 (Dawson notes) ; Sonoyta, January 15, 1894; Quitovaquita on the boundary (Arizona side), April, breeding (Hucy, 1912, p. 373). San Bernardino Ranch, August 6, 1892 ; San Pedro River, July 29, 1893 (U. S. Nat. Mus. catl.) ; Cajón Bonito Creck and Guadalupe Cañon, early July, 1892 (Mearns notes).$^{78}$

\section{AIMOPHILA QUINQUESTRIATA SEPTENTRIONALIS VAN ROSSEM}

\section{NORTHERN FIVE-STRIPED SPARROW}

Aimophila quinquestriata septentrionalis van Rossem, Bull. Mus. Comp. Zoöl., 77, No. 7, Dec., 1934485 (Hacienda de San Rafael, Sonora, México); ibid., in text, (Oposura; Guirocoba; Nuri).-Hellmayr, 1938, 717 (Sonora).-Peters, 1934, 95 (re. type).

Aimophila quinquestriata (not Zonotrichia quinquestriata Sclater) Ridgway, 1901, 236, part (Hacienda de San Rafael; Alamos; Camoa; Oposura).-Thayer and Bangs, 1906, 22 (Opodepe).-van Rossem, 1931c, 300 (Guirocoba).

Amphispiza quinquestriata Salvin and Godman, 1889a, 238 (Nuri).

Common, though apparently rather local, resident of central and castern foothills north to about latitude $30^{\circ}$. The life zones occupied are both

${ }^{78}$ After careful examination of large series of the Western Lark Sparrow, I am unable, in spite of a previous statement to the contrary (1934d), to make out more than one race. Not only are males grayer and females browner dorsally, but first year birds are slightly smaller and much browner than adults of comparable sex. These factors, combined with the not inconsiderable seasonal variation, have led to this conclusion. 
Tropical and Sonoran, with all records except one falling between 1,400 and 2,000 feet altitude. Additional specimens have been examined from Nuri, April 22, 1888 (Brit. Mus.); Guirocoba, May 25, 1937 (Dickey col.); Alamos, December 26 and 30, 1898; Camoa, January 20, 1899 (Biol. Surv.). These last are doubtless the basis for Ridgway's (1901) citation of Alamos and Camoa. The only record for the coastal plain is that from Camoa (alt. $200 \mathrm{ft}$.) ; it may be seasonal in nature.

\section{AIMOPHILA CARPALIS (COUES)}

\section{RUFOUS-WINGED SPARROW}

Peucaea carpalis Coues, Amer. Nat., 7, No. 6, June, 1873, 322, note (Tucson, Arizona).-Stephens, 1885, 228 (Altar).-Allen, 1893a, 39 (Granados).-A.O.U. Comm., 1895, 240 (Sonora).

Pencaea [sic] carpalis Evermann and Jenkins, 1888, 67 (Nogales).

Haemophila carpalis Sharpe, 1909, 296 (Sonora).

H.[aemophila] carpalis Coues., 1903, 427 (Sonora).

Aimophila carpalis Ridgway, 1901, 241 (Alamos; Ortiz; Granados).-Thayer and Bangs, 1906, 22 (Opodepe).-A.O.U. Comm., 1910, 271 (Sonora) ; 1931, 341 (Sonora).- - van Rossem, 1931c, 299 (Saric; El Alamo; Tesia; Guirocoba, and many other locs.).

Aimophila carpalis carpalis Moore, 1932b, 233, in text (Saric; northern Sonora).- -van Rossem, 1934d, 485 (Guaymas; Oposura).-Hellmayr, 1938, 521 (Sonora).

Spizella [!] carpalis carpalis van Rossem, 1936d, 144 (Sonora; habitat).

Aimophila carpalis bangsi Moore, 1932b, 232 (Guirocoba; central and southern locs.).-van Rossem, 1934d, 485 (Alamos).-Hellmayr, 1938, 521 (locs. in southern Sonora).

Present commonly in cactus, grass, and mesquite desert associations (Sonoran and Tropical zones) throughout the State except for the extreme northwestern and northeastern parts. Westernmost records to date are Sásabe and Altar at about longitude $111^{\circ} 45^{\prime} \mathrm{W}$. Present data strongly indicate that breeding is limited to the northern part of the range (juveniles from Altar in August and Rancho La Arizona in September) and that there is an extensive shift of population southward to the Tropical zone from late fall until carly or even midsummer. Some additional localitics are Hermosillo, December 21 ; Ures, January 31 ; San Carlos Bay, December 24 (Dickey coll.); Camoa, February 5 to 14 (Bishop coll.); Agiabampo, May 15 (van Rossem notes); Nuri, April 20; Santa Rosa, April 25 (Brit. Mus).; Buenos Aires, 13 miles N. W. of Navojoa, April 4 (Mus. Vert. Zool.). ${ }^{79}$

${ }^{29}$ Further field experience and re-examination of most of the existing material convinces me that "bangsi" is simply carpalis on its winter range, and that the 


\section{AIMOPHILA RUFESCENS MCLEODII BREWSTER}

\section{MCLEOD RUSTY SPARROW}

Aimophila mcleodii Brewster, Auk, No. 1, Jan., 1888, 92 (El Carmen, Chihuahua, México).-Ridgway, 1901, 246 (Oposura; Bavispe River; Puerto de Los Pinitos; Alamos: Mina Abundancia; Hacienda de San Rafael).

Aimophila rufescens mcleodii Bangs, 1930, 383, 384 (re. types of $A$. mcleodii and A. cabooni).--Griscom, 1934, 418, in text (crit.).--van Rossem, 1934d, 486 (Mina Abundancia; Hacienda de San Rafael; Oposura); 1942h, 435 (range; crit.).-Hellmayr, 1938, 522 (Sonora).

Aimophila mcleodi Allen, 1893a, 39 (Puerto de los Pinitos).

Haemophila macleodi Sharpe, 1909, 297 (Sonora).

Aimophila cabooni Brewster, 1888a, 93 (mountains near Oposura).- van Rossem, 1942h, 436, in text (crit.).

Peucaea megarhyncha Salvin and Godman, 1889b, 238 (Santa Ana).

Peucaea notosticla (not of Sclater and Salvin) Allen, 1893a, 39 (Bavispee River).

Fairly common resident in the Upper Sonoran zone (cañon oak association) of the Sierra Madre and closely adjacent ranges north at least to latitude $30^{\circ} 30^{\prime}$. Additional stations are Yécora, April, 1888 (Brit. Mus.) and Rancho Santa Bárbara, June 6 to 10, 1937 (Dickey coll.).

\section{AIMOPHILA RUFESCENS ANTONENSIS VAN ROSSEM \\ San Antonio Rusty Sparrow}

Aimophila rufescens antonensis van Rossem, Trans. San Diego Soc. Nat. Hist., 9. No. 36, Oct. 1, 1942, 436 (La Chumata Mine, alt. 4500 feet, Sierra de San Antonio. Sonora, México).-Peters, 1943, 96 (re. type).

Aimophila mcleodil (not of Brewster) Thayer and Bangs, 1906, 22 (La Chumata ).

Apparently confined to the Upper Sonoran zone in the Sierra de San Antonio in the central part of the State.

\section{AIMOPHILA RUFICEPS SCOTTII (SENNETT) SCOTT SPARROW}

Peucaea ruficeps scottii Sennett, Auk, 5, No. 1, Jan., 1888, 42 (Pinal County, Arizona).

Aimophila ruficeps scottii Ridgway, 1901, 248, part (Sonora).- Thayer and

chief character supposed to distinguish it (slightly smaller average size) results from a preponderance of first-year birds in the southern series. The species has never been shown to breed in southern Sonora, nor have streaked juveniles ever been taken within the supposed bangsi territory. Furthermore, there is a complete absence of southern records between June 22 (Tesia) and November 5 (San Marcial). In this connection it may be noted that specimens personally collected in southern Sonora between May 6 and June 22, 1937 showed only the beginning of sexual activity, none were paired, and all were in various stages of the complete prenuptial body and tail moult. The type of "bangsi" is in the midst of this moult. 
Bangs, 1906, 22 (La Chumata).--van Rossem, 1931c. 299 (Saric): 1934, 486 (Oposura).-Hellmayr, 1938, 529 (Bavispe River; Oposura; Saric; Cerro Blanco Mines).

Aimophila ruficeps scotti A. O. U. Comm., 1910, 272, part (Soncra); 1931, 342, part (Sonora).-Bailey, 1928, 730, part (Sonora).

Haemophila scotti Sharpe, 1909, 297, part (Sonora).

Peucaea ruficeps boucardi (not Zonotrichia boucardi Sclater) Allen, 1893a, 39 (Bavispee River).

Common resident of the Upper Sonoran zone foothills and mountains in the eastern part of the State, south to about latitude $29^{\circ}$. The westernmost stations are Rancho La Arizona and La Chumata; the southernmost, Cerro Blanco Mines. Additional localities are the San José Mountains, August 7 and 10, 1893 (U. S. Nat. Mus.) ; San Luis Mountains, July 20, 1892 (Mearns notes).

\section{AIMOPHILA RUFICEPS SIMULANS VAN ROSSEM}

\section{Sierra Madre Rufous-Crowned Sparrow}

Aimophila ruficeps simulans van Rossem, Bull. Mus. Comp. Zoöl., 77, No. 7, Dec., 1934, 486 (Mina Abundancia, Sonora, México).-Hellmayr, 1938, 529 (Sonora).-Peters, 1943, 96 (re type).

Fairly common and presumably resident in the Upper Sonoran and lower parts of the Transition zones in the southeastern mountains north, probably, to about latitude $29^{\circ}$. All specimens examined from Sonora have been taken between early April and mid-June; however, all races of the Rufous-crowned Sparrow are essentially resident. In addition to the initial series from Mina Abundancia, specimens have been examined from Yécora, April 11, 1888; Santa Ana, April 18, 1888 (Lloyd in Brit. Mus.) : Rancho Santa Bárbara, June 10 and 13, 1937 (Dickey coll.).

\section{AIMOPHILA BOTTERII BOTTERII (SCLATER)}

\section{Botteri Sparrow}

Zonotrichia botterii Sclater, Proc. Zool. Soc. Lond., 25, No. 311, 1857 [Jan. 12, 1858], 214 (Vic. of Orizaba, [Vera Cruz], in southern México).

Peucaea botterii Salvin and Godman, 1886, 389 (Los Nogales).-Harper, 1930, 177 (Los Nogales).

Aimophila botterii Hellmayr, 1938, 532 (Guirocoba).

Aimophila botterii botterii Ridgway, 1901, 257 (Los Nogales).--van Rossem, 1931c, 301 (Guirocoba).-Phillips, 1943, 243 (Guirocoba; crit.).

Peucaea aestivalis, var. Arizonae Ridgway, 1873, 615 (Los Nogales); in Baird, Brewer, and Ridgway, 1874 (2), 41 (Los Nogales).

Peucaea aestivalis Subsp. b. Peucaea arizonae Sharpe, 1888, 710 (Sonora). 
Peucaea arizonae A. O. U. Comm., 1886, 277 (Sonora) ; 1895, 239 (Sonora).Chapman, 1888, 401 (Sonora; crit.).-Coues, 1903, 424 (Sonora).

Peucaea cassinii (not Zonotrichia cassinii Woodhouse) Baird, 1858, 485, part (Los Nogales); 1859, 16, part (Los Nogales).

[Peucaea] aestivalis Var. cassinii Coues, 1872, 140, part (I.os Nogales).

(?) Peucaea cassini Sclater and Salvin, 1868, 323, part (Sonora).

P.[eucaea] mexicana Ridgway, 1887d, 594 (Sonora).

Common summer visitant in the southeastern Tropical zone foothills north, at least formerly, to the Arizona boundary. Fxcept for boundary occurrences, all Sonora records to date center in the immediate vicinity of Guirocoba. Unpublished records are Guadalupe Cañon, October 4, 1893 ; Sulphur Springs Valley on the boundary, "October 17," [Oct. 7 in Mearns' notes ], 1893 (U. S. Nat. Mus.); Guirocoba, May 27, 1931 (Bishop Coll.), and May 23 to June 17, 1937 (Dickey and Sheffler colls.; van Rossem notes). Dates of arrival and departure are May 8 (Guirocoba) and October 7 (Sulphur Springs Valley). ${ }^{80}$

\section{Aimophila CASSINII (WoOdhouse)}

\section{CaSsin Sparrow}

Zonotrichia Cassinii Woodhouse, Proc. Acad. Nat. Sci. Phila., 6, No. 2, Mch.April [June 9], 1852, 60 (Near San Antonio, [Texas]).

Aimophila cassinii Ridgway, 1901, 235, in key (Sonora).-van Russem, 1931c, 300 (Saric; Tesia).-Hellmayr, 1938, 535 (northern Sonora).

Aimophila cassini A. O. U. Comm., 1931, 343 (northern Sonora).

Haemophila cassini Sharpe, 1909, 298 (Sonora).

Peucaea cassini A. O. U. Comm., 1910, 271 (Sonora).-Bailey, 1928, 731 (northern Sonora).

Detected certainly only as a spring and fall transient at northeastern boundary points and in the extreme south. Records are as follows: San Bernardino Ranch on the boundary, August 14, 1892 (also August 18 and 21 in Mearns' notes) ; Sulphur Spring Valley on the boundary, October 17, 1893 (U. S. Nat. Mus.) ; Rancho La Arizona, September 21, 1929); Tesia,

80 This species appears definitely to be migratory, at least in the northwest part of its range in Sonora and Arizona. The arrival date probably varies from year to year depending on climatic conditions, for although Wright secured the first bird at Guirocoba on May 8, 1930, none was detected until the 23rd in 1937. Immediately after that date it became fairly common but even though pairs were the rule and sexual activity was strongly evident, no actual breeding was apparent at so late a date as June 17 . The association strongly favored was waist-high, coarse grass through which were scattered low mesquites or small oaks. I suggest a reappraisal of the proposed subspecies arizonae, based on the premise that it is migratory and that some of the variation in winter-taken "botterii" may prove to be racial rather than individual. 
March 2, 1930 (Dickey coll.); Guirocoba, March 27 and April 1, 1931 (Bishop coll.). The basis of the frequent inclusion of northern Sonora in the breeding range possibly is the old record of Baird (1858) who cites specimens of botterii from Nogales under the present species. Mearns lists several specimens as taken at Cerro Gallardo on August 14, 15, and 16, 1893, together with the notation "breeds-young on wing," but these may have been early transients.

\section{AMPHISPIZA BILINEATA DESERTICOLA RIDGWAY}

\section{Desert Sparrow}

Amphispiza bilineata deserticola Ridgway, Auk, 15, July, 1898 [separates publ. May 13], 229 (Tucson, Arizona) ; 1901, 265, part (Sonora).-A. O. U. Comm., 1899, 119, part (Sonora) ; 1931, 344, part (Sonora).-Brewster, 1902, 148, part (Cumpas; Bacuachi; Guaymas).-Coues, 1903, 428, part (Sonora).- Thayer and Bangs, 1906, 22 (Opodepe).-Bailey, 1928, 732, part (Sonora).- van Rossem, 1930i, 221 (range in Sonora) ; 1931c, 300 (Saric; 12 miles W. of Magdalena).1934d, 487 (Guaymas; Cumpas; Bacuachi).-Hellmayr, 1938, 539 (northern Sonora).

Amphispiza bilineata (not Emberiza bilineata Cassin) Stephens, 1885, 228 (Altar).-Allen, 1893a, 39 (Oputo).

Fairly common resident of Lower Sonora deserts from the Arizona boundary south to about latitude $30^{\circ}$. There are, however, no records from the extreme northwest in the Colorado River region. During the winter there is a southward movement as far as Guaymas, at which time it occurs in company with, and appears to outnumber, the resident pacifica in that area. Additional localities are San José de Guaymas, January 7, 1933 (Dickey coll.) ; El Alamo, December 2, 1932 (Lamb notes) ; Guaymas, March 17 and 18, 1905 (Mus. Comp. Zoöl.) ; Puerto Liberated, January 29 to February 9, 1935 (Nat. Hist. Mus.) ; Sierra Seri, November 16, 1941 (Mus. Vert. Zool.) ; Pilares, July 2 and 4, 1935 (Univ. Mich.); boundary south of Bisbee, September 25, 1892; San Bernardino Ranch, August 13 and 30, 1892 ; Pozo de Luís, January 1, 1894; Sonoyta, January 19, 1894 (U. S. Nat. Mus.) ; Guadalupe Cañon, early July, 1892 (Mearns notes).

\section{AMPHISPIZA BILINEATA PACIFICA NELSON}

\section{Sonora Black-throated Sparrow}

Amphispiza bilineata pacifica Nelson, Auk, 17, No. 3, July, 1900, 267 (Álamos, Sonora, México).-van Rossem, 1931i, 221 (range in Sonora; crit.); 1931c, 300 (Guaymas; 6 miles N. of Guaymas);-1932, 145 (Tiburon Island).-Hellmayr, 1938, 540 (range in Sonora). 


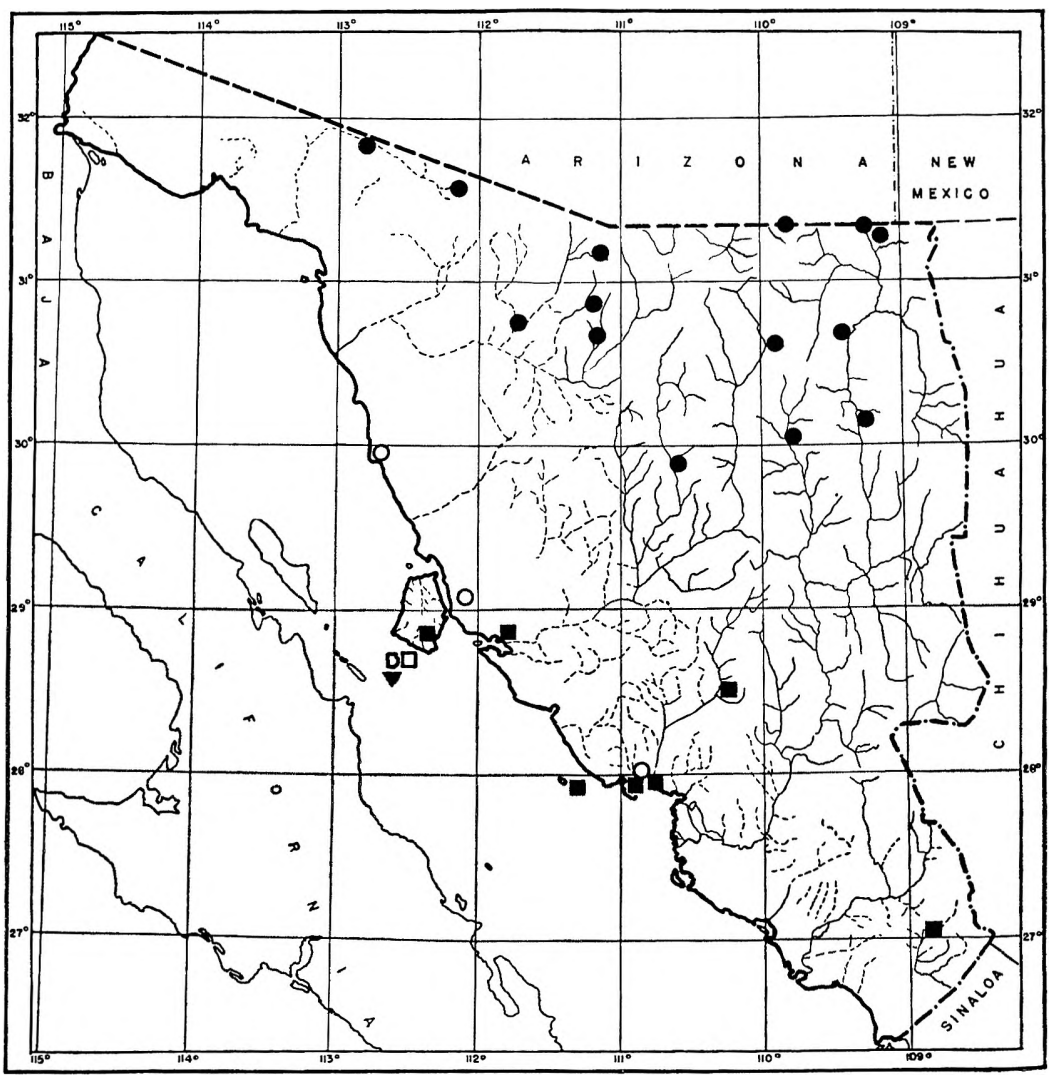

Map 26. Distribution of Amphispiza bilineata. Circles, A. b. deserticola; squares, $A . b$. pacifica; inverted triangle, $A . b$. cana; hollow figures, winter stations outside established breeding ranges.

Amphispiza bilineata (not Emberiza bilineata Cassin) Belding, 1883, 343 (Guaymas).-Salvin and Godman, 1886, 367, part (Guaymas).-Jouy, 1892, 779 (Guaymas).

Amphispiza bilineata deserticola (not of Ridgway, 1898) Ridgway, 1901, 265, part (Guaymas; Alamos).--Mailliard, 1923, 455, part (San Pedro Nolasco Island).

Fairly common resident of Tropical zone deserts and foothills from about latitude $29^{\circ}$ coastwise and about $28^{\circ} 30^{\prime}$ in the interior south at least to Álamos and probably to the Sinaloa boundary, and on the islands of San Pedro Nolasco and Tiburón. This race is seemingly resident. Additional specimens have been examined as follows: Aranjuez, March 22, 
1905; San Marcial, November 6, 1905 (intermediate toward deserticola; Mus. Comp. Zoöl.) ; Kıno Bay, February, 1935 (10 breeding specimens intermediate toward deserticola: Nat. Hist. Mus.) ; Alamos, December 29 and 30, 1899 (Biol. Surv. coll.). An accidental (probably windblown) occurrence, definitely of this race, is San Estéban Island, February 5, 1940 (Hancock coll.; Univ. So. Calif.).

\section{AMPHISPIZA BILINEATA CANA VAN ROSSEM}

\section{San Estŕban Black-Throated Sparrow}

Amphispiza bilineata cana van Rossem, Trans. San Diego Soc. Nat. Hist., 6, No. 14, Nov., 1930, 223 (San Estéban Island, Sonora, México) ; 1931c, 300 (San Esteban Island); 1932, 145, in text (San Esteban Island).-Hellmayr, 1938, 541 (San Esteban Island).

Amphispiza bilineata deserticola (not of Ridgway) Townsend, 1923, 20, part (San Esteban Island).-Mailliard, 1923, 455, part (San Esteban Island).

Common resident on San Estéban Island where it is by far the commonest land bird. 8 .

\section{AMPHISPIZA BELLI NEVADENSIS RIDGWAY}

\section{Nevada Sage Sparrow}

Poospiza Bellii var. Nevadensis Ridgway, Bull. Essex Inst., 5, No. 11, Nov., 1873, 182, 191 (Entire area of the Middle Province of the U. S. [etc.] =West Humboldt Mountains, Nevada).

Amphispiza belli nevadensis van Rossem, 1931c, 300 (El Doctor).-Hellmayr, 1938, 543 (northern Sonora).

Amphispiza nevadensis nevadensis Huey, 1935, 256 (Punta Peñascosa).

A midwinter visitant, evidently in fair numbers, in the northwestern desert region south to Kino Bay. Has been recorded from El Doctor in the Colorado delta, January 22, 1931, and from Punta Peñascosa February 8 to 28,1934 , when reported as fairly common. Additional specimens have been examined from Puerto Libertad, January 31 to February 3, 1935 and Kino Bay, February 19, 1935 (Nat. Hist. Mus.) and from Kino Bay, December 28, 1931 (Dickey coll.) ; Quitovaquita on the Arizona side of the boundary, March 5, 1939 (Nat. Hist. Mus.). There is a record in the U. S. National Museum catalogue of a specimen taken by Mearns and Holzner at Sonoyta on January 13, 1894.

81 There is in the Dickey collection a large series of midwinter specimens which fully substantiate the characters originally given for this race, namely, paler and more ashy gray coloration and smaller size as compared with deserticola. 


\section{Junco oreganus shufeldti Coale}

\section{SHUFELDT JUNCO}

Junco byemalis shufeldi Coale, Auk, 4, Oct., 1887, 330 (Fort Wingate, New Mexico).

Junco oreganus shufeldti van Rossem, 1931c, 301, part (Saric).--Hellmayr, 1938, 547, part (Saric).

Known only from a single specimen (Dickey coll.) taken by J. T. Wright at "Saric" (Rancho La Arizona) on May 12, 1929.

\section{JUNCO OREGANUS MEARNSI RIDGWAY \\ Pink-Sidei) JUnCO}

Junco mearnsi Ridgway, Auk, 14, Jan., 1897, 94 (Fort Bridger, Utah [ =Wyoming]).- - van Rossem, 1931 c, 301 (Nogales; 15 miles s. w. of Nogales [=Rancho La Arizona]).

Junco (oreganus?) mearnsi Hellmayr, 1938, 551 (Sonora).

Junco oreganus mearnsi Miller, 1941, 238 (northern Sonora).

An apparently rare midwinter visitant to the Upper Sonoran zone (oak association) in the extreme north. The only two certain records seem to be from the vicinity of Nogales and Rancho La Arizona where collected January 13, 1928, and February 17, 1929, respectively. So far as can be determined, the many citations of mearnsi from Sonora, previous to 1931, were based on Allen (1893a) who, under the name of Junco annectens, records it from "Rancheria de Los Apaches." This locality is in the Sierra Madre of Chihuahua, although close to the Sonora boundary.

\section{JUNCO CANICEPS CANICEPS (WOODHOUSE) \\ Gray-headei) Junco}

Strutbus caniceps Woodhouse, Proc. Acad. Nat. Sci. Phila., 6, No. 6, Dec. 28, 1852 [Feb. 7, 1853], 202 (San Francisco Mountain, Arizona).

Junco caniceps Allen, 1893a, 39 (Napolera; Bavispe River).-Ridgway, 1901, 295 (Napolera; Bavispe River; "etc.").-Sharpe, 1909, 305 (northeastern Sonora).-A. O. U. Comm., 1910, 268 (Sonora); 1931, 437 (Sonora).-Bailey, 1928, 742 (Sonora).-van Rossem, 1931c, 301 (Nogales).

Junco (oreganus?) caniceps Hellmayr, 1938, 551 (Sonora).

Junco caniceps caniceps Miller, 1941, 181 (Sonora).

Present, probably not uncommonly, in fall, winter, and spring, in the oak regions (chiefly Upper Sonoran zone) in the northeast. Verified records are as follows: Nogales, October 26, 1893 (U. S. Nat. Mus.) ; February 17, 1929 (Dickey coll.) ; Nopalera, December 12, 1890; Bavispe 
River (on the upper course), December 22, 1890 (Amer. Mus.); "Sonora," April, 1909 (M.C.Z.). This last record is from a small collection made by "Smith" without specific locality. Other specimens in this collec. tion would place it, almost to a certainty, in the mountains of the northeastern part of the State.

\section{JUNCO PHAEONOTUS PALLIATUS RIDGWAY}

\section{Arizona Junco}

Junco cinereus palliatus Ridgway, Auk, 2, Oct., 1885, 364 (Mt. Graham, Arizona).

Junco phaeonotus palliatus Ridgway, 1901, 301 (Sonora).-A. O. U. Comm., 1910, 268 (Sonora) ; 1931, 348 (mountains of Sonora).-Dwight, 1918, 300 (San Jose Mountains).-Bailey, 1928, 740 (Sonora).-Hellmayr, 1938, 553 (San Jose Mountains).-Miller, 1941, 211 (San Jose Mountains; San Luis Mts.; monog.). Junco palliatus Sharpe, 1909, 305 (Sonora).

Known to occur as a resident in the San José and San Luis Mountains in the northeast corner of the State, but not as yet collected elsewhere within Sonora boundaries. It is common along the Sierra Madre in Chihuahua, very close to the Sonora line, and possibly occurs on the west slope at some points also. However, in spite of the number of high altitude species secured by Cahoon in the Sierra de Oposura, palliatus is not represented in the collection, nor was it secured by Frazar at Mina Abundancia, nor by the Lumholtz party on the upper reaches of the Bavispe River.

\section{SPIZELLA PASSERINA ARIZONAE COUES}

\section{Western Chipping Sparrow}

[Spizella socialis] var. Arizonae Coues, Key No. Amer. Birds, 1872, 143 (Fort Whipple, Arizona).

Spizella socialis arizonae Allen, 1893a, 38 (Puerto de los Pinitos; Bacadehuachy; Nacori).

Spizella passerina arizonae Mailliard, 1923, 455 (San Pedro Nolasco Island).van Rossem, 1931c, 301, part (Nogales; Tecoripa; San Javier; Chinobampo; 12 miles W. of Magdalena; Saric, part; Tesia, part); 1934d, 488 (Mina Abundancia; Nacozari).-Huey, 1935, 256 (Punta Peñascosa).-Moore, 1937f, 204, in text (Guirocoba; Camoa; Guirojaqui; Mina Abundancia); 1938a, 27 (Guirocoba; Camoa; Guirojaqui).-Hellmayr, 1938, 557 (Sonora locs. above).

Common summer visitant in the Transition zone of the southeastern mountains; north probably to the Arizona boundary although specific data are lacking except from closely adjacent localities in Chihuahua. It is possibly significant that Cahoon collected no specimens in the Sierra de Opo- 
sura, nor did Brown in the Sierra de San Antonio. Very common and widespread at lower levels in Sonoran and Tropical zones in fall, winter, and spring, at which seasons the great majority are doubtless transients from the north. Further localities are Rancho Santa Bárbara, common in Transition zone where breeding in June, 1937 (Dickey coll.); San José Mountains, October 4 and 7,1892; Colorado River opposite mouth of the Hardy, March 19, 1894; Cajón Bonito Creek, September 8 to 28; San Luís Mountains, September 26; Santa Cruz, October 22, 1893 (U. S. Nat. Mus.; Mearns notes); Magdalena, May 12, 1925 (Dawson notes). Extreme dates outside of the Transition zone breeding range are September 8 (Cajón Bonito Creek) and May 12 (Magdalena) ${ }^{82}$

\section{SPIZELLA PASSERINA STRIDULA GRINNELL}

\section{Pacific Chipping SParRow}

Spizella passerina stridula Grinnell, Condor, 29, No. 1, Jan. 15, 1927, 81 (Pasadena, Los Angeles County, California).

Spizella passerina arizonae (not Spizella socialis var. arizonae Coues) van Rossem, 1931c, 301, part (Saric, part; Tesia, part).

Casual migrant and winter visitant in Sonoran and Tropical zones. Two specimens, typical of this race, were taken by J. T. Wright at Rancho La Arizona, ["Saric"], September 16, 1929, and Tesia, November 30, 1929. A few other specimens which are variously intermediate between this race and arizonae are cited under the latter.

\section{SPIZELLA PALLIDA (SWAINSON) \\ Clay-Colored Sparrow}

Emberiza pallida Swainson, Fauna Bor.-Amer., 2, 1831 [1832], 251 (Carleton House on Saskatchewan River).

Spizella pallida Allen, 1893a, 38 (Oputo).--Miller, 1906, 174 (northern Sonora; crit.).-Thayer and Bangs, 1906, 22 (Opodepe)-van Rossem, 1931c, 301 (Saric; Obregon, Tesia; Chinobampo; Guirocoba); 1934d, 489 (Alamos).

Common transient and winter visitant in Sonoran and Tropical zones except for the northwestern desert region. Westernmost records are San Pedro Bay and Rancho La Arizona, both localities at about latitude $111^{\circ}$ 15'. Additional occurrences are Guaymas, February 28 and March 19, 1905

82 The breeding birds from Rancho Santa Bárbara (like others examined from Pinos Altos and Colonia Pacheco in Chihuahua) differ from typical arizonae in slightly darker and richer coloration and wider dorsal streaking. These differences are evidently a tendency in the direction of the more southerly mexicana. 
(Mus. Comp. Zoöl.); San Pedro Bay, December 25, 1931 (Dickey coll.); Camoa, April 19, 1939 (Mus. Vert. Zool.). Extreme dates are September 15 (Rancho La Arizona) and April 30 (Opodepe).

\section{SPIZELLA BREW'ERI BREWERI CASSIN}

\section{BREWER SPARROW}

Spizella Breueri Cassin, Proc. Acad. Nat. Sci. Phila., 8, No. 1, Jan.-Feb. [March 25], 1856, 40 (California and New Mexico).-Belding, 1883, 343 (Guaymas).Salvin and Godman, 1886, 379 (Guaymas).- Townsend, 1890, 138 (Adair Bay).Allen, 1893a, 38 (Granados).-Ridgway, 1901, 327 (Sonora). Brewster, 1902, 145 (Oposura).- Thayer and Bangs, 1906, 22 (Opodepe).--van Rossem, 1931c, 301 (Tecoripa; Obregon; Tesia; Guaymas; 15 miles S. W. of Nogales).- Huey, 1935, 256 (Punta Peñascosa).

Spizella breu'eri breu'eri van Rossem, 1932, 145 (Tiburon Island); 1934d, 489 (Guaymas; Oposura; Granados).

Common, locally abundant, transient and winter visitant in Lower Sonoran and Tropical zoncs throughout the State, including some, and probably all, of the islands. Some unpublished record stations are Colorado River at Monument 205; Pozo de Luís; Sonoyta (U. S. Nat. Mus.) ; San Pedro Bay; San Carlos Bay; San Estéban Island (Dickey coll.); Puerto Libertad; Kino Bay (Nat. Hist. Mus.) ; San Luís Mountains; San Bernardino Ranch (Mearns notes). Extreme dates are September 21 (San Luís Mountains) and May 6 (Granados).

\section{SPIZEIII.A ATROGUI.ARIS EVURA COUES}

\section{Arizona Black-ChInNed Spàrrow}

Spizella ev'ura Coues, Acad. Nat. Sci. Phila., 18, 1866, No. 1, Jan.-Mch. [June 11], 87 (Fort Whipple, Arizona).

Spizella atrogularis erura van Rossem, 1935b, 282 (Oposura; crit.).-Hellmayr, 1938, 564 (Oposura).-A. (). U. Comm., 1944, 463 (northern Sonora).

Spizella atrogularis (not Spinites alrogularis Cabanis) Brewster, 1902, 146, part (Oposura).

Spizella atrogularis atrogularis van Rossem, 1934d, 489 (Oposura).

A summer visitant in the northeast. Known from a single specimen taken by Cahoon in the Sierra de Oposura on June 10, 1887.

\section{ZONOTRICHIA I.EUCOPHRY'S ORIANTHA OBERHOLSER}

\section{Western White-Crownei) Sparrow}

Zonotrichia leucophry's oriantha Oberholser, Sci. Pub. Cleveland Mus. Nat. Hist., 4. No. 1, Sept. 19, 1932, 12 (Barley Camp. Warner Mountains, Oregon).- - van Rossem, 1934d, 489 (Alamos; Cumpas; Nacozari; Oposura). 
Zonotrichia leucophrys (not Emberiza leucophrys Forster) van Rossem, 1931c, 302 (FI Doctor; Tecoripa; Obregon; Tesia, Chinobampo; 12 miles W. of Magdalena).

Zonotrichia leucophry's leucophrys Thayer and Bangs, 1906, 22 (Opodepe [no date]).-Hellmayr, 1938, 566, part (locs. in Sonora).- Huey, 1942, 373 (Gray's Ranch on the boundary).

Common winter visitant and transient; much less numerous, though, than Zonotrichia gambelii. with which it occurs in company and over much the same territory. Additional localities are Camoa, February 20, 1931 (Bishop coll.) ; San Carlos Bay, September 24, 1931 ; Rancho La Arizona, May 9, 1937 (Dickey coll.) ; San Pedro River, October 15 and 17, 1892 (U. S. Nat. Mus.) ; Magdalena, May 14 and 15, 1925 (I)awson notes) ; Cajón Bonito Creek, September 8 to 28, 1893 (Mearns notes). Extreme dates are September 8 (Cajón Bonito Creck) and May 15 (Magdalena). ${ }^{83}$

\section{ZONOTRICHIA GAMBELII GAMBELII (NUTTALL)}

\section{Gambel Sparrow}

Fringilla gambelit Nuttall, Man. Orn. L. S. and Canada, ed 2, 1, 1840, 556 (Near Fort Walla Walla, Washington).

Zonotricbia gambelii gambelii van Rossem, 1931c, 302 (El Doctor; Pesqueira; Tecoripa; San Javier: (Obregon: Tesia; Guaymas); 1932, 145 (Tiburon Island); 1934d, 489 (Guaymas; Cumpas; Nacozari; Oposura).

Zonotrichia leucophry.r gambelii Hellmayr, 1938, 567 (Cerro Blanco).

Zonotichia leucophrys gambeli Huey, 1935, 256 (Punta Peñascosa).

Abundant winter visitant everywhere in Sonoran and Tropical zones; in midwinter probably the most abundant passerine bird in Sonora. A certain number in spring and fall probably are transients from, or to, more scutherly points. Some additional localities where the Gambel Sparrow has been noted or specimens collected are Camoa; Chinobampo; Guirocoba; Kino Bay: Puerto Libertad; Santa Cruz River; San Pedro River; Nogales: Sonoyta; Caión Bonito Creek. Extreme dates are September 8 (Cajón Bonito Creek; Mearns notes) and April 24 (Guaymas).

${ }^{83}$ I agrte with Miller (Condor, 43, 1941: 262) that oriuntha is a recognizable race, and that its range includes the Rocky Mountains (of the United States at least). Four specimens in the Dickey collection, from Tecoripa, March 1, 1929; Ciudad Obregón, November 8 and 30,1929; and Tesia, March 21, 1930, might conceivably pass as the nominate race: however, until further evidence is forthcoming that leucophryi occasionally winters west of the Rockies they are listed under oriantha. 


\section{MELOSPIZA LINCOLNII LINCOLNII (AUDUBON)}

\section{NORTHERN LINCOLN SPARROW}

Fringilla Lincolnii Audubon, Birds Amer. [folio], 2, pl. 193, 1834; Orn. Biog., 2, 1834, 539 ([Near mouth of Natashquan River] Labrador [Quebec]).

Melospiza lincolnii lincolnii van Rossem, 1931c, 303, part (El Doctor; Nogales; Tecoripa; Obregon; Tesia); 1932, 145 (Tiburon Island); 1934d, 498 (Alamos; Mina Abundancia; Oposura; Nacozari).

Passerella lincolnii lincolnii Miller and McCabe, 1935, 157, map (central and southern Sonora).

Melospiza lincolni Allen, 1893a, 39 (Fronteras; Napolera; Nacory; Bavispee River).

Melospiza lincolni lincolni Townsend, 1923, 20 (Tiburon Island).-Huey, 1935, 256 (Punta Peñascosa).

Melospiza lincolnii gracilis (not Emberiza gracilis Kittlitz) van Rossem, 1931c, 303, part (Tecoripa).

Common winter visitant and transient; appearing almost anywhere regardless of zonal or associational considerations. Some additional stations are the boundary south of Bisbee, September 25, 1892; San José Mountains, October 2, 1892 ; Sonoyta, January 13, 1894 (U. S. Nat. Mus.) ; Cajón Bonito Creek, September 27, 1893 (Mearns notes). It is possible that some of the specimens listed by van Rossem (1934d) belong under the subspecies alticola; however, it seems certain that lincolnii is the prevailing race that occurs at any season in Sonora. Extreme dates are September 25 (boundary south of Bisbee) and April 23 (Oposura).

\section{Melospiza lincolnil alticola (Miller and McCABe)}

\section{SOUTHERN Lincoln Sparrow}

Passerella lincolnii alticola Miller and McCabe, Condor, 37, No. 3, May, 1935, 156 (Bluff Lake, San Bernardino Mountains, California).

Melospiza lincolnii lincolnii (not Fringilla lincolnii Audubon) van Rossem. 1931c, 303, part (Tecoripa; Tesia; Chinobampo).

Winter visitant and transient, apparently in limited numbers as compared with the nominate race. Specimens exhibiting the characters of alticola have been examined from Tesia, December 7, 1929 and March 24, 1930; Chinobampo, March 3, 1930; Tecoripa, March 7, 1929 (Dickey coll.) ; Yécora, April 12, 1888 (Brit. Mus.).

\section{MELOSPIZA LINCOLNII GRACILIS (KITTLITZ)}

\section{FORBUSH SPARROW}

Emberiza (Zonotrichia) gracilis Kittlitz, Denkw. Reise russ. Amer., Mikr., und Kamtsc., 1, 1858, 199 (Sitka, Alaska).

Melospiza lincolnii gracilis van Rossem, 1931c, 303 (George Island); 1934d, 489 (Oposura; Nacozari).-Hellmayr, 1938, 594 (Sonora). 
Detected only as a spring transient. Five specimens have been examined: Gcorge Island, April 20, 1925; Nacozari, March 22, 1887; Oposura, April 28 and May 30, 1887; Maicoba, April 7, 1888 (Brit. Mus.).

\section{Melospiza melodia montana HFnshaw}

\section{MOUNTAIN SONG SParrow}

Melospiza fasciata montana Henshaw, Auk, 1, No. 3, July, 1884, 224 (Fort Bridger, Utah $=$ Wyoming). - Allen, 1893a, 39 (Bavispee River).

Melospiza cinerea montana Ridgway, 1901, 328, part (Sonora).

Melospiza melodia montana A. O. U. Comm., 1910, 273, part (Sonora).

Melospiza melodia fallax (not Zonotrichia fallax Baird) Bailey, 1928, 756, part (Sonora).-van Rossem, 1934d, 490 (25 miles S. of San Pedro).-Hellmayr, 1938, 598, part (Sonora).

Winter visitant in the extreme north. Four specimens have been collected to date (all personally examined): Bavispe River near the headwaters, December 22 and 26, 1890 (Amer. Mus.) ; Sonoyta, January 14, 1894 (U. S. Nat. Mus.) ; and 25 miles south of San Pedro, March 11, 1887 (Mus. Comp. Zoöl.). Ridgway (l. c., in syn.) cites Scott's (1886) Arizona record from the San Pedro River as from northern Sonora, but seemingly in error.

\section{MELOSPIZA MELODIA FALLAX (BAIRD)}

\section{Baird Song Sparrow}

Zonotrichia fallax Baird, Proc. Acad. Nat. Sci. Phila., 7, No. 3, May-June [July 3], 1854, 119 (Pueblo Creek [New Mexico]=Walnut Creek, north of Prescott, Arizona).

Melospiza melodia saltonis (not of Grinnell) A. O. U. Comm., 1931, 361, part (Sonora).—van Rossem, 1931c, 302 (Saric; Magdalena; Hermosillo; crit.) ; 1934d, 490 (Oposura; Granados; Moctezuma; crit.).-Hellmayr, 1938, 607, part ([eastern] Sonora).

Melospiza melodia bendirei Phillips, 1943, 247 (northeastern Sonora; crit.).

Fairly common resident of Sonoran riparian associations from the vicinity of the Pajaritos Mountains eastward, and south in the Sonora, Moctezuma, and Bavispe valleys to Hermosillo, Moctezuma, and Granados. An additional locality is Pilares in the Moctezuma River Valley (Univ. Mich.). ${ }^{84}$

84 The status of the Song Sparrows of northeastern Sonora and southeastern Arizona has been a source of speculation, most authors considering them nearer to saltonis. The studies of Marshall and Behle (Condor, 44, 1942: 122-124, and 233) have determined that the type of fallax was to be identified with their "virginis" which was described from southern Utah on characters similar to those shown by 


\section{MelosPIZA MELODIA MERRILLI BREWSTER}

\section{Merrill Song Sparrow}

Melospiza fasciata merrilli Brewster, Auk, 13, No. 1, Jan., 1896, 46 (Fort Sherman, Idaho).

Melospiza cinerea merrilli Ridgway, 1901, 361, and footnote, 362 (Bavispe River; crit.).

Melospiza melodia merrilli A. O. U. Comm., 1910, 274, part (Sonora).-Bailey, 1928, 758 (Sonora).

Melospiza merrilli Sharpe, 1909, 311 (Sonora).

Melospiza fasciata mexicana (not Melospiza melodia var. mexicana Ridgway) Allen, 1893a, 39 (Bavispee River).-Ridgway, 1894a, 66 (Bavispe River; crit.).

Midwinter visitant. Known to date from two specimens (Amer. Mus.) taken at "Camp 40" on the upper Bavispe River, December 21 and 26, 1890 , by Robinette. A supplementary record which indicates wider distribution is from Quitovaquita on the Arizona side of the boundary, November 28, 1939 (Huey, 1942, p. 374; examined).

\section{MELOSPIZA MELODIA SALTONIS GRINNELL}

\section{Desert Song Sparrow}

Melospiza melodia saltonis Grinnell, Univ. Calif. Pub. Zool., 5, No. 3, April 9, 1909, 268 (Mecca [Riverside County], California).-A. O. U. Comm., 1931, 361, part ([northwestern] Sonora).-Hellmayr, 1938, 607, part ([northwestern] Sonora).-Phillips, 1943, 247, in text (Sonoyta).

Melospiza fasciata fallax (not Zonotrichia fallax Baird) Price, 1899, 93 (lower Colorado River).

Melospiza cinerea fallax Ridgway, 1901, 362, part ([northwestern] Sonora).Stone and Rhoads, 1905, 685 (Colorado River delta).

Melospiza melodia fallax A. O. U. Comm., 1910, 273, part ([northwestern] Sonora).

Common, locally abundant, resident in suitable localities in the Colorado River delta. Occurs, in winter at least and perhaps only casually, eastward to the Sonoyta River. No Song Sparrows are known to occur during the breeding season anywhere along the international boundary between the Colorado delta and the Pajaritos Mountains, so that the ranges of saltonis and fallax are there separated by some 250 miles. Additional localities

the Song Sparrows of northeastern Sonora. Dr. Behle has kindly loaned me the initial series of "virginis" [ = fallax] and I find them to be so very similar to Sonora birds (some appear identical) that any attempt to distinguish the latter by a separate name is not feasible. In view of the necessarily "spotty" distribution of Song Sparrows from southern Utah southeastward to northeastern Sonora, slight mass variations are normally to be expected in these isolated colonies. For this reason I cannot endorse the recent action of Phillips (l. c.) in proposing Melospiza melodia bendirei. 
from which specimens have been examined are Monument 204 in the Colorado delta, March 14 and 29, 1894; Sonoyta, January 12 and 14, 1894 (U. S. Nat. Mus.) ; common at San Luís and Colonia Independencia, May, 1937 (van Rossem notes).

\section{RHYNCHOPHANES MCCOWNII (LAWRENCE)}

\section{McCOWN LONGSPUR}

Plectrophanes McCownii Lawrence, Ann. Lyc. Nat. Hist. New York, S, 1851, 122 (High prairies of western Texas).

Rhynchophanes mccownii Ridgway, 1901, 165 (northern Sonora).

Rhynchophanes mccowni A. O. U. Comm., 1910, 252 (northern Sonora); 1931, 361 (northern Sonora).-Sharpe, 1909, 288 (Sonora).

Rhyncophanes mcrowni Bailey, 1928, 760 (northern Sonora).

A winter visitant, probably regularly, to grasslands and plains in the region of the boundary. Definite records are those of a specimen taken by Mearns and Holzner on the Santa Cruz River, October 20, 1893 (U. S. Nat. Mus.), and the statement in Mearns' notes that the species was observed (evidently not uncommonly) "on the plains both east and west" of Pozo de Luís between December 29, 1893 and January 8, 1894.

\section{CALCARIUS ORNATUS (TOWNSEND)}

\section{Chestnut-collared Longspur}

Plectropbanes ornata Townsend, Journ. Acad. Nat. Sci. Phila., 7, pt. 2, 1837 [Nov. 21], 189 (prairies of the Platte $=$ forks of the Platte River, western Nebraska).

Calcarius ornatus Ridgway, 1901, 162 (Sonora).--Sharpe, 1909, 287 (Sonora). -A. O. U. Comm., 1910, 252 (Sonora).-Dawson, 1923, 230 (Sonora).-Bailey, 1928, 762 (Sonora).-Hellmayr, 1938, 642 (Sonora).

Four specimens taken by Mearns and Holzner on the San Pedro River on the boundary, October 26, 1892 (U. S. Nat. Mus.), are seemingly the basis for the inclusion of Sonora in the winter range of the Chestnutcollared Longspur. Also noted by Mearns as seen "on the plains both east and west" of Pozo de Luís between December 29, 1893 and January 8, 1894. In all probability the species is common at that season, at least in some years, wherever suitable plains occur along the northern boundary. 


\section{SPECIES OF UNVERIFIED OCCURRENCE}

ThIS LIST CONTAINS the names of 37 species and subspecies currently in good standing which have been stated to occur in Sonora but which appear at this time to be unsatisfactory candidates for inclusion as birds of that State. Hardly any two cases are exactly alike and vary from the obviously impossible to little more than a difference of opinion. The list does not include cases such as the rejection of proposed races, or changes in names due to subsequent systematic revisions. These will be found in the appropriate synonymies.

\section{BUTEO JAMAICENSIS SOCORROENSIS NeLSON}

\section{Socorro Red-Tailed Hawk}

Buteo borealis socorroensis Nelson, Proc. Biol. Soc. Wash., 12, Jan. 27, 1898, 7, in text (Socorro Island, [México]).-(not of Nelson) Brewster, 1902, 85, in text, part (Alamos).

The specimen recorded by Brewster under the above name is similar to the Socorro Island race in color, but by the same token comes well within the range of darker specimens of calurus. In wing and tail length it agrees much better with the latter and in my opinion should be so identified, just as have the two "socorroensis" which Brewster at the same time recorded from California. It was collected at Álamos on March 8, 1888, by M. A. Frazar and is now Number 224780 in the collection of the Museum of Comparative Zoölogy.

\section{Buteo lineatus elegans Cassin}

\section{RED-BELLIED HAWK}

Buteo elegans Cassin, Proc. Acad. Nat. Sci. Phila., 7, No. 7 Jan.-Feb. [May 22] 1855, 281 ([Sacramento]) California).

Buteo lineatus elegans A. O. U. Comm., 1895, 132 (Sonora).--Stone and Rhoads, 1905, 689 (lower Colorado River).-Dawson, 1923, 1684 (Sonora).

Buteo lineatus (not Falco lineatus Gmelin) Salvin and Godman, 1900, 66, part (Sonora).

Ascribed to Sonora in the second edition (1895) of the A.O.U. Checklist, but on what basis I am unable to ascertain. The record by Rhoads of "several" seen in February, 1905, on the lower Colorado River is very unlikely and requires confirmation. Salvin and Godman, and Dawson, simply "borrowed" Sonora from the Check-list. 


\section{BUtEo PLATYPTERUS PLATYPTERUS (VIEILLOT)}

\section{BROAD-WINGED HAWK}

Sparvius Platypterus Vieillot, Tabl. Ency. Meth., 3, 1823, 1273 (Pennsylvania).

? Buteo platypterus Stone and Rhoads, 1905, 689 (lower Colorado River).

Rhoads thought he saw "two or three" on the lower Colorado River in February, 1905. The alleged occurrence is dubious, to put it mildly.

\section{FaLCo DEIROLEUCUS TEMMINCK \\ ORANGE-BREASTED FALCON}

Falco deiroleucus Temminck, Pl. Col., livr., 59, 1825 pl. 348 (Isla Săo Francisco Santa Catarina, Brazil).

Falco aurantius Coues, 1866, 43, in text (Sonora).

I do not know the basis for Coues' supposition that the range of this Central and South American species possibly extends through Sonora to southern Arizona. Probably pure speculation.

\section{CALLIPEPLA SQUAMATA SQUAMATA (VIGORS)}

\section{Mexican Scaled Quail}

Ortyx squamatus Vigors, Zool. Journ., 5, 1830, 275 (México).

Callipepla squamata squamata (not Ortyx squamatus Vigors) Peters, 1934, 44, part (southern Sonora).- Hellmayr and Conover, 1942, 231, part (southern Sonora).

Peters informs me that he is at a loss to account for his inclusion of Sonora in the range of squamata. Hellmayr and Conover simply followed Peters.

\section{COLINUS VIRGINIANUS GRAYSONI (LAWRENCE)}

\section{GRAYSON BOB-WHITE}

Ortyx graysoni Lawrence, Ann. Lyc. Nat. Hist. N. Y., 8, 1867, 476 (Guadalajara [Jalisco], México).-(not of Lawrence) Grinnell, 1884, 243 (Sonora).-Ridgway, 1887d, 189, part, 585 (Sonora).

The carliest, more or less fragmentary, specimens of the Masked Bobwhite were identified (by Ridgway) as Ortyx graysoni, and Sonora was included in the range of that species on authority of Herbert Brown. As late as 1887 , two years after the description of ridgwayi, Ridgway continued to assign both species to Sonora. 


\section{EREUNETES PUSILLUS (LINNAEUS) \\ Semipalmatei) SANDPiper}

Tringa pusilla Linnaeus, Syst. Nat., ed. 12, 1, 1766, 252 (in Domingo $=$ Santo Domingo, [West Indies]).

Ereunetes pusillus (not Tringa pusilla Linnaeus) Sharpe, 1896, 514, part (Hermosillo).-Salvin and Godman, 1903, 382, part (Hermosillo).-Bent, 1927, 244, part (Hermosillo).

The above record by Sharpe, followed by Salvin and Godman, was because of the refusal of those authors to recognize the validity of $E$. mauri as distinct from pusillus. Sharpe (l. c.) records the culmen measurement which surely should have been sufficient to keep the error out of modern literature. At any rate, I have examined the specimen ("Nov.," 1887) at the British Museum. It is Ereunetes mauri.

\section{EROLIA BAIRDII (COUES)}

\section{BAIRD SANDPIPER}

Actodromas Bairdii Coues, Proc. Acad. Nat. Sci. Phila., [13], sig. 14, June-Aug [Dec. 28], 1861, 194 (Fort Resolution=Great Slave Lake, Canada).

Heteropygia bairdi Salvin and Godman, 1903, 390 (Sonora).

Tringa bairdi (not Actodromas bairdii Coues) Price, 1899, 91 (lower Colorado River).

Although undoubtedly a transient, there are no authentic records for Sonora. Five specimens were taken by Mearns and Holzner at the San Bernardino Ranch on August 3 and 15, 1892 (U. S. Nat. Mus.), but (Mearns notes) these seem to have been taken on the Arizona side of the boundary. The record of Salvin and Godman is based on Allen (1893a) who lists a specimen without label and which may have been taken in Arizona, Sonora, or Chihuahua. Price's record of "abundant" in winter in the Colorado delta undoubtedly pertains to some other species.

\section{STERCORARIUS PARASITICUS (LINNAEUS)}

\section{PARASITIC JAEGER}

Larus parasiticus Linnaeus, Syst. Nat., ed. 10, 1, 1758, 136 (intra tropicum Cancri, Europae, Americae, Asiae= coast of Sweden).

Stercorarius parasiticus (not Larus parasiticus Linnaeus?) Abbott, 1941, 417 (off Guaymas).

Known only from the statement of Clinton G. Abbott that jaegers were seen "engaged in . . . banditry" outside of Guaymas harbor on April 14, 1940. Mr. Abbott states (in litt.) that while he believed the two indi- 
viduals seen to have been jaegers, they might have been dark-colored gulls. At his suggestion the record is accorded hypothetical status, especially since there is no known instance of occurrence of any species of jaeger in Gulf waters.

\section{ChLIDONIAS NIGRA SURINAMENSIS (GMELIN) \\ BLACK TERN}

Sterna surinamensis Gmelin, Syst. Nat., 1, pt. 2, 1789, 604 (Surinam).

In the U. S. National Museum there is a specimen taken by Mearns and Holzner at the San Bernardino Ranch on the boundary, August 12, 1892. Mearns' field book shows that it was collected on the Arizona side of the line.

\section{STERNA ANAETHETUS SCOPOLI}

\section{BRIDLEI) Tern}

Sterna Anaethetus Scopoli, Del. Flor. et Faun. Insubr., 1786, 92 (in Guinea = Panay, Philippine Islands).

Sterna anaestheta (not Sterna anaethetus Scopoli?) Stephens, 1885, 230, in text (Port Lobos).

Stephens found a dead tern at Port Lobos, August 20, 1884, which he thought answered "pretty well" to the description of this species. Since Stephens was uncertain of the identity the record must be discarded, at least for the present.

\section{OTUS FLAMMEOLUS FLAMMEOLUS (KAUP)}

Flammulated) Screech Owl

Str[ix] flammeola "Licht." Kaup, in Jardine, Contrib. Orn., 1852 [1853], 111 (Vera Cruz, México).

Megascops flammeolus Hasbrouck, 1893, map following p. 264.

The range of the Flammulated Screech Owl as outlined on the map cited includes the whole of the mountainous eastern half of Sonora. No specimen of flammeolus has been collected anywhere in the State.

\section{OTOPHANES MCLEODII BREWSTER}

\section{EARED POOR-WILL}

Otophanes mcleodii Brewster, Auk, 5, No. 1, Jan., 1888, 89 (Province of Chihuahua, México $=[$ probably $]$ near Durazno).-Ridgway, 1914, 554 (Sonora?).

Otophanes mcleodi Sharpe, 1900, 83 (Sonora).

I know of no basis for Sharpe's ascription of this species to Sonora. Ridgway simply followed Sharpe, but questioned the record. 


\title{
CyNANTHUS SORDIDUS (Gould)
}

\section{DUSKY HUMMINGBIRD}

\author{
Cyanomyia (?) sordida Gould, Ann. and Mag. Nat. Hist., 4, 1859, 97 (Oaxaca, \\ México). \\ Phaeoptila sordida Ridgway, 1911, 367 (Opodepe; La Chumata). \\ P. [haeoptila] sordida Simon, 1921, 297 (Sonora).
}

Ridgway cites Thayer and Bangs (1906) as reference for the above localities. However, this species is not mentioned in that paper and it seems certain that Ridgway's quotation was the result of a lapsus. Simon, of course, simply borrowed from Ridgway.

\section{[CYANOMYIA SALVINI BREWSTER]}

\section{SALvin HummingBiRD}

Cyanomyia salvini Brewster, Auk, 10, July, 1893, 214 (Nacozari, Sonora, México).-Griscom, 1934, 377 (crit.).-van Rossem, 1934d, 440 (crit.).

Uranomitra salvini Boucard, 1895, 400 (Sonora).-Bishop, 1906, 337, (Nacozari ; crit.).-A. O. U. Comm., 1910, 206, part (Nacozari).-Simon, 1921, 326 (Nacozari).

Uranomitra violiceps Salvini Berlioz, 1932, 132 (crit.).

Amizilis salvini Ridgway, 1911, 429, part (Nacozari).-Bangs, 1930, 219 (loc. of type).

Amazilia salvini Sharpe, 1900, 109 (Sonora).-A. O. U. Comm., 1931, 183, part (Sonora).- -van Rossem, 1931c, 253, in text (Sonora).-Bent, 1940, 446 (Nacozari; crit.).

Agyrtria salvini Dubois, 1899, 136 (Sonora).

Without much question the type of Cyanomyia salvini is a hybrid between Amazilia violiceps conjuncta Griscom and Cynanthus latirostris magica (Mulsant and Verreaux), as was first pointed out by Griscom (1934) and which opinion is concurred in by most ornithologists who since have examined it. While conjuncta exhibits a good deal of variation (47 specimens seen), the type of salvini cannot be considered an individual variant of that race even; as Peters (in litt.) expresses it, by the "wildest imagination." Incidentally, the writer once suggested (1931c) that possibility (!) before, however, he had examined the type of salvini.

\section{LAMPORNIS CLEMENCIAE CLEMENCIAE (LESSON)}

\section{Texas Blue-throated Hummingbird}

Ornismya Clemenciae Lesson, Hist. Nat. Ois.-Mouch, 1829, [xlv], 216, pl. 80 (México).

Lampornis clemenciae clemenciae (not Ornismya clemenciae Lesson) Moore, 1938a, 25 (Baromicon). 
Moore has recorded a single specimen from Baromico. This is a region of intermediates where bessophilus, on present cvidence, seems to be the best name to employ. See also footnote under that race.

\section{SELASPHORUS SASIN SASIN (LeSSON)}

\section{Allen Hummingbird}

Ornismya Sasin Lesson, Hist. Nat. des Oiseaux-Mouche, May, 1829, xxx, 190, pl. 66 (Monterey et San Francisco =San Francisco, California).

Selasphorus alleni (not of Henshaw) Allen, 1893a, 36 (Santa Barbara).-A. O. U. Comm. 1910, 204, part (Sonora).-Ridgway, 1911, 609, part (Santa Barbara). -Dawson, 1923, 924, part (Sonora).

S. [elasphorus] Alleni Simon, 1921, 406, part ("northeastern Chihuahua").

The various ascriptions of the Allen Hummingbird to Sonora and, in part at least, to Chihuahua, all stem from the record of Allen, who records (as alleni) a specimen taken at Santa Bárbara on September 21, 1890. John T. Zimmer informs me that this individual is Selasphorus rufus and that the late W. DeWitt Miller had also made an annotation on the label to that effect.

\section{TROGON CITREOLUS GOULD}

\section{Citreoline Trogon}

Trogon citreolus Gould, Proc. Zool. Soc. Lond., 1835, 30 (no locality = [probably] San Blas or Mazatlán).-Salvin and Godman, 1896, 497, in text (Sonora).

Although Salvin and Godman state that their collectors found this trogon in Sonora, they cite no Sonora localitics in their list of specimens taken by Lloyd and others. There are no Sonora-taken specimens in the collection at the British Museum.

\section{TROGON MEXICANUS CLARUS GRISCOM}

\section{Northwestern Mexican Trogon}

Trogon mexicanus clarus Griscom, Proc. New England Zool. Club, 13, November 7, 1932, 57 (Pinos Altos, Chihuahua, México); ibid., in text (Sonora).

Certain records for this trogon are from localities very close to the Chihuahua-Sonora boundary, but I can find no records or specimens which justify inclusion of the species as a bird of Sonora. 


\section{CENTURUS CHRYSOGENyS CHRYSOGENYS (VigORS) \\ GOLDEN-CHEeked WOODPECKer}

Picus chrysogenys Vigors, Zool. Beechey's Voyage, 1839, 24 (western México; [see Ridgway, 1914, 90, footnote]).

Centurus chrysogenys chrysogenys Ridgway, 1914, 89 (southern Sonora).

Centurus elegans Lawrence, 1874, 294 (Sonora).-Salvin and Godman, 1895, 424 (Sonora).

Melanerpes elegans Hargitt, 1890, 184, part (Sonora).

The various ascriptions of this species to Sonora date back to Lawrence (1874) who, presumably on the authority of Grayson, included Sonora in the range. I know of no specimens to substantiate the statement, and no recent collectors have encountered the species anywhere in the State.

\section{EMPIDONAX AFFINIS PULVERIUS BREWSTER}

\section{Sierra Madre Flycatcher}

Empidonax pulverius Brewster, Auk, 6, No. 2, April, 1889 [separates distributed January 31], 86 (Pinos Altos, Chihuahua, México).-Sharpe, 1901, 139 (Sonora).--Ridgway, 1907, 572 (Sonora).--Hellmayr, 1927, 212 (Sonora).

Empidonax affinis (not Tyrannulus affinis Swainson) Salvin and Godman, 1889, 78, part (Tutuaca in Sonora).

All ascriptions of pulverius to Sonora date from Salvin and Godman, 1889, who erroneously cited Tutuaca as in Sonora. The specimen in question was collected by W. Lloyd at Tutuaca, Chihuahua, April 2, 1888. It is now in the British Museum, where examined by me in 1938.

\section{EREMOPHILA ALPESTRIS APHRASTA (OBERHOLSER) \\ Chinuahua Horned Lark}

Otocoris alpestris aphrasta Oberholser, Proc. U. S. Nat. Mus., 24, No. 1271, June 9, 1902, 860 (Casas Grandes, Chihuahua, México).

Otocorys alpestris var. Aphrasta Dubois, 1903, 1099 (Sonora).

Dubois' ascription is based on no tangible evidence so far as can be determined.

\section{RIPARIA RIPARIA RIPARIA (LINNAEUS)}

\section{BANK Swallow}

Hirundo riparia Linnaeus, Sys. Nat., ed. 10, 1, 1758, 192 (Sweden).

? Clivicola riparia (not Hirundo riparia Linnaeus?) Evermann and Jenkins, 1888, 68 (Magdalena). 
Swallows seen by Evermann and Jenkins at Magdalena in July, 1887, and recorded as above would seem much more likcly to have been Roughwinged Swallows, which are common in that locality. At any rate, confirmation is required. Mearns' notes list a specimen of the Bank Swallow as taken at San Bernardino Ranch on August 18, 1892, but his field entry of "Arizona" places it out of bounds, possibly by only a matter of yards!

\section{PARUS INORNATUS PLUMBESCENS (GRINNELI.)}

\section{LeAD-COlorel) Titmouse}

Baeolophus inornatus plumbescens Grinnell, Condor, 26, Nov. 15, 1934, 251 (Silver City, New Mexico).

Baeolophus inornatus griseus (not of Ridgway, 1902, nor Parus griseur Müller) Ridgway, 1904, 390, part ("probably into Sonora").

Ridgway's perfectly reasonable supposition that the range of "grisens" (i. e., plumbescens) extends into northern Sonora has not, to date, been verificd.

\section{CERTHIA FAMILIARIS MONTANA RIIDGWAY}

\section{RoCky MOUNTAIN CREePER}

Certhia familiaris montana Ridgway, Proc. U. S. Nat. Mus., 5, July 8, 1882, 114 (Middle Province of North America [etc.]-Mount Graham, Arizona); 1904, 467 ("probably into northern Sonora").

The basis of Ridgway's conjecturc might conceivably have been a specimen taken by Mearns on the San Pedro River on the boundary line, October 15, 1892, and entered in his field book as "Certhia familiaris (?)," in contrast with his usual "Certhia mexicana" entries. Dr. Friedmann advises me that this specimen is not in the National Museum collection, and I have been unable to locate it elsewhere.

\section{Cincius mexicanus mexicanus Swainson}

\section{MEXICAN DIPPER}

Cinclus mexicanus Swainson, Philos. Mag., new' ser., 1, May, 1827, 368 (Temascáltepec, México).-Allen, 1893a, 41 (Chuhuichupa).

Cinclus mexicanus mexicanus Ridgway, 1904, 677 (Chuchuichupa, Sonora).Hellmayr, 1934, 107 (Sonora).

Chuhuichupa is well within Chihuahua territory. There is apparently no authentic record of the Dipper in Sonora, although it probably occurs at some points. 


\section{TROGLOdYTES TROGIodytes PACIFICUS BAIRD}

\section{WESTERN Winter WREN}

Troglodytes biemalis var. pacificus Baird, Rev. Amer. Birds, sig. 10, Sept., 1864, 145 (Simiahmoo, Puget Sound, W. T. [ =Washington].

Troglodytes hiemalis pacificus (not of Baird) Stone and Rhoads, 1905, 690 ("Colony" [=Colonia Lerdo $]$ ).

Just what species was seen by Rhoads in the Colorado delta in February is problematical,-possibly the House Wren, but almost impossibly the present specics.

\section{SALPINCTUS OBSOLETUS LATISIAASCIATUS (LICHTENSTEIN)}

\section{MEXICAN Rock WREN}

Troglodytes latisfasciatus Lichtenstein, Preis-Verz. der . . . Vögel . . Mexico ... , 2, Sept. 1, 1830 (México [City], México).

Salpinctes obsoletus notius (not of Ridgway, 1903) Ridgway, 1904, 648, part (Alamos).-Hellmayr, 1934, 274, part (Alamos).

The basis of Ridgway's determination is obscure. At any rate, the five Álamos specimens examined seem to be indistinguishable from obsoletus (Mus. Comp. Zoöl.). None, however, are in juvenile plumage. The case requires further study. For change in subspecies name from notius to latisfasciatus see van Rossem, 1931d, p. 416.

\section{TOOXOSTOMA CINEREUM CINEREUM (XANTUS)}

\section{SAN Lucas Thrasher}

Harporbynchus cinereus Xantus, Proc. Acad. Nat. Sci. Phila., 11, sig. 21, 1859 [Jan. 12, 1860], 298 (Cape San Iucas, Baja California, México).-(not of Xantus) Parker, 1887, 71 (Guaymas).

One, obviously "wild," record, that by Parker who records the species from Guaymas on the basis of eggs collected. What species is actually referred to is problematical.

\section{GUIRACA CAFRULEA DELT ARHYNCHA VAN ROSSEM}

\section{Nayarit Blue Grosbeak}

Guiraca caerulea deltarbyncha van Rossem, Bull. Brit. Orn. Club, 58, July, 1938, 133 (Tepic, Nayarit, México); ibid., in text (Guirocoba).

The individual recorded as of this race from Guirocoba is now regarded as a non-typical example of Guiraca caerulea interfusa (q. v.). 


\section{SPINUS PSALTRIA MEXICANUS (SWAINSON)}

\section{Mexican Goldfinch}

Carduelis mexicana Swainson, Philos. Mag., n. s., 1, No. 6, June, 1827, 435 (Temascáltepec and Real del Monte, México).

Astargalinus [sic] psaltria mexicanus (not Carduelis mexicana Swainson) Sheffler, 1931a, 137 (27 miles S. of Nogales).

The above record is the result of a lapsus (fude Sheffler). No specimens were taken.

\section{Aimophila notosticta (Sclater ani) Salvin)}

\section{OAXaca SParrow}

Peucaea notosticta Sclater and Salvin, Proc. Zool. Soc. London, 1868, 322 (in Mexico meridionali=State of México or State of Puebla).-(not of Sclater and Salvin) Allen, 1893a, 39 (Bavispee River).

The specimens from Sonora and Chihuahua listed by Allen under the above name are Aimophila rufescens moleodii (in Amer. Mus. Nat. Hist.; examined).

\section{AlMOPHILA RUFICEPS BOUCARDI (SClATER) \\ BOLCARd SPARrow}

Zonotrichia boucardi Sclater, Proc. Zool. Soc. London, 1867, 1, pl. 1 (Orizaba, Vera Cruz, and La Puebla, Puebla, México-La Puebla).

Peucaea ruficeps boucardi (not Zonotrichia boucardi Sclater) Allen, 1893a, 39 (Bavispee River).

The specimen listed by Allen is Aimophila ruficeps scottii. It has been examined in the collection of the American Museum of Natural History.

\section{[AMPHISPIZA PREGLACIALIS DAWSON]}

Amphispiza preglacialis Dawson, Birds of California, 1923, 280, in text (Sonora).

This presumed ancestor of " $A$. belli and $A$. nevadensis" appears to be perfectly at home in the hypothetical list.

\section{JunCo CANICEPS DORSALIS HeNRY \\ RED-BACKED) JUNCO}

Junco dorsalis Henry, Proc. Acad. Nat. Sci. Phila., 1858, [10], sig. 8, "May" 117 (Fort Thorn =Fort Stanton, New Mexico).-Ridgway, 1901, 297 (northeastern Sonora).-Bailey, 1928, 470 (Sonora). 
Junco phaeonotus dorsalis (not Junco dorsalis Henry) A. O. U. Comm., 1910, 268, part (Sonora); 1931, 347, part (Sonora).-Hellmayr, 1938, 552, part (Sonora).

Although dorsalis has several times been cited as from Sonora, the only basis is Allen (1893a, p. 39), who lists one specimen from "San Diego" under that name. San Diego is in Chihuahua; moreover, the bird is not dorsalis at all but Junco caniceps caniceps (Miller, 1941, p. 210). There is the probability that dorsalis occurs occasionally south of the United States boundary in Sonora, but no specimens have been collected to date.

\section{JUNCO OREGANUS MONTANUS RIDGWAY \\ Montana Junco}

Junco montanus Ridgway, Auk, 15, Oct., 1898, 321 (Columbia Falls, Montana).

[?] Junco oreganus shufeldti (not Junco byemalis shufeldti Coale) van Rossem, 1931c, 301, part (15 miles s. of Nogales).-Hellmayr, 1938, 547, part (15 miles s. of Nogales).

A specimen taken by, or for, Griffing Bancroft 15 miles south [west] of Nogales [ = at or near Rancho La Arizona] on February 17, 1929, cannot now be located, but according to my notes it would fall under montanus as defined by Miller (1941, p. 251). The several ascriptions to Sonora in earlier publications (A.O.U. Comm., 1910, p. 266, and Chapman, 1914, p. 443, under Junco byemalis connectens; Bailey, 1928, p. 737 ; A.O.U. Comm., 1931, p. 346, under Junco oreganus shufeldti; Dawson, 1923 , p. 289 , under Junco oreganus couesi) seemingly all date back to Allen, 1893a, in which paper "Junco byemalis shufeldi" is listed from Chuhuichupa, a Chihuahua locality.

\section{MELOSPIZA MELODIA MEXICANA RIDGWAY}

\section{Mexican Song Sparrow}

Melospiza melodia. var. mexicana Ridgway, in Baird, Brewer, and Ridgway, Hist. No. Amer. Birds, 2, 1874, 18, footnote (Puebla, México).

Melospiza fasciata mexicana (not Melospiza melodia, var. mexicana Ridgway) Allen, 1893a, 39 (Bavispee River).--Ridgway, 1894a, 66 (Bavispee River; crit.).

The two specimens taken on the Bavispe River, December 21 and 26, 1890, upon which Allen's "mexicana" record was based, are merrilli (q. v.). 


\section{GAZETTEER OF LOC.ALITIES}

So FAR AS I have bcen able to determinc there is no existing map of Sonora which can be considered accurate in all of its features. Indeed, more than a little time and energy have been expended in an inconclusive effort to determine the precise location of the eastern boundary. No two maps, even those designated as "official" or at least bearing the stamp of government approval, show boundarics or interior localities preciscly in the same manner. Additionally, there have been at one time or another four different supposed boundaries between Sonora and Chihuahua, and these criss-cross cach other to the inclusion or exclusion of varying amounts of territory. Even the most modern and accurate maps available, those issued by the American Geographical Socicty, frankly confess that a large part of the eastern section of the State has been "adjusted from compiled maps."

In the extreme northeast I have taken the crest of the San Luís Mountains near International Boundary Monument 65 as the boundary between Sonora and Chihuahua at that point. Not only is this indicated on two maps (particularly the "Coronado National Forest" map) but is the boundary accepted by local opinion. On this point I must acknowledge the advice of E. A. Goldman and J. S. I.igon of the Fish and Wildlife Service. Other maps indicate the Ánimas Valley or points still further west. In the extreme southeast I have made slight adjustments, based on personal observation, to the American Geographical Society map; but aside from these minor changes no departures from that map have been attempted. No difficulties have been encountered along the coast or the northern boundary, since these areas have been mapped, respectively, by the United States Navy (Hydrographic Office) and the International Boundary Commission.

Most of the localities here listed, particularly in the interior, have no importance other than in an ornithological sense. Many of them, even though on most maps, may be in fact nothing more than the name of an isolated ranch or group of two or three huts, a spring, a hill, a cross-roads, a perhaps abandoned mine, or a feature of the landscape. Names of ranches and mines, even though still in operation, may change to conform with that of the patron saint or through some other whim of a new owner. One of the chief purposes of the present list of place names, then, is to fix as accurately as possible the exact locations of the places cited in the present report. Locations are from the American Geographical Society maps unless otherwise specificd. Spanish or English names are used in accordance with 
those most frequently appearing in ornithological literature, for example Kino Bay and Tiburón Island instead of Báhia Kino and Isla Tiburón; however, cross indexing has been done in most cases.

Maps used in the compilation are as follows:

Baja California-Norle and Baja California-Sur, (H-11 and G-12), Provisional Edition, American Geographical Society, New York, 1924.

Sonora (H-12), Provisional Edition, American Geographical Society, New York, 1937.

Sonora No. 3, Secretaria de Agricultura y Fomento, D. F., México, 1922.

Mapa Oficial del Estado de Sonora, Sonora News Company, Nogales, Arizona, 1884.

Standard Map of Sonora, Rand McNally Company, Chicago, 1924.

Mat of the State of Sonora, Mexico, S. M. Greenidge, Dougl..s, Arizona (undated).

West Coast of Mexico and the Gulf of California, 619, 620, 621, U. S. Navy, (Hydrographic Office), Washington, 1922.

Topography, Cienega Springs [and other topographical sheets westward to the Colorado River], Department of the Interior, U. S. Geological Survey, Washington, 1918 -

Coronado National Forest. Department of Agriculture, Forest Service, Washington, 1927.

Contour Map of The Rio Mayo Basin, In Gentry's Río Mayo Plants, (See Gentry, 1942).

\section{LOCALITIES}

Adair Bay. On the mainland coast neas the head of the Gulf: lat. $31^{\circ} 30^{\prime}$. Báhia de Adair. Báhia de Aduar.

Agiabampo. At the northeastern end of Agiabampo Bay or Estero de Agiabampo: lat. $26^{\circ} 20^{\prime}$. There are two other locations of the same name inland from Tóbari Bay.

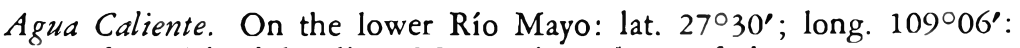
alt. 350 feet. Lloyd locality. Many other places of the same name are scattered throughout the State.

Agua Marin. 8 miles northwest of Alamos; lat 27007'; long. 108 ${ }^{\circ} 53^{\prime}$ : alt. 1500 feet (approx.). Seth Benson locality. Not on maps. 
Alamos. The Alamos of ornithological literature: lat. $27^{\circ} 01^{\prime}$; long. $108^{\circ} 58^{\prime}$ : alt. 1275 feet. Frazar's headquarters while there (1888) were at Hacienda Mercedes, 3 miles southeast of the town. Many other places of the same or similar names (Álamo, El Âlamo, Los Álamos) are numerous throughout the State.

Algodones Lagoon. Coastal lagoon about 15 miles southeast of Guaymas: lat. $27^{\circ} 45^{\prime}$. Laguna de Algodones.

Altar. Northwestern desert locality at the juncture of the Río Altar and Río Seco: lat. 3043'; long. 111 $44^{\prime}$ : alt. 2000 feet (approx.). Stephens locality.

Animas Valley. Across the New Mexico boundary at long. $108^{\circ} 50^{\prime}$, between the San Luis and Guadalupe Mountains; alt. at boundary, 5161 feet. Mearns and Holzner locality, chiefly.

Aranjuez. See Hacienda Aranjuez.

Arenas. In the interior foothills northeast of Guaymas: lat. $28^{\circ} 18^{\prime}$; long. $110^{\circ} 16^{\prime}$; alt. 1000 feet (approx.). Las Arenas of W. W. Brown labels.

Arispe. On the Río de Sonora: lat: $30^{\circ} 20^{\prime}$; long. $110^{\circ} 11^{\prime}$ : alt. 2700 feet (approx.).

Arroyo Hondo. On the Lumholtz route between Granados and Oputo. Not on maps.

Bacadehuachi. In the southeastern foothills of the Sierra de Nacori (q. v.) : lat. $29^{\circ} 47^{\prime}$; long. $109^{\circ} 12^{\prime}$ : alt. 2500 feet (approx.). Lumholtz (Robinette) locality. Bacadéhuachic of some maps. Bacadehuachu (Rhoads, 1893). Bacadehuachy (Allen, 1893a). Bacadelhuachy (Ridgeway, 1907). Boca de Hauchy (Bent, 1939).

Bacoachi. On the Río de Sonora in the northeast: lat. $30^{\circ} 38^{\prime}$; long. 109 ${ }^{\circ} 57^{\prime}$ : alt. 2400 feet. Variously, Bacoachic, Bacuachi, Bacuachic. A Cahoon locality.

Bábia de Adair. See Adair Bay.

Báhia de Agua Dulce. See Freshwater Bay.

Babia Kino. See Kino Bay.

Bábia San Carlos. See San Carlos Bay.

Báhia San Pedro. See San Pedro Bay.

Bábia de Tóbari. See Tóbari Bay.

Baromico. In the extreme southeast in the Sonora-Chihuahua-Sinaloa "corner": lat. $27^{\circ} 01^{\prime}$; long. 108 ${ }^{\circ} 4^{\prime}$ : alt. 3000-5000 feet. Moore locality which is cited variously by him as Baromicon, Barromicon, or Marromicon. Sonora No. 3 map. 
Basacori Island. See Masocari Island.

Batamotal. Railroad station about 3 miles north of Empalme (q.v.).

Batamoti. In the foothills about 60 miles northeast of Guaymas: lat. $28^{\circ} 25^{\prime}$; long. $110^{\circ} 08^{\prime}$ : alt. 1780 feet. Sonora News Company map. W. W. Brown locality.

Bavispe River. Main northern tributary of the Río Yaqui (juncture at lat. $29^{\circ} 13^{\prime}$; long. $109^{\circ} 13^{\prime}$ ) and enclosing most of the mountain mass known as the Sierra de Nácori. Near the headwaters a short distance south of latitude $30^{\circ}$ and close to the Chihuahua boundary (alt. approx. $6500 \mathrm{feet}$ ) is the location of Allen's (1893a) "Bavispee River."

Bocochibampo. On the Gulf coast at Guaymas. Abbott locality.

Bonancita. Lat. $28^{\circ} 17^{\prime}$; long. $110^{\circ} 09^{\prime}$ : alt. 1295 feet. La Bonanzita of W. W. Brown labels.

Buenos Aires. 13 miles northwest of Navojoa on the Southern Pacific Railroad: lat. $27^{\circ} 13^{\prime}$; long. $109^{\circ} 36^{\prime}$; alt. 100 feet (approx.). Seth Benson locality.

Caborca. In the northwestern desert: lat. $30^{\circ} 39^{\prime}$; long. $112^{\circ} 04^{\prime}$ : alt. 1500 feet. Stephens locality.

Cabo Tepoca. Lat. $30^{\circ} 16^{\prime}$ on the mainland coast. Point Lobos of Stephens.

Cajeme. Old name for Ciudad Obergón (q.v.).

Cajón Bonito Creek. In the extreme northeast: lat. $31^{\circ} 10^{\prime}$; long. $109^{\circ} 10^{\prime}$ : alt. 3200 feet at juncture with the San Bernardino River. Mearns locality.

Camoa. In the lower Río Mayo valley: lat. $27^{\circ} 1^{\prime}$; long. $109^{\circ} 18^{\prime}$ : alt. 300 feet.

Cañon de Guadalupe. See Guadalupe Cañon.

Cape Lobos. On the mainland coast at La Libertad: lat. 29 $54^{\prime}$. Huey locality. Cabo Lobos, but not Point or Punta Lobos of Stephens.

Capomas. About 55 miles northeast of Guaymas: lat. $28^{\circ} 22^{\prime}$; long. $110^{\circ} 14^{\prime}$; alt. 1500 feet (approx.). Las Capomas of W. W. Brown labels.

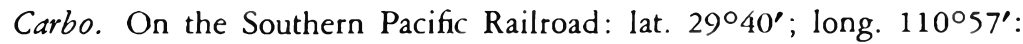
alt. 1526 feet. Lamb locality.

Cedros. Lat. $27^{\circ} 44^{\prime}$; long. $109^{\circ} 18^{\prime}$ : alt. 600 feet (approx.). Lloyd locality.

Cerro Blanco. Lat. 29 35'; long. 109 33': alt. 2200 feet (approx.). Rowley lorality. 
Cerro Gallardo. Just south of the Arizona boundary at Monument 82. Alt. 4508 fect. Mearns locality, sometimes known as Niggerhead or Niggerhead Mountain.

Chinchas. In the immediate vicinity of Batamoti (q. ı.). Las Chinchas of W. W. Brown labels. Not on maps.

Chinobampo. At the southwestern base of the Sierra de Alamos: lat. 26057'; long. 109 $18^{\prime}$ : alt. 300 fect (approx.). Wright locality.

Chivata. Lat. $28^{\circ} 45^{\prime}$; long. $110^{\circ} 37^{\prime}$; alt. 1600 feet (approx.). W. W. Brown locality.

Chumata. See La Chumata.

Cibuta. On the Southern Pacific Railroad: lat. $31^{\circ} 04^{\prime}$; long. $110^{\circ} 55^{\prime}$ : alt. 3477 fect. Wright locality. 205.

Cienega $W^{\prime}$ ell. On the Colorado River, 25 miles south of Monument

Ciudad Obregón. In the lower Yaqui River valley: lat. $27^{\circ} 29^{\prime}$; long. $109^{\circ} 58^{\prime}$; alt. 200 fect (approx.). Formerly known as Cajeme.

Cobriza. On the Río Cedros: lat. 27037'; long. 109 ${ }^{\circ} 6^{\prime}$ : alt. 550 fect (approx.). Rand McNally map. Lloyd locality. La Cobriza.

Cocorit. In the lower Yaqui River valley: lat. $27^{\circ} 35^{\prime}$; long. $110^{\circ} 00^{\prime}$ : alt. 100 feet (approx.). Wright locality.

Colonia Diaz. On the Colorado River, 30 miles south of Monument 205.

Colonia Independencia. On the Colorado River: lat. $32^{\circ} 20^{\prime}$ : alt. 66 feet. Las Carpas of Mearns' labels and notes is possibly an older name for the same locality.

Colonia Lerdo. On the Colorado River: lat. $32^{\circ} 10^{\prime}$ : alt. 50 feet (approx.). The "Colony" of Stone and Rhoads (1905).

Colorado River. The boundary between Sonora and Baja California; lat. $31^{\circ} 45^{\prime}$ at its mouth at the head of the Gulf. Río Colorado.

Cuchujaqui River. Northeastern branch of the Alamos River: lat. 26057'; long. 108053': alt. 1300 feet (approx.) at the junction. Sometimes applied also to the Alamos River. Chuchujagui River.

Cuchuta. On the Rio Frontcras: lat. 30 $46^{\prime}$; long. 109 $35^{\prime}$; alt. 4500 feet (approx.). Lumholtz locality. Cachuta (Allen, 1893a).

Cumpas. On the Río Moctezuma: lat. 3000'; long. $109^{\circ} 49^{\prime}$; alt. 2300 feet. Lieutenant Benson locality almost invariably cited as "Campos," particularly in connection with the Benson Quail and the Masked Bob-white.

Direction Hill. On the coast near the mouth of the Colorado River: lat. $30^{\circ} 40^{\prime}$; long. $114^{\circ} 25^{\prime}$. 
Dowling $W^{\prime}$ ell. Arizona locality on the boundary: lat. $31^{\circ} 53^{\prime}$; long. $112^{\circ} 48^{\prime}$. Huey locality. Not on maps.

Dutch Charley's. On the boundary (Arizona side) at Monument 88. Mearns locality.

El Álamo. Northwestern desert foothills: lat. $30^{\circ} 51^{\prime}$; long. $111^{\circ} 13^{\prime}$ : alt. 2575 fect. Bancroft, Lamb, Sheffler locality. Rancho Los Alamos of Sheffler (1931a).

El Cobre. Mountain locality in the extreme southeast: lat. $27^{\circ} 02^{\prime}$; long. $108^{\circ} 40^{\prime}$ : alt. 4000 feet. (approx.). Moore locality. Cobre. Sonora No. 3 and Sonora News Company maps.

El Doctor. Freshwater spring in the extreme northwest and near the Colorado River: lat. $32^{\circ} 00^{\prime}$; long. 114 $50^{\prime}$ : alt. 50 feet (approx.). Wright locality.

El Golfo. Coastal terminus of the road from Yuma to the Gulf and near the mouth of the Colorado. Probably synonymous with Puerto Isabel: lat. $31^{\circ} 48^{\prime}$; long. $114^{\circ} 42^{\prime}$. Anthony locality.

El Pinita. See Los Pinitos.

El Plomo. Mine in the northwestern desert: lat. $31^{\circ} 16^{\prime}$; long. $112^{\circ} 00^{\prime}$ : alt. 2700 fect.

El Puerto. On the Lumholtz route in the higher mountains, above Nopalera or Huerachi and very close to the Chihuahua boundary: lat. approximately $49^{\circ} 50^{\prime}$; long. $108^{\circ} 40^{\prime}$ : alt. probably over $6000 \mathrm{fcet}$. Not on maps.

El Tigre Mine. Lat. $30^{\circ} 37^{\prime}$; long. $109^{\circ} 20^{\prime}$ : alt. (probably over) 5000 feet. Campbell locality.

El Tigre Mountains. Sce Sierra de Madera.

Empalme. Railroad junction on the northeast part of Guaymas Harbor.

Ensenada del Perro. Small bay at the extreme southeast end of Tiburón Island, and just north of Monument Point. Benson and Sibley locality.

Estero [or Báhia] de Agiabampo. See Agiabampo.

Estero de Guásimas. See Guásimas Lagoon.

Estero de Tasiota. Small bay and lagoon on the mainland coast: lat. $28^{\circ} 23^{\prime}$. Usually appearing in Anthony's notes as Estero or Estrada dc Tasiola.

Freshwater Bay. On the north coast of Tiburón Island.

Fronteras. Lat. $30^{\circ} 54^{\prime}$; long. $109^{\circ} 35^{\prime}$ : alt. 3725 fect. Cahoon and Lumholtz (Robinette) locality. Fronteriza on Cahoon labels. 
Gcorge Island. Seven miles off the mainland coast: lat. $31^{\circ} 01^{\prime}$; long. $113^{\circ} 17^{\prime}$. Known variously as George's or Saint George Island, Isla Jorge or San Jorge.

Gorc Island. At mouth of the Colorado River: lat. $31^{\circ} 43^{\prime}$.

Granados. On the Bavispe River: lat. $29^{\circ} 52^{\prime}$; long. $109^{\circ} 20^{\prime}$ : alt. 1700 feet (approx.). Cahoon and Lumholtz locality.

Gray's Ranch. Arizona side of the boundary: lat. 31052'; long. $112^{\circ} 43^{\prime}$ : alt. 1460 feet. Huey locality.

Guadalupe. In the southeastern mountains: lat. $28^{\circ} 20^{\prime}$; long. $109^{\circ} 07^{\prime}$ : alt. 3300 feet (approx.). Lloyd locality.

Guadalupe Cañon. Headwaters in the Guadalupe Mountains on the Arizona-New Mexico side of the boundary and running southwestward to join the San Bernardino River at about lat. $31^{\circ} 15^{\prime}$; long. $109^{\circ} 14^{\prime}$ : alt. at Bcundary Monument 73, 4157 feet. Mearns locality.

Guadalupe Mountains. North-south range crossing the Arizona boundary at about long. $109^{\circ} 05^{\prime}$ : alt. on the Sonora side of the boundary approximately 6000 feet.

Guásimas Lagoon. Mangrove lagoon about 18 miles east of Guaymas: lat. $27^{\circ} 52^{\prime}$; long. $110^{\circ} 37^{\prime}$.

Guaymas. Largest (and only active) seaport in Sonora: 27 $55^{\prime}$; long. $110^{\circ} 52^{\prime}$.

Guirocoba. Cattle hacienda in the extreme southeast: lat. $26^{\circ} 58^{\prime}$; long. $108^{\circ} 42^{\prime}$ : alt. 1450 feet. Rancho Guirocoba. Sonora News map.

Guirojaqui. Moore locality a short distance (probably northeast) from Guirocoba. Not on maps.

Hacienda Aranjuez. Once large hacienda about 3 miles north of San Jo;é de Guaymas: lat. $28^{\circ} 00^{\prime}$; long. $110^{\circ} 55^{\prime}$. Visited by many collectors. Aranjuez of W. W. Brown labels. Not on maps.

Hacienda de San Rafael. Although for many years cited as in Chihuahua, this locality is about two miles within Sonora territory: lat. $27^{\circ} 08^{\prime}$; long. $108^{\circ} 42^{\prime}$ : alt. 1500 feet (approx.). J. T. Wright is the only collector to visit the place in recent years.

Hacienda la Casita. Banded duck return locality. Not identifiable.

Hall's Ranch. Just south of Boundary Monument 73 in Guadalupe Cañon $(q \cdot v \cdot)$. Mearns locality.

Hermosillo. Lat. $29^{\circ} 05^{\prime}$; long. $110^{\circ} 58^{\prime}$ : alt. 780 feet.

Huatabampo. Lat. $26^{\circ} 50^{\prime}$; long. $109^{\circ} 42^{\prime}$ : alt. 50 feet. (approx.) . 
Huerachi. Lat. $29^{\circ} 40^{\prime}$; long. $108^{\circ} 40^{\prime}$; alt. 4000 fect. (approx.). Lumholtz locality. Not on maps. (Río de Heuerachi on Greenidge map). Heurachi, Heuerachi, Huchucrachi.

Imuris. On the Southern Pacific Railroad: lat. $30^{\circ} 40^{\prime}$; long. 110 53': alt. 2713 feet.

Isla Alcatraz. See Pelican Island.

Isla Lobos. Sec Lobos Island.

Isla Patos. Sce Patos Island.

Isla Pelicano. See Pelican Island.

Isla San Estéban. Scẹ San Estéban Island.

Isla San Jorge. Sce George Island.

Isla San Pedro Mártir. See San Pedro Mártir Island.

Isla San Pedro Nolasco. See San Pedro Nolasco Island.

Isla Tassne. See Pelican Island.

Isla Tiburón. See Tiburón Island.

Isleta. On the lower Alamos (or Cuchujaqui) River: lat. $26^{\circ} 50^{\prime}$; long. $108^{\circ} 57^{\prime}$ : alt. 200 fect. The Ysleta of Salvin and Godman. Sonora News map.

Jobnson's Ranch On the Arizona side of the boundary at Monument 90: long. 109 $49^{\prime}$ : alt. 4561 feet. Mearns locality. Sometimes, "Boundary South of Bisbec."

Kino Bay. On the mainland coast opposite the south end of Tiburón Island: lat. $28^{\circ} 47^{\prime}$.

Kino Point. At the southern side of Kino Bay. Punta Kino.

La Bonancita. Sec Bonancita.

Lut Chumata. Mine in the Sierra de San Antonio: lat. $30^{\circ} 07^{\prime}$; long. $110^{\circ} 27^{\prime}$ : alt. 4500 fect. W. W. Brown is the only collector known to have visited the place, at least at the higher levels.

La Cobriza. See Cobriza.

La Libertad. See Puerto Libertad.

La Noria. On the Santa Cruz River near the Arizona boundary: lat. $31^{\circ} 19^{\prime}$; long. $110^{\circ} 37^{\prime}$ : alt. 4600 feet (approx.). Mearns locality.

La Osa. In the southern foothills of the Baboquivari Mountains, one half mile north of Boundary Monument 140. Specimens were taken apparently on both sides of the line (Mearns, 1907). 
Laguna de Algodones. See Algodones Lagoon.

Las Arenas. See Arenas.

Las Carpas. On the Colorado River in the delta, probably at or near the present site of Colonia Independencia $\left(q \cdot l^{\prime}\right.$ ). Mearns locality.

Las Capomas. See Capomas.

Las Chinchas. See Chinchas.

Las Cuevas. Lumholtz locality near (probably slightly north of) Oputo: alt. "1750-2300" feet. On Robinette's labels and in Allen's (1893a) account the place is written Las Cuevas, Los Cuevas, Los Cuevos, Los Cuervos. Whether Las Cuevas or Los Cuervos is intended it not determineable. Not on maps.

Las Trincheras. On the Lumholtz route somewhere very close to Fronteras. Not on maps.

Leoncita. Lumholtz locality apparently in the vicinity of Fronteras.

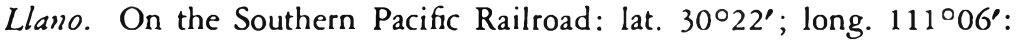
alt. 2305 feet.

Lobos Island. Lat. $27^{\circ} 20^{\prime}$. Sand island on the southern coast, separated from the mainland by a shallow lagoon. Bancroft locality.

López Collado. Banded duck return locality, not found on maps.

Los Médanos. See Médanos.

Los Nogales. See Nogales.

Los Pinitos. Lumholtz locality very close to (or actually) Cerro Pinitos at lat. $30^{\circ} 32^{\prime}$; long. $109^{\circ} 33^{\prime}$ : alt. 5000 feet. Robinette and Allen variations are Los Pinitos, El Pinita, Puerto, and Puerto de Los Pinitos, all from a very limited locality (Camps 14 and 15). This is not the "El Puerto" of December dates.

Los Vengos. Somewhere along the southwestern part of the Lumholtz route but not otherwise identifiable.

Madera Mountains. See Sierra de Madera.

Magdalena. Northcentral part of the State: lat. 30 $38^{\prime}$; long. $110^{\circ} 57^{\prime}$ : alt. 2480 .

Maicoba. In the southeastern mountains: lat. $28^{\circ} 23^{\prime}$ long. $108^{\circ} 42^{\prime}$ : alt. 5440 feet. Lloyd locality. Often Micoba, Maycoba.

Masocari Island. One of the larger mangrove islands in Agiabampo Bay: lat. $26^{\circ} 21^{\prime}$; long. $109^{\circ} 15^{\prime}$. A ppears, apparently incorrectly, as Isla Basacori (Rand McNally) or Cabo Basacori (Sonora No. 3.). 
Mayo River. Draining most of the southeastern part of the State between the Yaqui and Fuerte River systems: lat. at entrance to the Gulf, $26^{\circ} 45^{\prime}$. See Gentry (1942) for account of flora, topography, state boundary, etc.

Maytorena. On the Southern Pacific Railroad a short distance north of Guaymas: lat. $28^{\circ} 05^{\prime}$; long. $110^{\circ} 47^{\prime}$ : alt. 146 feet.

Médanos. Near the mouth of the Yaqui River: lat. 25038'; long. $110^{\circ} 32^{\prime}$ : alt. 50 feet. Benson and Sibley locality. Médano or Los Médanos of some maps

Miller Ranch. "64 miles south of Fort Huachuca." Most likely Ca. hoon's version of Rancho Molino or Molino Parson at lat. 30 $53^{\prime}$; long. $110^{\circ} 07^{\prime}$ : alt. 3500 feet (approx.).

Mina Abundancia. Exactly on the Sonora-Chihuahua boundary in Frazar's time but seemingly within Sonora limits as is certainly the case with the hacienda (San Rafael); lat 27009': long. 108 38': alt. 4000 feet. (approx.).

Mina Los Afanes. Benson and Sibley locality 6.8 miles north of Kino Bay. Not on maps.

Miramar Coastal beach on the Gulf directly west of Guaymas.

Mirasol. In the extreme southeast about 3 miles east of El Cobre. Moore locality.

Moctezumia. In the Moctezuma River valley: lat. 29 '48; long. 109 43'; alt. 1810 feet. Once, and occasionally still, known by the old Indian name of Oposura, the one invariably given on Cahoon labels.

Montague Island. Lat. $31^{\circ} 45^{\prime}$ at the mouth of the Colorado River.

Nácori. Lat. $29^{\circ} 40^{\prime}$; long. 108 53': alt. 3200 feet (approx.). Nacory of Allen (1893a). Nácori Chico of some maps.

Nacozari. On the Río Nacozari: lat. 30¹9'; long. 109 43': alt. 3550 feet. On most modern maps appears as Nacozari Viejo. The present railroad town of Nacozari or Placeritas de Nacozari, or Nacozari de Garcia is about 5 miles north and at a slightly higher altitude. Cahoon locality.

Nariz Temporal. Seasonal lake at the south end of the Nariz Moun-

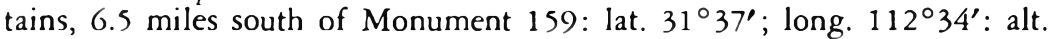
1640 feet. Mearns locality.

Navojoa. On the lower Río Mayo: lat. $27^{\circ} 08^{\prime}$; long. 109030': alt. 100 feet (approx.).

Niggerhead Mountain. See Cerro Gallardo.

Noche Buena. On the Colorado River in the general vicinity of Colonia Independencia. Exact location not determinable. Dickey locality. 
Nogales. On the Arizona boundary at Monument 122: long. 110 $57^{\prime}$; alt. 3852 feet. Usually, in early boundary reports (Baird, 1858, etc.), called Los Nogales. There is a location of this latter name in the extreme northeast which has been mistaken (in a recent mammalogical paper) for the present place.

Nopalera. On the upper reaches of the Río Huerachi a short distance north of the village of Huerachi but not located exactly. Approximately at lat. $29^{\circ} 40^{\prime}$; long. $108^{\circ} 40^{\prime}$ : approximate altitude, 4500 feet. On Robinette's labels the name is spelled indifferently as Nopalera or Napolera, the latter (incorrectly) selected by Allen on the basis of averages, apparently.

Nuri. On the Rio Chico: lat. $28^{\circ} 04^{\prime}$; long. $109^{\circ} 22^{\prime}$ : alt. 1445 feet. Lloyd locality.

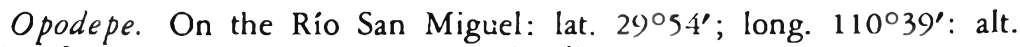
2400 feet (approx.). W. W. Brown locality.

Oposura. Old name for Moctezuma (q. $i$ ).

Oputo. In the northeast on the Río Bavispe: lat. $30^{\circ} 06^{\prime}$ long. $109^{\circ} 20^{\prime}$ : alt. 1925 feet. Lumholtz locality. Opata, Opoto, Oputa.

Ortiz. On the railroad, about 25 miles north of Guaymas: lat. $28^{\circ} 17^{\prime}$; long. $110^{\circ} 43^{\prime}$ : alt. 350 feet. Loring locality.

Pajaritos Mountains. Extending north and south of the International Boundary between longitude $111^{\circ} 00^{\prime}$ and $111^{\circ} 30^{\prime}$. Principal source of the Río Altar and the westermost Upper Sonoran-Transition area in the State. Local sections south of the boundary are known as the Sierra de los Pajaritos, Sierra de la Escondida, Sierra de San José, and, southernmost, as the Sierra de Huacomea or Guacomea. The peak elevation of the lastnamed is 2040 meters, or about 6700 fect. Jouy's "32 miles south of Nogales" would seem certainly to belong here.

Patagonia Mountains. Across the International Boundary at long. $110^{\circ} 45^{\prime}$ : alt. 5742 feet. The greater portion lies north of the boundary in Arizona. Mearns states that the Sonora portion is known as the Sierra de San Antonio; however, this apparently is not the case at the present time. Holzner collected a few specimens here. Patagone mountains.

Patos Island. Off the northern end of Tiburón Island: lat. $29^{\circ} 17^{\prime}$; long. $112^{\circ} 28^{\prime}$.

Pelican Island. Small, rocky island at the entrance to Kino Bay. Isla Alcatraz, Isla Pelicano, Isla Tassne.

Pesqueira. On the railroad, about 22 miles north of Hermosillo: lat. $29^{\circ} 23^{\prime}$; long. $110^{\circ} 54^{\prime}$ : alt. 1072 feet. Wright locality.

Petrel Ba). Shallow indentation on the scutheast coast of Tiburón Island, lat. $28^{\circ} 50^{\prime}$. Not on maps. 
Pichicuate River. Intermittant stream bed draining eastward from Guirocoba to the Rio Fuerte. This name was misapplied once (see Petrochelidon albifrons minima) to the Cuchujaqui River. Pichiquate.

Pilares. On the Río Bavispe: lat. $30^{\circ} 35^{\prime}$; long. $109^{\circ} 23^{\prime}$ : alt. 2500 feet (approx.). Campbell locality. Sonora No. 3 and Rand McNally maps.

Pinacate Mountains. Northwestern desert range: lat. $31^{\circ} 45^{\prime}$; long. $113^{\circ} 40^{\prime}$ : alt. 1415 meters, or about 4600 feet. See Dice and Blossom, 1937 , for account of region.

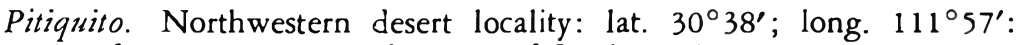
alt. 1600 feet (approx.). Pedroquito of Stephens (1885).

Plomosas. About 12 miles northeast of Álamos. Goldman locality. Sonora News map.

Plomoso. Given by Elliot as within the range of the Masked Bob-white. Not found on any available map.

Port Lobos. Puerto Lobos. Behind Cape or Cabo Tepoca. Stephens locality.

Potam. Near the mouth of the Yaqui River: lat. $27^{\circ} 37^{\prime}$; long. $110^{\circ} 27^{\prime}$ : alt. 50 feet.

Pozo de Luis. In the northwestern desert, 5 miles south of Monument 152: lat. $31^{\circ} 37^{\prime}$; long. $112^{\circ} 09^{\prime}$ : alt. 2300 feet. Mearns locality.

Providencia Mines. Rowley locality in the foothills of the Sierra de San Antonio: lat. $30^{\circ} 02^{\prime}$; long. $110^{\circ} 25^{\prime}$ : alt. 2300 feet. (approx.).

Pueblo Yaqui. Banded duck return locality. Probably synonymous with San José de Guaymas.

Puerto de los Pinitos. See Los Pinitos.

Puerto Isabel. See El Golfo.

Puerto Libertad. On the mainland coast behind Cape Lobos: lat. 29 ${ }^{\circ} 4^{\prime}$. Also known as La Libertad, Puerto de la Libertad, Libertad Anchorage.

Puerto Lobos. On the mainland coast behind Cape Tepoca. Tepoca Bay. Port Lobos.

Punta Kino. See Kino Point.

Punta Lobos. The Point Lobos of Stephens. Synonymous with Cabo Tepoca.

Punta Peñascosa. On the mainland coast near the head of the Gulf: lat. $31^{\circ} 20^{\prime}$. Variously, Punta Peñasca or Peñasco, Rocky Point. Huey locality. 
Punta Sargent. See Sargent Point.

Querobabi. On the Southern Pacific Railroad: lat. $30^{\circ} 05^{\prime}$; long. $111^{\circ} 02^{\prime}$ : alt. 2164 feet.

Questa del Tigre. Near the head of San Francisco Cañon (q. v.); alt. approximately 2000 feet. Wright locality.

Quijano. On the Southern Pacific Railroad: lat. $30^{\circ} 57^{\prime}$; long. $113^{\circ} 02^{\prime}$ : alt. 3300 feet.

Quiriego. On the Río Cedros: lat. 27032'; long. $109^{\circ} 17^{\prime}$; alt. 500 feet. (approx.).

Quitovaquito. Northwestern desert boundary locality just on the Arizona side of the line: lat. $31^{\circ} 57^{\prime}$; long. $113^{\circ} 02^{\prime}$ : alt. 1050 feet. Variously, Quitovaquita, Quitobaqita, or Quitobaquito.

Quotla. Unidentifiable coastal locality (for Haematopus).

Rancho Carrizo. Wright locality not on maps: lat. $30^{\circ} 06^{\prime}$; long. $111^{\circ} 15^{\prime}$ : alt. 2500 feet (approx.).

Rancho Costa Rica. Lat. $28^{\circ} 55^{\prime}$; long. $111^{\circ} 40^{\prime}$ : alt. 270 feet. Costa Rica. San Francisco de Costa Rica. Lamb locality.

Rancho Guirocoha. See Guirocoba.

Rancho La Arizona. In the western foothills of the Pajaritos Mountains: lat. $31^{\circ} 12^{\prime}$; long. $111^{\circ} 12^{\prime}$ : alt. 3200 feet. La Arizona. All "Saric" citations belong here.

Rancho Los Álamos. See El Alamo.

Rancho San José. On east side of Playa del Bartolo, 17 miles north of Kino Bay: lat. 29 $9^{\circ} 5^{\prime}$; long. $111^{\circ} 54^{\prime}$ : alt. (below) 300 feet. Benson and Sibley locality.

Rancho Santa Bárbara. In the extreme southeast and close to the Chihuahua boundary. About five or six miles northwest of Milpillas (on the boundary) and in the same mountain range, known as the Sierra Saguaribo. Lat. $27^{\circ} 16^{\prime}$; long. $108^{\circ} 35^{\prime}$ : alt. 4500-5000 feet.

Rancho Santa Rosa. See Tesia.

Ranken Ranch. "90 miles south of Fort Huachuca." Cahoon locality, possibly a site marked as "Rancho" on several maps: lat. $30^{\circ} 35^{\prime}$ long. $109^{\circ} 55^{\prime}$. Not unlikely a corruption of Rincón.

Realito. Lloyd locality in the lower mountains somewhere between Guadalupe and Nuri.

Río Colorado. See Colorado River.

Rio Cuchujaqui. See Cuchujaqui River. 
Rio Mayo. See Mayo River.

Rio Pichicuate. Sce Pichicuate River.

Rio San Bernardino. See San Bernardino River.

Rio San Ignacio. One of several names used for the lower reaches of the Altar-Magdalena drainage system. Hydrographic chart 619.

Rio San Pedro. See San Pedro River.

Rio Santa Cruz. See Santa Cruz River.

Rio Yaqui. See Yaqui River.

San Bernardino Ranch. On the San Bernardino River, just on the

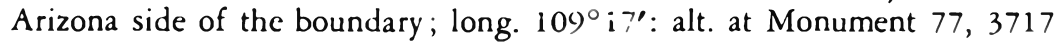
feet. One of the principal collecting stations of Mearns and Holzner.

San Bernardino River. In the extreme northeast, with headwaters in Arizona and flowing south to join the Río Bavispe at $30^{\circ} 48^{\prime}$.

San Carlos Bay. On the Gulf coast, just north of Guaymas.

San Estéban Island. In the center of the Gulf: lat. $28^{\circ} 43^{\prime}$; long. $112^{\circ} 36^{\prime}$. San Estévan.

San Felix Mine. Stephens locality in the northwestern desert; lat. $30^{\circ} 34^{\prime}$; long. $112^{\circ} 30^{\prime}$ : alt. 800 feet.

San Francisco Cañon. Small cañon draining into the Río Chínipas, partly in Sonora and partly in Sinaloa; lat. 26 $6^{\circ} 58^{\prime}$; long. 108 $27^{\prime}$ : alt. 1200-2500 fect. Not on maps.

San Javier. Wright locality: lat. $28^{\circ} 35^{\prime}$; long. $109^{\circ} 43^{\prime}$ : alt. 1650 fect (approx.). Rand McNally and Sonora News maps.

San José. Moore locality somewhere near Guirocoba. Not on maps.

San José de Guaymas. Site of old Guaymas on the northern arm of Guaymas Harbor.

San José Mountains. About five miles south of the Arizona boundary: lat. $31^{\circ} 15^{\prime}$; long. $110^{\circ} 10^{\prime}$ : alt. 8337 feet. Mearns locality.

San Luis. Boundary village on the Colorado River at Monument 205.

San Luis Mountains. Across the International boundary in the extreme northeast, the crest (Atlantic-Pacific divide) presumably forming the Sonora-Chihuahua boundary at this point: alt. at Monument 65, 6719 feet; at highest point in Sonora, 7874 feet.

San Marcial. On the Rio Matape northeast of Guaymas: lat. 28 $30^{\prime}$; long. $110^{\circ} 18^{\prime}$ : alt. 700 feet (approx.). W. W. Brown locality. 
San Pedro. On the San Pedro River, about 7 miles south of the Inter. national boundary: lat. $31^{\circ} 16^{\prime}$; long. $110^{\circ} 10^{\prime}$ : alt. 4400 feet. (approx.).

San Pedro Bay. On the mainland coast near Guaymas: lat. $28^{\circ} 03^{\prime}$.

San Pedro Mártir Island. In mid-Gulf: lat. $28^{\circ} 23^{\prime}$; long. $112^{\circ} 15^{\prime}$.

San Pedro Nolasco Island. Small, rocky island about 15 miles off the coast: lat. $27^{\circ} 57^{\prime}$; long. $111^{\circ} 25^{\prime}$.

San Pedro River. Across the International Boundary at long. $110^{\circ} 10^{\prime}$ : alt. at Monument 98, 4259 feet.

Santa Ana. In the eastern mountains: lat. $28^{\circ} 20^{\prime}$; long. $109^{\circ} 05^{\prime}$ : alt. 3500 feet (approx.). Lloyd locality; the Santa Ana of Salvin and Godman. Sonora News map.

Santa Ana. Large town on the Southern Pacific Railroad: lat. $30^{\circ} 32^{\prime}$; long. $111^{\circ} 07^{\prime}$ : alt. 2247 feet.

Santa Bárbara. Lumholtz locality, apparently very close to Fronteras. Not on maps.

Santa Cruz. On the Santa Cruz River: lat. $31^{\circ} 14^{\prime}$; long. $110^{\circ} 35^{\prime}$ : alt. 4425 feet.

Santa Cruz River. In the extreme northcentral part of the State, enclosing the Patagonia Mountains and crossing the International Boundary twice at long. $110^{\circ} 37^{\prime}$ and $110^{\circ} 32^{\prime}$, respectively.

Santa Rosa. On the headwaters of the Río Cedros: lat. 27055'; long. $109^{\circ} 15^{\prime}$ : alt. 2880 feet. Lloyd locality; the Santa Rosa of Salvin and Godman.

Santa Rosa. Mearns locality just south of the International Boundary and a little east of Sonoyta: alt. at Monument 161, 1693 feet.

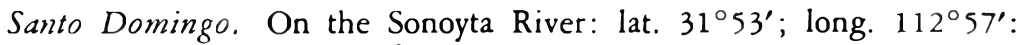
alt. at Monument 170, 1181 feet. Bay.

Sargent Point. Lat. $29^{\circ} 18^{\prime}$ on the mainland coast and enclosing Tepopa

Saric. See Rancho La Arizona.

Sásabe. On the International Boundary: long. $111^{\circ} 32^{\prime}$ : alt. 3500 feet. El Sásabe. On all maps except that of the American Geographical Society.

Sierra Azul. General name for the mountainous area at about long. $110^{\circ} 30^{\prime}$ and which extends south from the Arizona boundary to about lat. $30^{\circ} 30^{\prime}$.

Sierra de Alamos. Lat. $27^{\circ} 00^{\prime}$; long. 109 $00^{\prime}$ : alt. 5848 feet.

Sierra de Antonez. See Sierra de San Antonio. 
Sierra de Guadalupe. See Guadalupe Mountains.

Sierra de Huacomea. Sce Pajaritos Mountains.

Sierra de Madera. Northwestern part of the mountain mass usually called the Sierra de Nácori. Sometimes known locally as El Tigre Mountains. Lat. $30^{\circ} 33^{\prime}$; long. $109^{\circ} 15^{\prime}$ : alt. (probably) over 7000 feet.

Sierra de Nácori. Almost entirely enclosed by the Bavispe and Nácori Rivers, and with the axis roughly along longitude $109^{\circ}$. Maximum altitudes are over 9000 feet. Restrictive names for the more prominent sections are Tigre or El Tigre Mountains, Sierra de Madcra, Sierra de la Espejucla, Sierra de Bacadéhuachi, and Sierra de Nácori.

Sierra de Oposura. About 15 miles northeast of Moctezuma: lat. $30^{\circ} 00^{\prime}$; long. $109^{\circ} 35^{\prime}$ : alt. about 6000 feet. Cahoon locality.

Sierra del Pinacate. See Pinacate Mountains.

Sierra de San Antonio. Narrow north-south range which divides the San Miguel and Sonora River systems in the northcentral part of the State: lat. $30^{\circ} 00^{\prime}$; long. $110^{\circ} 35^{\prime}$ : alt. (approx.) 5000 fect. W. W. Brown locality.

Sierra de San José. See San José Mountains.

Sierra de San Luis. See San Luís Mountains.

Sierra Seri. Low, barren range along the coast opposite Tiburón Island: lat. $29^{\circ} 08^{\prime}$; long. $112^{\circ} 07^{\prime}$ : alt. 2500 feet (approx.). Benson and Sibley (Mus. Vert. Zool.) specimens are from the latitude and longitude given above, that of the pass between the northern and southern sections of the range: alt. above 700 feet.

Sonoyta. On the Sonoyta River, about two miles south of the Arizona boundary: lat. $31^{\circ} 51^{\prime}$; long. $112^{\circ} 50^{\prime}$ : alt. $1312 \mathrm{fect}$. Mearns locality. Indifferently on maps as Sonoita. Rancho La Sone of J. W. Audubon.

Soyopa. Wright locality: lat. $28^{\circ} 45^{\prime}$; long. $109^{\circ} 37^{\prime}$ : alt. 892 feet.

Sulphur Spring Valley'. Across the International Boundary at long. 109 ${ }^{\circ} 45^{\prime}$ : alt. at Monument 85, 3950 feet. Known in Sonora as Valle de Agua Prieta. Mearns locality.

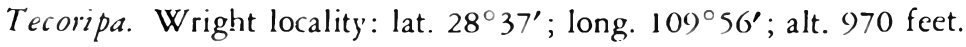

Tepoca Bay'. On the mainland coast: lat. $30^{\circ} 16^{\prime}$. Port I.obos or Puerto de Lobos of Stephens.

Tepopa Bay. Shallow bay on the mainland coast behind Sargent Point: lat. $29^{\circ} 18^{\prime}$. 
Terrenate Creek. Tributary of the Rio San Pedro: lat. $31^{\circ} 13^{\prime}$; long. $110^{\circ} 20^{\prime}$ : alt. 4600 feet. Holzner locality. Terenate. Toronato.

Tesia. On the lower Río Mayo: lat. 27009'; long. $109^{\circ} 24^{\prime}$ : alt. 200 feet. Benson and Sibley, van Rossem, and Wright specimens are all from Rancho Rosa, two or three miles east of the village.

Tiburón Island. Lat. $29^{\circ} 00^{\prime}$; long. $112^{\circ} 30^{\prime}$. Largest island in the Gulf and, except for San Estéban Island, the only one in Sonora waters of major ornithological importance.

Tóbari Bay. Extensive series of mangrove lagoons, separated from the Gulf by several low, sandy islands: lat. $27^{\circ} 05^{\prime}$; long. $110^{\circ} 00^{\prime}$. Tóvari. Táburi.

Tonichi. Lat. $28^{\circ} 36^{\prime}$; long. $109^{\circ} 34^{\prime}$ : alt. 600 feet. Wright locality.

Tres Marias. About 12 miles northwest of Álamos on the road to Navojoa: alt. 1000 feet (approx.).

Trinidad. In the eastern mountains: lat. $28^{\circ} 24^{\prime}$; long. $109^{\circ} 03^{\prime}$ : alt. 4480 feet. "6000" feet on Lloyd labels.

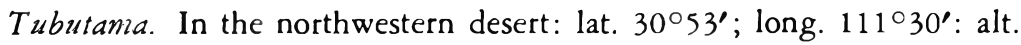
2237 feet. Bruner locality.

Ures. Lamb locality on the Río Sonora: lat. $29^{\circ} 24^{\prime}$; long. $110^{\circ} 23^{\prime}$ : alt. 1417 feet.

Valle de las Animas. See Animas Valley.

Viejo Yaqui. One of the several lagoons at the mouth of the old Yaqui River or Río Muerto. Practically synonymous with Guásimas Lagoon. (q. i.).

Warsaw Mills. In the Pajaritos Mountains in Arizona, about three quarters of a mile north of Monument 132: alt. 4003 feet. Mearns locality.

Yaqui River. By far the most important river in Sonora, and draining most of the eastern part of the State north of the Río Mayo system: lat. at entrance to the Gulf, $27^{\circ} 37^{\prime}$.

Yécora. In the eastern mountains: lat. $28^{\circ} 18^{\prime}$; long. $108^{\circ} 57^{\prime}$ : alt. 5500 feet. Altitudes on Lloyd's labels range from " $8500^{\prime \prime}$ to " $9500^{\circ}$ feet, but these are probably far in excess of actual altitudes, even for high points. Yecori. Yecaera. Yecera.

Ysleta. See Isleta. 


\section{BIBLIOGRAPHY}

THE COMPILATION of this bibliography, together with those of certain other Mexican states, was begun in a casual way in 1929 when plans for work in the field of Mexican ornithology were still rather nebulous. The "chore" of making it as complete as possible has been carried on at irregular intervals and with varying degrees of intensity ever since that time. In it I have included every formal reference to Sonora birds which has been found, no matter how trivial, except that reviews, as such, have been omitted unless they contain controversial comment or additional information. It would easily have been possible to eliminate some fifty or sixty other titles as of little consequence so far as Sonora is concerned, but on the other hand many of these are far from trivial in relation to other Mexican states.

In addition to strictly ornithological matter, a few of the more important papers dealing with the botanical, mammalogical and ecological or faunal aspects of the State have been included, as have two or three books which contain excellent descriptive accounts of certain areas.

Titles have been transcribed personally, in most cases from the original publication. Even so there will be errors and, of course, there are undoubtedly some items which have been overlooked. The closing date, after which no titles have been listed, is November 10, 1944.

Aввотт, C. G.

1941. Observations at Guaymas, Sonora, Mexico. Auk, 58: 416-418, July 9. Various water-birds seen in the vicinity.

ALDRICH, J. W.

1942. Specific relationships of the Golden and Yellow Warblers. Auk, 59: 447-449, July 1.

The Sonora Yellow Warbler becomes Dendroica petechia sonorana.

1944. Notes on the races of the white-breasted nuthatch. Auk, 61: 592-604, October 20.

Sitta carolinensis nelsoni and S. c. umbrosa occur in Sonora.

Aldrich, J. W. and Bole, B. P., JR.

1937. The birds and mammals of the western slope of the Azuero Peninsula [Republic of Panama]. Sci. Publ. Cleveland Mus. Nat. Hist., 7: 1-196, map, 12 ills, August 31. [Birds by Aldrich].

Buteogallus antbracinus antbracinus (p. 47) at Cajón Bonito Creek.

Allen, J. A.

1886a. The Masked Bob-white (Colinus ridgwayi) in Arizona. Auk, 3: 275276, April.

Critical remarks on the type specimen (from Sonora). 
1886b. The Masked Bob-white (Colinus ridgwayi) of Arizona, and its Allies. Bull. Amer. Mus. Nat. Hist., 1: 273-291, pl., July.

Historical account to date with discussion of systematic status and range in Arizona and Sonora.

1886c. The Type Specimen of Colinus ridgwayi. Auk, 3: 483, October.

Said to be in (i. F. Morcom collection. [Now in British Museum].

1892. The North American species of the genus Colaptes, considered with special reference to the relationships of $\mathrm{C}$. auratus and $\mathrm{C}$. cafer. Bull. Amer. Mus. Nat. Hist., 4: 21-44, map, March 8.

Casual mention of Colaptes cafer and Colaptes chrysoides in Sonora.

1893a. List of mammals and birds collected in northeastern Sonora and northwestern Chihuahua, Mexico, on the Lumholtz archeological expedition, 1890-92. Bull. Amer. Mus. Nat. Hist., 5: 27-42, March 16.

An atrociously careless list of 162 species of birds, with frequent mis-identifications, misspelling of localities, many incorrect localities and dates, and with only the vaguest indications as to the state in which some of the localities are situated. A large part of the "Hypothetical List" is derived from this source. The professed authorship of this paper may well be viewed with skepticism.

1893b. The geographical origin and distribution of North American birds, considered in relation to faunal areas of North America. Auk, 10: 97-150, 2 maps, April.

Various conceptions of the "Sonoran" life zone discussed. An important contribution on the distribution of Mexican as well as North American birds.

\section{American Ornithologists' 'Union Committee.}

1886. The code of nomenclature and check-list of North American birds.

(Amer. Orn. Union, New York), pp. viii-392.

At this date only five species, Spinus psaltria, Peucaea arizonae, Harporbynchus curvirostris palmeri. Harporbynchus lecontei, and Harporbynchus bendirei are mentioned from Sonora.

1890. Second supplement to the American Ornithologists' Union check-list of North American birds. Auk, 7: 60-66, January. Empidonax griseus added.

1891. Third supplement to the American Ornithologists' Union check-list of North American Birds. Auk, 8: 83-90, January. Otocoris alpestris pallida added.

1895. Check-list of North American birds. (2nd ed., revised, Amer. Orn. Union, New York), pp. xii-372, December 9. 19 species ascribed to Sonora, usually without definite locality.

1897. Eighth supplement to the American Ornithologists' Union check-list of North American birds. Auk, 14: 117-135, January. Sula gossi and Otocoris alpestris pallida are affected.

1899. Ninth supplement to the American Ornithologists' Union check-list of North American birds. Auk, 16: 97-133, January. Amphispiza bilineata deserticola added. 
1903. Twelfth supplement to the American Ornithologists' Union check-list of North American birds. Auk, 20: 331-368, July. Otocoris alpestris occidentalis and Sitta carolinensis nelsoni added.

1910. Check-list of North American birds. 3rd. ed., (Amer. Orn. Union, New York), 430 pp., 2 maps, August.

Some 50 additional species and subspecies are stated to occur in Sonora but only rarely are definite localities cited.

1912. Sixteenth supplement to the American Ornithologists' Union check-list. Auk, 29: 380-387, July 6.

Colaptes chrysoides mearnsi added.

1931. Check-list of North American birds. 4th. ed. (Amer. Orn. Union, Lancaster, Pa.), pp. xx-526, October 1.

So far as Sonora is concerned there are few changes from 1910.

1944. Nineteenth supplement to the American Ornithologists' Union checklist of North American birds. Auk, 61: 441-464, July 12.

Many cases involve, directly or indirectly, the nomenclature of Sonora birds.

ANONYMOUS.

1891. Notes and News. Auk, 8: 320-321, July.

Notice of J. C. Cahoon (death), with mention of his field work in Sonora.

ANTHONY, A. W.

1894. Notes on the genus Heleodytes with a description of a new subspecies.

Auk, 11: 210-214, July.

Including speculation on the type of [Picolaptes] brunneicapillus Latresnaye.

1897. New birds from the islands and peninsula of Lower California. Auk, 14: 164-168, April.

Critical comment on a Sonora specimen of Harporbynchus lecontei.

ARveY, D. M.

1941. A New Race of Bush-tit from Southeastern California. Condor, 43: 74-75, January 15.

Comment on the characters of Psaltriparus minimus cecaumenorum of Sonora.

Audubon, J. W.

1906. Audubon's western journal: 1849-1850 (The Arthur H. Clark Co., Cleveland), pp. ii-249, 6 pls., 1 map.

Chapter 3, "Across the Mexican mountains to Altar" is the Sonora portion of the narrative. None of the birds noted are treated forformally although many are identifiable, with more or less certainty. Most interesting, perhaps, is his reference to "plenty of the California partridge [i. e., the Gambel Quail] . . . and Gambel's blue partridge" [Arizona Scaled Quail] at Altar. At "Rancho La Sone" [Sonoyta] he noted the "Red-shafted woodpecker" in numbers (September 14), and along the Sonoyta River the "American avoset, longbilled curlew and Canada crane." 
BAILEY, F. M.

1928. Birds of New Mexico. Judd and Detweiler, Inc., Washington, xxiv-807 pp., 79 pls., 136 text figs., 2 diagrams.

Frequent mention of Mearns-taken specimens from the west slope of the San Luis Mountains, both north and south of the boundary. Most of the "Sonora" general range inclusions apparently are taken from the "Check-list," 3rd ed.

BAIRD, S. F.

1858. Birds. Pacific Railroad Reports, 9, (pt. 2), pp. Ivi-1005.

A few Sonora specimens recorded, mostly taken by Dr. Kennerly in the vicinity of Nogales.

1859. Birds of the boundary. Lnited States and Mexican boundary survey, 2 (pt. 2), 32 pp., 25 pls.

As concerns Sonora, mostly a repetition of 1858 .

1860. The Birds of North America. (J. P. Lippincott and Co., Philadelphia), 2 vols., text (1), lvi-1005 pp., plates (2), xi pp., 100 pls.

Letter press is almost identical with 1858. Both of these items are often cited under the triple authorship of Baird, Cassin, and Law. rence, since the latter two contributed certain specified sections. The main body of the work is that of Baird.

1866. The Distribution and Migrations of North American Birds. Amer. Journ. Sci. and Arts, 41, sec. ser., No. 121, January: 78-90; No. 122, March: 184-192; No. 123, May: 337-347.

Baird's designation of the mouth of the Yaqui River as a boundary between two major ornithological "provinces" is amazingly accurate in view of the scant data available at that time.

BAIRD, S. F., BREWER, T. M., and RIDGWAY, R.

1874. A history of North American birds. Iand birds. (I.ittle, Brown, and Company, Boston). Vol. 1, xxviii-596-vi pp., 26 pls.; Vol. 2, iv-590-vi pp., 30 pls.; Vol. 3, iv-560-xxviii pp., 8 pls.; 593 text figs. in 3 vols. Several species mentioned from Sonora, principally on previously published data.

1884. The water birds of North America (=Memoirs Mus. Comp. Zoöl., 12-13; Little, Brown, and Company, Boston). Vol. 1, xi-537 pp.; Vol. 2, vi.552 pp.; many text figs. in both vols.

Occasional references to the very few water birds known at that time to occur in Sonora.

BANCROFT, G.

1926. The faunal areas of Baja California del Norte. Condor, 28: 209.215, map, September 21.

Includes portions of Sonora in the "Colorado Desert District."

1927a. Breeding birds of Scammon's Lagoon, Lower California. Condor, 29: 29-57, January 15.

Includes some life history data on the birds of George Island.

1927b. Notes on the breeding coastal and insular birds of central Lower California. Condor, 29: 188-195, July 15.

Including data from San Pedro Mártir, San Esteban, and George Islands. 
1930. The breeding birds of central Lower California. Condor, 32: 20-49, January 20.

Incidental mention of a few Sonora birds.

Bangs, O. [See also Thayer, J. E., and]

1914. The geographic races of the Scaled Quail. Proc. New England Zoöl. Club, 4: 99-100, March 9.

Range of Callipepla squamata pallida "probably" includes northern Sonora.

1930. Types of birds now in the Museum of Comparative Zoölogy. Bull. Mus. Comp. Zoöl., 70: 147-426, March.

Lists many types of birds described from Sonora, usually without comment; however, Lafresnaye's type of Picolaptes brunneicapillus is critically discussed and the type locality fixed as Guaymas, Sonora (following Ridgway, 1904).

Bangs, O., and Penard, T. E.

1921. Descriptions of six new subspecies of American birds. Proc. Biol. Soc. Wash., 34: 89-92, June 30.

Geranospiza caerulescens livens and Melanotis caerulescens effuticius described, respectively, from Álamos and Hacienda de San Rafael.

1922. The northern form of Leptotila fulviventris Lawrence. Proc. New Eng. Zoöl. Club, 8: 29-30, May 8.

Specimens of Leptotila fulviventris angelica, here newly described from Brownsville, Texas, are cited from Álamos and Hacienda de San Rafael.

Bangs, O., and Peters, J. L.

1928. A collection of birds from Oaxaca. Bull. Mus. Comp. Zoöl., 68: 385-404, October.

Xiphorbynchus flavigaster tardus and Tyrannus cassirostris pompalis are described as new from Hacienda de San Rafael, "Chihuahua."

\section{BARTLETT, E.}

1888. A monograph of the weaver birds, Plocidae, and arboreal and terrestrial finches, Fringillidae . . . (Maidstone [England]), part 2, 13 pp., April.

Cardinalis virginianus in Sonora.

BeCKHAM, C. W.

1888. Observations on the birds of southwestern Texas. Proc. U. S. Nat. Mus., 10: 633-696, "1887"=September 19, 1888.

Believes Colinus ridguayi to be a race of $C$. virginianus.

BEHLE, W. H.

1936. [Minutes of Cooper Club Meetings] Condor, 38: 224, September. Mention of Seth Benson's collecting on Tiburón Island.

1942. Distribution and variation of the horned larks (Otocoris alpestris) of western North America. Univ. Calif. Publ. Zool., 46: 4+205-316, 13 text figs., May 20.

Discussion of the status of Otocoris alpestris pallida Dwight; careful analyses of the Horned Lark populations among the Arizona-Sonora boundary. 
BELDING, L.

1883. List of birds found at Guaymas, Sonora, in December, 1882, and April, 1883. [Edited by Robert Ridgway]. Proc. U. S. Nat. Mus., 6: 343.344, December 27.

This nominal list of 46 species was the first to be published for any Sonora locality, earlier bird records for the State being more or less in the nature of incidentals taken by survey parties or ship naturalists. An unfortunate sequel has been the tiresome repetition of these Guaymas citations in literature, many of them of little importance.

1890. Land birds of the Pacific district. Occasional Papers, Calif. Acad. Sci., 2: $4+1-274$.

Molothrus ater obscurus, Ammodramus rostratus, and Vireo vicinior at Guaymas.

1900. A part of my experience in collecting. Condor, 2: 1-5, January. Including his visit to Guaymas.

BENDIRF. C. E.

1892. Life histories of North American birds [etc.]. Special Bull. U. S. Nat.. Mus., 1, viii-446 pp., 12 pls.

1896. Life histories of North American birds [etc.]. Special Bull. U. S. Nat. Mus., 3, ix-518 pp., 7 pls., "1895"=October 1, 1896.

Both volumes contain incidental mention of Sonora species or localities.

BENT. A. C.

1919. Life histories of North American diving birds. Bull. U. S. Nat. Mus., 107, xiii-245 pp., 55 pls., August 1.

In this and the following volumes of the series are to be found many Sonora references for species which are included in the American Ornithologists' Union Check-list. There is also a small amount of original life history matter pertaining directly to Sonora in the in the form of contributions from several authors. I have not attempted to cite these items separately in the present bibliography [i. e., "Smith, in Bent"], since they are usually to be found, almost verbatim, under definite titles in other publications.

1921. Life histories of North American gulls and terns. Bull. U. S. Nat. Mus., 113, x-345 pp., 93 pls., August 27.

1922. Life histories of North American petrels and pelicans and their allies. Bull. U. S. Nat. Mus., 121, xii-343 pp., 69 pls., October 19.

1923. Life histories of North American wild fowl, order Anseres (Part). Bull. U. S. Nat. Mus., 126, x-250 pp., 46 pls., May 25.

1925. Life histories of North American wild fowl, order Anseres (Part). Bull. U. S. Nat. Mus., 130, x-376 pp., 60 pls., June 27.

1927a Life histories of North American marsh birds, orders Herodiones and Paludicolae. Bull. U. S. Nat. Mus., 135, xii-490 pp., 98 pls., "1926" = March 11, 1927.

1927b Life histories of North American shore birds, order Limicolae (Part 1). Bull. U. S. Nat. Mus., 142, ix-420 pp., 55 pls., December 31.

1929. Life histories of North American shore birds, order Limicolae (Part 2). Bull. U. S. Nat. Mus., 146, ix-412 pp., 66 pls., March 24. 
1932. Life histories of North American gallinaceous birds, orders Galliformes and Columbiformes. Bull. U. S. Nat. Mus., 162, xi-490 pp., 93 pls., May 25.

1937. Life histories of North American birds of prey, order Falconifomes (Part 1). Bull. U. S. Nat. Mus., 167, v-409 pp., 102 pls., May 3.

1938. Life histories of North American birds of prey, orders Falconiformes and Strigiformes (Part 2). Bull. U. S. Nat. Mus., 170, viii-482 pp., 92 pls., August 8.

1939. Life histories of North American woodpeckers, order Piciformes. Bull. U. S. Nat. Mus., 174, viii-334 pp., 39 pls., May 23.

1940. Life histories of North American cuckoos, goatsuckers, hummingbirds and their allies, orders Psittaciformes, [to] Micropodiiformes. Bull. U. S. Nat. Mus., 176, viii-506, 73 pls., July 20.

1942. Life histories of North American flycatchers, larks, swallows, and their allies, order Passeriformes. Bull. U. S. Nat. Mus., 179, xi-555 pp., 70 pls., May 8.

BERLEPSCH, H. VON.

1911. Revision der Tanagriden. Verhandlungen des V Internationalen Ornithlogen-Kongresses in Berlin: 1001-1148.

Euphonia godmani (p. 1016), and Pyranga rubra cooperi (p. 1063) in Sonora.

BerLioz, J.

1932. Contribution a l'etude des Trochilides du Mexique. I'Oiseau et la Rev. Francaise d'Ornithologie, new ser., 2:120-132.

Remarks on the Salvin Hummingbird.

1938. Notes critiques sur les Trochilides. L'Oiseau et la Rev. Francaise d'Ornithologie, new ser., 8: 3-19.

Two Sonora species, Uranomitra violiceps conjuncta and Uranomitra salvini receive comment.

Bishop, L. B. [see also Sanford, L. C., Bishop, L. B., and Van Dyke, T. S.]

1906. Uranomitra salvini in Arizona. Auk, 23, 337-338, July. Including comments on the type from Nacozari.

1933. Two apparently unrecognized races of North American birds. Proc. Biol. Soc. Wash., 46: 201-206, October 26.

On the validity of $H$ )locichla guttata oromela (recorded from Chinohampo), and Lanius ludovicianus sonoriensis.

Blake, E. R., and Hanson, H. C.

1942. Notes on a collection of birds from Michoacan, Mexico. Field Museum of Natural History. Zool. Ser., 22, No. 9, pp. 513.551, 4 ills., 2 maps, November 23.

Occasional comparative mention of Sonora birds.

Blossom, P. M. [See Dice, L. R., and].

Bole, B. P. [see Aldrich, J. H., and]. 
BOND, R. M.

1943. Variation in western sparrow hawks. Condor, 45: 168-185, Scptember 24 .

Critical survey of the western races. The brceding range of Falco sparverius peninsularis includes the coastal plain of Sonora.

Boucard, A.

1892-1895. Genera of hummingbirds. Being also a complete monograph of these birds. xiv-412 pp. [Reprinted from The Humming Bird (London), 2 January, 1892, to 5, December, 1895].

The only hummingbird definitely ascribed to Sonora is the unfortunate Uranomitra salvini.

BRENINGER, G. F.

1904. Passing of masked bob-white. Warbler, 2: 70, September.

Supposed extinction in the Altar district.

BREwer, T. M. [see Baird, S. F., Brewer, T. M., and Ridgway, R.]

BREWSTER, W.

1885. Additional notes on some birds collected in Arizona and the adjoining Province of Sonora, Mexico, by Mr. F. Stephens in 1884; with a description of a new species of Ortyx. Auk, 2: 196-200, April.

Commentaries on 19 species, four of them taken in Sonora. Original description of Colinus ridguayi. the type locality being 18 miles southwest of Sásabe.

1887. Further Notes on the Masked Bob-white (Colinus ridgwayi). Auk, 4: 159-160, April.

Critical comment on specimens from northeastern Sonora.

1888a. Descriptions of supposed new birds from Lower California, Sonora, and Chihuahua, Mexico, and the Bahamas. Auk, 5, 82-95, January.

Contains original descriptions of Icterus uagleri castaneopectus, Aimophila cabooni, and Troglodytes cahooni, all from near Oposura; also of other new forms, the ranges of which include Sonora.

1888b. On three apparently new subspecies of Mexican birds. Auk, 5: 136-139, April.

Mitrephanes phaeocercus tenuirostris and Dendroica aestiva sonorana newly described, with type locality "near Oposura."

1889. Descriptions of supposed new birds from western North America and Mexico. Auk, 6: 85-98, April [Separates publ. January 31].

Ten new birds, three of them, Psittacula cyanopyga pallida, Thryo. philus sinaloa cinereus, and Polioptila nigriceps restricta from Âlamos, and one, Compsothylpis pulchra. from Hacienda de San Rafacl. Sonora is included in the ranges of Empidonax griseus, and Euphonia godmani.

1893. Description of a new hummingbird from northern Mexico. Auk, 10: 214, July.

Cyanomyia salinini from Nacozari.

1902. Birds of the Cape region of Iower California. Bull. Mus. Comp. Zoöl., 41: 1.241, map, September.

Frequent mention, sometimes critical, of Sonora birds in the author's collection. 
BRODKORB, P.

1935. A new flycatcher from Texas. Occ. Papers Mus. Zool., Univ. Mich., 306: $1-3$, January 30.

Sonora included in the range of Empidonax difficilis difficilis.

1940. New birds from southern Mexico. Auk, 57: 542-549, October 2.

Critical comment on Sterna albifrons mexicana, Chordeiles acutipennis texensis, and Chloroceryle americana leucosticta.

1941. The pygmy owl of the District of Soconusco, Chiapas. Occ. Papers Mus. Zool., Univ. Mich., 450: 1-4, October 9.

Including critical comment on Glaucidium brasilianum cactorum.

1942a. Notes on some races of the rough-winged swallow. Condor, 44: 214217. September 15.

Status of Stelgidopteryx ruficollis serripennis and S. r. psammochrous in Sonora.

1942b. A new race of bob-white from interior Chiapas. Occ. Papers Mus. Zool., Univ. Mich., 467: 1-4, October 8.

Racial characters of Colinus virginianus ridgwayi included.

BROWN, $\mathrm{H}$.

1885. Arizona Quail Notes. Forest and Stream, 25: 445, December.

Historical data on Colinus ridgwayi in Arizona and Sonora.

1904. Masked bob-white (Colinus ridgwayi). Auk, 21, 209-213, April.

Further historical data.

BRUNER, S. C.

1926. Notes on the birds of the Baboquivari Mountains, Arizona. Condor, 28: 231-238, September 21 .

Mexican and White-necked Ravens near Tubutama.

BRYANT, W. E.

1889. A catalogue of the birds of Lower California, Mexico. Proc. Calif. Acad. Sci., ser. 2, 2: 237-320, map, December 17.

Occasional species mentioned from islands within Sonora waters.

Burleigh, T. D., and LOWery, G. H., JR.

1942. An inland race of Sterna albifrons. Occ. Papers Mus. Zool., Louisiana State Univ., 10: 173-177, March 4.

Includes critical remarks on Sterna albifrons mexicana.

Burleigh, T. D., and Sutton, G. M. [see Sutton, G. M., and]

BURT, W. H.

1938. Faunal relationships and geographic distribution of mammals in Sonora, Mexico. Misc. Publ. Mus. Zool., Univ. Mich., 39, 77 pp., 26 maps, February 14.

An important paper as concerns the "biotic provinces" of Sonora.

Certain races of quail (Lophortyx) are considered important in fixing province limits, but for some reason a score or more of other species and subspecies which would alter these limits somewhat are completely ignored. 
CASSIN, J.

1853-1856. Illustrations of the birds of California, Texas, Oregon, British and Russian America. (J. P. Lippincott and Co., Philadelphia, 1856), viii298 pp., 50 pls.

Occasional references to Heermann's observations at Guaymas.

Chapman, F. M.

1888. List of additions to the North American avifauna and of eliminations and changes in nomenclature proposed since the publication of the A. O. U. check-list. Auk, 5: 393-402, October.

Two cases involve Sonora.

1899. Nelson on New Birds from Northwestern Mexico. Auk, 16: 296, July. Review of Nelson's "Descriptions of new birds from northwestern Mexico" (1899c). Certain affinities of southern Sonora with southern Baja California re-emphasized.

1907. The warblers of North America. (D. Applcton and Co., New York), ix-306, pp., 24 pls.

Plumages, ranges, habits, etc., of most of the species known to occur in Sonora, although only one ( $W^{\prime}$ ilsonia pusilla chryseola) is cited definitely.

1914. Notes on the plumage of North American sparrows. Thirtieth paper. Bird-Lore, 16: 242-243, November.

Winter range of Junco byemalis connectens includes Sonora.

1915. Notes on the plumage of North American sparrows. Thirty-first paper. Bird-Lore, 17: 20-21, January.

Sonora mentioned in the ranges of five races of juncos.

1917. Notes on the plumage of North American birds. Forty-second paper. Bird-Lore, 19: 39, January.

Toxostoma crissale and $T$. lecontei lecontei in north Sonora.

1925. The relationships and distribution of the warblers of the genus Compsothlypsis: a contribution to the study of the origin of Andean bird life. Auk, 42: 193.208, 2 maps, April 3.

Includes range and relationships of $C$. pitiayumi pulchra.

Clark, J. H.

1898. Notes on the Nesting of Palmer's Thrasher at El Plomo, Sonora, Mexico. Auk, 15: 272-274, July.

As observed in that locality.

1899. Nesting of the White-necked Raven in Giant Cactus. Osprey, 3: 78, January.

At El Plomo.

1904. Curve-billed and Palmer's thrashers. Auk, 21: 214-217, April.

Nests and eggs of the latter collected at Fl Plomo.

Conover, B. [see Hellmayr, C. E., and]

COOKE, W. W.

1904. Distribution and migration of North American warblers. U. S. Dept. Agric., Biol. Surv. Bull. 18, 142 pp.

Wilsonia pusilla chryseola wintering in Sonora. 
1906. Distribution and migration of North American ducks, geese and swans. U. S. Dept. Agric., Biol. Surv. Bull. 26, 90 pp. Only Spatula clypeata specifically mentioned.

1910. Distribution and migration of North American shorebirds. U. S. Dept. Agric., Biol. Surv. Bull. 35, 100 pp., 4 maps, October 6. Gallinago delicata listed from Sonora.

1913. Distribution and migration of North American herons and their allies. U. S. Dept. Agric., Biol. Surv. Bull. 45, 70 pp., 21 maps, May 24. Heterocnus mexicanus recorded from Álamos.

1915a. The migration of North American sparrows. Thirty-second paper. BirdLore, 17: 18-19, January. Junco caniceps at Nogales.

1915b Distribution and migration of North American gulls and their allies. U. S. Dept. Agric., Biol. Surv. Bull. 292, 70 pp., 31 maps and figs., October 25. Larus delawarensis from Sonora.

CoOper, J. G.

1870. Ornithology of California. Geol. Surv. of California. Ornithology. Vol. 1. Land birds. Edited by S. F. Baird, from the manuscript and notes of J. G. Cooper. Published by authority of the Legislature. xii-592 pp., many text figs.

Incidental inclusion of Sonora in the ranges of a few species.

CORY, C. B.

1918. Catalogue of birds of the Americas and the adjacent islands . . . Field Mus. Nat. Hist., Zool. Ser., 13, Bubonidae [to] Trochilidae, Part 2, No. 1, 315 pp., 1 pl., March.

1919. Catalogue of birds of the Americas and the adjacent islands . . . Field Mus. Nat. Hist., Zool. Ser., 13, Trogonidae [to] Picidae, Part 2, No. 2, 317-607 pp., 1 pl., December 31.

Sonora is included in the ranges of several owls, goatsuckers, hummingbirds, woodpeckers, parrots, etc., treated in this and the preceding volume. There is little or no original matter in the present connection.

Cottam, C. P., and KNAPPEN, P.

1939. Food of some uncommon North American birds. Auk, 56, 138-169, April 7.

Stomach contents of Masked Bob-white and Coppery-tailed Trogon collected near Tecoripa.

Coues, E.

1866. List of the birds of Fort Whipple, Arizona: with which are incorporated all other species ascertained to inhabit the Territory [etc.]. Proc. Acad. Nat. Sci. Phila., 18: 39-100, "March"= June 11.

A few of the species are presumed, more or less hypothetically, to occur in Sonora.

1874. Birds of the northwest [etc.]. Dept. of the Interior. U. S. Geological Survey of the Territories. Misc. Publ. No. 3. xi-791 pp., December. Quotes occurrences of Callipepla squamata and Cyrtonyx massena in 
northern Sonora. Most curious is his belief (p. 378) that the "Queleli" of A. S. Taylor $(q . v$.) might be his unidentified vulture of Arizona.

1878. Birds of the Colorado Valley [etc.]. Part first. Passeres to Laniidae.

U. S. Geol. Surv. Terr., Misc. Publ., No. 11, xvi-807 pp., 66 text figs. Sonora included in the ranges of a few species.

1872. Key to North American birds [etc.]. (Naturalists' Agency, Salem), $8+361$ pp., 6 pls., 238 text figs.

1903. Key to North American Birds [etc.]. Fifth edition. (Dana Estes and Company, Boston), Vol. 1, xli-535 pp., Vol. 2, 537-1152 pp., many pls., text figs.

In this and the preceding volume are about twenty ascriptions, more or less casual, to "Sonora."

DAWSON, W. L.

1923. The birds of California [etc.]. (South Moulton Company, San Diego), 4 vols. paged consecutively [Booklovers' ed.], xviii-2122 pp., 1240 ills.

The general ranges of some 36 species include Sonora, chiefly or entirely on the basis of the 1910 edition of the "Check-list." The Roseate Spoonbill is stated to nest near Guaymas, although on what basis cannot be ascertained. The ancestral stock of the Bell and Sage Sparrows (here named "Amphispiza preglacialis"!) is believed to have originated in Sonora.

DE OCA, R. M.

1875. Ensayo ornitológico de los Troquilideos ó Colibríes de Méjico. (Escalante Press, México), 60 pp., 12 pls. 46 figs.

Repeats the erroneous nesting record (of Heermann, 1853) of the Black-chinned Hummingbird at Guaymas.

DICE, L. R.

1939. The Sonoran Biotic Province. Ecology, 20: 118-129, map, April.

An important paper which summarizes the author's conclusions on the subject. So far as Sonora is concerned, the "Province" corresponds almost exactly to the western, Lower Sonoran zone, desert.

DiCE, L. R., and Blossom, P. M.

1937. Studies of mammalian ecology in southwestern North America with special attention to the colors of desert mammals. Carnegie Inst. of Washington, Publ. 485, iv-129 pp., 8 pls., 8 text figs.

Although containing little or no ornithological matter, this paper treats in detail the physical and biotic aspects of the northwestern desert region of Sonora.

DICKEY, D. R.

1928. A new poor-will from the Colorado River valley. Condor, 30: 152-153, March 15.

Pbalaenoptilus nuttallii bueyi described from Bard, California. Specimens from [Oposura] Sonora are believed to be P. $n$. nuttallii.

1930. A new clapper rail from Sonora. Trans. San Diego Soc. Nat. Hist., 6: 235-236, December 24.

Rallus obsoletus rhizophorae described from Tóbari Bay. 
Dickey, D. R., and van Rossem, A. J.

1925. A revisionary study of the western gull. Condor, 27: 162-164, July 15. Larus occidentalis livens recorded from San Pedro Mártir and George Islands.

1926. A Southern Race of the Fan-tailed Warbler. Condor, 28: 270-271, November 15.

Specimens from Hacienda de San Rafael listed as Eutblypis lachrymosa tephra.

1938. The birds of El Salvador. Field Mus. Nat. Hist., Zool. Ser., 23, 609 pp., 24 pls., 29 text figs., March 21.

Occasional comment on specimens from Sonora.

Dubois, A.

1899-1904. Synopsis avium. Noveau manuel d'ornithologie. (Brussels, H. Lamertin), 2 vols. paged consecutively, xv-1339 pp., 4 pls.

Various species ascribed to Sonora. No original matter.

Dwighr, J., JR.

1890. The horned larks of North America. Auk, 7: 138-158, map, April.

Otocoris alpestris pallida "Townsend, MS." described. No type nor type locality designated, but type now known to be from Direction Hill near the mouth of the Colorado River.

1918. The geographical distribution of color and of other variable characters in the genus Junco: a new aspect of specific and subspecific values. Bull. Amer. Mus. Nat. Hist., 38: 269-309, 2 pls., June 1.

Junco phaeonotus palliatus the breeding race in the San José Mountains.

ElLIOT, D. G.

1897. The gallinaceous game birds of North America [etc.]. (Francis P. Harper, New York), xviii, 19-220 pp., 46 pls.

Only the Masked Bib-white ascribed definitely to Sonora.

EvermanN, B. W., and Jenkins, O. P.

1888. Ornithology from a railroad train. Orn. and Oöl., 13: 65-70, May. Narrative account of birds seen between Nogales and Guaymas. Of interest chiefly as an early list of Sonora birds. Some of the sight records are dubious.

Ferrari-Perez, F., and Ridgway, R.

1886. Catalogue of animals collected by the geographical and exploring commission of the republic of Mexico. 2.-Birds. By F. Ferrari-Perez. With descriptions of five new species, and critical remarks on others of great or less rarity or interest. By Robert Ridgway. Proc. U. S. Nat. Mus., 9: 130-182.

Three specimens of Pipilo fuscus from Guaymas receive critical comment.

FOSTER, L. S.

1892. The published writings of George Newbold Lawrence, 1844-1891. Bull. U. S. Nat. Mus., 40, xi-124 pp. (part).

Sonora records of Lawrence (1874) are re-cited. Not important. 
FRIEDMANN, $\mathrm{H}$.

1927. A revision of the classification of the cowbirds. Auk, 44: 495-508, October 19.

Sonora included in the range of Tangavius aeneus aeneus.

1929. The cowbirds. A study in the biology of social parasitism. (Charles C. Thomas Publisher, Springfield, Illinois), xvii-421 pp., 28 pls., 13 figs.

Tangavius aeneus aeneus cited from Hermosillo and Opodepe.

1933a Further notes on the birds parasitized by the red-eyed cowbird. Condor, 35: 189-191, September 15.

Records three species as victimized in localities in Sonora.

1933b Critical notes on American vultures. Proc. Biol. Soc. Wash., 46: 187 190, October 26.

Cathartes aura teter, here newly named from Riverside, California, recorded from Guadalupe Cañon.

1934. Further additions to the list of birds victimized by the cowbird. Wilson Bull., 46: 25-36, March; 104-114, June.

Sonora records include the Plumbeous Gnatcatcher and Pyrruloxia.

1941. The birds of North and Middle America. Bull. U. S. Nat. Mus., 50, Part 9, "By Robert Ridgway. Continued by Herbert Friedmann," ix254 pp., 16 text figs., October 2.

Full descriptions and synonymies of the species of Gruidae and Ralli. dae known to occur in Sonora.

1943. Critical notes on the avian genus Lophortyx. Journ. Washington Acad. Sci., 33 (No. 12): 369-371, December 15.

Review of the races of Lophortyx douglasii, with bensoni the only one specifically cited from Sonora. Lophortyx gambelii gambelii mentioned from Cajón Bonito Creek "Chihuahua."

GeNTRY, H. S.

1942. Rio Mayo plants. A study of the flora and vegetation of the valley of the Rio Mayo, Sonora. Carnegie Institution of Washington Publication 527 (The Lord Baltimore Press, Baltimore), vii-328 pp., 29 pls., 2 maps, 6 text figs., November 30 .

A detailed and excellent account of the subject.

Giebel, C. G.

1872-1877. Thesaurus ornithologicae [etc.]. (F. A. Brockhaus, Leipzig), 3 Vol. Vol. 1, 1872, pp. ix-868.

On page 628 the range of Chaetura saxatilis is given as "Sonora," but on what basis I do not know.

Godman, F. D. [see Salvin, O., and]

Goldman, E. A., [see Nelson, E. W., and]

Gorsuch, D. M.

1934. Life history of the Gambel quail in Arizona. Bull. Univ. Arizona, 5, No. 4, 89 pp., 4 text figs., May 15.

References to Lophortyx gambelii gambelii, L. g. fulvipectus, and $L$. g. pembertoni in Sonora. 
Goss, N. S.

1888. New and rare birds found breeding on the San Pedro Martir Isle. Auk, 5: 240-244, July.

Five species listed, including original descriptions of Sula gossi "Ridgw. (MS.)" and Sula brewsteri.

1891. History of the birds of Kansas. Illustrating 529 birds. (Topeka, Kansas, Geo. W. Crane and Co.), 692 pp., 35 pls.

Zenaidura macroura on "San Pedro Martir Isle."

Grayson, A. J,, and Lawrence, G. N.

1871. On the physical geography and natural history of the islands of the Tres Marias and of Socorro, off the western coast of Mexico. Proc. Boston Soc. Nat. Hist., 14: 261-302. [Systematics auth. of Lawrence] Sonora included in range of Picus scalaris.

GrinNelL, G. B.

1884. A quail new to the United States fauna. Forest and Stream, 22: 243, April 24.

"Ortyx graysoni" in northwestern Sonora.

GRINNELI, J.

1905. Where does the large-billed sparrow spend the summer? Auk, 22: 16-21, January.

Manner of occurrence in Sonora.

1906. [Review] Stone and Rhoads "On a Collection of Birds and Mammals from the Colorado Delta, Lower California." Condor, 8: 78, May.

Concerning the improbability of some of Rhoads' sight records of birds.

1928. A distributional summation of the ornithology of Lower California. Univ. Calif. Publ. Zool., 32: 1-300, 24 maps, November 6.

Only occasional reference, usually critical, to Sonora-taken specimens. This work is of first importance in any systematic study of the Gulf area.

1932. Type localities of birds described from California. Univ. Calif. Publ. Zool., 38: 243-324, map. January 30.

Includes discussion of the type locality [Guaymas, Sonora] of Picolaptes brunneicapillus Lafresnaye.

1939. Proposed shifts in names in Passerculus-a protest. Condor, 41: 112119.

Advocates specific distinctness for the rostratus complex.

Griscom, L. [see also Miller, W. D., and; Peters, J. L., and]

1929a. Studies from the Dwight collection of Guatemala birds. 1. Amer. Mus. Novit., 379, 13 pp., October 17.

Includes citation of four Sonora specimens of Hylocharis leucotis borealis, here described from Pinos Altos, Chihuahua.

1929b. Notes on the rough-winged swallow (Stelgidopteryx serripennis [Aud.]) and its allies. Proc. New England. Zoöl. Club, 11: 67-72, December 14. Stelgidopteryx ruficollis psammochrous described; type locality, Oposura. 
1930. Studies from the Dwight collection of Guatemala birds. 2. Amer. Mus. Novit., 414, 8 pp., March 24.

Believes Polioptila nigriceps restricta to be a synonym of Polioptila bilineata albiloris, and that Heleodytes gularis is a race of Heleodytes jocosus.

1932a The distribution of bird-life in Guatemala . . . Bull. Amer. Mus. Nat. Hist., 64, vi-439 pp., 2 maps, 11 illus., May 7.

Critical comment on several Sonora species.

1932b. New birds from Honduras and Mexico. Proc. New Eng. Zoöl. Club, 13: 55-62, November 7.

Trogon mexicanus clarus is stated to occur in Sonora.

1933. Notes on the collecting trip of M. Abbott Frazar in Sonora and Chihuahua for William Brewster. Auk, 50: 54-58, January 4.

Valuable data on Frazar's itinerary.

1934. The ornithology of Guerrero, Mexico. Bull. Mus. Comp. Zoöl., 75: $367-$ 422 , pl., January.

Contains original descriptions of Amazilia violiceps conjuncta, Icterus pustulatus microstictus, and Piranga erythrocephala candida with type localities in Sonora. Critical comment on many other Sonora species. An important paper.

Hachisuka, the Marquess [see A. J. van Rossem, and]

Hanson, H. C. [see Blake, E. R., and]

HARGITT, E.

1890. Catalogue of the Picariae in the collection of the British Museum. Cat. Birds Brit. Mus., 18, xiv-598 pp., 15 pls., many text figs, ante October.

Several woodpeckers, mostly collected by Lloyd for Salvin and Godman, are listed from localities in Sonora.

HARPER. F.

1930. A historical sketch of Botteri's sparrow. Auk, 47: 177-185, pl., April 17. Mention of the type of Peucaea clestivalis, var. arizonae.

Hartert, E. [ste Salvin, O., and]

Hasbrouk, E.

1893. The distribution of the genus Megascops in North America. Auk, 10: 250-264, map, July.

Sonora is included in the ranges of Otus flammeolus and Otus asio trichopsis. The latter apparently is a composite of several species and races.

HeERMANN, A. L.

1853. Notes on the birds of California, observed during a residence of three years in that country. Journ. Acad. Nat. Sci. Phila., 2nd. ser., 2:259-272, January 18.

Occasional mention of species observed at Guaymas. The statement that the Black-chinned Hummingbird breeds at Guaymas is erroneous and doubtless pertains to Calypte costae. 
1859. Report upon birds collected on the survey. Pacific Railroad Reports, 10, part 4, no. 2, pp. 29-80, 7 pls.

A few species observed at Guaymas included.

Hellmayr, C. E.

1901. Zur revision der gattung Polioptila. Novit. Zool., 8: 356-361, October 5 .

Including critical notes on Polioptila nigriceps restricta.

1903. Das Tierreich. (R. Friedlander und Sohn, Berlin), Part 18. Paridae, Sittidae und Certhiidae, 1-xxxl $+1,1-255,76$ text figs., March.

Polioptila nigriceps restricta and Sitta carolinensis nelsoni cited.

1911. Genera Avium. Conducted by P. Wytsman. (Verteneuil and Desmet, Brussels), 15th part, Certhiidae, 16 pp., 1 pl.; 16th part, Sittidae, 16 pp., 1 pl.; 17th part, Regulidae, 18 pp., 1 pl.; 18th part, Paridae, 84 pp., 3 pls. [February, 1912?]

Sonora citations here and there in the systematic revisions.

1913. Critical notes on the types of little-known species of neotropical birds.

Novit. Zool., 20: 227-256, February 24.

Sonora included in the range of Amazilis ellioti.

1925-1938. Catalogue of birds of the Americas and the adjacent islands . . . . Field Mus. Nat. Hist., Zool. Ser., 13. Part 4 (1925), FurnariidaeDendrocolaptidae, iv-390 pp., 1 pl.; Part 5 (1927), Tyrannidae, vi-517 Pp.; Part 6 (1929), Oxyruncidae-Pipridae-Cotingidae-Rupicolidae-Phytotomidae, v-258 pp.; Part 7 (1934), Corvidae-Paridae-Sittidae,CerthiidaeChamaeidae - Cinclidae - Troglodytidae - Prunellidae - Mimidae - Turdidae - Zeledoniidae - Sylviidae, vi-531 pp.; Part 8 (1935), Alaudidae Hirundinidae - Motacillidae - Bombycillidae - Ptilogonatidae - Dulidae Vireonidae - Vireolaniidae - Cyclarhidae - Laniidae - Sturnidac - Coerebidae - Compsothlypidae, vi-541 pp.; Part 9 (1936), Tersinidae - Thraupidae, v-458 pp.; Part 10 (1937), Icteridae, v-228 pp.; Part 11 (1938), Ploceidae - Catamblyrhynchidae - Fringillidae, vi-662 pp.

The standard systematic work on all known birds of the Americas down to the dates of publication, including full synonymies except that the references given in Ridgway (1901-1919) are not repeated. Sonora citations, too numerous to list here, are often with critical comment.

Hellmayr, C. E., and Conover, B.

1942. Catalogue of birds of the Americas and the adjacent islands . . . Field Mus. Nat. Hist., Zool. Ser., 13. Part 1, Number 1, Rheidae - Tinamidae Cracidae - Tetraonidae - Phasianidae - Numididae - Meleagrididae - Opisthocomidae - Gruidae - Aramidae - Psophiidae - Rallidae - Heliornithidae - Eurypygidae - Cariamidae - Columbidae, vi-636 pp., April 30.

Critical comment, full synonymies, etc., of many Sonora species.

Herrera, A. L.

1898. Ornithologia Mexicana. La Naturaleza, ser. 2, 3: 131-229. [1899].

An almost verbatim translation of the Biologia Centrali-Americana, at least so far as concerns Sonora. 
HINDS, R. B.

1843. The regions of vegetations .... Appendix (pp. 325-460) to Vol. 2 of "Narrative of a voyage around the world ..." by Sir Edward Belcher, R. N. (London).

The "Chihuahua Region," roughly corresponding to the subsequently defined Sonoran life zones, is characterized on pp. 350-351.

HueY, L. M.

1930. Comments on the marsh sparrows of southern and Lower California, with the description of a new race. Trans. San Diego Soc. Nat. Hist., 6: 203-206, August 30.

Lists a specimen of Passerculus rostratus rostratus from Punta Lobos.

1931 a The Occurrence of Myiarchus cinerascens inquietus in Lower California. Auk, 48: 429-430, July 9.

Otus asio cineraceus on the Sonora side of the Gulf at lat. $29^{\circ}$ $46^{\prime}[!]$.

1931 b Icterus pustulatus, a New Bird to the A. O. U. Check-list. Auk, 48: 606-607, October 18.

Range north to Tecoripa.

1935. February bird life at Punta Peñascosa, Sonora, Mexico. Auk, 52: 249256, July 2.

Annotated list of 75 species, some important from a distributional standpoint.

1942. A vertebrate faunal survey of the organ pipe cactus national monument, Arizona. Trans. San Diego Soc. Nat. Hist., 9: 353-376, map, February 17.

Contains much of interest concerning the bird life of a western desert section of the Arizona-Sonora boundary. A few specific Sonora records are included.

Jenkins, O. P. [see Evermann, B. W., and]

JoHNSON, I. M.

1924. Expedition of the California Academy of Sciences to the Gulf of California in 1921. The botany (the vascular plants). Proc. Calif. Acad. Sci., 4th ser., 12: 951-1218, map, May 31.

An exceedingly important consideration of the climatic conditions (past and present), zonal divisions, and the botany of the Gulf area, including the coast and islands of Sonora. All of this, of course, has direct bearing on the distribution of bird life of the region.

JONES, L.

1900. Warbler songs. Wilson Bull., 7: 1.56, January.

Sonora included in the ranges of Helminthophila luciae and Dendroica graciae.

JOUY, P. L.

1894. Notes on birds of central Mexico, with descriptions of forms believed to be new. Proc. U. S. Nat. Mus., 16:771-791, "1893"=April 18, 1894. Includes mention of a few species noted at Guaymas and in the mountains "32 miles south of Nogales." 
KELSO, L. H.

1937. Food of the scaled quail. Bureau of Biol. Surv., Wildlife Research and Management Leaflet BS-84, 9 pp.

Stomach content analyses in part from Sonora specimens.

KENYON, K. W.

1942. Hunting strategy of Pigeon Hawks. Auk, 59: 443-444, July 1.

As demonstrated by six individuals, listed as Falco columbarius bendirei, seen south of Nogales.

KNAPPEN, P. [see Cottam, C., and]

KURODA, N.

1930. A Collection of Birds made by Mr. H. Yoshida in Mexico. Tori, 6: November.

List of 67 species, mostly from Sinaloa, but with occasional comment on Sonora races.

LAFRESNAYE, F. DE

1835. Sur le genre grimpic (Picolaptes, Lesson). (Guerin's) Mag. de Zool., sme. ann. [not paged $=57-62$ ], pls. 46-47, [between April and December].

Description [61] and plate (47) of Picolaptes brunneicapillus from "Californie ou Perou"; almost certainly, though, from Guaymas.

LANTZ, D. E.

1899. A list of birds collected by Col. N. S. Goss in Mexico and Central America. Trans. Kansas Acad. Sci., 16: 218-224, "1897-1898"= June, 1899.

Four species recorded from San Pedro Mártir Island.

I.AUBMANN, A.

1942. Nomina mutanda Alcedinidarum. Verh. Orn. Ges. Bayern, 22: 165-166, January 25.

The Sonora green kingfisher renamed Cergle americana bachisuki because of the prior Chloroceryle leucosticta Reichenbach (1851).

LAWRENCE, G. N. [see also Grayson, A. J., and]

1874. The Birds of Western and Northwestern Mexico, based upon Collections made by Col. A. J. Grayson, Capt. J. Xantus and Ferd. Bischoff, now in the Museum of the Smithsonian Institution, at Washington, D. C. Mem. Bust. Soc. Nat. Hist., 2: 265-319.

Specimens of a few species recorded from Sonora, and still others included on the authority of Grayson.

LEOPOLD, A. S.

1944. The nature of heritable wildness in turkeys. Condor, 46: 133-197, August 4.

Questions validity of Meleagris gallopavo onusta (p. 133).

I.OWERY, G. H., JR. [see Burleigh, T. D., and] 


\section{LumHoltz, C.}

1902. Unknown Mexico, a record of five years' exploration among the tribes of the Western Sierra Madre .... (Charles Scribner's Sons, New York), 2 vols. Vol. 1, xxxii-530 pp., 5 pls., map, many ills. Narrative account (volume 1) of the expedition. Birds receive only casual mention but there is the specific record of Campephilus imperialis from the west slope of the Sierra de Nácori. Birds collected were earlier reported by Allen (1893a).

1912. New trails in Mexico. An account of one year's exploration in northwestern Sonora, Mexico. . . (Charles Scribner's Sons, New York), xxv-411 pp., 2 maps, many ills.

A good account of the Altar region with frequent informal mention of birds, mammals, and reptiles observed.

LUSK, R. D.

1900. Parrots in the United States. Condor, 2: 129, November.

Rynchopsitta pachyrbyncha in the Chiricahua Mountains, Arizona, believed to have come from Sonora.

Mailliard, J.

1923. Expedition of the California Academy of Sciences to the Gulf of California in 1921. The birds. Proc. Calif. Acad. Sci., 4th ser., 12: 443.456, August 21.

A few records from islands within Sonora waters.

Mathews, G. M.

1934. A check-list of the order Procellariiformes. Novit. Zool., 39: 151-206, December 7 .

Halocsptena microsoma and C)mochorea melania melania from San Estéban Island.

McCabe, T. T., and Miller, A. H. [see also Miller; A. H., and]

1933. Geographic variation in the northern water-thrushes. Condor, 35:192197. September 15.

Specimens from the San Bernardino River, on the Arizona-Sonora boundary, are Seiurus noveboracensis notabilis.

MEARNS, E. A.

1886. Some birds of Arizona. Auk, 3: 289-307, July.

Harporbynchus crissalis [interrogatively] and H. lecontei ascribed to Sonora.

1895. Description of a new heron (Avdea virescens anthonyi) from the arid region of the interior of North America. Auk, 12: 257.259, ante July 11 .

Specimens recorded from the boundary on the San Pedro and San Bernardino Rivers.

1901. An addition to the avifauna of the United States. Proc. Biol. Soc. Wash., 14: 177-178, September 25.

Petrochelidon melanogaster breeding in northeastern Sonora. 
1902a. Description of a hybrid between the barn and cliff swallows. Auk, 19: 73-74, January.

Petrochelidon melanogaster occurs from the San Luis Mountains to Nogales.

1902b. The cactus wrens of the United States. Auk, 19, 141-145, April.

Concludes that the type of Picolaptes brunneicapillus came from Guaymas or vicinity, and refers the Cactus Wrens of northern Sonora to Heleodytes brunneicapillus anythonyi, here newly described from Arizona.

1902c. Descriptions of three new birds from the southern United States. Proc.

U. S. Nat. Mus., 24: 915-926, June 2.

Sitta carolinensis nelsoni from the San José and San Luís Mountains, and the Santa Cruz River on the boundary line.

1907. Mammals of the Mexican boundary of the United States. . . Part 1.

Bull. U. S. Nat. Mus., 56: xvi-530 pp., 13 pls., 120 text figs., April 13. Although birds are mentioned only casually, this work is of first importance as descriptive of the boundary, delineation of faunal areas, designation of collection stations, etc. Although many birds were collected (now mostly in the National Museum collections), no complete report on them has yet appeared.

Meinertzhagen, $R$.

1926. Introduction to a review of the genus Corvus. Novit. Zool., 33: 57-121, 12 pls., map.

Cites Sonora as in the range of the Mexican Crow, here called Corvus mexicanus mexicanus.

MeISE, W.

1928. Die Verbreitung der Aaskrahe (Formenkreis Corrus corone L.). Journ. für Orn., 76: 1.203, 4 pls., 10 maps, January 27.

Like Meinertzhagen, Meise considers the Mexican Crow conspecific with the Fish Crow of the United States. Camoa is listed as a locality.

1938. Ueber die rassen des kernbeissers Pheucricus chrysopeplus Less. [sic].

Bull. Mus. Roy. d'Hist. Nat. Belgique, 14, No. 52: 1-4.

$P$. c. dilutus cited from southern Sonora. The names chrysopeplus and chrysogaster, together with their respective authors, Vigors and Lesson, are confusingly transposed in places and it is difficult to follow the comparisons offered.

MgrRlam, C. H.

1892. The geographic distribution of life in North America with special reference to the Mammalia. Proc. Biol. Soc. Wash., 7: 1-64, April.

Including a discussion of the Sonoran Division, its characteristics and relationships. A few birds are cited.

1895. The Leconte thrasher, Harporhynchus lecontei. Auk, 12: 54-60, map, January.

The only Sonora record of the species to date is "Cape Lobos."

Milier, A. H.

1930. Two new races of the loggerhead shrike from western North America. Condor, 32: 155-156, May 15.

The breeding shrikes of Sonora are Lanius ludovicianus sonoriensis. 
1931. Systematic revision and natural history of the American shrikes (Lanius). Univ. Calif. Pub. Zool., 38: 11-246, 65 text figs. and maps, October 24. Three subspecies of Lanius ludovicianus are ascribed to Sonora, two of them transients or winter visitants.

1941. Speciation in the avian genus Junco. Univ. Calif. Publ. Zool., 44: 173.434, 33 text figs, May 24.

The work is much more important than its title would imply, for the author has merely used the genus Junco as a vehicle for some sound ideas on the creation of species in nature. One species, Junco phaeonotus palliatus, is resident in the mountains of Sonora. Others are present in winter in the extreme north.

Miller, A. H., and MCCABe, T. T. [see also McCabe, T. T. and]

1935. Racial differentiation in Passerella (Melospiza) lincolnii. Condor, 37: 144-162, 4 text figs., May 15.

Winter stations of $P$. l. lincolnii in Sonora are shown on map, but no specimens are definitely listed from that State.

Miller. W. De W.

1905. List of birds collected in southern Sinaloa, Mexico, by J. H. Batty, during 1903-1904. Bull. Amer. Mus. Nat. Hist., 21: 339-369, November 24.

Considers Amazona albifrons saltuensis to be a valid race.

1906. List of birds collected in northwestern Durango, Mexico, by J. H. Batty, during 1903. Bull. Amer. Mus. Nat. Hist., 22:161-183, June 2.

Comment on characters of two Sonora specimens of Spizella pallida.

Miller, W. De W., and Griscom, L.

1921. Descriptions of proposed new birds from Central America, with notes on other little-known forms. Amer. Mus. Novit., 25:1-13, December 9 .

Comment on characters displayed by Sonora specimens of Asturina plagiata plagiata.

1925. Notes on Central American birds, with descriptions of new forms. Amer. Mus. Novit., 183: 1-14, July 18.

Mention of Certbia familiaris albescens of Sonora.

MOORE, R. T.

1932a. A new motmot from Mexico. Proc. Biol. Soc. Wash., 45: 109-111, July 19.

Momotus mexicanus vanrossemi described from Chinobampo.

1932b. A new race of Aimophila carpalis from Mexico. Proc. Biol. Soc. Wash., 45: 231-234, December 23.

The Rufous-winged Sparrow of southern Sonora is named Aimophila carpalis bangsi, with type locality Guirocoba.

1934a. A new race of Lepidocolaptes leucogaster from Sonora, Mexico. Proc. Biol. Soc. Wash., 47: 87-90, April 2.

Lepidocolaptes leucogaster umbrosus from near Guirocoba.

1934b. A review of the races of Geococcyx velox. Trans. San Diego Soc. Nat. Hist., 7: 455-470, text figs., May 31.

Geococcyx velox melanchima described from Guirocoba. 
1935. New birds from northwestern Mexico. Proc. Biol. Soc. Wash., 48: 111 114, May 3.

Including Pbloeoceastes guatemalensis dorsofasciatus from Guirocoba.

1936. Description of a new race of Carpodacus mexicanus. Condor, 38: 203208.

Includes comment on Carpodacus mexicanus sonoriensis of southern Sonora.

1937a. New races of the genus Otus from northwestern Mexico. Proc. Biol. Soc. Wash., 50: 63-68, April 21.

Two Screech Owls, Otus hastatus tomlini and Otus asio sinaloensis, hoth described from Sinaloa, are also recorded from Guirocoba.

1937b. A new house finch from central Mexico. Condor, 39:204-206.

Validity of Carpodacus mexicanus sonoriensis Ridgway is challenged with "a true scientific approach" and an "ardor for all the facts."

1937c. A new race of Finsch's parrot. Auk, 54: 528-529, October 8. Amazona finschi woodi is described (but not figured) from Guirocoba.

1937d. New races of Myadestes, Spizella and Turdus from northwestern Mexico. Proc. Biol. Soc. Wash., 50: 201-206, November 30.

The type locality of Turdus assimilis calliphthongus is Baromicon [Baromico], in extreme southeastern Sonora.

1938a. Unusual birds and extensions of ranges in Sonora, Sinaloa and Chihuahua. Condor, 40:23-28.

Several species cited from Sonora, three of them, Lampornis clemenciae clemenciae. Nuttallornis borealis cooperi, and Volutinia jacarini atronitens, for the first time.

1938b. A new race of wild turkey. Auk, 55: 112-115, January 17.

Southeastern Sonora is included in the range of Meleagris gallopanc onusta.

1939a. A new race of Cynanthus latirostris from Guanajuato. Proc. Biol. Soc. Wash., 52: 57-60, April 27.

The race in Sonora is determined to be Cyanthus latirostris magica. Many localities listed.

1939b. Two new races of Carpodacus mexicanus. Proc. Biol. Soc. Wash., 52: 105-112, June 24.

The House Finches from northwestern Sonora determined to be intermediate between the races ruberrimus and solitudinis, the latter newly described from Fallon, Nevada.

1939c. The Arizona broad-billed hummingbird. Auk, 56: 313.319, "July"= June 29.

Breeding of Cyanthus latirostris magica at Guirocoba, etc.

1939d. New races of the genera Sialia and Carpodacus from Mexico. Proc. Biol. Soc. Wash., 52: 125-130, July 22.

Certain winter Bluebirds are considered to be Sialia mexicana bairdi.

1939e. A review of the house finches of the subgenus Burrica. Condor, 41: 177-205. September 15.

Fourteen mainland races of Carpodacus mexicanus are recognized, seven of them described by the author in this and previous papers. 
No. 21

1940. Notes on Middle American Empidonaces. Auk, 57: 349-389, July 13.

Seven species and subspecies are ascribed definitely to Sonora.

1941a. New races of flycatcher, warbler, and wrens from Mexico. Proc. Biol Soc. Wash., 54: 35-42, March 21.

Sulpinctes obsoletus obsoletus cited from Guirocoba.

$1941 \mathrm{~b}$. Three new races in the genus Otui from central Mexico. Proc. Biol. Soc. Wash., 54: 151-160, November 17.

Including comment on Sonora specimens of Otus vinaceus sinaloensis.

1941c. Notes on Toxostoma curvirostre of Mexico, with description of a new race. Proc. Biol. Soc. Wash., 54: 211-216, December 8.

On the possible application of certain names. Toxostoma curvirostre celsum from Laguna Juanota, Chihuahua.

1942. Notes on Pipilo fuscus of Mexico and description of a new form. Proc. Biol. Soc. Wash., 55: 45-48, May 12.

Cites Pipilo fuscus intermedius from Guirocoba.

Moore, R. T., and Peters, J. L.

1939. The genus Otus of Mexico and Central America. Auk, 56: 38-56, January 19.

Ranges and comparative characters of the five species and subspecies of Screech Owls known to occur in Sonora.

MURPhy, R. C.

1925. Notes on certain species and races of oyster-catchers. Amer. Mus. Novit., 194: 1.15, November 17.

Specimens of Haematopus palliatus frazari cited from Quotla and San Fstéban Island.

NeLSON, E. W.

1898a. Descriptions of new birds from Mexico, with a revision of the genus Dactylortyx. Proc. Biol. Soc. Wash., 12: 57-68, March 24. Sonora included in the range of Meleodytes brunneicapillus brunneicapillus.

1898b. With bob-white in Mexico. Auk, 15: 115-122, pl., April. Sonora in the range of Colinus ridguiayi.

1898c. Notes on certain Mexican birds. Auk, 15: 155-161, April. Sonora included in the range of Heleodytes gularis.

1898d. The imperial ivory-billed woodpecker, Campephilus imperialis (Gould). Auk, 15: 217.223, pl., July.

History to date. The Sonora record of Ridgway, 1887b, is repeated.

1899a. Descriptions of new birds from Mexico. Auk, 16: 25-31, January. Including original description of Callipepla gambeli fulvipectus, the type locality of which is Camoa, on the Río Mayo.

1899b. Birds of the Tres Marias Islands. U. S. Dept. Agric., No. Amer. Fauna, 14: 21-62, April 29.

Occasional incidental mention of birds from Sonora localities.

1899c. Descriptions of new birds from northwestern Mexico. Proc. Biol. Soc. Wash., 13: 25-31, May 29.

Contains original descriptions of Amazona albifrons saltuenis, Pipilo fuscus intermedius, Cardinalis cardinalis affinis, Basileuterus rufi- 
frons caudatus, and Myadestes obscurus cinereus; all with type localities in southern Sonora.

1900. Descriptions of thirty new North American birds in the Biological Survey collection. Auk, 17: 253-270, July.

Including original descriptions of Amphispiza bilineats pacifica and Harporhynchus curvirostris maculatus, with Allamos the type locality for both.

1902. The nomenclature and validity of certain North American Gallinae. Auk, 19: 386-391, 2 pls., October.

Affirms validity of Callipepla gambeli fulvipectus, Lophortyx bensoni, and Cyrtonyx montezumae mearnsi.

1903. Notes on the Mexican cormorant. Condor, 5: 139-145, November.

Stated occurrence in coastal lagoons of southern Sonora.

1904a. Empidonax griseus Brewst. = E. canescens Salv. \& Godm. Auk, 21:80, January.

Believes canescens has priority. Range includes southern Sonora.

1904b. A revision of the North American mainland species of Myiarchus.

Proc. Biol. Soc. Wash., 17: 21-50, pl., March 10.

Specimens from Sonora (particularly $M$. inquietus) discussed.

1928. Descriptions of three new subspecies of birds from Mexico and Guatemala. Proc. Biol. Soc. Wash., 41: 153-156, October 15.

Includes short discussion of topography cf Sonora and description of Aratinga holochlora breu'steri from Hacienda de San Rafael.

Nelson, E. W., and Goldman, E. A.

1926. 1. Mexico. Section 3. The Tropics north of the Equator. Naturalist's guide to the Americas. (The Williams and Wilkins Company, Baltimore), pp. 574-596, map.

Sonora is divided into the "Sierra Madre District" and the "Sonoran District." Lists of birds, mammals. and plants considered to be characteristic of each district are appended.

Oberholser, H. C.

1896. Critical remarks on the Mexican forms of the genus Certbia. Auk, 13: 314-318, October.

Certhia familiaris albescens from Nopalera.

1897. Critical remarks on Cistothorus palustris (Wils.) and its western allies. Auk, 14, 186-196, April.

Sonora specimens of $C$. p. plesius and $C$. p. palulicola.

1898. A revision of the wrens of the genus Thryomanes Sclater. Proc. U. S. Nat. Mus., 21: 421-450, November 19.

The Patagonia and San José Mountains are included in the range of Thryomanes beuickii eremophilus, here newly described from New Mexico.

1902. A review of the larks of the genus Otocoris. Proc. U. S. Nat. Mus., 24: 801-883, 3 pls., 4 maps, June 9.

Otocoris alpestris leucolcema, occidentalis, adusta, and pallida are definitely ascribed to Sonora, the latter two as breeding races. The ranges of two others, aphrasta and leucansiptila, as given in Map 2, overlap the boundaries of the State. Full descriptions and distributions of all known races. 
1904a. A revision of the American great horned owls. Proc. U. S. Nat. Mus., 27: 177-192, January 22.

Specimens of Bubo magellanicus pallescens listed from several boundary localities.

1904b. A review of the wrens of the genus Troglodytes. Proc. U. S. Nat. Mus., 27: 197.210, map, January 23.

Troglodytes brunneicollis cabooni is the only member specifically cited from Sonora.

1906a. Description of a new Querquedula. Proc. Biol. Soc. Wash., 19: 93-94, June 4.

Querquedula cyanoptera listed from the Colorado River.

1906b. [Review] Miller on Birds from Southern Sinaloa. Auk, 23: 478. October.

Type locality of Amizilis beryllina viola, here considered of doubtful validity, is erroneously given as Japla, "Sonora" [=Sinaloa].

1911a. A revision of the forms of the hairy woodpecker (Dryobates villosus [Linnaeus]). Proc. U. S. Nat. Mus., 40: 595-621, map, June 3. Sonora is included in the range of Dryobates villosus icastus, here newly described from Durango.

1911b. A revision of the forms of the ladder-backed woodpecker (Dryobates scalaris [Wagler]). Proc. U. S. Nat. Mus., 41: 139-159, map, June 30. Ranges, comparative characters, etc., of Dryobates scalaris agnus (here described from Camoa) and D. s. cactophilus.

1912a. A revision of the subspecies of the green heron (Butorides virescens [Linnaeus]). Proc. U. S. Nat. Mus., 42: 529-577, August 29. Butorides virescens anthonyi in northern Sonora.

1912b. A revision of the forms of the great blue heron (Ardea herodias [Linnaeus]). Proc. U. S. Nat. Mus., 43: 531-559, December 12.

Ardea herodias treganzai from northern Sonora localities.

1914. A monograph of the genus Chordeiles Swainson, type of a new family of goatsuckers. Bull. U. S. Nat. Mus., 86, vi-123, 6 pls., inc. 4 maps, April 6.

Chordeiles virginianus henvi and $C$. acutipennis texensis from a few Sonora localities.

1917. Notes on North American birds. 2. Auk, 34: 321-333, "July"=June 30. Sonora included in the ranges of Vireo bellii arizonae and Baeolophus u'ollweberi annexus.

1918a. New light on the status of Empidonax traillii (Audubon). Ohio Journ. Sci., 18: 85-98, January.

Empidonax traillii brewsteri. here newly described from Nevada, is recorded from Nogales.

1918b. The common ravens of North America. Ohio. Journ. Sci., 18: 213.225, April.

Corvus corax sinuatus recorded from Guaymas.

1918c. Notes on the subspecies of Numenius americanus Bechstein. Auk, 35: 188-195, April 6.

Specimens of $N$. a. americanus and $N$. a. occidentalis recorded from "Naris," Arizona,-really from Nariz Temporal, Sonora. (Mearns, 1907). 
[1919-1930] The Migration of North American Birds. Bird-Lore, vols. 21-32. In 22 numbers of this 'popular' series, Sonora is included in the ascribed ranges. The items do not merit separate listing in the present connection and are not cited in the synonymies.

1919a. Description of a new subspecies of Piranga hepatica Swainson. Auk, 36: 74-78, January 5.

Specimen of Piranga hepatica oreophasma recorded from Alamos.

1919b. A revision of the subspecies of Passerculus rostratus (Cassin). Ohio Journ. Sci., 19: 344-354, April.

Passerculus rostratus rostratus listed from several localities in northwestern Sonora.

1919c. The geographic races of Hedymeles melanocephalus Swainson. Auk, 36: 408-416, "July" = June 28.

$H . m$. melanocephalus and $H . m$. papago, the latter here described as new from Arizona, are stated to breed in Sonora.

1920. A synopsis of the genus Thryomanes. Wilson Bull., 32: 18-28, March. Central Sonora included in the breeding range of Thryomanes bewickii eremophilus.

1921. A revision of the races of Dendroica auduboni. Ohio Journ. Sci., 21: 240-248, May.

Specimens of D. a. auduboni and D. a. memorabilis, the latter here described from Colorado, are listed from Sonora localities.

1930. Notes on a collection of birds from Arizona and New Mexico. Sci.

Publ. Cleveland Mus. Nat. Hist., 1: 83-124, pl., December 31. Catherpes mexicanus meliphonus described as new from Álamos. The range of Sturnella magna lilianae, described from Arizona, includes portions of Sonora.

1932. Descriptions of new birds from Oregon, chiefly from the Warner Valley region. Sci. Publ. Cleveland Mus. Nat. Hist., 4: 1-12, September 19.

Stelgidopteryx ruficollis psammochrous held valid. Oberbolseria chlorura zapolia and Pooecetes gramineus definitus, described as new, are cited from southern Sonora.

1934. A revision of the North American house wrens. Ohio Journ. Sci., 34: 86-96, March.

Specimen of Troglodytes domesticus parkmanii cited from Álamos.

1937. A revision of the clapper rails (Rallus longirostris Boddaert). Proc.

U. S. Nat. Mus., 84: 313-354.

Included is Rallus longirostris rbizophorae of the coast of southern Sonora.

Ogilvie-Grant, W. R. [see also Sharpe, R. B., and]

1893. Catalogue of the game birds (Pterocletes, Gallinae, Opisthocomi, Hemipodii) in the collection of the British Museum. Cat. Birds Brit. Mus., 22, xvi-585 pp., 8 pls., after November 17.

Sonora specimens of Lophortyx. Ortyx, and Cyrtonjx listed from the Salvin-Godman collection.

1902. Remarks on the species of American Gallinae recently described, and Notes on their Nomenclature. Ibis, 8th ser. 2: 233-245, April.

Denies validity of certain races of quail recently named by Nelson (1899a, etc.). 
PARKER, H. G.

1887. Notes on the eggs of thrushes and thrashers. Orn. and Oöl., 12: 69-73, May.

Records of the eggs of Harporbynchus cinereus from Guaymas [!].

Pearson, T. G.

1933. Crows, magpies, and jays. Nat. Geog. Mag., 63: 51-79, 8 pls., January. Sonora is cited as the ranges of several species pictured.

Penard, T. E. [see Bangs, O., and]

Peters, J. L. [see also Bangs, O., and; Moore, R. T., and]

1929a. The identity of Corvus mexicanus Gmelin. Proc. Biol. Soc. Wash., 42: 121-124, March 25.

The name of Sonora Boat-tailed Grackle is Cassidix mexicanus nelsoni.

1929b. An ornithological survey in the Caribbean lowlands of Honduras. Bull. Mus. Comp. Zoöl., 69: 397-478, October.

Critical remarks on a Sonora specimen of Pitangus sulpburatus.

1930. A review of the races of Picus lineatus Linné. Occ. Papers Bost. Soc. Nat. Hist., 5: 317-322, September 2.

Sonora specimens are considered to be Ceopbloeus lineatus scapularis.

1931-1940. Check-list of birds of the world. (Harvard University Press, Cambridge), Vol. 1 (1931), . . . Gaviiformes, Colymbiformes, Procellariiformes, Pelicaniformes, Ciconiiformes, Anseriformes, Falconiformes, pp. xviii-345. Vol. 2 (1934), Galliformes, Gruiformes, ... Chradriiformes, pp. xvii-401. Vol. 3 (1937), Columbiformes, Psittaciformes, pp. xii-311. Vol. 4 (1940), Cuculiformes, Strigiformes, Caprimulgiformes, Apodiformes (part), pp. xii-291.

Nomenclature of all species and subspecies within the orders so far published. Sonora is specifically included in the ranges given for many forms.

1931a. An account of the yellow-green vireo (Vireosylua flanoviridis Cassin). Auk, 48: 575-587, October 18.

Includes Sonora in the range of Vireosglia flaroviridis flavoriridis.

Peters, J. L., and Griscom, L.

1938. Geographical variation in the savannah sparrow. Bull. Mus. Comp. Zoöl., 80: 445-478, pl., January.

The status of the rostratus group discussed informally and with no definite conclusions save that all are races of Passerculus sandwich. ensis.

Phillips, A. R., [see also Sutton, G. M., and]

1940. Two new breeding birds for the United States. Auk, 57: 117-118, January 4.

Tyrannus melancholicus occidentalis and Cassidix mexicanus nelsoni believed to breed in Sonora only from Guaymas southward.

1943. Critical notes on two southwestern sparrows. Auk, 60: 242-248, April 5.

Sonora included in the ranges of Aimophila botterii botterii and 
Melospsiza melodia bendirei, the latter newly named from Tucson, Arizona.

Phillips, J. C.

1911. A years' collecting in the state of Tamaulipas, Mexico. Auk, 28: 67-89, January.

Comparison of Tamaulipas and Sonora specimens of Myiochanes pertinax pallidiventris.

1922-1926. A natural history of the ducks. (Houghton Mifflin Company, Boston and New York), 4 vols. Vol. 1 (1922) xii-264, 18 pls., 17 maps. Vol. 2 (1923), xii-409 pp., 26 pls., 38 maps. Vol. 3 (1925), xii-383 pp., 26 pls., 30 maps. Vol. 4 (1926), xii-489 pp., 32 pls., 23 maps. Thorough treatment of taxonomy, distribution, plumages, etc.

There are a few specific ascriptions to Sonora, all, apparently, from published sources.

PRICE, W. W.

1899. Some Winter Birds of the Lower Colorado Valley. Bull. Cooper Orn. Club., 1: 89-93, September.

Annotated list of 91 species observed in the Colorado delta in mid. winter. In many instances there is no indication as to whether the species was noted in Arizona, Baja California, or Sonora.

PyCRAFT, W. P.

1915. The Avifauna of Central America: a Study in Geographical Distribution. Ibis, 10th ser., 3: 761-780, October.

Various Central American and Mexican birds considered to be of Old World origin. One of these, Sitta nelsoni, is specifically ascribed to Sonora.

REED, C. A.

1904. North American birds eggs. (Doubleday, Page and Company, New York ), $[\mathrm{x}]-356$ pp., many ills.

Cites Brewster and Blue-footed Boobies breeding on San Pedro Mártir Island.

RENARDO, J.

1886. Notes on some birds of the United States which occur in the Mexican Fauna. [translated by F. H. Carpenter] Orn, and Oöl., 11: 117-118, August.

Salpinctes obsoletus and Icteria virens longicauda at Guaymas.

RHonds, S. N. [see also Stone, W., and]

1893. The Vireo buttoni group, with description of a new race from Vancouver Island. Auk, 10: 238-241, July.

Lists Vireo huttoni stephensi from "Bacadehuachu" and Mina Abundancia.

RidGway, R. [see also Baird, Brewer, and; Ferrari-Perez, F., and]

1873. On some new forms of American birds. Amer. Nat., 7: 602-619, October.

Peucaea aestivalis var. Arizonae described from Los Nogales. 
1887a. Description of a new plumed partridge from Sonora. Forest and Stream, 28: 106, March 3.

Original description of Callipepla elegans bensoni from "Campos."

1887b. The Imperial Woodpecker (Campephilus imperialis) in Northern Sonora. Auk, 4: 161, April.

"Within fifty miles of the Arizona boundary."

1887c. Description of a new plumed partridge from Sonora. Proc. U. S. Nat. Mus., 10: 148-150, July 2.

Redescription of Callipepla elegans bensoni.

1887d. A manual of North American Birds. (J. B. Lippincott Company, Philadelphia), xii-631 pp., 124 pls.

Occasional mention (sometimes critical) of Sonora specimens.

1892. The humming birds. Report of the U. S. Nat. Mus. for 1890: 253-383, 46 pls., 46 text figs., July.

Trochilus alexandri said to breed south to Guaymas.

1893. Description of a new storm petrel from the coast of western Mexico. Proc. U. S. Nat. Mus., 16: 687-688, November 24.

Oceanodroma townsendi, described as new from Baja California, is also recorded from Guaymas.

1894a. [Review] Allen's List of Birds collected in Northeastern Sonora and Northwestern Chihuahua. Auk, 11: 66-67, January. Justly skeptical as to certain identifications.

1894b. On geographical variations in Sialia mexicana Swainson. Auk, 11: 145-160, April.

Sialia mexicana occidentalis believed to be the resident race in Sonora.

1896. A manual of North American Birds. Second edition.

Occasional references to Sonora birds in appendix (Pp. 583-614) not in first (1887) edition.

1898. Descriptions of supposed new genera, species, and subspecies of American birds. 1. Fringillidae. Auk, 15: 223-230, July [separates publ. May 13].

Sonora included in the range of Amphispiza bilineata deserticola.

1901-1919. The birds of North and Middle America . . . . Bull. U. S. Nat. Mus., 50. Part 1 (1901), xxx-715 pp., 20 pls. Part 2 (1902), xx-834 Pp., 22 pls. Part 3 (1904), xx-801 pp., 19 pls. Part 4 (1907), xxii974 pp., 34 pls. Part 5 (1911), xxiii-859 pp., 33 pls. Part 6 (1914), xx-882 pp., 36 pls. Part 7 (1916), xiii-543 pp., 24 pls. Part 8 (1919), xvi-852 pp., 34 pls.

Full descriptions, synonymies, distribution, etc., of all forms known at the time of publication of the various parts. Contains many references to Sonora as well as the original descriptions of several Sonora races. For orders and families not covered in the eight parts cited above see the continuation by Friedmann, 1941.

1901b. New birds of the families Tanagridae and Icteridae. Proc. Wash. Acad. Sci., 3: 149-155, April 15.

Original description of Scaphidurus major nelsoni.

1911b. Diagnoses of some new forms of Picidae. Proc. Biol. Soc. Wash., 24: 31-36, February 24.

Sonora included in the range of Colaptes chrysoides mearnsi, here newly described from Arizona. 
ROGERS, C. H.

1939. A new swift from the United States. Auk, 56: 465-468, October 4.

Specimens of the White-throated Swift from Sonora determined to be Aëronautes saxatalis saxatalis.

SAlvadori, T.

1891. Catalogue of the Psittaci, or parrots, in the collection of the British Museum. Cat. Birds Brit. Mus., 20, xvii-658 pp., 18 pls., "December $13^{\prime \prime}=$ March, 1892?

Specimens taken by Lloyd in the Salvin-Godman collection listed.

1893. Catalogue of the Columbae, or pigeons, in the collection of the British Museum. Cat. Birds Brit. Mus., 21, xvii-676 pp., 15 pls., ante October.

A few Lloyd-taken specimens from Sonora are listed.

1895. Catalogue of the Chenomorphae, Crypturi, and Ratitae in the collection of the British Museum. Cat. Birds Brit. Mus., 27, xv-636 pp., 19 pls., "Sept. 6."

Lists a few Sonora specimens of ducks.

1906a. Notes on the parrots (Part 5). Ibis, 8th ser., 6: 451-465, July. Comment on the status of Psittacula pallida.

1906b. Notes on the parrots (Part 6). Ibis, 8th ser., 6: 642-659, October. Criticism of the validity of Chrysotis saltuensis.

Salvin, O., and Godman, F. D.

1879-1904. Biologia Centrali-Americana. Aves. (Taylor and Francis, London), 3 vols. of text issued in 74 dated parts. Vol. 1, xliv-512 pp. Vol. 2, [ii]-598 pp. Vol. 3, iv-510 pp. Vol. 4, Plates 1-79 plus 4. Still the standard general work on Mexican and Central American birds. There are numerous ascriptions to Sonora, some of them original and based chiefly on specimens collected for the authors by William Lloyd.

1889b. Notes on Mexican Birds. Ibis, 6th ser., 1: 232-243, April.

Original description of Peucaea megarhynicha from Santa Ana, [southern] Sonora. Campylorbynchus gularis recorded for the first time from this State.

1889c. Notes on Mexican Birds._-Part 2. Ibis, 6th seir., 1: 380-382, July. Myadestes tounsendi recorded from Sonora.

Salvin, O., and Hartert, E.

1892. Catalogue of the Picariae in the collection of the British Museum. Upupae and Trochili, by Osbert Salvin. Coraciae, by Ernst Hartert. Cat. Birds Brit. Mus., 16, xvi-704 pp., 14 pls., ante October.

Ascriptions to Sonora based chiefly on specimens taken by Lloyd.

Salvin, O., and Saunders, H. [see Saunders, H., and]

Salvin, O., and Sclater, P. L. [see Sclater, P. L., and]

SANDYS, E., and VAN DyKe, T. S.

1904. Upland game birds. (The Macmillan Company, New York), vii-429 pp., pls.

Range of the Masked Bob-white in Sonora. 
Sanford, L. C., Bishop, L. B., and Van Dyke, T. S.

1903. The water-fowl family. (The Macmillan Company, New York), ix-598 pp., 20 pls.

Dendrocygna fulva said to breed in western Sonora.

SAunders, G. B.

1934. Description of a new meadowlark from southwestern Mexico. Auk, 51: 42-45, January 8.

Critical remarks on Sturnella magna lilianae from Sonora.

Saunders, H., and Salvin, O.

1896. Catalogue of the Gaviae and Tubinares in the collection of the British Museum. Gaviae (terns, gulls, and skuas) by Howard Saunders. [Tubinares by Salvin]. Cat. Birds Brit. Mus., 25, xv-475 pp., 8 pls.

Lists a specimen of Larus delawarensis from Guaymas.

SClATER, P. L.

1859. A list of the Tyrant-birds of Mexico, with descriptions of some new species. Ibis, 1: 436-445, pl., October.

Empidonax pusillus from "Los Nogales."

1862. Catalogue of a collection of American birds belonging to Philip Lutley Sclater. (N. Trübner \& Co., London), [xvi]-338 pp., 20 pls.

A few specimens listed from Sonora, usually without definite locality.

1888. Catalogue of the Passeriformes, or perching birds, in the collection of the British Museum. Oligomyodae. Cat. Birds Brit. Mus., 14, xx-494 pp., 26 pls., June 28.

Tyrannus vociferans listed from Los Nogales.

Sclater, P. L., and Salvin, O.

1868. Descriptions of New or little-known American Birds of the Families Fringillidae. Oxyrbamphidae, Bucconidae, and Strigidae. Proc. Zool. Soc. Lond., for 1868: 322-329.

"Peucaea cassini" [= Aimophila botterii?] from Sonora.

Sclater, P. L., and Shelley, G. E.

1891. Catalogue of the Picariae in the collection of the British Museum. Scansores and Coccyges. Coccyges by G. E. Shelley. Cat. Birds Brit. Mus., 19, xii-484 pp., 13 pls., ante July.

Coccyzus americanus and Geoccocyx affinis from Sonora.

ScorT, W. E. D.

1886. On the avi-fauna of Pinal County, with remarks on some birds of Pima and Gila Counties, Arizona. Auk. 3: 383-389, July.

Colinus ridgwayi in northern Sonora.

Seebohm, H. [and Sharpe, R. B.]

1898-1902. A monograph of the Turdidae, or family of thrushes. . . Edited and completed by R. Bowdler Sharpe. . . . Henry Sotheran \& Co., London), Issued in 13 parts in 2 vols. Vol. 1, xii-337. Vol. 2, ix-250. 149 pls. in 2 vols.

A few Lloyd-taken specimens listed. 
SHARPE, R. B.

1888. Catalogue of the Passeriformes, or perching birds, in the collection of the British Museum. Part 3. Fringillidae. Cat. Birds Brit. Mus., 12, xvi-872 pp., 16 pls., text figs., ante July.

Apparently only Peucaea arizonae is mentioned.

1896. Catalogue of the Limicolae in the collection of the British Museum. Cat. Birds Brit. Mus., 24, xii-796, 7 pls., 19 text figs., ante October 21.

Occasional shore-birds listed.

1899-1909. A hand-list of the genera and species of birds. (Taylor and Francis, London), 5 vols. 1 (1899), xxi-303; 2 (1900), xv-312; 3 (1901), xii367 ; 4 (1903), xii-391; s (1909), xx-694.

Many ascriptions to Sonora, at least one erroneous,-Otophanes mcleodii.

Sharpe, R. B., and Ogilvie-Grant, W. R.

1892. Catalogue of the Picariae in the collection of the British Museum. Coraciae (contin.) and Halcyones, by R. Bowdler Sharpe. Bucerotes and Trogones, by W. R. Ogilvie-Grant. Cat. Birds Brit. Mus., 17, xii-524 pp., 17 pls., text figs., ante October.

Occasional Salvin-Godman specimens listed.

1898. Catalogue of the Plataleae, Herodiones, Steganopodes, Pygopodes, Alcae, and Impennes in the collection of the British Museum. Cat. Birds. Brit. Mus., 26, xvii-687 pp., 8 pls., October.

The Pygopodes section (by Ogilvie-Grant) contains citation of Podiceps californicus from Guaymas.

Sharpe, R. B., and WyatT, C. W.

1885-1894. A monograph of the Hirundinidae or family of swallows. (Taylor and Francis, London), 2 vols. issued in 20 parts. Vol. 1, 356 pp., 54 pls., 11 maps, text figs.; Vol. 2, viii- [357]-673 pp., 50 pls., 5 maps, 1 text fig.

The Tree Swallow at Guaymas.

SHEFFLER, W. J.

1931a. Aviculturists Seek the Masked Bob-white (Colinus ridgwayi) in Mexico. Aviculture, ser. 2, 3: 135-138, June.

Narrative account of various species observed in northern Sonora.

1931b. Aviculturists Seek the Masked Quail. Aviculture, ser. 2, 3: 164-167, July.

Continuation of the above.

Sheffler, W. J., and van Rossem, A. J.

1944. Nesting of the Laughing Falcon. Auk, 61: 140-142, January 22.

At Guirocoba. Seemingly the first account of the nesting of this species.

SHElley, G. E. [see Scläter, P. L., and]

SHIELDS, A. M.

1899. Nesting of the Fulvous Tree Duck. Bull. Cooper Orn. Club, 1: 9-11, January.

Cites Grayson [Lawrence, 1874] on occurrence in Sonora. 
SHUFELDT, R. W.

1889. Notes on the Brewster's and the Blue-footed Gannet. Auk, 6: 87, January.

On specimens from San Pedro Mártir Island.

Simon, E.

1921. Histoire naturelle des Trochilidae (Synopsis et Catalogue). (Encyclopédie Roret, L. Mulo, Libraire-Editeur, Paris), vi-416 pp., ante February 22.

Descriptions, synonymies, etc., of all Sonora species known to date. There are a few direct ascriptions.

SINGER, D. J.

1914. Big game fields of America north and south. (George H. Doran Company, New York), 368 pp., 74 ills.

Chapters 6 and 10 contain good accounts of the northeastern Sierra Madre, with several illustrations. Ornithological matter is limited and of interest chiefly because of the accounts of the abundance of turkeys and Mearns Quail.

SLEVIN, J. R.

1923. Expedition of the California Academy of Sciences to the Gulf of California in 1921. General account. Proc. Calif. Acad. Sci., 4th ser., 12: 55-72, map, June 2.

Itinerary with short descriptions of localities. Birds, mentioned casually, are reported by Mailliard, 1923.

STEPHENS, $\mathrm{F}$.

1885. Notes of an ornithological trip in Arizona and Sonora. Auk, 2: 225231, July.

Narrative account of some 25 species observed or collected, including the type of the Masked Bob-white.

StONe, W., and RhOADS, S. N.

1905. On a collection of birds and mammals from the Colorado delta, Lower California. Proc. Acad. Nat. Sci. Phila., 57: 676-690, December 6. Some species seen or collected at "Colony" [Colonia Lerdo] and other points on the Sonora side of the river. Others are indeterminable as regards locality. Some of Rhoads' sight records verge on the impossible.

STREETS, T. H.

1877. Contributions to the natural history of the Hawaiian and Fanning Islands and Lower California, made in connection with the United States North Pacific surveying expedition, 1873-75. Bull. U. S. Nat. Mus., 7, 172 pp.

In the ornithological section, Passerculus savanna and Sula leucogaster are recorded from Sonora localities.

StresemanN, E.

1922. [Untitled note under "Kurtze Mitteilungen"]. Ornithologische Monatsberichte, 30: 88, July.

Chionophilos alpestris dwighti proposed as a substitute name for Otocoris alpestris pallida Dwight (preoccupied). 
Sutton, G. M., and Burleigh, T. D.

1940. A new tufted flycatcher from Hidalgo. Wilson Bull., 52: 30-31 March 28.

Sonora specimens of Mitrephanes phaeocercus tenuirostris compared.

Sutron, G. M., and Phillips, A. R.

1942. June bird life of the Papago Indian reservation, Arizona. Condor, 44: 57-65, March 16.

Certain distributional aspects of this section of the boundary. Some Arizona records of Numenius americanus are shown to pertain to Sonora.

Sutron, G. M., and Van Tyne, J. [see Van Tyne, J., and]

SWANN, H. K.

1922. A synopsis of the Accipitres (Diurnal Birds of Prey). Second edition. (Wheldon and Wesley, Ltd., London), viii-233- [1] pp. [in 4 parts, between Sept. 28, 1921 and May 20, 1922].

Endorses validity of Geranospizias caerulescens livens (p. [1]).

1924-1930. A monograph of the birds of prey (order Accipitres). (Wheldon and Wesley, Ltd., London), Vol. 1, ix-487-lxvii pp., 33 col. pls. [in 9 parts; parts 8 and 9 edited by $A$. Wetmore].

Descriptions and synonymies of all species known to date. There are a few direct references to Sonora, all, however, previously published.

SWARTH, H. S.

1904. The Status of the Southern California Cactus Wren. Condor, 6: 17-19, January.

Northern Sonora specimens mentioned without conclusions as to systematic status.

1914. A distributional list of the birds of Arizona. (Cooper Ornithological Club, Hollywood, California), Pacific Coàst Avifauna No. 10, 133 pp., map.

The distributions of many forms along the Arizona-Sonora boundary are considered, although there is no direct ascription to the latter State.

1920. [Review of Oberholser's] A revision of the subspecies of Passerculus rostratus (Cassin). Condor, 22: 81-84, March 22.

Including remarks on the presumed breeding and winter range in Sonora.

TAYLOR, A. S.

1859. The Queleli, a rare bird of Sonora. San Francisco Herald, April [original not seen; title from Coues, 1874].

This is more appropriately an item for Couesiana' than for the present bibliography, for Coues credulity in accepting it as possibly descriptive of the "vultures" seen by him in Arizona is decidedly out of character. Queleli is the name for the Caracara throughout Sonora and, making due allowances for third-hand native accounts and newspaper embellishments, the description may be tentatively so identified. 
Thayer, J. E., and BANGs, O.

1906. Breeding birds of the Sierra de Antonez, north central Sonora. Proc. Biol. Soc. Wash., 19: 17-22, February 26.

Nominal list of 67 species from Opodepe (in the San Miguel River valley) and La Chumata Mine. There is occasional systematic criticism and one new race, Psaltriparus plumbeus cecaumenorum, is described from the latter locality.

1907. Birds collected by W. W. Brown, Jr., on Cerros, San Benito and Natividad Islands in the spring of 1906, with notes on the biota of the islands. Condor, 9: 77-81, May.

Critical comment on the status of Corvus corax in Sonora.

1909. Description of a new subspecies of the snowy heron. Proc. New England Zoöl. Club, 4: 39-41, April 29.

A specimen from Guaymas is referred to Egretla candidissima brewsteri.

TODD, W. E. C.

1913. A revision of the genus Chaemepelia. Ann. Carnegie Mus., 8: 507. 603, May 8.

Critical remarks on Sonora specimens of Chaemepelia passerina pallescens.

1929. A revision of the wood-warbler genus Basileuterus and its allies. Proc.

U. S. Nat. Mus., 74: 1-95.

Idiotes rufitrons caudatus cited from Sonora localities.

TOWNSEND, C. H.

1890. Birds from the coasts of western North America, and adjacent islands, collected in 1888-89, with descriptions of new species. Proc. U. S. Nat. Mus., 13: 131-142, September 9.

Cites several species from the coast of Sonora, one of which, Oto. coris alpestris pallida is described as new from "near mouth of Rio Colorado."

1911. [Letter from]. Auk, 28: 389-391, July.

Summary of zoological work on the "Albatross" expedition of 1911, with mention of bird collections made on San Estéban and Tiburón Islands.

1916. Voyage of the 'Albatross' to the Gulf of California in 1911. Bull. Amer. Mus. Nat. Hist., 35: 399-476, 45 ills., map, August 2.

Itinerary and rather informal account, including descriptions and photographs of Sonora stations. Birds are reported formally in 1923.

1923. Birds collected in Lower California. Bull. Amer. Mus. Nat. Hist., 48: 1-25, 1 pl., map, March 9.

Includes birds collected or observed at San Estéban, San Pedro Mártir, and Tiburón Islands, and Guaymas. Contains the original description (with colored plate) of Pipilo fuscus jamesi from Tiburón Island.

Twomey, A. C.

1942. Art. xvii. The birds of the Uinta Basin, Utah. Ann. Carnegie Mus., 28: $341-490$, map, January 19.

Comparison of Utah and Sonora specimens of Aëronautes saxatalis saxatalis ( $\mathrm{p} .403$ ). 
Van Dyke, T. S. [see Sanford, L. C., Bishop, L. B., and; Sandys, E., and]

van Rossem, A. J. [see also Dickey, D. R., and; Sheffler, W. J., and]

1926a. The Craveri murrelet in California. Condor, 28: 80-83, fig., March 15. Also recorded from George and Tiburón Islands, with description of downy young from first-named locality.

1926b. The California forms of Agelaius phoeniceus (Linnaeus). Condor, 28: 215-230, 5 ills., incl. 2 maps, September 21.

The coastal plain of Sonora included in the range of $A$. $p$. sonoriensis.

1927. A New Race of Sclater Oriole. Condor, 19: 75-76, January 15.

Cites Sonora specimens of Icterus pustulatus.

1930a. A new race of gilded flicker from Sonora. Trans. San Diego Soc. Nat. Hist., 6: 171-172, July 12.

Colaptes chrysoides tenebrosus, here described as new, listed from several points in southern Sonora in addition to [Ciudad] Obregón, the type locality.

1930b. The Sonora races of Camptostoma and Platypsaris. Proc. Biol. Soc. Wash., 43: 129-132, July 18.

Considers Campiostoma imberbe ridgwayi a valid race. Platypsaris aglaiae richmondi described as new with type locality "Saric."

1930c. Two new subspecies of birds from Sonora. Trans. San Diego Soc. Nat. Hist., 6: 197-198, August 30.

Columba flavirostris restricta, type locality Tecoripa, and Myiozetetes similis primulus, type locality Tesia, described as new.

1930d. The races of Auriparus flaviceps (Sundevall). Trans. San Diego Soc. Nat. Hist., 6: 199-202, August 30.

Auriparus flaviceps fraterculus described as new with the type locality Chinobampo.

1930e. New Sonora races of Toxostoma and Pheugopedius. Trans. San Diego Soc. Nat. Hist., 6: 207-208, September 30.

Toxostoma curvirostre insularum from San Estéban Island, and Pheugopedius felix sonorae from Guirocoba.

1930f. Some geographic variations in Piaya cayana. Trans. San Diego Soc. Nat. Hist., 6: 209-210, September 30.

Piaya cayana extima described as new from Guirocoba.

1930g. Critical notes on some yellowthroats of the Pacific southwest. Condor, 32: 297-300, map, November 22.

Including manner of occurrence of Geothlypis trichas modesta and Geotblypis trichas chryseola in Sonora, the latter described as new from "Saric" [= Rancho La Arizona ].

1930h. A Northwestern Race of the Mexican Goshawk. Condor, 32: 303-304, November 22.

Original description of Asturina plagiata maxima; type locality San Javier.

1930i. Four new birds from northwestern Mexico. Trans. San Diego Soc. Nat. Hist., 6: 213-226, November 28.

Including original descriptions of Passerculus sandwichensis atratus with type locality Tóbari Bay, and Amphispiza bilineata cana from San Estéban Island. 
1930j. A new least bittern from Sonora. Trans. San Diego Soc. Nat. Hist., 6: 227-228, November 28. Ixobrychus exilis pullus described as new with type locality Tóbari Bay. Sonora records of Ixobrychus exilis hesperis are also cited.

1931a. Concerning some Polioptilae of the west coast of Middle America. Auk, 48: 33-39, text fig., January 4.

Considers Polioptila nigriceps restricta a valid race.

1931b. Concerning some Western Races of Polioptila melanura. Condor, 33: 35-36, January 15. Polioptila melanura lucida described as new with type locality 10 miles north of Guaymas.

1931c. Report on a collection of land birds from Sonora, Mexico. Trans. San Diego Soc. Nat. Hist., 6: 237-304, map, April 30.

254 species and subspecies listed, frequently with systematic or distributional comment.

1932. The avifauna of Tiburón Island, Sonora, Mexico, with descriptions of four new races. Trans. San Diego Soc. Nat. Hist., 7: 119-150, 2 pls., map, July 28.

Faunal relationships considered. An annotated list of 82 species known to occur on the island, including original descriptions of Lophort)x gambelii pembertoni, Heleodytes brunneicapillus seri, Polioptila melanura curtata, and Richmondena cardinalis townsendi.

1933a. A northern race of Melozone rubricatum (Cabanis). Trans. San Diego Diego Soc. Nat. Hist., 7: 283-284, March 31.

Original description of Melozone rubricatum grisior with Hacienda de San Rafael the type locality.

1933b. Records of some Birds New to the Mexican State of Sonora. Condor, 35: 198-200, September 15.

13 species so reported and incidental mention made of others.

1934a. Notes on some types of North American birds. Trans. San Diego Soc. Nat. Hist., 7: 347-362, pl., May 31.

Sonora is included in the ranges of Pyrocephalus rubinus flammeus, Tangavius aeneus milleri, and Pyrrbuloxia sinuata fulvescens, here described as new from extralimital localities.

1934b. A northwestern race of the varied bunting. Trans. San Diego Soc. Nat. Hist., 7: 369-370, May 31.

Passerina versicolor dickeyae described as new; type locality Chinobampo.

1934c. Notes on some races of Ceophloeus lineatus (Linneaus). Trans. San Diego Soc. Nat. Hist., 8: 9-12, August 10.

Original description of Ceophloeus lineatus obsoletus from Alamos.

1934d. Critical notes on Middle American birds. Bull. Mus. Comp. Zoöl., 77: 387-490, December 29.

Three separate papers printed under one title, the sub-titles being: A. Notes on some species and subspecies of Guatemala birds; B. Notes on some types of Mexican and Central American birds; C. A systematic report on the Brewster collection of Mexican birds. Pagination is continuous. 26 new races are described. 
Part B includes original description of Centurus uropygialis fuscescens from Chinobampo; also change of specific name of the Ground Sparrow, Melozone. Part $\mathrm{C}$ is based entirely on the collections made by Cahoon, Frazar, and McLeod in Sonora and Chihuahua. New races described from Sonora, together with their type localities, are as follows: Ortalis uagleri griseiceps (Álamos), Anthoscenus constantii surdur (Álamos), Trogon ambiguus canescens (San Javier), Turdur rufopulliatus grisior (Guirocoba), Vireo hypochryseus nitidus (Hacienda de San Rafael), Aimophila quinquestriata septentrionalis (Hacienda de San Rafael), Aimophila ruficeps simulans (Mina Abundancia ).

1935a. The mangrove warbler of northwestern Mexico. Trans. San Diego Soc. Nat. Hist., 8: 67-68, August 24.

Dendroica erithachorides rhizophorae: type locality, Tóbari Bay.

1935b. Notes on the forms of Spizella atrogularis. Condor, 37: 282-284, November 15.

Cites Spizella atrogularis evura from Oposura.

1936a. The Bush-tit of the Southern Great Basin. Auk, 53: 85-86, January 8 .

Including comment on the type series of Psaltriparus minimus cecaumenorum.

1936b. Description of a race of Myiarchus cinerascens from El Salvador. Trans. San Diego Soc. Nat. Hist., 8: 115-118, March 12.

Integradation of Myiarchus cinerascens and Myiarchus inquietus in Sonora.

1936c. Birds of the Charleston Mountains, Nevada. (Cooper Ornithological Club, Berkeley, California), Pacific Coast Avifauna No. 24, 65 pp., 13 ills., May 1.

Critical comment on Sonora specimens of Bush-tit, Robin, Meadowlark, and Broad-tailed Hummingbird.

1936d. Notes on birds in relation to the faunal areas of south-central Arizona. Trans. San Diego) Soc. Nat. Hist., 8: 121-148, 2 pls., May 29. Distribution of certain races along the Arizona-Sonora boundary.

1937a. Concerning the Name of the Sonora House Finch. Condor, 39: 38, January.

Controversial: sonoriensis versus rhodopnus.

1937b. A race of the Derby flycatcher from northwestern Mexico. Proc. Biol. Soc. Wash., 50: 25-26, February 23.

Pitangur sulfuratus [sic] palliatus described; type locality, Álamos.

1937c. The ferruginous pigmy owl of northwestern Mexico and Arizona. Proc. Biol. Soc. Wash., 50: 27-28, February 23.

Original description of Glaucidium brasilianum cactorum, the type locality of which is between Guaymas and Empalme.

1938a. The Groove-billed Ani of Lower California and Northwestern Mexico. Condor, 40: 91.

The range of Crotophaga sulcirostris pallidula includes Sonora.

1938b. A Mexican race of the goshawk (Accipiter gentilis [Linneaeus]). Proc. Biol. Soc. Wash., 51: 99-100, May 19.

A specimen of Accipiter gentilis apache, here described from southern Arizona, is cited from Yécora. 
1938c. [. . . descriptions of twenty-one new races of Fringillidae and Icteridae from Mexico and Guatemala .... B. Bull. Brit. Orn. Club, 58: 124-138, July 13.

Sonora is cited as in the ranges of several of these.

1938d. Notes on some Mexican and Central American Wrens of the Genera Heleodyes, Troglodytes, and Nannorchilus; and four new races. Bull. Brit. Orn. Club, 59: 10-15, November.

Comparison of Sonora specimens of Troglodytes brunneicollis cabooni.

1938e. Descriptions of three new birds from western Mexico. Trans. San Diego Soc. Nat. Hist., 9: 9-12, November 21.

Sonora is included in the range of Herpetotheres cachinnans excubitor, here newly described from Jalisco.

1938f. A Colorado Desert race of the summer tanager. Trans. San Diego Soc. Nat. Hist., 9: 13-14, November 21.

Piranga rubra cooperi determined to be the race in eastern Sonora.

1939a. Four new races of Sittidae and Certhidae from Mexico. Proc. Biol. Soc. Wash., 52: 3-6, February 4.

Siitta carolinensis umbrosa, described from southern Chihuahua, is cited from Mina Abundancia.

1939b. A race of the Rivoli humming bird from Arizona and northwestern Mexico. Proc. Biol. Soc. Wash., 52: 7-8, February 4.

Sonora included in the range of Eugenes fulgens aureoviridis, here described from Arizona.

1939c. A new race of the sharp-shinned hawk from Mexico. Auk, 56: 127-128, pl., January 19.

A specimen of Accipiter striatus suttoni, here described from Nuevo Leon, is listed from Tesia.

1939d. A race of the yellow-breasted chat from the tropical zone of southern Sonora. Wilson Bull., 51: 156, September 28.

Icteria virens tropicalis; type locality, Tesia.

1939e. A new race of the mangrove swallow from northwestern Mexico. Proc. Biol. Soc. Wash., 52: 155-156, October 11. Iridoprocne albilinea rhizophorae; type locality, Tóbari Bay.

1939f. Some new Races of Birds from Mexico. Ann. and Mag. Nat. Hist., ser. 11, 4: 439-443, October.

Brachyramphus craveri believed to be a race of Brachyramphus bypoleucus.

1940. Notes on some North American birds of the genera Myiodynastes, Pitangus, and Myiochanes. Trans. San Diego Soc. Nat. Hist., 9: 79-86, April 30.

Concludes that the subspecific name of the Sulphur-bellied Flycatcher of Sonora should be swarthi, and that Pitangus sulphuratus palliatus is a valid race. Also includes Sonora in the range of Myiochanes virens placens, here newly described from southern Arizona.

1941a. A Race of the Poor-will from Sonora. Condor, 43: 247, September 18. The range of Phalaenoptilus nuttallii adustus, described from southern Arizona, includes part of western and central Sonora. 
1941b. The Thick-billed Kingbird of Northern Sonora. Condor, 43: 249-250, September 18.

Tyrannus crassirostris sequestratus described from Rancho La Arizona.

1941c. A race of the blue-hooded euphonia from Sonora. Occ. Papers Mus. Zool. Univ. Mich., 449: 1-2, October 9.

Tanagra elegantissima viscivora; type locality, San Francisco Cañon.

1941d. Further Notes on Some Southwestern Yellowthroats. Condor, 43: 291-292, November 17.

Distribution of races in Sonora. Geothlypis trichas riparia described from Tesia.

1942a. A western race of the tooth-billed tanager. Auk, 59: 87-89, January 10. Piranga flava zimmeri; type locality, Guirocoba.

1942b. Four new woodpeckers from the western United States and Mexico. Condor, 44: 22-26, 2 ills., January 15.

Distributions of the races of Centurus uropygialis and Dryobates scalaris which occur in Sonora. Original descriptions of Centurus uropy. gialis tiburonensis from Tiburón Island, and of $C$. u. albescens and Dryobates scalaris yumanensis from southeastern California.

1942c. Notes on some Mexican and Californian birds, with descriptions of six undescribed races. Trans. San Diego Soc. Nat. Hist., 9: 377-384, February 17.

Original descriptions of Cyrtonyx montezumae morio from Guirocoba, Calocitta colliei arguta from Chinobampo, Toxostoma bendirei can. didum from Guaymas, and Toxostoma bendirei rubricatum from Tecoripa. Tanagra elegantissima rileyi is provided as a substitute name for T. e. viscivora van Rossem, preoccupied. Sonora is included in the ranges Parabuteo unicinctus superior and Agelaius phoeniceus thermophilus, both described from southeastern California.

1942d. The Lower California Nighthawk Not a Recognisable Race. Condor, 44: 73-74, March 16.

Chordeiles acutipennis micromeris cited from localities in southern Sonora.

1942e. The Systematic Position of Ortalis wagleri Gray. Condor, 44: 77-78, fig., March 16.

Peneloides provided as a subgeneric name.

1942f. Fuertes Red-tailed Hawk in northern Mexico and Arizona. Auk, 59: 450 , July 1.

Cites a specimen of Buteo jamaicensis fuertesi from Hermosillo.

1942g. Range Extensions of Three Lower California Birds. Condor, 44: 184185, July 15.

Dryobates scalaris lucasanus, Myiarchus cinerascens pertinax, and Auriparus flaviceps flaviceps on San Estéban Island.

1942h. A new race of the rusty sparrow from north central Sonora, Mexico. Trans. San Diego Soc. Nat. Hist., 9: 435-436, October 1.

Aimophila rufescens antonensis; type locality La Chumata Mine in the Sierra de San Antonio. 
1942i The name of the Mexican Tiger Heron. Auk, 59: 572, October 10. The Sonora race becomes Heterornus mexicanus fremitus.

van Rossem, A. J., and Hachisuka, the Marquess.

1937a. A further report on birds from Sonora, Mexico, with descriptions of two new races. Trans. San Diego Soc. Nat. Hist., 8: 321-336, June 15. Annotated list of 78 species of water birds. Included are original descriptions of Colymbus dominicus bangsi (from Lower California) and Sterna albifrons mexicanus [sic] from Tóbari Bay.

1937b. A northwestern race of the Mexican black hawk. Trans. San Diego Soc. Nat. Hist., 8: 361-362, June 15.

Sonora is included in the range of Buteogallus antbracinus micronyx, here newly described from Arizona.

1937c. A new bat falcon from Sonora. Proc. Biol. Soc. Wash., 50: 107-108, August 7.

Falco albigularis petrophilus; type locality, Guirocoba.

1937d. The blue-gray gnatcatcher of southern Sonora. Proc. Biol. Soc. Wash., 50: 109-110, August 7.

Ranges of Polioptila caerulea amoenissina and Polioptila caerulea gracilis in Sonora, the latter named as new from Rancho Santa Bárbara.

1937e. The yellow-green vireo of northwestern Mexico. Proc. Biol. Soc. Wash., 50: 159-160, September 30.

Vireo olivaceus hypoleucus; type locality, San Francisco Cañon.

1937f. The tiger-bittern of northwestern Mexico. Proc. Biol. Soc. Wash., 50: 161-162, September 30.

Heterocnus cabanist [sic] fremitus; type locality, Guirocoba.

1937g. A new woodpecker of the genus Piculus from Sonora. Proc. Biol. Soc. Wash., 50: 195-196, November 26.

Piculus auricularis sonoriensis; type locality, Rancho Santa Bárbara.

1937h. A northern race of Tityra semifasciata. Proc. Biol. Soc. Wash., 50: 197-198, November 26.

Tityra semifasciata hannumi; type locality, San Francisco Cañon.

1937i. A race of Verreaux's dove from Sonora. Proc. Biol. Soc. Wash., 50; 199-200, November 26.

Leptotila verreauxi santiago; type locality, Guirocoba.

1938a. A new hummingbird of the genus Saucerottia from Sonora, Mexico. Trans. San Diego Soc. Nat. Hist., 8: 407-408, January 18.

Saucerottia florenceae named on a unique specimen from Rancho Santa Bárbara.

1938b. A Race of the Green Kingfisher from Northwestern Mexico. Condor, 40: 227-228, September 15 .

Chloroceryle americana leucosticta; type locality, Rancho La Arizona.

1938c. A new race of the cliff swallow from northwestern Mexico. Trans. San Dicgo Soc. Nat. Hist., 9: 5-6, November 21.

Petrochelidon albifrons minima; type locality, 7 miles east of Alamos.

1938d. A dimorphic subspecies of the bush-tit from northwestern Mexico. Trans. San Diego Soc. Nat. Hist., 9: 7•8, November 21.

Psaltriparus minimus dimorpbicus; type locality, Rancho Santa Bárbara. 
1939a. A northwestern race of the Mexican cormorant. Proc. Biol. Soc. Wash., 52: 9-10, February 4.

Phalacrocorax olivaceus chancho; type locality, Tesia.

1939c. A race of the military macaw from Sonora. Proc. Biol. Soc. Wash., 52: 13-14, February 4.

Ara militaris sheffleri; type locality, Guirocoba.

VAN TYNE, J

1925. An undescribed race of Phainopepla. Occ. Papers Bost. Soc. Nat. Hist., 5: 149-150, May 22.

Sonora is included in the range of Phainopepla nitens lepida, here described from southern California.

VAN Tyne, J., and Sutton, G. M.

1937. The birds of Brewster County, Texas. Univ. Mich., Mus. Zool., Misc. Publ. No. 37, 119 pp., 6 pls., map, August 24.

Petrochelidon pyrrbonola melunoguster recorded as breeding at Pilares.

VORHIES, C. T.

1934. The White-necked Raven, a Change of Status? Condor, 36: 118-119, May 15.

Recorded from between Magdalena and Hermosillo.

1936. Surf Scoter and Caspian Tern in Arizona. Condor, 38: 248-249.

The Royal Tern [Thalasseus maximus] mentioned from Puerto Libertad.

WeBster, J. D.

1943. The downy young of oyster-catchers. Wilson Bull., 55: 40-46, March 23. Description and racial characters of downy young, including Haematopus palliatus frazari of "Sonora." An excellent paper on the taxonomy of this genus.

WetMore, A.

1932. Seeking the smallest feathered creatures. Nat. Geog. Mag., 62: 64-89, 17 ills., July.

Hummingbirds, swifts, and goatsuckers of the United States, only one of which, the Black-chinned Hummingbird, is specifically cited from Sonora.

1939a. Notes on the birds of Tennessee. Proc. U. S. Nat. Mus., 86: 175-243. Critical remarks on the characters and range of Stelgidopteryx ruficollis psammochrous.

1939b. Birds from Clipperton Island collected on the Presidential cruise of 1938. Smithsonian Misc. Coll., 98, No. 22, 1-6 pp., August 11.

Critical review of the Pacific coast races of Sula leucogaster, including brewsteri of the Gulf of California.

1943. The birds of southern Vera Cruz, Mexico. Proc. U. S. Nat. Mus., 93: $215-340,3$ pls., map, May 25.

Critical notes on Colymbus dominicus bangsi, Pitangus sulphuratus palliatus, and Vireo flavoviridis bypoleucus.

1944. A collection of birds from northern Guanacaste [,] Costa Rica. Proc.

U. S. Nat. Mus., 95: 25-80, July. Including critical remarks on Piaya cayana extima and Herpetotheres cachinnans excubitor. 
Williams, C. S.

1944. Migration of the Red-head from the Utah breeding grounds. Auk, 61: 251-259, April 15.

Four Sonora record stations for Nyroca americana marked on the accompanying (p. 255) map.

Woods, R. A.

1931. An Historical and Descriptive Account of the Trip to Mexico. Aviculture, ser. 2, 3: 139-141, June, and 161-163, July.

Narrative account of a trip to northern Sonora, with informal mention of some birds (for which see Sheffler, W. J.).

WyatT, C. W. [see Sharpe, R. B., and]

ZIMMER, J. T.

1929. A study of the tooth-billed red tanager, Piranga riava. Field Mus. Nat. Hist., Zool. Ser., 17: 169-219, map, December 18.

Sonora is included in the range of Piranga flava bepatica, of which the race oreophasma is considered to be a synonym.

1937. Studies of Peruvian birds. No. 28. Amer. Mus. Novit. No. 963, 28 pp., November 18.

Critical comment on the Sonora races of the Sulphur-bellied and Derby Flycatchers.

1941. Studies of Peruvian Birds. No. 39, The Genus Vireo. Amer. Mus. Novit., No. 1127, June 26.

Critical remarks on Vireo olivaceus hypoleucus.

ZIMMER, J. T., and MAYR, E.

1943. New species of birds described from 1938 to 1941. Auk, 60: 249-262, April 5.

Comment (by Zimmer) on the status of Saucerottia florenceae, pp. 252, 261. 


\section{N D E X}

New systematic names and the principal page reference to each are printed in heavy-faced type.

abbreviatus, Buteo 56

abeillei, Icterus 239

aberti, Pipilo 265, 266

acaciarum, Auriparus 176-178

Acanthylis 119

Accipiter 53-55

accipitrinus, Asio 114

Actitis 82

Actrodromas 292

aculeata, Balanosphyra 135

Melanerpes 135

Sitta 181

acuta, Anas 47

Dafla 47

acutipennis, Chordeiles 115

adusta, Eremophila 163

Otocoris 163

adustus, Chionophilos 163

Phalaenoptilus 116, 117

Aechmophorus 29

Aegialites 78

Aegithalus 177

aeneus, Callothrus 235

Tangavius 235

Aëronautes 119

aestuarinus, Cistothorus 183

Telmatodytes 183, 184

aethereus, Phaëthon 31

affinis, Aythya 49

Campylorhynchus 184

Cardinalis 21, 251

Empidonax 296

Fulvigula 49

Geococcyx 106

Nyroca 49

Richmondena 21, 250, 251

Agelaius 243, 244

aglaiae, Hadrostromus 143

Platypsaris 219

agnus, Dryobates 18, 139, 140

Agyrtria 294

Aimophila 21, 267, 273, 274, 278, 299

Ajaia 43

ajaja, Ajaia 43

Platalea 43

alaudinus, Passerculus 268 alba, Crocethia 86

Guara 42

Scolopax 42

Trynga 86

albeola, Anas 50

Bucephala 50

Charitonetta 50

albescens, Centurus 133, 134

Certhia 182

albifrons, Amazona 103

Anser 44

Branta 44

Chrysotis 103

Petrochelidon 165

Psittacus 103

albilinea, Iridoprocne 168

albiloris, Polioptila 206

albiventris, Platypsaris 143

albociliatus, Phalacrocorax 33, 34

albonotatus, Buteo 56

alcyon, Ceryle 128

alexandri, Archilochus 124

Trochilus 124, 125

alleni, Selasphorus 127, 295

alticola, Melospiza 286

Amazilia 18, 121-123

Amazona 17, 103

ambiguus, Trogon 128

americana, Anas 47

Emberiza 257

Fulica 76

Fulvigula 49

Mareca 47

Mergus 51

Mycteria 42

Nyroca 49

Recurvirostra 88

Spiza 257

ammophilus, Polyborus 17, 62

amoena, Emberiza 256

Passerina 256

amoenissima, Polioptila 204, 205

Amphispiza 21, 24, 278, 279, 299

amplonotata, Ciccaba 113

anaethetus, Sterna 293

Anas 44-50 
anatum, Falco 63

anna, Calypte 125

Zephyrites 125

annectens, Junco 281

annexus, Baeolophus 175

Parus 175

Anser 43, 44

anthinus, Passerculus 268, 269

anthonyi, Butorides 36,37

Heleodytes 184

Anthoscenus 18, 124

anthracina, Urbitinga 59

anthracinus, Buteogallus 59

Anthus 209

antonensis, Aimophila 21, 269, 275

Antrostomus 116, 118

aonalaschkae, Turdus 201

apache, Accipiter $\mathbf{5 3}$

Aphelocoma 172-174

aphrasta, Eremophila 296

Otocoris 296

Aphriza 83

aquaticus, Seiurus 226

Aquila 59

aquila, Fregata 35

Ara 17, 101

Aratinga 17, 101

Archilochus 124

arctica, Sialia 204

Ardea 35-41, 74

Arenaria 84

arenaria, Calidris 86

arenicola, Otocoris 164

argentatus, Larus 90

arguta, Calocitta 19, 171

arizela, Geothlypis 227

americanus, Coccyzus 104

Cuculus 104

Numenius 80

Amizilis 121-123, 294

Ammodramus 269, 271, 272

ammolegus, Ammodramus 271

ammophila, Eremophila 163

Otocoris 163

arizonae, Antrostomus 118

Aphelocoma 172

Astragalinus 262

Caprimulgus 118, 119

Cyanocitta 172

Dryobates 140, 141

Dryocopus 140, 141

Peucaea 8, 21, 276, 277

Peucedramus 220
Spinus 262

Spizella 282, 283

Vireo 213

artemisae, Molothrus 235

Asio 113

aspersus, Megascops 108

Otus 108, 109

Astragalinus 261

Astur $\mathbf{5 3}$

Asturina 17, 57

Asyndesmus 135

Athene 111

atrata, Cathartista 52

atratus, Coragyps 52

Passerculus 21, 269, 270

Vultur 52

atricapillus, Astur 53

atricilla, Larus 92

atrogularis, Spizella 284

atronitens, Volatina 260

auduboni, Dendroica 223

Hylocichla 202

Polyborus 62

Sylvia 223

Turdus 202

audubonii, Dendroica 223

Polyborus 62

aura, Cathartes 52

Vultur 52

aurantius, Falco 291

aureoviridis, Eugenes 124

auricollis, Icteria 230

Auriparus 19, 176-178

autumnalis, Anas 45

Dendrocygna 45

Aythya 49

aztecus, Troglodytes 189

azurea, Sialia 202

Baeolophus 175, 297

bairdi, Dryobates 139

Empidonax 160

Heteropygia 292

Melanerpes 135

Thryomanes 189

Thryothorus 189

Tringa 192

Sialia 203

bairdii, Actrodromas 292

Ammodramus 272

Centronyx 272

Emberiza 272

Erolia 292 
Balanosphyra 135

bancrofti, Nyctanassa 40

bangsi, Aimophila 21, 274, 275

Colymbus 28

Basileuterus 20, 233, 234

beecheii, Cissilopha 172

Pica 172

beecheyi, Cissilopha 172

beckhami, Pyrrhuloxia 252

beldingi, Charadrius 79

Pagolla 79

bendirei, Falco 64

Harporhynchus 191

Melospiza 287, 288

Toxostoma 191, 192

bensoni, Callipepla 17, 69, 70

Lophortyx 17, 69, 71

bessophilus, Cyanolaemus 123

Lampornis 123, 295

bewickii, Thriothorus 189

Thryothorus 189

bicolor, Anas, 45

Calamospiza 267

Dendrocygna 45

Hirundo 167

Iridoprocne 167

bidentata, Piranga 249

bilineata, Amphispiza 278

Emberiza 278, 279

bimaculatus, Ammodramus 271

Coturniculus 271

Bombycilla 209

borealis, Buteo 55,56

Fa'co 56

Hylocharis 121

Nuttallornis 155

Tyrannus 155

boschas, Anas 45

Botaurus 41

botteri, Zonotrichia 276

botterii, Aimophila 21, 276-278

Peucaea 276

boucardi, Aimophila 299

Peucaea 276, 299

Zonotrichia 299

brachyptera, Tachycineta 168, 169

Leptoptila 100

Brachyramphus 96

Branta 44

breweri, Spizella 284 brewsteri, Aratinga 17, 101

Dendroica 221

Egretta 39

Empidonax 157

Leucophoyx 39

Sula 16, 33

Vireo 216

Vireosylva 216

brunneicapillus, Campylorhynchus $19,184,185$

Heleodytes 184, 186

Picolaptes 7, 19, 184, 185

Bubo 110

Bucephala 26, 50

bullockii, Icterus 237

Xanthornus 237, 238

Buteo 17, 55-58, 290, 291

Buteogallus 59

Butorides 36

butorides, Ardea 36

cabanisi, Ceryle 129

cachinnans, Falco 61

Gallinula 76

Herpetotheres 61

cactophilus, Dryobates 138-140

cactorum, Glaucidium 111

caerulea, Ardea 38

Florida 38

Loxia 255

Polioptila 204, 205

caerulescens, Ardea 38

Florida $\cdot 38$

Melanotis 197

cafer, Colaptes 130

cahooni, Aimophila 21, 275

Hemiura 190

Troglodytes 19, 189

Calamospiza 267

Calcarius 289

calendula, Corthylio 208

Motacilla 208

Regulus 208, 209

Calidris 86

californica, Saurothera 105

californicus, Colymbus 28

Dytes 28

Geococcyx 105

Icterus 241-243

Larus 91

Pelecanus 32

Podiceps 28 
calliope, Stellula 126

Trochilus 126

Callipepla 17, 66-69, 291

calliphthongus, Turdus 20, 199

Callothrus 235

Calocitta 19, 171

calurus, Buteo 17, 55, 290

Calypte 125

Campephilus 136

Camptostoma 162

Campylorhynchus $19,26,185-186$

cana, Amphispiza 21, 280

canadensis, Aquila 59

Ardea 74

Branta 44

Falco 59

Grus 74

candida, Piranga 21, 249

candidissima, Ardea 39

Egretta 39

candidum, Toxostoma 19, 192

canescens, Empidonax 159

Trogon 18, 128

caniceps, Junco 281, 300

Struthus 281

Capella 85

Caprimulgus 115-118

Carbo 34

Cardellina 232

Cardinalis 21, 250, 251

Carduelis 262, 299

carnivorus, Corax 169

carolina, Porzana 76

carolinense, Nettion 47

carolinensis, Anas 46

Columba 98

Falco 61

Pandion 61

Zenaidura 98

carolinus, Rallus 76

carpalis, Aimophila 274

Haemophila 274

Peucaea 274

Spizella 274

Carpodacus 21, 258-260

Casmerodius 38

caspia, Hydroprogne 93

Cassiculus 234

Cassidix 21, 236

cassini, Haemophila 277

Vireo 214 cassinii, Peucaea 277

Vireo 214

Zonotrichia 277

castaneiceps, Dendroica 221

castaneopectus, Icterus 21, 240

Pendulinus 240

Cathartes $\mathbf{5 2}$

Cathartista 52

Catherpes 19, 190, 191

Catoptrophorus 83

caudatus, Basileuterus 20, 234

Idiotes 234

caurina, Ceryle 128

Megaceryle 128

Streptoceryle 128

cecaumenorum, Psaltriparus 19, 179

cedrorum, Bombycilla 209

celata, Sylvia 216

Vermivora 216, 217

celsum, Toxostoma 193-195

Centronyx 272

Centurus 18, 132-134, 296

Ceophloeus 18, 136

Certhia 182, 297

Ceryle 128, 129

cestulatus, Turdus 202

Chaetura 119

Chaemepelia 100

Chamaepelia 99, 100

chancho, Phalacrocorax 16, 34

chapmani. Herpetotheres 61

Charadrius 77-79, 88

Charitonetta 50

Chaulelasmus 48

Chelidon 167

Chen 43

cheriway, Polyborus 62

chihuahuae, Sitta 182

Chionophilos 19, 162-164

Chlidonias 293

Chloroceryle 18, 129

Chloroenas 97

Chlorura 26, 262

chlorura. Chlorura 262

Fringilla 262

Oberholseria 263

Oreospiza 262

chlorurus, Pipilo 263

Chondestes 272, 273

Chordeiles 114, 115

chrysaëtos, Aquila 59

Falco 59 
chryseola, Geothlypis 20,228 Wilsonia 231

Chrysogenys, Centurus 296 Picus 296

chrysoides, Colaptes 131, 132

Chrysomitris 261, 262

chrysopeplus, Pheucticus 252-254

Chrysotis 103

Ciccaba 113

Cichlopsis 210

Cinclus 297

cineraceus, Corthylio 208

Megascops 107

Otus 107, 108

Regulus 208

cinerascens, Myiarchus 150-153

Tyrannula 150

cinerea, Thryophilus 187

cinereum, Toxostoma 298

cinereus, Harporhynchus 298

Myadestes 20,200

Myiarchus 150

Pheugopedius 187

Thryophilus 19,187

Thryothorus $19,187,188$

cinnamomea, Tringa 82

cinnamomeus, Totanus 82

Circus 60

Cissilopha 172

Cistothorus 183

citreolus, Trogon 295

clarionensis, Corvus 170

clarus, Trogon 295

Clavicola 166

clemenciae, Lampornis 123, 294

Ornismya 294

Clivicola 296

clypeata, Anas 48

Spatula 48

Coccyzus 104

Colaptes 18, 130-132

Colinus 15, 72, 291

collaris, Anas 49

Colaptes 130

Nyroca 49

colliei, Calocitta 171

Columba 17, 96-99

columbarius, Falco 63

Columbigallina 100

Colymbus 27-29

Compsothlypis 20, 219

confinus, Pooecetes 272
Conirostrum 176

conjuncta, Amazilia 18, 121, 122, 294

Uranomitra 121

connectens, Junco 300

conspersus, Catherpes 190, 191

Contopus 26, 155-157

Conurus 101

cooperi, Nuttallornis 115

Piranga 247

cooperii, Accipiter 53

Falco 53

Coragyps 52

coronata, Dendroica 222

Corthylio 208

Corvus 169-171

couesi, Campylorhynchus 184, 185

Heleodytes 184

Junco 300

costae, Calypte 125

Ornismya 7, 125

Coturniculus 271

crassirostris, Tyrannus 148, 219

crassus, Passerculus 268

craveri, Endomychura 96

Uria 96

craverii, Brachyramphus 96

crissale, Toxostoma 196

crissalis, Harporhynchus 196

Toxostoma 196

Crocethia 86

Crotophaga 105

cryptoleucus, Corvus 170

cucullatus, Icterus 242

Cuculus 104

culiacani, Empidonax 160, 161

cunicularia, Strix 112

currucoides, Sialia 203

curtata, Polioptila 20, 207, 208

curtatus, Pipilo 263

curvirostre, Toxostoma 193

curvirostris, Harporhynchus 193

cyanocephalus, Euphagus 236, 237

Psarocolius 236

Scolecophagus 237

Cyanocitta 172-174

Cyanogarrulus 174

Cyanolaemus 123

Cyanomyia 18, 294

cyanoptera, Anas 46

Querquedula 46

cyanopyga, Psittacula 102

cyanopygia, Psittacula 102 
Cyanospiza 257

Cymochorea 30

Cynanthus 18, 120, 294

Cypcelus 119

Cyrtonyx 17, 73

Dafila 47

definitus, Pooecetes 272

deiroleucus, Falco 291

delawarensis, Larus 90

delicata, Capella 85, 86

Gallinago 85

Scolopax 85

deltarhyncha, Guiraca 255, 298

Dendroica 20, 220-225

Dendrocopos 18, 26, 137-141

Dendrocycna 45

Dendrocygna 44,45

derbianus, Pitangus 150

deserticola, Amphispiza 278-280

deserticolus, Falco 65

diademata, Cynocitta 173, 174

diadematus, Cyanogarrulus 174

Dichromanassa 38

dickeyae, Passerina 21, 257

dickeyi, Dichromanassa 38

difficilis, Empidonax 159, 160

diluta, Volatinia 260

dilutus, Pheucticus 252

dimorphicus, Psaltriparus 19, 179, 180

discors, Anas 46

Querquedula 46

domestica, Fringilla 234

domesticus, Passer, 234

dorsale, Toxostoma 196

dorsalis, Junco 299

dorsofasciatus, Phloeoceastes 18, 137

douglasii, Lophortyx 69, 70

Ortyx 70

Dryobates 18, 137-141

Dryocopus 141

dwighti, Chionophilos 19, 164

Dytes 28

Ectopistes 98

effuticius, Melanotis 20, 197

Egretta 39

egretta, Ardea 38

Casmerodius 38

eidos, Parus 175

Penthestes 175 elegans, Buteo 290

Callipepla 70

Centurus 296

Lophortyx 69-71

Melanerpes 296

Ortyx 70

Sterna 95

Thalasseus 95

ellioti. Amazilis 121

Uranomitra 121

Emberiza 256, 257, 262, 269, 283, 286

Empidonax 157-161, 296

Endomychura 96

Eremophila 19, 26, 162-164, 296

eremophilus, Thryomanes 188

Ereunetes 86, 291

Erismatura 50

Erolia 87, 292

Erythrina 258

erythrogaster, Chelidon 167

Hirundo 167

erythrogastra, Hirundo 167

erythrorhynchos, Pelecanus 32

Eugenes 124

Euphagus 236

Euphonia 247

Eupoda 79

Euptilotis 127

Euthlypis 20, 233

evura, Spizella 284

exoubitor, Herpetotheres 61,62

excubitorides, Lanius 211

Extima. Piaya 17, 105

Falco, 53-56, 59-65, 291

fallax, Melospiza 287, 288

Zonotrichia 287

familiaris, Certhia 297

fasciata, Chloroenas 97

Columba 97

familiaris, Carpodacus 258

fedoa, Limosa 80

Scolopax 80

finschi, Amazona 103

Chrysotis 103

flammea, Strix 106, 114, 293

flammeola, Strix 293

flammeolus, Megascops 293

Otus 293

flammeus, Asio 114

Pyrocephalus 145 
flaviceps, Aegithalus 177

Auriparus 176-178

Scolopax 81

flavipes, Totanus 81 Tringa 81

flavirostris, Chloroenas 97 Columba 96

Turdus 199 .

flavoviridis, Vireo 215

Vireosylva 215

florenceae, Amazilia 18, 123

Saucerottia 123

Florida 38

Floricola 124

formicivora, Balanosphyra 135

formicivorus, Melanerpes 135

Picus 135

formosa, Sylvia 226

formosus, Oporornis 226

Forpus 17, 102

forreri, Chrysomitris 261

Spinus 261

forsteri, Sterna 93, 94

fraterculus, Auriparus 19, 176-178

Dendrocopos 141

Dryobates 141

frazari, Haematopus 77

Fregata 35

fremitus, Heterocnus 16, 40

Fringilla 234, 247, 254, 258-260, 262, 267, 285, 286

frontalis, Carpodacus 258-260

Fringilla 258

fuertesi, Buteo 56

fulgens, Eugenes 124

Fulica 76

fulicaria, Tringa 88

fulicarius, Phalaropus 88

Fuligula 49

fulva, Dendrocygna 44

Sialia 202

fulvescens, Pyrrhuloxia 252

fulvipectus, Callipepla 17, 68

Lophortyx 17, 67, 68

fuscescens, Centurus 18, 133, 134

fuscus, Pelecanus 32

Pipilo 265, 266

galbula, Icterus 238

Gallinula 76

gallopavo, Meleagris 74 gambeli, Callipepla 67

Lanius 210, 211

Lophortyx 67, 68

gambelii, Fringilla 285

Lophortyx 66, 68

Zonotrichia 285

gaurauna, Plegadis 42

Scolopax 42

Gavia 27

Gelochelidon 93

Geococcyx 18, 105, 106

Geothlypis 20, 227-229

Geranospiza 17, 60

gilmani, Otus 107, 108

glaucescens, Larus 92

Glaucidium 18, 111

godmani, Euphonia 247

Tanagra 247

gossi, Sula 16, 33

gossii, Sula 33

graciae, Dendroica 225

gracilis, Emberiza 286

Melospiza 286

Polioptila 20, 205, 206

graysoni, Colinus 291

Ortyx 72, 291

grisea, Procellaria 29

griseiceps, Ortalis 17, 65

griseus, Baeolophus 297

Empidonax 159

Puffinus 29

grisior, Melozone 21, 266

Turdus 20, 199

Grus 75

Guara 42

guarauna, Plegadis, 42

Scolopax 42

guatemalae, Tyto 106

Guiraca 253-255, 298

gularis, Campylorhynchus 185, 186

Heleodytes 187

guttata, Hylocichla 200

Muscicapa 200

guttatus, Passerculus 270

Habia 254

hachisukai, Chloroceryle 18, 129

Hadrostromus 143

Haematopus 77

Haemophila 274-277

haliaetus, Falco 61

Pandion 61

Halocyptena 31 
halseii, Dendroica 224

hammondii, Empidonax 158

Tyrannula 158

hannumi, Tityra 18, 143

Harporhynchus 20, 191-196, 298

harrisi, Buteo 58

Parabuteo 58

hastatus, Megascops 109

Otus 109,110

Hedymeles 253

heermanni, Larus 89

Heleodytes 19, 184-187

Heliomaster 18, 124

hellmayri, Empidonax 160

Helminthophaga 217, 218

Helodromas 82

helva, Dendrocygna 44

Hemiura 190

hendersoni, Limnodromus 85

henryi, Chordeiles 115

hepatica, Piranga 248

herodias, Ardea 35

Herpetotheres 61

hesperia, Progne 164, 165

hesperis, Corvus 170

Ixobrychus 41

hesperophilus, Astragalinus 261

Spinus 261, 262

Heterocnus 16, 40

Heteropygia 292

Heteroscelus 83

hiaticula, Tringa 77

Himantopus 88

Hirundo 165-168, 296

hoactli, Ardea 40

Nycticorax 40

holochlora, Aratinga 101

hoopesi, Sturnella 245

hooveri, Dendroica 222

Horizopus 156

hudsonicus, Circus 60

Numenius 79, 80

hudsonius, Circus 60

Falco 60

hueyi, Phalaenoptilus 117

Hydranassa 39

Hydroprogne 93

Hylatomus $18,26,136$

Hylocharis 120, 121

Hylocichla 200-202

hyloscopus, Dryobates 137

hyperborea, Chen 43

hypoboreus, Anser 43 hypoleucus, Vireo 20,215

hypochryseus, Vireo 212

Hypomorphnus 58

hypospodius, Buteo 55

Hypotriorchis 64

hypogaea, Speotyto 112

hypugaea, Speotyto 112

Strix 112

Iache 120

Ibis 43

icastus, Dendrocopos 137

Dryobates 137

Icteria 20, 230

icterocephalus, Xanthocephalus 245

Icterus 21, 234, 237, 238, 240-242, 245

Idiotes 234

igneus, Cardinalis 251

imberbe, Camptostoma 162

immer, Colymbus 27

Gavia 27

immodulatus, Empidonax 160

imparatus, Corvus 171

impedita, Lophortyx 70

imperator, Hydroprogne 93

imperialis, Campephilus 136

Picus 136

inca, Chamaepelia 99

Scardafella 99

incanus, Heteroscelus 83

Scolopax 83

inornata, Symphemia 83

inornatus, Catoptrophorus 83

inquietus, Myiarchus 150, 152

insularum, Toxostoma 20, 193-195

interfusa, Guiraca $254,255,298$

intermedius, Pipilo 21, 265

interpres, Arenaria 84

Tringa 84

Iridoprocne 19, 167, 168

Ixobrychus 17,41

jamaicensis, Anas 50

Erismatura 50

jamesi, Pipilo 15, 21, 264, 265

Junco 281, 299, 300

kriderii, Buteo 56

lachrymosa, Basileuterus 233

Euthlypsis 20, 233

Lampornis 123, 294

lamprocephalus, Auriparus 178

languens, Lophortyx 71 
Lanius 210, 211

Larus 89-92, 292

latirostris, Cynanthus 120 Iache 120

Phaeoptila 120

latisfasciatus, Salpinctes 298 Troglodytes 298

lawrencei, Astragalinus 262 Carduelis 262

Spinus 262

lawrencii, Myiarchus 154

lazula, Guiraca 255

lecontei, Harporhynchus 196

Toxostoma 196

lentiginosa, Ardea 41

Botaurus 41

leocadiae, Anthoscenus 124

Floricola 124

leocardiae, Floricola 124

lepida, Phainopepla 210

Tachycineta 168

Lepidocolaptes 18, 142

Leptotila 17, 100

Leptuas 127

leucansiptila, Eremophila 19, 164

Otocoris 164

leucogaster, Pelecanus 33

Picolaptes 142

leucolaema, Chionophilos 162

Eremophila 162

Otocoris 162

Leucophoyx 39

leucophrys, Zonotrichia 285

leucopolius, Vireo 217

leucoptera, Columba 99

Melopelia 99

leucopterus, Mimus 197

Orpheus 197

leucosticta, Chloroceryle 18, 129

leucotis, Hylocharis 121

Trochilus 121

lewis, Asyndesmus 135

Picus 135

lewisi, Asyndesmus 135

lilianae, Sturnella 245

limicola, Rallus 75

Limnodromus 84,85

Limonites 87

Limosa 80,84

lincolnii, Fringilla 286

Melospiza 286

Passerella 286

lineatus, Buteo 290 livens, Geranospiza 17, 60

Larus 91

lloydi, Psaltriparus 179, 180

lobata, Tringa 89

lobatus, Lobipes 89

Lobipes 89

loculator, Tantalus 42

longicauda, Icteria $\mathbf{2 3 0}$

longirostris, Agelaius 244

Numenius 80

Loomelania 30

Lophophanes 175

Lophortyx 17, 66-71

Loxia 255

lucasanus, Dendrocopos 138, 140

Dryobates 139, 140

Picus 140

luciae, Helminthophaga 218

luciae, Vermivora 218

lucida, Polioptila 20, 113, 207

lucidum, Syrnium 113

ludoviciana, Piranga 248, 249

Tanagra 248

lunifrons, Petrochelidon 165

luteiventris, Myiodynastes 148

lutescens, Helminthophaga 217

Vermivora 217

Macrocercus 101

macrolopha, Cyanocitta 173, 174

macromystax, Antrostomus 118

Caprimulgus 118

macropterus, Chrysomitris 261

Spinus 261

macroura, Columba 98

Zenaidura 98

macularia, Actitis 82

Tringa 82

maculata. Fringilla 254

Zamelodia 254

maculatum, Toxostoma 20, 193-195

maculatus, Harporhynchus 20, 194

Pheucticus 254

mayensis, Bubo 110, 111

magica, Cynanthus 18, 120, 294

Hylocharis 120

magnificens, Fregata 35

magnolia, Dendroica 222

Sylvia 222

Mareca 47

marginella, Zenaidura 98

marginellus, Ectopistes 98 
massena, Cyrtonyx 73

Ortyx 73

mauri, Ereunetes 86, 87, 292

maurii, Ereunetes 87

maxima, Asturina 17, 57

Sterna 94

maximus, Buteo 17, 57

Thalasseus 94

mccownii, Plectrophanes 289

mcleodii, Aimophila 21, 269, 275

Otophanes 293

mearnsi, Colaptes 131, 132

Cyrtonyx 73

Junco 281

Melopelia 98

Zenaida 98, 99

Megaceryle 128

megalonyx, Pipilo 263

Megaquiscalus 236

megarhyncha, Peucaea 21, 275

Megascops 107, 108, 293

melancerus, Bubo 111

melanchima, Geococcyx 18, 106

Melanerpes 132, 134, 135, 296

melania, Cymochorea 30

Loomelania 30

Oceanodroma 30

Procellaria 30

melanicterus, Cassiculus 234

Icterus 234

Melanitta 50

melanocephala, Arenaria 84

Habia 254

Zamelodia 253

melanocephalus, Hedymeles 253, 254

Pheucticus 253

Strepsilas 84

melanocorys, Calamospiza 267

melanogaster, Hirundo 165

Petrochelidon 165

melanoleuca, Scolopax 81

Tringa 81

melanoleucus Aëronautes 119

Totanus 81

melanopogon, Melanerpes $\mathbf{1 3 5}$

Melanotis 20, 197

melanotis, Sitta 181

Turdus 197

melanura, Polioptila 207, 208

Meleagris 73, 74

meliphonus, Catherpes 19, 191

Melopelia 98, 99

Melospiza 286-288, 300
Melozone 21, 266

memorabilis, Dendroica 223

Merganser 51

Mergus 51

merriami, Meleagris 73, 74

merrilli, Melospiza 288, 300

mesembrinus, Bubo 111

mesoleucus, Pipilo 264-266

mesonauta, Phaëthon 31

mexicana, Ara 101

Carduelis 299

Certhia 182, 297

Grus 74

Meleagris 74

Melospiza 288, 300

Peucaea 277

Sialia 203

Sitta 181

Spizella 283

Sterna 94

Sturnella 245

Tigrisoma 40

Tyrannula 151

Vermivora 219

mexicanus, Accipiter 53, 54

Astragalinus 262

Catherpes 191

Charadrius 88

Cinclus 297

Colaptes 130

Corvus 171

Falco 62

Heteroçnus 40

Himantopus 88

Momotus 130

Myiarchus 15, 151, 153

Phalacrocorax 34

Plegadis 42

Pyrocephalus 145, 146

Spinus 299

Sterna 17, 94

Tantalus 42

Thryothorus 191

Micrathene 26, 111

micromeris, Chordeiles 115

micronyx, Buteogallus 59

Micropallas 111

microsoma, Halocyptena 31

microstictus, Icterus 21, 243

militaris, Ara 101

Psittacus 101

milleri, Tangavius 235

Mimus 197 
miniata, Setophaga 233

miniatus, Myioborus 233

minima, Petrochelidon 19, 165, 312

Tyrannula 158

minumus, Empidonax 158

minutilla, Erolia 87

Limonites 87

Pisobia 87

Tringa 87

Mitrephanes 19, 161

modesta, Geothlypis 227-229

Molothrus 235, 236

Momotus 18, 129

montana, Certhia 297

Eupoda 79

Melospiza 287

montanus, Charadrius 79

Junco 300

Oreoscoptes 198

Pipilo 263

Podascocys 79

montezumae, Cyrtonyx 73

Ortyx 73

morcomi, Dendroica 220

morinella, Arenaria 84

Tringa 84

morio, Cyrtonyx 17, 73

Motacilla 203, 208, 220, 231, 232

motacilla, Seiurus 226

Turdus 226

Muscicapa 144, 145, 149, 200, 231, 232

musicus, Contopus 157

Myadestes 20, 199, 200

Mycteria 42

Myiadestes 199

Myiarchus $150-154$

Myioborus 233

Myiochanes . 155-157

Myiodynastes 148,149

Myiozetetes 19, 149

nataliae, Picus 141

Sphyrapicus 141

nebouxii, Sula $16,32,33$

neglecta, Sturnella 246

nelsoni, Cassidix 21, 236

Icterus 240-243

Megaquiscalus 236

Phoeoceastes 137

Scaphidurus 21, 236

Sitta 180,181 neoxenus, Euptilotis 127

Leptuas 127

Trogon 127

Nettion 47

nevadensis, Agelaius 244

Amphispiza 280

Lanius 210, 211

Passerculus 268

Poospiza 280

nigrescens, Dendroica 224

Sylvia 224

nigricans, Sayornis 144

nigriceps, Polioptila 206, 207

nitens, Cichlopsis 210

Phainopepla 210

nitidus, Phalaenoptilus 117

Vireo 20, 212

nivosa, Aegialitis 78

nivosus, Charadrius 78

notabilis, Seiurus 226

notius, Salpinctes 190, 298

notosticta, Aimophila 299

Peucaea 275, 299

nuchalis, Sphryapicus 141

Numenius 79, 80

nuttalli, Antrostomus 116

nuttallii, Caprimulgus 116

Phalaenoptilus 116, 117

Nuttallornis 155

nuttingi, Myiarchus 152,153

Nyctanassa 40

Nycticorax 40

Nyroca- 49

oahuensis, Arenaria 84

Oberholseria 263

oblita, Rynchops 95

obscura, Polioptila 204-206

obscurus, Empidonax 158

Molothrus 235

Sturnus 235

obsoleta, Troglodytes 190

Ceophloeus 18, 136

Hylatomus 18, 136

Salpinctes 190, 298

occidentale, Toxostoma 195

occidentalis, Aechmophorus 29

Coccyzus 104

Dendroica 225

Eremophila 163

Ereunetes 87

Geothlypis 227

Larus 91 
Myadestes 200

Numenius 80

Otocoris 163

Podiceps 29

Sialia 203

Sylvia 225

Tyrannus 147

Oceanodroma 30

Ochthodromus 79

olivascens, Myiarchus 154

onusta, Meleagris 74

opisthomelas, Puffinus 30

Oporornis 226

ordii, Ibis 43

oreophasma, Piranga 248

Oreoscoptes 198

Oreospiza 262

orestera, Vermivora 217

oriantha, Zonotrichia 284, 285

Oriturus 267

ornata, Plectrophanes 289

ornatum, Conirostrum 176

ornatus, Auriparus 176-178

Calcarius 289

Ornismya $7,125,294,295$

Ornithion 162

oromela, Hylocichla 201

Orpheus 197, 198

Ortalis 17, 65

Ortyx 66, 70, 72, 73, 291

Otocoris 15,19, 162-164, 296

Otophanes 293

Otus 107-110, 293

Oxyechus 78

Oxyura 26, 50, 78

pachyrhyncha Rhynchopsitta 101 pachyrhynchus, Macrocercus 101 pacifica, Amphispiza 21, 278, 279

Gavia 27

pacificus, Anthus 209

Bubo 111

Colymbus 27

Troglodytes 298

Pagolla 79

pallescens, Bubo 110

Chaemepelia 100

Chamaepelia 100

Columbigallina 100

palliata, Vermivora 219

palliatus, Junco 282

Oriturus 267

Pitangus 19, 150 pallida, Callipepla 66

Emberiza 283

Forpus 102

Otocoris 15, 19, 164

Psittacula 17, 102

Spizella 283

pallidiventris, Contopus 157

Myiochanes 157

pallidula, Crotophaga 105

pallidus, Forpus 17, 102

palmeri, Harporhynchus 194

palmeri, Toxostoma 193, 194

paludicola, Cistothorus 183

Telmatodytes 183

paluster, Vireo 211

palustris, Quiscalus 236

Pandion 61

papago, Hedymeles 253

parasiticus, Larus 292

Stercorarius 292

parisorum, Icterus 240

parkmanii, Troglodytes 189

Parula 20, 26, 219

Parus 175, 297

parvus, Icterus 237-239

Numenius 80

Passer 234

Passerculus 21, 268-270

Passerella 286

Passerina 21, 256, 257

passerina, Chamaepelia 100

Columbigallina 100

Coturniculus 271

pecoris, Molothrus 236

Pelecanus 32, 33, 35

pembertoni, Lophortyx 17, 67, 68

Pendulinus 240

penicillatus, Carbo 34

Phalacrocorax 34

peninsularis, Falco 65

pensilvanicus, Anthus 209

Penthestes 175

perpallidus, Ammodramus 271

Coturniculus 271

perspicillata, Anas 50

Melanitta 50

pertinax. Myiarchus 151, 153

Petrochelidon 19, 165, 312

petrophilus, Falco 17, 63

Peucaea 8, 21, 274-277, 299

Peucedramus 220

phaeocercus, Mitrephanes 161

Phaeoptila 120, 294 
Phaeopus 80

phaeopus, Numenius 80

Phaëthon 31

Phainopepla 210

phalaena, Falco 64, 65

Tinnunculus 65

Phalaenoptilus 116, 117

Phalacrocorax 16, 33, 34

phalaenoides, Glaucidium 111

phalaenoides, Strix 111

Phalaropus 88

Pheucticus '252-254

Pheugopedius 187

philadelphia Larus 92

Sterna 92

Phloeoceastes 18, 137

Piaya 17, 105

Pica 172

Picolaptes 7, 19, 142, 184, 185

picta, Setophaga 232

Piculus 18, 136

Picus 135, 136, 139-141, 296

pileolata, Motacilla 231

Wilsonia 231

pinicolus, Vireo 214

pinus, Fringilla 260

Spinus 260

Pipilo 15, 21, 263-266

Piranga 21, 247-249

Pisobia 87

Pitangus 19, 150

Pitylus 255

placens, Contopus 156

placens, Myiochanes 156

plagiata, Asturina 57

Plagiospiza 267

Platalea 43

platycercus, Selasphorus 126

Trochilus 126

Platypsaris 18, 143, 219

platypterus, Buteo 291

Sparvius 290

platyrhynchos, Anas 45

Plectrophanes 289

Plegadis 42

plesius, Cistothorus 183

Telmatodytes 183

plumbea, Polioptila 207, 208

Psaltria 178

plumbescens, Baeolophus 297

Parus 297

plumbeus, Psaltriparus 178

Vireo 213
Podascocys 79

Podiceps 28

podiceps, Colymbus 29

Podilymbus 29

Podilymbus 29

polionota, Hylocichla 201

Polioptila 20, 204-208

polioptilus, Catherpes 190, 191

Polyborus 17, 62

pompalis, Tyrannus 19, 147, 148

Pooecetes 272

Poospiza 280

popetue, Caprimulgus 115

Chordeiles 115

Porzana 76

Procellaria 29, 30

pratincola, Strix 106

Tyto 106

preglacialis, Amphispiza 299

primulus, Myiozetetes 19, 149

Progne 164, 165

propinquus, Turdus 198

Psaltria 178

psaltria, Chrysomitris 262

Psaltriparus 19, 178-180

psammochrous, Stelgidopteryx 19, 166

Psarocolius 236

Psittacula 17, 102

Psittacus 101

Puffinus 29, 30

pulchra, Compsothlypis 20, 219

Cyanospiza 257

Parula 20, 219

Passerina 256, 257

pullus, Ixobrychus 17, 41

pulverius, Empidonax 296

pusilla, Muscicapa 231

Tringa 291

Wilsonia 231

pusillus, Empidonax 157

Ereunetes 87, 292

Vireo 213

pustulatus, Icterus 242

pygmaea, Sitta 181, 182

pygmaeus, Empidonax 161

Pyranga 247-249

Pyrocephalus 145

pyrrhonota, Hirundo 165

Petrochelidon 165

Pyrrhuloxia 252

Querquedula 46 
quiescens, Sayornis 145 quinquestriata, Aimophila 273 Quiscalus 236

Rallus 17, 75

Recurvirostra 88

Regulus 208, 209

renominatus, Turdus 199

restricta, Columba 17,96, 97

Polioptila 20, 206, 207

restrictus, Icterus 21, 241, 242, 243

rhizophorae, Dendroica 20, 221

Iridoprocne 19, 168

Rallus 17, 75

rhodocolpus, Carpodacus 259

rhodopnus, Carpodacus 260

Rhynchophanes 289

Rhynchopsitta 101

richardsoni, Falco 64

Horizopus 156

richardsonii, Contopus 155, 156

Falco 64

Myiochanes 155, 156

Tyrannula 155

Richmondena 21, 250, 251

richmondi, Platypsaris 18, 143

ridgwayi, Antrostomus 118

Camptostoma 162

Caprimulgus 118, 119

Colinus 15, 17, 72, 291

Glaucidium 111

Hypomorphnus 58

Ornithion 162

Ortyx 72

Urubitinga 58

Vermivora 218

rileyi, Tanagra 21,246

Riparia 296

riparia, Clivicola 166, 296

Geothlypis 20, 229

Hirundo 296

Riparia 296

rostrata, Emberiza 269

rostratus, Ammodramus 269

Passerculus 267, 270

rothschildi, Fregata 35

ruberrimus, Carpodacus 258-260

rubescens, Anthus 209

rubida, Erismatura 50

Oxyura 50

rubidus, Anas 50

rubiginosa, Dendroica 220

Motacilla 220 rubineus, Pyrocephalus 145

rubinus, Muscicapa 145

rubra, Fringilla 247

Piranga 247

rubricatum, Toxostoma 19, 192

rubrifrons, Cardellina 232

Muscicapa 232

rufa, Tringa 86

rufescens, Dichromanassa 38

rufescentior, Buteo 17, 55

ruficollis, Egretta 39

Hydranassa 39

rufifrons, Basileuterus 234

rufo-palliatus, Turdus 199

rufus, Calidris 86

Selasphorus 127

Trochilus 127

ruticilla, Motacilla 232

Setophaga 232

Rynchops 95

sakhalina, Erolia 87

Scolopax 87

salicaria, Guiraca 255

salicarius, Guiraca 255

Salpinctes 190, 298

saltonis, Melospiza 287, 288

saltuensis, Amazona 17, 103

Chrysotis 103

salvini, Agyrtria 294

Caprimulgus 118

Cyanomyia 18, 294

Uranomitra 294

sancti-lucae, Ardea 36

santiago, Leptotila 17, 100

sasin, Ornismya 295

Selasphorus 295

saturatus, Contopus 155,156

Saucerottia 122, 123

Saurothera 105

saya, Muscicapa 144

Sayornis 144,145

Sayornis 144, 145

saxatalis, Acanthylis 119

Aëronautes 119

Chaetura 119

scapularis, Ceophloeus 136

scalaris, Dendrocopus 138, 139

Dryobates 138

Picus 139

Scaphidurus 21, 236

Scardafella 99

scirpicola, Geothlypis 227-229 
Scolecophagus 237

scolopacea, Limosa 84

scolopaceus, Limnodromus 84,85

Scolopax 42, 80, 81, 83, 85, 87

Scops 107

scotti, Haemophila 276

scottii, Aimophila 269, 275, 276

Peucaea 275

Seiurus 226

Selasphorus 126, 127, 295

semiatra, Muscicapa 144

Sayornis 144

semipalmata, Aegialites 78

semipalmatus, Charadrius 77

septentrionalis, Aimophila 21, 273

Cathartes 52

Ceryle 129

Chloroceryle 129

sequestratus, Tryannus 18, 147

sequoiensis, Hylocichla 201

Turdus 201

seri, Campylorhynchus 19, 185, 186

Heleodytes 19, 186

serrator, Merganser 51

Mergus 51

serripennis, Hirundo 166

Stelgidopteryx 166

Setophaga 232, 233

sheffleri, Ara 17, 101

shufeldti, Junco 281, 300

Sialia 202-204

sialis, Sialia 202

simulans, Aimophila 21, 269, 276

sinaloae, Progne 165

sinaloensis, Dendrocopos 18, 138-140

Otus 108, 109

sinuata, Pyrrhuloxia 252

sinuatus, Corvus 169, 170

Sitta 180-182

slevini, Hylocichla 201

smithsonianus, Larus 90

socorroensis, Buteo 55, 290

solitarius, Helodromas 82

solitudinis, Carpodacus 258

sonorae, Pheugopedius 187

Thryothorus 19, 187, 188

sonorana, Dendroica 20, 221

sonoriensis, Agelaius 243, 244

Carpodacus 21, 258-260

Erythrina 258

Lanius 211

Piculus 18, 136 sordida, Cyanomyia 294

Phaeoptila 294

sordidus, Cynanthus 294

sparverius, Falco 64, 65

Tinnunculus 65

Sparvius 291

Spatula 48

Sphyrapicus 141

spilurus, Thryothorus 189

Spinus 260-262, 299

Spiza 256, 257

Spizella 274, 282-284

squamata. Callipepla 66, 291

squamatus, Ortyx 66, 291

squamulata, Ciccaba 113

Strix 113

squamulatum, Syrnium 113

Squatarola 77

squatarola, Squatarola 77

Tringa 77

Steganopus 89

Stelgidopteryx 19, 166

stellata, Gavia 27

stellatus, Colymbus 27

Stellula 126

stephensi, Vireo 212

Stercorarius 292

Sterna 17, 92-95, 293

strenuus, Psittaeus 102

strepera, Anas 48

Chaulelasmus 48

Strepsilas 84

Streptoceryle 128

striatulus, Accipiter $\mathbf{5 3}$

Astur 53

stridula, Spizella 283

stridulus, Heleodytes 187

strigatus, Chondestes 272

Strix 106, 110-114, 293

Struthus 281

Sturnella 245, 246

Sturnus 235

subarcticus, Bubo 110

subis, Progne 164, 165

Sula 16, 32, 33

sulcirostris, Crotophaga 105

sulfuriventer, Centurus 134

superba, Richmondena 250, 251

superbus, Cardinalis 250

superciliosa Aimophila 267

Plagiospiza 267

superior, Parabuteo 58 
surdus, Anthoscenus 18, 124

Heliomaster 18, 124

surinamensis, Chlidonias 293

Sterna 293

suttoni, Accipiter 55

swainsoni, Buteo 57

Vireo 215

Vireosylva 216

swainsonii, Vireo 215

swarthi, Myiodynastes 148, 149

Sylvia 216, 222-226

Symphemia 83

Syrnium 113

Tachycineta 168,169

Tanagra 21, 230, 246, 247

Tangavius 235

Tantalus 42

tardus, Xiphorhynchus 18, 142

Telmatodytes 183

tenebrosus, Colaptes 18, 131, 132

tenuirostris, Mitrephanes 19, 161

Seiurus 226

tephra, Euthlypis 20, 233

teter, Cathartes 52,53

texensis, Chordeiles 114, 115

Muscicapa 149

Myiozetetes 149

Thalasseus 94, 95

thalassina, Tachycineta 168

thalassinus, Hirundo 168

thermophilus, Agelaius 244

Thriothorus 189

Thryomanes 188

Thryophilus 19, 187

Thryothorus 19, 187, 188, 191

thyroideus, Sphyrapicus 141

tiburonensis, Centurus 18, 133, 134

Tigrisoma 40

Tinnunculus 65

Tityra 18,143

tobata, Tringa 89

tolmiei, Oporornis 226

Sylvia, 226

tomlini, Otus 109, 110

Totanus 81,82

townsendi, Dendroica 224, 225

Oceanodroma 30

Richmondena 21, 250, 251

Sylvia 224

Toxostoma 19, 20, 191-196, 298

treganzai, Ardea 35, 36 trichopsis, Otus 107

Scops 107

tricolor, Steganopus 89

Tringa 77, 81-84, 86-89, 291, 292

trochiloides, Icterus 242,243

Trochilus 121, 124-127

Troglodytes 18, 189, 190, 298

Trogon 18, 127, 128, 295

tropicalis, Icteria 20, 230

tschegrava, Hydroprogne 93

Sterna 93

tuberculifer, Myiarchus 154

Turdus 20, 197-199, 201, 202, 226

Tyrannula $150,151,155,158$

Tyrannus 18, 146-148, 219

Tyto 106

tzitzihoa, Anas 47

umbrosa, Sitta 181

umbrosus, Lepidocolaptes 18, 142

Uranomitra 121, 294

Urbitinga 59

Uria 96

uropygialis, Centurus 132-134

Melanerpes 132-134

Urubitinga 58

ustulata, Hylocichla 202

vanrossemi, Gelochelidon 93

Momotus 18, 129

vauxi, Chaetura 119

Cypcelus 119

velox, Accipiter 54

Falco 54

Vermivora 216-218

versicolor, Cyanospiza 257

Passerina 256

verticalis, Amazilis 121

Trochilus 121

Tyrannus 147

vicinior, Myiodynastes 148

Vireo 213

vinaceus, Megascops 109

Otus 109

viola, Amazilia 122

Saucerottia 122

violiceps, Uranomitra 294

Vireo, 20, 211-216

Vireosylva 212, 215, 216

virescens, Ardea 37

Butorides 37

virgata, Aphriza 83

virgata, Tringa 83 
virginiae, Helminthophaga 218

Vermivora 218

virginiana, Strix 110

virginianus, Bubo 110

Rallus 75

virginis, Melospiza 287, 288

viscivora, Tanagra 21, 246

vociferus, Aegialitis 78

Charadrius 78

Oxyechus 78

Tyrannus 146

Volatinia 260

Vultur 52

wagleri, Icterus 240

Ortalida 65

Ortalis 65

whitneyi, Micrathene 111

Micropallas 111

Wilsonia 231

wilsonianus, Otus 113

wilsonius, Ochthodromus 79

wollweberi, Aphelocoma 173, 174

Lophophanes 175 woodhouseii, Aphelocoma 172, 174

Cyanocitta 172

woodi, Amazona 17, 103

wrighti, Empidonax 158

wrightii, Empidonax 158

Xanthocephalus 245

xanthocephalus, Icterus $\mathbf{2 4 5}$

Xanthocephalus 245

Xanthornus 237, 238

xantusii, Melozone 266

Xiphorhynchus 18, 142

yumanensis, Dendrocopos, 138, 139

Dryobates 139

Zamelodia 253, 254

zapolia, Oberholseria 263

Zenaida 98

Zenaidura 98, 99

Zephyrites 125

zetarius, Rallus 75

zimmeri, Piranga 21, 248

Zonotrichia 276, 277, 284, 299 


\section{ORNITHOLOGICAL LITERATURE}

A Distribltional Survey of the Birds of Sonora, Mexico. By A J van Rossem. Louisiana State University Museum of Zoology Occasional Paper No. 21, October 25, 1945: 379 pp., 26 maps. $\$ 3.50$

The publication of this report is an important milestone in the ornithology of Middle America. For the first time, the bird life of a Mexican mainland State is thoroughly reviewed, with discussion of the local status, migration, and breeding localities of each form. Those interested in the birds of the southwestern United States will find in the book information on the excellent collections and notes made by Mearns and Holzner along the Mexican border between 1892 and 1894. Van Rossem has examined and critically identified specimens that are scattered far and wide, and he has cleared up the confusion of the Sonora-Chihuahua boundary.

After a brief foreword and historical résumé, van Rossem lists the 69 persons known to have done field work on Sonoran birds, with comments on their itineraries and the present locations of their specimens. He then lists in systematic order the 111 names originally based on Sonoran specimens and gives the present allocation of each, the type locality of each form, and the collectors of the type specimens. The avifaunal areas of Sonora are shown in a colored map and described in a short chapter. A distributional synopsis is given for each subspecies of Sonoran bird, consisting of the scientific and English name; a synonymy with the bibliographical citations for the original description and all Sonora references in the literature, a brief statement of the bird's status and the dates of its occurrence. There are 25 helpful maps which show in detail the distribution of 7 genera and of 25 additional species The footnotes (occasionally lengthy) are mainly on taxonomic matters and include descriptions of two new orioles, Icterus bullockii parvus (p. 238) and I. cucullatus restrictus (p. 242). In all, 407 species, o: 533 forms (given as 532 on page 26), are recognized for Sonora. A list of 37 "species of unverified occurrence" follows, and the work closes with a useful gazetteer. a full bibliography, and an index of scientific names. The book is well printed on good paper.

Though it covers all data available to 1944 , this is decidedly a preliminary report, and the author expresses the hope that it will stimulate new work. Indeed, before van Rossem began this study in 1930, aside from such general works as those by Ridgway or Salvin and Godman, only eight papers of any importance had appeared concerning the birds of Sonora. Most of these were mere lists of names or short. unreliable accounts of birds seen; none of them treated the interesting country inland and south of Guaymas. Van Rossem, whose field work and extensive museum researches had already added 162 forms to the Sonoran list, here adds 32 more Evidence of how much work is still needed in the Sonoran field is the fact that several species (particularly geese and shore birds), recorded only once, were then recorded in numbers, while several fringillids (Evening Grosbeak, Pale Goldfinch, Crossbill, and such juncos as the Slate-colored, Cassiar, and Thurber) that occur regularly in southern Arizona have not been recorded for Sonora at all

Taxonomically, the International Code is followed, and several nomenclatural innovations result. Further, the genus Hedymeles is merged with Pheucticus; Myiarchus cinerascens mexicanus and Icterus cucullatus nelsoni are revived; and a number of proposed, or even accepted, races (e g. Lophortyx douglasii languens, Otus guatemalae tomlini, Dendrocopos scalaris agnus, Empidonax difficilis immodulatus, Vireo gilvus leucopolius, Dendroica nigrescens halseii, Aimophila carpalis bangsi, Melospzza melodia bendirei) are considered synonyms. On the other hand, a hummingbird (Amazilia florenceae) is recognized, though known only from a 
single skin, and two races (Aratinga holochlora brewsteri, Empidonax difficilis culiacani) are recognized although their breeding range is unknown Myiarchus nuttingi and cinerascens are considered distinct species, though van Rossem admits "hybridization on a mass scale." The ranges of several races (Ardea herodzas sancti-lucae, Sayornis saya quiescens, Polioptila caerulea obscura, Guiraca caerulea salicaria, and Carpodacus mexicanus ruberrimus) are extended, and Psaltriparus minimus cecaumenorum is recorded from Arizona.

Where Sonora data are deficient, van Rossem quite properly cites records for contiguous border localities. Apparently, however, records for Menager's Dam (Papago Indian Reservation, Arizona) are not cited, though this is only a mile or so from Sonora, and a few of the birds on the Sonoran list (notably the Bronzed Cowbird and Rufous-winged Sparrow) occur there.

Sonora data have been critically analyzed, and in most cases migration, breeding, and winter records are carefully distinguished. It is perhaps doubtful whether future observations will confirm the migration of the Prairie Falcon, Green Kingfisher, and Rufous-winged Sparrow which van Rossem predicates on the basis of the Sonoran records for these species. On the other hand, further field work will probably produce evidence of migration in the Turkey Vulture, Virginia Rail, White-throated Swift, Bridled Titmouse, Desert and Rock Wrens, and Mockingbird; it will perbaps contract the winter ranges van Rossem assigns to the Western Sandpiper, Black-necked Stilt, Avocet, Wright and Western Flycatchers, Rough-winged and Violet-green Swallows, and Clay-colored Sparrow. The two swallows, in particular, migrate north much earlier than is sometimes realized, and February 23, given by van Rossem for the Rough-winged Swallow, is most assuredly not a winter record; also, California and Arizona are not as van Rossem states, within the winter range of the Rough-winged.

Van Rossem has revised the breeding ranges of several birds and discredited some alleged breeding records. One might desire further details on the supposed breeding in Sonora of the Mallard, Western Tanager, and Black-headed Grosbeak, and a statement on how far south the Elf Owl breeds. It is interesting to learn that the breeding range of none of the Horned Larks, Meadowlarks, Red-wings, or Song Sparrows extends over the main part of Sonora; that there are gaps in the distribution of the Bob-white and Yellow Warbler, and apparently only isolated colonies of several species, notably flycatchers. Some historical data are given for the Black Vulture and Sonora Motmot, but nothing seems to be known of the history of the English Sparrow and Bronzed Cowbird in Sonora

Van Rossem adopts a middle course in the matter of sight records, including several species and even two subspecies on sight records alone, and it would seem that in places a more critical attitude would have been better.

Ecology is not extensively treated. Most birds are, quite correctly, assigned to life zones; yet the opening discussion is based on the "provinces" of Dice and others. The correspondence of the distributional maps of species with the map of the Sonoran avifaunal areas is often merely general. Here and there, however, there are some interesting ecological data, as, for example, that for the Inca Dove, Olivaceous Flycatcher, and Botteri's Sparrow. Van Rossem suggests that the Long-billed Dowitcher (Limnodromus scolopaceus) prefers fresh-water localities in the Southwest, while $L$. griseus hendersoni prefers the coast

Like all large works, this one has its minor flaws-the terms "vagrant" and "casual" are used loosely at times; the author, in identifying Audubon's "Rancho La Sone" with Sonoyta (p. 320) may have placed it too far to the west. But such details are trivial in comparison with the magnitude of the task accomplished. The report stands as a monument to the industry and scholarship of the author.Allan R. Phillips. 